AMERICAN

LABOUR'S

COLD WAR

ABROAD 


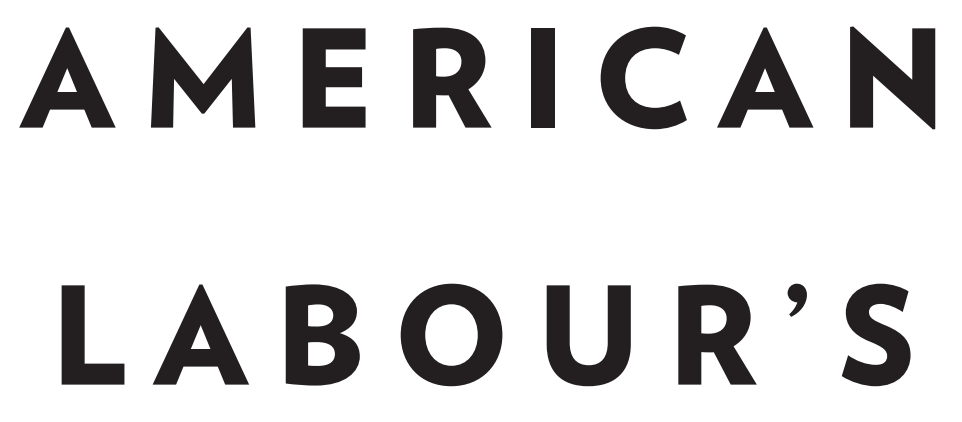

\section{COLD WAR}

\section{A B R O A D}

From Deep Freeze to Détente, 1945-1970 ANTHONY CAREW 
Copyright (C) 2018 Anthony Carew

Published by AU Press, Athabasca University

1200, 10011 - 109 Street, Edmonton, AB T5J 3S8

ISBN 978-1-77199-211-4 (cloth) 978-1-77199-212-1 (PDF) 978-1-77199-213-8 (epub)

doi: 10.15215/aupress/9781771992114.01

Cover design by Marvin Harder

Interior design by Sergiy Kozakov

Printed and bound in Canada by Friesens

Cover image: Irving Brown (second from the left), with Greek trade union leader Fotis Makris (left), during a visit to Athens in January 1950 [detail]. Courtesy of the Special Collections Department, University of Maryland.

Library and Archives Canada Cataloguing in Publication

Carew, Anthony, 1943-, author

American labour's Cold War abroad : from deep freeze to détente, 1945-1970 / Anthony Carew.

Includes bibliographical references and index. Issued in print and electronic formats.

1. AFL-CIO-History-2oth century. 2. Labor unions-Political activity-United States-History-2oth century. 3. Labor unions-Europe-History-2oth century. 4. Labor movement-United States-History-2oth century. 5. Anti-communist movements-United States-History-2oth century. 6. Anti-communist movementsEurope-History-2oth century. 7. International labor activities-History-2oth century. 8. Cold War. 9. United States_Foreign relations-1945-1989. I. Title.

HD8072.5.C37 2018

331.880973 '09045

C2018-902151-9

C2018-902152-7

We acknowledge the financial assistance provided by the Government of Alberta through the Alberta Media Fund.

\section{Albertan}

This publication is licensed under a Creative Commons License, AttributionNoncommercial-NoDerivative Works 4.o International: see www.creativecommons.org. The text may be reproduced for non-commercial purposes, provided that credit is given to the original author. To obtain permission for uses beyond those outlined in the Creative Commons license, please contact AU Press, Athabasca University, at aupress@athabascau.ca. 
For Marilyn 



\section{Contents}

LIST OF ILLUSTRATIONS IX • ACKNOWLEDGEMENTS XI • ABBREVIATIONS XV • INTRODUCTION 3

1 Facing the Future-Labour's World in 19459

2 Building Labour's Anti-Communist Opposition in Europe 29

3 For Multilateralism or "Independent Activities"? 67

4 The AFL and CIO Abroad: From Rivalry to Merger 107

5 A Wedding Without a Honeymoon 149

6 Into the 1960s: Claiming a Second ICFTU Scalp 191

7 Who Speaks for American Labour? 237

8 Toward an Independent Role 277

9 Au Revoir Becomes Adieu 323

10 Conclusion: The "Cold War" Within the Cold War 341

ABBREVIATIONS USED IN NOTES 355 • NOTES 359 •

BIBLIOGRAPHY 479 • INDEX 495 



\section{Illustrations}

Figure 1 Irving Brown, with Greek trade union leader Fotis Makris, during a visit to Athens in January 1950

Figure 2 Vincent Tewson, general secretary of the TUC, 1946-60, delivering his opening address at the ICFTU's Stockholm congress in July 1953

Figure 3 Walter Reuther, Vincent Tewson, and George Meany, at the December 1952 meeting of the ICFTU executive board

Figure 4 Victor Reuther, the key figure in the CIO's overseas operations

Figure 5 AFL representative Phil Delaney and Jay Lovestone in July 1953, at the ICFTU congress in Stockholm

Figure 6 Relaxing over a hand of gin rummy, David Dubinsky and George Meany

Figure 7 AFL-CIO Vice President Jim Carey, Victor Reuther, and Irving Brown, at the ICFTU congress in Tunis, July 1957

Figure 8 Mike Ross, director of International Affairs for the CIO, 1945-55, and for the AFL-CIO, 1957-63

Figure 9 Jaap Oldenbroek, general secretary of the ICFTU, 1949-60, in July 1953, at the ICFTU congress in Stockholm

Figure 10 Walter Reuther and George Meany, at the June 1960 meeting of the ICFTU executive board, in Geneva

Figure 11 George Woodcock, the TUC's general secretary, 1960-69, at a reception in London in 1963

Figure 12 Ludwig Rosenberg, DGB president, 1962-69, with Henry Rutz and Irving Brown

Figure 13 Omer Becu, the ICFTU's general secretary, 1960-67

Figure 14 Walter Reuther and Arne Geijer, ICFTU president, 1957-65

Figure 15 Jef Rens, with Ludwig Rosenberg, in 1951 
Figure 16 Bruno Storti, general secretary of CISL, 1958-76, and ICFTU president, $1965-72$

Figure 17 Harm Buiter, general secretary of the ICFTU, 1967-71, at a January 1961 conference of the European Trade Union Secretariat

Figure 18 Vic Feather, TUC general secretary, 1969-73, and Heinz-Oskar Vetter, DGB chairman, 1969-82 


\section{Acknowledgements}

As this book has been so long in preparation I have accumulated debts to a large number of people. Sadly, several of them are no longer alive, while others may have long forgotten that they ever rendered assistance. Nevertheless, I want to thank Walter Kendall and Richard Fletcher, who first steered me in the direction of this research, and Joan Keating and Amanda Lucas, who helped with early fieldwork at the Modern Records Centre and TUC Library. My good friends Ian Bullock and Victor Rabinovitch have observed my progress, or lack of same, from start to finish, reliably on hand to offer encouragement, read drafts, and suggest valuable textual changes. Their help has been invaluable.

There was more than an element of madness in my attempting to research in depth an aspect of the American labour movement from a base in Britain and on a shoestring budget. I am therefore deeply indebted to friends Bill Schaap, Ellen Ray, Louis Wolf, Dolores Neuman, Ann Harvey, Kevin West, Cleo Moran, and Ike and Fay Krasner, who at various times took me in, provided shelter, and otherwise pointed me in the right direction.

I have greatly appreciated the willingness of the following trade unionists to assist, in some cases by recalling their participation in events described in the book, in others offering their perceptions as close observers: Mark Anderson, Fabrizia Baduel Glorioso, Jim Baker, Dan Benedict, David Brombart, Harm Buiter, Byron Charlton, Mike Cooley, Nelson Cruikshank, André Dewil, Tom Donahue, Ken Eaton, Sven Fockstedt, Charles Ford, Douglas Fraser, Dan Gallin, Collin Gonze, John Harker, Veronika Isenberg, Newman Jeffrey, Jack Jones, Kalmen Kaplansky, Joe Keenan, Eugenia Kemble, Bill Kemsley, Lane Kirkland, Denis MacShane, Heribert Maier, Joe Morris, Len Murray, Marjorie Nicholson, Joanna Pilarska, Jack Otero, Victor Reuther, Rosy Ruane, Kaare Sandegren, Penny Schantz, Manuel Simon, Paul Symogyi, Virginia Tehas, Victor Thorpe, John Vanderveken, Michael Walsh, Leonard Woodcock, and Jerry Zellhoefer. I am especially grateful to Stefan Nedzynski, former general secretary of the Postal, Telegraph and Telephone International, who, before his death, invested considerable time in helping with an understanding of the politics of the ICFTU secretariat and developments in African trade unionism in the 196os. 
Several former labour attachés and labour counsellors have been generous in sharing insights gained from their unique vantage point, including Sir Peter Carr, George Foggon, John Mainwaring, Michael McDermott, Douglas Talintyre, Kari Tapiola, Birger Viklund, and Murray Weisz.

I am grateful to library and archival staff at institutions on both sides of the Atlantic, notably at the George Meany Memorial AFL-CIO Archives, University of Maryland; Walter P. Reuther Library, Wayne State University, Detroit; Kheel Centre for Labor-Management Documentation and Archives, Cornell University, Ithaca; Hoover Institution, Stanford; International Institute for Social History, Amsterdam; Tamiment Institute, New York University, New York; TUC Library, London Metropolitan University; National Archives, Kew; Library and Archives Canada, Ottawa; Friedrich-Ebert-Stiftung, Bonn; State Historical Society of Wisconsin, Madison; Arbetarrörelesens arkiv och bibliotek, Stockholm; UAW Library, Detroit; Special Collections Library, Penn State University, State College; Modern Records Centre, University of Warwick, Coventry; Labour Party Archives, People's History Museum, Manchester; and my friends at the Working Class Movement Library, Salford. I particularly want to thank Stephen Bird, Ben Blake, Steven Calco, Elizabeth Clemens, Christine Coates, Carolyn Davis, Jennifer Eidson, Lars Gogman, Pete Hoefer, Jeff Howarth, Mieke Ijzermans, Arieh Lebowitz, Gail Malmgreen, Jane Murphey, Silke Neusinger, Warner Pflug, Lee Sayrs, Kathy Schmeling, Patrizia Sione, Mike Smith, Sarah Springer, Laurie Townsend, Erhan Tuscan, Monique van der Pal, Mary Wallace, and Hubert Woltering. At Athabasca University Press, Karyn Wisselink proved invaluable in helping me transition to the digital age.

I have benefited immeasurably from the work of other scholars mining at the same or adjacent coalfaces, including Richard Aldrich, Julia Angster, Myriam Bergamaschi, John Boughton, Kevin Boyle, Alessandro Brogi, Alan Campbell, Eric Chenoweth, Barrett Dower, Michel Dreyfus, Ronald Filippelli, Alvin Finkel, Eleonora Guasconi, Rebecca Gumbrell-McCormick, Quenby Olmsted Hughes, Richard Hyman, Hans Krabbendam, Annie Lacroix-Riz, Ulla Langkau-Alex, George Martens, John McIlroy, Klaus Misgeld, Koji Nakakita, Leopoldo Nuti, Karen Paget, Bob Reinalda, Yevette Richards, Magaly Rodríguez García, Federico Romero, Giles Scott-Smith, John Stoner, Frances Stonor Saunders, Reiner Tosstorf, Douglas Valentine, Mathilde von Bülow, Marcel van der Linden, Geert Van Goethem, Rob Anthony Waters, Edmund Wehrle, Peter Weiler, Hugh Wilford, Chris Wrigley, and Bob Zieger. I am especially grateful to Nelson Lichtenstein and an anonymous reader who provided supportive feedback and made helpful suggestions for improving the final draft.

For research grants that made this project possible, I am most grateful to the British Academy, the Nuffield Foundation, the Lipman Miliband Trust, and the Henry Kaiser Foundation. I also benefited greatly from the award of a Rockefeller Fellowship 
at the Archives of Labor and Urban Affairs, Detroit, and a Visiting Fellowship at the International Institute of Social History, Amsterdam.

Finally, I owe a particular debt to Bob Reynolds, former archivist at the George Meany Memorial Archive, for help with documentation that went beyond the call of duty, to Sheila Blackburn at Liverpool University for coming to my rescue on occasions when library facilities available to me proved inadequate, and to my editor at Athabasca University Press, Pamela Holway, who kept the show on the road when, at one stage, it risked going into the ditch. Most of all, I wish to thank Harold Lewis, former general secretary of the International Transport Workers' Federation, who encouraged this research from the outset, read all my drafts, and commented extensively while guiding me with sound wisdom acquired in a lifetime of work in the cause of the international labour movement.

Anthony Carew

Marple Bridge, August 2018 



\section{Abbreviations}

AALC African-American Labor Center

AATUF All Africa Trade Union Federation

ACTU Australian Council of Trade Unions

AFL American Federation of Labor

AFL-CIO American Federation of Labor-Congress of Industrial Organizations

AFRO African Regional Organization, ICFTU

AFSCME American Federation of State, County, and Municipal Employees

AID Agency for International Development

AIFLD American Institute for Free Labor Development

ALCIA American Labor Conference on International Affairs

ATUC African Trade Union Confederation

AUCCTU All-Union Central Council of Trade Unions

AWU Australian Workers' Union

CCF Congress for Cultural Freedom

CFTC Confédération française des travailleurs chrétiens

CGIL Confederazione generale italiana del lavoro

CGT Confédération générale du travail

CIA Central Intelligence Agency

CIO Congress of Industrial Organizations

CISL Confederazione italiana dei sindacati lavoratori

CLASC Confederación latinoamericana de sindical cristiana

CLC Canadian Labour Congress

COMISCO Committee of the International Socialist Conference

CPSU Communist Party of the Soviet Union

CSLC Confédération des syndicats libres du Congo

CTC Confederación de trabajadores de Cuba

CVT Vietnamese Confederation of Labour (Confédération vietnamienne du travail) 
CWA Communications Workers of America

DGB Deutscher Gewerkschaftsbund

ECA Economic Cooperation Administration

EDC European Defence Community

EEC European Economic Community

ERGAS Workers' Anti-Fascist League (Greece)

ERP European Recovery Program

ETUC European Trade Union Confederation

FBI Federal Bureau of Investigation

FCLL Free China Labour League

FDGB Freier Deutscher Gewerkschaftsbund

FEA Federal Economic Administration

FGTB Fédération générale du travail belgique

FIET International Federation of Employees, Technicians, and Managers

FIL Federazione italiana del lavoro

FIM Federazione italiana metallmeccanici (affiliate of CISL)

FIOM Federazione impiegati operai metallurgici (affiliate of CGIL)

FO Force ouvrière (Confédération générale du travail-Force ouvrière)

FOA Foreign Operations Administration

FTUC Free Trade Union Committee

GSEE General Confederation of Greek Workers

IAM International Association of Machinists

ICA International Cooperation Administration

ICFTU International Confederation of Free Trade Unions

ICFTUE International Centre of Free Trade Unionists in Exile

IFCCTE International Federation of Commercial, Clerical, and Technical Employees (later FIET)

IFTU International Federation of Trade Unions

ILGWU International Ladies' Garment Workers' Union

ILO International Labour Organization

IMF International Metalworkers' Federation

INTUC Indian National Trade Union Congress

ISG International Study Group on Freedom and Democracy

ITF International Transport Workers' Federation

IUF International Union of Food and Allied Workers

JLC Jewish Labor Committee 
KFL Kenya Federation of Labour

LCGIL Libera confederazione generale italiana del lavoro

LLHR Labor League for Human Rights

LO Landsorganisasjonen (Norway) / Landsorganisationen (Sweden)

MPR Mouvement populaire de la révolution

MSA Mutual Security Agency

NAFTA North American Free Trade Agreement

NATO North Atlantic Treaty Organization

NCFE National Committee for a Free Europe

NSC National Security Council

NTUC Nigerian Trade Union Congress

NVV Nederlands Verbond van Vakverenigingen

OEEC Organization for European Economic Cooperation

OPC Office of Policy Coordination

ORIT Organización regional interamericana de trabajadores

OSS Office of Strategic Services

PSDI Partito socialista democratico italiano

PSI Partito socialista italiano

PTTI Postal, Telegraph and Telephone International

RAF Regional Activities Fund

SAK Suomen Ammattiliittojen Keskusjärjestö

SCAP Supreme Commander for the Allied Powers

SFIO Section française de l'internationale ouvrière (French Socialist Party)

SNTC Syndicat national des travailleurs congolais

SOBSI Central All-Indonesian Workers' Organization

SPD Sozialdemokratische Partei Deutschlands

SRATUC Southern Rhodesian African Trade Union Congress

SRTUC Southern Rhodesian Trade Union Congress

STEP Social, Technical and Educational Program

TUAC Trade Union Advisory Committee

TUC Trades Union Congress

UAW United Automobile Workers

UGO Unabhängige Gewerkschaft-Organisation

UGTA Union générale des travailleurs algériens

UGTT Union générale tunisienne du travail

UIL Unione italiana del lavoro

UILM Unione italiana lavoratori metalmeccanici (affiliate of UIL) 
ULC United Labour Congress (Nigeria)

UMT Union marocaine du travail

UNCTAD United Nations Conference on Trade and Development

UREP Union Research and Education Program

WFTU World Federation of Trade Unions

WiN Wolnosc i Niezawislosc (Freedom and Independence) 
AMERICAN

LABO UR'S

COLD WAR

A B R O A D 



\section{Introduction}

This book is about American trade unions and how their efforts in the international field during the Cold War helped decisively to shape our modern world. Today, in an age when the strength of organized labour is much diminished, it requires an effort of memory to recall that, for many decades, trade unions in America and Europe were a substantial force in national politics, whose views on matters of foreign and defence policy, no less than domestic affairs, had to be listened to by governments. Organized labour was a key player throughout the years of ideological confrontation between East and West-here a contributor to cold-war antagonisms, bringing the Cold War into the heart of trade union practice, there a vocal critic of dangerous cold-war initiatives by governments, but never a mere bystander. Indeed, understanding the role played by organized labour is essential to understanding the course and social dimension of the Cold War.

The present work has its roots in research I undertook in the late 1970s and early 1980 o on the Marshall Plan, a formative development in the early Cold War. My focus then was the American trade union contribution in shaping the Marshall Plan and helping to administer it, and the impact this had on national labour movements in Europe. Although the American labour movement gave overwhelming backing to the Marshall Plan, the trade unions did not speak with a single voice on international matters. A fault line broadly corresponding to, but not exactly coterminous with, the organizational split between the American Federation of Labor (AFL) and the Congress of Industrial Organizations (CIO) reflected different philosophical emphases. National trade union centres in Europe, beneficiaries of Marshall aid, were acutely aware of these American differences, and their reaction to developments in the aid program was conditioned by this understanding. Inevitably, international labour diplomacy was made complicated by such factors.

Among the records of the Marshall Plan administration are occasional stray items of internal trade union correspondence that had found their way into government files. They show not mere philosophical differences between the two American camps 
but at times animosity of a vitriolic nature between people engaged in labour aspects of the program. To me, this suggested a possible promising field for further research that would carry the story forward beyond the Marshall Plan years. However, the relevant archival material was not then available.

A good deal of documentation from the $\mathrm{CIO}$ was already accessible in the Walter Reuther Archives, though the AFL-CIO had yet to release material covering AFL international work from the end of World War II to the merger with the CIO in 1955, as well as subsequent international records of the unified organization. I spent several years pestering the AFL-CIO in the late 1980s and early 1990 os for access to these papers. Not until 1992 was I allowed to see President George Meany's international correspondence for the limited period up to 1960. More years were to elapse before I gained access to the vitally important papers of international staffers Jay Lovestone and Irving Brown.

The individuals who are central to this study have long since passed from the scene. They were key players in their day, and their personal biographies make them seem, at times, like characters from a Le Carré novel. Foremost among them were Lovestone and Brown. Jay Lovestone, one-time leader of the American communist party before falling afoul of Stalin in the late 1920s, went on to lead his small, anti-Stalinist Communist Party (Opposition) (the "Lovestoneites") and gradually sought a toehold in the mainstream American labour movement in the 1930s. Irving Brown became a Lovestone acolyte in the early 1930s, while still a student activist. He remained close to his leader throughout that decade while working for organized labour in the garment trades and auto industry in positions obtained through Lovestone's influence.

With their communism in the past, in 1945 the two were reunited as a close-knit team in the AFL's newly formed Free Trade Union Committee (FTUC), through which the AFL planned to operate overseas. Still in a master-apprentice relationship, with Lovestone as the FTUC's executive director in New York and Brown as its field representative in Europe, they shared a particular understanding of the role of organized labour based on their political grounding in Leninism, a mindset of central control and secrecy that never left them even as they operated as professional anti-Stalinists. The FTUC provided a congenial platform for their anti-communism, but they were never entirely defined or restricted by its policies. They had their own agenda and would refer in private to their "project."

In the late 1940s and 1950s, they established themselves as the chief foreign policy advisors to the handful of men who determined AFL international policy. Here, three people were especially important. The first was Matthew Woll, chairman of the FTUC and leader of the photo-engravers' union, a diminutive figure who seemed a relic of an earlier age, given his penchant for wearing wing collars and striped pants. Indeed, 
back in 1924, when Samuel Gompers, the founding president of the AFL, died, Woll had hoped to succeed him. The second was David Dubinsky, a refugee from Tsarist persecution who had been schooled in the ways of organized labour as a member of the Jewish Bund. In the United States, he rose to become the strong man of the powerful Ladies' Garment Workers' Union, the FTUC's biggest financial backer. Finally, there was George Meany, of Irish-Catholic descent, who had worked as a New York plumber and had risen through labour's ranks to become the AFLs pugnacious secretary-treasurer. Initially, the FTUC operated a de facto collective leadership, but over the years, and especially after he was elected AFL president, George Meany became the most powerful figure. It was through him especially that Lovestone and Brown sought to exert influence through to the closing years of the Cold War.

Lovestone and Brown were the two representatives who, on behalf of the AFL and, later, the AFL-CIO, interacted with officialdom in the International Confederation of Free Trade Unions (ICFTU) and the leadership of other national trade union centres abroad. It was largely through their negative reporting of developments within the ICFTU and their wounding personal criticisms of its leadership that the latter's relations with the Americans became increasingly bitter and recriminatory in the 1950 s and 1960s. The profound consequences of this for the cohesiveness of the international labour movement constitute a central theme of this book.

Other national labour centres had their foreign policy specialists, but they were typically backroom functionaries of a second order rather than, as with Lovestone and Brown, influential operatives engaged in high politics and sensitive labour diplomacy. The latter moved in altogether more exalted circles, having ready access to White House staff, State Department officials, and topmost CIA personnel at home, while abroad they mixed freely with heads of government, cabinet ministers, and ambassadors.

As the archival records amply show, it was Lovestone and Brown who dominated the scene, setting out the information, ideas, and strategies that essentially fixed the agenda for the AFL-CIO and its activities abroad. But beyond being significant "players," Lovestone and Brown were also major chroniclers of events through their extensive correspondence and reportage. In dense correspondence that spanned thirty years, they sometimes managed a double exchange of letters a week between New York and Paris. It was almost invariably business correspondence, with a deadly serious focus on the "big issues" in international affairs as they interpreted them. Much of it fed into briefings for George Meany. Other letters were private, an exchange of thoughts between two men sharing a strong ideological bond and with a special mission within the labour movement.

On the most sensitive issues, such as the financing of American trade union programs overseas-frequently from US government sources and of a covert 
nature-they wrote in a thinly disguised code. Yet, at the same time, they were frequently indiscreet in their discussion of events and personal criticisms of colleagues in their field. It is this that makes their letters so richly revealing as commentary on the Cold War and indispensable for an understanding of how events were perceived, possibilities assessed, and policy proposals developed.

The Lovestone-Brown archival collections lifted the lid on the handling of international affairs within the AFL and beyond, making it possible to write about the subject in detail for the first time. Based on material from these sources, in 1998 I wrote an article for Labour History, "The American Labour Movement in Fizzland: The Free Trade Union Committee and the CIA," reviewing the relationship between the AFL and the world of intelligence during the early years of the Cold War. One year later, Ted Morgan's groundbreaking biography of Lovestone, A Covert Life: Jay Lovestone, Communist, Anti-Communist, and Spymaster (1999), drew upon the same source material. However, Morgan concentrated heavily on Lovestone's communist years and his subsequent drift back to the mainstream labour movement in the 1930s, while passing up the chance to delve deeply into his postwar work for the AFL and AFL-CIO in the admittedly obscure world of international trade union politics, with its complex institutional structure.

In more recent years, as academic fashion has shifted away from institutional histories of the labour movement, the Lovestone-Brown collections seem to have been relatively little consulted. Certainly, no one has attempted to tackle in detail the central issue of American labour's often fraught relations with its partners in what became known during the Cold War as the "international free trade union movement," with the ICFTU as its most prominent agency. Yet there has long been a need for a study of international labour affairs that details the role of Lovestone and Brown, and it is to address this gap that the present volume covering the first twenty-five years of the Cold War has been written.

I have chosen to ignore the doubtless sound advice of colleagues that a slim volume covering the entire period of the Cold War would have more appeal to a general readership. I am more persuaded by the view that the time for a detailed treatment of key episodes in this saga is long overdue. This volume therefore ends with the AFL-CIO's momentous 1969 decision to withdraw from the ICFTU, which thereby lost its largest affiliate and its biggest source of finance. Forsaking multilateralism, the AFL-CIO thus chose to "go it alone" in its battle against communism. A second volume will address the lonely years of American isolation that followed and the AFL-CIO's cautious road back to partnership with other national centres in the late 1970 s and early 1980 .

I approach the history of this period through two broad narrative strands. The first is the AFL-CIO's relations with leading free trade union centres in Europe, 
most importantly the British Trades Union Congress (TUC). The TUC had, since the early years of the twentieth century, assumed a leadership role in international labour affairs, and the AFL was determined to challenge its primacy in this field. In practice, this meant working to undermine the World Federation of Trade Unions (WFTU), which the TUC and the CIO had helped to set up in partnership with the trade union centre of the Soviet Union. It would then involve replacing the WFTU with a new "free" trade union international, the ICFTU, and, within that body, forcing the pace in anti-communist programs and the movement for colonial freedom. In the latter field, which saw Americans pitted against the trade unions of the old colonial powers of Europe, the AFL was motivated by a genuine concern for national independence movements. But its anti-colonialism was also inextricably linked to the anti-communist struggle, reflecting the American conviction that European foot dragging over decolonization inevitably played into the hands of communists and fellow travellers among trade union leaders in the emerging African and Asian labour movements.

Despite its leading role in fomenting the breakup of the WFTU and in creating the ICFTU, the AFL quickly concluded that the new international body was more susceptible to European than American influence. From the earliest days, a pattern developed in which the AFL identified the ICFTU secretariat as part of "the problem." It accused the staff of being insufficiently forceful in the anti-communist cause and too cautious in implementing programs aimed at empowering workers in countries seeking colonial independence. AFL support for the ICFTU became half-hearted, its attitude toward the leadership increasingly hostile. The ICFTUs first two general secretaries were forced to resign, largely under American pressure. And eventually the AFL-CIO quit the organization, believing that it no longer served American interests. International solidarity fell victim to a perception that the ICFTU stood in the way of the full-blooded anti-communism that the AFL-CIO regarded as the motivating force of the international labour movement.

The second narrative thread in my account deals with the recurrent tension over international affairs between the AFL and the CIO, and then between leaders of the former independent centres in the merged AFL-CIO. Much of this was a product of historic rivalries dating back to the 1930s, but it acquired a new salience in the 1950 s over the contrasting philosophical approaches of AFL president George Meany and CIO president Walter Reuther, who led the autoworkers' union and was Meany's chief rival for the leadership of the US labour movement. Their differences covered both domestic and international matters, but they also stemmed from the CIO leader's burning ambition to replace Meany as president of the merged AFL-CIO.

That Reuther was staunchly anti-communist and, no less than Meany, a keen critic of European colonialism suggested to many that their policy differences were 
exaggerated and that the main issue dividing them was Reuther's personal ambition. However, Reuther differed from Meany in that his anti-communism was couched in the more liberal language of "peaceful co-existence," together with a willingness to dialogue with ideological opponents. Moreover, his political instincts were broadly social democratic, with the result that he enjoyed more common ground with European trade union counterparts than Meany ever did. In turn, this closeness to the Europeans affected the internal balance of the ICFTU.

Meany supporters believed that Reuther undermined American labour's ability to present a united front abroad; he was viewed as an ally of the Europeans and the ICFTU secretariat and thus as an obstacle to the attainment of American objectives within the ICFTU. The UAW president's stance made for a structural weakness on the American side that was only ended when Reuther, frustrated by the internal politics of the AFL-CIO, eventually withdrew the UAW from it in 1968. In turn this hastened the American centre's own departure from the ICFTU the following year. Union fragmentation at home and abroad was now the order of the day.

George Meany had rarely invested much faith in the ICFTU. He had threatened withdrawal before and had now delivered on that threat. To close observers it was half expected. Indeed, a perceptive observer of Meany's performance at a tumultuous British TUC congress twenty-five years earlier during his first ever visit to Europe would not have been surprised by his behaviour in 1969. It was on that earlier occasion that Meany first spelled out to a foreign audience his views on trade union contacts with communists. World War II had ended, the new Cold War with the USSR was in the wings, and the launch of the WFTU was imminent. And it is here then that the story begins-at the TUC Congress, Blackpool, England, September 1945. 


\section{Facing the Future-Labour's World in 1945}

Blustery weather typical of mid-September greeted delegates attending the first postwar conference of the British Trades Union Congress, held in 1945 at Blackpool's Winter Gardens on the Lancashire coast. On Wednesday, 12 September, midway through the conference, the forecast called for a mix of clear skies and showers, with winds from the Atlantic freshening to gale force. Prime minister Clement Attlee was to deliver the keynote address that day-his first public speech since Labour's landslide general election victory in July. During the intervening period, he had attended the Potsdam Conference, along with Joseph Stalin and Harry Truman.

The prime minister was well received. He spoke of the task of building a new world order, a task that governments alone could not complete. It required the painstaking efforts of the peoples of the world. Nor could it be fashioned according to fixed models or nostrums. Atlee was acutely aware of looming political problems in the old colonial world and the new Soviet sphere, and he warned in particular against assuming that democratic practices widely accepted in Britain were "necessarily either practicable or desirable in, say, Eastern Europe or India." Yet the speech looked ahead with optimism to the "New Jerusalem" that Atlee and the trade union delegates present felt was now on the horizon.

Following Attlee's address, the conference resumed its discussion of domestic affairs, notably proposals to speed up the demobilization of the armed forces. Then, in mid-afternoon, during a natural break in the debate, the conference took time out for one of a number of greetings from fraternal delegates representing foreign trade union centres. Earlier, Léon Jouhaux, of the French Confédération générale du travail (CGT) - recently released from a German prison and soon to become a Nobel Peace laureate-had spoken passionately of the importance of international trade union unity in the victory over Nazism. He had been followed by Mikhail Tarasov, of the Soviet All-Union Central Council of Trade Unions (AUCCTU), who 
stressed much the same theme: the future of mankind and lasting peace, declared Tarasov, depended mainly on the unity of the working class of all countries. Now it was time for a message of greeting from the fraternal delegate of the American Federation of Labor (AFL), a ritual part of annual TUC conferences since 1894. But this was to be no platitudinous speech by an American brother on a "holiday swing" through Europe. Outside the Winter Gardens, the predicted gale from the Atlantic Ocean had failed to materialize: inside the conference hall, it was about to hit with a force.

\section{George Meany at the TUC, September 1945: Laying Down a Marker}

At fifty-one, George Meany, the AFL's secretary-treasurer, was making his debut at a British trade union conference. He was a burly 220-pound cigar-smoking Irish American from the Bronx, once described by the New York Times labour correspondent as "a cross between a bulldog and a bull." A plumber by trade, for the past twenty-five years he had been working his way up the union hierarchy as a full-time official, but Meany was not yet the household name he would later become. He had come to Blackpool to explain his organization's deep disagreement with the British TUC over a central issue of trade union international policy. The AFL would not be accepting an invitation to attend the World Labour Conference that the TUC, along with the Soviet AUCCTU and the American Congress of Industrial Organizations (CIO), were jointly convening in Paris less than two weeks later and that was likely to lead to the creation of a new international body, a World Federation of Trade Unions.

The Paris conference was a follow-up to a preliminary gathering convened in London in February that the AFL had also boycotted. There were three simple reasons for its refusal to attend. The AFL was not prepared to associate with the Soviet trade unions, which it did not regard as authentic. Nor was it was willing to join forces with the CIO, a breakaway from the AFL of less than ten years' standing, which it accused of weakening organized labour by practising "dual unionism." A third issue was the AFL's legalistic contention that any attempt to restructure the international labour movement should have been initiated by the International Federation of Trade Unions (IFTU), the established international centre to which both the TUC and AFL belonged.

With the dawning of postwar reconstruction, international trade union relations were of particular importance, and since the AFL had not participated in the preliminary World Labour Conference in London, the remarks by this largely unknown American visitor were likely to be of interest. Unusual for a fraternal address, 
delegates remained in their seats as conference chairman Ebby Edwards introduced him - "Comrade" George Meany.

Observing protocol, Meany opened his speech with the polite sentiments that such occasions demanded. Expressing admiration for the indomitable courage shown by the British people during six years of war, he noted that, although he was paying his first visit to the TUC, he felt as though he was addressing old friends. But, leaving the niceties behind, he quickly came to his main theme-the attitude of the AFL to international labour cooperation. On this, he warned the delegates, he intended to be very frank.

Regarding first the position of the International Federation of Trade Unions, housed since the fall of France in the TUC's headquarters, with TUC general secretary Sir Walter Citrine as its long-serving president, he confessed to an element of puzzlement. Through their prominent role in organizing the London and Paris World Labour Conferences, Citrine and IFTU general secretary Walter Schevenels had been acting without a mandate or directive from the IFTU itself. And with Citrine sitting just two seats from him, Meany went on in accusing tone:

To make a rough analysis of the picture, as we see it, the two principal officers of the IFTU have been engaged for the past two years in an open effort to dissolve, or in other words to destroy the organization they are supposed to represent. We ... do not understand nor can we approve of such activity. No reasons of expediency can explain or condone these actions.

The AFL's position was simple and straightforward. They would neither seek nor accept membership in an organization that granted recognition to the AFL's rival in America, the CIO. This was not a case of petty organizational jealousy but rather of intense hostility on the part of the AFL to a breakaway organization that was guilty of dividing the American labour movement and hampering labour's effort in the fight against fascism. Meany referred to the significant effort of the AFL in contributing more than $\$ 100$ million toward the relief of victims of fascism, contrasting it with the isolationist position of the CIO leadership, strongly influenced by communists. He reminded the audience that these CIO leaders, who were now promoting international labour unity through the World Labour Conference, had campaigned against American involvement in the war during the years of the Soviet-German friendship pact, picketing outside the White House with placards proclaiming that "the Yanks are not coming." Addressing the charge that the AFL was now being isolationist, he insisted that the AFL was as internationalist as the TUC, but "if fidelity to the principles of true democracy isolates us from the intellectual acrobats who get their daily direction for their daily vocal exercises from the Daily Worker we are happy and proud of our position.” 
Meany was no spellbinding orator, one to capture or sway an audience with mellifluous phrases or theatrical delivery. But he was forceful, self-confident, and direct, and he warmed to his theme as he now took aim at his second target, the Soviet trade unions. "Let there be no mistake," he thundered:

We do not recognize or concede that the Russian worker groups are trade unions ... [but] are formally and actually instruments of the State... These so-called unions are designed to protect the interests of the Soviet State even if this means that the interests of the workers themselves must be subordinated or injured. These so-called trade unions actively support the Soviet system of worker blacklists and deportations to labour camps.

Muttering in the conference hall had grown louder as Meany developed his argument, and now, in an unprecedented display of anger toward a fraternal delegate, members of the audience attempted to interrupt. There were hisses, catcalls, and cries of "Shame!" and "Tommyrot!" Forced to shout to restore order, the chairman appealed to the conference to give the AFL spokesman a hearing. Unfazed, Meany pressed ahead with his message, goading his pro-Soviet critics by asking rhetorically, what common ground could there be with the Soviet trade unions? What was there to talk about? "The latest innovation being used by the secret police to ensnare those who think in opposition to the group in power," he suggested, "or perhaps bigger and better concentration camps for political prisoners?"

Turning to the workings of the World Labour Conference and the kind of politicized international trade union organization that was likely to emerge, he referred to the preliminary gathering in London, noting acidly that he was "impressed by the amazing turnout of delegates from the Crown Colonies" and "impressed too by the spontaneous creation and representation of large trade unions in liberated and ex-enemy countries where no unions had existed a few weeks before." But he was still more impressed by the way the CIO and the Soviet AUCCTU had brushed aside the TUC's intention that the gathering should be only consultative and exploratory and had caused it to focus more on political issues than trade union concerns. The AFL, he stressed, would not cooperate in the creation of "a world super state of labour designed to influence the economic and political affairs of all nations."

As an alternative, he repeated the AFL's willingness to pursue international trade union unity through the IFTU, an approach that would automatically exclude the Soviet trade unions and the CIO, neither of which was a member of that body. Concluding on a note of amity that ran counter to what had gone before, he expressed the bright hope that as the AFL "travelled down the road to a better future" it would enjoy the companionship and cooperation of the TUC, their "old and honoured friend." 
Inevitably, Meany's speech had injected a discordant note. It was not his style to dissemble, even in the interests of politeness. Plain speaking was his stock-in-trade. The fact that he was in England undoubtedly influenced his tone. Of Irish descent, he was no Anglophile, and as the years to come would show, he was easily irritated by what he and other American trade unionists often took to be the supercilious style of TUC officials who adopted the lofty pose of elder statesmen in international gatherings. Nor did it help that Citrine was "Sir Walter," the first of a long line of British trade union "knights" with whom he was forced to deal. The sarcastic reference to the preliminary World Labour Conference being packed with delegations from the "Crown Colonies" reflected his abomination of British colonialism. His negative assessment of the Soviet trade unions and his bitterness toward the CIO were entirely in keeping with the views of the AFL leadership. And given the haste with which these organizations were working to create a new world trade union body, Meany probably believed that he had nothing to lose by being outspoken. Indeed, this was a definitive public warning on behalf of the AFL that it was ready to part company with former allies over the issue.

As Meany sat down, TUC president Edwards was quick to rule that a fraternal delegate's speech was not open for debate. He was anxious to assure the American that the leaders of the TUC would want an opportunity during his visit to discuss with him their approach to the coming World Conference, but he stressed, as the Daily Worker report noted, "to tremendous cheers" that the TUC's firm objective was "to promote greater unity among the working class of the world." George Meany was then presented with "a good British watch." With just a trace of good-humoured sarcasm reflecting the strained atmosphere that had descended on the conference, President Edwards assured him that this was a gift and not "lend lease" (which, to British consternation, had been recently and abruptly terminated by the Americans). With some relief, he then announced that the conference would now move into private session before adjourning for the day. ${ }^{1}$

The chairman had also expressed the hope that other fraternal guests would avoid entering into a debate over issues raised by Meany. That evening Soviet representative Mikhail Tarasov complained formally to the TUC about Meany's attack but was told that he would not be allowed a public platform to answer the charges. Tarasov then drafted a letter to the TUC protesting Meany's "hostile and insulting calumnies" and declaring that his speech would provoke deepest resentment among the ranks of Soviet workers. The speech, he wrote, was as much an insult to the CIO and the TUC, but he had drawn comfort from the loud protests of delegates who had also demonstrated their resentment. ${ }^{2}$

Meany's message was at odds with the prevailing sentiment in favour of international trade union unity. A few months earlier, Walter Schevenels, general secretary 
of the IFTU, had referred to the widespread "mystical appeal of trade union unity" in 1945, a unity that necessarily embraced the Soviet Union. ${ }^{3}$ In Britain, enthusiasm for the USSR was at a peak in the wake of Red Army heroism on the Eastern front and the Anglo-Soviet entente in war production industries since June 1941. The cheerfully irreverent call by returning British troops of "Joe for King" reflected a positive, popular image of Stalin in the country's workshops. Hopes for the continuation of the spirit of the Great Power alliance were entirely understandable in the context of 1945. Nonetheless, in the trade union movement in Europe and North America, there was plenty of pre-war experience to suggest that cooperation with the unions of the USSR might prove difficult.

Even before becoming IFTU president in 1928, Walter Citrine had more experience than most of face-to-face dealings with Soviet trade union leaders. He had been the TUC's assistant general secretary for barely a year in 1925, and was actually on an official visit to the USSR, when he was summoned home early to take the reins at the TUC on the sudden death of the general secretary. Three years later he added to his responsibilities the presidency of the IFTU. Over the next seventeen years he made strenuous efforts to widen the organization's membership beyond its European base. To this end, he shuttled extensively between North America and the USSR while all the time safeguarding the organization's essentially social democratic concept of trade unionism, with its respect for parliamentarism and instinct for working closely with democratic socialist parties. The imminent World Labour Conference was in no small part the long-term consequence of those efforts.

Playing on growing fears of both fascism and communism, in 1937 Citrine had successfully canvassed the AFL to join the IFTU. Part of the AFL's reason for agreeing to do so was to close the door to possible membership in the IFTU by the newly emerging CIO, since affiliation was restricted to one centre per country. When, in 1939, the TUC proposed that the IFTU also invite the Soviet trade unions to join, the AFL threatened to withdraw, and the idea was voted down. ${ }^{4}$ However, in 1941, Citrine was in tune with the British trade union groundswell of support for the Soviet Union that resulted in the establishment of an Anglo-Soviet Trade Union Committee aimed at increasing military production to equip the Red Army fighting on the Eastern front. It met several times and promoted an extensive program of Anglo-Soviet factory exchange visits.

After Pearl Harbour, Citrine turned his attention to broadening the committee membership to embrace American trade unions and so mirror in the field of organized labour the Great Power alliance at government level. Canvassing the Americans, he explained to the AFL leadership that pro-Soviet sentiment in Britain meant that a link-up with their unions had been unavoidable. But he sought to reassure them that the organization was in dependable hands and that the TUC itself had taken the lead 
in this initiative rather than allow its more avid pro-Soviet members to control the British component. Nonetheless, the AFL rejected the proposed three-way link-up, agreeing only to form a separate AFL-TUC Committee. Citrine's subsequent efforts to bring the $\mathrm{CIO}$ into this joint body also failed because of AFL opposition. Unlike the Anglo-Soviet Committee, the AFL-TUC body only ever met once, and then in a strained atmosphere. The CIO remained on the sidelines, causing its president, Philip Murray, to remonstrate that the CIO was tired of "being kicked around like a trade union waif in this field of international labour collaboration." To escape from isolation, Murray then successfully pressed the TUC to initiate moves that would eventually lead to the World Labour Conference of 1945.

In issuing the call for this conference, the TUC's hope was that attendees would discuss the prosecution of the war effort (this, in Citrine's eyes, being the overriding purpose of the conference), as well as the question of reconstruction once peace had been restored, including possible reorganization of the world labour movement. "We intend," Citrine had insisted "that the voice of [the] Trade Unions shall be heard in the formation of any peace treaty or any post-war reconstruction." 5 The AFL felt betrayed by this latest British move to establish an all-inclusive world body and vainly hoped to enlist the support of the British minister of labour, Ernest Bevin, the former powerhouse of the British transport union, whom they understood was at odds with Citrine over his approach to the reorganization of the international labour movement. In fact, Citrine himself was still torn over the best way forward and hoped that somehow the IFTU would play a decisive role in uniting the unions of the allied powers.

The concerns of trade unions were not the only factors involved in this search for labour unity. The initiative leading to the World Labour Conference had government backing of the three big allied powers. In his wartime shuttling between the United States and the USSR, Citrine had been operating in no small measure as an emissary of the British government in pursuit of strategic wartime policy. Foreign Secretary Anthony Eden made clear his sympathy for the Soviet AUCCTU line that a completely new international body needed to replace the IFTU. Prime minister Winston Churchill was invited to address the preliminary conference in London, but because of his absence at the Yalta summit his deputy Clement Attlee delivered the government's greetings. As a reflection of government approval, all the delegates to the preliminary conference were invited to meet the king and queen. Likewise, the World Labour Conference proper in September 1945, held in the grand setting of Paris's Palais de Chaillot, had the stamp of approval of both the French and Soviet governments: delegates attended a dinner hosted by Chairman of the Provisional Government General Charles de Gaulle and a reception at the Soviet Embassy. 
Although the conference process began as a "consultative and exploratory" exercise, the CIO and AUCCTU delegates soon combined to seize the initiative, moving decisively toward the launch of a new world body. Both Citrine and Schevenels saw the danger and delivered warnings about mixing politics and trade unionism. However, brushing aside their appeals for caution and a continuing role for the IFTU, the preliminary conference appointed a committee to draft a constitution and prepare in short order for the conference in Paris in September where the new World Federation of Trade Unions would be launched. In effect the TUC had now lost control of the process it had initiated, and AFL leaders held it responsible. Meany was quick to describe this hoped-for cooperation with the Russians as "grovelling in the dust of false unity which would replace one form of totalitarianism with another." ${ }^{30}$ More pointedly, AFL president Bill Green denounced Citrine as a "traitor."

Without doubt, Walter Citrine was stung by such American criticism. The day following Meany's address at the TUC conference was given over to debating international policy, and the general secretary made little effort to disguise his extreme annoyance at the personal attacks he had suffered at the hands of AFL leaders. Referring to "misrepresentation" and "abuse" levelled at the TUC, he called for the exercise of restraint before irreparable harm was done to the international labour movement. He dismissed as less than forthright ("trifling with grave issues") Meany's suggestion that the IFTU should have been the body to convene the World Labour Conference, since the AFL had made it abundantly clear that it would strenuously object to such a conference.

As for Meany's criticisms of the Soviet trade unions, Citrine assured the delegates that the TUC was well aware of the way they operated. They worked in a different environment, experienced different problems and so had different structures. But he made light of this, suggesting that there could be no cause for complaint when government at the highest level consulted unions. To loud applause, he remarked that it was something he would welcome in Britain. Refusing to pass judgment on the unions in the Soviet Union, he argued:

The Russian method of defending the interests of their working people ... may be radically different from ours, but I do not think that any of us has the right to charge a great Trade Union Movement like the Soviet trade unions as being devoid of the purpose of defending the interests of its members.

Over 120 delegates had asked to speak in the TUC's international debate, but the conference chairman was anxious not to allow further expression of hostility to the AFL. This would surely have been the consequence of prolonged discussion. He pointed out that Citrine had not been trying to score debating points against Meany, and he won the delegates' agreement to treat Citrine's statement simply as a progress report 
and to move on. Later in the day, in what might be seen as President Edwards's final parting shot, following a plodding address by the second AFL fraternal delegate, postal union leader Bill Doherty, dealing with the AFL's domestic program (including details of the latest pay rates of US postmen), the chairman noted that the latter's contribution had at times "sacrificed eloquence for knowledge" but thanked him nonetheless for a speech that, he said pointedly, was "as good a one as I have heard from a representative of the AFL." George Meany, it is safe to say, had definitely got up the noses of the TUC. It would not be the last time. ${ }^{8}$

\section{The Birth of the World Federation of Trade Unions}

When the World Labour Conference proper met in Paris two weeks later, Walter Citrine made a final unsuccessful effort to preserve a role for the IFTU while delaying the creation of a new global trade union body. In the event, he merely managed to safeguard jobs for IFTU staff in the new federation while failing to secure the general secretaryship for Walter Schevenels, who had to settle for one of the three posts of assistant general secretary. The top position went to Louis Saillant of the French CGT, who had made his reputation as a leader of the wartime resistance. Though not a communist party member, Saillant was the Soviet nominee for general secretary and, interestingly, had arrived at the preliminary conference directly from Moscow and in the company of the Soviet delegation. Citrine himself was elected president. The World Federation of Trade Unions (WFTU) formally came into being on 3 October 1945, representing the first time since 1919 that the division at international level between communist and non-communist labour movements had formally been bridged. There were some who harboured reservations about the initiative, but the tidal wave of general enthusiasm for unity in the labour movement simply washed over them. As British steelworkers leader Lincoln Evans, a dedicated anti-communist, noted, it was impossible "to ignore Russia, at least in the European movement. ... We are bound to make our peace with them." Skeptical though he was, there was always a chance that the WFTU might work, and so it had to be given an opportunity to prove itself. ${ }^{9}$

Citrine surmised that fourteen of the twenty-one members of the new federation's executive committee were either communists or dependent on the Soviet Union. But the founding conference had received assurances that no single large organization would be allowed to dominate the federation, and Citrine believed that together with the CIO president, Sidney Hillman, he could probably contain the Russian trade union leader V. V. Kuznetsov. There was nothing particularly radical about the WFTU's stated objectives, which Hillman viewed simply as a global version of the 
New Deal. Even so, Citrine warned the federation against allowing political objectives to intrude into trade union activities:

Our job here is to build a Trade Union International . . to carry on practical day to day Trade Union work ... [and] to secure practical results for the individual members of our Unions. I say that because some of the speakers seem to be under the impression that our job is to build a Political International. I heard one speaker say yesterday that his organization ... wished to establish Socialism. However laudable those desires may be the World Federation of Trade Unions is not the medium whereby that is to be done. If once we get into the maze of politics ... this International will perish. ${ }^{10}$

The big unresolved issue at the founding congress was the future relationship between the new federation and the international trade secretariats (ITSs) that linked national unions according to their trade or industry and were firmly rooted in the bread-and-butter aspects of day-to-day trade unionism. The WFTU constitution envisaged their complete integration and subordination within its structure as mere trade departments. However, the trade secretariats themselves insisted on retaining their autonomy in matters of industrial policy, and their leading spokesman, J. H. Oldenbroek of the International Transport Workers' Federation (ITF), was personally opposed to membership in the WFTU. He told the congress that no one but the secretariats themselves were entitled to decide on their future.

With no agreement reached at the congress, this matter was left to be resolved through negotiation. Walter Citrine had previously favoured a subordinate role for the trade secretariats in an enlarged world trade union international, but he now changed tack and made it a condition of the TUC's continued membership in the WFTU that there had to be agreement between the federation and the secretariats on the terms of their relationship. It was a "get-out" clause for the TUC should relations within the WFTU sour. It also created an issue around which those hostile to the "political" WFTU could agitate and organize.

Just over two months following the formation of the WFTU, the last rites were performed over the IFTU when its general council met for a final time in London. The AFL was not represented and wrote objecting to the idea that the organization be dissolved. But with the two principal officers, Citrine and Schevenels, having already decamped to the WFTU, it was decided to wind up its affairs on 31 December 1945. To handle residual financial matters a board of trustees was established. For doubters it offered the promise that the organization might still be revived should the WFTU fail. The AFL leaders were incensed at the way the IFTU had been killed off, adding to their feeling of betrayal and creating a lasting source of acrimony. ${ }^{11}$ However, they were not the type simply to bemoan their defeat. Contesting the field 
of international labour with the WFTU now became their central focus. A whole new field of international activity was about to open up for them.

\section{The Free Trade Union Committee}

Despite the prominent role played by AFL president Samuel Gompers in the formation of the International Labour Organization (ILO) after World War I, the AFL had been traditionally isolationist, its involvement in international affairs relatively recent. It was at the urging of the International Ladies' Garment Workers' Union (ILGWU), with its large Jewish and Italian membership and under the dynamic immigrant leader, David Dubinsky, that the AFL first began to look outward and raise money for trade union victims of Nazism and fascism in the mid-1930s. In the process it helped to rescue many labour activists from persecution in Europe.

Once America was in the war, both wings of the labour movement participated in the international relief effort, and large sums of money were raised to help trade unionists working underground in the various resistance movements in Europe. From late 1943 the Office of Strategic Services (OSS) was responsible for channelling much of this aid through its Labor Division based in London. Its agents included American trade unionists with language skills working alongside refugees from the labour movements of enemy countries. For the AFL the key body in coordinating the wartime relief effort was the Labor League for Human Rights, with Abraham Bluestein as executive director. Again largely a garment workers' initiative, the labour league was established as a semi-independent organization under the umbrella of the federation, its leading offices held by senior AFL figures. The AFL's affiliates were free to identify or not with its program and to contribute financially.

After the Normandy landings, with the end of the war in sight, attention focused more on the revival of European trade unionism where it had been officially suppressed. For this activity the AFL convention in 1944 voted to establish a Free Trade Union Fund, with a target of $\$ 1$ million. A "Finance Committee" consisting of AFL president Bill Green; Matthew Woll, a past president of the photo-engravers' union; David Dubinsky; George Meany, and Dan Tobin, president of the teamsters union, was appointed to distribute money collected, and a sixteen-strong executive board was created with formal responsibility for oversight of the fund. However, the executive board never met, and the finance committee soon became simply the "Free Trade Union Committee" (FTUC) - the only tangible reflection of the unions that had contributed to the Free Trade Union Fund. The FTUC was formally established as a component part of the Labor League for Human Rights with the same personnel acting as officers. ${ }^{12}$ And as executive secretary they hired Jay Lovestone. 


\section{The Rise of Jay Lovestone}

Powerfully built, forty-seven years old with fair hair, Jay Lovestone had been born Jacob Liebstein in 1897, in Poland, and was aged nine when his Jewish family emigrated to America and settled in the Bronx. He studied at the City College, New York, and planned to be a lawyer, but having been caught up in the tide of enthusiasm for the Bolshevik revolution he became a founding member of the Workers Party of America, the American communist party, and began to work full-time in the revolutionary cause.

As a prominent member of this small, sectarian organization, waging bitter fights against socialists and anarchists as well as rival communists, Lovestone made lasting enemies in the labour movement. At twenty-nine he succeeded to the leadership of the party, but his position was immediately threatened when he balked at Stalin's then ultra-leftist policies. Travelling to Moscow in 1929 in an attempt to resolve his differences with Stalin, he found himself caught up in the deadly battle between the Soviet party secretary and Nikolai Bukharin, the party theorist with whom he had developed a warm relationship. Stalin's line in 1929 was that capitalism was in a state of collapse, whereas Lovestone, influenced by Bukharin, argued the case for "American exceptionalism," the view that American capitalism was far from dead. In private conversation with Stalin he pledged his loyalty and pleaded to be given a chance as party leader in America. But having been deemed to be a "right deviationist," he was removed from the leadership. Indeed, Lovestone was lucky to escape from Moscow with his life.

Back in the United States, Lovestone regrouped his supporters into the Communist Party (Opposition) (CPO), later known as the Independent Labor League of America, or more commonly as "the Lovestoneites." Throughout the 1930 s he maintained organizational links abroad with other communist opposition groups while being careful not to criticize Stalin publicly and even defending the execution of Zinoviev and Kamenev in the early show trials. At home he rejected the "dual unionism" that was the Comintern line in its posited Third Period of capitalism. Indeed, after his former party colleague and garment workers' member Charles (Sacha) Zimmerman had renounced the communist tactic of forming a separate clothing workers' union, Lovestone backed him in 1932, when he successfully ran for office on a Lovestoneite platform as president of ILGWU Local 22, the union's second largest local with 30,000 members. Under Zimmerman's powerful leadership, Local 22 became Lovestone's base in the labour movement for the rest of the decade. His odyssey would now gradually take him back to labour's mainstream, his direction of travel evident in 1934, when David Dubinsky, the recently elected international president of the ILGWU and rising star in the AFL, invited him to speak at its convention. ${ }^{13}$ 
When the CIO, with a significant communist presence among its leadership, broke away from the AFL in 1937, Dubinsky arranged for Lovestone to act as advisor to Homer Martin, the first president of the United Automobile Workers (UAW), who was engaged in a desperate struggle for control of the new union against a left wing of communists and socialists. With generous financing from the ILGWU, Lovestone became, in effect, chief of staff to Martin. The battle for control of the UAW lasted from 1937 to 1939, when Martin was defeated. The price of having fought the left wing of the UAW in the CIO for two years was that Lovestone had now added to his list of enemies the Reuther brothers. He would have to contend with them in the international field from the late 1940 on onward.

Not until the end of the 1930 did Lovestone formally break with the Comintern, outraged at Stalin's execution of Bukharin in 1938 and, in the context of the Spanish Civil War, opposed to the campaign waged by Moscow against the POUM, with which the Lovestoneites had close links. Once World War II broke out, he insisted that there was no longer room for "isms" in American politics and that what he called the "cherished illusions" of radicalism were sterile. He duly dissolved the Independent Labor League at the end of 1940. With the destruction of organized labour in much of continental Europe, he now reckoned that American trade unionism could become the decisive force in the field of international labour. Its new role would be to spearhead the fight against all forms of totalitarianism. ${ }^{14}$

\section{Lovestone Goes to War}

With the communist opposition movement now a thing of the past and Lovestone looking to embed himself in labour's mainstream, Dubinsky gave him a further helping hand by arranging a job for him as head of the labour division of the Committee to Defend America by Aiding the Allies, which was subsequently renamed Citizens for Victory. ${ }^{15}$ In this position, he was responsible for drumming up trade union support for Roosevelt's policy of aiding British resistance to Hitlerism and countering powerful isolationist tendencies in the American labour movement. It involved raising funds to support the underground labour movements in Europe, and it was here that Lovestone acquired his first experience of tapping government for assistance with what he described as "technical arrangements to facilitate our work." When the OSS Labor Division's operations in Europe began, Lovestone was able to supply its director, Arthur Goldberg, with over thirty letters of introduction to key European labour movement activists. ${ }^{16} \mathrm{He}$, too, tried to join the OSS but was rejected on grounds of political unreliability. Likewise he failed to land a post in the Department of Labor, with the Federal Bureau of Investigation (FBI) registering horror that he was even being considered for such government work. "Lovestone 
cannot be completely trusted," stated an FBI report. "Informants have stated that he continued working for the OGPU [forerunner of the KGB] after being expelled from the Communist Party . . . may still be a Communist." It was a charge he never completely shook off. Indeed, he was subject to regular surveillance by the FBI until the late 1950s, and particularly during the years 1951 to $1954{ }^{17}$

Only when Lovestone became executive secretary of the AFL's Free Trade Union Committee (FTUC) in 1944 did he find a new role that fully engaged him. Based in the ILGWU head office on 7th Avenue, in New York, and on Dubinsky's payroll, Lovestone would henceforth work closely with the top leadership of the AFL, which, besides Dubinsky, included Matthew Woll, the longest-serving first vice president of the federation, and the secretary-treasurer, George Meany, who had a particular interest in international affairs-both men Catholics and staunch anti-communists. With Lovestone in their midst they seemed an unlikely team, but Dubinsky assured Meany: "The son of a bitch is OK: he's been converted." ${ }^{18}$

Among the FTUC leaders, Dubinsky was, arguably, the most dynamic and imaginative, but as the Jewish leader of a non-craft union, with his heavily accented speech, he was conscious of being somewhat apart, and within the FTUC he was content to let Matthew Woll be the front man. Qualified in law and with a pompous manner, the sixty-five-year-old Woll had first been elected president of the small International Photo-Engravers' Union of North America forty years earlier, and his experience of international labour affairs dated back to 1915, when he had been AFL fraternal delegate to the British TUC. He had expected to succeed Sam Gompers as AFL president in 1924 but, outmanoeuvred by miners' leader John L. Lewis, who secured the post for his nominee Bill Green, Woll had to settle for being chair of innumerable AFL committees. In 1944, he added to these the chairmanship of the FTUC and remained for many years its public face. ${ }^{19}$ As for George Meany, in the generally undemanding role of AFL secretary-treasurer he set about claiming the field of international affairs as his own, though only after becoming president in 1952 did he really begin to assert his authority.

As well as being chairman of the FTUC, Matt Woll held the chair of the AFL's International Labor Relations Committee. The relationship between the two bodies became an enduring source of confusion. The international affairs committee was clearly an integral part of the AFL structure, whereas the FTUC represented only those unions that chose to contribute to the Free Trade Union Fund. It was not part of the AFL's formal structure and became in effect a convenient vest pocket operation controlled by fewer than half a dozen leading figures. With overlapping membership, the AFL international affairs committee and the FTUC concerned themselves with the same international issues. In practical terms the key difference was that whereas the international affairs committee discussed developments abroad and committed 
the AFL to lines of policy, it was the FTUC that had the necessary funding from a more restricted group of AFL unions and became responsible for implementing policies on the ground. In short, it controlled the money for programs overseas and engaged the personnel to conduct the operations. The relationship between the two bodies was conveniently opaque and would become a contentious matter in subsequent years when the FTUC came under attack for conducting its own program without full accountability.

Donations to the Free Trade Union Fund were slow coming in -the much-touted \$1 million target remained a distant prospect-and there was little for the FTUC to do for the first half of 1945. In the meantime it was another ILGWU-sponsored body, the American Labor Conference on International Affairs (ALCIA), that was most actively focused on postwar strategy for labour. Its chairman was Raphael Abramovitch, a former leading Menshevik and assistant to Julius Martov, the leader of the Russian Social Democratic Labour Party. After the 1917 revolution, Abramovitch escaped from Russia and led the party in exile while editing its paper, the Socialist Courier. For twenty years, he also served as Berlin and then Paris correspondent of the Jewish Daily Forward and up to 1945 was Dubinsky's chief consultant on international affairs. ALCIA's secretary was Varian Fry, a Harvard academic who had previously worked in France for the Emergency Rescue Committee on behalf of fugitive intellectuals. ALCIA's role was to develop plans for postwar reconstruction and to publish the quarterly journal International Post-War Problems. ${ }^{20}$

In April 1945, Matthew Woll commissioned a memorandum from ALCIA on possible activities in Europe. Drafted by Fry, the document envisaged the likelihood of Europe dividing between Soviet- and Western-controlled blocs. Nine months before Winston Churchill made the term famous in his Fulton speech, Konrad Ilg, general secretary of the Geneva-based International Metalworkers Federation (IMF), spoke of an "iron curtain" running through Europe. Varian Fry shared Ilg's fear. In his mind the trade union enemy would not be capitalist employers so much as western European communism backed by the USSR. The preliminary World Labour Conference had taken place in London a few weeks earlier and, reading between the lines, Fry assumed that it would give birth to an organization under heavy communist influence.

Fry's memorandum to the FTUC identified France and Italy as the two problem countries, both with powerful communist groups in the labour movement. The climate of the time made it almost impossible for any labour leader in these countries to speak out strongly against Soviet influence, and any attempt to split the unions between communists and non-communists would be impractical. Still it was necessary to try to build what Fry called "centres of moral and spiritual resistance against communist propaganda and plans for domination." This would require the 
publication of newspapers and other literature. He proposed a budget for the next twelve months of $\$ 250,000$ for grants and subsidies to these centres of resistance. He also recommended that $\$ 10,000$ be set aside to cover the cost of sending a representative to Europe for a longer period to make the necessary contacts within the labour movement for distributing literature. ${ }^{21}$ The memorandum was discussed at a meeting of the FTUC on 11 June 1945, especially Fry's proposal to send a representative to France to "look over the territory and get in personal touch with union leaders" as a preliminary to helping the free trade unions organize. The appointment in October of an FTUC representative to Europe was a direct outcome of this discussion.

The specific proposal had come from ALCIA, which for a short period rivalled the Labor League for Human Rights as an influence on AFL international policy. But ALCIA's role would soon come to an end. Various factors were at work here. Its social democratic chairman, Raphael Abramovitch, viewed the labour movement in its wider sense as involving both political and industrial wings, whereas the traditional "pure and simple" values of the AFL militated against the idea of giving help to political groups. But more important were sectarian and personality differences. Abramovitch came from a different political tradition and was not part of the Lovestone circle, and with Lovestone running the FTUC there would be no role for "outsiders," especially in producing literature for overseas consumption, the proposed mechanics of which Varian Fry had outlined in a memorandum to Dubinsky in August 1945. This proposal of ALCIA's was not acted upon for eighteen months, by which time ALCIA had been elbowed aside by the FTUC after being bypassed in the decision to send a representative to Europe. ${ }^{22}$ But it also took some time for Lovestone himself to establish his own authority within this constellation of agencies spawned by the AFL. The FTUC began life as a subordinate body of the Labor League for Human Rights, and until Lovestone could fully assert himself it was Abraham Bluestein, the league's executive secretary, who had overall responsibility for the exploratory mission to Europe by the FTUC's newly appointed field representative. That representative's name was Irving J. Brown.

\section{Irving Brown-Lovestone's Acolyte}

The son of Jewish parents, Irving Brown was raised in the Bronx, where his father, a milk delivery driver, was a member of the teamsters union. He was thirty-three when the FTUC sent him to Europe as its representative in 1945. Five feet eight inches tall, with dark-rimmed spectacles that survived all changes in fashion, he had brown eyes and a mop of wavy dark brown hair, and was invariably dressed in the same rumpled dark suit, grubby collar, and stained tie. A New Yorker to the core, he was unmistakably a man with "hustle." 
In the thirties, Brown had put himself through New York University, where he studied economics and became president of the Social Problems Club. He had briefly been a member of the Workers Party prior to Jay Lovestone's break with Stalin, and at NYU had cast the deciding vote in favour of inviting Lovestone to speak on campus when the student body was divided over the issue. This was his first encounter with the man who would become his mentor. On graduating, Brown married Lillie Smith, who was employed as Lovestone's secretary.

Brown became Lovestone's protégé, the latter obtaining part-time work for him as a researcher for ILGWU Local 22 and as a lecturer on labour economics in ILGWU adult education programs. Toward the end of 1936, Lovestone arranged for him to be hired as an organizer for the Homer Martin-led UAW working out of Baltimore, Western Michigan, St. Louis, and finally South Chicago, where he became a key part of the Lovestoneite faction during the internal battle with the union's left for control of the organization. By the end of the decade he had risen to the position of regional organizer for the Eastern United States and became a member of the executive council of the UAW-AFL formed by Martin following his loss of control of the original union.

With the Martin forces finally defeated, Brown was hired by the AFL as a representative in its organization department, based in Washington. He subsequently transferred briefly to the International Association of Machinists (IAM) with the prospect of becoming its research director. But in June 1943 he was nominated by the AFL for service in the War Production Board, initially having responsibility for advising on labour aspects of aircraft production but eventually becoming deputy to the board's vice chairman for labour production, Joe Keenan, secretary-treasurer of the International Brotherhood of Electrical Workers, who was also on secondment to the government.

There followed a period during which much of Brown's activity was shrouded in mystery. In April 1945, he transferred within government service to the Federal Economic Administration (FEA), responsible for advising on economic policy for countries under military occupation. In the case of Germany, it favoured restricting the level of industrial production in line with Morgenthau proposals for the pastoralization of the country. Brown, who bore the title Director of the Labor Division, disagreed with this policy and its negative implications for German trade unionism. Faced with this official policy, he resigned from the FEA in September 1945. In fact, people who were close to him at the time testify that he never really worked for the FEA at all.

The FEA had responsibility for recruiting civilians for positions in military government, and at the urging of the prominent socialist, Paul Porter, almost as soon as he joined the FEA, Brown signalled a readiness to transfer to the Manpower 
Division of the US Office of Military Government in Germany. That same month he was due to be posted to Germany along with colleagues Newman Jeffrey of the UAW and David Saposs, a consultant to the White House's Office of the Coordinator of Inter-American Affairs. In the event, Brown didn't go with them, but he did spend some months in Europe, and it was assumed by these colleagues that at this point he established a relationship with the OSS. ${ }^{23}$ These months remain a mystery. Brown hardly ever spoke about the period in later years, and he gave few details that could be verified. Intriguingly, an obituary notice by the AFL-CIO's African-American Labor Center, of which he was later director, briefly states that "in the final months of World War II, Brown acted as labour representative with U.S. occupation forces in Europe" and "worked with labour leaders exiled from Vichy France and Norway." ${ }^{24}$

It is impossible to corroborate these sketchy accounts of wartime activities. OSS files provide no indication of Brown's involvement with them. Likewise, among Norwegians who were prominent in the resistance and historians of the Norwegian underground there is no apparent knowledge of any role played by Brown. Norwegian Labour Party secretary Haakon Lie, who later knew Brown well in connection with CIA-financed support for the Finnish labour movement, noted that "if Brown was in Norway in wartime, he never mentioned it."25

Adding to the confusion, a biography of Brown by a journalist friend, Ben Rathbun, compiled on the basis of numerous discussions with him and published after his death, goes much further, claiming that Brown was actually working with the OSS as early as 1944 or even 1943 while formally employed by the War Production Board. According to Rathbun, to afford him cover during wartime visits to Europe, the intelligence service allegedly provided documentation under the signature of the secretary of state notifying his agency chiefs in the board, the Federal Economic Administration, and the heads of US foreign missions in London and Salzburg that he was there on a short and appropriately vague assignment. In this account, Brown claimed to have dealt in London with OSS head Bill Donovan, Labor Division Chief Arthur Goldberg, and Director of Organization (and eventually director of the CIA) William Casey in 1944-45, while "working on post-war programmes for the underground in Eastern Europe." Moreover, Rathbun recounts that, two days after D-Day, Brown parachuted into France behind "Allied [sic]" lines and was similarly due to parachute into Norway in November 1944 when the plan was scrapped because of fog. ${ }^{26}$

It is hard to know what to make of this. Elsewhere, Rathbun's biography of Brown is riddled with factual errors big and small and has been largely dismissed by people who were close to the subject. Brown was always happiest when operating in the shadows and seemed to have little interest in having his life's work recorded. In his later years, he did talk idly about writing an autobiography and got as far as a possible title, which, perhaps revealingly, was "From Resistance to Resistance." But it went no 
further than that. Traditionally guarded about giving much away to interviewers, he might well have been stringing Rathbun along with tall tales after a liquid lunch. ${ }^{27}$ Equally, Rathbun's obvious inattention to detail might have extended to a deliberate gilding of the lily in the interests of creating a more exciting yarn.

However inflated Rathbun's account, there appears to be enough smoke to indicate a certain amount of fire and that Brown was indeed inducted into the world of secret intelligence in the closing stages of the war. Why he should have been selected for such work-making contact with French trade unionists when he spoke no French, discussing sabotage with Norwegian partisans when he knew nothing of sabotage, and generally having no international experience-is puzzling. All that is certain is that Irving Brown was close to Jay Lovestone and that the latter was beginning to make his own contacts with US intelligence.

Irving Brown's departure for Europe as a one-man advance guard in the AFL's battle against the WFTU followed by just six weeks George Meany's stormy appearance at the TUC conference and by three weeks the launch of the WFTU in Paris. The decision to dispatch him had been taken hurriedly, without time to elaborate a clear strategy or program of action. The situation was fast moving, and the fear that developments already in train in the international labour movement might quickly help embed communism in Europe dictated the need for an American labour presence. Brown would have to play things by ear. But he was to be no mere observer, and his early interventions were to leave an impact on organized labour for a generation or more to come. 



\section{Building Labour's Anti-Communist Opposition in Europe}

In sending Irving Brown to Europe the AFL had no detailed plan. The first need was to assess the trade union situation and explore the possibilities for combined action with like-minded, anti-communist groups. Brown had to improvise a modus operandi in France and Germany, but whatever the context, he always reckoned that an American presence at the centre of events was essential in order to supply the drive that Europeans were assumed to lack. Only when his posting was made permanent in late 1946 was he able to open an office and work more systematically in France, Germany, and Greece and within the international trade secretariats (ITSs) that rejected the subordinate role offered them by the WFTU. It was principally by combining the AFL's efforts aimed at the trade secretariats in opposition to the WFTU, and, from 1947, linking this to the campaign for acceptance by European labour of the Marshall Plan, that Brown was able to claim significant success after three years in Europe.

\section{First Steps in France and Germany}

Irving Brown left for Europe on 23 October 1945 accompanied by Charles Zimmerman, the forty-eight-year-old director of ILGWU Local 22, which had provided a base for Jay Lovestone since the early thirties. It was a joint mission of the FTUC and Jewish Labor Committee (JLC), the latter another Dubinsky stronghold and a vehicle through which the needle trades helped fellow workers abroad. Their first port of call was Norway, in response to a request for assistance in replacing printing presses for the Labour Party and the central trade union organization, Landsorganisasjonen $\mathrm{i}$ Norge (the LO). Zimmerman was then to visit Poland on behalf of the JLC. Brown's assignment was to stay in Europe for an indeterminate period and assess prospects 
for supporting the trade unions now re-emerging on the continent. He was on a monthly contract and later anticipated returning to the United States, where a job as director of research and education for the machinists union was on offer. How long he would remain in Europe was unclear. The AFL was inching toward leadership of a future anti-WFTU crusade, but its approach was hesitant.

In his first report home, Brown recommended that the Norwegians be granted $\$ 15,000$ toward the cost of printing presses plus another $\$ 10,000$ to cement good relations. Sold on the notion of international unity, the Scandinavian unions had joined up with the WFTU. Brown found that he couldn't reason with them on this, but he still conceded that they were "our best friends in Europe."

Moving on to Paris in mid-November, he checked in to the fashionable Hotel California just off the Champs-Elysée, which was to be his base for the next year. France was suffering from shortages of foodstuffs and a consequent escalation in prices. This one item took up 60 percent of the average wage, and eating meat was typically a once-a-week affair. Brown wrote wistfully about missing his bacon, eggs, and orange juice, but at least he was spared the privations of most of the populace.

Shortages fed a growing popular resentment made worse by the fact that government-controlled wages lagged behind ever-increasing prices. France was entering the final phase of the all-party postwar coalition led by General de Gaulle, and as the largest component, the Parti communiste français (PCF) was beginning to flex its muscles. Communists were the leading proponents of the "battle for production," which prioritized output over wage improvements, but despite their backing for moderate trade union policies, the dynamism and clear sense of purpose they showed greatly appealed to the organized working class. Within a fractious coalition government, the PCF benefited from the respectability of holding office while retaining freedom to manoeuvre in populist fashion, with a keen eye on the electoral calendar. In the medium term it appeared to have a good chance of coming to power through the ballot box. ${ }^{2}$

With minimal ability to read French and unable to speak the language, Irving Brown nevertheless quickly found his feet. He was no mere American tourist in Paris; he had valuable contacts among American embassy officials. Richard Eldridge, the US labour attaché, helped him navigate the trade union scene and acted as a safe posting box for Brown's sensitive incoming and outgoing mail sent via the diplomatic pouch. Norris Chipman, a political officer with an intelligence remit to keep a watchful eye on the communist party, was especially close to Brown and, by the latter's reckoning, "one of the AFL's best friends in Europe." An OSS office still functioned in Paris, and Brown immediately teamed up with Bert Jolis of the labour division, a jeweller by profession who, both then and in later years when he was with the CIA, was able to provide the AFL with courier services to New York. Within a year 
Brown would also develop a strong relationship with Ambassador Jefferson Caffery, politically reactionary with little time for trade unionism but a man who recognized that, in the French context, the non-communist unions had to be supported. ${ }^{3}$

Back in the United States, through his relations with key figures in the State Department, Lovestone also had access to confidential information that he routinely fed to Brown. His contacts were typically people who shared a belief that the State Department was riddled with communists and fellow travellers. Lovestone kept a list of some thirty people working in the department whom he considered "pro-Soviet." Some of the names listed were cross-referenced "see FBI record for communist connections." The list was almost certainly supplied to him by Ben Mandel, who was employed by the State Department as a "security officer" but had once been the business manager of the Daily Worker. Among the department's veteran specialists on Soviet communism, Lovestone had ready access to Loy Henderson, who was then director of the Division for Near Eastern and African Affairs. Another invaluable ally and soulmate was Raymond Murphy in the shadowy EUR-X branch, which worked closely with the intelligence services in monitoring European communism. In the late thirties, Murphy had debriefed newly arrived communist defectors from Europe and was currently working to expose the communist sympathies of Alger Hiss. Lovestone and Murphy regularly shared intelligence, the latter providing the FTUC with confidential reports from the most reliably anti-communist foreign service officers such as Norris Chipman in France and Elbridge Durbrow in Italy. When the AFL lobbied Dean Acheson to appoint a person to the office of the secretary of state with particular responsibility for liaising with the AFL, Murphy was the person they specifically requested for the post. ${ }^{4}$

From the outset, Brown also benefited from having ready access to the top leadership of the French labour movement. Within days of arriving in Paris, he was able to arrange meetings with the socialist leader and former prime minister, Léon Blum, at his home, and also Léon Jouhaux, general secretary of the CGT and grand old man of French trade unionism. After only four days in the city, Brown's initial report from Paris clearly reflected a perspective gleaned from talks with Blum and Jouhaux. ${ }^{5}$

He saw a glimmer of hope in the limited but already growing opposition within the CGT to the pattern of meetings being dominated by communists and focusing on their sectarian political agenda. It would be these anti-communists that he set out to woo. Yet the scale of the challenge was daunting. The communists had recently secured a majority on the CGT executive committee, which included Louis Saillant, the WFTU general secretary (who continued to hold office in the CGT and, though not a PCF member, regularly followed the party line), and Benoit Frachon, now joint-general secretary alongside Jouhaux. In Brown's reading of the situation, Frachon was the key communist trade unionist in Western Europe, with a role extending 
beyond French borders. "The communist capture of the CGT was the prerequisite for communist control of Europe," he wrote, a process aided by the formation of the WFTU, which, with headquarters in Paris, now became the communist base of operations in Europe.

Lacking faith in the aging Jouhaux's readiness to stand up to the communists, Brown focused on a younger group of union leaders associated with the paper Résistance ouvrière (later renamed Force ouvrière), including Jouhaux's long-serving deputy, Robert Bothereau, who, together with Albert Gazier and Roger Deniau, was already talking about "the coming split" in the CGT. He met them toward the end of November and offered them financial assistance. They expressed interest but balked over practical difficulties: almost all the CGT industrial unions were either led by communists or had a sufficiently large number of communists in key positions that it was pointless to make a formal offer of American aid. The only realistic course was to give covert assistance to individuals and friendly factions, hoping to create a nucleus of one or two hundred "reformists" from among the ranks of anarcho-syndicalists, Trotskyists, and miscellaneous anti-communist trade union intellectuals. The channels that might exist for this were discussed at a second meeting on 29 November with Jouhaux present. Brown reported agreement in principle but no resolution of the practical difficulties. There the matter remained, and in the months ahead, with Jouhaux determined to avoid divisive, sectarian battles and Bothereau sympathetic but lacking in decisiveness, no progress was possible. ${ }^{6}$

Brown did find a promising ally in August Largentier, since 1914 secretary of the Paris region of the CGT printers' union. He had organized the underground press during the war, maintained a network of contacts in other CGT unions for whom he had arranged clandestine printing services, and advised Brown on where to begin his work. Brown loaned him $\$ 400$ of his own money as an initial float and wrote to Matt Woll requesting \$5,000 to cover him for the next three months. Woll quickly arranged to send this via the Jewish Labor Committee.

Otherwise, Brown's requests for funding went begging. In a separate report to Abe Bluestein, executive director of the Labor League for Human Rights, he vaguely requested between $\$ 20,000$ and $\$ 80,000$ for a trade union group in Lyon to help them maintain a socialist-oriented trade union paper. The lack of precision in the request suggests a man fishing to see how generous might be their commitment to funding. To Woll he wrote describing structural changes proposed by the communists for the 1946 CGT congress that would cement their power base. He requested a budget of $\$ 100,000$ for organizing work in the coming six months, accepting that it was a huge sum but insisting that "it would pay to aid in the entire job or not at all." As he added, "it is a very desperate situation but the stakes are high and are worth the fight for free trade unionism." Brown asked for a response before the end of 1945, but none 
was forthcoming. ${ }^{7}$ The AFL leaders were not yet clear in their minds about how and to what extent they should involve themselves in European trade union affairs. The FTUC had been launched amid talk of raising $\$ 1$ million for the Free Trade Union Fund, but so far it had collected only $\$ 124,000$, with another $\$ 74,000$ pledged.

Irving Brown spent Christmas 1945 in London and was encouraged by his meetings with TUC leaders, Jaap Oldenbroek of the International Transport Workers' Federation (ITF), and a group of German trade union émigrés from the Landesgruppe Deutscher Gewerkschafter who were preparing a manifesto for the new German trade union movement and who included future socialist party leader Eric Ollenhauer and ICFTU assistant general secretary Hans Gottfurcht. Restless and bursting with energy, Brown returned to his Paris base at the beginning of 1946 and reported enthusiastically on these latest contacts. But he was fretful at having no response to his budgetary requests and the lack of guidance as to what his AFL bosses expected of him. The German émigrés in London needed a mere \$200 to print 20,000 copies of their manifesto, yet he had no authorization to help them. He would later recall bitterly the days "when I bounced around Europe stewing in my own juice for months on end without ever hearing from New York [i.e., Bluestein] except after I would take the bit between my teeth and issue press statements as to AFL policy."

Charles Zimmerman, who had now returned to the United States from Poland, intervened with Matt Woll in urging more material support for Brown, and believed he had succeeded in winning a commitment that a permanent AFL international affairs department be set up to service activities abroad. ${ }^{9}$ Yet he reckoned without the glacial pace of AFL policy making. In fact, Brown was left to occupy himself as he thought best for most of 1946 while awaiting any sign that the AFL might commit itself wholeheartedly to a long-term presence in Europe. His few specific tasks involved standing in for AFL president Bill Green in a ceremonial capacity as fraternal delegate at congresses of national trade union centres in Europe.

Frustrated at the limited scope for activity in France, Brown turned his attention to Germany, where he spent three weeks in January and February 1946. The issue of the moment was how to approach the rebuilding the German trade union movement. Brown had resigned from the FEA over the implications of the Morgenthau Plan for trade unionism, and he now arrived in the midst of a bitter row within the Manpower Division of the Office of Military Government that flowed from this very policy. In dispute was whether the organization of trade unions in the US zone should be led by, or even involve at all, former German social democratic union leaders from the Weimar period, or whether they should be excluded and the task left to new leaders from the rank and file.

The American policy debate was cast in simplistic terms of a "bottom-up" versus a "top-down" organizing strategy, with the former reflecting current official policy. 
It was possible to see the options in less Manichean terms, but those centrally involved-Brown now among them-were inclined to polarize their differences. For the architects of this approach, the charge against the pre-war social democratic union leadership was that their failings were the proximate cause of Hitler's rise. To allow a role for them now in the US zone in a situation that demanded the closest cooperation with the trade unions of the Soviet zone would be to betray the essential anti-Nazi cause over which the Great Power alliance had been forged. Yet to those who questioned the policy and championed a role for the social democratic organizers, the attempt to sideline the latter while cultivating a new generation of rank-and-file leaders was tantamount to promoting a communist agenda in the interests of the USSR. ${ }^{10}$

The main protagonists were seasoned American trade unionists or NLRB staffers, veterans of pre-war labour movement battles between left and right. Here they served under career soldiers who had little grasp of the issues involved and were easily manipulated: Brown dismissed the head of the Manpower Division, General McSherry, as a mere "politically naïve, overgrown boy." By the time he arrived in Germany in early 1946, pressure from the AFL leadership in Washington to change the policy and weed out its adherents was beginning to have an effect. The leading proponent of the "bottom-up" approach, Mortimer Wolf, whom Brown dubbed a "skilled fellow traveller," had resigned. Concerned that the housecleaning was taking too long, Brown also called for the removal of Wolf's principal ally, George Wheeler, the director of the Labor Allocations Branch, whose efforts, he believed, were aimed at slowing down the organization of unionism in the American zone and thereby handing an advantage to the longer-established Soviet zone unions when eventually the trade unions of the various zones were united in a national body. They had benefited from an early start and plentiful help and encouragement from the Soviet military authorities..$^{12}$

A foretaste of what Brown feared might happen on a national scale was on view in Berlin, where the unions of the four sectors were in the process of combining in a unified Freier Deutscher Gewerkschaftsbund (FDGB). Brown was present at the founding congress, where there was a preponderance of communists among both delegates and leadership. He reported that the Berlin unions were about as free as the Soviet unions-essentially "instruments for the communists to push through their political programme" and a template for what might be expected in the Western zones if preventative action were not taken.

The simultaneous presence in Germany of a high-level WFTU delegation comprising Walter Citrine, Léon Jouhaux, and Sidney Hillman presented him with an opportunity for a public attack on the CIO leader. In a report intended for publication, Brown wrote that Hillman "more than anyone else is responsible for assuming 
to speak in the name of American labour in defence of the original [Military Government] attitude of suspicion and hostility towards the German trade unionists and their efforts to recreate a labour movement." He gave an interview to the AP news agency that appeared in the Sunday Herald Tribune and other papers, blasting Hillman's role in Germany. Making much of the fact that the WFTU delegation included a number of communists, he wrote of them touring "in the grand style of visiting potentates," spending four-fifths of their time wining and dining with the military high command while allowing little time and showing little courtesy to their German union counterparts. ${ }^{13}$

Brown recommended to Woll that the AFL allocate a budget of $\$ 10,000$ to assist the German unions over the next year. It would enable the appointment of an AFL representative in Germany, help with office supplies for trade union headquarters, and facilitate the production of a German-language AFL newspaper. He told Woll that he had been impressed by Kurt Schumacher, leader of the Sozialdemokratische Partei Deutschlands (SPD), with his opposition to the forced merger of the socialists and communists in the Soviet zone. Contrasting the poverty-stricken circumstances of the social democratic groups in the western zones with the well-endowed apparatus of the Kommunistische Partei Deutschlands-generously supplied from the Soviet zone, even though they enjoyed but a fraction of the electoral support-he therefore advocated aid for the social democrats. In particular, he forwarded to New York an appeal from Willi Richter, leader of the emerging trade unions in Hesse, to help buy printing presses that would enable the social democrats to produce an extra edition of their paper, the Frankfurter Runschau, for distribution by embattled social democrats in the Eastern zone. Their needs were but a drop in a bucket, and Brown hinted that $\$ 1,000$ sent to the Jewish Labor Committee account in Paris would enable him to help them. ${ }^{14}$

Brown returned to France and the work of encouraging the anti-communists in Résistance ouvrière, but when he came back to Germany in April he found that conditions had eased only marginally: union properties confiscated by the Nazis had not been returned, and the unions continued to suffer from lack of licensed publications and the shortage of newsprint. Communist propaganda in labour publications was flooding in from the Soviet zone but went mostly unanswered in the Western press. What concerned Brown most were the economic conditions, which, as a consequence of the Morgenthau Plan to restrict industry, showed no real sign of improvement. "All other German problems fade into insignificance alongside the economic problems," he wrote. "It will be sheer suicide for America to continue to underwrite the insane application of the Potsdam decisions, maintain an industrial vacuum ... and at the same time try to encourage the development of democratic forces." ${ }^{15}$ 
On a third visit to Germany in the summer of 1946, Brown first became acquainted with military governor General Lucius Clay and spent several hours with him one Sunday seeking his impressions of the trade union situation. Years later, after Clay had achieved iconic status as the hero of the Berlin airlift, the two men became firm friends, but at this stage Brown considered the general an intransigent "brass hat bureaucrat." Both Clay and his economics chief, General William Draper, were ideologically opposed to trade unions and against their developing industrial and political power. Under them, the Office of Military Government claimed to be politically "neutral," but from Irving Brown's perspective it amounted to an anti-labour policy, and a "bankrupt" one at that, given its results to date. ${ }^{16}$

That same summer, Ambassador Jefferson Caffery introduced Brown to Secretary of State James Byrnes, who was in Paris for the 1946 Peace Conference. With the help of Norris Chipman and Sam Berger, the US labour attaché to Britain, a meeting with Byrnes was arranged, at which Brown described current AFL activities in Europe and urged especially that the Office of Military Government provide greater assistance to the German trade unions. They also discussed Brown's assessment of the trade union and political situation in France and his belief that the key to reducing communist influence was to break the French communist party's hold on organized labour. "You talk a language I understand," Byrnes told him, indicating that he would welcome further concrete proposals from him. Brown proceeded to draft a memorandum for the State Department's Soviet expert, Charles Bohlen, for use in discussions with the secretary of state. However, Byrnes would shortly be leaving the department, and the promise here of an inside track to influence soon disappeared. ${ }^{17}$

Contact with high officials such as Byrnes and Clay led Brown to believe-or at least to have others believe-that he had their ear. In later years he could undoubtedly open doors to top decision makers. But at this stage in his career he was still essentially hustling and trying to become known-still a curious blend of brashness and insecurity.

Throughout much of spring 1946, Brown was on the road in France, attending union conferences from the Pas de Calais in the north to Bordeaux in the southwest and then across to the steel-fabricating towns of the east, gauging the trade union mood in advance of the April congress of the CGT. Much of what he saw was discouraging, but he was getting into the fray. At the solidly communist metalworkers' congress, Louis Saillant was present and Brown was drawn into a sharp exchange with him when the Frenchman demanded to know why the AFL still refused to join the WFTU. At a regional conference of the CGT in Lille, Brown was invited to explain through an interpreter the AFL philosophy of non-political trade unionism. He wasn't satisfied that his meaning was getting through and so took the plunge and for the first time attempted to speak in what was still a "lousy, halting French." 
Nobody laughed and, he noted ruefully, they gave him a round of applause. But he also doubted that anyone had understood him.

Still, he was making himself known. At the Café Lamand in the coal mining town of Lens, he first met Henri Mailly, the veteran anti-communist miners' leader who would become one of his most important union contacts. Similarly, during his tour of the Belfort region in eastern France he got to know André Bergeron, a printer who would later become general secretary of Force ouvrière (FO) and who was to be his most lasting ally in the French trade union movement. Soon after their meeting Brown began to send Bergeron small sums of money to help with the costs of a local union publication.

He seized eagerly on any sign of dissent in union ranks. The "battle for production"- under which the communists prioritized increased output over improved wages and terms of employment-was taking a toll on the morale of workers. So Brown tried to identify people who were prepared to "do a trade union job," concentrating on bread-and-butter issues. Yet such people invariably lacked leadership and resources. "We ought not to let them down now in their fight against the CP," he wrote to Abe Bluestein. But getting money from the FTUC was like pulling teeth. He complained to Charles Zimmerman of having received only $\$ 1,000$ since the beginning of the year, merely enough to cover his own personal expenses: "It is the most heart-breaking experience of my life to see what can be done and then be paralyzed for lack of resources," he wrote. ${ }^{18}$ Zimmerman was indignant and told David Dubinsky that "we should be ready to assume the responsibilities of our decision." He went on to point out that "to send a representative to Europe to carry it through and then to deny him the resources with which to do so effectively" was "unfair" to Brown and also "bound to discourage large numbers of European trade unionists." 19

The summer of 1946 saw the first breakaways from the CGT, including groups of railway and Paris Métro workers. More significantly, a strike over wages led by disaffected Trotskyists and socialists in the postal service became the biggest postwar dispute to date and resulted in the formation of an autonomous union. ${ }^{20}$ It was a sign of things to come, but Irving Brown played no part in these events: at the time of the strike, he was away in Amsterdam representing the AFL at another national union congress, followed by further foreign travel in Europe. ${ }^{21}$ The events in France had passed him by. He would later be identified as the man who "split" the French trade unions, but even without his intervention unity was fragmenting almost from the time he arrived in the country.

During his summer travels, Brown returned to Norway as AFL fraternal delegate at the congress of the Norwegian LO, where he delivered a sharp attack on the WFTU. Once again Louis Saillant shared the platform with him and was forced to rebut the AFL's criticisms. Some months later, Brown would be back in Scandinavia at the 
congress of the Swedish LO (Landsorganisationen i Sverige), where a speech by the WFTU's Russian assistant secretary, Mikhail Faline, attacking the foreign policies of the American and British governments was answered in kind by a forthright anti-Soviet contribution by Brown. ${ }^{22}$

Brown relished the publicity that such events gave him, and it was in these months that his image as a belligerent anti-communist was fixed throughout Europe. These well-publicized exchanges also helped alert a wider trade union public to the ideological tension at the heart of the international labour movement. Writing to Matthew Woll, Brown sought to convey his growing enthusiasm for the assignment, though only if the job prospects were made clearer: "I should like to stay in Europe . . . to be of any service that the AFL thinks necessary and is willing to support in international affairs ... to see this thing thru to the end (even in terms of years)-dependent on being able to eventually bring my family over." ${ }^{23}$ Woll now asked him to draft a budget for activities in France.

This time Brown's modest proposal was for a six-month program costing \$15,00o. Of this, $\$ 3,700$ would cover the cost of an office in Paris to act as a headquarters from which to distribute literature and to dispatch temporary organizers to key locations. The balance was to be divvied up into sums of from $\$ 125$ to $\$ 300$ for activities in twenty-one listed towns and three industries of strategic importance. The Paris office would function as a shadow Bureau confédéral for the non-communists in the CGT who were currently issuing propaganda and organizing activities independently of one another. Brown's aim was to bring them together around a program of militant economic demands in opposition to current wage restraint policies that were a product of communist political control of the CGT. He wrote Woll: "As you know, I want to stay in the field . . . but I must know soon in order to make a decision about returning to my own union. It is now a question of just how far we intend to go." He added that the future "appears to have possibilities that we didn't dare dream of eight months ago."24

Still, AFL deliberations continued at their sedate pace throughout the summer of 1946. Woll asked Raphael Abramovitch of ALCIA to produce another think piece. In it Abramovitch agreed the time was right for intervention by the AFL to build on the "psychological and moral rift" that was emerging between communism and democratic socialism in the wake of the USSR's heavy-handed behaviour in the occupied countries of Eastern Europe. He proposed opening a permanent European office headed by Brown and assisted by two Europeans to coordinate the industrial and political activities of labour groups dissatisfied with the WFTU. More ambitious than Brown, he suggested an annual budget of $\$ 85,000$, of which $\$ 35,000$ would cover the cost of the central office, with research services and a monthly bulletin produced by ALCIA. ${ }^{25}$ 
However, in AFL leadership circles the idea that political groups of the left might have a role to play in the program was never likely to be accepted. And Brown had also made known his personal opposition to the suggestion that Europeans be given staff positions in an AFL operation. His own emphasis was on the need for it to be led by people who knew America and the American labour movement. Naturally they needed to understand Europe, but the first requirement was an ability to explain American labour-its history, organization, methods, and goals. Much more so than Abramovitch, Brown saw the whole operation in terms of missionary work-by Americans.

\section{The AFL Commits to Remaining in Europe}

After a year away from home, Irving Brown returned to the United States in October 1946 for the AFL's Chicago convention, where, following months of indecision, the federation leadership committed itself to extending his assignment in Europe. He was now authorized to open a permanent office and even given discretion over where to locate. Seemingly indicating a firmer AFL commitment to a European program, the convention voted to establish an international affairs department. The Labor League for Human Rights was closed down in December 1946 and Abe Bluestein, Brown's nominal boss to date, dropped out of the picture. The Free Trade Union Committee, hitherto a subsidiary body, came fully into its own under Jay Lovestone's direction, and Brown now reported directly to him. In November, the FTUC founded a monthly paper, the Free Trade Union News, published internationally, and very much under Lovestone's editorial control. From this point on, the FTUC had an unmistakable public voice: no one could doubt that it articulated the world view of Jay Lovestone.

News that Brown was to be permanently based on the continent aroused protests from those Europeans who saw him as a disruptive influence. Over the preceding months he had deliberately sought publicity for his presence, relishing his image as a tough-talking American with powerful contacts. For opponents he had a sinister quality. The WFTU executive board meeting in December spent time discussing the AFL's activities in Europe, and there was an element of braggadocio in Brown's account written for Matt Woll:

There was a spectre haunting every [WFTU] meeting-namely, the AFL.

The fear of future AFL moves seemed to dominate their every action. We are accused of planning all sorts of splitting tactics such as keeping the German trade unions out of the WFTU. The greatest fear was aroused over the question of our affiliating the various [US] international unions to the [international trade] secretariats which would prevent their affiliation to the WFTU. ${ }^{26}$ 
The CGT journal La Vie ouvrière now railed against the possibility of the AFL's opening an office in Paris as an invasion of French national sovereignty. General Secretary Benoit Frachon wrote of "insolence on the part of United States reactionaries" and of Brown's attacks on European and Soviet trade unions being such as "would not have been disavowed by the late Goebbels." Lovestone hit back in the Free Trade Union News, deriding him in an article titled "The Frantic Mr. Frachon." ${ }^{27}$

In fact, no decision had yet been taken on where to locate the European office. Paris was Brown's preferred city, from where he would be able to continue to cultivate the non-communists in the CGT while also being the physical embodiment of opposition to the WFTU, which had its head office there. Jaap Oldenbroek, however, was keen for him to base his operations in London so as to be able to link up more readily with the activities of the ITF. But Brown never felt entirely comfortable in Britain, and he also noted that his presence in London might "embarrass our friends in the TUC." ${ }^{28}$

However, the vehemence of the CGT attack caused Brown to have second thoughts about locating in France: his personal safety could not be assured, and he attempted to make political capital out of this. Having briefed the press that he intended to make an important statement just after the New Year holiday, he secured wide publicity for his announcement that he had decided against having his office in Paris. Though the French capital was noted for its openness and hospitality to people of different beliefs, he explained that he had abandoned his plans because of political warfare being waged by the French communists. He was thus justifying his change of mind in terms of the growing cold-war atmosphere-and, of course, reinforcing that very atmosphere with his announcement. Irving Brown's decision was that the sedate and slightly out-of-the-way Belgian capital, Brussels, would be the place from which the AFL would fight its corner in labour's Cold War. ${ }^{29}$

The passion generated over the opening of an AFL office in Europe was itself just a reflection of larger forces in world politics. The previous twelve months had seen the evaporation of hopes for a continuation of the big-power wartime alliance, now replaced by the dawning reality of the Cold War. It had been a gradual process. Joseph Stalin's election speech before the Supreme Soviet in February 1946 seemingly reasserting Bolshevik orthodoxy, George Kennan's subsequent "Long Telegram” warning of the threat of Soviet expansionism, and Winston Churchill's ominous "iron curtain" speech in March might not in themselves have been total proof that the promises of the Yalta conference were dead. But with the passing of the months, the difficult relationship between America and the USSR was increasingly obvious, and suspicion of the Soviet Union became almost universal in Washington as advocates of military preparedness and the security state set the tone of public debate. By the end of the year a consensus existed in the United States that Soviet aims were, as one historian 
puts it, "aggressive, expansionist, devious and unlimited." ${ }^{\circ}$ The imminent merger of the British and American zones in Germany into the Bizone was evidence that the division of the country was becoming a reality, while tensions within the coalitions of Communists, Socialists, and Christian Democrats that governed in France and Italy raised doubts over their long-term viability. The slide toward a polarized world was unmistakable.

The changes introduced at the AFL's October convention in Chicago marked the real start of the FTUC's engagement on the continent. By the spring of 1947, Brown had set up shop in the Brussels suburb of Stockel in a house that afforded office space alongside the living accommodation. His wife Lillie, Jay Lovestone's former secretary, now joined him with their four-year-old son. Multilingual, Lillie would serve as his unpaid secretary and translator, and he would be in a position to live a more orderly life than he had in the months camped out in the Hotel California. A more determined phase of work would now begin.

The decision to make Brown's appointment permanent highlighted an anomaly in the AFL structure. International issues were already the responsibility of an "international representative" who spoke for US labour at the ILO in Geneva while also handling the routine and mostly decorous relations with other national trade union centres. For the past decade Robert Watt, soon to be succeeded by Frank Fenton, had held the post, both working without support staff or bureaucratic structure. The establishment of the FTUC was clearly intended to add substance to AFL work overseas, but it remained semi-detached, without any clear linkage to the work done by Watt or Fenton, and the limited coordination between them developed only in ad hoc fashion.

Indeed, Lovestone would have been very reluctant to be imprisoned within a bureaucratic framework that involved central direction from Washington. Formally, he was on the staff of the ILGWU, where he combined the role of FTUC executive secretary with the directorship of the ILGWU's international affairs department. With his office in the ILGWU's New York headquarters and his salary paid by the union, for all practical purposes he worked for Dubinsky and ran the FTUC with the logistical support of the ILGWU. Operating "ultramontane," he enjoyed a measure of freedom and tended to view any international initiative originating from the AFL headquarters with suspicion. ${ }^{31}$

Irving Brown experienced the dysfunctional relationship between the FTUC and AFL in another way. At his recommendation, the AFL had appointed Henry Rutz, former director of education of the Wisconsin State Federation of Labor, as its representative in Germany. Until recently, as a major serving in the army in Germany, Rutz had played a useful role in opposing the Wolf-Wheeler policy on union organization. However, he soon began signing his correspondence "European Representative, 
AFL," implicitly elevating his status above that of Brown, the FTUC representative. It was trivial, but rank was at issue, and Brown clearly regarded himself as the senior man in Europe. He could be very sensitive over perceived slights, and he wrote to Lovestone threatening to have no truck with Rutz if he persisted with his "pompous, bureaucratic use of that title": "Unless there is a clear mandate as to who is who ... I don't intend to jeopardise my own position by staying away from America for several years to get this second-hand kind of deal. If this continues ... I will just get out and return." ${ }^{32}$ Brown's anomalous position was not rectified until 1950, when he was appointed to the AFL staff and Meany, then asserting himself more in the international field, became his nominal boss.

Within the AFL, Lovestone was still an "outsider" with whom few would have had any truck a decade earlier. His relationship with Dubinsky had begun as a marriage of convenience and took some time to deepen. With the other leading lights in the AFL, circumspection on Lovestone's part was required initially. He needed to show deference to the men who ran the federation and headed the FTUC. With some familiarity he might address Dubinsky as "DD," but the others were "Mr. Green," "Mr. Woll," and "Mr. Meany." All shared a deep anti-communism, but they had arrived at their positions through different routes: Woll, for example, as a Republican and fervent disciple of free enterprise capitalism, Dubinsky a social democrat. They spoke for different constituencies, but it was because of this that Lovestone came to value the FTUC as a sensitive barometer of the cross-currents in the AFL. ${ }^{33}$

AFL president Bill Green had little involvement in international affairs, but for the other officers of the FTUC this was an area of considerable interest. It was a particular hobby of Woll, who was the long-serving chairman of the AFL international affairs committee. In George Meany's case, operating uncomfortably as Green's number two in the undemanding post of secretary-treasurer, he had identified the international field as one he could stake out as his own, something that would lend meaning to his job. But Meany had not led a large union and, like Woll, didn't command any big labour battalions. His strength lay in his bureaucratic acumen, sharp mind, command of detail, and bluff, no-nonsense style in committee. Within the FTUC, it was Dubinsky alone who brought to international work the authority derived from being a leader of a large, dynamic union with a healthy treasury. And his interest in international labour politics was an expression of his largely immigrant memberships' consciousness of their ideological roots in Europe.

Lovestone and Brown were closest to Dubinsky, the man they were likely to approach first with any problem. Meany was someone they warmed to and grew to respect later as he began to play a more forceful role and emerged after 1947 as the likely eventual successor to Bill Green. Matt Woll, a generation older than Brown and a man full of his own importance, was someone to respect rather than befriend. What 
all this meant in practice was that if David Dubinsky gave backing to Lovestone and Brown on an issue, and if Matt Woll could be brought on board, then the committee's support could usually be assured.

By now the partnership between Lovestone and Brown dated back fifteen years. They were close, sharing a sense of being two alone, having fickle and often unreliable colleagues, yet waging the good fight against great odds. Lovestone was clearly the senior partner and, as their exchanges sometimes showed, still the "teacher." When Brown complained that his letters to Matt Woll had gone unanswered, he was reminded sharply of the hierarchical structure: "He doesn't write to you," Lovestone explained, "I do ... I'm handling all their stuff with you." ${ }^{44}$ In a report of a visit to Britain in late 1946, Brown recorded his approval of the Labour government's domestic policy and his belief, following a meeting with Harold Laski, that the Labour Party chairman was not the fellow traveller that some Americans thought. Lovestone then read him a lecture on the facts of life: "You know the AFL . . . is not in favour of British or any other kind of socialism. They might be frightened by your committing them so closely to ... the British Labour Party ... Remember ... who you are dealing with and whom you are representing." ${ }^{35}$ On another occasion Brown complained that FTUC pronouncements were often crudely negative and appeared to support "extreme forms of free enterprise." He also criticized the indiscriminate use of the terms "totalitarian" and "slave state" to describe not just Soviet communism but by inference other versions of socialism as well. Again Lovestone refused to yield an inch, insisting:

I am in complete disagreement with you on your attitude towards our use of the term Russian Slave State. That is the issue of the day ... The slave labour issue is the biggest issue confronting world labour today. Mark my words: on this issue the WFTU will be wrecked. Not by the AFL but from within. ${ }^{36}$

Safely ensconced in his Manhattan redoubt, Lovestone could indulge in sweeping pronouncements and deliver anathemas, whereas Irving Brown, in regular contact with the European labour movement, understood that proponents of nationalization and state intervention in the economy were by no means necessarily "Stalinists" and that to suggest otherwise was a big mistake.

\section{Interventions in Greece, France, and Germany}

Brown's first assignment under the new structure in late winter 1947 was in Greece to ensure that efforts to unify the General Confederation of Greek Workers (GSEE) did not reopen the door to communist influence. WFTU-supervised elections for the GSEE executive committee the previous year had produced a clear majority for 
the communists and socialists belonging to the leftist Workers' Anti-Fascist League (ERGAS), only for the results to be set aside by the Greek government. A new executive committee led by Fotis Makris of the National Reformist Workers' Group-an energetic but essentially opportunistic man with political roots in the right-wing Populist Party-was then appointed by the government. With Greece falling within its sphere of influence, the British government, supported by the TUC and WFTU, attempted to reunify the GSEE through a formula that reinstated the dismissed executive committee members sitting alongside the government's appointees. Yet these efforts coincided with Britain's announcement that it was pulling out of Greece. The US decision to step in and assume responsibility for keeping the country safe from communism within the terms of the Truman Doctrine now propelled the AFL into the GSEE's affairs.

At the request of the GSEE leadership, Lovestone dispatched Brown to Greece in February 1947, the same month that Britain made known its decision to withdraw. Brown set about ensuring that the latest British-backed attempt to reinstate the duly elected executive committee would not be implemented. He reported to Lovestone that, as Makris had the backing of the Greek government, he was best placed to form the nucleus of an effective non-communist front. It was, however, important to bring in other groups from the political centre, especially the followers of the more moderate John Patsantzis, who, he reckoned, included "sincere, intelligent and militant elements. ${ }^{37}$ Lovestone quickly requisitioned $\$ 20,000$ for assistance to Greece from the War Relief Fund to be spent on food parcels for activists in the Patsantzis group. These parcels would be a vital resource, supplementing the meagre diet of recipients, but also with an inflated resale value should they be needed as a hidden cash subsidy. ${ }^{38}$

Brown insisted that Greece was the last Balkan country where a free trade union movement was possible, and that the threat of communism in the country had to be viewed in the context of Soviet strategic designs on the Middle East and the warm-water ports of the Mediterranean. Brown's support for a firmer anti-communist line, the appointment of a permanent labour attaché to Athens to guide the unions, and a delay in efforts to reconstitute the GSEE until the United States had a firmer grip on the situation was well received in the State Department. ${ }^{39}$ British foreign secretary Ernest Bevin was alarmed by the Americans' new, harder line, and at the Foreign Ministers' Conference then taking place in Moscow argued vigorously with Secretary of State Marshall on this very issue, insisting that the American approach toward Greek trade unions risked damaging Anglo-American relations..$^{\circ}$

In part at Bevin's suggestion, the American labour attaché in London, Sam Berger, was dispatched to Athens pro tem to negotiate with his British counterpart in search of a formula for the reunification of the GSEE. Berger invited Brown to participate in the reunification talks with the unions, and while at a formal level a 
formula purporting to offer equal representation to all factions was on the table, Brown's efforts behind the scenes were devoted to unifying the representatives of the political centre and right and resisting any compromise of benefit to ERGAS. The anti-communist front held long enough for the talks to collapse after the two labour attachés gave up the task, and ERGAS's call for the WFTU to be allowed to supervise future GSEE elections was rejected. ${ }^{41}$ This was the last attempt at establishing trade union unity; the civil war in Greece intensified, with more than a hundred communist trade unionists arrested and executed over the next three years while three recent GSEE executive committee members belonging to ERGAS were imprisoned.

However, the coalition of centre-right-wing leaders that Brown had helped bring together failed to forge a cohesive free trade union movement and within a matter of months were fighting among themselves for the spoils of leadership. At the GSEE's 1948 congress, Brown blamed the lack of progress on the new labour attaché appointed following his intervention the previous year. The appointment was made without Woll or Lovestone being consulted, and over this they protested loudly. "We have the purse strings in Greece," Brown complained, "and we could have accomplished much in forcing Makris and his crowd to play ball with the united front set up." At the congress Brown imposed himself, taking responsibility for organizing the balloting for elections to office and acting as arbiter of points of contention between delegates. The outcome of the congress was still in the balance when he departed for business elsewhere, ostentatiously refusing to hand over money that he was authorized to give. Keeping the Greeks on a short leash, he told Lovestone, "I have not given a penny ... and do not intend to do so" until satisfied with the news coming from the GSEE. ${ }^{42}$

The problem with the Greek centre was that those who had demonstrated leadership qualities in the past and enjoyed the support of trade union members were excluded from the organization now led by people approved by Brown who were mainly attracted by the trappings of office. Deriving their regular finances from compulsory dues levied by the government, they inevitably became clients of the state. "Many of the so-called leaders who live on the contributions of the workers would disappear overnight if there weren't forced trade union contributions," commented the British labour attaché. Less than six months after Brown had helped sabotage any chance of leftist participation in a unified GSEE leadership, the same official noted that the "irresponsibility and calculated intrigue of prominent leaders and their complete disregard of genuine trade union interests has again become painfully obvious." The situation was still unsatisfactory in 1949 when the GSEE requested \$25,00o from the AFL to pay for its annual congress. Lovestone instructed Brown to tell Makris that the federation was in no position to help; the GSEE were too much of a headache.43 
In his detailed study of this phase of Greek trade unionism, Peter Weiler observed that as a result of the failed unification attempt in 1947, the Greek trade union movement was now in the hands of unscrupulous and unrepresentative men running it on behalf of industrialists and conservative politicians. The country would fade as a focus of urgent interest for the FTUC once communist influence in the GSEE had been averted and the WFTU eliminated from the picture, though Brown visited periodically and provided a "financial shot in the arm" to one or another of the GSEE factions if there were signs of a new communist challenge. His involvement in 1947 had been a classic spoiling operation targeted at communist trade unionists that succeeded in the short run but hardly benefited the cause of Greek trade unionism. It was a pattern to be repeated in other locations. ${ }^{44}$ Meanwhile, Makris, who had begun his trade union career under the pre-war Metaxas dictatorship, would continue in office through the years of the military dictatorship of 1967-74.

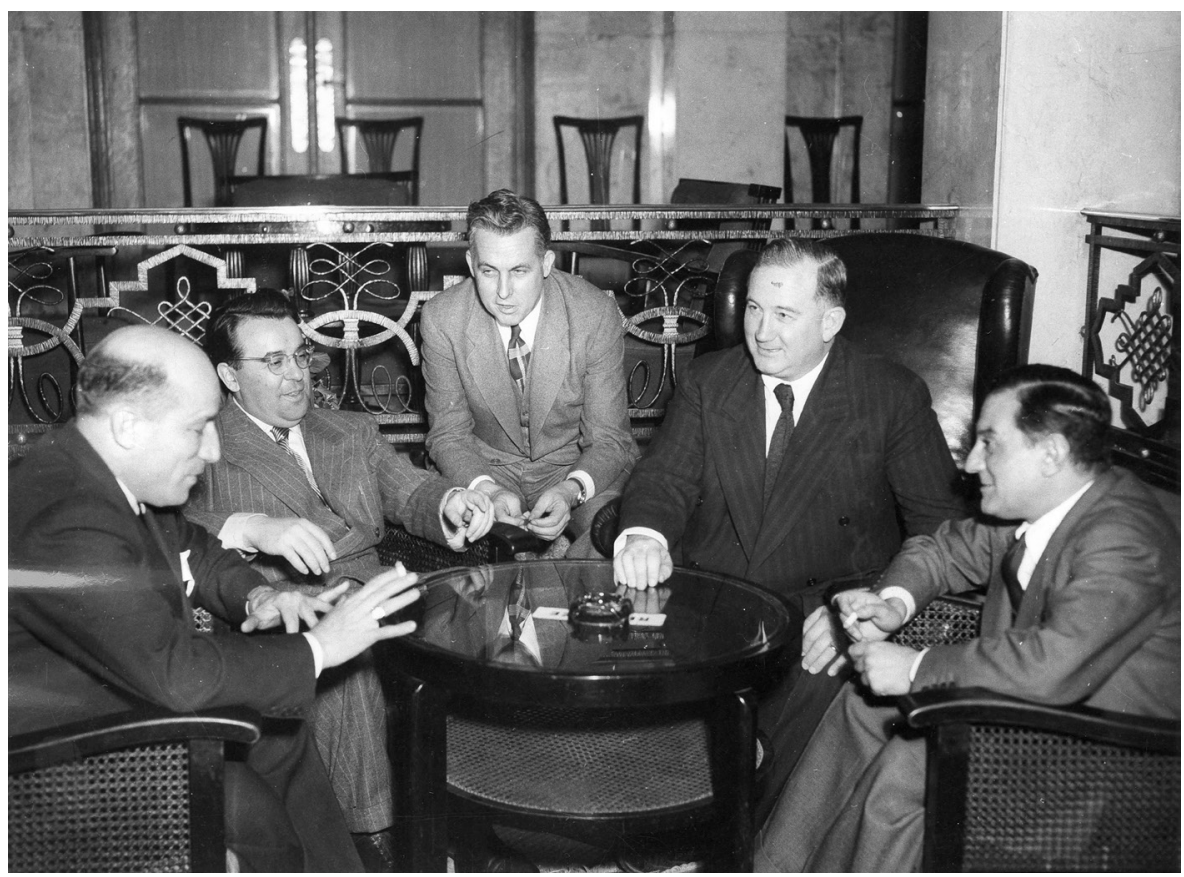

Figure 1. Irving Brown (second from the left), with Greek trade union leader Fotis Makris (left), during a visit to Athens in January 1950. Intent on keeping the GSEE free of communist influence, Brown periodically appeared in Greece to give the organization a "financial shot in the arm." Courtesy of the Special Collections Department, University of Maryland. 
In Germany, from the autumn of 1946 through 1947 the main concern of the FTUC was with a series of conferences intended to unite the zonal unions in a national structure. The AFL was initially excluded from the process, which began under WFTU auspices, until, following vigorous protests, it was granted observer status. At the first of the conferences in Mainz, the WFTU's new American assistant secretary, Adolph Germer-a veteran CIO colleague of Sidney Hillman during the battle with Homer Martin for control of the UAW-noted in his diary how "Irving Brown, one of Homer Martin's 'stooges" tried to "gate crash" the conference, "distributing [food] parcels to anyone who would say he is against Communists" and announcing that the AFL would "put up \$500,000 at the disposal of the German labour movement." In practice, the aid was far more modest, though still important: by early 1947 the AFL was supplying food parcels to five hundred American zone union officials each month. It would also soon be distributing 8,00o copies each month of its German-language edition of the Free Trade Union News. ${ }^{45}$

As steps toward German union unification gathered pace, Brown was again in Germany in August 1947 to meet the union leadership of the US zone and secure agreement on a policy that would delay plans for a unification congress the following spring until more progress had been made in uniting the unions of the British and American zones as part of the process of bizonal economic integration. ${ }^{46}$ But what finally derailed the plans for an all-German trade union congress was an announcement by General Clay that unification of the labour movement would not be permitted until the four zones were integrated economically, a prospect that was by now distant and receding. Clay had been the AFL's bête noir in resisting demands for the return of trade union property and the lifting of restrictions on newsprint supplies to unions, but this recent decision alone made him a hero. In 1948, at the height of the Berlin blockade and airlift, Brown helped make permanent a trade union breakaway in Berlin by non-communists from the unified citywide FDGB over alleged communist electoral manipulation. A timely $\$ 1,000$ FTUC appropriation for the newly created Unabhängige Gewerkschaft-Organisation (UGO) ensured its continued viability as a pro-Western body. ${ }^{47}$

A particular achievement of Brown was his nurturing relations with the chairman of the SPD, Kurt Schumacher, in 1946-47. Schumacher had impressed him with his magnetic personality, impeccable anti-Nazi credentials, and uncompromising opposition to Stalinist communism. On being confirmed as permanent FTUC representative in autumn 1946, Brown had secured a promise from Dubinsky that the ILGWU would provide $\$ 10,000$ for use in support of the German Social Democrats. He met Schumacher for the first time in December 1946 in London, where they struck up a rapport and discussed possible uses of this money. Brown proposed to Lovestone that $\$ 8$, ooo be used to purchase for the SPD typewriters and other office 
equipment from the US army's surplus property unit. The balance of $\$ 2$, 000 would be available to publicize the SPD's position abroad through a travel grant for Hans Gottfurcht, who handled external relations for the unions in the British zone. Brown wrote Lovestone: "It is not enough for us merely to oppose the WFTU in Germany. There is a great yearning for international recognition on the part of the Germans ... [who] once played a great role in international trade union organization." ${ }^{48}$

Brown also suggested that Schumacher be invited to the AFL's 1947 convention, giving him an overseas forum from which to make the case against German communism. He had to overcome the skepticism of General Clay and reservations among the AFL leadership before funding for the trip was agreed to and an invitation to Schumacher extended in the early autumn. Brown chaperoned the German leader at the San Francisco convention, where, in his rasping voice, Schumacher spoke powerfully warning of the threat of communist totalitarianism. Very much in tune with Lovestone, he argued that the great question of the day was whether freedom or slave labour would prevail. He welcomed the role of US labour in Germany, called for American help, and backed the recently announced Marshall Plan. It was the first time since the war that any German political leader had participated in such a gathering abroad, and his presence in San Francisco did much to boost his personal standing in Germany and that of his party. ${ }^{49}$

Brown and Lovestone remained confidants of Schumacher until his death in 1952 and were arguably his most important friends outside Germany. In their opposition to communist-leaning trade unions in various parts of the world, they in turn would often quote Schumacher on the essential choice between freedom and slave labour. The link between the SPD leader and the AFL — the latter often criticized in international labour circles for its conservative business unionism-was a remarkable feature of this period. It was undoubtedly Schumacher's implacable anti-communism that most appealed to the Americans. He was the best-known opponent of communism in Germany and, from the AFL's point of view, their most effective foil. But their support for him also helped indirectly to publicize and popularize German social democratic policies of socialization and democratic planning, and in this they were operating far outside official US policy in Germany.5.

The FTUC's biggest challenge in spring 1947 was in France, where strains within the communist-led CGT were coming to a head, principally over its moderate wages policy. A strike by Renault workers at the communist stronghold of Boulogne-Billancourt in April, which forced the CGT to abandon its wage moderation and resulted indirectly in the expulsion of communist ministers from the coalition government led by Paul Ramadier, began to open up space for opposition by the Force ouvrière faction. Of the group's leadership, Brown had no faith in Léon Jouhaux's capacity to lead the anti-communist struggle but rather placed his hopes 
in a younger cohort "who will some day break through this fuzzy myth of unity." He had recently been allocated $\$ 6,000$ for activity in France, and he now arranged to mail out copies of a French edition of the Free Trade Union News to a list of 24,000 potential activists. ${ }^{51}$

The role of the AFL-and especially Irving Brown - in helping to split the CGT has gone down in mythology. The essential facts bear restating. In the summer of 1947 the communist leadership of the CGT set out to restore its battered credibility by leading a succession of strikes that were increasingly "political" in that they were influenced by communist opposition to the recently announced Marshall Plan. These strikes among rail workers, miners, and metalworkers caused splits in the ranks and were accompanied by attempts at organizing an opposition, but all such efforts suffered from lack of resources and the relative isolation of one group from another. To overcome these handicaps, Brown urgently requested a further allocation of \$5,000 from the FTUC and was given clearance to spend an extra $\$ 500$ per month over the next four months in assisting the dissident groups. By the end of July, sensing that the tide was running his way, he was pleading for a further \$2,500. In August he submitted still another request for $\$ 4,000$ for use in France, and suggested also a "supplementary aid programme" financed by the American rail unions, telling Lovestone, "In spite of what may happen in other parts of Europe, for the moment the best of American plans will go for naught if this French situation is not broken. ... It is still France that must be cracked or else every move we make will be paralyzed in advance. I urge you to meet my latest request." ${ }^{2}$

The decisive phase came in November and December 1947 with a wave of insurrectionary strikes launched by the CGT that were more violent than any since the war. The buildup had been coming for months: "Power is already on the streets," reported the British labour attaché at the end of September..$^{53}$ Tapping into genuine economic grievances, the CGT embarked on action by dockers and rail and metalworkers for higher wages: it became de facto a general strike and lasted for three weeks. The political purpose was clear. At a meeting of the Franco-Soviet Trade Union Committee ahead of the strikes, Benoît Frachon had denounced the "anti-democratic and anti-Soviet propaganda" of the AFL and its support for "a small group of French splitters," against whom the Soviet delegates called for "resolute action." The CGT's subsequent national council meeting declared opposition to Marshall aid as "a plan of subjugation of the world by the capitalist American trusts and preparation for a new world war." That same meeting decided to consult all workers (not just union members) on whether to strike.

The non-communist minority among the CGT leadership opposed the insurrectionary nature of the action, the unconstitutional way that it had been called, and the fact that it was directed not by the CGT executive committee but by an ad hoc 
strike committee dominated by communists. CGT members who rejected the strike call were subjected to threats and beatings. The government introduced controversial legislation to protect property and non-striking workers and called up army reservists in a show of force. As the strike began to crumble with people drifting back to work, the CGT leadership called the action off in order "to regroup for further combat." 54

Although Léon Jouhaux still tried to resist the inevitable, this action led to the permanent split in the French labour movement and the formation of Force ouvrière (FO) as a separate centre. Even then, Jouhaux was still determined that the new body would remain within the WFTU fold if possible. The AFL had been working diligently to foster the split, and Irving Brown drew great personal satisfaction from the development, telling Lovestone, "Our work and our propaganda of the last two years in spite of all inadequacies have had their effect." 55 Yet during this latest phase, he had been a mere spectator. His budget depleted, he could only act as a messenger for Léon Blum in requesting financial assistance from Dubinsky for the socialist paper, Le Populaire. The schism within the CGT was the work of the non-communist rank and file. Brown's efforts had certainly helped: without the material aid from the FTUC, they would have struggled to create an organization. But the basis of the split had been present since 1945 when supporters of Résistance ouvrière began to balk at the systematic efforts of the communists to take control of the CGT as a vehicle for their political program. Brown was a catalyst in the formation of Force ouvrière, not the cause. However, he was happy enough to be seen in that capacity, writing to Lovestone: "The big drive is on and I am right in the middle of it and the communists never cease letting me know about it."56

Relations between Jouhaux and Brown were now deeply strained. Brown was unsure of being invited to Force ouvrière's founding congress in April 1948, as Jouhaux complained that the Free Trade Union News was publishing copy by the labour historian Georges Lefranc, a man with pro-Vichy connections. Even so, it was to the AFL that FO leaders turned for material assistance. Brown arranged to procure $\$ 10,000$ worth of typewriters from US government surplus stores in Europe, equipment that was then distributed to various FO offices. He had acted without waiting for formal approval, paying for the equipment out of his existing budget and then asking Lovestone to seek a refund from the AFL. In cavalier fashion he suggested: "You don't have to tell anyone about the fact that we have already bought the machines." Five months later, as Lovestone haggled over whether this was properly an FTUC or an AFL debt, and with Brown impatient to be reimbursed, Raymond Murphy, director of the State Department's EUR-X branch, stepped in to clear the outstanding sum. ${ }^{57}$

Force ouvrière's resources were still meagre. Preferring not to deal with the AFL if possible, Jouhaux was hoping for financial assistance from the CIO-there had been wild talk of sums ranging from $\$ 10,000$ to $\$ 100,000-$ but if anything was seriously 
promised the $\mathrm{CIO}$ failed to deliver. FO then turned again to the AFL and requested a "loan" of \$30,000. It fell to Dubinsky, while on a high-profile visit to Europe in the summer of 1948 , to agree to initiate a series of instalments paid by the ILGWU. Yet when FO general secretary Robert Bothereau failed to acknowledge in sufficiently fulsome terms the first payment of $\$ 5,000$, further instalments were suspended. Sensibilities were offended, and Lovestone railed:

We are not used to such transactions. Our money is honest, earned by workers themselves. When our organization makes a contribution to another ... we expect clear-cut precise acknowledgements and not vague generalities.... We are careful as to whom we call friends, but once we call friends friends we are proud of them and we expect the same morality from our friends. ${ }^{58}$

With FO still awaiting a further instalment three months later, Brown protested to Lovestone that the loss of time was "disastrous." "We just cannot go back on our word at this time and it is suicide to delay on such a vital question."59 With a war chest estimated at between $\$ 55,000$ and $\$ 140,000$ amassed from contributions from communist sources abroad, the CGT was on the point of launching another strike by miners in autumn 1948, and FO risked being without resources to support its members who would be involved. As a stopgap, Brown borrowed $\$ 9,000$ on behalf of FO from Rothschild's Bank in the expectation of receiving a refund from the ILGWU. ${ }^{60}$

Closely linked to the newly formed Force ouvrière was a Paris-based international organization of Soviet bloc trade union refugees that began to take shape under AFL aegis as the International Centre of Free Trade Unionists in Exile (ICFTUE). Brown had been cultivating this group for several months as part of a project through which the FTUC hoped to lend support to anti-communists behind the Iron Curtain. ${ }^{61}$ His key contact among the Paris exiles was Sacha Volman, a twenty-four-year-old Romanian and one of the more colourful characters in Brown's circle. Something of a chancer, he had fled to the West in a great hurry in 1947, hidden in a crate on an RAF transporter plane, after the communist authorities discovered that he was working for British and American intelligence. In Paris, he became secretary of the planned exile centre. Dubinsky handed him a start-up grant of $\$ 1,000$ during his visit to Paris in July 1948, with the promise of more toward the cost of a founding congress. Volman would soon be fully absorbed into the CIA's operational network. ${ }^{62}$

In total, the FTUC planned a $\$ 5,000$ annual grant to the ICFTUE, paid in quarterly instalments. Delegates from ten national émigré groups met on 4 October at the Force ouvrière HQ in Avenue du Maine to launch the centre, which would subsequently be housed in FO premises. Three weeks later Lovestone authorized Brown to 
secure a second tranche of $\$ 1,000$ for the ICFTUE from the Jewish Labor Committee. Brown went on to help the centre to establish links with Marshall Plan labour staff in Paris and acted as liaison with Voice of America, for whom the émigrés would be a valuable resource in broadcasting propaganda to Eastern Europe. ${ }^{63}$

CGT efforts to disrupt the Marshall Plan resumed in early October 1948 with industrial action by miners and attempts to spread the strike to the ports and railways. Once again, troops and police were deployed, and in the ensuing violence three strikers were killed and hundreds wounded. By the beginning of December the action had ended in failure, with mining communities close to starvation. Several weeks into the dispute, Brown had been authorized to make payments of $\$ 5,000$ to Force ouvrière every three weeks over the coming three months-some $\$ 20,000$ in all. ${ }^{64}$ Given the new centre's meagre resources, the AFL money constituted a vital lifeline. But it was merely temporary cushioning: financing sufficient for the organization's long-term survival still needed to be found. The solution would not always involve-as in Lovestone's recent boast-funds that were "honest and earned by workers."

\section{The Uncertainties of FTUC Finance}

Irving Brown's repeated requests for finance for anti-communist activities might suggest the existence of plentiful reserves on which to draw. However, many of his appeals were turned down. FTUC funding was uncertain; Jay Lovestone operated on a shoestring, with contributing unions having to be cajoled into voting donations. Other than for small sums of $\$ 100$ to $\$ 200$, Lovestone had little discretion, and each tranche voted for Brown's use had to be agreed to at a meeting of the full FTUC. Even in a recognized emergency several weeks might pass before the next scheduled meeting was able to deal with a request. Just how tight the budgeting was is evident from the internal discussion of where Brown should locate his office and what rent might be afforded. Lovestone told him: "All I can advise you is that the financial situation here is so tight, that the treasury is so low, that it is important that we operate on the most economical basis." Brown asked permission to hire as an assistant Francis Henson, an old Lovestoneite from Homer Martin days in Detroit. But Lovestone turned him down flat: "Just continue as best you can ... not stretching out too far. You know the AFL tempo. I am handling six people's work myself and I don't dare waste any time ... requesting assistance." ${ }^{65}$ The minutes of FTUC meetings for March, May, July, and November 1947 all indicated that funds were very low. Lovestone told the Committee in April, "We are sort of beginning to scratch the bottom." Brown complained regularly that they were operating on a five-and-dime basis; Lovestone concurred, bemoaning having to spend so much time passing the hat around. 
No consolidated set of accounts was ever included in the minutes, but based on the details of financial transactions reported to the FTUC and referred to in Brown-Lovestone correspondence, the evidence suggests that in 1947 the funds delivered to Brown for his various activities-mostly in France but also in Germany and Greece-totalled somewhere between $\$ 20,000$ and $\$ 30,000$. FTUC financial aid was clearly invaluable, but it was far from the vast sums that mythology has credited it with spending.

For Irving Brown, uncertain funding was a fact of life. It was exacerbated by frequent delays in processing allocations already agreed on, often a consequence of the circuitous way in which funds were transferred from America to Europe. Various methods were in use. Sometimes travellers' cheques were wired directly to him. The Jewish Labor Committee in New York, of which David Dubinsky was treasurer, was also an important conduit, and funds credited to it in New York by the FTUC would be transferred to JLC accounts in Europe. For his operational needs, the JLC would credit sums to accounts held in banks in Geneva or Paris, where Feivel Shrager, a Russian-born socialist acting as volunteer agent for the JLC, would pass on the money to him. Brown maintained a "revolving fund" of Swiss francs held in Geneva worth some $\$ 5,000$, through which he would purchase local currencies at the cheapest possible rates. This way he was often able to exchange at 50 percent or more above the official rate.

On occasion, when he had urgent need of funds, Brown would borrow from former OSS agent Bert Jolis, whose frequent business trips from New York to Paris enabled him to undertake courier services. But this was not always possible. While awaiting a decision on the $\$ 5,000$ he had requested for use in France in May following the Renault strike, Brown was advised by Lovestone to borrow half the amount from Jolis, who would then be refunded by the FTUC. However, Jolis was not able to meet this particular request, and though the FTUC finally approved the transfer, Brown had to wait two months to receive it. ${ }^{66}$ Flying by the seat of his pants, Brown sometimes borrowed money on his own account, from other people he knew as well as banks, without authorization but in expectation that sufficient money to allow repayment would eventually be approved in New York.

These financial transactions were often complex and opaque, but Brown liked to have a free hand in how to use the money and vigorously resisted attempts to pin him down to close accounting. Verbal understandings were as common as written agreements. He considered it an affront to be asked to supply a receipt. When Lovestone requested details of transactions Brown's response would often be along the lines that a full explanation would be given when next they met. Explaining a request for a credit in Swiss francs, he wrote, not altogether helpfully: "The biggest part of the Swiss franc deal will end by being a book keeping operation and dollars will be paid 
in New York. I cannot give you the details now but please rely on my judgement." ${ }^{\text {67 }}$ With Brown seeking reimbursement after negotiating one unauthorized loan, Lovestone insisted it was no use his saying that he could get a receipt: did he actually have one? - if not, he told him, "you are out of luck, brother." ${ }^{38}$

Brown was ever the hustler, and on another occasion seemed to be trying to get the FTUC to pay twice for one project they had approved. He claimed not to have received a tranche of funds that had actually reached him and so resubmitted the original request. Letters crossing in the post may have contributed to the confusion, but Lovestone struggled to pin him down, pointing out that Brown had actually signed a receipt for the travellers' cheques in question: "Are you asking for funds in addition to the above? Answer yes or no. Did the JLC turn over the proper equivalent for the $\$ 6,500$ to you?" 69 Yet Brown and Lovestone were two of a kind, streetwise operators seeing themselves as the advance scouts of an under-resourced army and having to do battle at times with their AFL paymasters almost as much as their communist enemy, and such sharp "misunderstandings" were soon smoothed over and "normal" operations resumed.

In April 1947, Brown lunched with Bill Bullitt, former US ambassador to Moscow, who was passing through Paris and whom Brown sensed was in Europe to assess the possibilities of underground activities in the East-West struggle. In a report to Lovestone, Brown claimed that Bullitt had been impressed with what the FTUC was doing. Whether or not there was any significance in this meeting, beginning two months later there was evidence of small sums of money of mysterious provenance beginning to show up in FTUC accounts. Brown tipped off Lovestone that he should expect shortly to receive an amount of $\$ 905$ that was to be added to their account for France. He promised an explanation when he was next in the United States. Lovestone responded cautiously that it wasn't clear how he would be able to handle the bookkeeping in relation to this. Six months later, Lovestone notified him that in addition to "the book of poems of 905 pages," he had recently received "from the same book collector another form of lyric poems-446 pages" and asked whether he should put it in "the committee reading room collection" or give it to "the JLC circulating library." Brown suggested that they be kept in the "general reading room" and advised Lovestone that he should expect to receive soon "an anthology just collected of about 2000 pages." ${ }^{\circ 0}$ The unusual sums of $\$ 905$ and $\$ 446$ sound rather like small change accruing from freelance work, possibly for the intelligence services. Trifling though the amounts were initially, over time they would become larger and more regular.

As 1947 drew to a close, Lovestone announced that the FTUC budget was "sub-zero" and would remain so until the annual fundraising dinner held for AFL union presidents before Christmas. A pitch was made by the leadership for more funding for the FTUC, but the result was disappointing. "It may be the Christmas 
season," noted Lovestone gloomily, "but so far there haven't been many bells ringing and not enough has been raised even to pay the musicians." Begging letters to some of the larger unions went unanswered, whereupon Dubinsky proposed that the FTUC seek a commercial bank loan to tide them over. He and Woll agreed to stand surety for a $\$ 25,000$ four-month loan from the Sterling National Bank. ${ }^{71}$

At this point, Lovestone seems to have concluded that there was no way funding sufficient for the FTUC's purpose would be forthcoming from the labour movement. He now turned to what he coyly referred to as "private individuals." ${ }^{22}$ The transformation in FTUC finances was not dramatic, but over the coming months new income streams were clearly beginning to be tapped. In April 1948, the FTUC's accounts were credited with a deposit of $\$ 10,000$ from one Randolph Aborn without further explanation. Coincidentally that month, CBS broadcaster David Schoenbrun announced that Irving Brown had access to a fund of $\$ 2$ million. ${ }^{73}$ This claim helped to feed the perception, encouraged by the AFL's own publicity since 1944, that their international work was backed by the full resources of US labour. Others began to quote similarly inflated figures. The sums cited were greatly exaggerated, but the source of financing was certainly no longer exclusively organized labour. The following month, Lovestone told Brown that he was arranging some money from "a mutual friend." It turned out to be the Rockefeller Foundation, which made a grant of $\$ 5,500$ to help with the travel expenses of a five-man team of German-Austrian union leaders brought over later in 1948 to the AFL's Cincinnati convention. The funding for this venture was kept strictly confidential. ${ }^{74}$ In October 1948 , just ahead of his annual return to the United States for the AFL convention, Brown was advised by Lovestone: "Before you leave for New York, a friend of mine will make a loan to you of at least 15 . Besides that, George Meany has wired directly to your French friends 5. That should relieve the pressure until you get here when more money will be sent."75 The source of this loan is obscure, but the evidence that the FTUC was becoming more dependent on secret outside funding was now unmistakable.

For some years Lovestone had been close to General William Donovan, former head of the OSS, whom he had met through EUR-X's Raymond Murphy. In autumn 1948, Donovan acted as intermediary between Lovestone and Winthrop Aldrich, former president of the Chase National, America's largest bank, and brother-in-law of John D. Rockefeller. At Aldrich's request, Donovan had shown him samples of the literature produced by the FTUC. In December, Donovan and Aldrich met at the latter's Manhattan apartment to discuss possible financing for the FTUC, following which the banker wrote encouragingly (with copies to Lovestone, Brown, and Ray Murphy) of his willingness to "talk to several people about the situation." A donation of $\$ 1,190.24$ was received from the Rockefeller Foundation that same month, but substantially larger sums soon began to flow Lovestone's way. ${ }^{76}$ 
Donovan had put in a word for Lovestone with Secretary of Defence James Forrestal, to whom Lovestone had first been introduced the previous year at a meeting of the National Security Council. ${ }^{77}$ In turn, Forrestal introduced him to Admiral Roscoe Hillenkoetter, the first director of the CIA, who would become a lasting friend. Reinforcing his social-business ties within the intelligence community, in 1948 Lovestone struck up a romantic relationship with a Boston socialite, Mrs. Louise "Pagie" Morris, who had worked for the OSS during the war and had had an affair with General Donovan. A year after meeting Lovestone, she went to work for the CIA's head of counter-intelligence, James Angleton, on a personal basis. She continued in that role throughout the dozen or so years during which she was one of Lovestone's "girl friends," operating at times under the cover of the FTUC and having use of its letterhead, although her activities were not directly focused on the labour movement. ${ }^{78}$

The year 1949 constitutes a dividing line in terms of source and size of FTUC funding. For most of the two preceding years the organization had struggled financially in pursuit of what was still a comparatively modest program. But by 1949 Frank Wisner, head of the State Department's agency for covert operations, the Office of Policy Coordination (OPC) - later to be merged into the CIA-had drawn Lovestone into the covert network. Recognizing organized labour's potential utility for his work, Wisner made overtures to Matt Woll, who duly referred him to Lovestone: "This will introduce Mr. Lovestone ... He is duly authorised to cooperate with you on behalf of our organization and to arrange for close contact and reciprocal assistance in all matters." A formal relationship between the OPC and the FTUC was discussed in December 1948 and agreed upon in early $1949 .{ }^{79}$ In January 1949, FTUC accounts show two donations of $\$ 35,000$ and $\$ 12,000$ received from Robert Pager and John E. Anderson, both-like Randolph Aborn, the mystery donor of April 1948-fictitious names. In the course of the year, eleven further donations for a total of $\$ 18$, ooo were received and credited to a variety of innocent-sounding fictitious characters.

Future payments tended to be for sums ranging between $\$ 2,000$ and $\$ 5,000$, always in convenient multiples of $\$ 1,000$ and recorded in the accounts as though gifts from generous individuals. Whereas in the past the FTUC had had to manage on the annual grant of $\$ 35,000$ from the AFL plus whatever smaller sums it could raise from individual unions, by 1950 income from intelligence sources was running at an annual rate of $\$ 170,000$, far exceeding the donations from sponsoring unions. ${ }^{80}$ But this is to run ahead of the story. 


\section{Combining Opposition to the WFTU and Support for the Marshall Plan}

Irving Brown's activities in France, Germany, and Greece were all aimed ultimately at undermining the WFTU and replacing it with a "free" trade union international. There was no shortage of tension within the WFTU and plenty of people who doubted its capacity to remain united. ${ }^{81}$ As the strains of the early Cold War began to increase pressures within the organization, Brown's role was to keep stirring the pot and cultivating those who were increasingly disaffected. The British TUC had made it a condition of continued support for the WFTU that the latter reach an accord with the international trade secretariats (ITSs) on their mutual relationship. Such agreement was increasingly unlikely; Brown was therefore pleased with the rapport he had established with J. H. (Jaap) Oldenbroek, the Dutch general secretary of the largest trade secretariat, the International Transport Workers' Federation (ITF) and a man whose knowledge of secret intelligence in the international labour field was at least as great as his own. Steeped in experience of the world of international labour, urbane, multilingual, and supremely self-assured, Oldenbroek had already emerged as de facto spokesman for the trade secretariats generally and, crucially, was strongly opposed to the WFTU plan to incorporate them as subsidiary bodies. As Oldenbroek set out to be obstructive in dealings with the WFTU, Brown was only too happy to position himself at his elbow, telling Lovestone: "Oldenbroek is really fighting a valiant battle. He's reached the point where, with our support we can lick the WFTU." ${ }^{2}$

Brown urged AFL unions to take out membership in their respective trade secretariat and suggested that he personally be allowed act as their representative in Europe. In the United States, he was a member of the machinists' union (IAM), and when the International Metalworkers' Federation (IMF) began to solicit the affiliation of American metalworkers' unions it was Brown who acted as the key intermediary. A soulmate of Oldenbroek in the campaign to resist WFTU control, IMF's general secretary Konrad Ilg calculated that if he had the machinists' 800,000 members on board by the time of the IMF congress of July 1947, he would have the votes that would ensure the IMF's independence of the WFTU. Thus prompted, Brown set out to persuade IAM president Harvey Brown: "The [Machinists] should seek affiliation and remain within the IMF as long as it remains outside the WFTU—-without stipulating it in so many words. Then, within the IMF, we can do the real job." Within a month the machinists were signed up to the IMF; Irving Brown represented them at the July congress and was immediately elected to the executive committee. ${ }^{{ }^{3}}$ From that vantage point he would later play a major role in representing the IMF among US unions and in shepherding the fledgling German IG Metall into membership in 1948, thereby blocking off further scope for the WFTU to influence this key union. He 
was also a delegate at the IMF's central committee meeting in March 1948 in Lugano, where the IMF finally decided on a complete break with the WFTU.

Just a few weeks after the IAM agreed to join the IMF, Brown's efforts were rewarded in another field when the American unions belonging to the Railway Labor Executives' Association, representing almost all the major railroad unions, took their 750,000 members into the ITF. It was made clear from the outset that opposition to the WFTU was the principal focus. As Lovestone insisted: "The American unions will not stay for one minute in any trade secretariat if ... [it] affiliates to the WFTU ... the moment [the ITSs] seek an American affiliation ... they are themselves through with the WFTU." ${ }^{4}$ Mirroring the role he was playing in the IMF, in April 1948 Brown represented the American railway unions at the ITF conference in Luxembourg, where the organization came out formally in favour of the Marshall Plan. Later in the year he acted as a courier for the ITF in carrying to Europe \$4,000 in currency (bills of $\$ 50$ and $\$ 100$ had been requested) on behalf of the Railway Labor Executives' Association, funds destined eventually for the Force ouvrière transport unions. ${ }^{85}$ Brown and Lovestone were also instrumental in helping Martin Bolle, general secretary of the public services trade secretariat, the International Federation of Unions of Employees in Public and Civil Services (later Public Services International), to secure the affiliation of the American state, county, and municipal employees' union led by Arnold Zander. ${ }^{86}$

It was the response to the American offer of Marshall aid in June 1947 that finally confirmed the division of Europe into two blocs. The Marshall Plan also caused a permanent rift in the WFTU, ideological differences and big power entanglement ending whatever capacity it previously had to pursue basic trade union interests. The final split was slow in coming: neither side wanted to appear responsible for the schism that seemed inevitable. Irving Brown worked tirelessly to draw together those supportive of Marshall aid in an embryonic free trade union centre, though his efforts to force the pace and assert AFL leadership of the process were much resented by potential allies. His aim was to secure agreement among European union leaders to convene an international trade union conference that would endorse the Marshall Plan in principle. He first floated the idea in a letter to Woll in July 1947. The Benelux unions were interested: Brown had already discussed the idea with Louis Major, the general secretary of the Fédération générale du travail belgique (FGTB). Lovestone arranged for the proposed conference to be discussed at the AFL convention in October, but in typical belligerent style he insisted that the AFL would need to take the initiative in convening it, rather than the Americans being invited "by some British lord or some Dutch baron." He regarded the TUC in particular as the reincarnation of "Perfidious Albion" and told Brown: "They are still to pay for some time the price of joint parenthood of the WFTU." 
The debate over the Marshall Plan injected a new urgency into the AFL's approach to international affairs, and it was decided to expand the distribution of FTUC literature overseas. A report by Brown to the AFL's international committee conjured up a dramatic picture of a beleaguered Europe, with the AFL-and himself in particular-in the vanguard of what was becoming a titanic struggle against the forces of darkness:

Our trade union programme and relationships have penetrated every country of Europe. We have become ... an army which is about 1,00o miles from its supply bases. Our challenge to the WFTU, to the Soviet Union, and to world Communism means that the AFL has become a world force in conflict with a world organization in every field affecting international ... labour.

He stressed that the AFL had become the focal point in the struggle for freedom: friends and enemies had elevated it to the top rung in this international struggle, as target for both attack and support. ${ }^{88}$ It was heady stuff, and press briefings conveyed the impression that the new free trade union organization the AFL aimed for was well on the way to becoming a reality. "History is on the side of the AFL," recorded the Times of London. To overcome British TUC reluctance to rush a split within the WFTU, Brown won AFL backing for an attempt by him to enlist support for the proposed Marshall Plan conference from Foreign Secretary Ernest Bevin, British trade unionism's elder statesman. Ahead of his visit to London to meet Bevin, he had tipped off friends in the British press, and the day before his arrival the Times carried an editorial commenting on the fact that the TUC might soon have to choose between the Marshall Plan and the WFTU. ${ }^{89}$

There was considerable chutzpah surrounding this mission to see the British foreign secretary, who was currently hosting the latest conference of the Council of Foreign Ministers of the United States, the USSR, the United Kingdom, France, and China, established at the Potsdam Conference to address the major problems of the postwar world. As with Brown's encounter with Secretary of State Byrnes twelve months earlier, it was an attempt at wheeler-dealing at the highest level, on this occasion hoping to sow a difference between the foreign secretary and the TUC of which Bevin had once been the most powerful figure. Wiser heads in the labour movement who were otherwise in sympathy with the AFL considered it ill judged. As Norwegian Labour Party leader Haakon Lie observed to an American friend: "Neither Dubinsky, Woll, Lovestone-nor Irv-know Europe well enough to act entirely correctly in this very serious manoeuvring. The time is not yet ripe for a split ... a hothead like Irv can be dangerous just now."90

With the help of Undersecretary of State Robert Lovett and representations by the US embassy in London, the meeting with Bevin was arranged. An obvious question 
arises as to why the British foreign secretary would find time to meet a field representative of the FTUC. No doubt Bevin was showing courtesy to AFL leaders such as David Dubinsky, whom he knew well and respected. But he had also become aware of Brown's capacity to make life difficult given his influential contacts in Washington, as his recent involvement in Greece had demonstrated. ${ }^{91}$

Early on in their London talks, Brown persuaded himself that the foreign secretary was in favour of the proposed Marshall Plan trade union conference, delighting at hearing "the Big Boy," as he called him, badmouthing the WFTU and those principally responsible for its creation. But before they parted, Bevin made it quite clear that he was not going to be played off against the TUC and that he fully agreed with its position of biding its time on the issue of splitting from the WFTU. Indeed, during this latest session of the Foreign Ministers' Conference, Bevin actually suggested to Secretary of State Marshall that the AFL be urged to slow down on the matter of the proposed Marshall Plan trade union conference..$^{22}$

That Brown's effort to create discord between Bevin and the TUC leadership failed is hardly surprising. But his report to Lovestone concluded on an upbeat note: "In spite of the delaying tactics of the British, I came away from England with the definite conviction that the die is cast and that because of Russian attacks the British labour movement will be forced into an aggressive anti-Communist fight." ${ }^{93} \mathrm{He}$ had also succeeded in drawing the British foreign secretary into the trade union discussion about the appropriate reaction to the Marshall Plan. As the British labour leader with the most credibility in the United States, it fell to Bevin to put the AFL leadership straight about TUC thinking. Following his meeting with Brown, the Foreign Office instructed the British labour counsellor in Washington to tell the AFL that the TUC would remain loyal to the WFTU until there was a break, after which it would be able to take part in the proposed conference. The difference with the AFL, he assured them, was simply over tactics. ${ }^{94}$ The encounter with Bevin certainly served to increase Brown's sense of his own importance. Meantime many Europeans concluded that the FTUC representative had shown brashness and lacked judgment.

For all Jay Lovestone's talk about the AFL taking the lead in convening the Marshall Plan trade union conference, and despite his personal opposition to it being held in London-"too foggy, literally and metaphorically" - there was no way the event would take place without the central involvement of the TUC. Indeed, when the Soviet trade unions persisted in dragging their feet on a discussion of Marshall aid within the WFTU, the TUC decided that it was now justified in acting independently outside the framework of the world federation. At this point, the TUC seized the initiative and, without consulting other centres, convened a European Recovery Plan Trade Union Conference in London for 9 March 1948. It also decided unilaterally 
that the conference must not be anti-WFTU, anti-communist, or anti-Soviet in tone but rather a constructive gathering to promote Marshall aid.

The TUC had "taken the play" away from the AFL over the calling of the conference, and the latter was understandably angered at being presented with a fait accompli it first learned about through the press. Matt Woll telephoned Brown and instructed him to seek a postponement of the conference, failing which the AFL would not participate. Brown was distraught at this turn of events, which threatened to undo much of what he had worked hard for. He cabled Dubinsky and requested that he be brought home for consultation; otherwise he planned to ask for his permanent recall. In emotional language, he wrote to Lovestone about the "bitterness and anger welling up" inside him and his "European world caving in."

Setting aside bruised American feelings, the main difference now between the AFL and the TUC was over the timing of the conference-whether it should be in early March as determined by the TUC or a few weeks later. Once again it was left to Ernest Bevin on behalf of the TUC to calm ruffled feathers, letting the AFL know that he accepted responsibility for having suggested to the TUC the date for the conference and cabling that the delay now sought by the AFL would play into the Russians' hands and allow them to pin the blame for the WFTU's internal difficulties on the TUC: "The Russians have already been making propaganda capital out of the allegations that the AFL is calling the tune. ... Any delay would be seized on and used as proof that European unions were completely under AFL domination."95

It was Lovestone who came up with a face-saving compromise. He understood that the Americans had been "bounced," but he convinced the AFL leadership to accept the TUC invitation provided it was announced as a preparatory meeting to be followed by a full conference at a later date. ${ }^{96}$

The crisis averted, Brown was rhapsodic in his expression of gratitude to his boss, the uncharacteristically gushing tone suggesting that he really had been near emotional breaking point: "It was with such joy that I read your last two letters ... I must tell you of my deepest appreciation and gratitude for your ability and wisdom ... your vision and statesmanship ... please take care of yourself . . I thank my lucky stars for having you around." ${ }^{7}$ These months of frustrating indecision and shortage of financial resources in the FTUC had evidently unsettled Brown, and there are clear signs that he was tempted by other opportunities. In late 1947 the aging Konrad Ilg was contemplating retirement as IMF general secretary and was lining up Brown as a possible successor. Brown was keen for Lovestone to know this, if only as a sign of his marketability. ${ }^{98}$ Whether Brown knew it or not (and the likelihood is that word would have reached him), he was also number three on a shortlist of possible candidates proposed by George Kennan, the director of Policy Planning in the State Department, for the post of director of the Office of Special Projects, in the State 
Department's Office of Policy Coordination, which was later incorporated into the CIA with responsibility for handling covert operations. ${ }^{99}$

More seriously, in April 1948 AFL President Green nominated Brown for one of the two top positions of labour advisor within the Marshall Plan administration. Brown was sorely tempted and even urged the AFL to press for the job to carry the diplomatic title of "Minister" to ensure recognition in US embassies throughout Europe. Savouring the possible benefits, he suggested to Lovestone: "A real, conscientious, intelligent trade unionist if given a top post and a high degree of freedom can make all the difference in the world ... [and become] a political weapon." ${ }^{100}$ But Woll, Dubinsky, and Lovestone were reluctant to see him caught up in the apparatus of government. Whether Brown then had second thoughts or Lovestone decided unilaterally to spike his ambitions is unclear, a week later Lovestone wrote to Dubinsky telling him that he had received a letter from Brown expressing appreciation that his name had been put forward for the Marshall Plan post but preferring not to give up his present work..$^{101}$ Interestingly, no such letter from Brown exists in the files.

The fleeting prospect of a high-ranking post in a government agency highlights an interesting side to Brown's makeup. He enjoyed working as a field "rep" - a fixer, an operator-often in a shadowy role. Contrasting himself with Henry Rutz, he once told Lovestone: "I don't like titles and never mention them." He was being truthful, but it was a little more complex than that, since he could be very hurt if he failed to receive the recognition he felt was his due. His brashness aside, Brown was an easy-to-meet, affable character who rubbed along well with people of all ranks. Throughout his career he was mostly content to be working behind the scenes. Yet it pleased him when others suggested that he was cut out for high office with an impressive title to match. He liked to be "in" with high-level contacts, was flattered when prominent figures took him into their confidence, and was always adept at name dropping.

\section{The ERP Trade Union Conference: Hopes for a New International}

The European Recovery Program (ERP) Trade Union Conference, called by the TUC and held in London in March 1948, would later be vested with mythic importance in the history of AFL international activity-allegedly the first tangible step in the creation of a free trade union international. At the time, Brown was more inclined to see it as a wasted opportunity. "English crowd is beginning to give me a pain in the neck ... jealous of maintaining all control of international operations in their own hands." Lovestone was in full agreement, resentful of recent TUC tactics so reminiscent of "Citrine's filthy manoeuvring" in the past. ${ }^{102}$ 
The London conference did serve to end the international isolation of the German trade unions and for the first time admitted to an international gathering Force ouvrière and the Italian Christian trade unionists, then about to bolt from the unified CGIL. However, with the TUC in firm control, the conference was careful to damp down any suggestion that it was the basis of a new "international." The declaration adopted refuted any policy of aligning West against East. The TUC was working to a different diplomatic agenda. Vincent Tewson, its general secretary since 1946, proved to be every bit as adept at bureaucratic manoeuvring as his predecessor, Citrine. His first close encounter with Irving Brown had been in Greece a year earlier when he first attempted to dissuade the American from becoming involved and then saw the TUC's plans for uniting the GSEE thwarted by the FTUC representative. The TUC was determined that any future replacement for the WFTU would not be forced through and dominated by the AFL. ${ }^{103}$

A follow-up conference-in AFL eyes the real conference-was held in July in London, allowing an opportunity for the AFL delegation to state how "flabbergasted" and "disappointed" they were at the lack of urgency in building a new international. An ERP Trade Union Advisory Committee (ERP-TUAC) had been established as the "continuing body," but it remained effectively under TUC control and was not amenable to American influence. "Our British friends," Lovestone wrote, "must in the future be careful that they do not continue the lousy traditions and practices of Sir Walter [Citrine]. The AFL will never again accept or allow the domination of the world trade union movement by any one group."104 Brown argued the need to strengthen the TUAC and broaden its role, but Tewson reacted sharply and told him that this was a European matter and that Americans needed to be more self-effacing. It was a clear sign of Tewson's growing irritation with Brown, increasingly seen now as overly assertive and meddlesome. ${ }^{105}$

Manoeuvring by the TUC, CIO, and the Soviet Union's AUCCTU continued throughout 1948 for command of the moral high ground ahead of the anticipated split in the increasingly lame-duck WFTU. With the end of the organization as a unified entity still some distance away, Brown was forced to curb his impatience. Then, at a press conference in Paris at the end of 1948, just weeks before the TUC, CIO, and Dutch Nederlands Verbond van Vakverenigingen (NVV) finally induced the split by walking out of the WFTU, Brown talked up the prospect of a new international being created "soon": it had, he said, been discussed by President Truman and the AFL leaders. He also boasted privately that the AFL could push ahead with plans for this regardless of the TUC.

However, his claim that he had the continental unions "in the palm of his hand" and would be able to "dictate policy in the new international" was dismissed by Walter Schevenels, then still hanging on as WFTU assistant general secretary while 
concurrently eying up his prospects for heading up a new free trade union international. Union leaders from Holland and Belgium-his home base-had assured Schevenels that Brown would never manage to split them from the TUC. The former IFTU general secretary was also convinced that leaders such as Jouhaux and Bothereau of Force ouvrière were too old and wise to be taken in by Brown. At bottom, he insisted, the AFL had nothing to offer Europe except money. And though it would elicit gratitude for its financial support, it would never buy these unions. ${ }^{106}$

Schevenels had a point; the assessment was prescient. There would be exceptions in the short run and situations where "money talked" - especially in France and Italy. But even there the beneficiaries often brought a cynical, calculating approach to their financial dealings with the Americans. In the short run, the process of extricating most Western trade union centres from the WFTU and securing agreement on the formation of a new international would be fraught-largely because of the AFL's determination to force the pace. And within four or five years Brown was to bemoan the fact that in Europe the AFL was running out of friends.

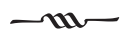

In just over three years Irving Brown had established a firm AFL presence in Europe. He was personally well known in labour circles, warmly welcomed by some, reviled as a "splitter" by others. In Germany he had successfully thrown the AFL's weight behind those opposed to the affiliation of the trade unions of the Western zones to the WFTU. His efforts in Greece had served to isolate the communist-led unions, while leaving the mainstream labour movement in the hands of a corrupt and largely ineffective leadership. France had been his major theatre of activity, where material assistance channelled to labour's non-communist wing ensured that when the CGT split in 1947 the breakaway Force ouvrière managed to survive, albeit that from the very outset a pattern of financial dependence on the AFL was established and would endure.

More generally, by binding the campaign for trade union acceptance of Marshall aid to the efforts of the international trade secretariats to retain their independence of the WFTU, Brown helped to exacerbate the tensions within the WFTU that had, from the earliest days, threatened its long-term survival. By the end of 1948, most national trade union centres in Europe backed the Marshall Plan to some degree and were becoming resigned to the fact that the WFTU's future was in grave doubt.

AFL finance had been invaluable in these various campaigns, though the sums involved were far more modest than sensational reports often maintained-the Free Trade Union Committee was never as well endowed as AFL leaders sometimes led 
the world to believe. It was on account of its dwindling resources that by 1948 , the federation began to rely heavily on funding from outside the labour movement, and especially from the newly created CIA. Such dependence would have an important bearing on the AFL's pattern of activities, and especially its relations with the CIO, in the years immediately ahead. 



\section{For Multilateralism or “Independent Activities”?}

Once the schism in the World Federation of Trade Unions had occurred, the way was open for the creation of a "free" trade union international. Yet the process of establishing the International Confederation of Free Trade Unions (ICFTU) in opposition to the WFTU was fraught, not least over differences of emphasis as to what the word "free" meant in the world of trade unionism. At a basic level it involved unions being free from state or political party domination; but was it compatible with any organic link to a political party or partnership role with the state? Would collective bargaining be its raison d'être at the expense of political engagement? And would Christian trade unions qualify as "free," if they were subject to heavy influence from the church hierarchy? Such matters were vigorously contested ahead of the establishment of the ICFTU and resolved by compromises broadly satisfactory to the AFL. Less easily resolved was the undeclared competition between the AFL and the British TUC for influence in the new organization. Tensions between the two dating back to 1945 and the foundation of the WFTU persisted and contributed to an AFL boycott of ICFTU meetings for several months when the new body was little more than two years old.

The ICFTU was launched with the Cold War at its height and amid a proliferation of areas of tension between "East" and "West." Keen to engage fully in the anti-communist struggle, the AFL found the ICFTU slow to respond, whether for lack of resources or out of a belief that trade unionism's legitimate area of activity was more circumscribed than envisaged by the AFL. In these circumstances, the FTUC was quickly drawn into what were termed "independent activities" - in effect an extension of the work it had engaged in when the AFL was free from outside ties from 1945 to 1950 . Its scope for engaging in such activity was greatly facilitated by its access to secret CIA funding that originated in 1948-49 and was at a peak in the 
eighteen months following the launch of the ICFTU. Much of the AFL's effort via the FTUC continued to focus on France, but Italy was increasingly important as a theatre of activity following the 1948 split in its formerly unified but communist-led trade union movement. Meanwhile, the situation in Finland called for urgent intervention between 1949 and 1951 to keep it from being fully absorbed into the Soviet sphere. The AFL's entanglement with the CIA also led to its embroilment in areas beyond the normal sphere of trade unionism-notably in the realm of anti-communist propaganda and in intelligence gathering through activities focused on Eastern Europe. Strains induced by such involvement would soon emerge, highlighting for both CIA and AFL the limitations of their partnership.

\section{The ICFTU's Short-Lived Honeymoon}

The long-anticipated split in the WFTU took place at a meeting of its executive board in Paris on 19 January 1949 when the TUC, CIO, and NVV walked out of the organization for good. The AFL's fear now was that the TUC and CIO, acting in unison, might launch a new international without consulting it. Although Irving Brown had no specific instructions, the cyclostyled bulletin he issued from his Brussels office pressed the case for a new body and aired his personal views on the form it should take. He was the source of recurring press reports that the AFL would be in the forefront in forming a rival to the WFTU. ${ }^{1}$ The CIO's European representative, Elmer Cope, until recently a WFTU assistant general secretary, observed that the AFL was making a serious error with the tone of its literature on Europe: "It rings too much of the confident American who has all the answers to the European workers' problems."

The tenor of Brown's pronouncements irritated the TUC, contributing to its decision to slow down any steps to establish a rival international. Prior to the walkout, its general secretary, Vincent Tewson, had deliberately turned down Brown's request for private talks, and he now declined an invitation to the AFL's executive council meeting in Bal Harbour, Florida. It didn't go down well with the AFL, but the TUC saw the need for a decent interval following the walkout before holding formal talks with friendly organizations over the way forward. It would allow time to explain the decision to quit the WFTU, countering any suggestion that the British had been cynically conspiring to undermine the organization, and also allowing time for other centres to follow suit and sever their links.

There was ill-tempered sparring between Brown and Tewson at an OEEC-TUAC meeting in Bern later that month, where the main item was the appointment of the TUAC's secretary. Walter Schevenels, the TUC's nominee, was the front-runner though he was still a member of the WFTU secretariat. This fact confirmed the AFL in its view that he was running with the hares and hunting with the hounds, 
altogether too much of a survivor to find favour in its uncomplicated, monochrome view of the world. This TUAC appointment would also be more significant than appeared on the surface, for the successful candidate would later have a springboard in bidding for the bigger job as general secretary of a future international-exactly what Schevenels aspired to be. In anticipation of this, Jay Lovestone had commissioned a dossier on Schevenels by a disaffected former assistant in the IFTU that called into question his moral character and credentials as a trade unionist. The document was forwarded for Brown's use at the TUAC meeting. ${ }^{3}$

At the sessions in Bern, Irving Brown fought tenaciously to block Schevenels's appointment. He protested that the Americans had not been consulted over his candidacy and forced an adjournment for six hours in order to telephone home for instructions. TUC representatives Tewson and Arthur Deakin complained that Brown was interfering in what was essentially a European matter and accused him of threatening unity and dictating to the Europeans. Only when it proved impossible to get through to Washington did Brown agree to abstain and so allow the appointment to be made unopposed. But when he received cabled instructions from Dubinsky and Woll the next morning he insisted that the AFL vote be recorded as "against."

As soon as TUAC business was complete, there was an informal session held in secret to consider strategy in the aftermath of the walkout from the WFTU. In line with TUC thinking, the meeting rejected any rushed move to create a new organization. Schevenels was given the task of drafting a report explaining the reason for the action of the British, Americans, and Dutch in the hope of winning over other centres who might question why they were being bounced into a split at this particular time and without wider consultation. It was agreed that a new international would need to include both the AFL and CIO, and to this end a liaison committee was established with seats for both American centres. However, Brown declined on principle to accept membership since it would mean sitting alongside the CIO. ${ }^{4}$

Irving Brown's obstructiveness put him in bad odour with many of the Europeans and reinforced a growing indignation that this relatively junior American representative should presume to throw his weight around on behalf of the AFL. Tewson's preference for someone other than Brown to speak for the AFL in the TUAC was barely concealed. In TUC circles there was muttering that they would "get rid of him" in due course. Rumours circulated that someone high in the State Department had called AFL president Bill Green and requested that he put a stop to Brown's activities in Europe, which were causing harm. ${ }^{5}$ In fact, British foreign secretary Ernest Bevin had written personally to David Dubinsky, diplomatically expressing confidence that "you will do all in your power to remove any obstacles 
which might arise in promoting a development so important to free trade unionists and free men everywhere." 6 Fearful that he might have overstepped the mark, Brown requested a recall to the United States for clearer instructions, only to be told that this was not possible. The AFL international affairs committee did, however, register its strong disapproval of Walter Schevenels. Lovestone was also on hand to offer Brown reassurance, telling him that the TUC would be in for a rude awakening if it felt it could treat him like a mere clerk.?

Pending any agreement leading toward the formation of a new international, Brown busied himself with arrangements to ensure AFL influence whatever the region or sphere of activity. In March at a general conference of the international trade secretariats held in Britain under Oldenbroek's chairmanship, Brown combined forces with the ITF general secretary in a move to establish a permanent organization of trade secretariats should the idea of a new international fail to materialize. The AFL had already helped launch a regional trade union organization for the Americas in 1948 in the shape of the Confederación interamericana de trabajadores, and now Brown also turned his attention to Asia, where an equivalent body was under consideration at a conference in Indore in May 1949 that he attended along with anti-communist trade union representatives from eight Asian countries. On this occasion, his judgment was that the proposed Inter-Asiatic Trade Union Federation was premature and that the establishment of an FTUC office in Calcutta would be more productive. The FTUC office in India opened by Richard Deverall in 1949 was an early beneficiary of secret funding from the OPC/CIA, with $\$ 10,000$ earmarked for it. ${ }^{8}$

When Tewson and Deakin travelled to the United States for a March-April meeting of the Anglo-American Council on Productivity, the atmosphere was calmer and it was possible for AFL and TUC leaders to have general talks about a new trade union international. The AFL leadership still refused to admit the CIO to the talks, but the TUC insisted that without the participation of both American centres there would be no new organization. The AFL took the opportunity to press the TUC on certain preconditions: agreement that a new international would have to be open to all free trade unions, not restricted to those of social democratic orientation; and that larger affiliates must not dominate the organization, thereby making it a weapon for big power politics. Mollified by the TUC's assurances, the AFL agreed to the TUC's calling a preparatory conference for Geneva in June 1949 to lay the groundwork for the new International Confederation of Free Trade Unions (ICFTU). 9 The AFL and CIO subsequently reached an understanding over their respective membership strengths - a formula that would recognize the numerical dominance of the AFL in any future international. On the basis of such an understanding, the AFL was prepared to accept equal representation with the $\mathrm{CIO}$ in the governing body of the ICFTU and to coordinate their approaches to policy and choice of leader. 
However, at the preparatory conference in Geneva it was evident that achieving agreement over a new international would still not be easy. In his keynote speech George Meany emphasized the importance of the ideological battle against communism, whereas Vincent Tewson and the CIO's Jim Carey insisted that it was necessary to be more than just anti-communist. It was a foretaste of a debate that would run through the international trade union movement over the coming thirty years. Attitudes to communism would determine precisely who were considered friends and enemies - who was acceptable and who was not.

For all that this preliminary conference seemed to symbolize the coming together of the British and Americans, privately the AFL criticized the way the TUC exercised control in deciding which centres to invite to Geneva, while the British would later mutter their resentment at the AFL's "bossing the show," forever colloquing on the fringes with other delegations. But as Lillie Brown commented, as a result of her husband's efforts there was hardly a delegation present in Geneva with whom the AFL had not had friendly contact, and naturally they looked to the AFL for leadership: "three years of hard work cannot be denied nor the fact that the AFL was politically on the right track since $1945 .{ }^{\prime \prime 0} \mathrm{~A}$ preparatory committee was set up to draft a constitution and to reconcile differences revealed in Geneva. It met as international tension in the Cold War reached a new peak: NATO had been formed four months earlier; the committee's initial session coincided with the USSR's first atom bomb test; and its final meeting was held just as Mao Tse-tung's communist forces swept the Nationalist leader Chiang Kai-shek from the Chinese mainland.

Chaired by the Belgian Paul Finet, with Vincent Tewson as secretary, the preparatory committee included Jaap Oldenbroek, Evert Kupers of the Dutch NVV, and Giulio Pastore of the recently formed anti-communist Italian centre, Libera confederazione generale italiana del lavoro (LCGIL), while Irving Brown and CIO international affairs director Mike Ross represented the two American centres. The meetings themselves became protracted bargaining sessions in which the AFL and TUC spokesmen dominated proceedings. They were frequently at odds and loath to yield on issues they claimed to be trade union "principles," but which were as much to do with securing a strategic advantage in the new international. Exchanges between Brown and Tewson had a personal edge-the two men rerunning under new headings old battles and, as it turned out, honing their weapons for confrontations yet to come."

Debate turned on such questions as how to define "free trade unionism": Did it include Christian as well as social democratic organizations? Argument was fierce over whether to incorporate into the constitution specific references to issues of the day such as "totalitarian aggression," "free labour versus slave labour," and the Atlantic Pact, as the AFL wanted, or to aim for a "positive" as distinct from "anti-communist" 
document as Tewson preferred. Should the Soviet bloc exiles of the ICFTUE be admitted as full members, thus strengthening the anti-communist thrust of the international, or would they be confined to the fringes? All were agreed that a regional structure for the international was a much-needed new departure, but there were sharp differences over whether it should be accompanied by extensive decentralization of power, as advocated by Brown, and whether a rapid move in this direction or the phased development preferred by the TUC was more appropriate. ${ }^{12}$ Even the location of the headquarters was bitterly contested, with Brown's preference for Paris and Tewson's proposal for London reflecting a tit-for-tat call and response. Both proposals were in conflict with the sentiment in the wider labour movement that the choice of general secretary and headquarters location should be decided in favour of the smaller affiliates.

In view of all this, it was some surprise that the AFL and TUC were able to agree on a candidate for ICFTU general secretary-J. H. Oldenbroek. As his close collaborator in the struggle against the WFTU, Brown was initially in his corner. Yet the preparatory committee sessions revealed signs of friction between the two men. Oldenbroek differed sharply with Brown on the approach to regional machinery, the admission of the Christian trade unions proposed by the AFL, and the relationship with the ICFTUE. For the first time, Brown began to express surprise at how "tradition bound" Oldenbroek was with his "lack of imagination on the new and vital problems" they faced, while Lovestone bridled at news of Oldenbroek's "intemperate and impudent remarks." At one stage in the committee proceedings Brown and Oldenbroek were literally shouting at each other in anger across the table. ${ }^{13}$ Disturbed by this new insight into Oldenbroek, Brown looked around for an alternative candidate but concluded that there was really no one of equal calibre. For its part, the TUC had seen in Oldenbroek's recent behaviour someone unafraid of acting independently of the Americans. In a move that surprised many, the TUC agreed to move his nomination, with the AFL seconding. ${ }^{14}$ It was an intriguing question as to whose candidate Oldenbroek really was. Certainly the fraught relationship between the AFL leadership and Oldenbroek, which later became such a crippling factor in ICFTU politics, traced its origin back to the differences that emerged in the preparatory committee.

Compromises reached in the preparatory committee were only tentative, and several issues were to be fought over again at the ICFTU founding congress in London in November 1949. Defending its corner to the last, the AFL arrived with five pages of proposed amendments to the very draft constitution Brown had helped write. The bruising battles of the London congress were keenly remembered years later as veterans of that experience engaged in successive rounds of trench warfare over the evolving shape of ICFTU policy. Four years on, Walter Reuther recalled 
how the prospects for the London congress even starting had been in doubt over AFL demands that the Christian trade unions be admitted. And Jay Lovestone subsequently remembered with bitterness how, at Vincent Tewson's insistence, his exclusion from the congress committee on resolutions had paved the way for Walter Reuther to foist on the ICFTU what Lovestone was keen to remind people was the original Leninist slogan of "Bread, Peace and Freedom.".15

Yet, on balance, Irving Brown was satisfied with the gains made in the struggle to shape the ICFTU constitution. The AFL could claim that it had shifted the emphasis from the social democratic focus of the IFTU's European veterans: implicitly the emphasis was more on freedom than economic equality. He had helped sharpen the formal anti-communist thrust and had strengthened the possibilities for regional activism by addressing the concerns of what would later come to be known as the "Third World." The TUC's control, he reported, was slipping away, slowly but inevitably, since the British lacked drive and "any conception or imagination for the job to be done." Nevertheless it was his personal view that unless the ICFTU proved to be a big improvement on what had gone before, the AFL should not for one minute consider giving up its independent activities. ${ }^{16}$

"Independent activity" had a special meaning for the AFL. It was rooted in a perception that only the Americans were capable of undertaking certain projects. It had much to do with the virulence of AFL opposition to communism; even among anti-communist trade unionists, their hostility to the secular religion spawned by the Russian revolution was pronounced. But it was also bound up with a sense that Americans now had a manifest $d u t y$ to lead, especially in view of the ravaged state of organized labour in much of postwar Europe. It was Lovestone's view that no other national labour movement had the requisite "drive" to qualify them for leadership. In the past, the British labour movement had claimed, and had been accorded, a leadership role among European trade unions, but the TUC was suspect in Lovestone's eyes because of its unprincipled role in 1945 in killing off the IFTU and launching the WFTU. And, of course, neither the British nor any other national trade union centre in the free world commanded material resources that matched those of the Americans and that were now required to build an international free trade union movement. While other centres might consider that the essence of trade union internationalism - the business of being "one's brother's keeper"-was best expressed in multilateral assistance programs, for key figures in the AFL an effective approach required a significant element of autonomy for national centres.

Thus, AFL independent activities-several of them highly sensitive and only recently launched with OPC-CIA financing-were hardly likely to be dropped, however well the ICFTU performed. Apart from continuing with its interests in France and Germany, the FTUC was now heavily involved in Italian and Finnish trade union 
affairs. In Asia and the Far East, the FTUC had recently stationed representatives in Formosa, Indonesia, and India. An immediate issue was the need to help extricate trade union centres from their continuing membership in the WFTU-calling for the AFL to focus on Australia and Israel, among other places. Over the next two years, Brown and the AFL would also attempt to establish a toehold behind the Iron Curtain with activities focused on Poland and Czechoslovakia and a window on East Germany via the Ostburo operated by the AFL-backed Unabhängige Gewerkschaft-Organization (UGO) in Berlin. Meanwhile, through its financial control of the Confederación interamericana de trabajadores, forerunner of the ICFTU's regional arm, Organización regional interamericana de trabajadores (ORIT), the AFL kept a close watch on Latin American labour movements. In this sphere AFL representative Serafino Romualdi reported directly to President Green-an operation in which Lovestone played no role. ${ }^{17}$

In its early months, there was a spirit of harmony among the ICFTU's affiliates and idealistic talk of national centres agreeing to combine their international effort through multilateral programs. Under this suggestion, the more powerful centresthe TUC, AFL, and CIO-were to assign their international specialists to work as assistant general secretaries under Oldenbroek. The latter proposed such a role for Irving Brown while on a visit to the AFL. Brown would have been personally content to wear the title if it also left him free to operate as a representative of the AFL, and he suggested that his superiors negotiate appropriate terms that would avoid his being bureaucratically "handcuffed." Meanwhile, he was happy to run errands on behalf of Oldenbroek in the shape of missions to Greece or Tunisia, where the national centre had recently disaffiliated from the WFTU. Lovestone fretted that some of this was a distraction, but Brown assured him: “The meetings to which I am going are not of great importance in themselves but provide me with excellent reasons or camouflage for other activities. . . . It is absolutely essential . . that I maintain personal and direct contact with the individuals, groups and organizations involved." ${ }^{18}$ On one mission to Greece to represent Oldenbroek at a GSEE congress, Brown was accompanied by Elmer Cope of the CIO, which had as yet no international program of its own and was content to channel its financial and manpower resources through the ICFTU. During the visit Cope became concerned over what he saw as Brown's uniquely close relationship with Oldenbroek and wrote home anxiously: "If we [the CIO] are not careful we will have to fight like hell to get a look in." ${ }^{19}$

Irving Brown used his influence with Oldenbroek to ensure as best he could that people approved by the AFL handled important aspects of ICFTU work. In his capacity as chairman of the ICFTU executive board's subcommittee on publicity, he brought Arnold Beichman onto the staff of the press department to pep up what the Americans bemoaned as the organization's unimaginative approach to publicity. 
Based in New York, Beichman would become a key Lovestone ally within the ICFTU and a purveyor of the Lovestoneite view of the world for decades to come through his columns in the Christian Science Monitor. ${ }^{20}$ At the United Nations, Lovestone had already ensured that the AFL would have decisive input into ICFTU activities by persuading Oldenbroek to take over wholesale the AFL's New York office and staff already established to monitor the UN under the direction of German socialist refugee Toni Sender. For the sake of convenience (because they were located in New York), Matthew Woll and David Dubinsky were named as the ICFTU's consultants to the United Nations Economic and Social Council. And when the UN established a Commission on Forced Labour, Lovestone asked Brown to lean on Oldenbroek to allow the AFL rather than the ICFTU to nominate to the trade union seat. ${ }^{21}$

Jaap Oldenbroek began his stewardship of the ICFTU amid a spirit of goodwill, promising that in opposition to the WFTU it would be a "fighting organization." 22 Yet with the general secretary's early efforts focused on assembling a staff and creating a headquarters machinery, Lovestone and Brown worried at the lack of external activity. Three months on from the founding congress Lovestone was concerned about the ICFTU's silence over tense cold-war confrontations that were shaping up in various parts of the world. It had yet to issue a public statement of any kind, and even a recent foreign ministers' conference in London had gone unremarked. ${ }^{23}$

In truth, Oldenbroek did not regard these as priorities for the trade union movement. It reflected a difference in attitude that assumed greater significance just months later when the Korean War broke out. Lovestone wanted the general secretary to convene an emergency committee and publicly declare support for the position taken by the United States at the UN. ${ }^{24}$ Brown lobbied Oldenbroek but got no further on this issue than he had in arguing the case for the ICFTU to take a firm stand against the communist-sponsored Stockholm Peace Campaign. Oldenbroek was certainly anti-communist, but he understood that there were limits to what trade unions could and should do about such matters. Brown, in contrast, responded to the Korean emergency by offering to work with "anyone else in Europe who is ready to start up a steady and consistent campaign of psychological warfare." His idea was to cover France with posters and leaflets to capitalize on what he optimistically described as "a new spirit in Western Europe, especially in France." But in view of the ICFTU's inaction he told George Meany: "Unless we can show more desire on the part of the ICFTU to play a role in these hot issues, the reason for [its] existence . . . becomes less and less." ${ }^{25}$ Lovestone shared his misgivings, which soon narrowed down to a specific complaint arising from the ICFTU's first tentative foray into Asia. It would lead to a permanent souring of relations between himself and Oldenbroek and would blight dealings between the AFL and the ICFTU secretariat for years to come. 


\section{The Souring of Relations with the ICFTU and the British TUC}

In summer 1950, the ICFTU dispatched a delegation on a mission to fifteen Asian countries to solicit affiliations and make preparations for the establishment of an Asian Regional Organization as required by the constitution. The secretary to the delegation was Jay Krane, a twenty-seven-year-old American of bookish appearance, latterly with the CIO, who had transferred only weeks earlier to the ICFTU payroll. To balance the CIO-AFL ticket on the delegation, Lovestone pressed Oldenbroek to name as co-secretary Richard (Dick) Deverall, who had been representing the FTUC in India since July 1949. By stationing him in India, the AFL had signalled its determination to be fully involved in the formation of an Asian regional trade union body whenever it took place. ${ }^{26}$

Unfortunately, Deverall had a controversial past, and having been advised to be wary of him Oldenbroek demurred over including him in the mission. Up to 1947, he had served on the staff of the military government in Japan under General Douglas MacArthur, Supreme Commander Allied Powers (SCAP). However, he was dismissed that year as a disruptive influence. In the highly politicized labour education division, he was regarded as obsessively anti-communist, having reported several of his colleagues to G2, the military intelligence division, as fellow travellers. In hiring Dick Deverall, Lovestone's original intention was to send him back to Japan as FTUC representative, but MacArthur barred him from entering the country, and he was then deployed in India instead. ${ }^{27}$

In the face of persistent lobbying by Lovestone, Oldenbroek finally agreed that Deverall could be part of the ICFTU mission while it was in India but would be required to cover his own expenses in other countries visited. In the event, General MacArthur again refused Deverall admittance when the mission reached Japan, blame for which was laid at the door of Val Burati, the acting chief of SCAP's labour division and a former CIO organizer with the textile workers. The ICFTU visit to Japan was timed to coincide with the launch of Sōhyō (the General Council of Trade Unions of Japan), the culmination of a long, painstaking effort by the Japanese non-communist unions, overseen by Burati, to unite in a single organization. From his Calcutta office, Deverall had been sniping at this initiative, suggesting that "communists" were behind it and writing to this effect to Japanese union leaders. Well aware of Deverall's campaigning and of the mischief he was capable of causing if permitted to travel to Tokyo at this critical juncture, it was Burati who had warned Oldenbroek against including him in the delegation to Japan..$^{28}$

Outraged over the way Deverall had been treated, and especially Oldenbroek's reluctance to allow him full participation in an exercise for which the AFL had been preparing for almost a year, Lovestone warned Oldenbroek: “This is inexplicable and 
unpardonable ... Rest assured we will follow this matter up further." He told Brown: "I do not intend to conduct with Oldenbroek any personal, friendly, unofficial correspondence in the future. I shall deal with him strictly on an official basis hereafter." Only twelve months earlier Oldenbroek had been a close ally in the campaign against the WFTU, but now he was persona non grata. Ominously, Lovestone observed: "I think our friend, for whose tenure of office we are responsible more than anyone else, is making a very bad mistake in his behaviour."29

In the months following the return of the Asia delegation, Oldenbroek tried to appease Lovestone with hints that Deverall could be offered assignments as a roving representative for the ICFTU in Asia, but no specific commitments were made. ${ }^{30}$ In this situation nothing could repair the damage to the personal relationship between Lovestone and the ICFTU general secretary. But more significant was the long-term damage to AFL-ICFTU relations that would flow from this.

Perversely, Lovestone also attached blame to Jay Krane for the blackballing of Deverall, dubbing him "the self-appointed dictator of the delegation." Virtually unknown within the labour movement, and one of the youngest and least experienced members of the ICFTU staff, Krane was suddenly elevated to the status of villain. The delegates to Asia returned, proposing that the ICFTU establish a regional headquarters and labour college in Singapore-a British colony. Deverall's reports to Lovestone had highlighted Krane's role in shaping this proposal. "It is suicidal idiocy," Lovestone wrote, "to have the Asian Labour College in Singapore as Professor Krane wants it-it can't be in any section of the British Empire." In his view the proposal amounted to a fatal blunder; the British colonial connection would provide free propaganda to Asian communists. "If Krane is to have anything to do with the Asian Labour College the AFL will not contribute a cent ... You know how much work we have put into cleaning out the Communist rats and WFTU in Japan. I don't propose to bring the rodents back in any shape or form." Krane was now a marked man. Yet over the next decade he would become Oldenbroek's most trusted staffer, and the consequence of this was to deepen Lovestone's suspicion of the entire ICFTU headquarters in Brussels. ${ }^{31}$

Lovestone's persistent backing for Deverall highlighted a curious lack of judgment. He sided with him in the face of a welter of trade union opinion and experience that considered Deverall to be psychologically unstable and a potential liability. Irving Brown was privately dismissive of Deverall for his poor judgment and "low grade," "phoney impressionistic" reports from the field. Over time, George Meany would likewise come to mistrust information emanating from Deverall, though for many years he still allowed Lovestone to protect his friend. ${ }^{32}$

The essential point about the Lovestone-Deverall relationship was that the latter's loyalty was unquestioned: as a witch-hunting anti-communist, he never once failed 
Lovestone. As for the collapse of Lovestone's personal relations with Oldenbroek, a central factor was Lovestone's realization that the ICFTU general secretary would not be dictated to. The Dutchman was a shrewd operator, ever inclined to bob and weave rather than stand up directly to Lovestone's bullying. Yet ultimately he was his own man, not biddable and, fatally for him in his relations with the Americans, inclined to look for compromise solutions in situations where Lovestone could see only black and white. ${ }^{33}$

The Deverall affair left Lovestone in little doubt of the need to conduct FTUC activities independently of the ICFTU. His personal view became the AFL view over the course of the next few months in a chain of developments that also saw a concurrent deterioration in the already febrile relations between the AFL and the British TUC. In 1950, the latter unveiled plans for assistance worth over $\$ 100,000$ to unions in India, Pakistan, and other British territories awaiting decolonization. The moral drawn by Lovestone was inescapable: if independent activities by the British were acceptable in Commonwealth countries, the same ought to apply where the AFL believed its special interests were at stake.

The TUC's plans were reported in an FTUC circular letter drafted by Lovestone and issued under Woll's name. In passing it commented in unflattering terms on the state of trade unionism in Britain, observing that despite its organizational strength the TUC had a "rather weak national leadership." 34 This line was consistent with the caustic criticisms of other national centres and their leaders that regularly flowed from Lovestone and Brown. Vincent Tewson now sought to put an end to the backbiting in a private letter to Meany. Aware that relations between Meany and Woll were not the best, and regarding Meany as the one more amenable to reason, he complained about the tone of the circulars emanating from Woll and suggested that it would be more helpful if such material were issued officially by the AFL, and through Meany's office rather than by the "ad hoc" FTUC. ${ }^{35}$ But whatever the current state of his relations with Woll, Meany was not prepared to act against his FTUC colleague, and in a personal letter to Tewson's home address suggested that "we just forget it for the time being." ${ }^{36}$ However, by the time the two men next met privately in November, TUC-AFL relations had taken a sharp turn for the worse, and when Tewson attempted to revive the issue of Lovestone's role in the FTUC he was immediately cut short. As Brown reported back to Lovestone: "Of course, George let him have it on that question, and the matter was settled." Tewson's relations with Meany were about to enter a disastrous downward spiral. ${ }^{37}$

The new issue that was acting adversely on relations between the British and the Americans was Tewson's decision to seek the presidency of the ICFTU in 1951. It flew in the face of the understanding that the powerful affiliates would not seek to dominate the ICFTU. At the 1951 congress in Milan where Tewson's election was 
secured, Irving Brown spoke out against his candidacy. From the AFL perspective, the ICFTU risked being run by Oldenbroek and Tewson working in tandem, just as the duo of Citrine and Schevenels had controlled the pre-war IFTU. Lovestone suggested that the two men had morphed into one composite character and took to referring to them disparagingly as "Sir Vincent Oldenbroek." ${ }^{8}$ The ICFTU had plans afoot for a \$750,000 Regional Activities Fund (RAF) to finance organizing work in the developing world, and the AFL feared that day-to-day control of the fund would devolve to a coterie of European-based union leaders around Tewson and Oldenbroek. With Irving Brown's reports linking the RAF to what he sensed was "a growing and inspired campaign in the British-controlled press" against the AFL's independent activities, the AFL wavered over whether to support the project. ${ }^{39}$

American disquiet over developments in the ICFTU and a rise in anti-British feeling were evident at the AFL's convention in September 1951. Attending as a distinguished guest, having just stepped down as ICFTU president and soon to become the first president of the European Coal and Steel Community, Belgian union leader Paul Finet was disturbed by the tone of the convention, in particular what he termed the "Catholic-Irish antipathy" toward the TUC and the British that he detected among people like George Meany. It concerned him that AFL leaders with little first-hand experience of Europe were being fed a distorted picture from Irving Brown and the "professional anti-communists of the FTUC." Finet was also unimpressed by some of the other overseas trade union guests present and concluded that the AFL was hoping they would serve as an echo chamber for its own policy line. He considered the AFL's independent operations misguided and likely to injure the ICFTU, and on returning to Europe warned his European trade union colleagues against becoming too dependent on American assistance. ${ }^{40}$

Animosity between George Meany, on the one hand, and Tewson and Oldenbroek, on the other, over policy issues that were dear to the American's heart marked the ICFTU executive board meeting in December 1951, chaired for the first time by the newly elected President Tewson. Meany was deeply at odds with the ICFTU over the acceptability of applications for affiliation from centres in Australia and Italy. Questioning Tewson's call when the votes were cast, Meany demanded a recount. When he further requested a roll call vote, the TUC's Arthur Deakin asked pointedly whether his purpose was to make a note of who should be cut off from AFL funding. ${ }^{41}$

More politically sensitive still was the issue of whether the ICFTU should condone affiliates having contacts with Yugoslavia's communist labour movement, recently expelled from the WFTU. Many within the ICFTU accepted the pragmatic case for maintaining a line of contact with the Yugoslav unions so as not to drive them back into the Soviet fold, and some affiliates would have welcomed their admission to the ICFTU. Oldenbroek argued that he was in no position to instruct affiliates on the nature of their 
relationship with the Yugoslavs. Other speakers tried to distinguish between Soviet and non-Soviet communism-in Meany's eyes an exercise in sophistry. In the event, a motion by Meany condemning the anti-democratic nature of the Yugoslav regime and demanding the creation of free trade unions in the country fell for the want of a seconder. Meany's failure to secure a vote on this motion would by no means be the end of the matter. His intervention was but the opening shot in a debate over the benefits and risks involved in establishing a dialogue with communist-led labour organizations that would run for the next thirty years. For the AFL, it was a red line that could not be crossed. As with the issue of WFTU membership in 1945, the AFL considered it a matter of fundamental principle to have nothing to do with communists.

It was not just the outcome of these debates but the way the meeting had been conducted that rankled with Meany. He questioned Tewson's consistency and impartiality as chairman and maintained that Oldenbroek had been less than honest in reporting the background to the applications for affiliation by the Australian Council of Trade Unions (ACTU) and the Unione italiana del lavoro (UIL), both of which Meany opposed. Sitting at Meany's elbow throughout the meeting, Irving Brown observed "a growing chasm between Oldenbroek, the British, the CIO on one side and ourselves." He recorded that, as chairman, Vincent Tewson had engaged in "bureaucratic manoeuvring" and "factional trickery," while Oldenbroek was said to have played "the British game." Lovestone put it more bluntly: Oldenbroek was "a semi-skilled liar." Meany's angry reaction was to announce that the AFL would now definitely not contribute to the RAF. Brown correctly anticipated a year of "tough sledding" ahead. ${ }^{42}$

So unhappy with the ICFTU was Meany that he now considered diverting the sum the AFL was expected to contribute to the RAF to additional independent activities by the FTUC. That was fine by Brown; he was convinced that the AFL was likely to do a better job than the ICFTU. Indeed, in taking off the gloves to the ICFTU, Meany was inclined to go further in demonstrating his dissatisfaction. Lovestone was instructed to prepare a report for the AFL executive council highlighting the "dishonourable" and "high-handed" treatment meted out by Tewson and Oldenbroek. It would signal that the AFL intended "a full and frontal fight," while applauding Meany's "energetic efforts." ${ }^{43}$ The reaction of some executive councillors was to favour a complete break with the ICFTU, though most drew back from "going into isolation now." Lovestone was called on to draft a list of specific AFL complaints-a "bill of particulars"-for circulation among ICFTU affiliates. In the meantime the AFL announced that it would not attend ICFTU meetings. A boycott was now on: it was rather more than Lovestone and Brown had bargained for.

There was a clear danger of the war of words spinning out of control. Lovestone had no shortage of ammunition for his charge sheet; he had spent the previous two years logging complaints about almost every facet of the ICFTU. Indeed, through 
their negative reports on the ICFTU and the vilification of its officials, he and Brown bore much responsibility for the disenchantment among AFL leaders that led to the boycott. The ICFTU, it was frequently suggested, was staffed by-even dominated by-incompetents who lacked drive. The AFL self-image of being more dynamic than other centres, and especially the European affiliates, was a recurrent theme. Lovestone would contrast the "speed and energy" displayed by the FTUC with the failure of others to work with "the same tempo, the same zeal, the same dynamic faith." In particular Brown would berate the tendency of the cautious TUC to avoid anything other than "the policy of wait-and-see or, more precisely, do nothing." Linked to this was the further political criticism that European trade union leaders who proclaimed their socialism often tended to be "prisoners of past clichés," displaying a "pseudo radicalism," which in practice led to "appeasement." Of course, it wasn't organizational vigour in a general sense that the FTUC wanted so much as total, unrelenting commitment to fighting communism. ${ }^{44}$ Such hostile reportage had a cumulative effect that inevitably led AFL executive councillors with limited first-hand experience of the international field to wonder what the AFL was doing belonging to such a body. Less committed to the boycott than his fellow FTUC leaders, David Dubinsky wanted Lovestone to limit the charge sheet to just a few items of disagreement, but Meany and Woll were pushing in the opposite direction. ${ }^{45}$

The irony was that both Irving Brown and Jay Lovestone were against the boycott tactic. They were firm believers in the need to be part of the ICFTU, even if such engagement involved an ongoing war of attrition with its leading officials-"keeping up the strife," in Lovestone's cynical expression. Brown always felt that top AFL leaders should be devoting more time and effort to ICFTU business, not merely at biennial congresses but through systematic participation in committee work and with an American presence in the secretariat. Even if the organization was of limited effectiveness, membership had clear advantages. In Europe, Brown did whatever he had to do-mostly for the labour movement; sometimes for the CIA, quite often combining assignments-and if it was helpful to operate under the ICFTU label, so much the better. However, the notion of the ICFTU providing respectable "cover" for independent activities was not something that the generality of AFL leaders were likely to understand or sympathize with. In that sense, Brown and Lovestone were victims of their own confrontational style of operating. They found themselves riding a tiger, and it wasn't clear where it would take them. Boycotting the ICFTU prevented Brown from attending a conference on labour and the North Atlantic Alliance, which was central to AFL concerns. He complained that the tactic was leading them nowhere. Lovestone agreed: without the AFL's presence the event risked becoming "a Bevanite concoction." But Meany insisted on maintaining the boycott. ${ }^{46}$ 
Irving Brown was disconsolate over these developments. In dealing with Europeans he was on the front line, forced to bear the odium of an AFL policy he personally opposed. And when he discovered that in his dealings with European union leaders the AFL's ILO representative, Phil Delaney, was distancing himself from AFL policy, Brown gave vent to his resentment, telling Lovestone, "While I am ready to carry out this [boycott] decision, although I think it is wrong, I think the same loyalty should be demonstrated by other reps of the AFL," and "I don't treasure the idea of being the only SOB representing the AFL in Europe." 47

It was an indication of Brown's unsettled state of mind that when the post of labour advisor to the US military aid program in Turkey was established, he wrote to Bill Green and expressed an interest in being appointed. How serious was his interest is unclear; in all probability he was simply signalling to his superiors his sense of disillusion over the latest phase of AFL international policy. ${ }^{48}$

Lovestone's "bill of particulars" amounted to a motley collection-fourteen suggestions ranging from matters of high politics, including a call for more vigorous support for national independence movements in the Near and Middle East, to petty administrative measures such as the need to reduce the length of written reports to the executive board. It was hardly a charge sheet to justify the breakup of the ICFTU, yet the AFL was clearly determined to force the issue by absenting itself from an important meeting of the general council in July $1952.4^{49}$ Behind the specifics listed by Lovestone was a genuine, gnawing resentment within the AFL that Tewson and Oldenbroek were looking to run the ICFTU as if it were the pre-war International Federation of Trade Unions in which the AFL was merely welcomed for its dues payments..$^{50}$

Six months into the boycott, and with no sign of the AFL backing down, it was clear that the standoff could only be resolved by Tewson and Oldenbroek agreeing to travel to Washington and eating humble pie in a meeting with the AFL international affairs committee. It was a tense occasion; what Tewson and Oldenbroek had to say cut little ice. A resentful Meany rehearsed old complaints of how, in the months prior to the ICFTU's formation in 1949, the TUC was determined to remain in overall control; that pattern was now being repeated. However, the highly respected leader of the railroad clerks, George Harrison, rescued the session by getting the visitors to recognize that the AFL needed to feel like "partners not appendages" and that the British "consciously or unconsciously" had dominated the show. It still wasn't enough for the AFL to call off its boycott straight away, but a press release was issued stating that the air had been cleared and agreement reached on holding the next ICFTU executive board meeting in New York, where the AFL would seek a discussion of its bill of particulars. ${ }^{51}$ 


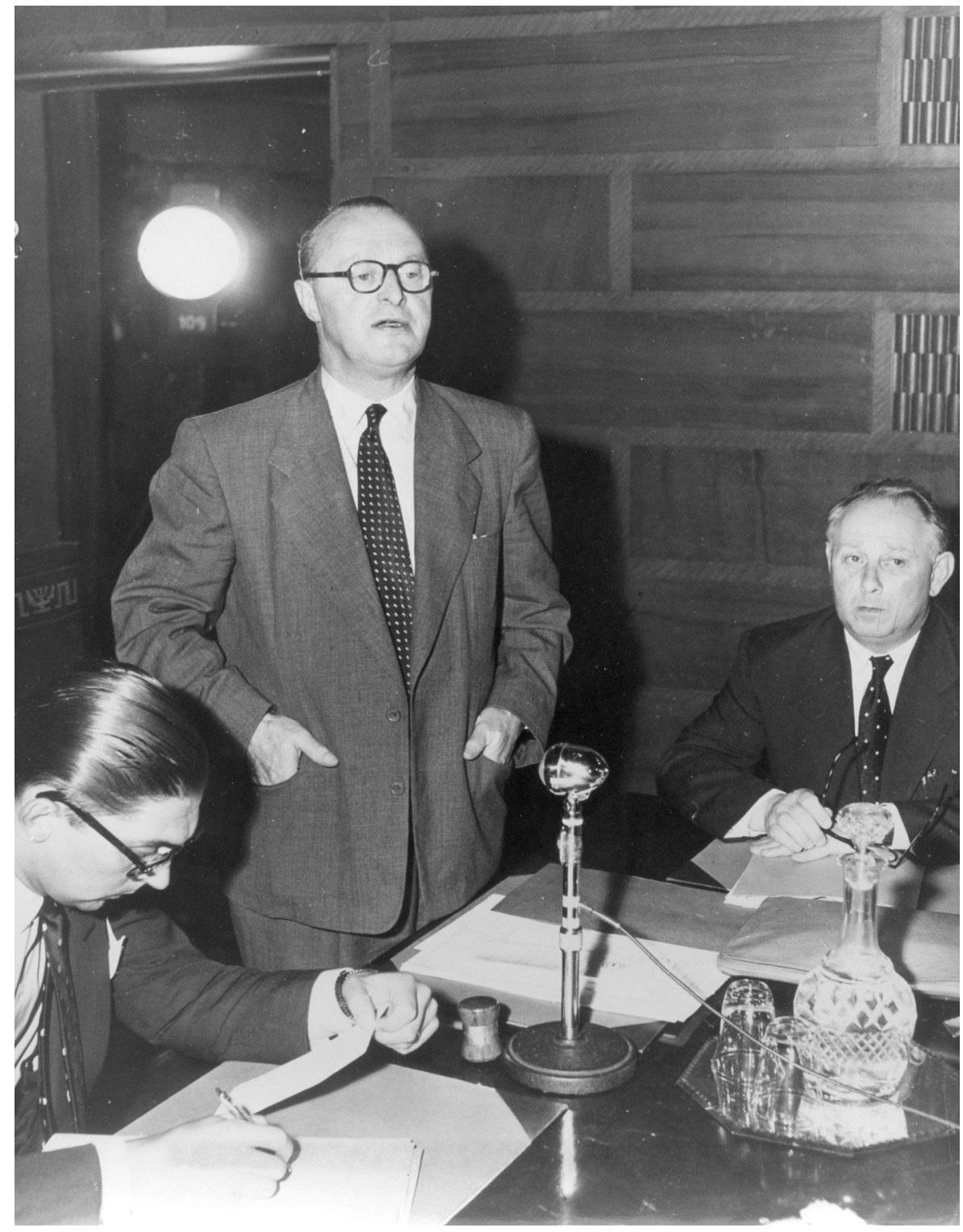

Figure 2. Vincent Tewson, general secretary of the TUC, 1946-60, delivering his opening address at the ICFTU's Stockholm congress in July 1953, toward the end of his two-year term as ICFTU president. Seated to his rear is Jaap Oldenbroek, general secretary of the ICFTU, 1949-60. The AFL's strained relations with the ICFTU were prompted in part by what it saw as the tendency of these two men to "boss the show." Courtesy of the Walter P. Reuther Library, Archives of Labor and Urban Affairs, Wayne State University. 
Interestingly, given their recent concern over the AFL's wavering commitment to the ICFTU, Lovestone and Brown were all for hanging tough at the board meeting in New York-a prospect that Lovestone relished as the looming "battle of Murray Hill." ${ }_{52}$ The main task for him was to pre-empt any ICFTU criticism of independent AFL activities by going on the offensive. Lovestone savoured the prospect of Oldenbroek "hitting the roof" when he learned of the AFL's recent decision to appoint a field representative in Turkey. Winding Meany up on an issue calculated to arouse his ire, Brown reminded him that what divided the Europeans from the Americans was the Europeans' attachment to socialism and their criticism of the Americans for being anti-socialist. And yet these same self-proclaimed European socialists were weak union leaders, wholly lacking in dynamism. He portrayed the ICFTU headquarters staff as exuding an anti-American bias, suggesting to Meany the need for careful scrutiny of their effectiveness. Warming to a familiar theme, he wrote Lovestone: "Some day when I am no longer stationed in Europe, I shall have the freedom to say precisely what I think of the European Labour movement which will be extremely uncomplimentary."53

In the event, the New York board meeting avoided the sharp confrontation that Lovestone and Brown anticipated and seemed to want. A banquet and a Broadway show for the visitors lightened the atmosphere. An emollient Meany suggested that the bill of particulars amounted to no more than constructive criticism, enabling its specific points to be fed into the ICFTU committee system for eventual resolution in anodyne formulations that allowed all sides to save face. For the time being passions were spent. ${ }^{54}$ It helped greatly that Tewson's two-year term as ICFTU president was drawing to a close and he was about to be succeeded by someone far more acceptable to the AFL. Whether Oldenbroek would learn the lesson of the boycott and knuckle under to the AFL remained to be seen. What the recent standoff hadn't done and couldn't do was eliminate the differences that existed over the appropriate way to address the issue of communism and its challenge to the labour movement. At root, this was what lay behind the AFL's gesture of protest in the 1952 boycott.

\section{Independent Activities: Funding from Intelligence Sources}

The activities that the AFL was determined to conduct independently of the ICFTU had at their heart the battle against communism rather more than for trade unionism, although AFL leaders would insist that the two were inextricably linked. Those for which Irving Brown was primarily responsible took place in France, Germany, Finland, and Italy. Farther afield, Lovestone also handled the financing of operations in India, Japan, Indonesia, and Formosa, where FTUC control was necessarily more devolved. Former Lovestoneite Willard Etter directed an operation in Formosa with 
intelligence funding through which "trade unionists" of the Free China Labor League (FCLL) with military training sought to infiltrate the Chinese mainland as part of Chiang Kai-shek's counteroffensive against Mao's communist regime. ${ }^{55}$ Another long-standing disciple of Lovestone, Harry Goldberg, represented the FTUC in Indonesia, where an intelligence-funded program aimed to undermine the main labour centre SOBSI, an important WFTU affiliate. And Dick Deverall, who had bided his time as FTUC representative in India while barred by the US military government from entering Japan, returned there when Japan became fully self-governing, and directed the FTUC's second largest program with expenditures totalling $\$ 66,900$ between 1952 and $1956 . .^{.6}$

Once the ICFTU was established at the end of 1949, it was important to attract into membership national centres that were still resisting disaffiliation from the WFTU. Histadrut in Israel and the Australian Council of Trade Unions (ACTU) were centres the AFL considered capable of being won over with financial help. In Israel the AFL campaign focused on Histadrut's anti-communist Mapai wing. In spring 1950, Lovestone noted: "The Kosher business situation has taken on a rather urgent character. If we were able to give them a decent push within the next couple of months, things will be much better." A first payment to Mapai of $\$ 3,000$ was duly made in May 1950, and by the end of the year $\$ 13,500$ had been passed to it, by which time the Histadrut executive committee had resolved to leave the WFTU. Further payments totalling $\$ 6,000$ were contributed the following year to consolidate the anti-WFTU position adopted..$^{57}$

In Australia, faced with an ACTU leadership determined to retain membership in the WFTU, the FTUC set out to help the centre's anti-communist wing via the office of Herbert Weiner, the US labour attaché. Weiner transferred \$10,000 in 1950 and a further $\$ 5,000$ the following year to the anti-communist faction in ACTU and the pro-American Australian Workers' Union (AWU), whose general secretary, Tom Dougherty, was invited to the AFL's 1950 convention. ${ }^{8}$ Over the next twelve months, ACTU withdrew from the WFTU and both Australian centres competed for affiliation to the ICFTU at the executive board meeting in December 1951, where Meany's ire was aroused over Oldenbroek's preference for the larger ACTU over the AWU. More strategically important in the global struggle with communism were the situations in Finland, France, and Italy-all part of Irving Brown's beat-where finance from intelligence sources was of critical importance. How were these transactions effected?

Secret funding of FTUC programs by the OPC-CIA began in 1949. From then until 1958, when FTUC operations were discontinued, it received \$464,167 directly from the OPC-CIA, with individual donations earmarked for specific projects. In addition, Irving Brown also had a separate budget of indeterminate size that was 
made available directly to him rather than through the FTUC and was not recorded in the committee's accounts. Overseen by Paul Birdsall, who operated under the cover of military attaché in the US embassy in Paris, Brown's paymaster was John Philipsborn, the embassy's assistant labour attaché. It was referred to as Brown's "French account," though it was not restricted to activities in France..$^{59}$

Under this arrangement, with transactions typically agreed on by word of mouth, little was committed to writing. In their correspondence with one another, Brown and Lovestone were careful to use coded language. Lovestone dealt directly with intelligence officials in Washington, having periodic meetings with OPC director Frank Wisner- "my luncheon friend" as he referred to him-or later with "Squinty," his sobriquet for the CIA's deputy director, Allen Dulles. Birdsall was "the birdman." Much of the interaction was ad hoc; problems were apt to arise over delayed payments for which simple bureaucratic foot dragging or political infighting within the faction-riven intelligence community appeared to be responsible. The two partners were mutually mistrustful. the OPC-CIA was never entirely happy with Lovestone's accounting for sums received and resorted to opening FTUC mail to discover more about the projects it was financing. ${ }^{60}$ Lovestone resented its "book-keeping psychology" and "laundry methods" and complied with requests for details in minimal fashion. Such tensions undermined the partnership and at times brought it close to breaking point. Lovestone developed a deep antipathy toward the CIA, and especially its many staff members drawn from privileged Ivy League backgrounds. To some they were the "Park Avenue Cowboys," but Lovestone simply dismissed them as "Fizz Kids" or "Fizzers," inhabitants of "Fizzland." They had little understanding of the labour movement, and he doubted their capacity to maintain confidentiality about FTUC operations-but he badly needed their money.

For the AFL leadership the sudden availability of this generous outside funding also posed problems in maintaining control of operations and expenditures. Limited bureaucratic regulation and informality of approach meant a recurrent risk of things "getting out of hand," especially given that Brown had his own source of financing in Paris. Right at the outset his cryptic request for Lovestone to deliver urgently "10 volumes" in cash in the name of "Marron" (i.e., Brown) to a Forrest Hills address for immediate transmission caused concern in the FTUC. ${ }^{61}$ After consulting Woll, Lovestone cabled back: "You asked about the 10 volumes of O. Henry. I couldn't handle the circulation or distribution or reallocation of books without Committee authorization. All I am allowed is to handle little pamphlets." He added later:

Strictly between us . . the Committee, particularly DD, have expressed anxieties regarding various volumes of literature you have gotten from other book 
shops and which you have been despatching. ... The Committee would like to have full knowledge in a basic sense how each volume is distributed and the reaction to its contents.

Lovestone made it clear that he was referring to Brown's "French account": "DD and Matt have in mind particularly the volumes you have picked up at a bargain rate from the settlement of Frank's [i.e., Wisner's] estate." ${ }^{2}$

Often it was a case of needing to contain Brown's headstrong instincts and penchant for wheeler-dealing. Meany was taking closer control of international affairs, and in spring 1950 Brown was transferred to the AFL's payroll, where the secretary-treasurer would have a closer supervisory role. Initially Brown bridled under the new regime, which he considered too cautious, telling Lovestone on one occasion:

I do not feel free any more to accept commitments ... without the backing and knowledge of the AFL leaders... There are many activities which involve not only operations in Western Europe but behind the Iron Curtain ... [concerning] our complete operations and relations with our friends in Washington [i.e., the CIA]. I am now being pressed on a number of questions ... but feel I cannot commit myself as a representative of the AFL without complete understanding and agreement among ourselves. This cannot be handled by correspondence. ${ }^{63}$

Yet, in practice, Brown managed to retain considerable freedom. In later years, following much first-hand experience of his European representative, Meany would make light of this, joking that "nobody controls Irving Brown."

Concurrently Brown faced pressure from his CIA handler, Birdsall, over the FTUC's failure to release funds already authorized, asking Lovestone:

What's going on the financial front? I just cannot understand why we are sitting on the ten volumes. I have received an additional ten from Washington but cannot utilize them in their present condition. The donor [Birdsall] was extremely concerned and somewhat annoyed ... when I told him. ... He rose up in all the dignity of his military rank to suggest that I immediately . . . let him know what was happening. ${ }^{64}$

The inability of the CIA to exercise control over Lovestone and Brown was, in fact, the reason the initial financial arrangement with the FTUC began to be revised in 1951 and was eventually phased out by 1958 . 


\section{Finland, 1949-51}

Precariously situated and sharing a long border with the USSR, Finland was permanently at risk of being absorbed into the Soviet sphere of influence, its social democratic government only tolerated so long as it avoided giving offence to Moscow. Within the Finnish national trade union centre-Suomen Ammattiliittojen Keskusjärjestö (SAK), which retained its WFTU affiliation-communists, powerfully backed by the Soviets, comprised 40 percent of the membership and were engaged in an ongoing struggle with social democrats for control. It was this contest that the FTUC set out to influence.

Brown first visited the country in October 1949 in the aftermath of communist-led strikes that had failed in their effort to destabilize the government and force acceptance of rule by a united workers' party. Basing himself in the American legation in Helsinki, he attended a crucial congress of the woodworkers union where the socialists captured control. It was a major blow to the WFTU, whose Building Trades Department was heavily dependent on its Finnish affiliate and also had its headquarters in Helsinki. The building department's continued presence in the city was now problematical. Led by Väinö Leskinen, the social democrats requested $\$ 500,000$ from Brown to enable more effective non-communist organization within the unions. The aim was to engage up to a hundred organizers and so match the large number of communist organizers flooding in. "Perhaps the amount is too high," admitted Brown, "but I think we ought to recommend to our [OPC] friends some kind of aid programme for what I consider to be one of the finest groups of men in the European labour movement.... Leskinen is tops ... tough, intelligent and the organizational brain of the movement." For good measure, he reported that within the unions there were 200,000 men who were ready to bear arms and "take to the woods" in partisan warfare against any Soviet military threat. ${ }^{65}$

In the spring of 1950, while on a visit to the United States, SAK secretary Olavi Lindblom presented a revised request for $\$ 200,000$ in aid. This time the stated object was to help pay for training of non-communist leaders at the national and local level and also the cost of publishing a journal and pamphlet material. The OPC agreed to help, and a month later the SAK executive committee resolved to stop paying their fees to the WFTU as a first step toward disaffiliation. ${ }^{66}$ Financial contributions destined for use by the Finns now began to show up in FTUC accounts: \$5,500 in September, $\$ 10,000$ in November, and a similar sum the following month. The June 1951 SAK congress would need to ratify the decision to disaffiliate from the WFTU, and with this in prospect a fierce battle raged over the selection of delegates.

Bidding to match the large sums poured in on the communist side, Lovestone opened a special bank account in Rome in the name of "Mr. Joseph Brown," and by 
the spring of 1951 the CIA had passed " 37,500 pages" to the FTUC for use of "the northern lumber men." Brown was instructed to meet up with Leskinen outside Finland and "go over the whole matter of banking arrangements." Meanwhile, a further " 15 books" were earmarked for the Rome account for use ahead of the crucial SAK congress. ${ }^{67}$ However, having been urged by Lovestone to hurry with the transfer of the $\$ 15,000$, Brown discovered in Rome that the money had not in fact been deposited, and duly complained to the FTUC secretary. It provoked one of their periodic exchanges in which Lovestone hinted at suspicion of the way Brown was using the funds. He told Brown that he would be happy to accommodate him "provided any benefits thereof will affect and accrue only to the interests of the northern lumber merchants." Indignantly, Brown demanded: "To whose benefit do you think they would be going. ... What do you expect of me on our northern transaction?"68

Reassured that the Finns would indeed be the beneficiaries, Lovestone promised to arrange the transfer ahead of the SAK congress: "We have given the lumber merchants the green light that they can spend up to fifteen volumes in preparation for their salesmen and stockholders' gathering." There was a possibility that he could obtain more, but he cautioned Brown: "I have no confidence in the promises of the Fizzers." ${ }^{9}$ Two months later a further $\$ 12,500$ was credited to the FTUC account for Finnish activities, and Lovestone told Brown: "I am definitely going into the northern woods. They have been apprised of available resources and have contracted and paid for merchandise on that basis." As distinguished guests at the SAK congress, Irving Brown and Leonid Solovjev, secretary of the Soviet AUCCTU, exchanged polemics in their fraternal addresses. The Russian later stormed out when delegates voted 3:1 to withdraw from the WFTU and to adopt a cautious policy of neutrality between it and the ICFTU. $7^{\circ}$ The FTUC campaign had been effective.

Overall some \$27,500 passed through the FTUC books in 1951 destined for Finland. By the end of that year a total of $\$ 52,500$ had been made available to the Finnish social democrats. The FTUC had broadly achieved its objective in helping consolidate the non-communist ascendancy in SAK and reducing Western trade union support for the WFTU. There would be further American funding of the Finnish labour movement, but never again exclusively through the FTUC. The CIA had revised its approach; henceforth the $\mathrm{CIO}$ would also be involved in intelligence-backed initiatives. It was a matter of much concern for the AFL leadership.

\section{France: In Harness with Ferri-Pisani}

In France, Brown's primary focus was always the strengthening of Force ouvrière, and by early 1949, $300 \mathrm{FO}$ activists were benefiting from the monthly food parcel program first begun in Germany and Greece. He reported how even Force ouvrière 
general secretary Jouhaux now seemed to accept that he no longer "controlled" the organization; over dinner with Jouhaux the Frenchman joked weakly: "the word is going around that Force Ouvrière is in the hands of Irving Brown." They had both laughed at this.

The training of organizers featured prominently in Brown's project. Coal miners were a key target, and in the immediate aftermath of the collapsed strike of December 1948 Brown organized a training school for forty activists, the first of many such initiatives. Mining was a relative success story, but elsewhere Force ouvrière generally failed to attract into its ranks former CGT members who were now drifting away disillusioned at the failure of successive insurrectionary strikes. The beneficiaries were more often than not new independent unions that now claimed 150,000 members. Hoping to build bridges between FO and the independent unions in metalworking, Brown arranged training schools and food parcels for a select fifty of the latter's leaders. However, Force ouvrière was, and would remain, essentially an organization of white-collar workers and civil service functionaries, with a feeble presence in private sector industries. On the railways, the centre was actually losing members to the CGT, and by 1950-51 Brown was engaged in a desperate attempt to reverse the trend by extending the training program, planning in 1951 to put as many as 750 local organizers through courses. Yet even more was needed. He saw the communist party transforming itself into a fighting cadre of partisans bent on destroying the economy. Faced with this, he believed it was insufficient to rely on traditional means of organization building. Schooled in Leninism, he was convinced of the need for a disciplined counterforce capable of preventing the communists' quasi-military apparatus from commanding the streets. This would be his new emphasis, but it would only be possible as a result of the new OPC-CIA funding: Force ouvrière itself, he conceded, would not be able to afford this in "a million years." 71

He focused his main effort on FO's dockers' union, whose leader was forty-nine-year-old Pierre Ferri-Pisani, for many years a prominent figure among socialists and trade unionists in Marseille. ${ }^{72}$ Ferri-Pisani's deployment of Corsican toughs of the Guerini crime family to protect his members from CGT violence on the Marseille waterfront in the early months of the Marshall Plan is endlessly reprised in accounts of the period - a famous or infamous episode depending on the narratorthough most accounts are devoid of dates and details. For historian Alexander Werth it was part of the "mythology and martyrology" of French labour history. ${ }^{73}$ It is also vaguely cited as Irving Brown's signal contribution, although his main financial support for Ferri-Pisani in fact came later, when a willingness to meet physical force with physical force became an essential component of FO's organizing strategy among waterfront workers more generally. Brown's project was to establish disciplined cadre 
organization mirroring the communists' own formations and capable of resisting their attempts at moral and physical intimidation. ${ }^{74}$

With Ferri-Pisani's support, Brown set about extending the strategy devised initially for the Marseille docks to other ports. Against the background of the WFTU's announced plans to disrupt the shipments of American armaments under the Atlantic Pact, in 1949 Ferri-Pisani was instrumental in persuading an ITF docks conference of the need to maintain a close watch on the WFTU's Maritime Trades Department, which was based on the CGT unions. He called for tight organizational discipline and coordination on an international scale. A six-man Central Vigilance Committee of dockers' and seamen's leaders, including Ferri-Pisani, was established in January 1949. It conducted little real business, but it provided an impressive-sounding international platform for Ferri-Pisani to perform on. There were also plans for regional vigilance committees along the Baltic and Atlantic coasts and in the Mediterranean. No concrete organization ever resulted for the Baltic or Atlantic ports, but the Mediterranean vigilance committee was where Ferri-Pisani would later preside over his own personal fiefdom. The ITF launched a financial appeal and raised $£ 650$ over a two-year period. But this paltry sum was hardly needed; nor in truth was the ITF machine itself except as a form of respectable trade union cover.

Once the Central Vigilance Committee was formed, OPC-CIA money began to flow in. Brown opened a bank account in Zurich in Ferri-Pisani's name, and by the end of 1949 deposits amounted to $\$ 9,150$. Though formally accountable to the ITF, the secret financing from intelligence sources meant that in all major respects the Central Vigilance Committee was an independent operation run by Brown and Ferri-Pisani. Other committee members were not privy to the financial arrangements. It functioned on the basis of strictest secrecy, with sketchy or non-existent minutes of its infrequent meetings and virtually no upward reporting to the ITF, whose leadership diplomatically chose not to ask about its detailed work.

What was expected to be the big trial of strength for European dockworkers came in March-April 1950 with the first Atlantic Pact arms shipments to France. From January there were a growing number of "incidents" at French ports - rioting, demonstrations, and sabotage-aimed at stopping the loading of arms destined for French use in the deeply unpopular war in Indochina. But there was no widespread or prolonged strike action, and generally arms shipments were loaded and unloaded without serious disruption, not least in Cherbourg, which was the main entrepôt for Atlantic Pact consignments. ${ }^{75}$ The pattern reflected a growing reluctance of CGT members to follow strike calls for purely political objectives. However, in Marseille, the CGT's anti-NATO campaign ran in parallel with a wages dispute and as such engendered more popular support. Even so, the strikes called over a five-week period received only token backing by dockers belonging to Force ouvrière, with picket 
line violence the inevitable consequence. One version of the episode depicts it as a seminal conflict between CGT dockers and "the mob"; another sees it as the moment when "the communist reign of terror" ended and Marseille became "safe for free trade unionism."

Either way, the action in Marseille eventually failed: the CGT had overplayed its hand. And although the Force ouvrière dockers union had proved itself to be a disciplined anti-communist strikebreaking force, it also failed at a basic level to establish itself as a representative body capable of securing the workplace interests of its members. ${ }^{76}$ Jay Lovestone dubbed it "one of our brightest episodes in the history of our effort to help European labour." From the opposite side, a witness account by a CGT loyalist described it as one of the finest actions in working-class history, although he conceded it achieved "nothing much." 77 That was indeed an understatement. The real winners in Marseille were the dock employers who ceased to recognize any union and tore up existing agreements, leaving Marseille a non-union port for well over a decade.

It was not until six months later, in September 1950, that the Mediterranean Committee (formally the Regional Vigilance Committee for the Mediterranean) came into being at a conference in Naples. Reflecting the fact that he had pretty much a free hand, Ferri-Pisani was installed as "Chief" - an unusual title for a leader of a union body that also sometimes referred to itself as the "Association for the Study of Maritime Questions." There was not now any obvious reference to the ITF; indeed, ITF embarrassment at being identified with such an operation began to show at the Naples conference. ${ }^{78}$

For the next few years, the committee maintained twin offices in Paris and Rome and issued propaganda through an effective monthly journal, Air-Terre-Mer. ${ }^{79}$ None of this would have been possible without American financing. Following the launch in Naples there were only ever two further delegate meetings of the Mediterranean Committee-in Marseille in January 1951 and six months later in Salonika, attended by union representatives of waterfront unions from France, Greece, Trieste, Malta, Algeria, Tunisia, and Morocco. Throughout, the committee's activities were cloaked in secrecy. As Ferri-Pisani later explained to the Force ouvrière congress in 1952, the organization had "entered a new stage of difficult underground action," since "the secret agents of the Cominform" could not be beaten "without promising protection to the one side and reprisals to the other." ${ }^{\text {"8o }}$ Ferri-Pisani was the committee's solitary spokesman, and at the AFL's 1951 convention, where he was given a hero's welcome, Irving Brown praised him in suitable terms as "a virtual one-man brains trust in the battle against Soviet imperialism." ${ }^{81}$ 
Brown was now firmly of the view that within the trade union movement there needed to be an elite force capable of operating in a disciplined, clandestine fashion. He wrote to Lovestone:

There are certain non-trade union tasks which must be assumed by the most reliable and most determined elements in the European labour movements. I am in constant conversation with such people, and we are moving towards ... the building up of a small but determined group who can be of great service in any future political and military tasks awaiting us.

The union members concerned were ready to "go all the way," but they needed to have closer links to the military, and this was something to discuss with NATO's supreme commander, General Eisenhower, since it was as much a military as a labour matter: "There cannot merely be an orthodox approach to the problem of Western European defence," he wrote. "Liaison between any military operation and those groups engaged in quasi-military activities is essential." ${ }^{2}$

What did it all amount to? Clearly Brown had come to see Ferri-Pisani's operation as a potential component of the "stay behind" military force being assembled by NATO in the event of a Soviet invasion - a component of what was later revealed as "Operation GLADIO." ${ }_{3}$ Yet for all that the Mediterranean Committee is vaguely remembered as a "major initiative" in labour's Cold War, it is almost impossible to detail any precise achievements.

The CGT campaign to stop the landing and loading of armaments in European ports had passed its critical stage before the committee's foundation. That the threat from the communists subsequently faded may have been assisted by the work of the committee-the intelligence gathering by trusted anti-communists on ships and wharves, for example-but the more significant fact is surely that the CGT was itself a weakened force after 1949, having called out its supporters too often in actions doomed to fail. The propaganda put out by the committee through Air-Terre-Mer was valuable in presenting the Atlantic Pact as an essentially peaceful initiative, its weaponry intended for the defence of democracy. ${ }^{84}$ But it was also a vehicle for anti-communist propaganda more generally, with concerns that went far beyond the specific trade union interests of waterfront workers. At its two 1951 conferences in Marseille and Salonika (for which latter there were no minutes), the resolutions adopted contained more than a hint of Lovestone's authorial hand. They variously described the war in Indochina as part of a Kremlin plot to conquer the world; deplored conditions of life in the USSR; demanded that the Atlantic Pact be widened to include Greece and Turkey, while a resolution on Far Eastern problems stated that it was unthinkable to negotiate with Mao Tse-tung without the participation of Chiang Kai-shek. 
The Mediterranean Committee did provide Irving Brown with a forward base for surveying options in the Mediterranean basin as he attempted to extend his operations away from Western Europe, south toward North Africa, and east toward the Balkans, Turkey, and Egypt. The recent diplomatic rapprochement between Greece and Yugoslavia had contributed to the defeat of the Greek communist partisans, opening up prospects, so Brown thought, for an ideological offensive throughout the region. He wrote: "Unless the difficulties continue to mount for Stalin in Eastern Europe ... we are heading for war.... Every situation must be exploited, every instance must be intensified."

Under ICFTU auspices, and ahead of the conference in Salonika, Brown had returned to Greece in the spring of 1951, considering the visit an opportunity to play "a very serious role in making things difficult for Stalin in his own backyard." While there he was able to make plans for the Salonika conference and arrange extensive coverage by Voice of America. However, he was also particularly excited by prospects for penetrating beyond the nearby Greek-Bulgarian border and reported back on how the incidence of desertions by Bulgarian soldiers opened up possible lines of intelligence gathering behind the Iron Curtain. He had funds at his disposal, and after giving the GSEE "a small shot in the arm," he then travelled on for a first exploratory visit to Turkey, attending the congress of the Istanbul Federation of Labour and also making arrangements for three Turkish trade union leaders to visit the AFL later in the year. ${ }^{85}$

What Harold Lewis describes as Ferri-Pisani's "consciously cultivated . . . almost romantic air of 'secrecy' and sense of physical danger" undoubtedly had a resonance that helped Irving Brown "sell" the Mediterranean project to his Fizz Kid contacts. ${ }^{86}$ And as dollars flowed in, reputations and careers rode on the "success" of this clandestine project, whose precise results were never thoroughly documented. No detailed account of Mediterranean Committee financing exists: the main channel for funding the operation was Brown's own "French budget," which he received direct from the OPC-CIA. Fragmentary evidence, however, suggests a substantial outlay until around 1954, when US intelligence began to lose interest.

FTUC financial statements show that Ferri-Pisani's Zurich bank account was credited with \$33,860 in August 1953 and a further \$10,000 in November. In March of that year, with Brown in Washington to meet the newly promoted director of the CIA, Allen Dulles, Brown's then CIA assistant in Paris, Leon Dale, handled finances and recorded disbursements. These included a payment of $\$ 6,000$ to a representative of Ferri-Pisani who simultaneously placed a request for a further $\$ 3,000$ to $\$ 4,000$. That same month $\$ 5,000$ was also paid to Force ouvrière general secretary Robert Bothereau. At the same time $\$ 4,000$ per month was going to Paolo Giornelli, who ran the Italian section of the Mediterranean Committee. ${ }^{87}$ These were 
significant payments to union leaders whose own organizations were impecunious and might only employ two or three full-time officials. When the CIA became more parsimonious and Giornelli's monthly subvention was reduced to \$2,500 later in 1953, he complained of being in "serious trouble ... like Ferri." The following year, when Brown himself wrote of the Mediterranean Committee being in danger of "going under," Ferri-Pisani himself was already fading from the scene and no longer appeared at ITF meetings. In mid-1955, his situation was described as "rock bottom." 88 Without the artificial crutch of external finance, the operation could not be sustained. But for as long as funding had been assured, it had continued in being, and with Brown able to "bury" some expenditures in his accounting, there was always scope to accumulate a slush fund for other pet projects.

\section{Activities Outside the Field of Labour}

For several years David Dubinsky had been subsidizing the French socialist party paper Le Populaire, with its circulation of 35,000, but the AFL's sometimes strained relationship with the publication over its editorial line led the Americans to look around for other suitable publications to support. ${ }^{89}$ The CIA also had a general interest in supporting approved propaganda outlets, and the FTUC became the channel through which financial assistance was made available to various publications in France. One candidate for assistance was the Jewish publication Notre parole, which was widely read in Paris and promoted a social-democratic line. But the publication's plans for expansion through a merger with Unzer Stimme, known for its Zionist outlook, went against the grain for Dubinsky, and the word went out to Brown to disregard their request for a $\$ 60,000$ grant. ${ }^{\circ}$

A more powerful ally in the Cold War was the Paris-based journal Franc-Tireur, with a circulation of 300,000-bigger than that of the French Communist Party's paper, L'Humanité. Caught up in its own internal struggle against the communists, Franc-Tireur was assisted financially by the FTUC from 1949 to 1951, a period during which it removed a number of communists and sympathizers from its editorial staff. Under its editor, the wartime resistance leader, Georges Altman, who was close to Brown, Franc-Tireur sponsored a new political grouping, the short-lived Rassemblement democratique revolutionaire, which initially included among its supporters Jean-Paul Sartre, Albert Camus, and the AFL favourite, David Rousset. ${ }^{91}$ Brown also arranged for Franc-Tireur to sponsor the initial conference in Paris that led to the establishment of the Congress for Cultural Freedom (CCF) by anti-communist intellectuals.

In 1951, Franc-Tireur was hoping to secure a further \$200,000 grant from the FTUC, but Lovestone was increasingly uncomfortable with its off-message political 
line, taking exception to its sometimes unfavourable treatment of the North Atlantic Alliance. He exploded with anger when in 1950 the paper came close to advocating the seating of communist China at the United Nations, threatening to dissociate the AFL from "any organization which calls the Quisling Mao Tse Tung regime... a people's China." Lovestone was all for ending the subsidy and was bitterly critical of the CIA's Bert Jolis, who undermined AFL criticisms by urging continued agency funding. Brown was forced to mediate, urging Altman to placate Lovestone by indicating his willingness to reorganize the paper. Lovestone was thereby persuaded to persevere with financial aid until after the French general election in summer 1951, but he was adamant about ending it thereafter. "Tell our [CIA] friends," he ordered, "we want to wash our hands clean of this outfit.".92

As the FTUC link with Franc-Tireur withered, Leon Dale responded favourably to a proposal by two Paris journalists, Marzet and Clouzet, to launch an anti-communist publication in association with a "Centre of Study and Propaganda." Their publication was to be targeted at employers and would advocate a reform of industrial relations practices combined with measures to improve productivity-ideas much in vogue in Marshall Plan circles. Dale conceded that the funding sought $-\$ 80,000$ for one year-was high, but argued that the paper would fill a definite need and the centre would provide "useful cover."93

Much more ambitious than subsidies to individual publications was Irving Brown's involvement in setting up the CIA-financed Congress for Cultural Freedom, with its objective of challenging globally the attraction that Soviet communism held for so many in the intellectual community. On the surface this association of leading intellectuals and the AFL's field representative was a strange affair, even allowing for their shared anti-communism. But the simple fact was that the project needed someone experienced at launching and running an organization, able to handle the humdrum practicalities of equipping an office, arranging meetings and follow-up activities, and, crucially, with the capacity to move money about discreetly. This was Irving Brown's forte, whereas such talents were not readily found among the poets, artists, writers, and musicians who populated the congress.

During the Cultural Congress in Berlin in 1950, at which the CCF was launched and Brown worked closely with Sidney Hook, James Burnham, and Arthur Koestler, the OPC-CIA credited the FTUC with $\$ 14,000$ for "cultural activities." Brown oiled the wheels of the embryonic organization, paying expenses of fellow members of the steering committee to meet at the ICFTU's Brussels headquarters in October and again at a founding meeting of the CCF executive committee the following month. He was a key member of the group that drafted the CCF's articles of association and appointed a secretariat. He was also responsible for renting and equipping the Paris head office in the Boulevard Haussmann, pending which 
the CCF operated out of his own rooms in the Hotel Baltimore. During the CCF's formative period, with Brown centrally involved, there was briefly a suggestion that it should take responsibility for intelligence programs in the labour field, work that subsequently became the responsibility of Tom Braden's International Organizations Division of the CIA. ${ }^{94}$

Over the next twelve months Brown continued to pay the bills, running at $\$ 15,000$ a month in 1951. He was the CCF's paymaster-its bagman-and a driving force in the organization. During this period he was one of the few people involved in the cultural project who knew where the money came from. As François Bondy, the congress's director of publications noted: Brown was "more helpful than all the Koestlers and [Ignazio] Silones put together." ${ }^{55}$ Overall, Brown appreciated the benefit of working with the CCF, not least because it provided an extra source of CIA funding, a wider range of contacts, and further room for manoeuvre in a game where he and Lovestone played their cards close to their chest. Allen Dulles assigned the CIA's Laurence de Neufville to monitor what Brown was up to in the CCF, but the latter reported that it "was almost impossible because he was running it like it was his own operation, and he never said much about what he was doing." Only when the Farfield Foundation was created in 1952 as a wholly owned CIA conduit and took over responsibility for CCF finance did Brown slip into the background. He remained on the CCF executive committee until 1956, when he resigned, believing that the CCF was softening its anti-communist line. ${ }^{96}$

Acting on behalf of the CIA, and working through the émigré International Centre of Free Trade Unionists in Exile (ICFTUE) based in Paris and launched with ILGWU financial help, Brown had many lines of contact to Eastern Europe. The centre's treasurer, former Romanian miner Eftimie Gherman, boasted having a network of trustworthy people in every big plant, mine, and government office from Warsaw to Sofia. ${ }^{97}$ It thus had great potential for intelligence gathering in the Soviet bloc. Brown's most valuable contact in the early 1950 s was the Czech, Jaroslov Profous, a lawyer in his mid-forties who had gone into exile and was vice president of the Czech National Confederation of Political Prisoners and Resisters in Exile. He and an Austrian colleague, Rudolf Stark, were encouraged to open a refuge in Salzburg for Czechs fleeing the country-what Brown referred to as his "Salzburg housing operation." Commencing in October 1950, with a start-up budget of $\$ 7,000$ from the CIA to establish the refuge and $\$ 600$ per month in operating expenses, the project ran smoothly for a year. However, by late 1951, in the context of increasingly strained relations between FTUC and CIA, the "Fizzlanders" were keen to take direct control of the operation. It was another project beyond the FTUC's central field of interest, and Lovestone treated the links with Profous-whose reliability he had begun to doubt - as a bargaining chip through which to bid for a more satisfactory relationship 
with the agency and an expansion of funding for core activities. He instructed Brown: "They need your merchandise. Let them pay for it and also for an insurance policy"”8

The souring of Lovestone's relations with Profous was a factor behind a contemporaneous clash between Brown and the CIA over his dabbling with a dissident group in Poland. Through the ICFTUE's Polish national section, Brown had made contact with Josef Maciolek, international director of the clandestine group Freedom and Independence (Wolnosc i Niezawislosc, or WiN). Nurtured by both the British secret service and the CIA, WiN was a magnet for anti-Soviet dissidents, but it also proved to be a honey trap for foreign agents. In September 1952, on the promise of intelligence from Maciolek, Brown gave him an advance of $\$ 3,000$ from his own funds, planning to obtain retrospective CIA authorization and confirmation of funding when next in the United States. However, Maciolek had also earlier contracted directly with the CIA for WiN to serve as a part of a "stay behind" army, for which he had been paid \$1.16 million. When the CIA realized that Maciolek was also dealing with Brown it demanded an end to the relationship. Indeed, the entire WiN connection with the agency collapsed, and the whole matter came to light when, soon after, its leadership handed over to the Polish communist authorities their file of incriminating evidence. The details were published by the WFTU and were neither rebutted nor in any way commented on by the AFL. 99

During the previous two years, the CIA had gradually taken over responsibility for funding the ICFTUE through the National Committee for a Free Europe (NCFE) ${ }^{100}$ The agency's interest in the exile centre had less to do with its character as a "trade union" body than its potential for intelligence gathering and its utility as disseminator of anti-communist propaganda through the NCFE's broadcast arm, Radio Free Europe. Initially financial assistance took the form of a $\$ 650$ fee paid monthly for scripts supplied by different national exile groups for broadcast by Radio Free Europe. The money was passed to the ICFTUE by Alois Adamczyk, a former Polish trade union official and currently unofficial leader of a section of the ICFTUE domiciled in New York. This group liaised closely with Lovestone through former Lovestoneite Henry Kirsch, who headed the NCFE's "American Contacts Division." However, in 1950 tension developed between the New York exiles and the ICFTUE in Paris over the former's claim to be best placed to organize covert activities in Eastern Europe ${ }^{101}$

The NCFE settled this dispute in favour of the Paris group, doing so in a way intended to reduce Lovestone's influence. It dispensed with the services of Kirsch, who had acted as Lovestone's eyes and ears within the NCFE, and appointed as its official representative to the ICFTUE in Paris Leon Dennen, a forty-three-year-old former garment workers' staffer and representative in Europe of the Jewish Labor Committee. Although he was close to David Dubinsky and expressed his loyalty to 
the AFL, Dennen had no formal relationship with the FTUC and insisted on the need to work independently of it. ${ }^{102}$

Dennen had a secret budget of $\$ 71,000$, from which he now made monthly payments of $\$ 5,000$ to the ICFTUE. Lovestone was up in arms about these changes, unwilling to accept an arrangement that excluded him from full knowledge of all ICFTUE financial transactions. He noted that while others in Washington saw Dennen's reports to the NCFE, he was not on the circulation list. "I know a rotten deal when my nose tells me it stinks," Lovestone told him. ${ }^{103} \mathrm{He}$ appealed Kirsch's dismissal to C. D. Jackson, chairman of the NCFE, who was on secondment from his position as managing director of Time-Life International, but Jackson insisted that he would not have any AFL "stooges" in the NCFE: "We will not allow Lovestone to dictate or control our committee." Jackson's line was upheld by his successor, the former assistant secretary of state, Adolf Berle, who stated bluntly that Kirsch was unacceptable because he was a "Lovestoneite." Jay Lovestone's loss of favour was the direct product of a sharp deterioration in relations between the FTUC and the CIA. The agency's deputy director, Allen Dulles, strongly supported the new arrangement and let it be known that he, too, would have occasional chores for Dennen. ${ }^{104}$

Describing the NCFE as a "committee of crooks and charlatans," Lovestone urged the FTUC to sever all links with it, with the result that Matt Woll resigned from its board of directors. Lovestone won the backing of Meany and Woll for his line, but Dubinsky, who remained attached to Dennen, was not persuaded and preferred to maintain an AFL presence on the board and fight its corner from within. Links were eventually severed some months later, but it was only a partial victory for Lovestone. Dennen remained the channel through which the NCFE dealt with the ICFTUE, and he now developed plans for an expansion of its activities with new offices opened in Berlin and Stockholm. ${ }^{105}$ NCFE president, Admiral H. B. Miller, proposed a tit-for-tat reaction to the FTUC's withdrawal by "cutting off our [FTUC] friends in Europe," but Allen Dulles waved away the suggestion. He understood that in this bruising encounter the CIA had broadly achieved its objective and told Miller: "We have enough trouble as it is with Lovestone; let us not look for more." ${ }_{106}$

\section{Italy: Splits Financed by “Irregular" Funds}

The financial dependency of the Italian maritime unions on the Americans, so evident at the conference of the Mediterranean Committee in Naples in September 1950, was a direct product of the splits in the Italian labour movement that developed over Marshall aid. These occurred in the aftermath of the Christian Democrats' overwhelming success in the general election of April 1948, a victory achieved with no small support from the Americans, and especially the CIA. Irving Brown's expression 
of support for the continuation of AFL independent activities abroad at the time of the formation of the ICFTU had much to do with American attempts to manage the politics of this trade union fragmentation in Italy.

The country was not a regular part of Brown's beat until 1949. He had paid occasional visits to Italy and had spoken of the need to be more active there, but that would require more resources than he initially possessed. In any case, the Italian-American Labor Council, headed by the ILGWU's Luigi Antonini, was the AFL's established point of contact with the Italian labour movement. The United States also had an extremely active labour attaché in Rome in the person of Colonel Tom Lane, whose high profile was further enhanced by combining his role as attaché with that of labour advisor to the Marshall Plan mission. As former legal counsel to the bricklayers' union, he appeared to some to carry the imprimatur of the AFL, and he didn't hesitate to capitalize on this. In reality he pursued a line independent of the AFL, and over time this became a cause of great concern to Lovestone and the FTUC.

Irving Brown turned up in Rome four days after the landmark 1948 general election. Accompanied by Tom Lane, he met the leaders of three non-communist groupings within the then unified Confederazione generale italiana del lavoro (CGIL)—Giulio Pastore (Christian Democrat), Giovanni Canini (Social Democrat), and Enrico Parri (Republican) - and urged them to split away from the communist-led organization. From the outset the social democrats and republicans were reluctant to do so, the former in particular encouraged by the British to remain within the unified body and work to take control. To Brown they were "the weakest part of the picture": "Saragat [Social Democrat leader] doesn't know a damn thing about workers and trade unions." With far fewer trade union members than the Christian Democrats, both groups feared becoming a minority in an organization dominated by the Catholic Church-"sextons and bell ringers for Pastore," as one social democrat put it. ${ }^{107}$

Three months later, an insurrectionary general strike called by the CGIL in response to an assassination attempt on Communist Party secretary Palmiro Togliatti provided Pastore with the excuse for withdrawing his Christian Democrat members from the CGIL. But despite the personal urging of Dubinsky, Antonini, Lovestone, and Brown during a highly publicized visit to Rome, and their offers of financial help, no other non-communist group joined them. Pastore launched a new "free trade union confederation," the Libera confederazione generale italiana del lavoro (LCGIL), in October 1948, having submitted to Lane a request for no less than $\$ 1.5$ million in assistance over the coming nine months-including wage costs for 1,430 staff! US Ambassador Dunn cabled the State Department, urging that all means of obtaining the funds be explored: "We believe we could handle financial transfers here discreetly". 108 That same month, Tom Lane attended a meeting of the AFL international affairs committee where it was agreed to support Pastore's attempts to 
establish the new organization on non-confessional lines and so increase its attraction to the Social Democrats and Republicans. As the LCGIL embarked on an organizing drive, and with Lane predicting that it would have a membership of a million and a half within six months, he and his embassy staff were prominent at many of the recruiting rallies. Lane was soon spending large sums of money on the LCGIL from Marshall Plan counterpart funds quite independently of the American labour movement. ${ }^{109}$

During a Marshall Plan-sponsored trip to the United States in 1949, Canini and Parri, the leaders of the CGIL Social Democrat and Republican factions, were subject to intense American pressure to join up with the LCGIL. They were given red-carpet treatment, including a meeting with President Truman, and they finally gave a commitment to withdraw from the CGIL by the end of June and to merge with the LCGIL before the end of November. It was hoped that such a consolidation of forces would enable the Italian unions to attend the founding congress of the ICFTU as a unified anti-communist centre. Funding in the amount of $\$ 200,000$ was promised by the FTUC-half for the Christian Democrats, the other half shared between the Social Democrats and Republicans. But once Canini and Parri returned to Italy they encountered deep-rooted reservations about the proposed unification among their rank and file. Social Democrats in particular believed in the need for wider unity of the non-communist left, which would include members of the CGIL belonging to Pietro Nenni's larger Socialist Party before creating a new trade union centre. The compromise response of Canini and Parri was to form the Federazione italiana del lavoro (FIL), which some saw as a staging post on the road to merger with the LCGIL while others regarded it as a permanent body, independent of both the Communist and Catholic wings of the movement.

Renewed American pressure was brought to bear on Canini and Parri to honour their commitment to immediate unification. Brown was sent to Rome on three occasions in July, August, and September 1949 to work on these two men and their political associates. He reputedly told the Social Democrat, Enzo Dalla Chiesa, that he could have suitcases of money if he would only leave the CGIL. ${ }^{10}$ However, so much money had been offered as an inducement to merger, most of it by labour attaché Tom Lane, that it was being devalued. Lovestone was appalled at the costings supplied to him by Pastore $-\$ 6,500$ for 150,000 copies of a manifesto and $\$ 3,000$ for 500,000 membership cards: "They must think we are a bunch of innocents," he told Brown. "I think our Italian friends have been overfed ... If they keep on with their high caloric diet they will get acute indigestion." ${ }^{\prime 11}$ Dubinsky wrote to Averell Harriman, head of the Marshall Plan in Europe, threatening to wash his hands of the operation in Italy if this use of counterpart funds didn't stop. He also called for the AFL to issue a statement dissociating itself from any irregular financing of the 
Italian unions. But Meany successfully opposed this particular suggestion, arguing that it would cast doubt on the legitimacy of the entire Italian program. ${ }^{112}$ The FTUC's principal source of funds was, after all, hardly regular.

The course now decided on by the FTUC was to restrict carefully the distribution of its assistance so as to benefit only those parties that committed themselves to a merger with the LCGIL. Brown was instructed to open a bank account in Rome in the name of the FTUC from which withdrawals would be permitted, but only on the telegrammed instructions of either Woll or Dubinsky. Brown resented his loss of freedom under these new banking arrangements, but Lovestone put his foot down and told him: "You have got to get one thing clear, Irving, the Committee here will leave no stone unturned to make it clear and irrefutable that it is the AFL and not, as the Communist slanderers say, the other [CIA] sources which are giving material support for trade union realignment in Italy."113

At a meeting in the Grand Hotel in Rome on 8 September, Brown turned up the pressure on the Italians and set 3 October as the deadline for merger, failing which he threatened to cut off funds. But this tactic served only to antagonize the union leadership: Parri described it as blackmail and referred to Brown and Lane as "clowns," while Canini considered it stupid and predicted that it would result in only a few joining the LCGIL. ${ }^{114}$ L'Umanità, the Social Democrat organ, lambasted American ignorance of the situation and Brown in particular as the "naïve labour ambassador from the other side of the Atlantic." In New York the expatriate Social Democrat, Vanni Montana, aware that Brown did not even speak Italian and that people were thereby forced to turn to Tom Lane for an interpretation of AFL policy, induced American Socialist Party leader Norman Thomas to complain to the secretary of state about the crudeness of American policy toward the Italian trade unions. The publicity generated by this caused a sensation in Italy. ${ }^{115}$

The deadline for merger passed, and negotiations were still taking place during the founding congress of the ICFTU in London in December 1949. When, in February 1950, FIL leaders finally committed themselves to merge, it provoked a walkout of its own left-wing Social Democrats, who formed a new Unione italiana del lavoro (UIL). UIL would later seek independent affiliation to the ICFTU at the highly charged executive board meeting under Vincent Tewson's chairmanship in December 1951. In the event, a mere rump of Social Democrats and Republicans led by Canini and Parri finally merged with the LCGIL to form the new Confederazione italiana dei sindacati lavoratori (CISL) on May Day 1950. Making the best of a messy outcome, Irving Brown described it as a victory for democratic workers against the "relentless and fabulously financed Communist fifth column." As he knew only too well, the "democratic workers" had also been "fabulously financed." For their part in this 
venture, Canini and Parri were both viewed as traitors and, as such, expelled from their respective political parties.

It was against this background of hardball American tactics and generous financial inducements intended to influence the direction of Italian trade unionism that Brown and Ferri-Pisani prepared for the international conference of maritime workers in Naples in September 1950. Two months earlier Brown had released \$2,000 to Canini for him to begin to make the arrangements. ${ }^{116}$ Historian Ronald Filippelli notes that the Italian anti-communists were now an international charity case. CISL was largely a creature of AFL pressure, and from the outset American funding bred a dependency that was hard to break. As Brown later reported, CISL had too many full-time paid officials among whom a spirit of comfortable fonctionarism had developed, with few of them displaying any willingness to self-sacrifice. Only weeks after the merger between the LCGIL and the FIL rump, Lovestone noted cryptically:

The wedding which recently took place improves the picture from a certain point of view but ... the requests of the ailing pottery workers flabbergasted us. I am comparing the requested hospital bills with others and find that the Italian demands are fantastic.... We believe that the present request should be handled over a period of two years instead of one year.

And the role of the embassy in distributing finance had become a major problem:

We are particularly concerned about our very-well intentioned friend Tom [Lane] who presumes that all he has to do is make a commitment and come willy-nilly, the AFL-FTUC will have to accept it... . Neither DD, nor Woll, nor George Meany want ... individuals holding such official positions to make commitments on behalf of the AFL without consulting them. ${ }^{117}$

Meanwhile, UIL, led by the left Social Democrats Dalla Chiesa and Italo Viglianesi, favoured cooperation between all the various strands of the fragmented labour movement, including the communist-led CGIL. For this and for voicing criticism of the North Atlantic Treaty, UIL was inevitably cut off from AFL financial assistance. With no other source of funding available, UIL then turned to the CIO for help. A new dimension was about to be added to American trade union activity in Italy. Highly critical of the AFL and State Department strategy in that country, and attempting to tap into finance from US government sources for trade union work abroad, the CIO would soon begin to develop plans for a European program of its own, competing with the FTUC in the Italian theatre and elsewhere. The CIO's presence in Europe was set to become a major issue of contention between the two American centres.

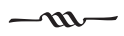


Established with strong American support to foster pluralism in international trade unionism, the ICFTU underwent a severe test in its first two years, and was found wanting by the AFL. It was seen as slow to react to critical developments in the Cold War and to be dominated by a small group of Europeans, foremost among them leaders of the British TUC, with a conservative approach to trade unionism and little stomach for a real fight against communism. As early as 1952, such factors led the AFL to conduct a boycott of ICFTU meetings for most of the year, while some of its leading figures even questioned the value of membership tout court.

The latter view owed much to the strident criticisms and personalized attacks on ICFTU personnel in reports from Irving Brown and Jay Lovestone. Within months of its foundation, the ICFTU's first general secretary, Jaap Oldenbroek, had gone from close AFL ally in the fight to extricate Western trade union centres from the WFTU to arch-villain with whom Lovestone would have no truck. His and Brown's fiercely combative approach in dealing with sister organizations plainly limited the scope for fraternal give and take and generated wariness of the FTUC in Europe. Yet while whipping up this negative AFL view of the ICFTU, Lovestone and Brown never had any doubt about the need to maintain the international affiliation. Indeed, they considered that the AFL had an obligation to provide world leadership, meaning a special role for Americans in international labour affairs but with scope for "independent activities" where necessary.

Such an approach was greatly facilitated by the extra financing that the FTUC's links with the OPC-CIA made available. It was central to FTUC programs involving the non-communist trade unions in Finland and the Mediterranean Committee. The source of funding dictated the need for secrecy, to which Lovestone and Brown adapted easily: they were essentially Leninists whose politics may have changed but who still retained a penchant for conspiratorial work. To this mix they also brought the passion and single-mindedness of zealots prepared to battle against heavy odds in pursuit of the abiding anti-communism that characterized their whole approach.

Of particular note in Irving Brown's work in Finland, and even more so with the Mediterranean Committee, was his championing of the concept of an elite, anti-communist trade union force schooled in Leninism and trained to do battle with communists in a physical sense for control of the streets and the workplace. He plainly saw this as an adjunct to the American military presence in Europe, indeed a component of the "stay behind force" as envisaged in "Operation GLADIO," prepared to go underground in the event of a communist takeover.

With its secret channel of finance, the FTUC spread its effort in Europe more widely. Subsidizing newspapers that were considered to have an acceptable political line in France, sponsoring the International Centre of Free Trade Unionists in Exile whose main function was the dissemination of propaganda and gathering of 
intelligence in Eastern Europe, and even assisting the launch of the Congress for Cultural Freedom and sustaining it organizationally over its first two years, were all initiatives far removed from the field of trade unionism proper. Indeed, an interesting feature of the extensive Brown-Lovestone correspondence is the patent lack of interest they displayed in routine trade union affairs, save where there was an anti-communist angle to exploit. Yet others in the AFL leadership had misgivings about the range of FTUC activities; Brown was urged to limit the time he devoted to the CCF, and Lovestone himself balked at the request of the US ambassador to India for help in preparing for the launch of a CCF section in the subcontinent. There was piquancy in his reminder that, after all, the FTUC was still a trade union body.

The potential for trade union intentions to be compromised by this funding arrangement was most evident in Italy, where the favoured centre, CISL, had access not only to assistance from the AFL but also to extensive financial resources liberally doled out from the US embassy in Rome by Tom Lane and made available on the fiction that this was money from the American trade unions. This practice of "buying" the support of trade union favourites was to arouse concern in the CIO-hitherto largely content to channel its international effort via the ICFTU—and prompt its leaders to seek a more prominent role in Europe. The CIO's presence on the continent from 1951 as a competitor of the AFL would now lead to a heightening of conflict between the two American affiliates of the ICFTU in the first half of the decade. 



\section{4}

\section{The AFL and CIO Abroad \\ From Rivalry to Merger}

The emergence of the Congress of Industrial Organizations (CIO) as a player on the international stage following its withdrawal from the WFTU in 1949 was an unwelcome development for the AFL and revived old animosities. The two organizations had worked alongside one another in the administration of Marshall aid and were cooperating in the rearmament program that accompanied the war in Korea. Government agencies now looked to the two wings of the American labour movement to work abroad in tandem, but the AFL was unwilling to accept the CIO as a partner. Despite the fact that the CIO had purged its communist-led unions at a cost of a quarter of its membership in 1949-50, the AFL feared that it still included people regarded as security risks whose presence would compromise the anti-communist crusade at the heart of AFL activity abroad. Thus the attempt by the Central Intelligence Agency (CIA) to draw the CIO into the funding arrangement for overseas labour programs that it had already established with the AFL was met by complete opposition from the latter. The AFL's partnership with the CIA suffered in consequence, although funding of operations by the Free Trade Union Committee continued on a diminishing scale until 1958.

The CIO was hardly less anti-communist than the AFL, but its approach to fighting communism was different and involved demonstrating the greater effectiveness of free trade unionism in advancing the material interests of workers. Opposed to the "negative anti-communism" of which the AFL was accused, Walter Reuther's dictum at the founding congress of the ICFTU_ "neither Standard Oil nor Stalin"guided the CIO's approach. Focusing on core union activities, its program aimed to strengthen foreign unions in their essential dealings with employers. The CIO 
also prioritized work undertaken through the ICFTU. Yet the steadily deteriorating relationship between the AFL and ICFTU in the early 1950s accentuated differences in international policy and practice between the two American centres. The friction over international affairs persisted even as the two wings negotiated merger terms during 1953-55. Indeed, international issues presented the single most difficult challenge in the pursuit of labour unity in the United States and were hardly dealt with in the protracted pre-merger talks. When eventually unification was achieved within the AFL-CIO in December 1955, all the major differences over international affairs remained to be resolved.

\section{The AFL at Odds with the CIA}

There was never a golden age in the AFL's relations with the Office of Policy Coordination (OPC) and its successor, the CIA, and within eighteen months of the start of their formal funding arrangement, mutual mistrust was all too apparent. Disputes between Lovestone and his contacts in intelligence had been ongoing from the outset. He balked at their reluctance to share information freely with him. He resented the CIA's assuming the right to manage FTUC field staff and to utilize Irving Brown on more general intelligence work outside the field of labour. Lapses in security resulting from too many people being privy to confidential information also troubled him. ${ }^{1}$

Problems over finance were, of course, central. In the final months of 1950, the renewal of Irving Brown's "French budget" was put on hold as a consequence of the restructuring of the OPC within the CIA. The OPC's buccaneering days under Frank Wisner were coming to an end. A new CIA director, General Walter Bedell Smith, was installed in October 1950 to take firmer control. With Allen Dulles, former head of the OSS in Europe, as Bedell Smith's new deputy, Wisner would gradually lose influence over labour programs- "stripped of all union labels," as Lovestone noted. ${ }^{2}$ But another important factor in the program review was the imminent arrival on the international stage of the $\mathrm{CIO}$, which had only recently established its own international affairs committee. Senior figures in both the Marshall Plan and CIA had been hoping for a new, combined AFL and CIO labour operation in Europe, and Lovestone's intelligence was that the Marshall Plan (now the MSA) head in Europe, Milton Katz, was querying the value of Brown's financial assistance to Force ouvrière.

These various issues were on the agenda at a top-level meeting with Bedell Smith and Wisner to review progress in the labour program in November 1950. Attending for the AFL were Dubinsky, Woll, Meany, Lovestone, and Carmel Offie, the latter a significant figure in the Lovestone-CIA operation for some years in the first half of

the 1950s. To Lovestone's complaint that the funds involved were not all that large, Wisner countered that in addition to upward of \$250,000 channelled to the FTUC 
over the previous year there had been considerable sums available from Marshall Plan "counterpart funds" for labour projects in France and Italy. ${ }^{3}$ This went to the nub of the matter. Counterpart funds, or "sugar funds," served a number of functions. They existed to finance major social and economic projects in Marshall Plan countries. Five percent was placed in an "Administrator's Fund" to cover American administrative costs in Europe, and within this fund was an amount for use on secret, unvouchered projects. The Economic Cooperation Administration (ECA) had access to this money, and so did the CIA, and between them there was always a potential problem of conflicting aims, especially now that the CIO was bidding for a role in the labour program. ${ }^{4}$

Very tentatively, Bedell Smith introduced the hypothetical question of future CIO participation. Woll immediately rejected the idea, with Lovestone noting that it would present a security risk because of the CIO's penetration by communists. ${ }^{5}$ Meany chipped in with names, dates, and places where the CIO had proved to be a security liability and stated that he would prefer to withdraw the FTUC from the funding arrangement rather than work in tandem with the organization. But wasn't the CIO already benefiting from CIA assistance? On this point, the CIA chiefs were evasive. Wisner conceded that approaches had been made to bring the CIO into the labour program, but he assured the meeting that, if the $\mathrm{CIO}$ were to have a partnership role, its activities would have to be controlled by a small group who would be sworn to secrecy. Only when the CIO met such conditions would he be prepared to deal with it on a project-by-project basis. This didn't satisfy Lovestone, who wanted to know whether money hadn't already gone to the CIO. Wisner prevaricated and asked for discussion to be deferred before finally admitting that he had learned that some of the funding for a recently arranged $\mathrm{CIO}$ mission to Europe was from a division of the CIA. In closing the meeting and attempting to damp down fears, Bedell Smith expressed doubt that the $\mathrm{CIO}$ would ever be included in the world of secret funding. For Lovestone, this was hardly reassuring. The outcome was an agreement that Offie, acting for the FTUC, and Wisner would draft a charter of operations clarifying the respective roles and responsibilities of the FTUC and CIA. ${ }^{6}$

Lovestone's fond hope was to negotiate a better funding arrangement, to which end he submitted a proposal for the FTUC to be allocated a block grant that would avoid close financial monitoring by the CIA. He also resurrected the idea of having his friend Raymond Murphy, of the State Department's EUR-X branch, assigned to the office of the CIA director as a direct channel of liaison, but the CIA would not bite. Discussions between Wisner and Offie continued for some weeks, but without agreement.? Allen Dulles was becoming increasingly influential, and with him came a more discriminating attitude toward the various programs then in existence. Some were to be terminated, others scaled down, whereas, for some of the intelligence 
gathering outside the labour field that Irving Brown had engaged in, there was scope for an increase in activity. The CIA position was that the FTUC operation still had some usefulness, but the agency was not going to let Lovestone have the free rein he sought.

Lovestone was scathing about his contacts in intelligence, remarking on their "irresponsibility" and "slovenliness." He told Brown that his relations with Wisner were strained, the latter complaining that he was a hard man to work with. In that case, Lovestone snapped, "Maybe he better try the other crowd"-referring, of course, to the CIO. The FTUC reacted by cutting back on some activities that were not strictly "labour" in character. In Berlin, where two members of UGO's Ostburo, "Diderich" and "Mueller," had been cleared by US intelligence and supplied with papers for clandestine operations in the Eastern zone, Lovestone objected to their being too close to the CIA and wrote them off as "damaged goods." Another casualty of the FTUC's more selective approach was support for Franc-Tireur. Elsewhere Brown was advised to scale down his efforts on behalf of the Congress for Cultural Freedom. Lovestone was concerned at the prospect of the agency coming between himself and Brown. He feared being sidelined while Brown's intelligence-gathering activities beyond the FTUC's immediate concerns were encouraged. To avoid this, the two men talked of restricting the flow of intelligence they passed on to the agency, with Lovestone insisting that all confidential information be channelled through him. ${ }^{8}$

The CIA responded in kind: Lovestone's long-term friend Henry Kirsch was removed from his post as director of the NCFE's American Contacts Division precisely because, as former assistant secretary of state Adolf Berle put it, he was a "Lovestoneite" and hence unacceptable. ${ }^{9}$ Brown was particularly concerned that the renewal of his "French account" was still stalled and, in protest, dragged his feet over the agency's plan to station Leon Dale as its financial administrator in his Paris office, telling his handlers that under no circumstances could they use the FTUC's name until such time as his budget was confirmed. He returned to Washington in February 1951 for further negotiations with the CIA. On the grapevine, Lovestone learned of agency complaints of Brown's "roughness and brusqueness" during this meeting. ${ }^{10}$

With key issues still unresolved-most notably the proposal to admit the CIO into the world of intelligence-funded labour programs-a further top-level conference with Bedell Smith was held at New York's Waldorf Hotel in April 1951. The meeting went badly and degenerated into a shouting match, as Dubinsky's subsequent account made clear:

We told them they [CIO] would ruin things [in Italy], but they wouldn't stay out. General Smith kept sounding more and more dictatorial at our conference. Finally, Lovestone said to him: "You're a general, but you sound like a 
drill sergeant." When he protested, I said to Smith, "You're not telling us what to do: we are from the labour movement." Then I turned to Matt Woll and said, "Why are we sitting here, let's get out." And that was good-bye."

Lovestone then wrote to clarify matters with Sam Berger, labour advisor to Averell Harriman and de facto intermediary between the State Department, CIA, and FTUC, who often acted as post box between Lovestone and Dulles:

1 The Fizz kids have a perfect right to do business with whom they want. 2 We have the same right ourselves. 3 The decision of the Fizz kids to do business with the CIO is ... cheap opportunist and petty political patronage. . . 4 [It] ... is an attempt dictated by aspiring politicians like the one in Paris [Katz] who developed the theory that the trouble with European labour is that it has met American labour and only one wing of it-the AFL.

In tones that suggested they were approaching the parting of the ways, he told Berger: "A lot of the problems that have been placed on your shoulders should no longer be a source of interest or grievance to you. Consider that phase just that much water over the dam." ${ }^{12}$ In reality the relationship between the AFL and the CIA was by no means over; it continued in this particular form, though on a gradually diminishing scale, until 1958. Lovestone persisted in demanding more favourable terms, sometimes bullying, sometimes cajoling, and on one occasion, in an apparent show of compassion, appearing at Allen Dulles's hospital bedside. But Dulles had Lovestone's measure. He hired Tom Braden, an old OSS hand, urbane and well connected, to oversee relations with the FTUC, and Braden himself was soon keen to draw the CIO into the trade union program. ${ }^{13}$ Lovestone could huff and puff, but he had little choice but to accept the existing situation.

\section{The $\mathrm{CIO}$ in Europe}

The key figure in CIO international operations was Victor Reuther, the youngest brother of Walter Reuther, president of the UAW since 1946 and soon also to become CIO president, in November 1952. Standing just under six feet tall, of upright bearing, Victor Reuther was a powerful orator, with a resonant baritone voice, and was regarded as the intellectual member of the Reuther family. His politics were to the left of Walter's, and over the years he retained a more radical image as a socialist. Together with Walter and a third brother, Roy, he had been a founder member of the UAW-CIO in the 1930s. He was thus ranged against Jay Lovestone during the factional struggle for control of the autoworkers' union in the late 1930s, when the former communist party secretary worked as chief of staff to Homer Martin and 
supplied him with a network of Lovestoneite organizers, including Irving Brown. Deep personal animosity, the bitter legacy of that period, coloured Reuther's relations with Lovestone and Brown throughout the remainder of their working lives and had an incalculable impact on American labour's conduct of international affairs for a generation. ${ }^{14}$

On winning the presidency of the UAW, it took two years for Walter Reuther to consolidate his hold on the organization. However, by 1948 , as a strong supporter of the Marshall Plan, he was able to turn his attention to international questions, which became the direct responsibility of his youngest brother. To his existing role as UAW education director, Victor Reuther thus added an international dimension as co-director of the US side of the Anglo-American Productivity Council, an outgrowth of the Marshall Plan, under whose auspices he undertook a number of trips to Europe. In 1948, he was also a member of the CIO delegation to the second ERP trade union conference in London, where he took the lead in criticizing the administration of Marshall aid and the program's failure to make the welfare of European workers its top priority. He insisted that Europeans were justified in suspecting ulterior motives, arguing that US aid should not be for the purpose of exporting American capitalism, and concluding that "there must be a full recognition of the right of the people here to establish democratic socialism." Also present that day was Jay Lovestone, who, twenty years later, derided the fact that Reuther had made a "speech for socialism" when this was not an issue for the conference. ${ }^{15}$

Victor Reuther spent a month in summer 1948 travelling in France, Germany, and Austria, taking particular note of the extent to which Irving Brown and the AFL had been able to do a "hatchet job" on the CIO as a result of its membership in the WFTU and its failure to date to have its own distinct presence in Europe. That would need to be corrected. The Reuthers themselves had played no role in CIO dealings with the WFTU, were free from any personal identification with its operations, and were among the loudest labour voices then calling for the CIO to disaffiliate. Equally strong was their backing for the concomitant purge of communist-led unions from the CIO in the wake of multiple differences generated by the Cold War. An opportunity was now opening up to recast CIO international policy shorn of any need for communist apologetics and reflecting the radical democratic values of the CIO, of which the UAW was an exemplar. The idea of having a higher-profile CIO presence in Europe with Reuther, like Irving Brown, performing the role of roving ambassador was beginning to germinate. By the end of 1948 , friends and enemies of the Reuthers in the international field were conscious of the presence among them of a new "big shot" in the shape of Victor Reuther. ${ }^{16}$

His international activities were interrupted in May 1949 when he was the victim of an assassination attempt. He lost an eye and sustained shotgun wounds to his arm 
and collarbone when he was shot through the window of his house in Detroit. Fear for his own and his family's safety now provided an extra reason for him to work overseas in an international capacity. That same year the UAW affiliated to Konrad Ilg's International Metalworkers' Federation (IMF), the union becoming a powerful force and financial mainstay of the IMF. Formerly an organization in which Irving Brown had exercised influence, the IMF would now be the Reuther brothers' international power base, with Victor increasingly on the scene to offer guidance to Ilg and successor general secretaries.

Victor Reuther reappeared in Europe in May 1950 just as his personal reservations about the administration of Marshall aid were beginning to be echoed more generally in the American labour movement. A combined AFL and CIO delegation, commissioned by the ECA to assess the situation in France after two years of pressure for improved productivity under Marshall aid, reported on the program's "serious threat to the welfare of workers" and lack of protection against wage cuts or anything to "prevent the direct benefits of increased production made possible by the Marshall Plan aid from going entirely to the employer." Suggested policy responses ranged from, on the one hand, insistence on the secondment to the ECA/ MSA of American trade union representatives who would provide heft to its labour programs, to, on the other hand, the development of an independent CIO program that would nevertheless be financed from Marshall Plan counterpart funds. ${ }^{17}$ Victor Reuther featured in both approaches.

Speculation that the Marshall Plan's supremo in Europe, Milton Katz, had offered Reuther the post of chief labour advisor to the ECA hung heavily over the FTUC's meeting with CIA director Bedell Smith in November 1950. ${ }^{18}$ Likewise, AFL leaders were fully aware that a proposed international policy program drafted by Reuther was under consideration within the CIO and that he had been named to lead a mission to Europe in January-February 1951 to take stock of what might be needed in a CIO program directed from Paris. As Lovestone suspected, and as Wisner reluctantly confirmed at the November meeting with the FTUC, funding for the CIO's delegation came from the CIA. On delivering the report of the delegation to the CIO in February 1951, Reuther was immediately appointed its permanent European representative, with instructions to open an office in Paris. The FTUC's dramatic walkout from the April 1951 meeting with Bedell Smith, essentially over the role of the CIO, followed just over a month later. Lovestone's stringer in London, Irish-born newspaperman Jack Carney, reported what could only have been unwelcome news: "Victor Reuther is being played up in these parts. He is the new international figure. Walter Reuther at the moment is the darling of both the Tribune and the New Statesman. The guy who can command such varied support is going places." ${ }^{19}$ 


\section{Competing Approaches of $\mathrm{ClO}$ and AFL}

The international program drafted by Reuther for the CIO was intended as a medium-term commitment that would be taken over in due course by the ICFTU. The CIO had no plans to remain indefinitely in the field as an independent player. Its operation was never large; Victor Reuther had a staff of only three-Lew Carliner in charge of publications, Helmut Jockel assisting with work in Germany, and, most importantly, Charles (Chip) Levinson, until recently a technician with the ECA, who would be a close collaborator of Reuther in Europe throughout the 1950s. ${ }^{20}$

Yet from the moment in February 1951 when Reuther was installed in a dingy Paris office at 15 rue du Temple in a run-down district near Les Halles, he set about trying to alter the thrust of US labour activities in Europe, and especially in France and Italy. He rejected the AFL emphasis on wooing national leaderships, the practice of buying the loyalty of those Europeans most willing to denounce communism, and the playing of favourites as between the competing sections of the non-communist labour movement. In contrast, he saw the need to galvanize members at shop floor level to fight for basic union principles. ${ }^{21}$ The focus would be on strengthening union capacity to achieve economic gains by working with the grain of Marshall Plan productivity initiatives when these conformed to trade union principles. The aim was to help build rank-and-file confidence through self-activity and the use of militant action where necessary.

Reuther was critical of the AFL's "negative anti-communism" that left it more adept at breaking political strikes than fighting for better conditions. Rather than engaging in cloak-and-dagger activities, he believed the best way to defeat communism was to build an effective trade union base to represent the economic interests of members, thus leaving them less susceptible to communist demagoguery. The unions needed to put their members' interests first rather than appear as a stage army in the Cold War. "Neither Standard Oil nor Stalin" was the way his brother Walter had put it at the ICFTU founding congress. Taking the wrinkles out of the bellies of the poor was the best antidote to the appeal of communism.

Lovestone and Brown derided Reuther's approach as "belly communism"; it was folly to see communism simply as a product of unfilled economic needs. For them the ideological battle against Moscow had to be waged more directly. AFL activities already under way or in preparation in Italy and France reflected Brown's concern to "take on" the communists. Even in West Germany, where there was little risk that communist policies would enjoy general acceptance, Brown bemoaned the ideological "flabbiness" of the unions and their failure to respond in kind to communist propaganda. It irked Lovestone that Reuther-a "boy scout" with a penchant for clichés about "butter before guns"-had been invited to address the 
1951 May Day rally in Berlin. Lovestone felt it reflected poorly on the judgment of the Deutscher Gewerkschaftsbund (DGB), and it led him to spend some weeks in Germany immediately afterward in the hope of counteracting some of Reuther's "vicious, demagogic propaganda." He reported back to George Meany that Reuther had promised lavish funds for Germany. "Where he expects to get the money you can guess as well as I."22 Meanwhile, Brown's immediate priority for the German labour movement was to encourage the formation of a joint SPD-DGB committee to take inventory of the communist party's strength. He hoped for the establishment of a German "counter-action squad" along the lines of the Mediterranean Committee, charged with weeding out fellow travellers from holding office in unions and works councils, checkmating possible attempts at sabotage in industries such as transport and docks, and organizing anti-communist demonstrations throughout the country. He also wanted to see the DGB put more effort into support for the Ostburo in Berlin originally created by UGO and which he admired for "keeping the Eastern zone pot boiling." ${ }^{23}$

In France, Brown focused on possible organizational splits among the communists, hoping to capitalize on a growing malaise within the PCF that he detected and associated with the extended absence of party leader Maurice Thorez, who had suffered a stroke and was now convalescing in Moscow. In this situation, the PCF was prone to sharp swings in direction between legal-parliamentary and extra-parliamentary activity. The latter was evident in the increase in anti-American street protests occasioned by the arrival of the new NATO commander, General Matthew Ridgway. Events such as the purges of leading party members André Marty and Charles Tillon, accused of being police spies, Georges Guingouin, the wartime resistance leader in Limoges, and Auguste Lecoeur, a leading critic of Thorez's dictatorial style, led Lovestone and Brown to believe in the possibility of destabilizing the PCF from within and the encouragement of splinter movements. "I am a great believer in the notion that the best way to fight the enemy is from inside his own home," Lovestone wrote Brown. To this end, Brown was "running" contacts who were in touch with dissident communists in the North and the Midi and were engaged in building an informal opposition group. Georges Guingouin was prominent among them, and when Auguste Lecoeur was expelled from the PCF, Brown was quickly in contact with him and guiding him to the CIA, a pattern that was to be repeated whenever a prominent communist left the party. ${ }^{24}$

Similarly in Italy, Brown was also keen to exploit internal tensions in the CGIL and capitalize on divisions emerging in the Italian communist party. Rather than it being a task for the non-communist unions, in his view this required a quite separate operation using what he termed a "politico-syndicalist" approach that avoided all publicity. American support would enable a small committee of trade union 
members who still belonged to CGIL unions to publish a journal and build up a secret network of cadres within the centre. He talked ambitiously about "integrating all of the diverse opposition tendencies into a more unified policy approach [to] ... prepare for the next break in CGIL which must come." ${ }^{25} \mathrm{~A}$ practical example was in Trieste, where, on the back of a split among communists between the pro-Moscow majority and a smaller Titoist group, the AFL collaborated with the US embassy in an attempt to help anti-communists win control of the maritime union. In August 1952, Brown and Carmel Offie were in Italy specifically to discuss this project with Ambassador Dunn. ${ }^{26}$

In contrast, Victor Reuther's central concern in France and Italy was to overcome the organizational divide in the labour movement resulting from splits between secular and church-linked unions. Hitherto in France, the AFL had concentrated exclusively on the secular Force ouvrière, distancing itself from the Confédération française des travailleurs chrétiens (CFTC), especially as the latter became more amenable to united front tactics with the communist-led CGT. Seeking a change in emphasis, Reuther hoped to work with both of these non-communist centres and help them develop a more effective labour movement. The CFTC contained a vigorous left-wing minority among its membership attracted by the idea of membership in the ICFTU, and taken as a whole the national centre was a more substantial organization than FO. ${ }^{27}$ In his initial discussions in Europe with Milton Katz, Reuther complained about the way Irving Brown had vetoed ECA-MSA assistance to the CFTC and had also threatened reprisals against any organization accepting help from the CIO.

Reuther faced a more complex situation in Italy. Though dominated by Catholics, CISL was formally a non-confessional organization, and the AFL considered it the best prospect for building a secular anti-communist union movement in Italy. In contrast, Reuther saw CISL as the product of a premature merger pushed through by the AFL in a bid to "colonise" the organization. Italy's Social Democrats and Republicans also regarded CISL as a church-run body and, like Reuther, believed UIL to be a potentially more attractive refuge for CGIL members who might think of quitting the organization out of disillusionment with their communist leaders. UIL had received no help from the FTUC, and Reuther was determined to correct that situation with funding from the Marshall program. At the same time, he hoped to encourage united action with CISL. Before leaving for Europe, he had discussed his thinking with David Dubinsky, and there was agreement between them over the need to change State Department policy in Italy and especially to have Tom Lane removed as labour attaché. ${ }^{28}$ 


\section{Conduits for Marshall Plan/CIA Finance}

Less than a month after establishing his office in Paris, Reuther requested a meeting with Milton Katz and Irving Brown in which he appealed for closer liaison between the two wings of the US labour movement and the ECA along with financial support by the latter for UIL. Brown took great exception to the way the meeting had been called, without an agenda and without any prior attempt by Reuther to reach an agreed trade union position ahead of the meeting. ${ }^{29}$ However, Katz sympathized with Reuther's approach, and, as Lovestone soon gleaned from remarks made by Allen Dulles, the CIA was evidently willing as well to give some encouragement to CIO work in Italy. Lovestone notified Brown that money was going to "Art Goldberg's law firm [CIO] ... I am now convinced that Victor and his friends are operating not only with a lot of Cat Nip [counterpart funds via Katz] but with the aid of substantial injections from Dr Fizzer." ${ }^{30}$ Indeed, the CIO would shortly have two men, Frank Bellanca and Joe Salla, in Genoa examining the prospects for cooperation between UIL and CISL dockers in keeping the port open to American shipping-an operation potentially in competition with Ferri-Pisani's Mediterranean Committee.

This Genoa project was a first, cautious initiative arranged between CIO international affairs director Mike Ross and Tom Braden, who had been appointed head of the CIA's International Organizations Division three months earlier. ${ }^{31}$ In correspondence with Ross, Braden expressed hope that the CIO would do "a hell of a job" but stressed that its two representatives in Genoa were only there on an exploratory basis and were not to impinge on Irving Brown's terrain. This point had been agreed on in advance between the CIO’s Jake Potofsky and David Dubinsky. ${ }^{32}$ Braden noted that the CIA still had doubts about the reliability of UIL, and so he hoped that Bellanca would refrain from making any commitments to the centre. He also stressed the need for Ross to preserve security and to keep word of the assignment from Lovestone: "I have had a couple of complaints about my friendship with you from our New York friend [Lovestone] via a fellow in this town named Sam [Berger].... He seems to know a little but is not sure and has jumped at some wrong conclusions ... so keep it quiet for both our sakes." ${ }^{33}$ In fact, Lovestone was fully aware of Bellanca's presence in Genoa, warning Meany darkly: "There is trouble ahead. We wonder where the $\mathrm{CIO}$ is getting the dough." ${ }^{34}$

Evidence points strongly to further CIO-CIA collaboration later in 1951 in the battle for control of the Finnish labour movement. Lovestone certainly suspected that this was happening through CIO covert funding of the social democrat-led unions. On a trip to the United States in the autumn of 1951, during which he had a meeting with Victor Reuther, SAK general secretary Olavi Lindblom purchased seven Buicks 
and three Chevrolets that were subsequently sold in Helsinki for 1.2 million Finnish marks, making a healthy profit and helping to fund the social democrats' struggle with the communists for control of SAK. Thirty years later, Lindblom recorded in his autobiography that while in the United States he was handed a cheque for \$20,000 that he used to purchase the ten cars. He did not name the donor, though Lovestone's reaction at the time makes it clear that it was not the AFL. ${ }^{35}$

Lovestone was naturally curious as to the source of this donation and confided his suspicions to Brown in a letter reminding him that the AFL was not currently engaged in any transactions in Finland: "As you know, we are no longer in the lumber business [i.e., Finland] . . I do know that the Fizzlanders have become great admirers of the Laplanders." Two weeks later, after further inquiries, he wrote Brown: “The Fizzmaniacs have made a heavy investment in the lumber business but they didn't use our brokerage house. We have nothing to do with that. When you get up to the north country it would be most interesting for you to use your nostrils." ${ }^{36}$ Whether or not the CIO was the source of the initial \$20,000, Lindblom certainly looked to the $\mathrm{CIO}$ for further funding. In a letter to Victor Reuther two months later he described in detail the trade union campaign against the communists in the north of Finland and requested $\$ 65,000$ worth of assistance in kind-preferably in the form of twenty Chevrolets or outboard motors to an equivalent value. These, too, could be sold in Finland and so realize funds for the campaign within SAK. ${ }^{37}$

Whatever encouragement Reuther might have been receiving from the CIA during his early months in Europe, he encountered serious obstruction at US embassy level. The labour attachés in Paris and Rome, Dick Eldridge and Tom Lane, were hostile to his wider aim of working with the French CFTC and Italian UIL, and this forced him to go over their heads and raise the issue with the two ambassadors concerned. In October 1951 he became embroiled in a furious row with Ambassador David Bruce in Paris, and threatened to report the embassy's obstructiveness to higher levels in Washington. Irving Brown dismissed Reuther's petulance as a sign of frustration at the lack of embassy support for his "hair brained schemes." He also made a point of seeing Bruce personally to assure him of the AFL's full backing for his stand against the CIO. Following the clash with Bruce, Reuther also sent a sharply worded letter to Ambassador James Dunn in Rome demanding a change in the embassy's attitude toward UIL and claiming that the centre was "considerably handicapped" by a policy that was both "wrong and unwise." He called specifically for the replacement of Tom Lane as labour attaché and warned that Dunn's response might well need to be discussed between the CIO leadership and the White House. ${ }^{38}$ 


\section{Organizing and Training}

Reuther's detailed plans for 1952-53 revolved around two related projects intended to energize the combined non-communist wing of the French and Italian labour movements and to be conducted under the umbrella of the ICFTU. First, there was to be a concerted and well-funded recruiting campaign. ${ }^{39}$ Supporting this was an ambitious plan for the creation of an ICFTU training college in Europe that would equip a corps of activists and secondary leaders with the skills thought to be lacking among European trade unionists. Yet, as initiatives that would depend heavily on American funding, these ICFTU projects were broached at a singularly inopportune time. Reuther's early months in Europe had coincided with the deterioration in relations between the AFL and the ICFTU following Vincent Tewson's controversial assumption of the presidency. In the ensuing standoff between Meany, on the one hand, and Tewson and Oldenbroek on the other, the AFL clearly regarded Reuther as being in Tewson's camp. Yet, for months, Brown had been warning Oldenbroek that he was making a mistake in treating the $\mathrm{CIO}$ as if it were the equal of the AFL. And as long as he did so, Oldenbroek could expect difficulties because of the AFL's belief that it spoke for the real American labour movement. ${ }^{40}$ Now Reuther's suggested organizing and training program was unveiled precisely as AFL-ICFTU relations hit rock bottom and the AFL began its year-long boycott of the ICFTU.

These two CIO-inspired projects were particularly contentious because of the way they were to be financed. The organizing drive alone was expected to cost up to $£ 50,000(\$ 140,000)$ at a time when the ICFTU's total budget for activities in Europe was only a tenth of that. The balance would need to come from the new Regional Activities Fund (RAF), but the AFL had withheld any contribution, while harbouring grave misgivings about the source of the CIO's proposed contributionsome $\$ 200,000$ (later officially recorded as $\$ 150,000$ ).

The CIO had announced this contribution following a meeting of its international affairs committee in November 1951. In the course of the meeting it became evident that the CIO did not have such an amount to spare. Mike Ross then explained that the CIO's three-man delegation to Europe led by Victor Reuther earlier in the year had been paid for from government funds, a fact that most committee members were probably learning for the first time. It was in this context that the meeting agreed that a delegation comprising President Philip Murray, International Affairs Committee Chairman Jake Potofsky, and Walter Reuther should see "top people in Washington"-meaning MSA Administrator Averell Harriman, now based in the White House and responsible for ironing out differences between the CIA and MSA. That meeting with Harriman would review CIO complaints about the obstruction 
Victor Reuther was encountering in the Paris and Rome embassies, but it would also be about access to counterpart funds for the CIO's overseas program..$^{41}$

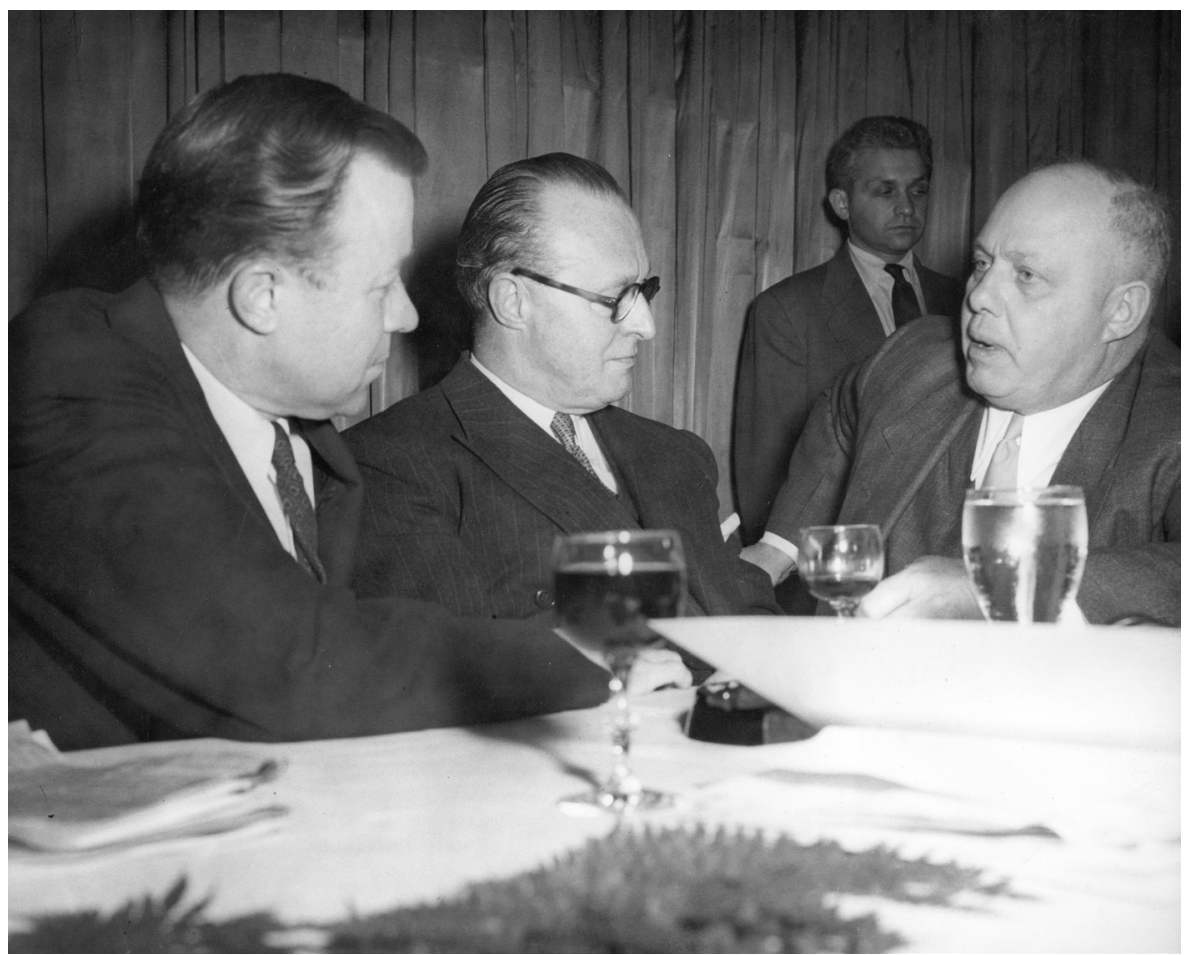

Figure 3. Walter Reuther (left), Vincent Tewson, and George Meany, at the December 1952 meeting of the ICFTU executive board. In the standoff with Meany, Tewson was assumed to enjoy the sympathy of Reuther and the CIO. Courtesy of the Walter P. Reuther Library, Archives of Labor and Urban Affairs, Wayne State University.

From the outset Lovestone doubted that the CIO's much-publicized $\$ 200,000$ pledge to the RAF could be met from union funds. He challenged CIA deputy director Alan Dulles on this and suggested knowingly that the agency had made "a very handsome Christmas present to Sir Vincent Oldenbroek." Dulles protested that he knew nothing of such a gift: "It was without my knowledge." But as Lovestone observed, it was a "typical lawyer's answer, and not a categoric denial that would withstand a lie detector test." 42 In the intensely competitive climate of the period, the AFL leadership also arranged to meet Harriman in January 1952, aiming to block any concessions that he might be inclined to grant following the CIO's representations. At the AFL meeting with the MSA administrator, Lovestone challenged Harriman 
and his labour advisor, Sam ["the Prophet"] Berger, as to the basis on which Victor Reuther had "joined the nouveau riche set." Harriman chose to interpret this as a question about MSA funds for UIL and denied that any had been agreed. But Lovestone remained suspicious of the entire basis of CIO international funding, telling Brown that: "there must have been some blood transfusion into Victor's carcass by the Fizz maniacs." 43 In reality, the $\$ 200,000$ figure was still only a pledge, and although government funds had yet to be paid over, Lovestone was undoubtedly correct in suspecting that the CIO was angling to obtain a good deal of its finance for international work from US government sources. ${ }^{44}$

In other respects, the meeting of the AFL leaders with Harriman left them satisfied that there would be no significant concession to the CIO's approach in Italy. According to Lovestone, they had received assurances from Harriman that "the firm employing the Prophet [ECA/MSA] would do nothing to assist the UIL except perhaps on occasion include one of them on a team or trade union outfit visiting our country for ECA. [. . . W We were pledged . . . there would be nothing down there now which would give the impression of pursuing an anti-AFL course."

The AFL also successfully argued against the CIO's call for the sacking of labour attaché Tom Lane. This was a measure of the AFL's hostility toward the CIO, since the federation also greatly resented the role played by Lane and regarded his profligate distribution of cash to CISL as counterproductive. Yet George Meany spoke out against replacing the labour attaché; it was evidently more important for him to prevent the CIO from being able to claim a victory in securing Lane's scalp. ${ }^{45}$ Not only did the AFL trump the CIO in these encounters with Harriman, it also retained the edge over the $\mathrm{CIO}$ in dealing with the CIA. True, Lovestone was losing influence within the NCFE, but Brown was recalled to Washington in March 1952 for top-level meetings with Dulles at which he would "go over the entire European situationlibrary, budgetary and every other way." There was to be no equivalent meeting involving Reuther and the agency. ${ }^{46}$ While in Washington, Brown also consulted the AFL leadership over the boycott of the ICFTU that had just begun. But Lovestone knew that the CIA business was the principal reason for Brown's trip and so insisted that his travel expenses claim be submitted to the agency. ${ }^{47}$

Initial planning for the ICFTU's CIO-inspired organizing project began in January 1952. Having failed to contribute to the RAF, the AFL was never more than peripherally involved. In any case, as a born conspirator, Irving Brown was wary of open discussion of such plans for organizing, even within the ICFTU. Confidentiality was paramount, and he doubted that a committee of fifteen trade union representatives could maintain the secrecy he felt was essential. Unsure of whether to participate at all, he turned to Lovestone and was told to attend the meetings but not to speak. Lovestone's instruction captured perfectly the FTUC attitude: "Keep them in suspense. 
Don't show your hand. Hear what is being planned. You can act later. But patience will only lend interest and in some cases promote anxiety." ${ }^{88}$ The AFL's boycott announced shortly afterward certainly ratcheted up the degree of anxiety felt in the ICFTU while confirming Brown in his role as a mere spectator.

In contrast, Victor Reuther took a leading part in planning the organizing drive. Focusing on Force ouvrière in the first instance, the strategy was to help its industrial federations become more effective bargaining agents under new French collective bargaining law and thus able to deliver greater benefits to their members. In part, unions were encouraged to increase their level of dues and professionalize their services to members, with the ICFTU providing a subsidy to offset any short-term loss of dues income. The plan envisaged FO achieving financial self-sufficiency by 1954 as a consequence of an expanding membership attracted by collective bargaining gains. The fond hope was that in the foreseeable future the combined strength of the non-communist unions-FO and CFTC-would more than match that of the CGT. ${ }^{49}$ In broad outline this was also a project to woo French workers from their historic, exclusive reliance on political mobilization with the pursuit of benefits through national legislation and to steer them toward a state of self-reliance through devolved collective bargaining activity. The real test would be in Marshall Plan "pilot plant" schemes intended to raise levels of productivity based on new methods of working and higher negotiated wages..$^{\circ}$

Reuther proposed a coordinating role for the international trade secretariats in organizing specific industries. Yet only the International Metalworkers' Federation (IMF) was primed to begin activities, having a costed program and a modest budget of $\$ 18$,00o (two-thirds intended for France, one-third for Italy). Reuther himself, as the American representative on the IMF executive committee, had become a powerful voice, exerting a strong influence on the aging general secretary, Konrad Ilg, and he was given to making pronouncements in the name of all the IMF's American affiliates. Through his prominent role within the IMF, Reuther hoped to establish a presence among Italian metalworkers belonging to CISL, whose secretary, Franco Volonté, had requested \$30,000 to finance organizing activities. Konrad Ilg responded with an offer of assistance for organizing at FIAT and other key plants, conditional on Volonté accepting an IMF “controller.” But when Ilg informed him that he had Reuther in mind for this task, Volonté replied pointedly that the union would prefer someone it regarded as a "friend." Shortly afterward, public statements critical of CISL made by Reuther caused offence and CISL secretary Pastore was led to complain to Oldenbroek. The CIO's hoped-for entrée to CISL was killed off at birth. ${ }^{11}$

Meanwhile, Brown looked in vain for ways of blocking Victor Reuther's influence in the IMF. His once-prominent position within that trade secretariat had faded, 
but he encouraged the machinists' international representative, Rudy Faupl, to play a more energetic role. When that ploy failed, he tried to exploit a growing divide between Reuther's autoworkers and the steelworkers' union by siding with the latter's international representative, Elmer Cope, in IMF policy discussions. AFL reckoning was that Victor Reuther didn't always act with full CIO authorization and that existing animosities within the organization could perhaps be intensified. As Lovestone observed: "I think Victor is playing a lone hand in a number of situations." ${ }^{2}$ In Italy, Brown stepped into the breach left by Reuther's failed attempt to woo CISL's metalworkers: by the end of 1952, with his own source of funds, he was channelling $\$ 1,500$ a month to Volonté with the promise that a longer-term package of help might be put together in early 1953. In addition, he was making efforts to bolster the standing of the social democrat minority in CISL, who had been treated as outcasts by their own party during the formation of UIL. Brown's purpose was to counter the persistent charges that CISL was a purely Christian organization. ${ }^{53}$

Given the scale of the task it set itself, especially in France, the CIO's strategy for organizational change was never likely to achieve much in the short run; indeed, the high hopes that the non-communist metal unions operating within the MSA pilot plant scheme for steel foundries would point the way forward soon proved to be illusory. The scheme's success depended on workers gaining through collective bargaining a "fair" share of the benefits of rising productivity. However, French employers resisted such an outcome while, within the Marshall Plan, American business interests drowned out the voices of labour advisors who argued for a better deal for the French unions. Within a few months, Reuther was forced to conclude that the pilot scheme was "a disgrace ... a labour exploitation programme," while his assistant, Charles Levinson, warned of the damage that was being done to the FO metalworkers by their participation: "If it continues you can kiss FO goodbye within a year." ${ }^{54}$

Reuther then pulled the plug on the pilot plant scheme by withdrawing his support, in the process helping to promote a successful revolt among FO metalworkers against continued participation by the organization's confederal leadership. By the end of 1952, FO and UIL had withdrawn from the French and Italian pilot schemes, the French Christian CFTC was deeply disaffected by its experience, and the CISL leadership was under strong rank-and-file pressure to redefine its approach to the issue of productivity. By changing tack and helping to extricate FO and UIL from involvement in the pilot schemes, the CIO had preserved its own credibility. However, in the process Reuther had ruffled the feathers of some senior trade union figures, especially in France.

The CIO's proposal for the establishment of an ICFTU training college in Europe was no freer from AFL criticism than had been the scheme for organizing. The MSA 
was prepared to make significant funding available for the project, but only on the basis that the AFL and CIO cooperated in the venture. Yet the "team psychology," as Lovestone dubbed it, was unacceptable to the AFL, which refused to support the ICFTU project. Brown saw the college as an "an abstraction," its emphasis on classroom instruction simply serving to provide cover for the "factional work" that Reuther was planning to undertake with Marshall Plan money.55

In contrast to the standard fare of training for organizing, administration, and collective bargaining in the ICFTU scheme, Brown favoured a more ideological curriculum. A flavour of his preferred approach to training can be glimpsed from his own plans for activity in the Lyon area of France. With its important armament firms, chemical plants, coal mining, and railway centre, it was a key location in the rearmament program that accompanied the Korean War. As Brown reported to the FTUC, he was concerned to ensure that anti-communist forces were strong enough "to protect the major industries in the area." His proposal was to send carefully selected activists from Lyon across the Swiss border to Geneva to attend the Centre d' education syndicale internationale, where his close associate, Lucien Tronchet, the Swiss building workers leader, ran what Brown freely conceded were "indoctrination programmes." The aim was to strengthen the anti-communist forces in Lyon by having one or two trained men in each factory, a vanguard highly conscious of their membership in an activist network. ${ }^{56}$

Denied the funds for a full-fledged college, the ICFTU was forced to scale back its training plan. However, it acquired from the Swedish trade unions a residential home, La Brevière, in the Compiègne woods close to Paris, and there launched a first training program from March to May 1952 for 126 militants from FO's mining, transport, and metalworking unions. The ICFTU kick-started the program with \$22,000 allocated from its Regional Activities Fund, while simultaneously seeking ways of tapping into Marshall Plan funds to sustain the program over the longer term. To this end, assistant general secretary Hans Gottfurcht and Walter Schevenels, now the secretary of the ICFTU's European Regional Organization, were in close contact with MSA officials in trying to identify ways of securing grant aid for the project. The ICFTU's ploy was to set up an Educational Trust Fund registered in the United States through which to attract money from government sources and charitable funds. It prompted a warning from Lovestone: "the contamination of Schevenels in his present position and his present manipulations will go a long way towards estranging our relations with the European movements." Within the ICFTU, Brown argued against seeking funds from government sources, as distinct from grants from charitable trusts. Yet Brown's position offered no foolproof solution, and Matt Woll still worried that the Ford Foundation, run by what he described as "subversive" elements, might serve as a conduit for MSA money to the ICFTU.57 
Headed up by former ECA Administrator, Paul Hoffman, the Ford Foundation had indeed become a home-away-from-home for Marshall Plan alumni following government service, providing continued funding for several projects that had originated as part of the aid program. Particularly troubling to the AFL was that Clinton Golden, former CIO vice president and until recently chief labour advisor to the ECA, had become a Ford Foundation trustee and that the former Marshall Plan supremo in Europe, Milton Katz, was now associate director of the fund. The MSA and the Ford Foundation were indeed combining in an effort to channel funds to the ICFTU Trust. Katz persuaded Sam Berger to encourage both AFL and CIO to apply for Ford funding for educational programs. The proviso was that the two centres would have to agree to act as joint trustees over what Lovestone termed "any assistance to be given to Sir Vincent's stockholders overseas." When Berger put the suggestion to him, Lovestone turned him down flat, claiming to be concerned to protect the ICFTU from any taint of sub rosa funding. As he explained: "what I am afraid of is that all this will enable the Commies in their typical demagogic fashion to denounce the [ICFTU's] Brussels bureau as a Ford international., 58

With or without an ICFTU Educational Trust Fund, Reuther was determined to access MSA funds, and in June 1952 the MSA channelled \$23,000 to the ICFTU via his Guarantee Trust bank account, without mention of the original source. Oldenbroek gratefully recorded that "trade union circles in the U.S.A." had donated the sum: "The CIO has paid the money into our account on behalf of the donators [sic]." "The "CIO" gift was almost identical to the cost of the first series of courses at La Brevière, and its availability enabled the ICFTU to avoid scaling back the courses to weekends only. Indeed, it was now possible to roll forward the training program into the autumn of 1952. "I'm sure you know what that means," commented Brown in forwarding the news to Lovestone. "This sum of money ... is only one of many others which have been spent or squandered in France." However, he also noted that there was no "Fizz" involvement in the transaction: these were "sugar funds" courtesy of the Marshall Plan. ${ }^{60}$

Yet CIA funding was still needed if the La Brevière program was to continue to the end of 1953, thereby training 840 additional activists as planned. To this end, sometime in the summer of 1952 Tom Braden of the International Organizations Division travelled to Detroit and passed $\$ 50,000$ to Walter Reuther for use by Victor Reuther in assisting unions in France and Italy. This CIA transaction was revealed by Braden fifteen years later in a bid to counter allegations by Victor Reuther of more recent CIA funding of AFL-CIO international work. ${ }^{61}$ On top of this, additional funding for the CIO appears to have been arranged by Ford Foundation trustee Clinton Golden. It was donated under the Ford label although it actually originated from the Michigan Fund-a CIA front. ${ }^{62}$ 
At Reuther's insistence, ICFTU training at La Brevière was extended to CFTC as well as FO members. As he hoped, one of the consequences was to increase the prospects for joint activity between the two centres. However, his efforts in support of the more left-leaning section of the French Christian trade unions had contributed to a near split in the CFTC in 1952, and his attempt to force the pace of non-communist trade union cooperation in the metal industries antagonized the leadership of both FO and the CFTC. Early in 1953, the two general secretaries, Robert Bothereau (FO) and Maurice Bouladoux (CFTC), were considering a formal protest to the CIO over such interference. Reuther had also upset a section of the FO metal union, for which he was widely criticized at the IMF executive committee. As Irving Brown reported, "the red headed American saviour has been somewhat rebuffed." IMF general secretary Ilg complained that Reuther tended to support only the activities by the federation that he, himself, controlled. On the other hand, Ilg's deputy, Henry Svensson, apportioned the blame equally between the AFL and CIO, arguing that their rivalry had reduced the effectiveness of any organizing campaign among French and Italian metalworkers. Reuther was certainly unafraid of stepping on others' toes, and CFTC president Gaston Tessier, for one, made it clear that he would be happy to see him return to the United States. ${ }^{63}$

Yet Victor Reuther could claim that he had reinforced American links with the more militant sections of the French Christian trade union movement. That would pay dividends in the long run as the strength of church influence waned. Likewise in Italy, CIO support for UIL certainly reinforced the determination of its social democratic members to retain organizational independence and so offer a potential refuge for socialist members of the CGIL disenchanted with their own communist leadership. In early 1953 Reuther was pressing within the CIO for expansion of the European program, seeking an increase in the budget to $\$ 4,000$ per month (a 30 percent rise) and requesting the appointment of a full-time representative in Italy and other staff with responsibility for specific industrial sectors in Europe. ${ }^{64}$ At the same time, Bill Kemsley of the MSA education branch, and a close ally within the UAW, had secured a grant of $\$ 118$, oo for the IMF to train organizers to work in the French and Italian metalworking industries. Despite a rear-guard effort by Irving Brown and Rudy Faupl of the IAM to hold up approval of the program, a contract to finance the scheme was signed in the summer of $1953 .{ }^{65}$ The CIO office in Paris was now effectively the base for the IMF campaign in France, with Reuther directing ten full-time organizers in the field and, in provocative fashion, attributing the recent progress made to the absence of the AFL from the ICFTU organizing drive. This had been a great help. "Ever since the end of the War the strong trade union centres in Europe have had a hopeless attitude about what might be done 
in France and Italy," he told the CIO international affairs committee.$^{66}$ Fortunately that phase had now ended.

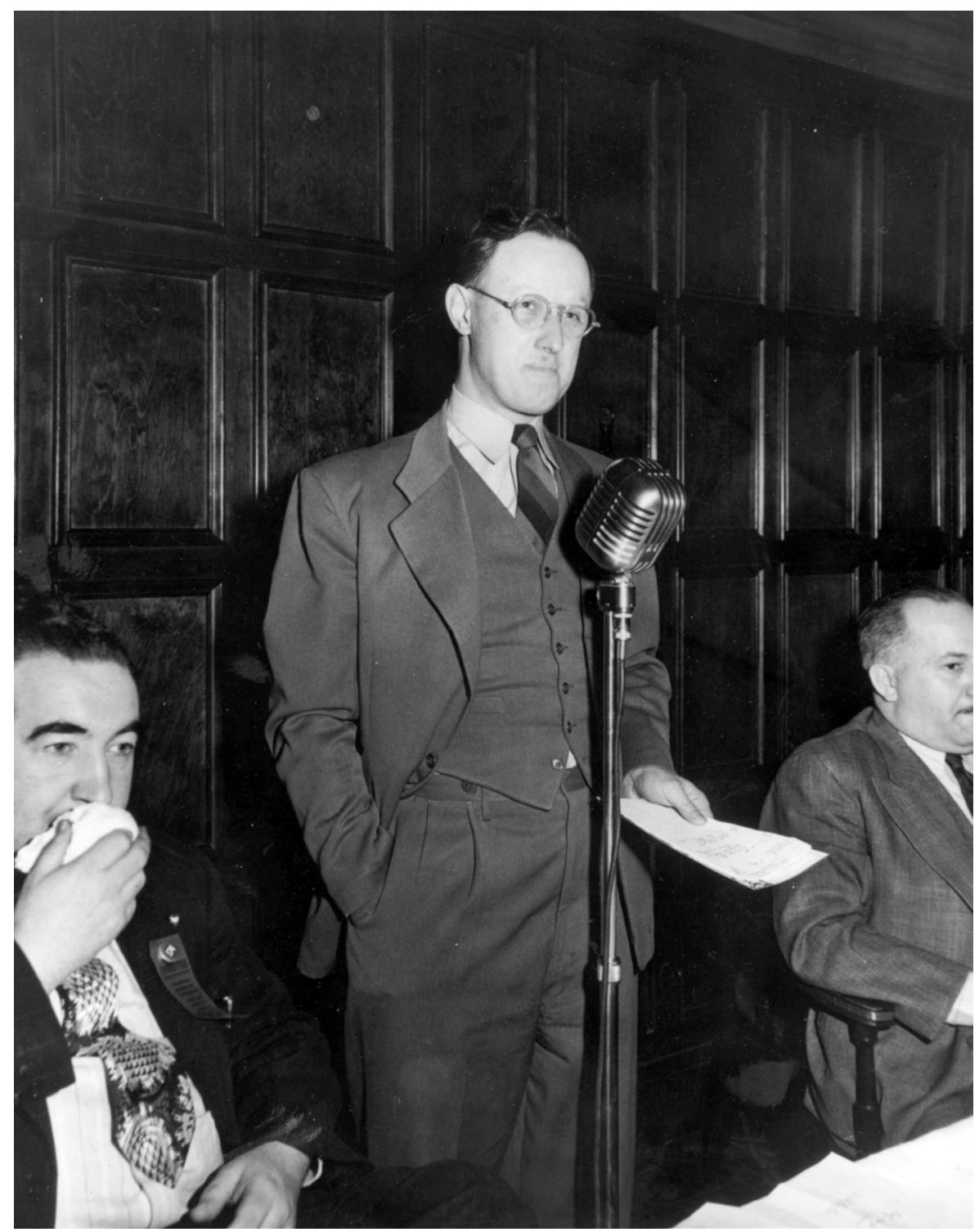

Figure 4. Victor Reuther, the key figure in the CIO's overseas operations-a "big shot" to Mike Ross, a purveyor of "vicious, demagogic propaganda" to Jay Lovestone. Courtesy of the Walter P. Reuther Library, Archives of Labor and Urban Affairs, Wayne State University. 


\section{International Issues and the "Unity Process"}

If persistent conflict between AFL and CIO marked their relations in the international field, the trend was different in domestic affairs. By the early 1950s, philosophical and policy differences that had divided the movement since the mid-1930s were fading, and when in November 1952 the old guard leaders, Bill Green and Phil Murray, died within weeks of each other, to be replaced by George Meany and Walter Reuther, prospects for rapprochement were greatly enhanced. Immediately following his election as AFL president, Meany announced that his only instruction from the executive council was to seek reunification of American labour and that he was willing immediately to appoint members to a joint unity committee to negotiate with the CIO. Two weeks later, Reuther also endorsed the objective of unity and agreed to formal talks beginning in $1953{ }^{67}$

Throughout this process, which moved forward by fits and starts over a two-year period, it was Meany who showed the most commitment to unity. Early on he sensed that Reuther might merely be going through the motions and warned him that he would not spend an undue amount of time on the talks if there were no likelihood of progress. ${ }^{68}$ Reuther's lack of decisiveness reflected the diminished strength of the CIO following the expulsion of communist-led unions in 1949 and the relative weakness of his own position, subject as he was to constant sniping from opponents unreconciled to his leadership and critical of his style. As a consequence the CIO president's hand in negotiation with Meany was weakened.

In February 1955, agreement was reached in principle to merge by the end of that year, though to the very end Meany feared that Reuther might be looking for a way out. The most contentious matter-international affairs-had been left to the last and still remained unresolved. This troubled Reuther, though Meany seemed less concerned, confident of being able to "handle" it to his satisfaction with the help of Reuther's less ardent CIO union colleagues once the merger was complete. Even before the name of the organization had been formally agreed on, Meany was certainly assured enough to instruct builders to inscribe "American Federation of Labor-Congress of Industrial Organizations" in marble on the new Washington headquarters then under construction.

Throughout the negotiations, the conduct of international affairs was the subject of a fierce internal struggle, the two centres vying for advantage on key issues. Most contentious were the related questions of whether the new centre should continue with an independent program of activities through the FTUC and how the merged organization would relate to the ICFTU. Still in its infancy, the ICFTU was struggling to make an impact in the first half of the 1950s. The absence of cohesion between the two American affiliates and George Meany's deep mistrust 
of General Secretary Jaap Oldenbroek created fundamental problems. Against this background, the prospect of a unified American labour movement captured the imagination of many Europeans, offering hope that the large affiliates would then all "get behind" the ICFTU. ${ }^{69}$

Following his election as $\mathrm{CIO}$ president, Walter Reuther recalled his brother from Paris and in October 1953 appointed him as his administrative assistant based in the CIO's Washington headquarters with responsibility for the international field. The Paris office was closed at the end of 1953, with Victor Reuther's assistant, Charles Levinson, transferring to the IMF staff. Though it appeared to reflect a scaling down of CIO ambitions abroad, Walter Reuther claimed it signalled a "considerable increase" in the CIO's international effort, now to be channelled into ICFTU programs. ${ }^{70}$

In late 1953, the CIO revived the idea-dormant since 1950-that the TUC, AFL, and CIO, the "big three" affiliates, should each appoint an ICFTU assistant general secretary and so help strengthen the Brussels secretariat. Victor Reuther told his CIO colleagues that the ICFTU was "in crisis and cannot survive if something is not done to strengthen it." Most understood the proposal to mean that Irving Brown and Mike Ross would fill the posts earmarked for the AFL and CIO. ${ }^{71}$ It offered a way of tackling the problem of rivalry between the two centres. Through this proposal, the CIO was also hoping to reset the agenda for the discussion of international issues in what were proving to be difficult negotiations over unity conducted with a weak hand.

CIO secretary-treasurer Jim Carey worked hard to sell the proposal, discussing it with Meany, Tewson, and Oldenbroek. Claiming a greater consensus than was in fact justified for the principle of "all through the ICFTU," Carey kept up the momentum by submitting the proposal for adoption at the ICFTU's executive board meeting in November-December 1953. It was presented as a formula for the "intensification of the work and strengthening of the personnel of the ICFTU secretariat." ${ }^{22}$

Initially, Carey's enthusiastic "boosterism" caught the AFL off guard, causing uncertainty and a hint of disagreement in FTUC ranks. Always less committed to the independent program and financial link with the CIA than his FTUC colleagues, Dubinsky was already querying whether it was wise for the FTUC to be providing help on an almost permanent basis to organizations such as the Mediterranean Committee. Defensively, Brown reassured him that the CIA funding was on a diminishing basis and the organizations concerned were beginning to show signs of self-sufficiency.73 Dubinsky was also open to the CIO's proposal for additional assistant general secretaries and was willing to give it a year's trial. He supported the idea of Irving Brown being one of the appointees, proposed recalling Henry Rutz 
from his field posting in Germany, and was already cutting back on the ILGWU's material help to the FTUC.74

Distracted by the unity negotiations, Meany also dithered over the CIO proposal, unwilling to reject it but unsure of how to respond. The result was that for a time in October-November 1953 uncertainty began to surround the future of the AFL's independent program. ${ }^{75}$ Meany seemed willing to consider having an AFL appointee as ICFTU assistant general secretary, if only to keep a close watch on Oldenbroek. But his readiness to abandon the independent AFL program was more in doubt, and deep down his animosity toward the ICFTU was undiminished. Walter Reuther was convinced that Meany would abandon the ICFTU if he could do so without wrecking the free trade union movement. ${ }^{76}$

Lovestone was very conscious of the danger posed by the CIO initiative, viewing it as a ploy to disguise its "defeat" in Europe while at the same time neutralizing the AFL. He told Brown: "Our reports are that there is a desperate and expanding drive, particularly against you by Victor and his friends and that no effort is being spared to have you close your office at the same time that the CIO closes its Victor record shop." He scoffed at the idea of Brown going to work for the ICFTU: "no self-respecting union official (other than a refugee) would work with Oldenbroek with his temperament, arrogance, sneer and incompetence." And as for the proposal that the TUC should also be entitled to appoint an assistant general secretary, it was "too silly for words," since the person currently in post, German-born Hans Gottfurcht, who had spent the war in London, was now a naturalized Briton.77

He pulled out all the stops in arguing within the FTUC for a continuation and expansion of the existing independent program, managing for the time being to restore unity in the committee. The key to bringing Dubinsky back into line was Lovestone's argument that the AFL should not renege on its policy of opposition to "big power" domination of the ICFTU that was implicit in Reuther's proposal. This was a point on which the AFL had been consistent from the outset. ${ }^{78} \mathrm{He}$ also made much of the fact that Omer Becu, the ICFTU president recently elected with strong AFL backing, had not been consulted by the CIO. Becu had heard of the "all through the ICFTU" approach only late in the day and was annoyed to find that it had been placed on the agenda for the next executive board meeting, the first board meeting over which he would preside..$^{79}$ FTUC officers were thus persuaded that Jim Carey's advocacy was not motivated by a genuine concern for the ICFTU but was merely a factional manoeuvre. As the AFL's spokesman at the executive board, Brown was instructed not to oppose the proposed increase in the number of ICFTU assistant general secretaries, but neither to seek a post for the AFL. Brown congratulated Lovestone for holding the line and having "prevented a calamity ... a 
lot of important work would have been wrecked by any summary closing up of our independent work abroad."

Discussion of the CIO initiative at the ICFTU's November-December 1953 executive board reflected a general mood of caution. The TUC and AFL both steered clear of any reference to that part of the proposal to end independent activities. Mike Ross's presentation of the CIO's case for structural reform of the ICFTU was generally regarded as lacklustre, giving Brown the impression that he was neither committed to it nor personally interested in becoming an assistant general secretary. Playing for time, Brown called successfully for more consultation.

That meeting proved to be the high point for the CIO's proposal to strengthen the ICFTU secretariat. Support for it drained away noticeably in subsequent months. Within the CIO executive board, the Reuthers fulminated against "the Lovestone crowd" whose "evil influence" would keep the ICFTU "ineffective and in constant turmoil." "This is the last International," insisted Victor Reuther, and only the CIO working with the TUC could save it. "The alternative is to let Lovestone nullify every step and let the ICFTU die." ${ }^{{ }^{81}}$ Attempting to keep the proposal alive, Walter Reuther offered to attend in person the next discussion scheduled for the ICFTU emergency committee in March 1954 if George Meany would also attend. However, Meany was unavailable, and he later noted that for several months thereafter Reuther seemed to lose interest in the unity process, missing meetings and seeing little of his opposite number. It was clearly related to CIO disappointment over AFL refusal to cooperate in the international field. ${ }^{82}$

\section{Defence, Rearmament, and Soviet Communism's “New Look”}

Of course, how the AFL and CIO related to the ICFTU was all about means to an end. The end in question - the objective of international trade unionism-was still very much a matter of contention. For the AFL, everything was secondary to the battle against communism, whether waged through a reformed ICFTU or independently. All issues were judged in terms of whether they helped or hindered that fight. And from Stalin's death in March 1953, with the "new look" emanating from Moscow suggesting that his successors might be bent on a more emollient approach, the key issue for the AFL was the danger of the West letting down its guard in response to this changing climate.

Six months into the merger negotiations, George Meany and Walter Reuther passed through London en route to the July 1953 ICFTU congress in Stockholm and were entertained separately at the House of Commons, following which both gave press conferences. Their important differences over international policy could not be disguised. Asked by British reporters about Prime Minister Churchill's interest 
in East-West dialogue, Meany answered with a disparaging reference to Neville Chamberlain: "We do not want appeasement with a long cigar any more than with an umbrella." By contrast, the following day Reuther told the press that free nations had a moral responsibility to explore every possible means of talking out the world's problems. He was also dismissive of Meany's fear of appeasement; no responsible leader in Europe was advocating it..$^{83}$

At the Stockholm congress itself, Meany's differences with the TUC's Vincent Tewson over the threat of communism were also on full display, their set speeches at the opening ceremony parading divergent assessments almost as point and counterpoint. Tewson welcomed signs of a change in the attitude of the new Soviet leadership, while Meany insisted that a tactical switch did not mean an accompanying change in the basic Soviet aim of world domination. Tewson was for caution; Meany insisted it was no time for backsliding under the pretext of caution. Tewson warned against talk or action that undermined the promise of international talks; Meany noted that no dictator in history had ever been converted to a policy of reason or human decency by appeasement. ${ }^{84}$ An editorial in the AFL News-Reporter subsequently commented witheringly that Tewson's presidency of the ICFTU had "disappointed those who had expected the ICFTU to assume an aggressive role and take a firm stand in international affairs opposing communism." ${ }^{85}$

In dealings with mainstream European labour leaders-deep-dyed anti-communists almost to a man (there were no women in this world)-Meany would still shake his head at their tame acceptance of big power spheres of influence as defined by the Yalta agreement and the "false notions" of co-existence now being promoted. Writing in the Free Trade Union News, he expressed "deep shock" at British Labour's support for the recognition of communist China. In a litany of wrongs, he found it guilty of "appeasing, rewarding, recognizing, banqueting or doing 'business as usual with totalitarian aggressors" while all the time exuding "apathy, appeasement, complacency, neutralism and a false sense of security." With some bitterness he maintained that too many Europeans were attracted to totalitarian Russia and China even as they turned their back on America "because we do not pretend to be socialist." In his formulation, they preferred "socialism without democracy" to "democracy without socialism." 86

In Europe, attitudes to the proposed European Defence Community (EDC) and especially German rearmament were the litmus test. Irving Brown worried about an emerging perception among European workers that the main danger came from the burden of defence spending rather than from Soviet communism. From France, where "peace campaigns" were much in evidence and the National Assembly refused to ratify the EDC Treaty, Brown reported in alarmist terms that the country was in "complete chaos and confusion politically ... and morally" and "practically 
three-quarters in the Soviet camp." Even formerly reliable Force ouvrière leaders such as International Secretary André Lafond were reckoned to be losing their political bearings on the question of the EDC. ${ }^{87}$

In Brown's view, the political situation in Italy was no better. There his main effort was to establish a program to train an elite force of disciplined, anti-communist trade unionists at FIAT's Turin plant, capable of standing up to the communist leadership in the workplace and "politically and physically ready to fight and resist to the end." This initiative was meant to complement the US government's offshore procurement policy for Italy under which US defence contracts would only be awarded to firms that committed themselves to a policy of weeding out communists from their workforce. Brown was successful in persuading FIAT management to cover 50 percent of the cost of the program but was unable to win backing from the US embassy in Rome or the CIA to match FIAT's financial contribution. ${ }^{88}$

In Germany, the death of Kurt Schumacher in 1952 had robbed the social democrats of their most effective anti-communist leader, and Lovestone and Brown were unimpressed by those about to take the helm. "Pygmies on parade" was Lovestone's assessment of upcoming figures such as Willy Brandt, Fritz Erler, and Carlo Schmidt. ${ }^{89}$ Whereas the Reuthers were clearly supportive of the SPD, there was little AFL enthusiasm for the party in the 1953 federal elections, where the social democrats went down to defeat. Lined up solidly behind the SPD, the DGB also disappointed the AFL, with Brown complaining that it continually punched below its weight and failed to speak out against Soviet foreign policy. When, following the 1953 election, Chancellor Adenauer threatened to retaliate for the (formally non-party) DGB's partisan support for the SPD by fostering a rival Christian trade union organization, it was to the Reuthers that the DGB leadership first turned for assistance..$^{90}$ Yet it was from George Meany that the centre received its most effective backing.

The DGB's relationship to the SPD hardly followed the Gompers maxim of rewarding friends and punishing enemies, but Adenauer's threat to split the movement was too much for Meany to countenance. He promptly delivered a stern warning to the chancellor and urged the German people: "don't let this government take the first false step which will lead ... down the path to war." ${ }^{\text {'1 }}$ DGB chairman Walter Freitag privately acknowledged that Meany's intervention had saved the unity of the German labour movement, but his organization remained wary of the AFL. As Lovestone complained to former Schumacher aide, Fritz Heine:

Your colleagues continue to be plagued with the notion that the $\mathrm{CIO}$ is the more progressive organization, the more militant. Perhaps some of them have the notion that they have more Socialist ideology in common with them.... That ... doesn't bode well for international labour understanding and cooperation..$^{92}$ 
The DGB's continuing wariness of the AFL was evident from its resistance to the Americans having a seat on the ICFTU's German-led "Berlin Committee" set up after the Berlin uprising to extend the ICFTU's intelligence-gathering activities in the Eastern zone and to foster links with anti-communist groups there. The committee's German chairman, Albin Karl, justified the DGB stance, saying that Irving Brown's approach to the task in hand went beyond trade union work and involved "politics." For Brown, this highlighted "the nasty side of the Germans": not only were they against the AFL, he wrote, but also against those among their own members who were "really fundamentally and basically anti-communist." ${ }^{93}$ The deep resentment that George Meany would later show for the German labour movement's lack of gratitude for American favours rendered can be traced back to this period.

Once the French National Assembly had rejected EDC Treaty, it was no longer possible for the German labour movement to avoid discussing as an alternative the idea of rearming the country under the 1954 Paris Accords and, beyond that, German membership in NATO. Adenauer made an unprecedented visit to the DGB headquarters to appeal personally to Walter Freitag for support for the policy, but to no avail. At Brown's urging, Meany then went over the head of the DGB leadership and issued a public "appeal" to German trade unionists, arguing that the Paris Accords were the "indispensable next step in developing international democratic unity ... to deter further Soviet aggression" and that "the readiness ... to defend one's own free country and to cooperate with other people in the preservation of peace ... must never be confused with aggressionist militarism." 94 The appeal had a major impact: it was seized upon by Adenauer, who quoted it approvingly in a speech ahead of the ratification vote in the Bundestag and urged all German workers to read it. Christian Democrat deputies welcomed it in the debate on ratification, and trade unionists among their ranks backed the government line, thus guaranteeing ratification of the accords.

Lovestone travelled to Germany to be present for the Bundestag vote and boasted that Meany's appeal had hit the country "like a thunderbolt." It was, he wrote, "one of the soundest, timeliest, most helpful, effective and historic steps ever taken by the AFL in international affairs." The AFL's voice was the "first and only voice" raised against opposition to the accords. The ICFTU was silent and the TUC was "floundering leaderless and without a sense of direction or inspiration." ${ }^{95}$ After meetings with top leaders of the SPD and DGB, he reported home optimistically that the worst, in terms of relations with the German labour movement, was over. Whether the DGB leadership would now come to trust the AFL remained to be seen. But there could be no doubt that Meany's intervention had helped forge an important bond between himself and Chancellor Adenauer that would grow in importance over the coming decade. While the Reuthers looked to Willy Brandt as a future leader of the SPD, 
Meany was more comfortable in dealing with the conservative Christian Democrat, Konrad Adenauer.

\section{The Ross-Brown Axis and "Unorthodox" Financing}

Victor Reuther's reassignment to take charge of international affairs for the CIO in 1953 was at the expense of Mike Ross, who had been the responsible officer since 1945. Ross was reassigned to Europe in 1954, his remit being to liaise with the ICFTU and the European trade union centres in building support for the CIO's reform package. But early on he confided in Irving Brown his intention to tell Meany privately that the ICFTU's real need was for an experienced director of organization with a team of organizers seconded from affiliates to work for the ICFTU in developing counties, rather than three additional assistant general secretaries. There was no indication that Ross had shared this thinking with his CIO superiors. He was no devotee of Walter Reuther, and his relationship with Victor Reuther was distinctly frosty. At the same time, his predisposition to cooperate with Brown made him an object of suspicion for the younger Reuther. ${ }^{96}$

For their part, Brown and Lovestone were unsure whether to embrace Ross or keep him at arm's length. Brown had known him for several years and regarded him as no threat. Ross was "at best too weak to base any hopes for the future." He was "nice, ineffective and pliable," Brown wrote to Lovestone: "I would not expect him to be a very strong tree on which to lean," though "I regard [him] as a personal friend." Lovestone concurred: "He is a lazy, weak character. . . Otherwise he is quite a decent fellow, but the woods are full of them." Nonetheless, the Ross-Brown relationship grew stronger in the months ahead in parallel with the stately progress of the merger talks. In a similar way, Victor Reuther maintained friendly relations with the AFL's decidedly "non-Lovestoneite" representative at the ILO, Phil Delaney. It was obvious to the FTUC that the Reuther leadership viewed Ross as an outsider, whereas they regarded him as infinitely preferable to Victor Reuther. But they were also discomfited by Oldenbroek's clear preference for Ross rather than Brown to represent a unified American centre in the ICFTU following the merger. ${ }^{97}$ It was in this spirit of condescension laced with a measure of cautious mistrust that Lovestone and Brown came to regard Mike Ross as the "acceptable" face of the CIO in international affairs, someone they could work with and even control when, three years later, he became the nominal head of the international affairs department of the merged AFL-CIO.

The Ross-Brown link came into its own as the CIO and AFL played cat and mouse in their search for funding for international work in 1954-55. A legacy of Reuther's spell in Europe was the well-oiled channel through which government aid funds were accessed through former CIO staff now engaged by the MSA/Foreign 
Operations Administration (FOA) productivity division - graphically characterized by Brown as "Victor's stooges" carrying out "termite operations in Europe."98 The key intermediary was Bill Kemsley, who had previously steered MSA funds to the IMF for use by Victor Reuther. He was now responsible for various disguised subsidies to the ICFTU through such devices as FOA bulk purchase of ICFTU publications and FOA payment for training materials developed by the ICFTU for its own purposes but also "available" for use by the American centres. ${ }^{99}$

Kemsley was happy to resort to subterfuge, proposing a fictitious organization and personnel as conduits for FOA payments, telling ICFTU assistant general secretary Gottfurcht privately:

Anything that I had to address to you officially on this would be under the phoney title. I am sure you can understand that such things as this are somewhat commonplace in MSA operations.... Please do not give any publicity as it will get me into the soup. ... Please drop me a line at my home address and let me know your reaction. ${ }^{100}$

Gottfurcht was willing to play ball, though beyond a certain point he recoiled in view of the risk involved. Responding to a further unorthodox funding proposal in mid-1954, he told Kemsley that he was deluded if he thought he could operate this way without running into trouble:

Neither Oldenbroek nor I can take the risk of being challenged on this matter as accepting anything through the back door would be in direct contravention of existing decisions.... Have a word about it with Vic.... Tell him that it would be extremely dangerous if anyone knew of our private correspondence. ${ }^{101}$

The MSA/FOA Labor Advisory Committee, comprising Victor Reuther, Phil Delaney, and Art Lyon of the railroad brotherhoods and based in Washington, had general oversight of FOA relations with the labour movement but was never going to blow the whistle on such transactions. ${ }^{102}$ Irving Brown did, however, complain bitterly when, representing the AFL, Delaney failed to object to FOA funding of scholarships worth \$26,00o for ICFTU training in Brussels. In mitigation, Delaney pleaded that the amounts were too small to make a fuss about and that in any case Reuther and Lyon would have outvoted him. Guessing that some of the FOA projects might somehow be CIA-related, and alluding to one of Brown's aliases, Delaney suggested mischievously that he hadn't dared oppose them in view of "Walgreen's relationship with Fizzland."

To arrest this milking of the MSA/FOA productivity budget, Meany arranged for FOA Administrator Harold Stassen to appoint Brown and Ross as a two-man vetting team for suggested projects in Europe. In due course, they were presented 
with a list of proposals, often with incomprehensible titles and little explanatory detail. With no time to investigate fully, many items were nodded through, although Brown insisted on referring back to Meany those involving the ICFTU, including an item under which it was to receive $\$ 90,000$ for labour education. ${ }^{104}$ Increasingly suspicious of Ross's tendency to defer to the more forceful Brown, Victor Reuther gave him a dressing down: "I am somewhat confused and disturbed by reports ... that you are not sympathetic to the idea of FOA providing ... assistance.... I should like to hear directly from you as to your attitude... I would appreciate your giving support to these projects." Ross explained his caution in terms of the sensitive state of play in the unity talks. But he was also unhappy with the sub rosa channels, noting pointedly that one of the named sources of finance was a "Philip Murray Foundation." In all his years of working closely with Murray, he had never heard of such a trust. ${ }^{105}$

As for FTUC funding arrangements, its independent operations were diminishing in the course of 1953-54, and a question mark hung over the relationship with the CIA. Dubinsky remained disenchanted and pressed Lovestone for a stocktaking of "the whole Fizzlandia situation," complaining that the information available to him was "inadequate and incomplete." But what alternative was there to CIA backing? "I cannot see how we can make a real mark in the world merely by declarations and by having a correct position," wrote Brown. They needed to be backed up with "some essentials" that the trade unions were unable to supply: "Considering the odds against which we are fighting... I cannot conceive of an effective fight which is conducted only on moral grounds." Lovestone reassured him: there was no disagreement between the two of them over the basic issue of "Fizzlandic navigation," but relations with the agency had to change.

In fact, he was inching toward a new arrangement that would see the AFL linked to the CIA through the latter's counter-intelligence division directed by James Angleton, for whom Lovestone's girlfriend, Pagie Morris, already worked. The emphasis would shift from field operations to intelligence gathering. Once it was agreed on, Angleton would make payments to Lovestone's shell body-a notional "Samuel Gompers Library," staffed by Pagie Morris-in exchange for reports from Lovestone. These would originate from Lovestone's stringers in the field, who would in turn be paid from the "Gompers Library" funds. But the arrangement still needed approval by "the holders of the patent." Lovestone told Brown: "Our [CIA] friends are interested ... but you know what the obstacle is."106

The "obstacle" referred to was a McCarthyite campaign then being waged in the press, inspired by hostile sections of the intelligence community, that portrayed Lovestone and Brown as closet communists. Heading the campaign since 1951 with a series of articles in the New York Journal-American was the right-wing syndicated columnist Westbrook Pegler, who claimed that Lovestone and Brown 
were part of a communist cell responsible for American labour policy overseas while simultaneously benefiting from the support of a US administration blind to the real threat of international communism. The campaign intensified in late 1953 when the assistant secretary of labour, Spencer Miller, approached the FBI with the claim that Lovestone - "a shrewd, brilliant Jew" - was still an active communist agent. Until the storm aroused by these allegations abated, Lovestone's strategy was to lie low. ${ }^{107}$

Yet, before that point was reached, Irving Brown was likewise forced to adopt a low profile in Europe for several weeks in autumn 1954 when his close association with the world of intelligence threatened to draw him into a French political scandal that rocked the government of Pierre Mendès France. At the centre of these developments was the newly appointed interior minister, François Mitterand, who in an early ministerial initiative fired Paris's virulently anti-communist prefect of police, Jean Baylot, and his deputy, Jean Dides. Amid countercharges by Dides that Mitterand had leaked defence secrets to the communist party, and an investigation ordered by the president of France that threatened to expose links between Dides and American secret intelligence, Brown slipped out of the country and went to ground in Germany until the excitement in Paris subsided. ${ }^{108}$ It was deeply ironic that, at one and the same time, the Lovestone-Brown operation was being attacked as "communist" in the United States and threatened with exposure for supposed ties with anti-communist police work in France.

Hampered by the need for caution at the height of the Pegler-Miller campaign and by Brown's insecure position in France during l'Affaire Dides, it was only in January 1955 that Lovestone's plans for a new relationship with James Angleton and the CIA through the "Samuel Gompers Library" began to take shape. Grants in support of the venture from Angleton's budget would allow Lovestone to pay modest retainers to his stringers overseas-Jack Carney and John Bruegel in Britain, Klaus Dohrn in Switzerland, and Mohan Das in India-who, over the next twenty years, provided him with regular written reports that were shared with Angleton and were known as the "JX reports." In return, Lovestone gained access to intelligence that crossed Angleton's desk relating to activities of communists. ${ }^{109}$

\section{Approaching Merger}

The agreement in principle reached by the AFL and CIO in February 1955 to merge by the end of the year concentrated minds and intensified the struggle for advantage in the international field. At a joint meeting of international affairs committee personnel from AFL and CIO that same month, Victor Reuther revived the proposal for the British and American centres each to appoint an ICFTU assistant general secretary. 
Meany was asked directly whether there were any AFL activities that could not be handled by an adequately resourced ICFTU. He confirmed that there weren't and observed that the only thing preventing the AFL from relinquishing its independent program was a lack of confidence in Oldenbroek's leadership. Victor Reuther then drafted a statement proclaiming a newfound unity of purpose: "There is no AFL point of view or CIO point of view. ... There is an American labour point of view . . . to build the ICFTU into a more effective and dynamic international." To this end, he claimed agreement that the combined delegations of the AFL and CIO to the ICFTU's Vienna congress in May would support the CIO's long-standing proposal for the appointment of assistant general secretaries. He further suggested that George Meany and Walter Reuther put their names to his statement and send it to Oldenbroek. However, when the four FTUC officers discussed it, Meany "hit the roof" and declined to sign. All that the AFL had agreed to, he claimed, was to examine whether the independent work of the FTUC could be handled by a strengthened ICFTU secretariat. ${ }^{110}$

Lovestone had been quick to remind Meany: "The ICFTU is bankrupt as a leadership. This cannot be remedied by office arrangements in Brussels. . . . It cannot be done by our dropping [independent] activities." Indeed, he noted that without the AFL's independent work in the late 1940s, the ICFTU itself would never have come into existence. Yet he was also aware that Dubinsky and Woll were weakening in their support for FTUC activities and wanted to withdraw all its field representatives except Brown. Brown, himself, dismissed the latest episode as "Victor's manoeuvring." However, he continued to believe that a more positive AFL approach to the ICFTU was needed. He started from the premise that the organization could be strengthened. It made no sense for the AFL to continue half-in and half-out, simply criticizing the ICFTU's failures. It was time to "move in on the ICFTU" and for the Americans to start asserting themselves. ${ }^{111}$

Brown's alternative to the CIO proposal had at its heart Mike Ross's earlier idea for the creation of a department of organization within the ICFTU, with the larger affiliates seconding experienced organizers to work under a strong figure as director. To smooth the way for this, Ross had suggested privately to Brown that their two European offices be merged, a proposal that Brown reported to Meany with approval. In pressing the case for an ICFTU department of organization, Brown naturally expected that the AFL would have a decisive say in the choice of director.

Over this issue, Lovestone enlisted the support of ICFTU president Omer Becu, whom the AFL leaders always hoped would act as a counterweight to Oldenbroek. Prompted by Lovestone, Becu now showed an interest in becoming an executive president with special responsibility for organizing. ${ }^{112}$ The British objected to the prospect of yet another constitutional change made specifically for the benefit 
of Becu, but Lovestone managed to win broad support for the proposal at the ICFTU's 1955 congress in Vienna. A high-powered "director of organizing" was to be appointed. Crucially, the person chosen was also to report directly to the executive board rather than to the general secretary, thereby clipping Oldenbroek's wings and diminishing his standing. Becu lost interest in the post when it became clear that he would not be able to combine it with the presidency, and it was therefore left to Meany to find a possible alternative nominee from the AFL. His inclination was to name Irving Brown. ${ }^{113}$

Victor Reuther was angry at being outmanoeuvred over the issue of the director of organization in the run-up to the Vienna congress. He felt let down by Mike Ross's failure to make a strong case for the CIO proposal and was now faced with a quite different proposal from the AFL. In a briefing for the CIO's delegation he reminded them that in the joint meeting of the two international affairs committees only three months earlier "we got everything" - with the prospect opening up for cleaning out the unsavoury elements of the FTUC's work. In this category, Reuther listed "Irving Brown's men ... his Corsican pistol carriers"; his assistant Leon Dale, "who is more familiar with activities having their source elsewhere than in the labour movement"; Lovestone's personal connection with the China Lobby; and his "assistant" Pagie Morris, whose activities were also "outside the labour field."114

Reuther berated Ross once more for his ineffectiveness in advancing the CIO proposal as an agenda item in Vienna:

You can understand how disappointing $[s i c]$ a number of us were ... to find that these basic $[\mathrm{CIO}]$ proposals had all but been washed down the drain.... A review of ICFTU meetings over the last several years clearly indicates that on too many occasions the independent views of the CIO have not been put forward as vigorously as they might have been.

It was Ross's tendency to yield to Brown that most troubled Reuther, and he lectured him: "one can have a good personal relationship with Irving Brown without necessarily yielding to his ultimatums ... or advancing his name for positions of responsibility." ${ }_{115}$

Though defeated over the CIO's particular proposal to strengthen the ICFTU secretariat, Reuther made it clear that Irving Brown would not be acceptable as the nominee of the unified American labour movement for ICFTU director of organizing:

If anyone is so naïve as to think that Irving Brown is a possible choice or that a weak character whom Irving can control will be acceptable, they are even more naïve than those who thought that a few letters chiselled in the stone on the face of the new AFL building would prejudge the decision on the name of the new merged operation. ... Having won some important victories long 
overdue ... I'll be damned if we are going to ... see them now washed down the drain for lack of competent people to carry them out. ${ }^{116}$

The emerging stalemate over the choice of director of organizing reflected the gulf between the warring factions. Despite the high hopes of the Vienna congress, the ICFTU post would remain unfilled for over a year. And the absence of agreement here also frustrated CIO ambitions to see the back of the FTUC. Asked at a press conference in June 1955 about his willingness to recall FTUC representatives from the field, Meany replied that this would take place once the ICFTU had begun its organizing in the field. However, that process was stalled by the absence of agreement on the choice of director of organizing. ${ }^{117}$ And when Walter Reuther pressed within the unity process for a discussion on the future of the FTUC, Meany resisted all talk of winding it up. The AFL president may have been losing the support of Woll and Dubinsky in this respect, but during a prolonged joint tour of Europe in the summer of 1955, observers noted how Lovestone's personal influence with Meany seemed to be on the rise. It was certainly a matter of concern to the TUC's Vincent Tewson, who had once regarded Meany as the most reliable of FTUC's leaders. Likewise alarmed, American Socialist Party leader Norman Thomas asked Victor Reuther: "Can you give me any hope that the new [union] organization ... won't be simply a rather docile sounding board for Lovestone, Brown et al.?"118

With so much at stake in the unity process for international labour affairs, the personal animosity overlaying long-standing political differences was unmistakable. For the CIO, it was Lovestone who was the real hate figure. Bill Kemsley, a close observer of the FTUC secretary, wrote to CIO colleagues of the need to eradicate the poison of Lovestonism, which "continues to write the policy of the ICFTU, either through positive influence or through the pressures of fear." Citing the "gangsterism that controls the Marseilles docks; the divisive tactics used in Italy; the splitting of the anti-Takano forces in Japan; the support of corruption in Greece; the attacks on the social democrats in Austria and Germany ... the all-out support of the dictatorship of Chiang Kai Shek," he proposed an anti-Lovestone intelligence-gathering exercise aimed at collecting as much information as possible about the former communist party secretary and his associates for dissemination among American labour activists. The problem of Lovestonism had its roots in America, and the process of tackling it needed to begin at home by bringing it into the open. Kemsley was well aware of how difficult it would be to beat him. But he was impatient for action, and in his peroration exhorted Walter Reuther: "The time is now. The people are us. The leader is you. Let's go." 119

In the opposite corner, Lovestone hammered away at Meany with a simple message: "We are in complete and unbridgeable disagreement with them [CIO]. Unless 
we organize forces after unity, these demagogic soap boxers and semi-skilled intellectuals will cause far more damage abroad than they were able to do before unification." He complained that in Germany recently Victor Reuther had been telling DGB officials that Irving Brown was not so much a trade unionist as a government man doing government work with government money. "If he'd said any of those things to me," wrote Lovestone, "he would have run a strong risk of losing the other eye." Meanwhile, with Brown's alarmist reporting from Paris painting a picture of a steadily deteriorating situation in the Cold War-a popular front in the making in Greece; a general let-up in rearmament of NATO countries; the British Labour Party and trade unions "caving in on the smiling cultural front"; Tito's policy abroad succeeding where the Soviets had failed-Lovestone urged Meany to call Brown home for "a private session before trying to iron out matters with the CIO and some of its soapboxers," in the final phase of unity talks. ${ }^{120}$

\section{Unity of Sorts: The Choice of International Affairs Director for the AFL-CIO}

The date for the resolution of outstanding decisions on the merger was scheduled for mid-October 1955. Four days before this, Victor Reuther buttonholed Phil Delaney for a drink to ask him what he had heard about plans for the international affairs department and to let him know that the CIO was ready to nominate him for departmental director. "Christ, why are you asking me?" Delaney said. "That's up to the 7 th floor. Don't get me involved. I don't want any part of the job. Why don't you talk to Mike Ross? How about Irving?" But Reuther persisted, telling him, "You are the best one." Delaney was nervous that word of the conversation would leak out and be wrongly interpreted. Accordingly, he went straight to Lovestone and reported the meeting: "You know, Jay, it is you they are after. He is not after anybody else. I told Victor that he would not stop Mr. Meany if [he] wants to consult Lovestone or take his advice. Who are you to prevent it?" Toying with Delaney, Lovestone feigned incomprehension as to why Reuther would be out to "get him," given that "I have nothing against him ... against his mistakes in the UAW when he and Walter refused to fight the communists." He went on to say, "I am not fighting old battles. I am not looking for titles or jobs. If Victor Reuther wants to talk to me about policies, and that is the only thing I am interested in, I would be glad to talk to him, but he always dodges policy discussions with me." As the hapless Delaney left the room, he asked anxiously: "This conference between Reuther and me. Nobody knows about it but you and I?" Lovestone reassured him: "I understand." That same day Lovestone sent a verbatim record of the conversation to Meany and Brown. ${ }^{121}$ 


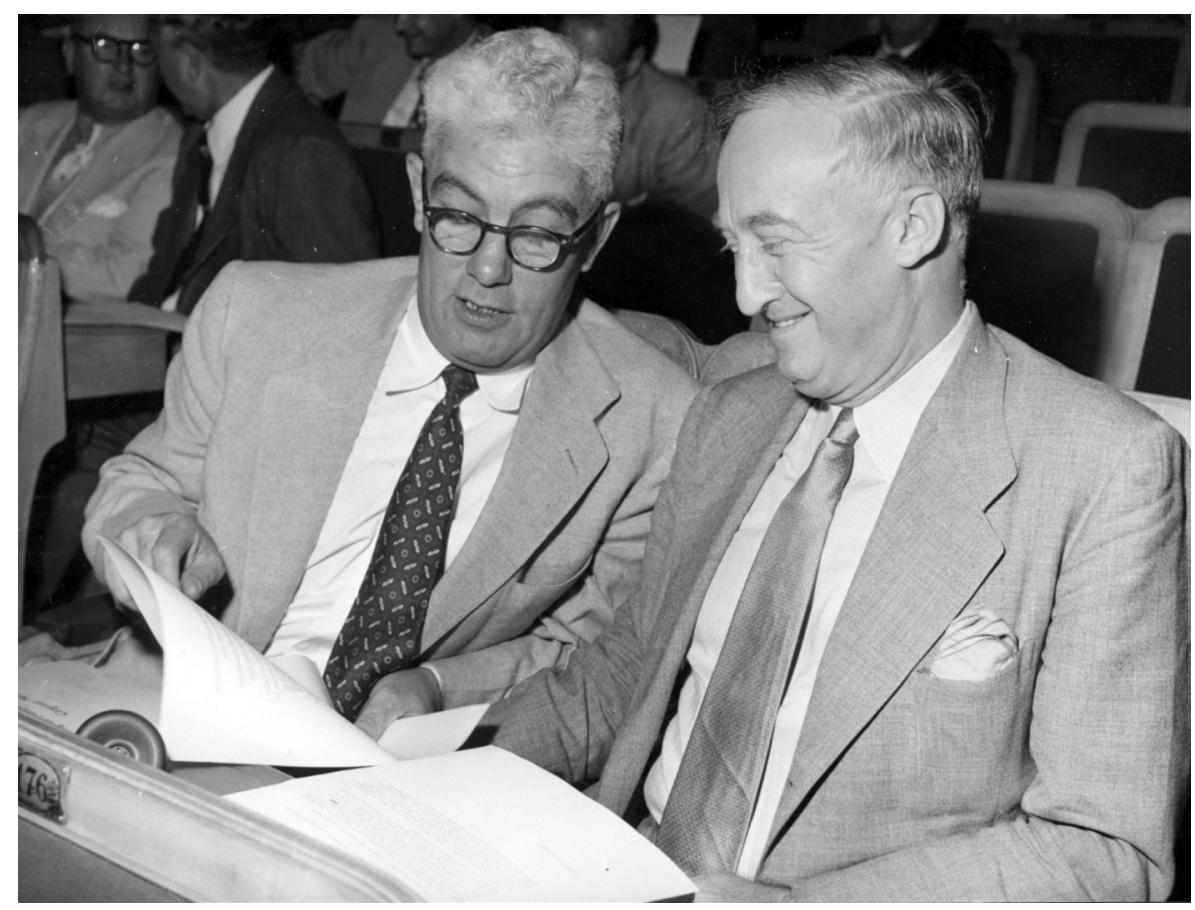

Figure 5. AFL representative Phil Delaney (left) and Jay Lovestone in July 1953, at the ICFTU congress in Stockholm. A social encounter with Victor Reuther left Delaney anxiously asking Lovestone: "This conference between Reuther and me. Nobody knows about it but you and I?" Courtesy of the Walter P. Reuther Library, Archives of Labor and Urban Affairs, Wayne State University.

Senior figures from both sides met on 14 October to agree on departmental directorships for the AFL-CIO. For international affairs director the CIO proposed Delaney. The AFL nominated Mike Ross. In both cases they represented the least objectionable member from among the opposite side and yet the person least trusted by their immediate colleagues. To break the deadlock, in a well-rehearsed coup de théâtre, George Meany then proposed the name of Brown. The CIO representatives were aghast-until Meany explained that he meant not Irving but George Brown, one of his administrative assistants who had previously worked as research director for the plumbers' union. He was a man of little standing in the labour movement with no experience of international affairs. The nomination was simply a way of avoiding the real issue. The CIO side readily agreed to it as a temporary arrangement. Mike Ross was named deputy director. Phil Delaney would continue to concentrate on issues within the ILO. Jay Lovestone was to remain in New York running the FTUC, whose future role was still undecided. It was a situation fraught with unknowns. To 
guarantee continuity, Bill Kemsley advised the CIO leaders that their best precaution would be to transfer the CIO's international affairs department to the UAW. Indeed, that would be the chosen course. ${ }^{122}$

Irving Brown was deflated at the appointment of his namesake. As a tactical manoeuvre it was clever, and he could understand Meany's motive, but he was unable to disguise his bitterness, telling Lovestone:

From the point of view of human dignity and really trying to do a job, it is a pretty shoddy business. ... It leaves no room for incentive and makes one want to say: "What's the use?" The trouble is that you, Jay, and I are taken too much for granted. ... Frankly it leaves me a bit disgusted and about ready to re-examine what I should do in the future. This is all the more intensified by the kind of campaign that Reuther, Delaney and associated stooges continue to carry on over here among the Europeans. ${ }^{123}$

The unification of the American labour movement duly took place at the Unity Convention in New York in December 1955, without agreement on basic aspects of international policy and practice. It was also consummated in an atmosphere of intense personal antagonism between key figures. On the very day the convention closed, Lovestone lunched with a reporter from the Washington Post who asked him about the AFL role in splitting the French and Italian labour movements between 1948 and 1950, for details on how much money it was receiving from the CIA, and, tellingly, how it was that when any prominent communist in Europe split from their party they immediately got in touch with Irving Brown. In this connection the reporter mentioned that when Auguste Lecoeur had recently broken with the French Communist Party he contacted Brown, who put him in touch with US intelligence. It was the nature of this last question that convinced Lovestone that the journalist had been primed to ask this by Victor Reuther. Lovestone complained to Meany that the CIO had plants in Fizzland who were seeking to slander the AFL while drawing government salaries. ${ }^{124}$

Despite the safe launch of the AFL-CIO, there was still no progress in appointing a director of organization for the ICFTU. The latter's executive board met in New York immediately following the convention with no nominations before it. Only when there was a measure of accord within the AFL-CIO could the ICFTU begin the search for candidates with any real hope of success. Yet during those post-convention executive board sessions, hostility between Victor Reuther and Irving Brown-substituting for Walter Reuther and George Meany-was as raw as ever. At times the two men were in open discord. Reuther demanded to know why, as representatives of the FTUC, Dick Deverall and Harry Goldberg were present at the board meeting, and threatened to protest officially. When Irving Brown objected to a decision by 
Oldenbroek to name a replacement as secretary of the Asian Regional Organization without prior consultation with the Americans, Reuther intervened to berate him publicly, telling the board: "There are certain people who are not so concerned about the issues, but are interested merely in creating differences where differences do not exist." And on the ever-contentious question of contacts with Soviet bloc labour organizations, Reuther voiced opposition to the wording of an executive board statement that Meany himself had been responsible for drafting.

Afterward, outside the meeting, Brown confronted Reuther and told him that if he intended to start where he had left off, it would be regrettable, but he could have it that way. "Start?" asked Reuther. "Why, it's never stopped." ${ }^{25}$ The unified AFL-CIO was all of seven days old.

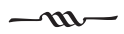

From the outset, mutual mistrust characterized relations between the AFL and CIA over their secret funding arrangement, but the attempt by the agency to extend the scheme to the CIO created a veritable crisis that all but ended their relationship. Financing available for the FTUC programs began to decline, though Jay Lovestone did subsequently reach a separate arrangement with CIA counter-intelligence chief James Angleton to exchange anti-communist intelligence in return for token payments.

Though not unique to American labour-the TUC also benefited from government grant aid for its work among British Commonwealth trade unions-this American reliance on secret finance from government sources was new. Recognizing that the WFTU was heavily subsidized by the Soviet state, the AFL and CIO both accepted that their work in this field could not be funded from union sources alone. However, the CIO differentiated itself from the AFL in claiming that the government funds it sought were from the Marshall Plan administration and its successor agencies, the MSA and FOA-indeed, counterpart funds that were publicly voted and intended for economic and social programs of benefit to Europe. Yet the CIA also had access to counterpart funds, making it difficult to determine on what basis, and with whose backing, grants to the $\mathrm{CIO}$ were made. The Reuthers always claimed to be unaware that money received came from the agency, though it is quite clear that various other attempts by the CIO_-and through it the ICFTU—-to access MSA and FOA finance were made in the full knowledge that it would prove embarrassing were the source to be made public.

CIO entry into the international field reawakened old animosities with the AFL: ill will at institutional level was compounded by personal animosity between Lovestone 
and Brown on the one hand and the Reuthers on the other, rooted in their competitive relationship during the unionization of autoworkers in the 1930s. It set the tone of relations between the two camps over international issues for a generation to come.

Though hardly less anti-communist than its rival, the CIO approached international work differently, starting from a critique of the AFL record in helping to split unions in France and Italy and steering the Greek labour movement away from "communist" control-picking favourites among non-communists rather than supporting bona fide unions more broadly. Its preferred course was to strengthen European unions as fighting organizations in a traditional union sense, looking to heal divisions among non-communist unions and so making them better able to defend the interests of workers vis-à-vis employers, a dimension that rarely featured in FTUC calculations.

With mixed results, Victor Reuther's CIO program emphasized the provision of standard union educational courses to train organizers, help in exposing the exploitative, pro-employer bias of the Marshall Plan's pilot plant programs, and the need for extensive organizing among French and Italian metalworkers. In contrast, Irving Brown's predilection was to focus on organizing a tightly knit elite of selected trade unionists equipped specifically for anti-communist campaigning, their training in propaganda techniques explicitly ideological. As applied to aircraft manufacture at FIAT in Italy, the program was conceived in terms of support for the North Atlantic Alliance by equipping union leaders for "the showdown" with communists that Brown and Lovestone anticipated sooner or later. Elsewhere this close AFL identification with NATO was reflected in Lovestone's judgment that Meany's 1955 public appeal to German trade unionists to back the Paris Accords (leading to German rearmament and membership in NATO) was the AFL's most decisive intervention in Europe.

The closure of the CIO's European operation after two years followed agreement with the AFL to begin merger talks-a drawn-out process lasting over two years in which the lack of accord on international issues was all but total. The CIO urged the AFL to join in working abroad strictly through the ICFTU, whose secretariat would be strengthened by each appointing an assistant general secretary, a measure equally designed to maintain CIO parity of influence with the AFL. Intent on preserving its independent program, the AFL rejected this, seeing it as an unwarranted CIO ploy to claim an equivalent status in circumstances where it considered that the CIO's European operation had largely ended in failure.

The AFL's counterproposal to strengthen the ICFTU was through the creation of an all-powerful director of organization. Adopted by the ICFTU as a possible way of breaking the deadlock in the unity talks, the proposal's unstated purpose here was to clip General Secretary Oldenbroek's wings, with Irving Brown appointed to this 
important new post. Such an appointment was unthinkable to the CIO, and consequently the post went unfilled for over a year. In the meantime, driven by domestic imperatives, the unity talks moved slowly to a successful conclusion in December 1955, while remaining deadlocked over basic international issues. At the AFL-CIO's launch, all important aspects of its international orientation remained unresolved, a condition that would plague the new body for the next two years. 



\section{5}

\section{A Wedding Without a Honeymoon}

The merger of the AFL and CIO resolved none of the important, long-standing differences between them over international affairs. Indeed, initially these were exacerbated. The leaders from the former separate wings disagreed fundamentally over how to respond to broad developments in the Cold War, and in that context it proved difficult even to make progress in the short run in merging the international apparat of the two organizations. The question of how strong the American identification with the ICFTU should be, and whether undertaking some activities by the FTUC independently of the international risked damaging that relationship, was fiercely contested for two years. At bottom it turned on the intractable issue of how organized labour should address the challenge of communism in the international labour arena. Not until December 1957, and under much international trade union pressure, was it finally agreed that the FTUC would be closed down, with a broad commitment to channel the American effort through the ICFTU. By this point, the FTUC was, in any case, a weakened body, with its secret source of funding drying up and its scope for operating with much effect in Europe significantly diminished because of changes in the political climate in Germany, France, and Italy.

The AFL-CIO's international focus began to turn to Africa, a developing front in the Cold War. Here a new theatre of operations opened up as the anti-colonial movement, led to an important degree by trade union centres infused with the spirit of nationalism, forced the question of home rule and independence to the top of the political agenda. While attempting to operate within the broad framework of ICFTU policy, the AFL-CIO became increasingly critical of the international, firstly as it struggled to service its African affiliates adequately, and then as it floundered in the wake of the pan-African tide that swept the continent in the closing years of the 1950s. Around a shared criticism of the ICFTU leadership's deficiencies in this 
particular area, it proved possible for George Meany and Walter Reuther temporarily to join forces in seeking a sweeping change in the top leadership of the ICFTU. The Americans led the campaign to force the retirement of the ICFTU's first general secretary, Jaap Oldenbroek, thereby paving the way for a fresh start with a reinvigorated organization and, just possibly, a less centralized modus operandi that would attract the enthusiasm of American labour.

\section{Organizational Paralysis at Home: Conflict over "Neutralism" in India}

The lack of agreement on basic aspects of AFL-CIO overseas policy and practice at the time of merger left international staff from the two wings of the movement in limbo. Under the stopgap leadership of George Brown-new to the field and lacking authority-the international affairs department was directionless. The question of how policy would be developed or who would implement it was unclear, as was the new international affairs committee's relationship to the FTUC. George Brown complained that he was being kept out of policy making, but Jay Lovestone told him dismissively that "policy" had never been part of his remit. Meanwhile, Brown's deputy, Mike Ross, bridled at having to play nursemaid to someone he described as a "small, naïve fool."'

Members of the new international affairs committee meeting in February 1956 had no stomach for addressing the future of the FTUC or the question, closely related to it in AFL-CIO eyes, of whom to support for the ICFTU's newly created position of director of organization. Irving Brown had his eye on this job, but Lovestone advised him to forget the idea. Given the right director, Meany and Lovestone had hoped to diminish the authority of General Secretary Oldenbroek, their bette noir. However, Lovestone recognized that Irving Brown would never be nominated by a divided American leadership, and he anticipated what he termed "the paralysing and bankrupt bureaucracy at the helm of the ICFTU" to continue unchanged. ${ }^{2}$ Mike Ross described this first meeting in Bal Harbor as a lethargic gathering of mostly aging leaders whose main interest was in playing gin rummy. Jim Carey tried to generate a discussion of Lovestone's role but, ever the one for wisecracks, succeeded only in baiting Meany with his jibe that the latter had won Lovestone from Dubinsky in a hand of rummy. He asked, "Why the hell should AFL-CIO foreign policy be determined by the fact that Lovestone didn't sell enough subscriptions to the Daily Worker in 1929 and got kicked out of the party?" Meany snapped that he was ready to discuss the matter "any time"; other committee members thought better and agreed to defer consideration until another day. ${ }^{3}$

Lovestone came away from Bal Harbour feigning confidence about his own position following private reassurances from Meany. He informed Brown: "I have a 
very specific and definite understanding ... with George." The work of the FTUC would be "continued and expanded," with its name unchanged. Meany's plan was for it to be removed from ILGWU control and taken "in-house" by the AFL-CIO, with Lovestone also transferring his employment to the federation. Meanwhile, he kept his head down and continued putting out the Free Trade Union News. The only visible change was the substitution of "AFL-CIO" for "AFL" on the masthead, but with the volume and issue numbers indicating continuity with the original Lovestoneite journal first published in $1946 .{ }^{4}$

Victor Reuther seethed at this and other anomalies. George Brown's request for permission to publish an international affairs department bulletin for overseas distribution had been turned down pending a decision on the status of the FTUC. What right, Reuther now asked, had the Free Trade Union News to speak for the AFL-CIO when neither the federation's director of international affairs nor its director of publications had any input? Moreover, the FTUC's staff had not transferred to the merged body, so why was the Lovestoneite, Harry Goldberg, allowed to pass himself off as an AFL-CIO representative? And most fundamental of all, how was the FTUC being financed? With the AFL-CIO's increasing financial commitments to the ICFTU, there could be hardly any money to spare, so did it mean that the FTUC was still being kept afloat by sub rosa payments?5

Such keenly contested office politics were a reflection of sharp differences among the federation's leaders over the state of the Cold War. Topping that agenda was the process of de-Stalinization of the Soviet Union by the "new look" Bulganin-Khrushchev leadership and the consequent easing of cold-war tension. The four-power Geneva summit of July 1955 had been the first attempt to resolve East-West differences since Potsdam a decade earlier, and the Reuthers gave a warm welcome to the subsequent opening of doors to East-West cultural exchanges. In contrast, Lovestone was filled with "shame and disgust" when he heard that Walter Reuther had cabled congratulations to President Eisenhower for his part in generating "the spirit of Geneva." As he told CIA director Allen Dulles, Geneva was "a colossal catastrophe."

In similar vein, Lovestone interpreted Nikita Khrushchev's "Secret Speech" in February 1956 essentially as a tactical ploy to woo developing countries. It merited utmost suspicion and provided the best possible justification for the expansion of the FTUC's independent activities in the Third World. For this reason, Lovestone welcomed the prospect of the FTUC being freed from David Dubinsky's tutelage. The garment workers' leader was proving increasingly unreliable in the struggle with the Reuthers, and as for the FTUC's roots within the ILGWU, Lovestone explained: "We have outgrown it. We need more authority."

The sharpest of international differences at the time of the merger saw George Meany and Walter Reuther publicly at odds over the recent Indo-Soviet treaty of 
friendship signed by the Bulganin-Khrushchev leadership and India's prime minister, Jawaharlal Nehru. A long-term critic of America's policy of ringing the USSR with military alliances, Nehru had recently joined with Tito and Nasser in launching the Non-Aligned Movement. In a speech in New York scripted by Lovestone and delivered before a gathering of international trade union leaders present for the merger, Meany denounced Nehru's self-proclaimed "positive neutrality": "No country, no people, no movement can stand aloof and be neutral in this [cold-war] struggle. Nehru and Tito are not neutral. They are aids and allies of Communist imperialism." Sitting beside him, Reuther bit his tongue, determined to avoid public disagreement so soon after the unity conference. However, the remarks caused outrage in India and Asia more generally. K. P. Tripathi, the general secretary of the Indian National Trade Union Congress (INTUC), was present for Meany's speech and reacted by raising the possibility of the INTUC withdrawing from the (Western) ICFTU. The US ambassador to India also sought out Meany to explain how damaging to international relations his remarks were. ${ }^{8}$

When Walter Reuther proposed to go to India himself to help repair the damage to relations with the country's trade unions, the INTUC and the government of India quickly stepped forward to issue a joint invitation to visit for eleven days in April 1956. Reuther wrote to secretary of state John Foster Dulles calling for a change in US foreign policy to prioritize economic over military aid to allies. At a press conference in New York before departing, he also made clear his disagreement with Meany's assessment of Nehru. ${ }^{9}$ Treated as an international statesman in India, Reuther toured extensively and addressed large crowds, stressing everywhere his opposition to the military emphasis in current US aid programs. He dined privately with Nehru, addressed MPs in the Indian Parliament, and expressed support for India's non-aligned status, describing Nehru as "truly one of the great statesmen of the world." Speaking as a union leader, he reiterated his view that the free trade union emphasis should not be on negative anti-communism so much as positive action for social justice. ${ }^{10}$

Meany was most upset at being publicly repudiated by Reuther. Two weeks after the UAW president's return, he retaliated by nominating Irving Brown to attend the INTUC congress. Reuther may have been in India as a personal guest of Nehru, but Brown would be the official representative of the AFL-CIO, his fraternal greeting bearing a warning to India's trade unions of the danger of the USSR's growing influence in the region. David Dubinsky felt some sympathy for Meany but criticized his choice of Brown as fraternal delegate; it was tantamount to a declaration of war on Reuther-better, he thought, to let the "red head's" enthusiasm burn itself out as such "spasms" frequently did. ${ }^{11}$ Victor Reuther kept the pot boiling by picking a fight with the AFL-CIO publicity department over its reluctance to give general circulation 
to the recording of Reuther's controversial press conference. And throughout the spring of 1956, public utterances by Walter Reuther and George Meany, together with extensive coverage of the Meany-Nehru dispute in the Free Trade Union News, kept alive the awareness that there were fundamental foreign policy differences between the two labour leaders. ${ }^{12}$

Reuther and Meany clashed at a bad-tempered session of the AFL-CIO executive committee shortly after his return from India. Citing Walter Reuther's remarks to the press and his brother's efforts to have them disseminated more widely within the labour movement, Meany protested: "I am not used to working in this sort of atmosphere." Reuther countered that certain former AFL staff members seemed to have a vested interest in causing trouble and insisted that "Lovestone doesn't speak for me. ${ }^{{ }^{13}}$ Briefing the press anonymously on this acrimonious exchange, Lovestone suggested that Reuther was still trying to live down his former communist ties and that his primary aim was "to cut Lovestone's throat" in order to get even over the smashing of the WFTU and Reuther's failure to fight the communists in the UAW in the 1930s. Lovestone hoped to be the ultimate beneficiary of this animus between Reuther and Meany, but privately he and Brown continued to worry at the prospect of the FTUC being closed down. ${ }^{14}$

Yet neither Reuther nor Meany wanted disagreement over international issues to undermine hopes for the unified labour centre. Both had invested much in the new organization, and however fiercely contested international matters might be, these differences had to be contained. Reuther was keen to secure agreement on the AFL-CIO's first major unionizing campaign among American textile workers, and Meany was beginning to be immersed in the problem of eradicating corruption within a number of AFL-CIO affiliates, for which he needed all the allies he could muster. Not for the last time, labour's domestic problems forced the contending factions temporarily to tone down their differences on foreign policy.

\section{The Carleton Hotel Agreement}

The fundamentals of AFL-CIO international work and the status of the FTUC were eventually addressed at an informal dinner at the Carleton Hotel in Washington in June 1956 attended by George Meany, Walter Reuther, David Dubinsky, and Jake Potofsky. Agreements were reached to support the candidacy of the Canadian steelworkers' leader, Charles Millard, for the key post of ICFTU director of organization - so ending the year-long stalemate-and to raise a levy of members to finance the work of the new department. ${ }^{15}$ These commitments paved the way for a parallel agreement to close down the FTUC as a separate operation twelve months hence, provided that the ICFTU's organization department was functioning. At that point, 
consideration would be given to placing Irving Brown on Millard's organizing staff or assigning him to other work as an ICFTU field representative. Until then the FTUC would operate under the auspices of the international affairs committee and would continue to publish the Free Trade Union News, but now in conjunction with the international affairs department. The deal gave Walter Reuther essentially what he had long been pressing for. ${ }^{16}$

Meany was most reluctant to have a Reuther-supported candidate for this key ICFTU post, having earlier deemed Millard unacceptable because he was "a socialist and a Canadian," and adding for good measure that Canadians were simply "tools of the TUC who are stooges of the [British] Foreign Office." But he was outvoted at the Carleton Hotel meeting, with David Dubinsky siding with Reuther and Potofsky and even moving support for Millard's candidacy. To his FTUC colleagues, Dubinsky justified his action in terms of the need to end the standoff with Reuther. But he also tried to reassure them by arguing that since Millard was likely to fail in such a demanding job, the pressure would be off to close down the FTUC. Lovestone rejected this analysis, telling Dick Deverall: "I think the entire strategy of Dubinsky was false and I think Mr. Meany made a mistake in yielding to it. . . It doesn't speak very well for the leaders of our movement to propose knowingly people unfit for such high jobs. . . . The effect will be very bad.” Elsewhere he wrote: "No-one in the [AFL-CIO] Executive Council has confidence in Millard . . . [who is] incapable of handling the job ... [ [and a] fourth rater."17 Millard had not sought the post but was willing to take it on, informing Oldenbroek that he did so to block an "unwelcome choice"; he had in mind Irving Brown. He also intended to confront Meany over the issue of his being a socialist and the suggestion that he would be a tool of the British. ${ }^{18}$

News of the Carleton Hotel agreement went round the international labour movement like wildfire. Observing the reaction of the ICFTU secretariat, Lovestone noted that "the rats in Brussels are jubilant," while from London a demoralized Irving Brown reported that "the Tewson et al. crowd are the proverbial cat that swallowed the canary." Desperately hoping to close down the story circulating that the FTUC's days were numbered, Lovestone wrote to DGB president Walter Freitag: "These rumours are malicious lies ... inspired by the Communists." ${ }^{19}$ There was nothing he could do about the choice of Millard, but the possibility of the FTUC being wound up twelve months hence was too much for him to contemplate and had to be resisted.

Following the Carleton Hotel meeting, George Meany spent some days vacationing at Unity House, the garment workers' holiday centre in the Pocono Mountains of Pennsylvania. It was a favourite haunt, somewhere to wind down and play cards with Dubinsky. But Lovestone began to pester him daily with news and gossip of "Reuther activities." He forwarded a report from Dick Deverall—newly 
installed at ICFTU headquarters as special assistant to Assistant General Secretary Gottfurcht-that spoke of the "hatred" felt for Meany and Dubinsky by ICFTU officials and staff alike. ${ }^{20}$ After comparing notes with Omer Becu at his ITF office in London, Brown also complained of "the Meany cave-in," the "policy of appeasement," and the fact that their friends in Europe felt "let down." He, too, was unconvinced by Dubinsky's reasoning that Millard was unlikely to make a success of the organization department, thereby obviating the need to wind up the FTUC. "No matter how the baloney is sliced, it remains, baloney-which means, as Becu kept repeating, 'a Reuther victory.' . . When is the President of the AFL-CIO going to understand that there is an international cabal against him and anyone who goes along with him?"21

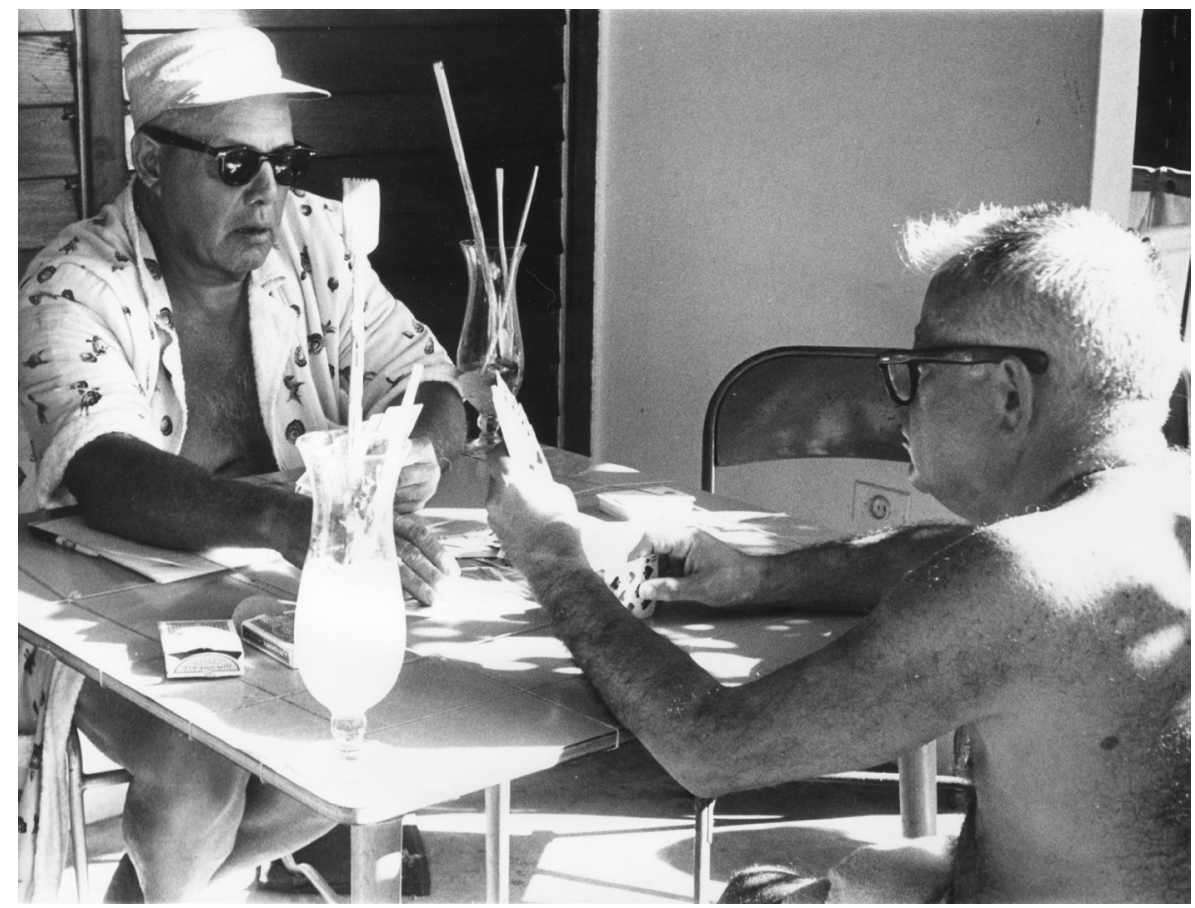

Figure 6. Relaxing over a hand of gin rummy, David Dubinsky (right) and George Meany. The two differed over the continued usefulness of the FTUC as well as over its links to the CIA. Courtesy of the Kheel Center for Labor-Management Documentation and Archives, ILR School, Cornell University.

Forwarding these reports, Lovestone wrote Meany apologetically: "I did not want to strike any jarring note for your vacation ... [but] I prefer forthrightness and 
frankness above all." He asked for clarification of the status of the FTUC. Did "discontinuation" refer to "head office activities" or only to "fieldwork"? More generally, he objected to the implication that the chances of the FTUC surviving depended on a negative assessment of Millard's achievements after twelve months:

Brown, Goldberg and I-are entitled to the protection of an official clarification so that the Commie-type factional apparatus working within the AFL-CIO will at least not have a fully free hand.... One does hate like hell to see the results of years of work and soundness of position ... rubbed away, gnawed away, nibbled away.

Lovestone pressed Meany to issue a statement countering the "misrepresentation and poisonous atmosphere in Brussels." ${ }^{22}$ Irritated by his pestering, Meany instructed him to travel to the Poconos to talk the matter through. The upshot of their meeting at Unity House was agreement that Lovestone would draft a letter for Meany to send to Becu and Oldenbroek putting a new slant on the Carleton Hotel agreement. ${ }^{23}$

Lovestone's draft redefined the role of ICFTU director of organization almost exclusively in terms of the battle against communism. The future of the FTUC and other international activities of the AFL-CIO would be "reviewed" a year hence against Millard's performance in this area. The letter, which Meany sent to Becu and Oldenbroek, warned against believing press reports that a definite decision had been taken to close down the FTUC. The new formulation gave Lovestone something to cling onto. Irving Brown was under instruction to read it into the record at the ICFTU's July executive board meeting when the appointment of Millard was being discussed. Lovestone was satisfied and predicted that it would come as "a bombshell in the camp of the phonies and disrupters." As for the British TUC: "Perhaps after this letter is read, the Colonial Office cronies will change their mind on the Millard proposition." ${ }^{24}$

George Meany stayed away from the July 1956 meeting of the ICFTU executive board, in Brussels, at which Millard's appointment was confirmed; as Lovestone explained, it was because of his low opinion of Oldenbroek and the "entire ICFTU set-up." Brown read out Meany's reinterpretation of the Carleton Hotel understanding and reported back that it had deflated the triumphalism of those present who willed the end of the FTUC. In reality, there was much criticism of this AFL-CIO attempt to lay down conditions for the appointment; board members protested that Millard was being set up to fail. His compatriot, Donald MacDonald of the newly formed Canadian Labour Congress, and the TUC's Tewson both took exception to the notion that Millard would be "on probation" for a year. Victor Reuther supported their argument and, claiming to be the voice of a united AFL-CIO, disavowed the 
AFL's original intention for the new organization department to operate independently of Jaap Oldenbroek. ${ }^{25}$

Despite Meany's letter, Millard's appointment was unanimous. Isolated within the meeting, Brown found it an uncomfortable experience, dubbing it "the worst ever." He reported home that Victor Reuther had seized every opportunity to set himself against the FTUC. With evident feeling, he described the atmosphere as he sat beside Reuther in the meeting; the conference room was "dull," the speeches were "dull," and "on my right sits a viper." ${ }^{26}$ In contrast, and clearly intent on underscoring Irving Brown's isolation, Victor Reuther telephoned Meany on arriving back in the United States to report "the most constructive executive board he had ever attended." Events seemed to be moving the Reuthers' way, and Walter had a spring in his step. He was keen for an update on progress in implementing the terms of the Carleton Hotel agreement. What steps were being taken to redeploy Irving Brown, either as an assistant to Millard or as an ICFTU field representative? Had the money owing from the new levy been paid to the ICFTU? What moves were afoot to bring the FTUC under the supervision of the AFL-CIO international affairs committee?27

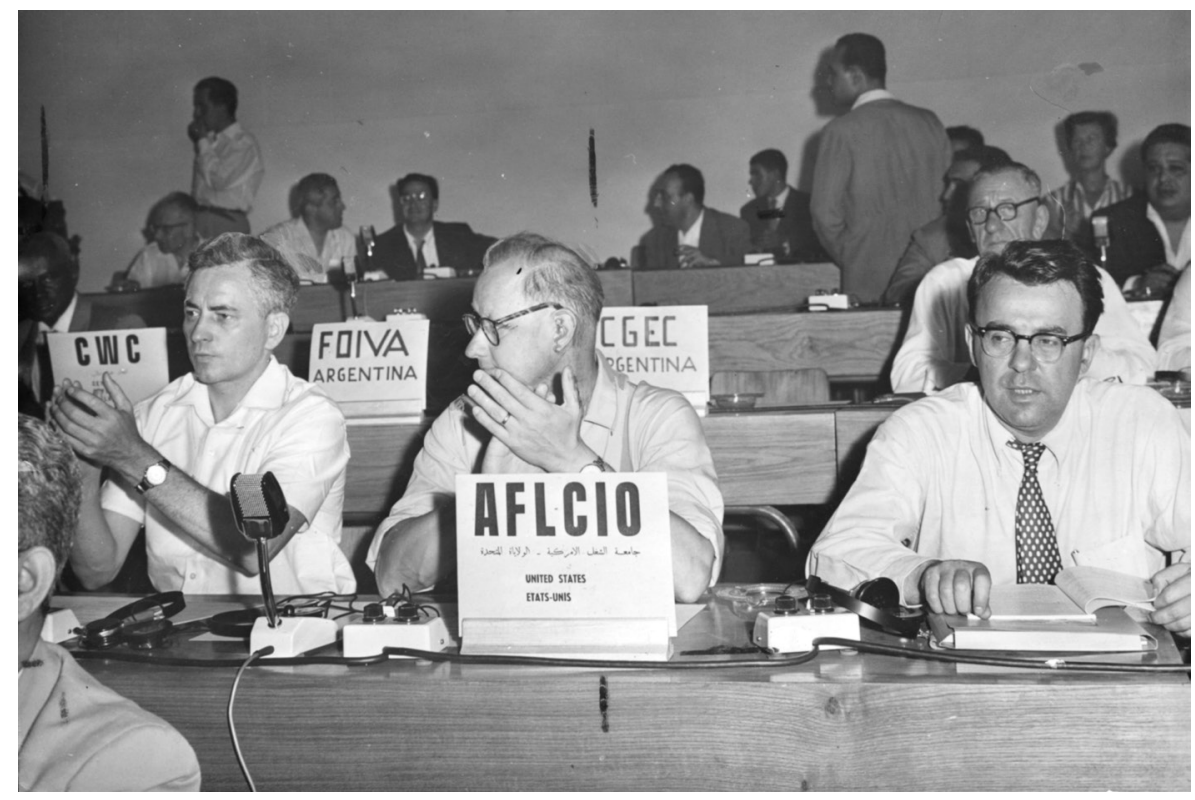

Figure 7. The CIO's Jim Carey (left), Victor Reuther, and Irving Brown, at the ICFTU congress in Tunis, July 1957. Brown had also been seated beside Reuther a year earlier, at meeting of the ICFTU executive board in Brussels. "On my right," he commented, "sits a viper." Courtesy of the Walter P. Reuther Library, Archives of Labor and Urban Affairs, Wayne State University. 
Reuther would soon be further cheered by news that Brown was out of the running for appointment as Millard's departmental deputy. With little hesitation, Millard chose as his assistant none other than Jay Krane, the epitome of all that Lovestone found unacceptable in the ICFTU secretariat. It was read as a deliberate throwing down of the gauntlet and inevitably fuelled FTUC resentment. But Millard reassured his new number two: "Don't worry about Meany and his reactions to your appointment.... We have passed the point where we can afford to let him call the tune on such matters.... The majority rather than the minority, no matter how powerful, must prevail." To Victor Reuther he wrote: "we might just as well find out now who is going to call the tune as far as my close associates are concerned.". ${ }^{28}$

If Meany had been forced to give way over the appointment of Millard, the purse strings were under his control and he still held back on contributions to finance the work of the organizing department. Refusing to commence payment of funds from the membership levy from the date of its introduction in 1955, he claimed that it was only payable from the time of Millard's appointment twelve months later. Again Dubinsky found himself in disagreement; it was wrong to withhold necessary funding while at the same time criticizing the ICFTU as ineffective. But nothing the garment workers' president could say would budge Meany. When Millard subsequently filed a progress report showing the AFL-CIO in arrears to the tune of $\$ 47,808$, Meany's pique led him to suspend payment for a further nine months. ${ }^{29}$ Jim Carey later withdrew from the international affairs committee in protest. The decision caused resentment among other national centres and calls for the AFL-CIO to "put up or shut up." Lovestone dismissed this as "yapping from Europe" that might prompt the AFL-CIO to curtail contributions still further. "If Lord Tewson and Lady Oldenbroek want to put pressure that way, they will begin to be without American dollars," he warned. ${ }^{30}$

Meany's antipathy toward the ICFTU resulted in a similarly parsimonious response in the first instance when the ICFTU appealed for "solidarity funds" for Poland following the workers' uprising in Poznan in June 1956-a curtain raiser for the even more dramatic popular revolt in Hungary that would follow in November. It placed Irving Brown in an embarrassing position, and he wrote to Meany arguing the need to support the ICFTU's important anti-communist work. His own credibility in Europe was at stake. The AFL-CIO's negative response was leading it up a blind alley and handing the advantage to its opponents within the ICFTU. He wrote: "Our friends are few and the resistance to our militant, dynamic anti-communism is varied. . . It is difficult to work in committees, in organizations with other nationalities if one is deprived of the complete moral and material support of this base." ${ }^{31}$ 


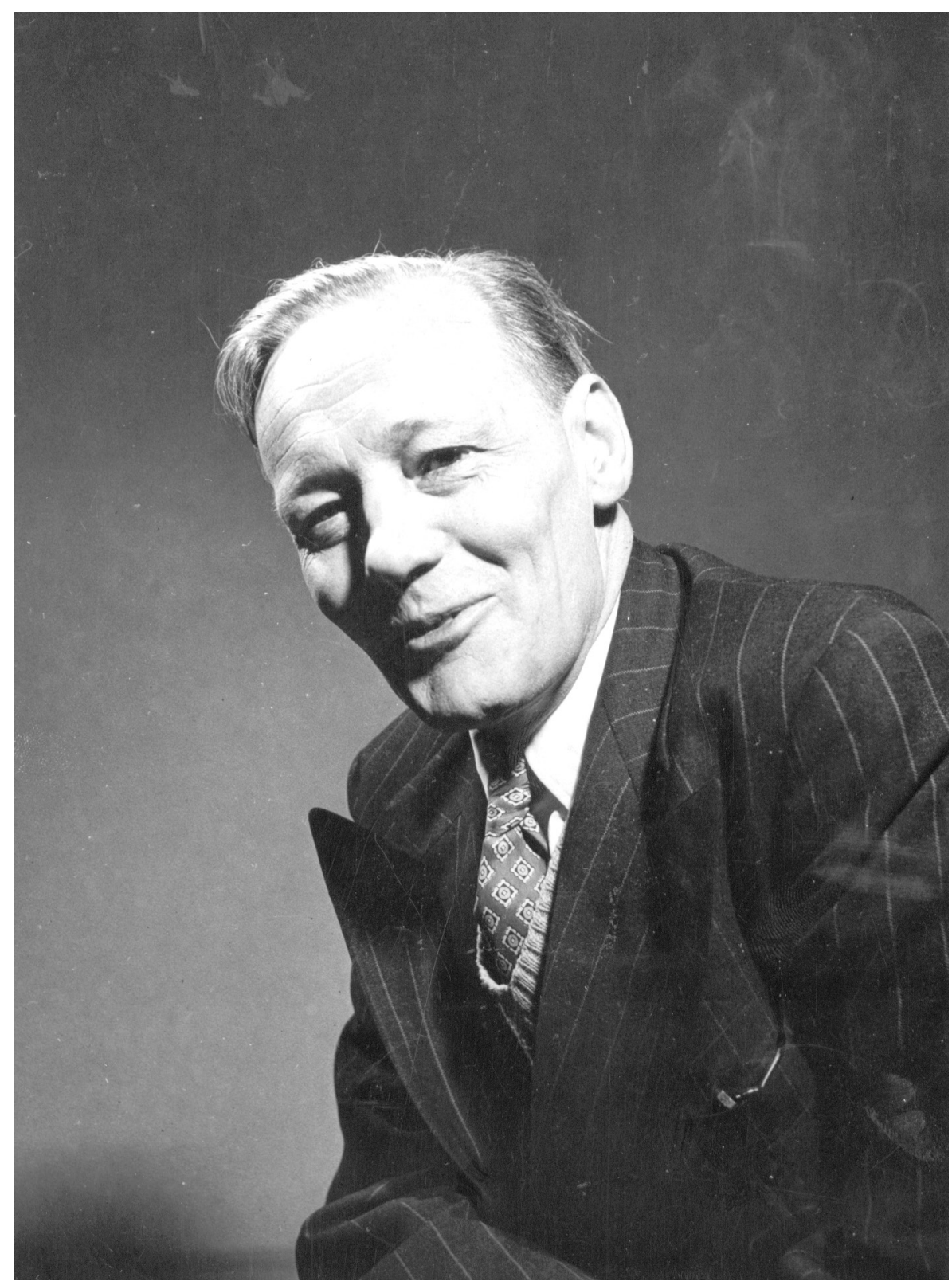

Figure 8. Mike Ross, director of International Affairs for the ClO, 1945-55, and for the AFL-CIO, 1957-63. Victor Reuther never trusted Ross, Irving Brown regarded him as "nice, ineffective and pliable," while Ross himself wondered whether Jay Lovestone had ever really left the Communist Party. Courtesy of TUC Library Collections, London Metropolitan University. 
These were dog days for the FTUC, which, apart from continuing to publish the Free Trade Union News, was barely limping along. "The Committee finds itself absolute[ly] broke and [with] not enough money to operate with," Lovestone informed Dubinsky. Chairman Matt Woll had died in June, without anyone designated to replace him even as co-signer of cheques. It left Lovestone unable to meet a request from Brown for money for Spanish trade unionists operating in exile. "I have no authority", he explained helplessly. "I can't initiate anything big ... until such time as.... Well!" $3^{2}$

The FTUC's line of communication to the international affairs department in Washington was through Mike Ross, but Lovestone was never sure what to make of the new assistant director. Privately, Ross had informed him that if ever the merger fell apart, he would stay put and sever his connection with the CIO wing. Heartened, Lovestone noted that "somehow or other, I have a feeling that Mike is genuine." But, more recently, Ross had ordered Henry Rutz to exclude copy supplied by Lovestone for the international affairs department's bulletin, explaining that it was likely to offend some executive council members. When Lovestone confronted him directly over this, Ross dissembled, claiming that the type had been "overset." Unimpressed, Lovestone duly complained to Meany about the episode. ${ }^{33}$

Ross was undoubtedly correct in noting the strong differences that existed between members of the international affairs committee. Following a row with Meany, the mild-mannered Potofsky was soon to resign as committee co-chairman, giving ill health as the cause, though the real reason was his inability to work with Meany in such an embittered atmosphere. Meany then offered the post to Reuther, but the autoworkers' leader declined it. Something more substantive than musical chairs was needed if harmony were to reign in the international affairs committee. ${ }^{34}$

\section{Waning of FTUC Influence Within European Labour}

There was now diminishing scope for Irving Brown to be effective in Europe; despite the challenges faced in West Germany, France, and Italy, it was harder for him to build alliances in the labour movement. The political climate was unhelpful and his material resources were shrinking. Back in 1949, Walter Schevenels had predicted that Brown would have nothing to offer Europeans but money, and now his main funding source was drying up.

Despite the West German move to join NATO, at the time of the merger, Brown and Lovestone were both particularly exercised over a perceived lack of enthusiasm for the Atlantic Alliance, fearful that in its desire for reunification the country might be tempted to reach a separate understanding with the Soviet Union. In this respect, the SPD and DGB caused Lovestone more concern than the arch-conservative 
Chancellor Adenauer, whom he had praised in spring 1955 as "all that stood between us and chaos ... and the loss of Europe to the Russians." His confidence in Adenauer did waver briefly in September when, caught up in the "spirit of Geneva," the chancellor visited Moscow for talks that established diplomatic relations. Lovestone complained that it was a "grovelling" visit and a "disastrous cave-in." But in a world where so few people could be trusted, Adenauer was still a more dependable ally than most, and Lovestone's faith in "Der Alte" would soon be restored, whereas his tendency to fulminate against the two wings of the German labour movement for being partners in a foolish "pacifist campaign" continued throughout the decade. ${ }^{35}$

In 1956, Irving Brown was still hopeful of being able to generate an active, labour movement campaign against the threat of domestic communism in West Germany. Recent communist gains in trade union and works council elections had caused some alarm in sections of the DGB and SPD, and Brown wrote of his new hopes for building on this welcome reaction by reviving an idea he had long harboured of establishing some central agency within or alongside the DGB to concert ongoing anti-communist activities among shop stewards and works councillors. He talked of a permanent factional organization capable of producing factory newspapers, leaflets, manuals, and guides to communism and with capacity to organize factory-level meetings. His key co-operator in this venture was Otto Stolz, the deputy director of the DGB weekly, Welt der Arbeit, who was also associated with Brown through the Congress of Cultural Freedom. Brown told Meany that he had also discussed this idea with Fritz Heine of the SPD national executive, Ernst Scharnowski, head of the DGB in West Berlin, and the centre's international secretary, Ludwig Rosenberg, along with others "whose names cannot yet be mentioned." ${ }^{36}$

It is quite possible that Brown's efforts in this area lent encouragement to the pro-Atlantic wing among members of the construction and other unions who came to identify with the SPD's right-wing Kanalarbeiter group, but nothing more was heard of his more ambitious plan as presented to Meany in January 1956. Given the prevailing lack of enthusiasm for NATO among West Germans, Brown was unlikely to draw support from among the trade union mainstream, and his main co-collaborator, Stolz, who resigned his post with the DGB in 1957, was later expelled from the SPD for associating with an anti-communist organization the party judged to be altogether anti-labour.

Lovestone and Brown were never on intimate terms with the topmost DGB leaders. They had not been close to Chairman Walter Freitag, and they were unimpressed by the field of candidates to succeed him in 1956. Reporting on the 1956 congress that elected Willi Richter as the new chairman, Brown regretted the DGB's preference for a low-key international role. Lovestone was particularly disappointed by the foreign policy resolution that equated the lack of freedom and dignity in the East 
with the evils in the West; such relativism was never acceptable. ${ }^{37} \mathrm{He}$ also damned Willi Richter with faint praise, rating him "not a strong man" and unlikely to hold onto the job for long-his one saving grace being that he was "a nice fellow." Brown soon concluded that Richter was "kidding us along" in calling for more cooperation within the ICFTU, and that they would need to put pressure on him when he came as a guest to the AFL-CIO convention in 1957, where "both you and Meany and myself can be a little more blunt and direct." ${ }^{38}$ However, Richter proved to be made of sterner stuff than Brown imagined.

The simple fact was that the sympathies of Meany and Lovestone were always more with the Christian Democrat Konrad Adenauer, given his commitment to the Atlantic Alliance, than with the SPD and DGB. An important moment in restoring their close bond with the chancellor following his lapse in seeking talks with the Soviet leadership was at a congenial one-to-one meeting between Meany and Adenauer in June 1956 in the course of an official visit to Washington. It contrasted with a visit later in the year by SPD leader Erich Ollenhauer, who also hoped to benefit politically from a White House reception, or at least an enthusiastic welcome by the AFL-CIO, so bolstering his domestic standing ahead of Germany's federal election in September 1957. But as Victor Reuther recognized, following Adenauer's visit, Meany was reluctant to display the same warmth to the SPD chairman. ${ }^{39}$

Significantly, a call by Germany's Catholic bishops for workers to vote for the CDU in the 1957 elections, and to abandon the DGB in favour of its Christian rival, saw Lovestone pointedly advise Meany against jumping into the fray on behalf of the DGB. As AFL president, he had done precisely that and to great effect in 1953 when he warned Adenauer against retaliating for the DGB's partisan support of the Socialists by launching a rival Christian trade union centre aimed at splitting the movement. But this time Lovestone considered that it was better to remain silent. ${ }^{40}$ Indeed, a well-publicized pronouncement by Lovestone in 1957 that an SPD victory would be damaging to West Germany was itself of considerable assistance to Adenauer's successful re-election campaign. Commenting on the influence that Lovestone had on the chancellor, Der Spiegel was drawn to observe that while Adenauer made much political capital from the fact that the SPD's deputy leader, Herbert Wehner, was a one-time Comintern representative and aide to communist party leader Ernst Thalmänn, the chancellor was careful never to mention his own close links to Lovestone, who had once been an actual leader of a national communist party. ${ }^{41}$

The political climate was also an impediment to Irving Brown's work in France, where the central issue was the war in Algeria. The communists had emerged as the largest party in France's National Assembly elections in January 1956, but Brown drew comfort from the outcome of subsequent negotiations to form a government that eventually produced an SFIO-led coalition with Guy Mollet as prime minister. Brown 
particularly approved of the way Force ouvrière's leaders had manoeuvred behind the scenes in helping to block the undesirable prospect of Pierre Mendès France emerging as leader of a popular front administration. But within days the political climate changed completely, with Mollet adopting a hard line against Algeria's nationalists rather than, as Brown had hoped, seeking a peaceful settlement of the colonial war. Brown reported a "debacle" in the making, correctly predicting that Algeria would become the Mollet government's "graveyard." ${ }^{2}$ It would also make his own work in France particularly difficult and even dangerous.

Brown's main focus in 1956 was to support Algeria's emerging nationalist trade union movement-an act of considerable courage in the circumstances. His first contact with dissident Algerian members of the CGT had been in 1952 when he was approached for assistance in establishing a breakaway national trade union centre. His Algerian interlocutors on that occasion were soon arrested; it would be four more years before an embryonic, pro-nationalist trade union organization re-emerged in the form of the Union générale des travailleurs algériens (UGTA), which Brown assisted and guided toward affiliation with the ICFTU. However, his efforts on behalf of UGTA coincided with the new repressive measures against Algerian nationalists directed by Mollet's minister resident, Robert Lacoste.

Faced with a deteriorating situation in Algeria, the ICFTU named a delegation, including Brown, to seek talks with Prime Minister Mollet and then proceed to Algeria to consult with moderate nationalist elements. However, before they left France, Lacoste singled out Brown from the rest of the delegation and banned him from entering Algeria, claiming that "under the pretext of trade unionism" he was "carrying out hazardous activities with dubious characters." It was alleged that he was working with the CIA to help finance a trade union centre aimed at undermining French influence throughout North Africa. Brown responded by denying that he had been engaged in passing money to anyone. Whether that was true or not, it is possible that the French authorities had intercepted his correspondence with Lovestone urging the need for UGTA to affiliate to the ICFTU speedily before it was upstaged by the rival Union des syndicats des travailleurs algériens. ${ }^{43}$

A month later Lacoste again publicly denounced Brown in a speech to the Council of the Republic, referring to him as "a master corrupter" in North Africa-a phrase originally coined by the CGT's leading communist, Benoit Frachon. George Meany wrote to Mollet, protesting at Brown's exclusion from Algeria and Lacoste's efforts at character assassination. ${ }^{44}$ However, the French government refused to reconsider its exclusion order, and Brown felt betrayed when fellow members of the ICFTU delegation suggested that he stand down so as to enable them to proceed to Algeria. It was evident that he lacked allies in this quarter. "There is practically no day that passes without some reference [within the ICFTU] 
to Lacoste's phrase of 'master corruptor," he wrote. "How Oldenbroek would love for Lacoste to prove some of his fantastic charges." 45 There was now a proposal that he be substituted by Victor Reuther on the delegation, causing Lovestone to instruct Brown: "Victor is a foul rat. . . . Vote against his being put on any North African Commission." In the event, the ICFTU decided to call off the mission, but not without leaving considerable rancour within the FTUC at the lack of solidarity shown toward its European representative. ${ }^{46}$

While Brown's wholehearted backing for the nationalist cause in Algeria was earning him notoriety in French government circles, it also put him at odds with his erstwhile close allies in the Force ouvrière leadership, especially André Lafond and Raymond Le Bourre, who were open supporters of the government's repressive colonial policy. Not only was Brown's scope for collaborative work with them thus severely constrained, his personal safety in France was threatened and friends advised him to "get out." He opted to remain, but his status as a resident was soon under threat. In the course of 1957 the French foreign minister informed the US ambassador that Brown might have to leave the country. The reason advanced was that he was not performing a trade union function so much as interfering in domestic politics. The minister alleged that Brown had recently visited certain political figures in northern France and that soon afterward they had become the owners of new cars. These developments naturally put a strain on Brown's family and led to his wife giving up their Paris apartment and returning alone to the United States in summer 1957.47

The fall of the Mollet government in 1958 and de Gaulle's return to power backed by dissident elements of the military did finally prompt Brown to seek safety outside France for a couple of months. In a move reminiscent of his departure from Paris in 1954 during the l'Affaire Dides, he feared reprisals by rogue elements within the police, and in coded language-referring to himself in the third person-he wrote to Lovestone:

Paris activity of certain milieux has all the signs of a "complot" [conspiracy] which can be very ugly and dirty. Our friend refuses to fall into a trap and has therefore chosen the next month or so to visit a number of countries. ... In France there is a steady evolution to an authoritarian system in which certain police services are becoming a state within a state.

He asked that mail be addressed to Lucien Tronchet in Geneva, telling Lovestone that he would be calling in there occasionally to collect it..$^{8}$

Brown's evasive action was evidently prompted in part by fear that his close dealings with Force ouvrière since 1948 - and especially his links to André Lafond-risked being exposed. Lafond was involved in the coup that brought de Gaulle back to power and was identified with a right-wing movement to establish armed militia groups 
within trade unions. FO general secretary Bothereau pressed him to step down, but Lafond refused, threatening to go public with information on the centre's internal affairs that would inevitably include dealings with Brown. ${ }^{49}$ Unless Lafond were forced out, Brown's secrets were still safe, yet his difficulties renewed hopes among his American opponents that he would now be exposed. The tantalizing prospect of gaining access to the French Sûretés dossier on Brown led Bill Kemsley to suggest:

If I was close to the French socialists I'd try to find [Jules] Moch's ear. ... Moch was formerly Minister of the Interior and undoubtedly still has friends there. Shouldn't be too difficult to arrange just a peek into the Brown file. And such a peek might well pay off by getting just enough ammunition to isolate one of the greatest cancers in the body union. ${ }^{50}$

Personal rancour between members of what was now a "united" American labour movement remained extreme.

Irving Brown lamented the fact that the bad odour generated by the Soviet suppression of the 1956 Hungarian uprising had still failed to stall the growth of communist influence within organized labour in Western Europe. "One can feel the slow but steady conceding by labour to co-existence, neutralism, outlawing of atom bomb tests, disarmament, various forms of anti-Americanism," he intoned. ${ }^{51}$ Yet, in Italy, the most immediate challenge to the FTUC policy of unwavering support for CISL and the four-party Christian Democrat-led coalition government was the call for a "turn to the left"- a policy of the non-communist left.

The idea of the much-discussed opening to the left was to heal the decade-long breach between Pietro Nenni's socialists (PSI) and Giuseppe Saragat's social democrats (PSDI), thereby opening up the prospects for a future centre-left government. It posed a direct challenge to the common front of communists and Nenni socialists that had existed since the end of the war but was now being called into question following the Soviet action in Hungary in 1956. Nenni had handed back his Stalin Peace Prize, and the electoral pact between the two parties was downgraded to a commitment merely to consult over policy. It was a strategy clearly intended to liberate Italian socialists from the communist embrace, but Lovestone understood the dynamic quite differently. He had no doubt that "socialist unity" was simply a clever ploy orchestrated from Moscow under which Nenni's task would be to "soft pedal and occasionally utter a cuss word" against the communist party while using his "wrecking crew" to break up the Christian Democrat-led coalition and manoeuvre Italy into a neutralist position. Irving Brown saw the likely consequence in the shape of a growing tendency toward an Italian form of "Bevanism" among Saragat's forces, with dire implications for the free trade union movement. While stationed in Rome as FTUC representative, Harry Goldberg had warned against such a development, 
but following the merger he was recalled to the United States, leaving no permanent American trade union presence to argue against the realignment on the centre-left. ${ }^{52}$

The Reuthers, by contrast, were keen to exploit the new political mood in Italy, especially when their persistent lobbying for embassy support for the Unione italiana del lavoro (UIL) began to pay off. Although smaller than the communist-led CGIL and the former Catholic CISL, UIL's membership was drawn from supporters of both the PSI and PSDI, and it was therefore was of pivotal importance if the consolidation of centre-left political forces was to extend into the trade union field. Victor Reuther advised his brother: "The general political situation in Italy makes the climate ideal for a push on the trade union front."

Working through the International Metalworkers' Federation, and in partnership with the German and Swedish metalworkers, the UAW focus was on strengthening the metalworking membership of both UIL and CISL at the expense of the communist-led CGIL. Their project was given a significant lift in 1956 when, in a wholly new departure, UIL benefited from a $\$ 160,00$ grant for training purposes from the International Cooperation Administration (ICA)'s (successor to the MSA and FOA) productivity unit in Rome. The scale of the support took all but those most closely involved by surprise. As an astonished Bill Gausmann, labour information officer in the American embassy in London, reported to Victor Reuther: "The next hot rumour is Italy. ... Someone in America-and it isn't at all clear who-has sunk a big chunk of dough into Italy unbeknownst to the ICFTU. ... [It] all sounds too weird for words.... TUC as well as myself would appreciate any light you could throw on this one." ${ }^{33}$

The American intention had been to divide this ICA grant between CISL and UIL, but the former procrastinated over the fine print and UIL scooped a bigger-than-intended share. The sum enabled UIL to open a training school at Anzio that soon became part of an ambitious training program by the IMF conducted by Charles Levinson and aimed at devolving the focus of trade union activity from the level of the confederations-UIL and CISL-to the respective industrial federations of metalworkers-UILM and FIM. The IMF objective was to build the industrial unions with a rank-and-file leadership trained in the ways of militant economic unionism. Five thousand local activists were trained in the late 1950s, the seeds of a shop steward system that would begin to establish a presence with the growth of plant bargaining in the early 1960 s and come into its own fully during Italy's "hot autumn" of 1969. In the opinion of IMF general secretary Adolphe Graedel, it was the most important trade union development in Italy since the formation of UIL in $1950 .{ }^{54}$ Without doubt it marked a sharp move away from the pattern of FTUC influence over the non-communist trade unions in Italy. 
Arguably one European country where Irving Brown still felt confident enough to intervene as in the past was Greece, where, in 1957, he acted decisively to counter an emergent united front within the trade unions. In national elections the previous year a leftist coalition including the communists came close to winning power. The following summer the trade union centre GSEE, led by Fotis Makris, joined with Greek communists in a rolling general strike that continued for several weeks. On the eve of this action, Brown travelled to Athens to warn Makris against participation. If it failed, he argued, it would be a catastrophe for the labour movement, whereas, if it succeeded, it would still only be a victory for the communists. When Makris rejected his advice, Brown interceded with ministers in the conservative Karamanlis government hoping to mediate a settlement to the dispute. In what was seen as an attempt to break the strike, he made it clear to all concerned that the planned action did not have American support. He also retaliated against Makris by diverting money intended for his GSEE faction to Dimitris Theodorou, who led a rival faction in Salonika. ${ }^{55}$

Brown's intervention in Greece aroused Victor Reuther's ire, and he wrote to Walter Schevenels at the ICFTU: "We are eager to dig deeper into this so as to have some frank discussions at the highest level in the AFL-CIO so as to put an end to this kind of unilateral interference in the internal affairs of ICFTU affiliates." ${ }^{36}$ Greek government officials put a price tag of $\$ 200,000$ on the cumulative amount previously channelled to the GSEE by Irving Brown - a claim that Makris was understandably keen to deny. In private correspondence, Brown observed wryly: "There would not have been a Makris or a GSEE if it had not been for our continuous aid and assistance since the days of $1947 .{ }^{\prime \prime} 7$

Brown's pre-eminence as American interlocutor in Greek trade union affairs began to be challenged in 1958 when a version of the IMF's training scheme already operational in Italy was then extended to Greece. It set a pattern for similar initiatives in other industries and led to a coordinated attempt by international trade secretariats in transport, food, oil, chemicals, textiles, and mining to strengthen the organization of the unions, running in parallel with an ICFTU-led scheme to wean Greek unions away from their historic dependency on government finance. Brown was skeptical that the program would succeed, confident that little could be done "to save the Greeks from themselves." But he chose to stay away from the country for the time being, figuring that his presence might provide the ICFTU with an alibi or allow it to scapegoat him when its program inevitably failed. He calculated that the AFL-CIO would have to go in again later to "pick up the pieces," noting with sarcasm that so long as the ICFTU did not interfere "too badly", it would be possible for the AFL-CIO to get "the Greek thing back on the rails, at least for a little while." 58 


\section{The Developing Focus on Africa}

With the future of the FTUC uncertain, and following his mission to India as fraternal delegate at the INTUC congress in April 1956, Brown spent much of the rest of the year focused on North Africa, an area with which he was already familiar and from where his interests would soon extend to sub-Saharan Africa. Back in May 1954 he had spoken out on African issues at the first ever Bilderberg Conference of international affairs luminaries. As a member of an American delegation that included Paul Nitze, David Rockefeller, Henry Kissinger, and C. D. Jackson, on that occasion Brown had warned of the turbulent times ahead if the Europeans did not tackle problems brewing in Africa. Now, in the summer of 1956, he acted as chaperone to the AFL-CIO's internationally inexperienced secretary-treasurer, Bill Schnitzler, on a landmark visit to Tunisia, following a tour of European trade union centres. In affording Schnitzler some international exposure, Brown hoped to convince him of the need for a continuing role for the FTUC. Lovestone derived mischievous pleasure from their chosen itinerary, telling Brown: "It is good to know Sir Vincent Oldenbroek is puzzled by the trip to Tunisia. The more puzzling, the more pain and the more pain the more progress for some people." 59

In fact, Schnitzler and Brown were in Tunisia as honoured guests at the congress of the trade union centre, Union générale tunisienne du travail (UGTT), soaking up plaudits for the important assistance the AFL, and Brown in particular, had given Tunisian nationalists over many years in their campaign for independence. The AFL had long since adopted a principled stance against colonialism, willing to risk offending allies such as Force ouvrière and the British TUC in the process. Lovestone had correctly argued that the continuation of colonialism would play into the hands of communists within the nationalist movement. Brown more than anyone had been responsible for cultivating relations with Habib Bourguiba, the moderate pro-Western nationalist leader who, with France recently granting independence to the country, had now become Tunisia's first prime minister. Lovestone regarded him as the best alternative to Colonel Nasser as a potential leader of the Arab world.

The AFL had entertained Bourguiba at its convention in 1951, having appealed personally to President Truman to overturn a State Department rejection of his application for a visa. When the French colonial authorities subsequently stepped up repression of nationalist trade unions in Tunisia, Brown had supervised the distribution of $\$ 350,000$ in aid. ${ }^{60}$ And when nationalist sentiment then spilled over from Tunisia to Morocco, it was Lovestone who supplied the funds to launch a purely Moroccan trade union centre. ${ }^{61}$ Now basking in the gratitude of his UGTT hosts, Brown was seated next to Prime Minister Bourguiba among the distinguished guests. 
Following the congress he and the prime minister travelled together to Paris, and Brown agreed that he would assist in drafting a request for aid for Tunisia-including military aid - to be submitted to the US government. ${ }^{62}$

A concurrent development that helped pull together the threads of Brown's growing interest in Africa as a theatre of activity was the ICFTU's decision in 1956 to convene a regional conference of African affiliates for January 1957. Brown had supported such an initiative since it was first proposed in the ICFTU executive board in 1954. The hope was to launch an African regional organization such as already existed for Latin America, Asia, and Europe to guide ICFTU policy and service affiliates. However, the European centres with a colonial interest in Africa-especially the TUC, FO, and the Belgian FGTB-had dragged their feet for two years, and Brown now feared that African unions would turn away from the ICFTU in disillusionment. ${ }^{63}$

To help with arrangements for the ICFTU's regional conference, the youthful and extremely able general secretary of the Kenya Federation of Labour (KFL), Tom Mboya, was assigned to the Brussels headquarters in 1956 to prepare documentation. Following his stint there, Mboya-as much a nationalist politician as a trade union leader-undertook a three-month lecture tour of the United States in the autumn of 1956, establishing contact with AFL-CIO leaders for the first time and, after meeting Jay Lovestone, contributing articles to the Free Trade Union News that the ICFTU secretariat judged to be "unfriendly." Mboya's main purpose in the United States was to raise funds for studentships and for the construction of an elaborate headquarters for the Kenyan labour centre. The ICFTU had previously turned down a KFL request to finance this building project on grounds that it was a misuse of the labour movement's scarce resources. However, the AFL-CIO was willing to step in and donated $\$ 35,000$ toward the cost of the new headquarters. This act of generosity was to be hugely controversial within the international labour movement. Victor Reuther advised his brother, Walter, against the UAW giving Mboya money for the building, as such appeals were supposed to be coordinated through the ICFTU. The AFL-CIO's donation was widely read as an indication of the Americans' readiness to "interfere" in Africa and would greatly influence the atmosphere in which the African regional conference took place some weeks later. ${ }^{64}$

The ICFTU's regional conference was staged in Ghana's capital, Accra, suffused by an atmosphere of nationalist pride; the country's formal independence was only weeks away, and Prime minister Kwame Nkrumah, black Africa's most prominent politician, was the keynote speaker. The AFL-CIO had no territorial stake in Africa, and the ICFTU had not seen fit to extend an invitation. Nonetheless the federation sent a delegation including Brown and Schnitzler, and the latter delivered a sharply worded speech drafted by Lovestone criticizing Europe's colonial record and 
announcing the AFL-CIO's determination to stop the US government "appeasing colonial interests."

Among the Europeans present it was regarded as a provocative intervention. Hitherto, the Americans had limited themselves to calling on the ICFTU to act with more urgency in the colonies: now the AFL-CIO was hinting at a more direct role for itself in Africa. Through the $\$ 35,000$ gift to the KFL and Schnitzler's crowd-pleasing speech in Accra, Brown considered that they had demonstrated to African trade unionists that "the American unions can do the job." ${ }^{5}$ In this, the AFL-CIO was a step ahead of the Eisenhower administration's evolving policy for Africa. Two months later, Vice President Nixon made a groundbreaking tour of seven African countries during which he told labour leaders of his admiration for the work of Irving Brown-“a personal friend" for over a decade-and later submitted a report recommending the establishment within the State Department of a Bureau of African Affairs. Its first head would later consult Brown on how to "handle the labour angle" - a harbinger of what the AFL-CIO representative considered "a real labour programme." Pointing out to Meany that the Soviet Union had just established a special academy in Moscow to study African problems, Lovestone now argued that Africa had become the "real battleground" and "the next field of the big test of strength" between the super powers. ${ }^{66}$

\section{Rowing Back on the Carleton Hotel Agreement}

The summer tour of Europe and North Africa by Irving Brown and Bill Schnitzler in 1956 had concluded with an appearance at the TUC annual conference, where Schnitzler was the American fraternal delegate. They were present to hear the British coalminers' communist general secretary, Arthur Horner, call for the re-establishment of the wartime Anglo-Soviet Trade Union Committee and learned that the new leader of the large transport workers union, Frank Cousins, was also planning to send a fraternal delegation to the USSR. TUC general secretary Vincent Tewson had offered no objection to the latter announcement provided that the purpose of the Soviet visit was to gather "technical and industrial information." Reporting on these developments, Brown deplored, not for the first time, the lack of strong leadership within the TUC and predicted a complete acceptance of exchange visits with the Soviet bloc within a year. ${ }^{67}$ It was grist to Lovestone's mill, and with Schnitzler echoing the warning, he sounded the alarm to Meany:

Frankly, the bankruptcy of the TUC leadership as personified by the role of the pompous clerk [Tewson] is a cause for deep concern.... The frontal challenge of the Communists to guide or, at least to influence profoundly, the 
politics of the TUC is of the greatest concern to American labour... [and] to the entire international labour movement. ... I cannot think of a more serious blow to the ICFTU than a pollution and permeation of the TUC at a dangerous level by pro-Moscow elements in Britain. ${ }^{68}$

Lovestone persuaded Meany to convene a special meeting of the AFL-CIO international affairs committee the following month to discuss the situation facing the ICFTU in the context of the Soviet Union's "new look." For this, Lovestone was charged with drafting a document dealing with "the encroachments and encirclement to which the situation is being rapidly and dangerously subjected." It would include proposals aimed at strengthening ICFTU opposition to union visits to the Soviet bloc. ${ }^{69}$

Lovestone's document contained ten proposals intended for submission to the ICFTU's next executive board meeting in November. Mostly they called for existing policy to be applied more vigorously, including stepped-up anti-colonial campaigning. The two main proposals came first and last on the list and were a clear expression of mistrust of the present leadership. One called for the establishment of an advisory committee to assist the ICFTU's department of organization under Millard to achieve its objectives. The last proposal was for another ad hoc committee to conduct a catch-all review of the ICFTU's record since its formation and recommend ways to improve its performance. ${ }^{70}$ The effect of these two key proposals was clearly to undermine the Carleton Hotel understanding of three months earlier whose thrust had been to close down the FTUC and throw American labour's international effort behind the ICFTU. Now it was the ICFTU, and especially its recently established department of organization, that was to be placed under critical review.

Once again Meany had no plans to attend the November executive board and argue personally for the AFL-CIO's proposals. Instead, his intention to tour Latin American trade union centres at that time was taken as a reflection of his true priorities. Irving Brown was again tasked with introducing the proposals at the board meeting. He was to represent them as the unanimous view of the AFL-CIO international affairs committee, though Jim Carey made it clear to Meany that he had opposed them vigorously and would not now support them. ${ }^{11}$ Rather than fall out publicly with Meany, Walter Reuther also chose not to attend the board. It had been billed as an important meeting in that Charlie Millard was scheduled to map out his long-term plans for vital organizing activities. However, reacting against what was widely recognized as a vexatious American ploy, the DGB's new president, Willi Richter, came late, Vincent Tewson attended only on the final day, and the Nordic unions stayed away altogether. ${ }^{72}$ 
In the event, the Americans found themselves once again outmanoeuvred. Little time was allotted to debate Lovestone's proposals; Brown was the only person to speak in favour, while the British intervened to denounce them as unacceptable. Vincent Tewson argued that Millard didn't need a three-man advisory committee looking over his shoulder-but rather someone to do the organizing work. Likewise the proposed ad hoc panel to pronounce on the ICFTU's effectiveness since its foundation was attacked as unacceptable: the assumption that the performance of the ICFTU had been useless since its inception was simply wrong. Unstated, but adding passion to Tewson's opposition, was his concern at recent news of the AFL-CIO interfering in a British colony through its generous grant to Tom Mboya for the KFL headquarters building.

From the secretariat, only Millard intervened-to ask Brown whether the AFL-CIO proposals had the unanimous support of its international affairs committee. "Yes" was the answer. Most present would have known that this was not so. There were no plans for further discussion until the board met during the following summer's congress in Tunis-too late for the proposals to frame that congress's agenda as Lovestone had hoped. In that respect, it was another bad day at the ICFTU for the AFL-CIO representative, with Jay Krane recording that Brown took "an awful shellacking."

Distraught at the outcome, Brown cabled Lovestone: "Our proposal treated scandalously. ... Organization completely British controlled. Situation impossible and sterile." Still smarting a week later, he wrote from a hotel room in Istanbul: "What a fiasco-the ICFTU now led by Oldenbroek, Millard and Krane. How can we go on? Or should we go on? More of this later when I am more restrained and balanced. You can guess what I would like to do."73

Despite this setback, there was no let-up in the effort by Lovestone and Brown to highlight for Meany's benefit the lack of firm anti-communist direction of the ICFTU. In this, Millard provided an easy target, his public pronouncements revealing an unwillingness to deal in anti-communist rhetoric or denunciations of the neutralist yearnings of many trade unions in the developing world. Brown considered his approach to be "anti-anti-communist," while Lovestone told Meany: "Some people might say Millard should be given a chance. ... For my two cents worth ... Mr. Millard should be given no chance to violate them [ICFTU policies], not even for minutes, let alone months or years." The TUC-always regarded as the power behind Oldenbroek-was also targeted for criticism, especially now that it seemed to be looking for a showdown over the AFL-CIO's threatened interference in colonial affairs. ${ }^{74}$ 
In spring 1957, a Times of London leader, clearly informed by TUC thinking, defended Oldenbroek's leadership of the ICFTU while identifying Lovestone as the villain of the piece:

The fighting had previously all been on one side. The TUC and other organizations withdrew before every attack ... anxious to avoid dissension which might hamper American trade union unity. Now ... they ... ask that all American representatives should behave as cooperative members of the international. ${ }^{75}$

Lovestone read the piece as evidence of an international conspiracy against the AFL-CIO that involved both Reuther and the British Colonial Office. He warned Meany: "You are the one they are after. I am . . . merely the whipping boy." The charge made was that the AFL-CIO stood for "negative anti-communism." Lovestone fumed: "This is the rub. They just hate to be anti-communist." Rolling together trade union issues with developments on the world stage, he held that the TUC line was prompted by resentment at Eisenhower's forcing the French and British governments to end their recent military intervention at Suez. Retaliation by Britain had now come in the field of international labour policy because, Lovestone maintained, it was the one area where they felt they had an advantage over the Americans, given the "divided and paralyzed" state of the US labour movement. The problem dated back to the merger - what he referred to as the AFL's "original sin." ${ }^{76}$

Meany responded to the Times leader in a letter criticizing the TUC's role in Britain's colonies - he had in mind particularly the TUC's recent action over Cyprus, where a guerrilla war for colonial independence was now raging-and he stated defiantly that the AFL-CIO had no intention of withdrawing the ten-point program, least of all its advocacy of a more aggressive fight against colonialism. ${ }^{77}$

The very future of the ICFTU was now uncertain as the Tunis congress approached. How much longer could it withstand destabilizing tactics by the AFL-CIO and the denial of material resources necessary for its basic tasks? Was continued AFL-CIO membership in the ICFTU even assured? And with the TUC-happy to ignore ICFTU policy when it got in the way of its own independent policy in the coloniesthreatening a confrontation with the Americans over the ten-point program, how long before open conflict broke out between the international's two largest affiliates?

Throughout the first half of 1957 , leading up to the ICFTU's Tunis congress, Walter Reuther tried patiently to restrain Meany, hoping to penetrate his "mental iron curtain" by calling for an end to "this cold war" with the ICFTU. He made clear that he was no longer prepared to go along with Lovestone setting the international affairs committee's agenda, and he threatened to stay away from meetings unless members had the chance to discuss fully policy statements such as the recent ten-point 
program. He warned that if Meany continued to attack the ICFTU, he would be forced to oppose him publicly at the Tunis congress. ${ }^{78}$ Reuther was convinced of the need ultimately to remove Lovestone from his strategic position at Meany's elbow, but he reckoned that a start in that direction might be made by ending Irving Brown's role as de facto permanent AFL-CIO representative in the councils of the ICFTU. To this end, he was prepared to strike a deal with Meany under which both Brown and Victor Reuther would cease to attend executive board meetings as his and Meany's substitutes. In effect, he was prepared to sacrifice his brother and right-hand man in international affairs, in order to be rid of the contentious figure of Irving Brown with his slanted reporting of ICFTU affairs. ${ }^{79}$ Finally, to clear the air with other leading affiliates of the ICFTU, he proposed that he, Meany, and senior AFL-CIO vice presidents travel to Europe for informal talks with their counterparts. Meany was agreeable, but it proved impossible to arrange a meeting ahead of the Tunis congress.

The one substantive change agreed to by the international affairs committee was to bring to an end George Brown's feeble leadership of the international affairs department and to appoint Mike Ross as titular head. What effect this would have on the balance of contending forces in the AFL-CIO was unclear. As Bill Kemsley in the ICFTU's New York office noted: "No one seems certain of Mike's relations (or lack of them) with Lovestone. Many however think he has the same government connections." But with Ross lacking Lovestone's drive and influence with George Meany, he was hardly likely to set a new tone, and it soon became evident that decisions on international affairs were being taken without his involvement. Kemsley still reckoned that Meany would try to oust Oldenbroek as ICFTU general secretary at the Tunis congress in July, replacing him with Omer Becu. Certainly he had no doubt that Lovestone was "determined to scuttle the ICFTU."

At the AFL-CIO executive council in June just ahead of the Tunis congress, Reuther finally succeeded in having Meany agree to withdraw the contentious ten-point program from the ICFTU agenda, the latter recognizing that the climate wasn't right. Belatedly Brown had cautioned Meany against being seen to oppose Jaap Oldenbroek, noting that although the general secretary was prone to trim from time to time, on the fundamentals of ICFTU policy he was not vulnerable to criticism. Omer Becu, who was planning to stand down as ICFTU president out of disdain for Oldenbroek, was the person on whom Lovestone and Brown had pinned their hopes as a possible candidate for the post of general secretary, but he now lacked the stomach to challenge Oldenbroek for his job, and there was no other credible candidate in the offing. A further factor was that Meany was currently preoccupied domestically with the problem of corruption in the teamsters union, and with this sordid affair making headlines abroad, it was hardly the best time for the AFL-CIO 
to be projecting itself as moral leader of the international labour movement or seen to be throwing its weight around within the ICFTU. ${ }^{{ }^{11}}$

The previous autumn's campaign against the ICFTU leadership thus petered out. Meany now told Ross and Lovestone that his instinct was "to play the game on an easy basis" in Tunis and "support passively" the re-election of Oldenbroek as general secretary. Meanwhile, Schnitzler was given the job of extricating the AFL-CIO from the corner into which it had painted itself. He duly wrote to Oldenbroek requesting the removal of the ten points from the executive board agenda, explaining coyly that "we learn of a number of misunderstandings that have arisen as to our motives in making this proposal." ${ }_{2}$

Lovestone found this policy reversal hard to take. In a rearguard action, he urged Schnitzler, who was to lead a second-string American delegation at the Tunis congress-Meany and Reuther had opted for discretion and chose not to go to Tunis-to do his utmost to persuade Omer Becu to stay on as ICFTU president by assuring him that "this is the last time we impose on you." ${ }^{3}$ It was all in the interest of derailing the possible candidature of the Swedish metalworkers' leader, Arne Geijer, a close ally of Reuther in the IMF. However, Becu declined to play along, and in the event, Geijer was the overwhelming choice of the congress for ICFTU president. From the Reuther standpoint, his election in Tunis opened up the prospect of more constructive work through the ICFTU. ${ }^{84}$

Membership in the AFL-CIO's delegation at Tunis was a miserable experience for Lovestone; after only two days he was contemplating asking to be called home. ${ }^{85}$ Yet the congress offered some comfort to the AFL-CIO. In particular, a resolution critical of the labour legislation in Britain's East African colonies was adopted, along with a decision to send a delegation to investigate the situation. This one development helped create a climate conducive to continued AFL-CIO involvement in Africa. Around it a meeting of minds would later develop between Meany and Reuther that was to have particular significance for the future leadership of the ICFTU.

\section{The Atlantic City Accord-and Aftermath}

As the AFL-CIO's 1957 convention in Atlantic City loomed, the continued existence of the FTUC was still the main bone of contention in both the federation and the wider international labour movement. Walter Reuther won some backing for his position at a meeting of the executive council in August with an attack on Lovestone's obsession with Soviet affairs. At issue was a lengthy draft document analyzing the current power struggle within the Kremlin that he had prepared for the meeting. Reuther exploded with impatience: 
I am sitting here representing my union as a trade unionist. I am not sent here to participate in the exercise of semantics of dialectical materialism.... I don't know what the internal power play is in the Soviet bureaucracy. I don't know really where Bulganin fits in terms of Zhukov and how many notches Zhukov came up in the power struggle. ... I want to fight them, but I will be damned if I want to analyze the internal manipulations. ${ }^{86}$

Victor Reuther noted that "the sentiment was rather overwhelmingly for getting back to a more practical trade union participation in international affairs." To hasten such changes, he pressed for a firm date when the year's notice to the FTUC would at last run out. In a related move, he also took aim at Lovestone's undue influence on labour attaché appointments and, as a first priority, argued that the time had come for the Lovestone-approved attaché in London, Joe Godson, to be replaced. ${ }^{87}$

The fate of the FTUC was finally settled during the AFL-CIO convention in Atlantic City in December 1957 at the long-delayed informal meeting with leaders of the ICFTU's main European affiliates that Reuther had first proposed in the summer. The event found Meany still preoccupied with the internal issue of corruption and the imminent expulsion of the teamsters union, with little time to spend in defending Lovestone and his operation. At the "summit" meeting on Sunday, 8 December, attended by Jaap Oldenbroek, Arne Geijer, Willi Richter, and Vincent Tewson, along with members of the AFL-CIO international affairs committee, Meany bowed to the general will of his invited guests and finally agreed to terminate the activities of the FTUC. Lovestone was to relocate to Washington and work in the international affairs department as deputy to Mike Ross, while continuing to have responsibility for editing the Free Trade Union News. Irving Brown would remain as European representative based in Paris and serve as executive secretary to the AFL-CIO's representatives at the ICFTU executive board but with full powers when (as was frequently the case) they were not present. As the British labour counsellor put it, it was "an unexpectedly satisfactory agreement." ${ }^{38}$

This concession allowing Brown to remain in Europe was small comfort to him. He had recently complained to Lovestone: "As far as we are concerned, we can yell, complain, etc., but the Brussels bureaucracy has things in hand. We are not in the works since the division back home permits Oldenbroek and company to counter anything that I propose or push. I have never felt so helpless and frustrated." ${ }^{89}$ For some months to come he was in an unsettled state. To a vague suggestion by Lovestone that he might replace Phil Delaney, who was vacating the post of worker delegate at the ILO, his hangdog reply was that "controversial people do not get such assignments." On another occasion, he gave vent to his disillusionment: "I am 
convinced more than ever there is no future for me in this whole business-in terms of what we originally set out to achieve."9o

Lovestone hand-delivered an anguished letter to Meany at his hotel room in Atlantic City, incredulous at the New York Times report of the agreement that he reckoned had the hand of Reuther and Carey all over it:

I was pained and puzzled no end by the astounding revelation in today's New York Times. ... Once again the [British] Colonial Office has succeeded in opening wide the doors for Communist agents. ... If they [Reuthers] persist in the factional drives as they have in the past, then the results of the last twenty-five years of American labour activity in the international field will still be more gravely jeopardized. I am sure you do not mind my being frank and forthright with you..$^{11}$

For the Reuthers, the "Atlantic City Accord," as it came to be known, was naturally a gratifying outcome. "At long last, I think we have reached a turning point, and for the better," wrote Victor Reuther. With their Swedish ally, Arne Geijer, presiding over the ICFTU, there seemed genuine hope for a fresh beginning in relations with it. ${ }^{92}$ Soon after the Atlantic City meeting, the chairmanship of the federation's international affairs committee also changed hands. The experiment with Meany and Potofsky as co-chairs had not been a success-Potofsky finding it impossible to work with Meany-and George Harrison, the widely respected president of the railroad clerks who was considered independent of Reuther and Meany factions, now became chairman amid hopes that he would be able to bring the parties together. ${ }^{93}$ Whether the accord would have a lasting effect on the AFL-CIO's conduct of foreign policy, as Victor Reuther believed, remained to be seen.

In fact, Lovestone quickly regained his swagger, reassuring Dick Deverall: "I shall be continuing all the work I did under the new title. Please note there is no mention of any dissolution of the Free Trade Union Committee. It can always be brought back since it was never dissolved." Two weeks later, as the chimes for the New Year rang out, he boasted: "I have been buried many times and I've had my carcase picked at. There will be many a vulture forced down before getting at me. I take a special delight in strangling vultures before they get to me."94 Arnold Beichman, close to Irving Brown and Jay Lovestone and responsible for handling press relations in the ICFTU New York office, similarly refused to believe that the effect of the changes would be as far-reaching as some hoped, quickly pointing out to colleagues in the Brussels headquarters that Lovestone still continued to enjoy Meany's confidence and that, despite his being crestfallen, Irving Brown's position was still very strong. ${ }^{95}$ Other seasoned observers shared that view and declined to write off Lovestone. Arnold Steinbach, director of the Federal Department of Labor's Office of International Affairs, advised 
the British labour counsellor that the FTUC executive secretary was likely to "lose all battles but the last one." He would certainly not take this loss lying down. ${ }^{96}$

Nonetheless, open conflict within the AFL-CIO over international issues now subsided. The signs were that Meany was prepared to accept the new settlement. Less than a year on from Atlantic City, Lovestone urged him to press again for ICFTU acceptance of his ten points but there was no response, and Reuther was satisfied that Meany was "playing fair." ${ }_{97}$ "Very much of the old spirit of initiative and drive in the international work is gone," Lovestone complained. He believed that Meany's forced "retreat" and Reuther's growing influence reflected the ideological flabbiness that was spreading within the Western alliance: "appeasement, confusion, self-deception and suicidal actions are gripping the entire western world," and were also becoming embedded in the labour movement. Coexistence was the order of the day, as reflected in the increasing number of East-West exchanges in various fields-cultural, political, and labour. ${ }^{98}$

\section{Engaging with Pan-Africanism}

What gave Jay Lovestone and Irving Brown renewed heart was the scope opening up for influencing the direction of African trade unionism, especially in the context of American plans for a major training program for the coming generation of African leaders. After attending the ICFTU's Tunis congress in 1957, A. Philip Randolph, the black president of the sleeping car porters' union, had visited East Africa at Tom Mboya's invitation to assess training needs. On returning home, Randolph won AFL-CIO agreement to earmark \$50,00o for the launch of an African training scheme. ${ }^{99}$ The federation's instinct was to conduct the training in the United States, and within a matter of days, with little attempt at wider consultation, Lovestone arranged for Maida Springer, a black staffer from the garment workers, to travel to Africa in October 1957 to select the first batch of students. The ICFTU was disturbed by this precipitate initiative, considering training to be its responsibility. The State Department was also concerned that the AFL-CIO initiative might damage Anglo-American relations, and for the next several weeks confusion over responsibility for the program reigned until the Atlantic City meeting in December, where one of the key concessions made by Meany was for the $\$ 50,000$ to be handed over to the ICFTU and for it to lead the program. ${ }^{100}$

Launching the training program was now seen as a test of the ICFTU's capacity to deliver results, though from the outset it ran into opposition. The TUC, in particular, opposed the plan to set up a residential college; it would be costly and involve training comparatively few students, whereas a team of peripatetic teachers would be able to offer courses to larger numbers at lower cost. There were disputes over 
the staff to be engaged and nature of the curriculum, which the TUC in particular feared would be too political. In fact, the TUC was rapidly finding itself at odds with the ICFTU over its own independent work in African colonies, or, as Tewson put it, over its right "to be concerned about people who carry British passports." The British rejected Millard's plea that all TUC aid to its colonies be routed through the ICFTU. And when Oldenbroek tried to insist, the TUC spoke of being at "breaking point," warning that in future it might not contribute to the recently established International Solidarity Fund (to which it had so far pledged $£ 500$, 000 over three years) that was now to become the permanent fund for ICFTU development and organizing work. Bill Gausmann, labour press officer in the American embassy in London, noted: "The British brothers are tending privately to write off the ICFTU. It is difficult to disagree with their assessment." ${ }^{101}$ Millard began to threaten resignation over the lack of cooperation from the TUC, whereas Brown was buoyed up by this deterioration in TUC-ICFTU relations, viewing it optimistically as "the biggest and most decisive turning point in the international labour movement."

Leading Africans were also highly critical of the ICFTU's plans. They regretted that the AFL-CIO was no longer in charge of the training program and were angered to have first learned of this from the press. They also resented not being consulted about new plans to locate the training college in Uganda's capital, Kampala. Mboya issued a report on behalf of three East African trade union centres that held the European leadership of the ICFTU at fault for the international's past lack of attention to Africa. The East African unions were insistent that they would not tolerate the posting of a British union official as ICFTU representative in the region in future. In contrast, Mboya complimented George Meany for his "wide vision and interest in the problems of underdeveloped countries." 103 In follow-up correspondence with Meany, Mboya reinforced his preference for the Americans, telling him: "The position is very definitely one which requires urgent and immediate attention if the ICFTU connections in Africa are to be saved." 104 There was more in this vein in further letters from the KFL president, pressing the right buttons in assuring Meany that he was keeping on top of "the communist menace" in Kenya (in fact, there was virtually no indigenous communist threat) while soliciting more American funding for his headquarters building. ${ }^{105}$

The Reuthers were also concerned over the friction surrounding the African labour college. They recognized that the various strands of the Atlantic City accordwhich had ruled that training in Africa was the responsibility of the ICFTU-might unravel altogether if its program failed. When Mboya complained that a Willys jeep, originally presented by the autoworkers for the use of the African labour movement, was effectively under the control of the ICFTU and locked away for use only when one of its officials was in the region, it could hardly fail to register with them. ${ }^{106}$ And 
beyond the problems associated with the training program, the ICFTU's continuing delay in establishing the permanent African Regional Organization (AFRO) that the regional conference in Accra had called for in January 1957 was becoming a source of worry for the UAW leadership.

Although the ICFTU was held to blame for this delay, there were also important differences between its East African and West African affiliates that had held up progress, and these highlighted an issue central to the future shape of free trade unionism in Africa. The Ghana TUC under John Tettegah wanted to hold off forming the regional organization pending unity with the French-speaking national centres of West Africa, led by Guinea's Ahmed Sékou Touré, that were outside the ICFTU fold. The latter centres favoured a purely African trade union organization unaffiliated with either the ICFTU or WFTU and "neutral" in cold-war terms. It was a formula that would later underpin the All-Africa Trade Union Federation (AATUF), and it already had a growing number of supporters, including some ICFTU affiliates disillusioned with the international's performance in Africa. Ranged against Tettegah on this issue was Tom Mboya, who, though critical of the ICFTU on many issues, strongly identified with the West and was wary of the concept of African "neutrality" that the Soviet Union and the WFTU supported as a means of weaning African labour away from the ICFTU camp. Support for "neutrality" in trade union term clearly involved a risk of being drawn into the Soviet orbit. ${ }^{107}$

With the ICFTU yet to give institutional form to the African unions' desire for a regional organization, pan-African sentiment was on the rise throughout the continent and threatened to leave the ICFTU behind. The issue of trade union neutrality was high on the agenda at the launch of the All-Africa Peoples' Conference (AAPC) in Accra in December 1958, a gathering of utmost importance in the unfolding struggle against colonialism. Among the two hundred delegates attending from fifty organizations and twenty-five African territories, trade unionists played a prominent role and in their separate meeting took a decision in principle to form an All-Africa Trade Union Federation. Kwame Nkrumah, the driving force behind the conference and its host, selected Tom Mboya as its chairman, while John Tettegah served as assistant secretary. Irving Brown, Maida Springer, and George McCray (an American lecturer at the African training college in Kampala) attended on behalf of the AFL-CIO and made a significant contribution on the conference fringes.

Brown was particularly influential, convening a "social get-together" of delegates on the eve of the conference and then serving as English-French translator during the conference's special trade union session, managing thereby to inject himself into the debate. Among the delegates he met was Patrice Lumumba, a postal clerk from the Congo and a member of the AAPC steering committee. Brown formed the opinion that he was politically sound; he would soon be in correspondence with 
him, arranging to send French-language copies of the Free Trade Union News. By their presence, the Americans assisted Mboya in his successful effort to defer a final decision on whether the planned AATUF would insist on trade union neutrality and require member centres to disaffiliate from international organizations outside Africa. But it was no more than a temporary victory; indeed, there would soon be a move within the AAPC steering committee to unseat Mboya himself as an agent of the United States. ${ }^{108}$

African nationalist passion spread like wildfire as news of the deliberations in Accra was broadcast throughout the continent. There were mass disturbances, first in Portuguese East Africa and then in the Belgian Congo, after Lumumba returned home from the conference calling for national independence. "The two hundred million people of Black Africa have awakened from her slumber," a jubilant John Tettegah wrote to Brown. ${ }^{109}$

Just two weeks after the conference, Brown's initial optimism turned to anxiety as he warned Meany: "the tide is definitely beginning to run against us and especially against the ICFTU." Events risked speeding out of control. "Pan-Africanism was pregnant with many evils and dangers," "black racialism" was in the air, and there were increasing signs of "communist penetration." The conference had "opened up possibilities to the Soviet bloc which did not exist previously, especially in the British territories." And with more states due to achieve independence in the coming twelve months, he worried that "we may soon see a much stronger, neutralist, pro-Soviet policy in Africa." His perception was that the TUC and ICFTU were losing prestige, while the AFL-CIO suffered from identification with the ICFTU in general and more specifically for having surrendered control of the African training program. To strengthen AFL-CIO influence, he recommended that Maida Springer and George McCray remain in Africa on a permanent basis. Irving Brown was finally putting his post-Atlantic City depression behind him, and on a personal note he told Ross: "This second visit to Africa got under my skin. It makes me rather more frustrated than ever that we seem to be so inactive."110

Wondering whether he had conveyed a sufficient sense of urgency, Brown "beseeched and urged" Lovestone to do everything in his power to get Meany to act. Lovestone needed no prompting, having already told the AFL-CIO president in his customary apocalyptic style:

Had it not been for American labour's activities in the past and the participation of the AFL-CIO representatives in this Accra Conference, our country and the free world would have been out in the cold here entirely and the movement towards African freedom would ... have been completely in Moscow's grip. As it is we still have a good chance. It is clear that the help which you once gave to Tom Mboya and the KFL has been more than rewarded in deed. ${ }^{11}$ 
Inclined now to regret the concessions made at Atlantic City that had left the AFL-CIO too much a bystander in international affairs, Meany was spurred into action by these reports. He wrote to Oldenbroek offering to send a team of black American labour organizers to Africa to help "stem the anti-ICFTU tide." Fatally for ICFTU relations with the AFL-CIO, Oldenbroek turned down the offer, preferring to highlight what he described as the "remarkable progress" being made in the continent. AFL-CIO executive councillors were indignant at being cold-shouldered in this way, and at their winter meeting in February 1959 called on the US government to establish an economic and technical assistance program for Africa, resolving at the same time to assemble a team of labour officials qualified to work on such a program. ${ }^{12}$

In contrast to the trade unions of the European colonial powers, the AFL-CIO position was to support the pan-African movement as an expression of African solidarity opposed to all that colonialism represented. As a fluid concept, Pan Africanism produced different strands and competing spokesmen. At one end of the spectrum was the Marxist-tinged version of Kwame Nkrumah and Guinea's President Sékou Touré, with their common goal of political and economic union to tackle the fragmented legacy of colonialism. They pursued their objective with aid from Moscow, where they were seen as Africa's only genuine revolutionaries. In marked contrast were the moderate views of Tom Mboya, for whom pan-Africanism was a means of engaging with the West on the basis of freedom and equality in place of colonial exploitation. For the AFL-CIO, the aim from the outset was to prevent pan-African sentiment form turning the labour movement eastward, while at the same time demonstrating a firm commitment to the idea of "Africa for the Africans."113

\section{Reuther Turns Against Oldenbroek}

Of crucial significance in this situation was Walter Reuther's growing acceptance that Oldenbroek's complacent attitude toward the rapidly moving developments in Africa was jeopardizing the position of the ICFTU. On this issue he regarded Meany's criticism of the general secretary as justified. What confirmed his view was a meeting with Mboya in spring 1959, when the Kenyan was visiting the United States. Mboya persuaded him that time was running out for the ICFTU, with the distinct possibility of unions in Africa deserting the international for a neutral pan-African body. ${ }^{114}$

Mboya himself was already under challenge in Kenya, where hitherto he had been the dominant figure in nationalist politics as well as general secretary of the KFL. On the trade union front, he faced a growing breakaway movement within the KFL that he only temporarily averted by expelling six of his nine executive committee members. As the leading pro-Western voice of pan-Africanism, he was opposed more widely in Africa. Even as Mboya was in the United States in 1959 meeting Reuther, 
Prime Minister Nkrumah, who resented the prestige Mboya derived from being standing chairman of the AAPC, was manoeuvring to remove him from its steering committee and eventually from the chairmanship. Mboya's warning to Reuther proved prophetic; eight months later, Nkrumah called a preliminary conference to plan for a new All-Africa Trade Union Federation, the date for which clashed with plans to inaugurate the African Regional Organization (AFRO) that the ICFTU had for so long delayed convening. The challenge to the ICFTU was direct: Ghana's John Tettegah told Mboya that if he failed to attend the AATUF conference, he would be viewed as a "traitor": from the outset AFRO faced an organizational split. ${ }^{115}$

From this point, it was Walter Reuther who led the campaign to oust Jaap Oldenbroek. At a meeting with ICFTU president Arne Geijer in May 1959, the two men decided that the general secretary had to go; he was simply too complacent in the face of the existential challenge to the ICFTU. ${ }^{116}$ And when Charles Millard again threatened to resign in early 1959 because of the lack of cooperation of the big affiliates, there were no voices asking him to reconsider; increasingly the talk was of the need for a "clean sweep" at the top of the ICFTU, with Oldenbroek, Millard, and Jay Krane all targeted for replacement.

Inevitably, attention once again focussed on ITF general secretary Omer Becu as a potential successor to Oldenbroek. Brown phoned him see whether he was interested in the job. Becu's response was equivocal, but Brown took it to mean "'Barkis is willin,"' and he advised him to talk it over with the AFL-CIO leadership. Becu was sufficiently interested in the job to cross the Atlantic within days for meetings with Reuther, Lovestone, and Meany. He told them again that he wouldn't challenge Oldenbroek directly for the job at the 1959 ICFTU congress, but he would be available if the post became vacant. As Lovestone summed it up, it boiled down to Becu being "ready to accept whatever someone else will fight for and get." Brown had long since ceased to regard the ITF general secretary as a potential saviour, though he reckoned that if he were surrounded by "strong men"-and that meant the Americans getting involved and remaining involved-he would be willing to pursue a policy line acceptable to the AFL-CIO. As for the man himself, Brown had little enthusiasm: "[Becu] is okay-but are we sure... . No one can be sure.... We have to take a chance because there is no one else. It is the 'lesser evil."'117

The first opportunity to begin the process of removing Oldenbroek was the ICFTU executive board meeting in late June 1959 in West Berlin. In the course of this, Meany led a three-man delegation, with Arne Geijer and Willi Richter, to see Oldenbroek to inform him that he no longer had their confidence. Meany warned that if he continued in office, the AFL-CIO would reduce its involvement in the ICFTU and refuse to pay the 20 percent increase in affiliation fees that the board meeting had just agreed to. But Oldenbroek faced them down and refused to resign. 
He was aged sixty-one, and he told them that he intended to stand for re-election and serve one more term. ${ }^{118}$ Once back in the United States, Meany was adamant that if there were no change in leadership at the December congress, the entire AFL-CIO relationship with the ICFTU would have to be reviewed. Reuther, too, was unwavering: "We cannot continue to permit the domination of the ICFTU by the inflexible personality of Oldenbroek.... If we do not act at the December congress, then we might forfeit our opportunity. History will not wait." ${ }^{19}$

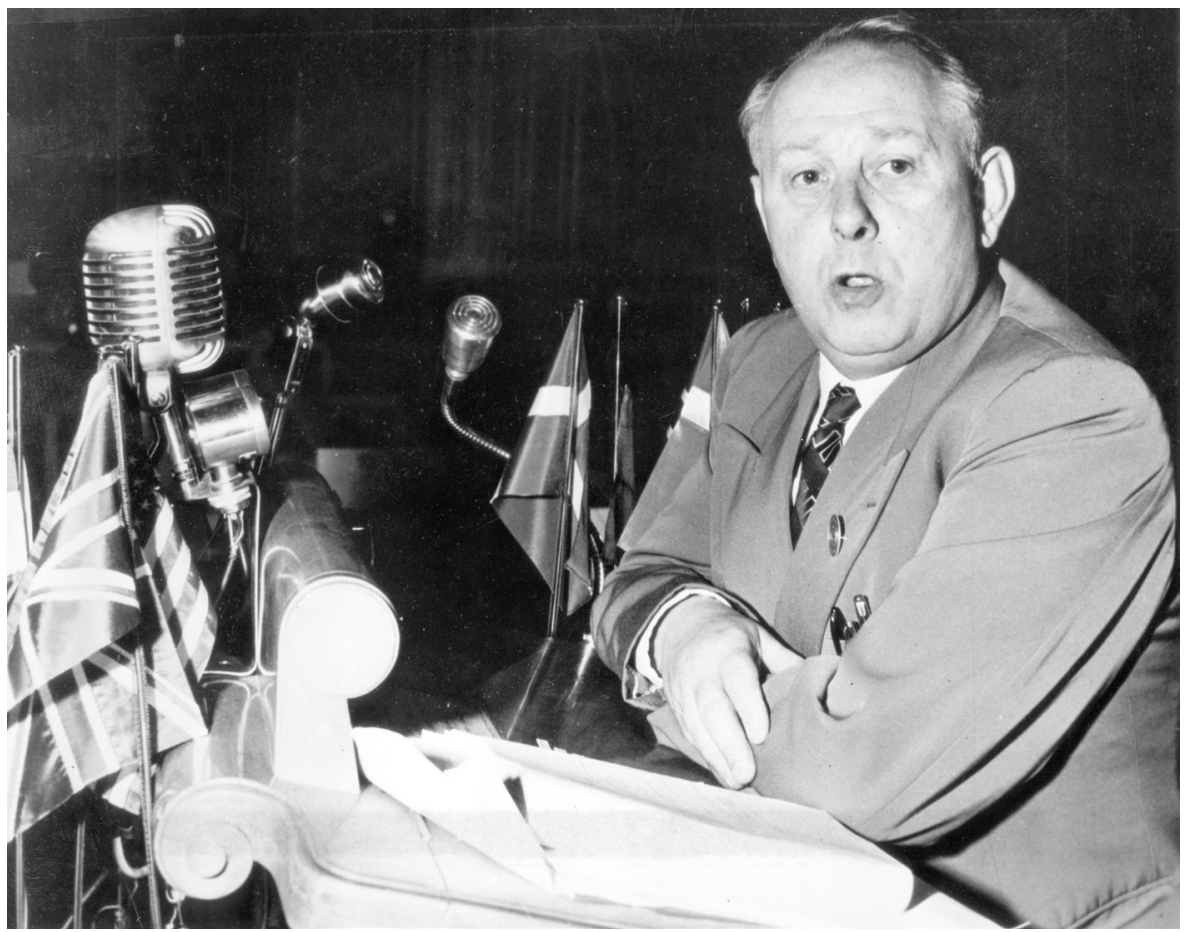

Figure 9. Jaap Oldenbroek, general secretary of the ICFTU, 1949-60, in Stockholm, addressing the ICFTU's July 1953 congress. By 1959, Walter Reuther saw the ICFTU as dominated by his "inflexible personality." Courtesy of the Walter P. Reuther Library, Archives of Labor and Urban Affairs, Wayne State University.

The convergence of views between Meany and Reuther on this issue was all the more interesting given that on the substantive question of how organized labour should respond to the Soviet "new look" they were still poles apart. In the course of 1959, Soviet deputy prime minister Anastas Mikoyan, followed later by Communist Party secretary Nikita Khrushchev, visited the United States in the context of the growing crisis in Berlin. Both men sought a meeting with AFL-CIO leaders 
in the course of their visits. Mikoyan's request failed get beyond Meany's desk, but when Reuther heard about it he and two other AFL-CIO vice presidents agreed to meet the deputy prime minister. Meany duly voiced sharp criticism of those who "feel they can meet the Soviet challenge at the conference table." ${ }^{120}$ When President Eisenhower subsequently invited Khrushchev for talks at Camp David in September 1959, the Soviet leader asked for an opportunity to address the AFL-CIO convention then meeting in San Francisco. Predictably, Meany declined to be in the same room as Khrushchev, but again Reuther adopted the position that it was always worth speaking to an opponent, and he and a small number of federation leaders arranged a dinner followed by a discussion with Khrushchev. However, Reuther's request that the AFL-CIO subsequently endorse their action was rejected by the executive council. ${ }^{121}$ In the event, the attempts at dialogue with each of the Soviet political leaders descended into bad-tempered exchanges, generating more heat than light. Whether anything was achieved beyond gaining international publicity for Walter Reuther is debatable, but it was clear that the disagreement between Reuther and Meany over the former's willingness to talk to Khrushchev soured the tone of the AFL-CIO convention. In particular, it made it impossible for Arne Geijer to convene an informal meeting in San Francisco of leaders of ICFTU affiliates to further the process of securing agreement on Oldenbroek's replacement.

Undaunted, and with Meany opting to sit on the sidelines, the ICFTU president persevered throughout the autumn, hoping to coax Oldenbroek into resigning. Yet his best efforts failed, and as the ICFTU's December congress loomed it seemed the AFL-CIO might not even bother to send a top-level delegation; Meany's personal attendance in Brussels was certainly in doubt. For Irving Brown, it was a demoralizing state of affairs and highlighted yet again the AFL-CIO's lack of imagination in dealing with the ICFTU. He argued that more was needed than simply replacing Oldenbroek with Becu, "about whose qualifications we are not too certain." The AFL-CIO needed to secure recognition by other national centres of its special role within the ICFTU, and he criticized the federation's leadership for failing to win acceptance of such. ${ }^{122}$ Again he complained that they had failed to devote sufficient time and energy to make the ICFTU operate successfully, and as a result the organization was now becoming a "tarnished shingle." He argued that "whether we like it or not, we have ... contributed to the downgrading of its attractive power." And while Brown recognized the damage caused by Oldenbroek as a consequence of his "methods of work and character," he insisted that it was "too simple at this late stage to explain the deficiencies of the ICFTU on the basis of the devil theory of history." ${ }^{123}$ It was fair comment, though he bore considerable personal responsibility for the generally negative image of the ICFTU in AFL-CIO circles. 
The 1959 congress in Brussels-which marked the tenth anniversary of the ICFTU-proved to be a querulous affair with little to celebrate. Were it not for Chancellor Adenauer's invitation to George Meany and Jay Lovestone to receive the West German government's Order of Merit in Bonn while the ICFTU congress was in session a short 200 kilometres away, it is doubtful that the AFL-CIO president would have bothered to cross the Atlantic. ${ }^{124}$ During a truncated appearance at the congress, Meany spoke out against Western colonialism as being "morally wrong and politically destructive," and offered help to workers in newly independent countries in spite of the "dead hand" of the ICFTU. British delegates in turn defended their record in the colonies, pointed to the inadequate funding of the ICFTU, and reproached the AFL-CIO for preaching anti-communism to empty bellies in developing countries. ${ }^{125}$

In the congress's final session, after Meany had packed and left for home, the issue of the leadership was finally addressed in an anodyne resolution. It called for the appointment an ad hoc committee to review the structure of the international and report back to the executive board six months hence. There was no explicit reference to changing the leading officer, though that was its intention. The committee was a device to negotiate the retirement of Jaap Oldenbroek, its supporters ready to sacrifice him in the interests of harmony. Practically all the speakers in the debate, especially the delegates from developing countries who were just becoming aware of the bitter American-led campaign to ditch the general secretary, condemned it as a deceitful and essentially unconstitutional measure. But it carried nonetheless. ${ }^{126}$

Although George Meany was nominated to the ad hoc committee, he was already inclined to write off the ICFTU and played but a limited role in its deliberations. The committee's report was effectively the work of Arne Geijer, who focused on how to strengthen the ICFTU secretariat and came to the unsurprising conclusion that under Jaap Oldenbroek it was not possible to recruit staff of suitable calibre: the idea of appointing assistant general secretaries from the ranks of the largest affiliates was back on the agenda. The question now was to determine whether Omer Becu was still available to replace Oldenbroek, a task for which Walter Reuther assumed personal responsibility. He invited Becu to Detroit for talks in January 1960 and promised an increase in funding for the ICFTU, making clear his support for a clean sweep of the senior officials-Oldenbroek, Millard, and Krane-and for Becu to have freedom to choose among Americans who might go to work for him. More generally, he assured him that he and Geijer would cooperate closely with the general secretary on future plans for the ICFTU, writing: "I believe the three of us working together will be able to keep things moving in the right direction. I am confident that we can bring about effective reorganization of the ICFTU around your leadership and with four competent assistant general secretaries, with greater resources and with effective integration and cooperation of the ITSs." Under such persuasion, Becu agreed to be a candidate. ${ }^{127}$ 
The ad hoc committee's report was presented at a closed session of the ICFTU executive board in Geneva on 15 June 1960. With Jaap Oldenbroek identified as the root problem, it was proposed that the post of general secretary be "declared vacant." ${ }^{{ }^{212}}$ Reuther nominated Becu for general secretary, at which point Oldenbroek finally agreed to resign-but not before Meany made a key concession.

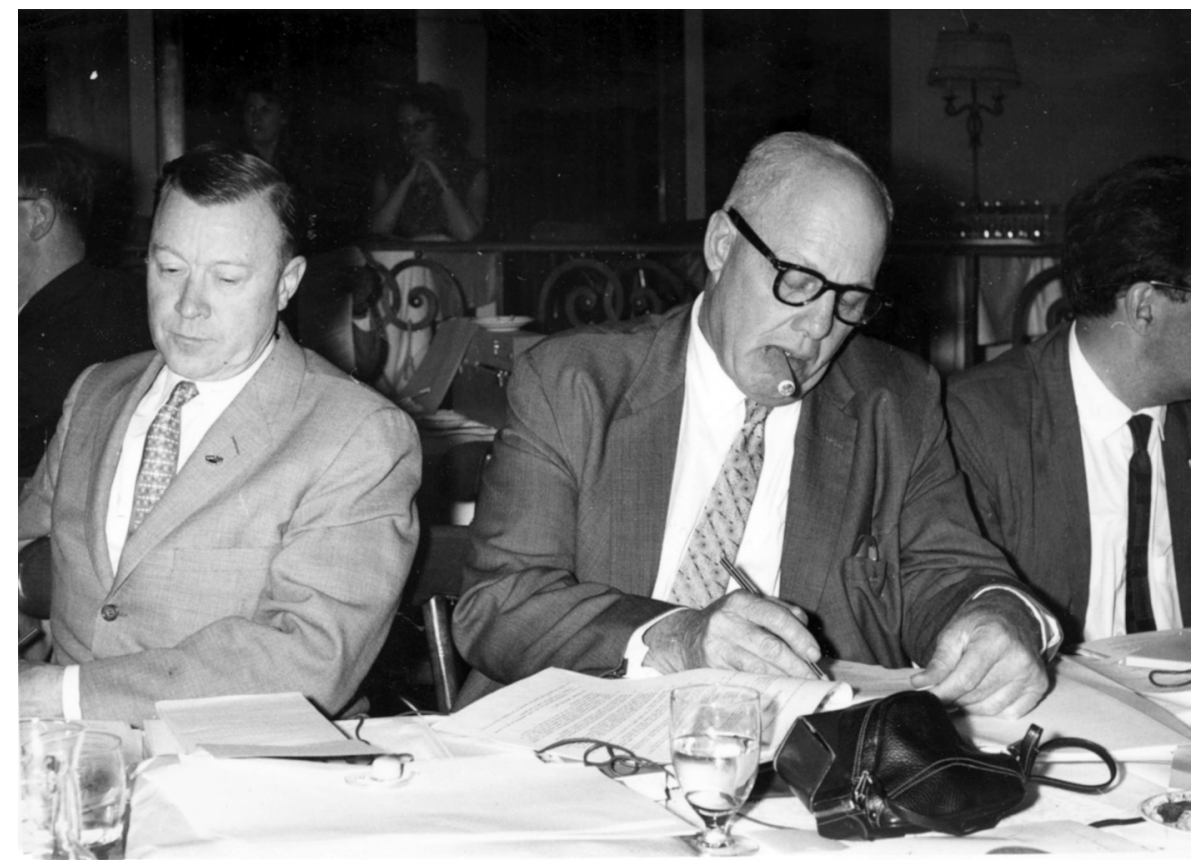

Figure 10. Walter Reuther (left) and George Meany, at the June 1960 meeting of the ICFTU executive board, in Geneva. Despite deep differences over international policy, the two men briefly united during this meeting to force the resignation of Jaap Oldenbroek. Reuther proposed Omer Becu as his replacement, and Meany made a commitment that, if Oldenbroek agreed to resign, the AFL-CIO would operate abroad strictly within the framework of the ICFTU. Courtesy of the Walter P. Reuther Library, Archives of Labor and Urban Affairs, Wayne State University.

Ahead of the meeting, Oldenbroek had indicated to Geijer that he would be prepared to stand down if Meany were to give an undertaking to abandon AFL-CIO independent activities. Privately Geijer sounded out Meany on this and received a positive response. In the course of the closed session Geijer then posed the question again, and Meany confirmed to the meeting at large that in future the AFL-CIO would work strictly within the framework of ICFTU programs. On the basis of that commitment, Jaap Oldenbroek tendered his resignation. ${ }^{129}$ When, next day, 
Omer Becu was introduced to the board as a putative general secretary, Oldenbroek congratulated him, noted that his resignation had been tied to the commitment by national centres to end independent activities, and observed that if this undertaking were not carried out, he would not expect Becu to remain in the job for very long. ${ }^{130}$

Having disappointed George Meany for most of the past decade, Oldenbroek had now gone, soon to be followed by those closest to him in the ICFTU secretariat-the "clean sweep" so long talked about by the AFL-CIO leadership. ${ }^{131}$ Yet, for Jay Lovestone, satisfaction at finally seeing the end of the Oldenbroek era was overshadowed by his misgivings over Meany's commitment on independent activities. He wrote: "If it were not for such independent activities of the AFL-CIO ... we would have nothing in Africa. Today the ICFTU could have its flag, its shingle, its dirty linen and nothing else." ${ }^{132}$ The issue that had been the cause of such friction over the previous decade had by no means gone away.

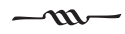

That Walter Reuther and George Meany found themselves at one in seeking to replace the ICFTU general secretary in 1960 stood in contrast to their record of disagreement over key international issues in the preceding five years. Whether it was about the emerging alliance between Nehru's India and the USSR or the question of agreeing to dialogue with Soviet leaders Mikoyan and Khrushchev during their visits to the United States, their responses pointed to sharply differing understandings of the dynamic of the Cold War. Beyond the substantive issues involved was Reuther's competitive jockeying for position with Meany, with his self-image as an international statesman and his keenness to appear on the world stage as spokesman for American labour plainly irritating the AFL-CIO president.

Following the merger, little progress in the conduct of international affairs had been possible without firm agreement on the future role of the FTUC and its independent activities and, relatedly, clarification of the AFL-CIO's attitude toward working in partnership with the ICFTU. The litmus test would be the Americans' willingness to act as "good citizens" of the ICFTU and offer full support to the new organizing department headed by Charles Millard. Yet here the signals were mixed. David Dubinsky's loss of enthusiasm for the FTUC as a semi-detached body led him to support Millard, thus tipping the AFL-CIO vote in favour of his appointment. Yet the logic of this shift in position seemed to be that Millard would not make a success of the organizing function-indeed that he was being set up to fail-and that in consequence the FTUC would live to fight another day. Fearing the risks involved in "peaceful coexistence" and "appeasement" by the free trade movement, Lovestone 
declined to accept that independent activities by the FTUC were a thing of the past, and fought a determined rear-guard action against the terms of the 1957 Atlantic City accord under which the AFL-CIO was prevailed upon to wind up the FTUC in favour of ICFTU-led international programs.

Forced eventually to accept what appeared to be a signal victory for the Reuther camp, Irving Brown's focus now shifted from Europe to Africa, where a new theatre of activity was opening up. The demise of the FTUC and changes in the political climate as they affected the labour movement in various European countries-the impact in France of the colonial war in Algeria and the attendant differences between the AFL-CIO and Force ouvrière, the West German labour movement's lack of enthusiasm for membership in the North Atlantic Alliance, and the growing attraction for non-communist Italian unions of the political "opening to the left"-had made it more difficult for him to exercise influence in his European bailiwick, whereas Africa seemed to offer promise.

Within the ICFTU secretariat, and among European trade union centres with colonial ties to Africa, the Americans were regarded as interlopers in this theatre of operations. High-profile initiatives such as the financial support the AFL-CIO extended to the Kenyan labour movement, and its major initiative in seeking to assume responsibility for training a cadre of African trade union leaders in the United States, aroused suspicions that it was trying to bypass the ICFTU. Yet the principled stance in opposition to colonialism adopted by the American labour movement over many years, and its support for swift and unimpeded progress toward home rule and independence, found immediate favour with the African trade union leaders who often tended to lead the nationalist movement. The explosion of pan-African sentiment at the end of the 1950s-a major landmark in the drive for decolonization-was initially greeted with American approval, though it was soon apparent to Irving Brown that the African unions risked playing into the hands of "communist" elements within the pan-African movement.

Here the lack of urgency with which the ICFTU approached the requirement to build its organization in Africa proved fatal, especially in the face of growing Soviet and East German interest in helping the independence movement. The ICFTU risked the loss of support of African affiliates that were already attracted by the competing call to establish a "neutral" All-Africa Trade Union Federation. When, backed by the British TUC, General Secretary Oldenbroek declined the AFL-CIO offer to send a team of black American trade union organizers to work with the ICFTU in Africa and inject some urgency into its organizing work, it proved to be the final straw for the Americans. Walter Reuther lined up with Meany over this issue and actually took the lead in campaigning for the general secretary to be replaced. Omer Becu was invited to offer himself as an alternative, doing so on the back of a commitment from 
Meany to abandon activities independent of the ICFTU. It opened up the possibility of a new start for the ICFTU, especially in its relations with the AFL-CIO. Yet Meany's commitment over independent activity greatly troubled Lovestone; just how firm a commitment it was in practice became a central issue in the 1960 . 


\section{6}

\section{Into the 1960s \\ Claiming a Second ICFTU Scalp}

From the earliest days of the ICFTU it was the contention of the AFL, and later the AFL-CIO under George Meany's leadership, that the international lacked effectiveness in opposing communism. The point frequently made was that both organizationally and in terms of personnel the ICFTU was not up to the task. Under a new general secretary, Omer Becu, Meany expected and was promised that a central role within the ICFTU would be found for Irving Brown as the AFL-CIO's leading representative in the field. However, it was soon apparent that Becu could not deliver on his promise in the terms that Meany and Brown considered essential for effective performance. Virtually the entire period of Becu's general secretaryship was subsequently marred by his inability to establish a smooth working relationship with Meany and Brown. It would damage the ICFTU as a credible organization in the international labour field and led the Americans to focus more on their own program abroad.

\section{AFL-CIO in Africa-"sans ICFTU"}

The gathering pace of decolonization at the beginning of the 1960s heightened the sense of anticipation among African nationalists, and 1960 itself was to become known as "the year of Africa." In February, British prime minister Harold Macmillan spoke of the "winds of change" blowing across the continent as those very expectations forced his government to accelerate the timetable for home rule in colonial territories. Nationalist movements that had hitherto focused exclusively on the anti-colonial struggle now prepared for power. Sixteen African states took their seats in the United Nations General Assembly, where, with other developing nations, they soon formed the largest bloc. 
Where colonialism and white rule clung on, Africa witnessed a spread of violence that rendered much of the continent a tinderbox. After six years, the vicious war for independence continued in Algeria, with rioting by Europeans in January and December in protest at President de Gaulle's willingness to dialogue with the FLN provisional government. In South Africa, the apartheid regime intensified its hold as the shooting down by police of eighty Africans protesting over the pass laws at Sharpeville in March led to a state of emergency and propelled a non-violent campaign into armed struggle. In the Congo, the precipitate granting of independence in June by the Belgian colonial authorities, without planning for what would follow the handover, quickly plunged the country into chaos and bloodshed and within weeks brought about a rapid return of the Belgian army. The fate of the Congo became the single most contentious issue in African politics, splitting the pan-African movement between the pro-Western "Monrovia group" and the "Casablanca group" backed financially by the Soviet bloc. Africa moved toward the top of the list of international priorities of both the United States and the Soviet Union. In the closing days of 1960, the US president-elect, John Kennedy, declared: "The fate of Africa which is now the object of a giant Communist offensive will affect vitally the security of every citizen of the United States." Four weeks later, Nikita Khrushchev promised that "subjugated" colonial peoples "will not be alone in their struggle."

1960 was also the year the AFL-CIO set out to establish an ongoing presence in Africa. American labour's growing interest in the continent was reflected in a new arrangement entered into with Histadrut, Israel's national trade union centre, to launch an Afro-Asian Institute as a vehicle for training up to 160 African union leaders each year on six-month long courses. ${ }^{3}$ For some time Histadrut had been operating in tandem with official Israeli government policy as directed by Foreign Minister Golda Meir, successfully cultivating relations with African trade unions and extending help to African nationalists. The benefit of this new link-up for the AFL-CIO was that whereas Africans might look on the West with suspicion, they were generally happy to accept assistance from Histadrut, which was offered "without condescension or paternalism." ${ }^{4}$

In January, Irving Brown was sent to Tel Aviv to iron out the details. What was apparent was the Americans' intention to maintain a low profile so as to avoid accusations of breaching the terms of the Atlantic City accord by sidestepping the ICFTU. It wasn't quite what the Israelis had understood "partnership" to mean, and there was confusion until George Meany made clear that the AFL-CIO would only act as a sleeping partner. His name would appear on the letterhead as "honorary co-chairman," but beyond that the Americans would restrict themselves to funding student scholarships. On that understanding, in April 1960 Meany sent \$50,000 as an initial contribution to the budget. ${ }^{5}$ 
Yet, whatever the public impression Meany hoped to create, Maida Springer, who had recently spent a year in Israel helping to establish a vocational training school for African women, noted: "looks as though we are moving in unison on a unilateral or bilateral activity sans ICFTU." "That same month she joined the AFL-CIO international affairs staff from the ILGWU as an African specialist. The commitment that Meany gave later in the year to end independent activities as part of the price for Jaap Oldenbroek's agreement to step down as ICFTU general secretary would prove to be no barrier to the continuation of the joint arrangement with Histadrut. And with his usefulness in Europe significantly reduced, Irving Brown now concentrated on Africa, making two more extensive tours in May-June and September-November that saw him visit Morocco, Tunisia, Mali, Senegal, Kenya, Tanganyika, Uganda, Nigeria, Congo, and Southern Rhodesia. It didn't yet amount to a full-blown program for Africa-the necessary funding wasn't available-but it went beyond the intermittent trips that Brown had previously made to the continent.

With Kwame Nkrumah planning a conference to launch the All-Africa Trade Union Federation in May 1960 (subsequently postponed for twelve months), Brown's purpose was to reinforce opposition among ICFTU affiliates to any call for mandatory withdrawal from the ICFTU as favoured by centres belonging to the Casablanca group. Nkrumah had chosen Casablanca as the location for the AATUF launch and Mahjoub Ben Seddik, leader of the Union marocaine du travail (UMT), as the conference chairman. Clearly with that in mind, Brown spent a good deal of time in Morocco cultivating Ben Seddik. The latter had opted not to attend the inaugural conference of AFRO in November 1959, and Brown was specifically instructed to convey to him George Meany's "extreme concern."

A visit in May to the Federation of Mali (the planned union of French Sudan and Senegal that proved stillborn) serves to illustrate Brown's modus operandi. Financial assistance was to be given to the moderate, pro-Western Senegalese unions in the hope that they would gain the upper hand when the two national trade union federations merged. From a budget of \$20,000, Brown planned for four Senegalese organizers each to be paid $\$ 100$ per month plus per diem expenses. There would be funds for transportation ( $\$ 4,000$ specifically earmarked for the purchase of cars for the organizers); leaflets; a regular journal, Travailleurs $d u$ mali; and a $\$ 2,000$ reserve fund for possible "emergencies" occurring during the unification congress in October. The aim, Brown explained with no sense of irony, was to prevent the opposition "buying up people."

The following month he visited Nairobi for several weeks to help Tom Mboya prepare for the dedication ceremony of the gleaming new KFL headquarters, which also served as headquarters for the newly created party, the Kenya African National Union, of which Mboya was also general secretary. The ceremony was an event 
of great symbolism, attended by the Governor of Kenya as guest of honour and a host of labour leaders from abroad flown in at KFL expense. The AFL-CIO's total contribution to the cost of the building already stood at $\$ 56,000$, but Brown recommended that further grants of $\$ 3$, o o o be made to cover the cost of the ceremony and $\$ 2,500$ for air tickets for guests. ${ }^{9}$ In the context of mounting opposition to Mboya's leadership, the high-profile event was meant to shore up his position among trade unionists and nationalists. He had overextended himself with his combined union and political roles - now added to by his participation in independence talks with the British government at Lancaster House, London-and had barely secured election as first general secretary of the Kenya African National Union by a single vote. His relations with Nkrumah had soured as the Ghanaian leader now bestowed his favours on Mboya's chief Kenyan rival, Oginga Odinga. The latter would shortly return from an Nkrumah-financed tour of the Soviet bloc with generous communist funding for his faction. In contrast, KFL finances were in a parlous state, and Mboya's requests to the Americans for financial help-mostly to cover the cost of internal political battles-were unceasing. ${ }^{10}$

Irving Brown returned to Africa with Maida Springer for several weeks from September to November, visiting half a dozen countries, including Ghana, Tanganyika, and once again Kenya, but also making important new contacts in Nigeria, Southern Rhodesia, and the Congo. It was only a matter of weeks since Patrice Lumumba had been removed from office-a mere three months into his term as Congolese prime minister-after requesting Soviet military assistance to expel Belgian troops. Brown had previously urged AFL-CIO support for Lumumba as "the only one with whom we can get somewhere." His purpose now was to demonstrate backing for Alphonse Kithima, leader of the Syndicat national des travailleurs congolais (SNTC), the labour federation closest to Lumumba, who had been a guest at the AFL-CIO's recent Labour Day celebrations. Brown's shorthand notes of his visit record: "Must re-establish the [Lumumba-led] coalition. ... It is a grave error to write off Lumumba or to fight him openly as a Soviet agent which is not true or at least an oversimplification." As a result of Brown's visit, the AFL-CIO earmarked \$25,000 of its contribution to the ICFTU's International Solidarity Fund to support the SNTC. ${ }^{11}$

Brown and Springer spent a busy two weeks in Nigeria as guests of the Trades Union Congress of Nigeria as the country celebrated its independence. Brown addressed mass meetings in Lagos and Ibadan and made an arduous 570-mile road journey upcountry to Kaduna to meet one particular group of union members. The ICFTU had approved a long-term organizing program, but earlier in the year Oldenbroek turned down Meany's offer to involve Brown in the project. Now, under Omer Becu, the ICFTU was about to release $\$ 28,000$ for spending on approved activities, but Brown still criticized the lack of visible effort. He recommended that 
the AFL-CIO earmark $\$ 75,000$ of its total contribution to the International Solidarity Fund for a more ambitious program in the country, though the Nigerian unions had made no such request for funds. ${ }^{12}$

The most productive visit by Brown and Springer was their two days spent in Southern Rhodesia, where, because of the level of industrialization, the prospects for unionization were greater than in all other countries except South Africa. The established union leaders were languishing in prison, but Brown and Springer met officials of the recently formed Southern Rhodesian African Trade Union Congress (SRATUC) and encouraged them to be represented at the second AFRO conference scheduled for Tunis in November 1960 and later at the Casablanca conference in May 1961. SRATUC's president, Reuben Jamela, hitherto little known but an outspoken anti-communist, was chosen to go to Tunis; Brown purchased plane tickets for him and supplied a letter of introduction, and Jamela arrived in Tunis announcing that he had sufficient funds to affiliate his organization to the ICFTU.

The British TUC would later oppose SRATUC's application to join the ICFTU on grounds that its membership was "racially exclusive." But with AFL-CIO support, the objection was overcome in April 1961 by a simple name change in which the organization agreed to drop the word "African" from the title of what became the Southern Rhodesian Trade Union Congress (SRTUC). At the conference in Casablanca to launch the All-Africa Trade Union Federation the following month, Jamela proved himself an effective speaker in opposition to the proposal to withdraw from the ICFTU. Within weeks, Brown recommended an AFL-CIO grant of $\$ 3$, 00o for the SRTUC. Evidently visualizing Jamela as a potential equivalent of Tom Mboya for southern Africa, he observed: "Jamela is fast developing into one of the best trade union assets in Africa." In fact, Jamela soon faced strong opposition from nationalist leaders Joshua Nkomo and Robert Mugabe-hostility that eventually led to his expulsion from the political wing of the nationalist movement. ${ }^{13}$

\section{Becu’s Dilemma over Irving Brown}

Irving Brown's travels in Africa mattered greatly to Omer Becu, whose term of office as the new general secretary of the ICFTU commenced between Brown's stay in Nairobi in June and his visit to the Congo in September. Still ringing in his ears was Oldenbroek's parting warning that he would soon be out of a job unless Meany kept his promise to refrain from independent activities. Yet here was Brown embarking on a whole new field of activity on behalf of the AFL-CIO. Becu himself was widely seen as "the Americans' man," a burden intensified by his need to tackle the "Irving Brown problem"- how to integrate the AFL-CIO representative into his operational plans as he had promised Meany he would. His first designated task was to revitalize the 
secretariat through the appointment of three new assistant general secretaries, and Brown was naturally spoken of as a potential candidate. Decisions on the appointments were expected in his first few months in office, but over this issue Becu was paralyzed by uncertainty.

The new general secretary was a puzzle. As head of the ITF for over a decade, Becu had been an authoritative figure, comfortably in control, especially when handling the interests of seafarers and dockers in a world that was familiar to him. Harold Lewis, who worked under him in the ITF secretariat and later succeeded him as general secretary, recalls that, though intense and highly strung, he thrived on stress. ${ }^{14}$ Yet the challenge of high office in the ICFTU was of a different magnitude, and the expectations placed on him by the Americans proved crippling. His years as ICFTU president in partnership with Oldenbroek had not been a happy time; in his relations with the general secretary he suffered from an inferiority complex and often appeared to be intellectually dominated by the Dutchman. In 1957 and 1959, when the Americans looked to him as a potential candidate for general secretary, he plainly lacked the confidence to challenge Oldenbroek, and only agreed to be a candidate in 1960, when AFL-CIO animosity meant that the latter's days were numbered. Yet, even then, Becu had vacillated, misleading his ITF colleagues as to his true intent and losing much face and respect in consequence.

As for the prospect of becoming an assistant general secretary under Becu, Irving Brown shrank from the idea of being deskbound in Brussels. His preference was for a flexible role-working closely with the general secretary, possibly as a special ICFTU representative in Africa, and on important missions elsewhere-while at the same time retaining the independence that went with having his own base in Paris. "If Becu were smart," Brown mused, "he would go along and I could certainly have a good relationship with him." ${ }^{15}$ Indeed, retaining scope for independent initiatives was the top priority. As Lovestone put it:

There will have to be ... a certain amount of AFL-CIO International activities of the kind which ... led to the foundation of the Regional Organizations in Asia and Africa and to the saving of the free trade union organizations in Germany, Italy and France. Frankly, if it were not for such independent activities of the AFL-CIO ... we would have nothing in Africa. ${ }^{16}$

Five weeks into his tenure as general secretary, Becu was in Washington for discussions with Meany and Walter Reuther on questions of staffing and finance. Meany argued the case for Brown to be appointed as assistant general secretary, but with Reuther's support Becu fended him off, maintaining that there would be too much opposition to his candidacy. Yet Becu still indicated to Meany his willingness to grant him a significant role. In a throwaway remark to Brown during a private talk, Becu 
suggested that he might become the director of the ICFTU's New York office, which carried responsibility for work at the United Nations and from which Bill Kemsley was about to retire. However, Brown brushed it aside and the suggestion was not pursued. In the meantime Meany and Reuther discussed between themselves the idea of offering Becu a choice of George Weaver of the electrical workers or Rudy Faupl of the machinists as American nominee for one of the posts of assistant general secretary. ${ }^{17}$

Over the next couple of months it became increasingly apparent that Becu, desperate to avoid being labelled "an American stooge," was reluctant to make any commitment to Brown. He studiously avoided including him in a delegation to Turkey that Brown wanted to join, or even discussing with him its purpose. ${ }^{18}$ At a meeting of African union leaders in Geneva in September to prepare for November's AFRO conference, where Brown happened to be the only non-African participant, Becu told him that his presence was an embarrassment. Explaining that he personally had no problem with Brown being there, his concern was over the likely reaction of Europeans. Becu's identification with the Americans clearly weighed on him, as Brown reported to Meany: "He will do everything to prove his 'independence.' ... He wants to appoint Americans but what I would call 'non-controversial ones.' ... He wants us to continue as before hoping eventually [to ease me] into the picture." ${ }^{19}$ For the AFRO conference proper in Tunis some weeks later, Brown received no formal invitation from the ICFTU but attended anyway. He was staying in the same hotel as Becu but the general secretary gave him the cold shoulder, avoiding any serious discussion. Full of resentment, Brown wrote to Ross and Lovestone:

I have developed a relationship [with the Africans] which I can say in all modesty is unequalled by anyone in the ICFTU. However, I refuse to be put in a position any more of merely being on the periphery or appearing as an outsider in the eyes of the general secretary of the ICFTU. ... I am not seeking any titles ... but I do want a clear agreement as to [our] relationship. ... There is no objection ... for some of us to do the dirty jobs but not to be too obvious when the show is in the big city. In other words, I am one of the boys for the road show and not for Broadway. ${ }^{20}$

Ahead of the ICFTU's December executive board meeting, Brown reported to Meany the strong support there was among African union leaders for him to become an assistant general secretary responsible for Africa. It was, they claimed, a necessity if their voice in the ICFTU was to be heard. Yet, despite the commitment made to Meany in Washington that he would utilize Brown's services, Becu evidently still lacked the courage to follow through. Meany was thus fired up and determined to challenge the general secretary in the board meeting where he was expected to unveil plans for a wholesale restructuring of the ICFTU. 
At this board meeting, his first in charge, Becu's proposed structural changes failed to satisfy Meany. General ideas of a discursive nature were advanced for a more devolved system of administration. The regional organizations were to have greater freedom to plan their activities, there was to be a greater role for the international trade secretariats, and the national affiliates would have leeway to act independently or in a "supplementary" manner, provided the ICFTU was notified of their intentions. Becu's argument that the interests of the "ICFTU whole" would be "best expressed through its parts" went a long way to meeting the American attachment to independent operations. However, paralyzed by his inability to decide what to do about Irving Brown, and fearful of the reaction in Europe were Brown to be handed a prominent job, he had no proposals for appointing assistant general secretaries and asked for a further six months to make a decision. ${ }^{21}$

Now on the warpath, Meany told Becu bluntly that he had been given a job to do and had failed to do it. At a private lunch he complained to Arne Geijer that he had received no formal request to nominate for assistant general secretary. $\mathrm{He}$ demanded to know what was wrong with Irving Brown. Which affiliates were opposed to his appointment? His personal view, forcefully made, was that Brown was the best-qualified person, capable of addressing the problems in Africa "single handed." Meany produced a cheque for \$230,00o toward settling the AFL-CIO's outstanding debt to the solidarity fund and said he would hand it over if he were granted what he wanted for Irving Brown. But when Becu failed to bite, he put the cheque back in his pocket.

Later in the session, at a formal dinner in honour of Jaap Oldenbroek where several speakers paid friendly tributes, Meany intervened just as Oldenbroek was about to respond. He told the assemblage that more than anyone else present he had campaigned for the Dutchman's replacement but that events over the past two months had shown that his support for Becu had been the biggest mistake of his life. "The Brussels meeting was really horrible," recorded Mike Ross. "The honeymoon with Becu was the shortest on record. Becu was much worse than you ever dreamed-evasive, indecisive, and you can imagine the effect on 'bluff' GM." As the British labour counsellor in Washington noted, it had put the clock back ten years. The fly in the ointment was still Irving Brown..$^{22}$ If Becu needed any further warning, he was now fully alerted as to the battleground he was entering. In due course, it would claim his scalp.

George Meany turned down a request from ICFTU president Arne Geijer that he be invited to America to discuss his concerns, and, deeming the ICFTU a "cesspool," the AFL-CIO president flew back to the United States intent on expanding the federation's independent work abroad. Within days of his return, the AFL-CIO News carried a critical report of the ICFTU board meeting, laying personal blame 
on Becu and Geijer for failing to deliver on the expected reorganization. Meany convened a meeting of the international affairs committee to agree on proposals for future activity in Africa and summoned home the key representatives-Brown, Springer, and McCray-to be present. He reported that the ICFTU board meeting was the worst he had ever attended, making clear that his personal preference was for pulling out of the organization and making no further financial contributions.

Walter Reuther challenged his account with a different interpretation of the meeting in Brussels, where, in fact, Becu had accepted much of the American thinking on reorganization. The autoworkers' president criticized Meany for the public attack on the ICFTU leadership in the AFL-CIO News. He also raised eyebrows among committee members when he elicited the fact that Meany had failed to pass over the cheque representing money owed to the ICFTU over the past two years, and that he had omitted to report Geijer's request for a conciliatory meeting in the United States. Reuther won international affairs committee support for Becu and Geijer to be invited to the executive council meeting scheduled for two weeks later. Meany's initial reaction was that he would not attend, but he subsequently relented under pressure from executive council members. ${ }^{23}$

The appearance of Becu and Geijer at the AFL-CIO executive council was an occasion for them to tender olive branches and restate in conciliatory terms the case for a new partnership between the ICFTU and its leading affiliates. Geijer reassured the Americans that they were alert to the threat of international communism and that their biggest challenge was in Africa. He stressed the importance of having an American assistant general secretary to be responsible for organizing work and also invited the AFL-CIO to nominate someone for the directorship of public relations, activities of particular interest to the AFL-CIO that had not previously been earmarked for Americans. For the benefit of executive councillors who had not been privy to their earlier discussion with Meany on the merits and demerits of Irving Brown, Becu explained that although the latter was highly regarded, he was too controversial to be considered as a possible assistant general secretary.

The visitors cut no ice with Meany, and in a final exchange he made clear to them his determination to retain as much independence as possible in international relations consistent with membership in the ICFTU. This would be achieved by "earmarking" American contributions to the solidarity fund for very specific usage. He later told colleagues that he was not going to see Brown "crucified," and he issued a press statement to counter any negative report that the latter had been "turned down" for an ICFTU job. No such proposal had been made, and thus Brown would continue in his current role. ${ }^{24}$

Despite George Meany's obvious reluctance, the executive council went on to confirm the AFL-CIO’s previous decision to contribute at least $\$ 3.25$ million to the 
ICFTU solidarity fund over the next three years. At Walter Reuther's urging, this figure was even rounded up to $\$ 4$ million through a temporary levy of affiliates. At his regular post-council press conference, however, Meany indicated that \$330,000 would be made available for "special work in Africa" outside the commitment to the ICFTU's solidarity fund. Without describing it as such, this was to be the budget for planned activities by Irving Brown in Gambia, the French Cameroons, Guinea, and Ghana. ${ }^{25}$ Privately, Reuther made a final attempt to reach agreement with Meany on possible American nominees for assistant general secretary. When that failed, he left it to Meany to submit a proposal, but no nomination was forthcoming. It wasn't clear whether Meany or Reuther had emerged on top from these events in the aftermath of Becu's first abortive executive board meeting as general secretary, but the passions of the previous three months were, for the time being, exhausted. ${ }^{26}$

\section{Brown and Becu Privately Reconciled: Concord Between the "Two Georges"}

What took the heat out of the debate more than anything else was a private reconciliation between Irving Brown and Omer Becu achieved following the latter's appearance before the AFL-CIO executive council. It was Brown who took the initiative, writing to Becu in friendly but businesslike terms to tell him that he would be going back to Africa within a week representing the AFL-CIO on an eight-country visit and that he would be "happy to be of assistance to the ICFTU or to receive any advice from you or any ICFTU representative in Africa." He would be travelling to Southern Rhodesia, where the ICFTU had plans to station a representative, and he offered his services in investigating the current trade union situation. He gave details of his last trip to East Africa and reported on the problems posed for the Kenya Federation of Labour by the Oginga Odinga forces, which were now backed financially by East Germany. ${ }^{27}$

Brown knew Becu better than any of his AFL-CIO colleagues, and the ICFTU general secretary reacted positively to the overture. The strained relations of recent months had taught him the need to mend fences with George Meany and, in particular, to try to put some distance between himself and Arne Geijer and Walter Reuther, with whom he had been publicly associated since the three of them joined forces the previous year in campaigning to oust Oldenbroek. He would be more likely to achieve these aims with the help of Irving Brown.

They arranged to meet in Brussels the following week, and over lunch they made their peace. Becu explained that his intentions regarding an appointment for Brown had always been misunderstood. He regarded him as the one American who ought to be an ICFTU assistant general secretary-the time simply had not been right. He had been "on the spot" in discussing the issue in Geijer's presence and had not been able to reveal that the ICFTU president was the real source of opposition to Brown. 
The problem was in fact Geijer's close relationship with the Reuthers. Becu criticized the ICFTU president for insisting on being intimately involved in the appointment process. The question then was: Could the two of them work together-forgetting titles-for the moment? Becu was amenable to the suggestion and, as Brown reported, "Things began to come thick and fast." ${ }^{28}$

Becu asked Brown to go to Greece the following month on his behalf and with the full authority of an ICFTU representative to bring together the warring factions of the GSEE led by Makris and Theodorou and to strive for an accommodation between them ahead of the Greek centre's congress in the autumn. In doing so, he ceded full authority to Brown, agreeing to the latter's demand that he be allowed to handle the assignment alone and that no other person from the ICFTU secretariat be involved. ${ }^{29}$ They discussed the likely shape of the new trade union advisory committee to the OECD that the AFL-CIO was keen to join (the OEEC as a European body was about to be transformed into the geographically wider OECD, occasioning a consequent change in the remit of the TUAC). Becu confirmed that he was happy for the AFL-CIO to "help out" in Kenya until the ICFTU had its own representatives in place. He requested a copy of Brown's report on Southern Rhodesia, which had identified a need for financial support for the SRTUC to cover the cost of office equipment, vehicles, and salaries for full-time officials. He subsequently signalled that the Americans could initiate this with a grant of $\$ 5,000$, pending his being able to overcome British objections to the Southern Rhodesian centre..$^{30}$

Reporting their conversation to Mike Ross, Brown still harboured a measure of skepticism about Becu's new openness, but on balance he believed the Belgian was signalling "an honest and sincere desire to use me." On his return from Greece in March, a trip he claimed as a success, Brown assured Ross that relations with Becu were sound: "our understanding is good and working." ${ }^{31}$ Becu went out of his way to support the AFL-CIO representative in an argument with fellow American Jim Carey and George Woodcock of the British TUC later that month at a solidarity fund committee meeting. And to make sure that Lovestone also understood that the frost had thawed, Becu wrote apologetically, regretting their failure to meet when he was in Washington. ${ }^{32}$

Feeling more confident and hoping to take full advantage of this positive turn in his relationship with Becu, Brown decided to tackle head-on the negative attitude toward him held by several European union leaders. At an informal meeting of European members of the ICFTU executive board in May 1961, he raised the issue of "character assassination and rumour mongering" aimed specifically at himself and that took place behind the backs of the Americans, telling the TUC's new general secretary, George Woodcock, in particular, "we cannot continue the whisperings 
and rumours that have been going on for ten years about myself ... as well as the AFL-CIO." Brown was satisfied with the "very frank discussion" that followed, believed that a new atmosphere might now be possible, and reported to Mike Ross: "I think a good start has been made." ${ }_{33}$

The arrival on the scene of George Woodcock as TUC general secretary changed the climate of relations between the AFL-CIO and TUC for the better and was to have an important bearing on the internal chemistry of the ICFTU. Woodcock's predecessor, Vincent Tewson, had been a close ally of Oldenbroek and was at the heart of ICFTU affairs from the very first. He had helped draft its constitution and shape its program and, in subsequent years, whether as president or as chairman of the regional activities committee or its successor, the solidarity fund committee, he was arguably the most influential figure on the executive board. He was also a person George Meany found it almost impossible to work with: in style and temperament the two men were miles apart. But George Woodcock was a different kettle of fish, not least in the fact that he was less absorbed by international affairs. In this respect the path was thus cleared for a more relaxed relationship between the British and American trade union centres. And now that Meany had replaced Tewson as chairman of the solidarity fund committee, he was also more centrally placed than ever to determine the course of policy within the ICFTU.

Aged fifty-six when he took over the TUC's reins in September 1960, Woodcock had spent thirteen frustrating years as Tewson's deputy, during which period he made a reputation as the formidably intellectual architect of TUC economic policy. He had served on the British government's Constitutional Commission for British Guiana in the mid-1950s and thereby acquired some knowledge of the Caribbean region, but international affairs generally were outside his sphere of interest and certainly not high on his personal agenda. His relations with Tewson had been no more amicable than were Meany's, and he was in no way identified with his predecessor's personal commitment to international policy initiatives. In fact, Woodcock would soon show himself to be operating on a quite different wavelength. If he had one objective for international policy it was to cut down on the overseas expenditures he considered wasteful.

There had been a hint of things to come in May 1959 when he deputized for Tewson at a meeting with Walter Reuther, then in Europe to address the May Day rally in West Berlin and to canvass support for a shakeup of the ICFTU's top leadership. Characterizing the ICFTU in terms that Tewson would never have used, Woodcock told Reuther that it suffered in appeal and reputation in Britain and elsewhere because of a perception that it had been set up as a rival to the WFTU and because of its continuing and undue emphasis on negative anti-communism. He would soon distance himself from those, like Reuther, who argued the urgent need for greater financial resources for the ICFTU. ${ }^{34}$ Indeed, he reflected a growing TUC 
disillusionment with the ICFTU following the latter's criticism of independent British trade union initiatives in colonial territories. This mood was beginning to affect the TUC's attitude toward the solidarity fund, whose biggest contributor it had been in the years from 1958 to $1960 .{ }^{35}$

Woodcock's first appearance at an ICFTU executive board was in November 1960 when Becu unveiled his half-formed plans for reorganization. They were based on the ambitious assumption that $\$ 10$ million would be raised for the solidarity fund in the period from 1961 to 1964 and that this would include a contribution of \$2 million from the TUC. Woodcock was quick to point out that this was the first he had heard of such a figure and that the TUC general council would certainly object to it. ${ }^{36}$

From the outset, Woodcock's approach toward international affairs would be characterized by a general skepticism about the ICFTU's basic raison dêtre and, more specifically, a highly critical attitude toward the manner in which international trade union programs were financed. It was largely predicated on the TUC belief that the expensive, "top-down" organizing that the ICFTU undertook in developing countries was wasteful and that, rather than leading to "genuine trade unionism," it often produced hastily formed national centres that existed more for political reasons than as manifestations of viable trade unionism. But this thinking ran quite contrary to the prevailing view in the ICFTU, and the TUC general secretary found himself largely isolated on the executive board and in a minority of one on the solidarity fund committee.

Of course, Meany had his own deep reservations about the capacity of the ICFTU to achieve much, but thanks to Walter Reuther's initiative the AFL-CIO was now formally committed to contributing generously to the solidarity fund, and, as chairman of the committee, Meany's approach was to spend freely. Indeed, he authorized allocations worth $\$ 1$ million at his first meeting as chairman of the International Solidarity Fund Committee. ${ }^{37}$ As the recently appointed assistant general secretary with responsibility for organizing, Stefan Nedzynski was instructed to expand the ICFTU's financial assistance to unions in developing countries "as quickly as it could efficiently be done." Woodcock routinely objected to such spendthrift practices, but, as Nedzynski noted, during 1961 and 1962 the TUC leader was the odd man out on the solidarity fund committee; his views were listened to respectfully but then voted down. ${ }^{38}$

The chemistry between Meany and Woodcock benefited from the fact that the latter's criticisms of spending proposals tended to be directed at the ICFTU secretariat rather than at Meany, whose own federation was often the driving force behind the proposal under consideration. The result was that although they were often on different sides of the argument, "the two Georges," as they were referred to by the ICFTU secretariat, managed to establish a mutually respectful and harmonious relationship. 
The TUC leader spent some days with Meany at the ILGWU retreat in the Pocono Mountains in June 1961 to explore amicably whether they could at least "agree to disagree." 39

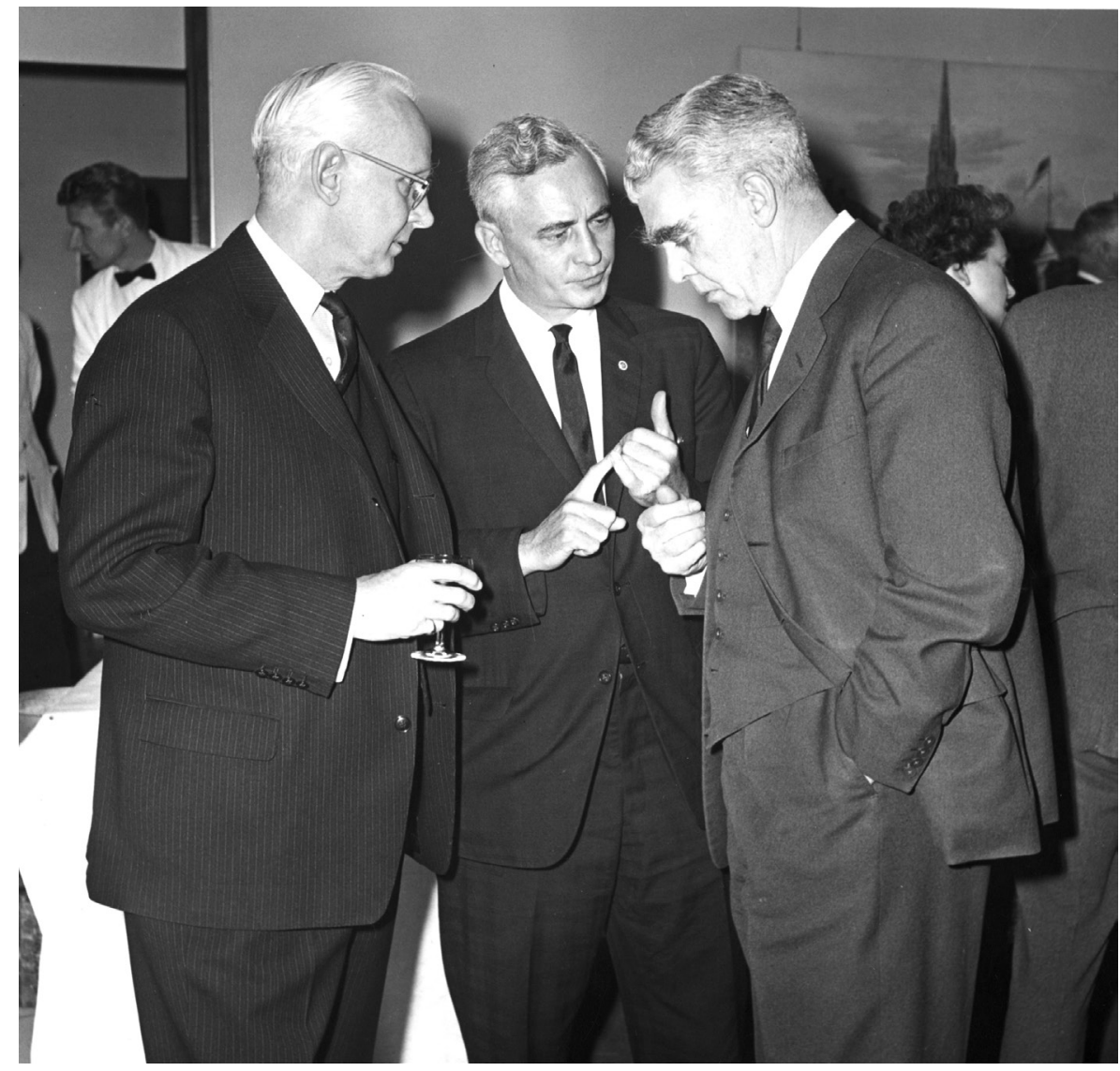

Figure 11. George Woodcock, the TUC's general secretary, 1960-69 (right), at a reception in London in 1963, with US labour attaché John Correll (left) and Jim Carey. While Carey delighted in taunting George Meany, Woodcock and Meany agreed to differ over international policy, before joining hands to cut off funding for ICFTU projects. Courtesy of TUC Library Collections, London Metropolitan University.

In this relatively benign interlude in AFL-CIO-ICFTU relations, Omer Becu, whose tenure had begun so inauspiciously, began to thrive. Reconciled with Irving Brown on a personal and business level, he was also shielded by George Meany from criticisms in the solidarity fund committee that were now more likely to come from the TUC leadership. With funds being pumped into regional organization at 
an annual rate of $\$ 2.5$ million-nearly double the level of 1960-the years 1961 and 1962 proved to be, relatively speaking, a "golden age" of achievement for the ICFTU.

In the field, Brown's efforts in the first months of 1961 were focused on the Casablanca conference in May, where a decision to set up the neutralist All-Africa Trade Union Federation (AATUF) was taken together with a requirement that African national centres disaffiliate from the ICFTU within ten months. On the eve of the conference, Brown took the initiative in convening a strategy meeting of delegates of ICFTU affiliates. But in the conference proper, with voting rights loaded to favour members of the Casablanca group, and the Moroccan Mahjoub Ben Seddik chairing proceedings in partisan fashion, the ICFTU group was outmanoeuvred. The best they could do was to ensure that the conference ended without formal agreement on statutes, organizational structure, or on broader policy issues, and this they did by staging an ICFTU boycott of the final session..$^{40}$

Following the conference, Brown's reaction was to urge a flexible approach to AATUF. His motives were never entirely clear or consistent, but he evidently harboured a private view that this new African organization could still somehow be taken over from within or steered in the interests of the West. National centres like the Moroccan UMT, he judged, were capable of being won back to support for free trade unionism. For a year he had been carefully cultivating relations with UMT president Ben Seddik, and though the latter was now the president-designate of AATUF, Brown reckoned that he would be able to influence him: after all, Ben Seddik still hoped for AFL-CIO bilateral assistance for the UMT. Brown recognized that aspects of communism and the policy of the WFTU held attraction for certain members of the Casablanca group, but he maintained that this was often superficial. AATUF was far from being a mere cover for the WFTU. African politics were in flux, and there were many labour groups whose nationalism was beginning to set them at odds with communist objectives..$^{41}$ It gave Brown grounds for optimism.

Despite his efforts to act as shepherd to the ICFTU's African affiliates during this phase, and despite his recent rapprochement with Becu, in his reports to the AFL-CIO it still suited Brown's purpose to run the ICFTU down. The organization was depicted as a secondary, almost dispensable, part of the African equation, counting for little. "I don't believe that AFRO means anything," Brown wrote in August 1961, arguing that "to do the job in Africa we must have people who are ready to be most unorthodox in the handling of trade union problems." Indeed, he routinely painted a negative picture of the ICFTU's influence: it is "difficult to believe the ICFTU can hold out"; "We're at a low ebb in terms of the ICFTU"; "The ICFTU at this stage is on the ropes"; "I fear for the ICFTU's future." ${ }^{2}$ Early in June, Brown had noted sharply that "our greatest weakness still lies not in Africa but in Brussels. I believe Becu is willing but still a very prudent man and as yet I can see no one in 
his staff who measures up to the tremendous responsibility of steering a course of intelligent leadership for our friends in Africa." ${ }^{43} \mathrm{He}$ criticized "Brussels" for being "dead and faceless as far as Africa goes" and for "incredible passivity and stupidity" over the fact that no one seemed to be in the head office when he phoned in July: Becu off work ill, Stefan Nedzynski on holiday, others about to go on vacation. "I must be nuts," he told Mike Ross. "I thought we were in crisis." He conceded that Becu and Nedzynski were doing their best; he just wondered whether it was good enough. ${ }^{44}$

Omer Becu and Stefan Nedzynski did in fact have a shrewd suspicion of Brown's tactics in trying to keep AATUF "in play," and naturally they disagreed with him, considering it a dangerous gamble. After all, AATUF's line-that African unions should stay clear of the ICFTU and WFTU until such time as these two organizations got back together-was in reality identical to the policy long pushed by the WFTU. But the delicate relationship with Brown and the AFL-CIO was such that Becu and Nedzynski avoided any direct challenge. Of Brown himself, and the personal game of footsie he was attempting to play with AATUF and its general secretary, Ben Seddik, Nedzynski observed years later: "His reports to the AFL-CIO aimed to showcase his expertise and command of the situation. The question was whether his talents here were as great as he imagined." 45 Either way, Becu became conscious of the need to keep Brown away from Africa. And to do so he revived his earlier proposal that Brown should take over the directorship of the ICFTU's New York office with responsibility for the United Nations.

\section{Brown in New York-or Africa?}

At an informal lunch with Becu, Geijer, and Meany on 19 September 1961, held during a meeting of the solidarity fund committee, Brown inquired casually about the candidates being considered to fill the vacant directorship of the New York office that had existed for a year since Bill Kemsley's resignation. Taking this as a sign of Brown's personal interest, the general secretary inquired if he would be available for it on a permanent basis. The AFL-CIO representative discussed the idea with Meany, who quickly gave his approval.

Why Brown was now interested in a proposal he had brushed aside a year earlier is not entirely clear. In part the move had some appeal given that his marriage was in difficulties and that his wife and son had moved back permanently to New York. ${ }^{46}$ But he also clearly sensed that he would be able to parlay this position into something significantly more important than it had previously been during Kemsley's incumbency. The United Nations had sprung to life as the place where newly independent states, and especially former African colonies, sought to register their 
presence and concert their strength. Brown relished the prospect of becoming an influential player in such a milieu.

For Becu, a beneficial consequence of Brown's move to New York was likely to be the closure of the AFL-CIO's Paris office, which, as he admitted to Water Reuther, had long been a bone of contention among the Europeans. But it was precisely this point that caused Jay Lovestone serious misgivings. The Paris office symbolized the AFL-CIO's presence in Europe and was "the nudging force, the activating agency" of the free trade union movement on the continent. True enough, Brown had spent less time there in recent years-indeed, it was a matter of regret for Lovestone that trouble spots like Germany and Italy had been ignored-but he warned Meany that if Brown were to relocate away from Paris, the Reuthers would take advantage and substitute via the International Metalworkers' Federation "the phoney and pseudo-liberal 'American presence' ... in Europe." ${ }^{47}$

A certain froideur now crept into the Lovestone-Brown relationship. Over the changed focus of Brown's work abroad there was a palpable sense of the two men drifting apart. Lovestone made clear his disapproval of the amount of time Brown was spending on African affairs, reminding him pointedly of his recent inability to keep up with his reports. Indeed, Brown was now emerging as his own man and felt less need to write in depth about his dealings with African trade unionists. As the person who had introduced Irving to his wife, Lillie, Lovestone also appeared pained to be learning at second hand from Mike Ross the personal reasons Brown had for the move back to New York. And when finally Lovestone acceded to the transfer to New York-from where Brown still hoped to concentrate on African affairs-he did so with regret. He took issue with George Meany for agreeing to the move, telling him: "You have my opinion and I understand your position, do as you want to do." Refusing to buy into the idea that the ICFTU would "put on a burst of activity" once Brown joined the staff, he wrote to Brown:

There are some in our ranks who very optimistically welcome the difference in personality between Becu and Oldenbroek ... [and] conclude that there is a ... really healthy situation in the ICFTU. I reckon I am a little too old to swing from pessimism to optimism like a pendulum. I think the bureaucratic set-up in the ICFTU is stultifying. ... Nor will your work in the ... UN stimulate Geijer into a transformation. ${ }^{48}$

Becu offered Brown the directorship of the ICFTU's New York office in principle in early November 1961, and Brown was left to deal with the general secretary according to his own lights in determining the nature of the job. Haggling of a Byzantine nature between the two men now began and was not completed until five months later. 
Brown was soon telling Lovestone that he had a verbal understanding with the general secretary as to what the job entailed. He envisaged having wide-ranging, albeit vaguely defined, responsibilities, with extensive freedom to travel and to involve himself in international issues:

I believe that I have in general an understanding which throws an entirely new light on the nature and implications of the job.... This kind of operation will be quite different from the past and will also still involve quite a bit of continuing and permanent contact abroad even into regions about which up to now I have had nothing to say or do. ${ }^{49}$

Just how much freedom to travel Brown was contemplating is perhaps suggested by the fact that only days after filing this report, he paid a four-day visit to South Vietnam - way beyond his already wide-ranging beat in Western Europe and Africa. The circumstances of this trip are obscure. The pretext was that he was delivering funds for flood relief, but his report is more interesting for envisioning a role for the anti-communist trade union centre, the Vietnamese Confederation of Labour (CVT), as a possible paramilitary force. The formula that Brown had previously advocated for French dockworkers and Italian metalworkers at FIAT was once again being promoted. The likelihood is that this visit to Southeast Asia was essentially a CIA mission..$^{50}$

From the start of his negotiations with Brown, Becu knew that he was playing with fire. He was fully aware that those hostile to the American would take a keen interest in any "special conditions" attached to the job. Like Brown, he saw the need to keep agreed details informal. At times he appeared to entertain second thoughts about the wisdom of offering him the post at all. Indeed, he would subsequently try to pin blame on Arne Geijer with the claim that the ICFTU president had pressured him into making the appointment before he had sufficient time to fully consider the implications. ${ }^{51}$ The negotiating process took its toll on Becu, and for some weeks from before Christmas 1961 into the New Year he was away from his Brussels office suffering from stress..$^{52}$

Given Brown's version of what had already been agreed to, Becu's angst becomes easier to understand in the context of a report filed by the British labour counsellor in Washington. It was based on a briefing by Jim Carey and recorded that at a lunch during an ICFTU executive board meeting involving Becu, Brown, and Carey, "clear conditions were laid down to Irving Brown that if he accepted the ICFTU job in New York, he had to stay there and was not to embark on trips to Europe, Africa or elsewhere independently or on behalf of the AFL-CIO." Carey claimed that Irving Brown accepted these conditions without reservation. However, the attaché observed that many others doubted that he would abide by them..$^{53}$ 
Brown promised Lovestone that, at a future tête-à-tête, "I will give you more details verbally about some of the basic reasons ... not to ... demand too many guarantees in writing." He was intent on avoiding detailed discussions with Arne Geijer, whom he didn't trust. In lofty tone he wrote to Becu saying that although he had talked with the ICFTU president in general terms about the job, he had avoided issues of finance, personnel, and structure-these being matters for him and the general secretary alone. Later, he made it clear to Becu that he would consider himself as working strictly for the general secretary and no one else. ${ }^{54} \mathrm{Becu}$, unlike Geijer, was someone Brown believed he could dominate.

On returning from sick leave in January 1962, Becu bowed to a further demand from Brown for a substantial increase in the budget for the New York office. The solidarity fund committee subsequently doubled the budget for 1962 and contemplated a trebling for 1963 . The two men also discussed a requirement by Becu that Brown spend five or six months a year in New York, a condition implying, in Brown's eyes, an entitlement to travel for up to seven months a year during which he would involve himself in "the regional activities of the UN." Anticipating opposition from Europeans, Brown also raised the possibility that the TUC and the DGB might question his appointment, in which case Becu would need to "square" them, since the American would not accept a situation in which they continued to snipe at him.55

As their negotiations proceeded and rumours circulated that the AFL-CIO representative might be transferring to the ICFTU, some African leaders were alarmed at the prospect of "losing" him, construing the proposed move as a victory for the "European colonialists" in eliminating the "dynamic anti-colonialist element" from the equation. Brown flew to Nairobi for Tom Mboya's wedding, where the Kenyan took time out from his reception to remonstrate with him on this point. According to Brown's account, Mboya declared that his transfer to New York would be a "calamity": Africa was at a turning point and his presence was needed, as only someone like Brown could be trusted. When Africans expressed such views to Meany, the federation president replied exactly as Brown hoped he would, telling them that as an ICFTU official Brown would be able to continue to service them without any change in AFL-CIO aid and assistance, even if this was handled in a different fashion..$^{56}$

In a memorandum prepared for Ross and Becu in late January that was to take on great importance, Brown set out how he conceived of his likely role. A key passage read:

It would be important for the Director to have access to the different meetings that take place in different parts of the world, especially in connection with the UN and its subsidiary organizations... Given the special situation in Africa, this could become a very serviceable instrument to maintain our contact as 
a sort of regional servicing of our African organizations. ... In any event, the Director ... must have sufficient mobility to move in on all these regional extensions of the UN.

In an imperious tone, Brown also set out his demands for the staffing of the New York office, rejecting the general secretary's idea that it would be beneficial to have the ICFTU's long-serving Austro-American economist, Alfred Braunthal, as co-director responsible for dealing with the UN Economic and Social Council. He told Becu that "'there shall be a single Director. There must be a thorough housecleaning," because there still existed "too many loyalties to the former regime as well as habits of thought and action that cannot be changed.... I must have an office set-up in which I can have full confidence based upon their complete loyalty..$^{57}$ Becu responded to the memo with caution, observing that although he was in general agreement, certain things should not be written down, as Brown had suggested. As a reason, he cited the opposition he was experiencing from the TUC and the international trade secretariats. $^{58}$

Yet despite Becu's injunction against committing things to paper, he now proposed to draft a job description: it was just not possible to leave everything to trust. Brown interpreted this as an attempt to backtrack on existing verbal understandings. He protested to Meany that he, personally, didn't want any "written bureaucratic statement" and was ready to accept Becu's verbal agreement regarding the substance of the job. Yet Becu now insisted that there had to be something in writing for the executive board to see. Irritated, Brown told him that he could write whatever he wanted for the board's consumption, but he wouldn't accept any divided authority in the UN office or any restriction on his freedom to handle all issues relevant to the UN, "at summit, regional or subsidiary level." In the end Becu chose to supply the executive board with only the sketchiest outline of Brown's remit.

Still skeptical of the whole project, Jay Lovestone disapproved of Brown's handling of the negotiations. Recognizing that the job involved more than his former protégé seemed to anticipate-and certainly more than simply changing his letterhead-he doubted the efficacy of "crossing out the word Paris and replacing it with New York and then operating from the latter city as he did in Paris." In a letter to Meany, Lovestone criticized Brown's self-important tone and insistence on becoming a "universal ambassador" with "universal authority." "Modesty is a very great and infrequent virtue," he reflected, adding: "it is more true to say that the man makes the job than the job makes the man." In a backhanded compliment, he expressed confidence that "if Irving drops his grandiose notions and stops heralding in advance all he intends and plans to do, he will do a good job. He will grow in the job."59 
The tortuous haggling dragged on to the end of March 1962, by which time "agreement" had been reached, or at least scope for fudging unwritten understandings exhausted. The letter of appointment under which Brown was to start his new job on 1 April, together with a press release, were all that was committed to writing. Becu's letter to Brown itemized his general responsibilities in the vaguest of terms. Interestingly, there was no specific mention of "travel." The press release added little more hard information with its statement that "with this appointment the ICFTU ... will embark on an increasingly active world-wide campaign to implement these [UN] principles in practice." Yet all that mattered for Brown was his "special understanding" with Becu, about which he promised to inform Meany when next he saw him. To Lovestone he wrote: "The mandate is very clear. .. I have an honest and firm understanding. My private memo of some weeks back is considered to be a definite and private understanding between us as to our future relationship and work." ${ }^{60}$ Whether Becu had quite the same understanding of what was agreed to was very much open to debate.

The test came three months later at the ICFTU's July 1962 congress in Berlin. The congress proved to be the high-water mark in the brief period of harmony that had characterized AFL-CIO-ICFTU relations since Brown and Becu had made their peace in February 1961. The event was largely free of the discord that had been evident at several earlier congresses. Looking to the future, Becu was optimistic that the coming period would be marked by consolidation and further improvement in its method of working, while his deputy, Nedzynski, recalled simply that at Berlin there was an atmosphere of mutual understanding and friendship and the recognition that progress was being made. ${ }^{61}$ That perception would soon change.

Irving Brown attended the congress in his formal capacity as director of the New York office. Following the congress, he planned to travel on to Africa, visiting Morocco, Senegal, Kenya, and Southern Rhodesia. In Berlin he was also named as secretary of a delegation to Algeria, where UGTA was planning a congress in the aftermath of the country's recent independence. However, the British delegates at the congress took exception to his continued activities in Africa and George Woodcock made a formal complaint. Becu's response was to inform Brown that he was against his plan to travel to Africa since it could expose him to criticism by the British and others. For his part, Brown protested that this was a violation of Becu's commitment made when he took the job. ${ }^{62}$

While still in Europe, Brown wrote telling Becu of "serious information" just received from Africa concerning an offensive by the "Casablanca group" in over half a dozen countries from Kenya to Southern Rhodesia. It was the product of a recent trip by Mboya's rival, Oginga Odinga to Moscow, from where he had returned with $£ 60,000$ for “anti-western activities." If he couldn’t travel on behalf 
of the ICFTU, Brown was inclined to take a leave of absence for several weeks to attend to the problem. ${ }^{63} \mathrm{He}$ would shortly have information from East Africa that students were making their way to Moscow in growing numbers, travelling via Cairo, where they picked up second passports. Brown's intelligence was that 150 Kenyans had followed this route in the last six months, while eighty Tanganyikan students were already in Moscow- "and they are organized," he emphasized. ${ }^{64} \mathrm{He}$ met Becu a few days later to talk the matter over, and according to his account, Becu agreed that he should be in Africa, but it simply wasn't politic to go now. Claiming that he was beset by enemies in Europe-not only the British but also the Dutch and Belgians as well as Geijer and Reuther-the general secretary told Brown: "After all, the British regard you and me as one and the same." A week later a disconsolate Brown notified Becu that, regretfully, he had decided against the trip, but would discuss the situation with George Meany. He resented being "half-in and half-out as an accepted representative of the ICFTU" as a consequence of being "too controversial." ${ }^{65}$

After hearing Brown's oral report, Meany wrote to Becu demanding an explanation for his reneging on the commitment to Brown about travel in Africa; without it the AFL-CIO representative would not have taken the job in New York. Meany was also personally aggrieved. He had "gone out on a limb" at the Berlin congress in reassuring worried African delegates that Brown would be visiting them shortly. His own credibility was now at stake, and he asked Becu to stand by the commitment given. Becu responded three weeks later, arguing on the narrow grounds that "team work" in the ICFTU would suffer if staff could challenge the decision of the responsible officer. Meany cabled back to say that he was "puzzled and confused" by the response. By this point he had also heard directly from Mboya of "a serious erosion" of the ICFTU position in Africa that required an on-the-spot visit by Brown.

George Meany now decided that Brown should travel to Africa in November regardless of Becu's ruling. There was evidently a strong sentiment in favour of pushing ahead with independent AFL-CIO activity as a priority. ${ }^{66}$ Warming to the new situation, Jay Lovestone joined in what was clearly to become another round of Brussels-baiting, attacking individual members of the secretariat by name. ${ }^{67}$ On receiving confirmation that Brown had already been dispatched to Africa, Omer Becu cabled Meany requesting a chance to talk to him in Washington. Meany contacted Brown in Kenya and instructed him to fly back for the meeting. He expected little of it and commented to Lovestone: "I see no hope in Becu changing-he is just a small man who is stubborn and standing on his rights (!) as Gen. Sec."

Indeed, the encounter in Washington was wholly unproductive, with Mike Ross recording what an unhappy experience it was for Becu. Prompted by the TUC and 
the DGB, he came with a list of complaints about Brown's activity in Africa, while Meany in turn expressed consternation at the general secretary's attitude. ${ }^{68}$ Nothing was resolved, and Irving Brown returned to Tanzania the following day to resume his participation in the government's independence celebrations. Becu travelled on to Ottawa and unburdened himself to leaders of the Canadian Labour Congress (CLC). The CLC's international director relayed to Lovestone's office the essence of Becu's thinking: "You fellows in the ICFTU New York office had better make up your minds whether you are working for the ICFTU or the AFL-CIO." ${ }^{69}$

In correspondence over Christmas 1962, Becu attempted to resolve his disagreement with Irving Brown, but the latter rejected any suggestion that "foreign travel" was the only issue. Addressing him formally as "Dear Brother Becu," he insisted that principles were involved and that he was continuing to abide by the terms of their understanding. "If you wish to deny or repudiate that agreement then that is another matter." ${ }^{\circ 0}$ Plainly upset, he told Meany: "I don't want to continue-if possible-in this [ICFTU] morass. I look forward to being liberated from a set-up where intrigues, untruth and anti-Americanism plus political ignorance rule the day." And in a similar vein he wrote Lovestone that he could no longer work for a man who lied and hid behind "bureaucratic arguments" to sabotage any dynamic action associated with the Americans. ${ }^{71}$ These outbursts reflected Brown's anger. But in calmer moments his instinct was always to keep one foot in the ICFTU camp, and it would be some time yet before he accepted the inevitability of choosing between the AFL-CIO and the ICFTU.

\section{Origins of the African-American Labour Centre}

Sensing that Brown's time in the ICFTU's New York office might be coming to an end, Lovestone was already working on a proposed reshuffle in AFL-CIO international affairs department responsibilities, with Brown restored to his role in Europe and another American taking over his current responsibility to the ICFTU. With the recent Cuban missile crisis fresh in mind, and insisting that American world leadership was confronted by new challenges, Lovestone argued that once again an AFL-CIO presence in Europe was "indispensable," which meant Irving Brown resuming his AFL-CIO role in Paris with primary responsibility for Europe but also able to make side trips to Africa. ${ }^{72}$ Yet in making this case for a "return to Europe," Lovestone stood alone, apparently without support. The ground around him was beginning to shift.

A recent addition to the staff of the international affairs department toward the end of 1962 was Meany's son-in-law, Ernest Lee, appointed as executive assistant to the international affairs director, Mike Ross. He would come to serve as a 
gatekeeper to Meany, with the result that Lovestone found it harder to gain the president's ear. Mike Ross himself was terminally ill and absent from the office for several months in 1963, and when he died in November some close observers already assumed that Ernie Lee was likely to be appointed to replace him. That no announcement of a successor to Ross was made for three weeks following his death suggested that this was at least under consideration. Indeed, the British labour counsellor's intelligence was that during this hiatus "the New York group"-essentially Dubinsky and his colleagues in the needle trades-had been forced to apply pressure on Meany to ensure that Jay Lovestone was named as director. When the latter's appointment was confirmed, he was a month short of his sixty-fourth birthday, and the assumption was that he would hold the post for just a couple of years and then stand down in favour of Lee.

Ernie Lee, a former US Marine, was widely regarded as a lightweight; Irving Brown rarely referred to him by name but rather as "the son-in-law." With scant trade union background, he would bring little by way of knowledge or experience to the international affairs department. Yet the possibility that Meany had toyed with the notion of appointing him ahead of Lovestone suggests that the federation president was relaxed about the idea of conducting AFL-CIO foreign policy largely according to his own lights without the need of help and advice from people whose forte was their familiarity with the personalities and politics of myriad foreign labour organizations. There was nothing dramatic to suggest that Lovestone was positively out of favour, but occasional signs suggested that with Lee as the interface between Meany and Lovestone, the latter was not always as well informed of Meany's thinking as he would like to be. Some months after he was named international affairs director, the British labour counsellor discovered that Lovestone knew nothing of an impending visit to the United States by the TUC's George Woodcock during which the TUC leader was scheduled to speak alongside Meany at a union convention. The labour counsellor noted that Lovestone's lines of communication to Meany were perhaps not as good as he pretended "apart from the family pipe-line to Ernest Lee."73

Meany's international focus was now increasingly on the idea of regional institutes-auxiliary bodies of the AFL-CIO- of which the American Institute for Free Labour Development (AIFLD), established for Latin America and funded principally by the US government, served as a model. While Lovestone wanted to restore Irving Brown to Europe, Meany was more interested in the latter's latest ideas for a stepped-up program of work in Africa. In a letter to Meany, Brown wrote of the need for "someone with overall authority to put into effect a master plan of action and organization." ${ }^{74}$ Overall, he reckoned the challenge from Soviet and Chinese communism in Africa to be as great as ever. The free trade union battle against AATUF was certainly not lost—that body had achieved little-but the appeal of 
"positive neutrality" was proving strong in labour circles and the ICFTU was clearly losing the fight to retain the affiliation of African trade union centres. In the circumstances, Irving Brown saw the need for a dedicated American body equipped with a wide-ranging program and adequate long-term funding to address the new situation. He first discussed his idea with Meany in February 1963, reporting to Lovestone:

As for the question of our labour institute ... on Africa, he [Meany] is all for the idea.... It is clear he is leaning more and more towards ... promoting and supporting many of these activities through such an institution as ... we are planning. ... He seemed increasingly receptive to the idea of moving out into fields through what could be called "American instruments" on a tripartite basis, and if necessary in cooperation with other governments.

The Kennedy administration was currently reviewing its strategy for foreign aid through a committee chaired by retired General Lucius Clay. Brown had private talks with Clay over the idea of an African labour institute and reported to Meany on Clay's favourable reaction. ${ }^{75}$

Asked to draft a resolution for the AFL-CIO executive council, Brown wrote of a "new chapter" opening up in Africa. He noted that the task of African unions was significantly different from that in developed economies, with a primary emphasis on nation building. Beyond this, African unions needed help in launching and managing cooperative enterprises, along with assistance in teaching vocational skills. To these, Brown added two more important tasks-help with workers' housing and community planning. To tackle such issues there was a need to go beyond the traditional type of American trade union solidarity and to mobilize the resources of government, labour, and employers in the United States. He was thinking in terms of a version of AIFLD for Africa, and the resolution adopted by the executive council instructed Meany to explore the possibility of establishing such an institution. ${ }^{76}$ Under the Kennedy-Johnson presidencies the AFL-CIO was pushing at an open door in its quest for government funding. As Irving Brown observed, "the idea is in tune with the times." 77

Talks with government only began in 1964 and without fanfare, but by summer George Meany had secured the full support of AID director David Bell for the AFL-CIO proposal..$^{8}$ When rumours of the new initiative first leaked out, Victor Reuther, who was a member of the Labour Advisory Committee to AID, was anxious to prevent it becoming yet another "Brown operation," wrote to Lovestone requesting further details and for the matter to be placed on the agenda of a forthcoming meeting of directors of international affairs of AFL-CIO affiliates. Lovestone fobbed him off, saying that the proposal was "nowhere near any concrete shape."79 Approval was now a formality, simply requiring the official submission of an AFL-CIO prospectus 
to AID's Labor Advisory Committee. The formal proposal submitted under Brown's name was a fifteen-page document loosely listing a series of general suggestions for activities in a dozen African countries: there was no attempt at rigorous discussion or careful costing. For most of the countries listed there was general talk of the need for unspecified vocational training courses and help with cooperatives of various kinds. A press release in September announced that Irving Brown would be the executive director of the new institute-to be named the African-American Labour Centre. ${ }^{80}$ The public launch at New York's Commodore Hotel followed in mid-October. An important new venture was about to get under way under Irving Brown's directionbut with it also another chapter in the long-running battle with Omer Becu arising from Brown's continuing insistence on combining his ICFTU responsibilities with work undertaken for the AFL-CIO.

\section{Taking the Fight to Becu}

An assessment of the ICFTU's 1962 congress in Berlin written shortly after the event by the American labour historian John Windmuller was upbeat in noting that Omer Becu had emerged as "an important power in his own right" and had transformed the ICFTU secretariat into "an entity to be reckoned with," the self-confidence and esprit de corps of staff now plainly evident. Income had doubled since the previous congress (largely through the trebling of solidarity fund contributions), with the result that organizing and educational activities were expanding at a faster rate than ever before and the "moral authority of the ICFTU" within the wider labour movement was on the rise. The article heralded the advent of a new phase in ICFTU development. Yet even before the article found its way into print, Victor Reuther advised Windmuller that it was six months out of date. ${ }^{81}$ What had changed, of course, were Meany's relations with Becu, which had been seriously damaged over Irving Brown's travel and the AFL-CIO president's instruction to him to defy the ICFTU general secretary. Renewed hostilities had broken out, and the main weapon to hand for Meany as chairman of the solidarity fund committee was his ability to restrict the flow of funds available for spending on development work-in the parlance of the New York plumbing trade where his roots lay, "turning off the water." The free spending of the solidarity fund committee witnessed in 1961-62 was now about to go into reverse.

George Meany no longer believed he could trust Becu's word. The extent of his resentment became apparent at a landmark meeting of the solidarity fund committee over which he presided at AFL-CIO headquarters in January 1963. It was a brutal encounter that was etched in the memory of those present. In the chair, Meany opened the meeting in a foul temper, complaining that the voluminous 
documentation made it hard to derive an overall picture of solidarity fund projects. Hitting his stride, he said he was "very disturbed"; the fund had become a "financial giant" faced with never-ending demands of "ridiculous proportions" that were bound to lead to "absolute collapse." As Stefan Nedzynski recalled, it was now less a meeting than a monologue by Meany. He would occasionally put an irate question to Becu without allowing him a chance to reply and then plough on through the agenda, turning down spending proposals left and right without taking a vote. In sweeping terms, he insisted that many areas had seen "no progress at all," and he complained that everyone working in the African trade union movement seemed to be on the ICFTU payroll. The general thrust was that the ICFTU had been living beyond its means, but the party was now over.

In this situation, Becu was a man backpedalling ineffectually before an advancing steamroller, conceding that "perhaps too much money had been spent" here, acknowledging that "some waste" had been incurred there, but protesting that the nature of the work made it difficult to quantify success. Other committee members failed to speak up forcefully in defence of programs, though Ludwig Rosenberg, the DGB's recently elected president attending the committee for the first time, was plainly offended by Meany's bullying manner, muttering "quatsch, quatsch" (rubbish) to himself throughout the proceedings. ${ }^{82}$

The outcome was that many new spending proposals were rejected. No grants were allocated to the trade secretariats for organizing work, though previously 10 percent had gone to them and their share had been expected to increase in this latest round. Meany argued that they were capable of standing on their own feet, and he was particularly dismissive of the idea of granting funds to the International Metalworkers' Federation. Hadn't Walter Reuther's UAW recently established its own solidarity fund of $\$ 2.4$ million, much of which was likely to find its way into the IMF ${ }^{83}$ Ongoing ICFTU regional programs requiring a further injection of funding were granted only sufficient funds for the next six months. Perversely, proposals rejected included some that were close to the heart of the AFL-CIO-in Nigeria and Kenya, for example-that Meany had previously been only too happy to finance.

Irving Brown had played a decisive role in whipping up Meany's animosity toward Becu, but core ICFTU's programs were now in the line of fire and that wasn't something he had bargained for. Whatever his personal relations with Becu, Brown regarded the ICFTU as an important agency in international affairs. His own value to Meany was as an advisor on tactics and strategy to be adopted with regard to the politics of this body; it was his theatre of operations, the organization that enabled him to exert a personal influence. Now he manoeuvred behind the scenes hoping that Meany would agree to a financial lifeline for strategically important 
ICFTU programs. "I haven't been fired yet," he pointed out with reference to his insubordination of Becu, and Meany assured him: "Don't worry, you won't be fired." Meany mused that had Becu been "more of a man" at the solidarity fund meeting, defending his proposals more vigorously, he might have been able to get some of these programs through. ${ }^{84}$ But now in a mellower frame of mind, the federation president relented and basic allocations were made. Yet it was abundantly clear that a new situation had arisen and relations between George Meany and Omer Becu would never be restored. ${ }^{85}$

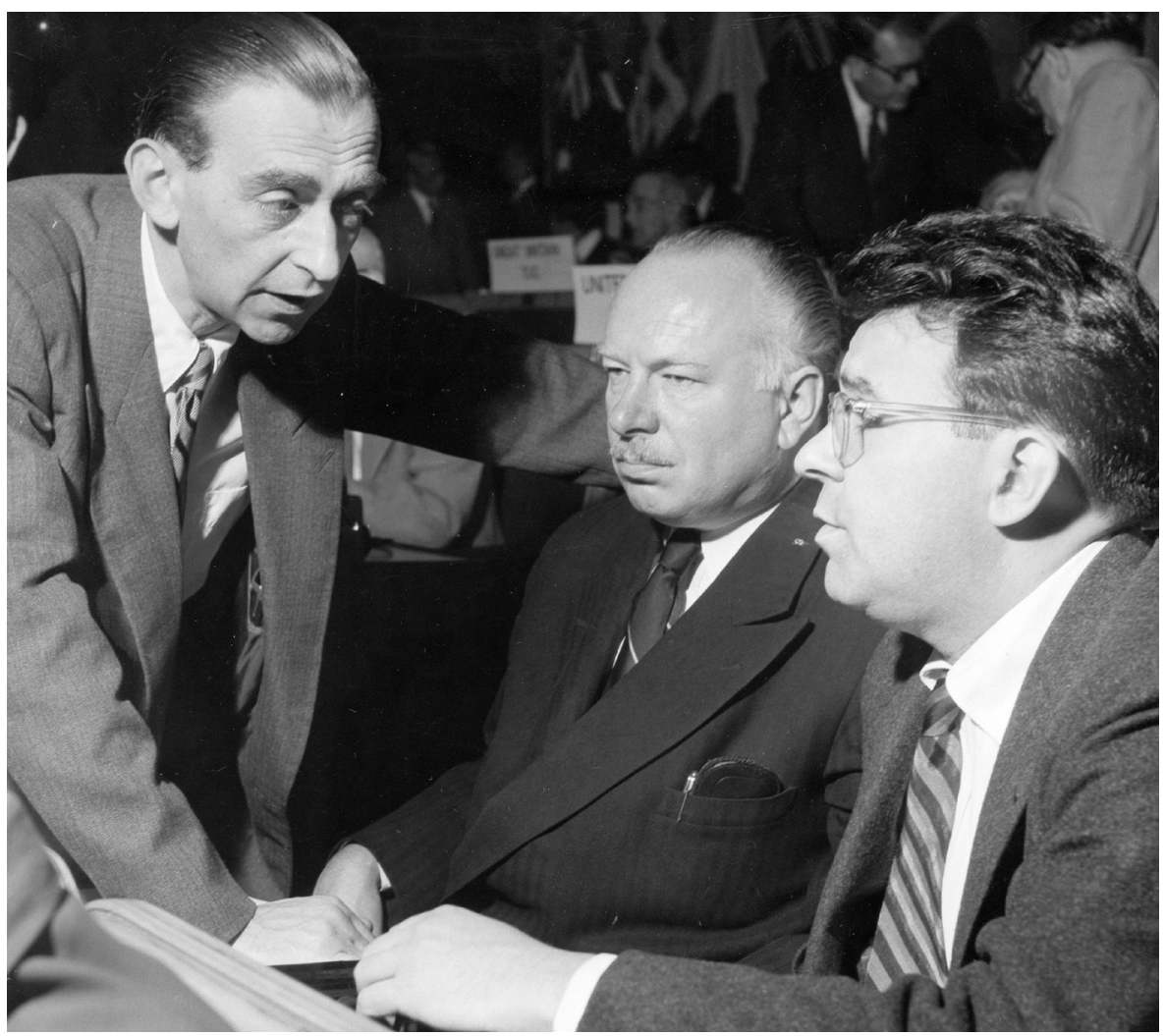

Figure 12. Ludwig Rosenberg, DGB president, 1962-69 (left), with Henry Rutz and Irving Brown, at the Stockholm congress of the ICFTU, in July 1953. Rosenberg grew to detest George Meany. The sentiment was reciprocated. Courtesy of the Special Collections Department, University of Maryland.

Walter Reuther was particularly irked to learn that the grant application submitted by the IMF for organizing work in Latin America had been rejected and asked Becu for the verbatim minutes of the meeting together with documentation on the 
background to the dispute with Brown. He intended to challenge any attempt by Meany to have the AFL-CIO executive council nod through approval of the new constraints on solidarity fund expenditure, and he put in a rare personal appearance at the next ICFTU executive board in March 1963 to argue against the recent turn of events. Yet he had to settle for a reduced scale of funding for fieldwork by the international trade secretariats, and he largely failed to prevent a further reduction in AFL-CIO contributions to the solidarity fund, which in August 1963 was cut by almost half, translating into a reduction in the ICFTU's budget for regional development of at least 30 percent. ${ }^{86}$

In the solidarity fund committee, "the two Georges" now formed a powerful alliance to curtail expenditure. From 1963 their shared concern was to confine funding to the maintenance of ICFTU regional offices and staff and the administration of training schools. Organizing activities beyond this would largely be the responsibility of the trade secretariats, which would need to find their own sources of funding. In Woodcock's case, the new, parsimonious regime was a reflection of his personal belief that the ICFTU had been misconceived from the outset. For Meany, it signalled the fact that the ICFTU was declining in importance, as he visualized the growth of AFL-CIO independent international activity undertaken with the benefit of generous US government funding for the AFL-CIO "auxiliary institutes," one already operational in Latin America and another under consideration for Africa. ${ }^{87}$

Reuther's attendance at the ICFTU's board meeting in March appeared briefly to embolden Becu to stand up to Irving Brown. When the latter turned up in Brussels, having travelled to the meeting without authorization, Becu challenged his presence and ordered him back to New York. Brown immediately notified George Meany in Washington, who in turn instructed Bill Schnitzler, his substitute at the board, to leave the meeting as well in the event that Brown was ejected. It was a crucial test of Becu's authority. Over the previous five months, Brown had travelled to Africa on four occasions, twice on ICFTU business but twice also purely at Meany's behest on behalf of the AFL-CIO. His appearance in Brussels in March 1963 was yet another instance of his thumbing his nose at Becu. In the event, the general secretary was unwilling to take on Meany directly. Faced with the prospect that Schnitzler would walk out, he was forced to knuckle under and live with the fact that Irving Brown was a law unto himself, performing his ICFTU functions as he saw fit and otherwise bypassing Becu when it suited him. ${ }^{88}$ The long-term damage to Becu's standing as general secretary caused by this episode was incalculable.

In the months ahead, Becu would make attempts to restrict Brown's travel, but always on technical grounds and never alluding to the real political reason for doing so-the fact that other powerful affiliates were up in arms at the cavalier way in which the AFL-CIO used Brown's services for its own purposes. He challenged Brown over 
air travel expense claims submitted for trips from New York to Nairobi, New York to Leopoldville, and New York to Paris, Athens, and Addis Ababa, pointing out that he had no recollection of asking him to undertake the journeys and asking for an explanation: "We have nothing on record to show that you made these trips on ICFTU business," he wrote. It spoke volumes for Becu's complete loss of authority that Brown simply disregarded the letter, forcing the general secretary to write again six months later to remind him that an answer was still awaited. ${ }^{89}$

Brown's attendance at all UN regional meetings could not be guaranteed, Becu explained patiently, since the general secretary had to have the final word on matters of spending. He declined to ask for a further increase in Brown's budget that had previously been in the cards, noting that travel was an item on which savings could be made. Wearily he wrote:

Dear Irving,

I regret very much that this personal correspondence has to continue, but I hope that I can make the position clear so that we can finally achieve a fruitful working relationship.... I could never have made any firm agreement with you ... [over] your being given authority to go anywhere you felt your presence was necessary. .. . You must realize ... that final decisions ... remain with me.

But Brown's defiance continued, and he replied:

It is quite clear ... that you no longer have the same conception of the UN post.... I am questioning your concept of my job which is not in line with the basis on which I came to work for the ICFTU. I shall continue on that basis until informed otherwise-which is to work within the UN as a total operation and not merely as an office in New York..$^{\circ}$

Having assured Brown that his defiance would not lead to the sack, Meany now backed him to the hilt, with the result that Brown simply continued to combine his official position with his de facto role as roving AFL-CIO representative. As John Windmuller's contemporaneous review of ICFTU "progress" noted coyly: "It is not yet quite clear, however, whether Brown has completely switched roles from an AFL-CIO to an ICFTU representative." ${ }^{11}$

Brown returned to Africa twice more that year, in July-August and NovemberDecember. As Kalmen Kaplansky, international director for the Canadian Labour Congress, noted, Brown was spending as much time in Africa as ever on Meany's behalf, while foreign visitors to the ICFTU's office in New York never knew for sure whether they were being received by the AFL-CIO or the ICFTU. ${ }^{92}$ Out of these trips came a further tranche of AFL-CIO assistance for sections of the Southern 
Rhodesian and South African labour movements, each of which received \$5,000 in August 1963. ${ }^{93}$ From East Africa, Brown wrote to Lovestone expressing satisfaction with his visits: "Someone has to pick up the pieces since the ICFTU is in its greatest crisis-except it is unconscious of it all." Significantly, it was to Meany rather than his official boss that he cabled a request for permission to interrupt his travels and fly back to the United States to consult and advise before the AFL-CIO executive council formalized its new approach to the solidarity fund committee in August $1963 .{ }^{94}$

In late 1963, Stefan Nedzynski initiated one last attempt to restore Omer Becu's all-important personal relations with Meany. He convinced Becu of the need to make a conciliatory gesture, and through Irving Brown he got Meany to agree to a private meeting in New York shortly before the next scheduled meeting of the solidarity fund committee. On the surface their tête-à-tête seemed to go well. Relieved, Becu persuaded himself that Meany wanted a reconciliation and, forgetting the time difference with Europe, put in a call to Brussels and awoke Nedzynski in the early hours of the morning to report that they had "turned a corner." Aware that Meany would want to talk about finance with Becu, Nedzynski had prepared a one-page briefing note for his boss that contained the key headline figures. But when the solidarity fund committee met formally just days later and Meany raised the question of total anticipated expenditure, Becu cited a figure $\$ 500,000$ higher than the one he had mentioned at their earlier private meeting. Confusing the totals on Nedzynski's briefing paper, he had inadvertently misled Meany. The AFL-CIO president was outraged. Again it boiled down to a question of personal trust, and Meany concluded that his money was no longer safe with Becu. There was now no way back for the ICFTU general secretary. ${ }^{95}$

The meeting proved to be another disaster, with Meany again on the offensive. More proposals were turned down and new spending restrictions imposed. It was decided that unspent allocations could no longer be carried forward from one year to the next. The result was to be an accumulation of "unspent balances" that would become the subject of Meany's next onslaught on Becu. The secretariat found itself squeezed from opposite ends, with Woodcock on the one hand complaining of profligacy and, on the other, Meany accusing the Brussels secretariat of hoarding unspent balances in interest-accumulating investment accounts as though this was a corrupt use of funds originally intended for constructive purposes. In light of these "swollen reserves," Meany now proposed a further cutback of 25 percent in American contributions to the solidarity fund while the unspent balances were run down. Ominously, he also warned that he would be sending in his own AFL-CIO auditors to check on where the money went..$^{96}$ 


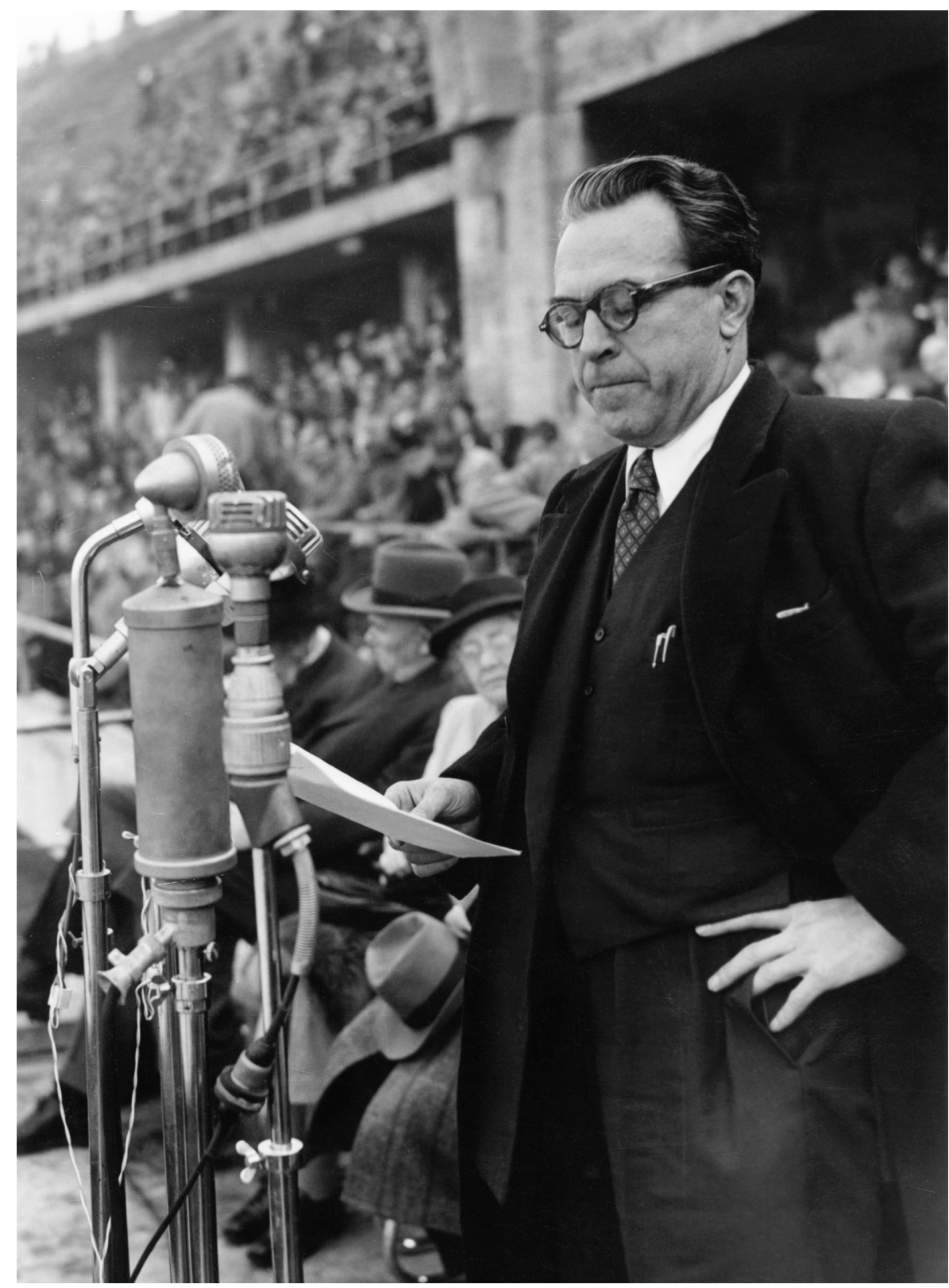

Figure 13. Omer Becu, the ICFTU's general secretary, 1960-67. This photograph was taken in 1950, at the start of Becu's decade as general secretary of the International Transport Workers' Federation. Already by 1964 he seemed to Stefan Nedzynski a "finished, beaten man" — and, in January 1967, his would become the second ICFTU scalp claimed by Meany and company. Courtesy of AMSAB-Institute of Social History, Ghent. 
Becu's demoralized deputy, Nedzynski, made a final effort to encourage the general secretary to fight back. He informed Becu that he had recently been offered the general secretaryship of the Postal, Telegraph and Telephone International (PTTI) but assured him that he would stay and fight alongside him at the ICFTU if Becu was prepared to mount a resistance to the policy of spending cutbacks. Becu was weary and suggested they defer the discussion until another day. But that day never came, and, in September 1964, Nedzynski tendered his resignation as ICFTU assistant general secretary. Omer Becu, he maintained, was now "a finished, beaten man, pitiful in his attempt to hold on." In Brown's eyes, too, the International was led by a "sick man" for whom "I even began to have pity . . . watching his helplessness and ineptness." Yet he and Meany were largely responsible for Becu's mental and physical condition. ${ }^{97}$

\section{A Law unto Himself}

It is hard to assess Irving Brown's performance purely in terms of his role as the ICFTU's director for United Nations affairs, since he combined this with a wider range of activities. Following his appointment, he quickly recruited a small team of able assistants, including the Czech exile Paul Barton (Jiří Veltruský) as economist and José Maria Aguirre, former editor of the ICFTU's Free Labour World, with responsibility for publicity. Although Brown complained of being prevented from hiring an African and an Asian so as to fully "internationalize" his staff, the general impression created was of a New York office demonstrating more dynamism than previously when Bill Kemsley supervised an undermanned and underfunded operation. Brown wanted to make his presence felt in and around the UN and early on preened himself when a statement on political prisoners that he had issued to the General Assembly prompted a supporting editorial in the New York Times. ${ }^{98}$

He was also in at the beginning of the discussions in the UN's Economic and Social Council in July 1962 that led to the convening of the UN Conference on Trade and Development and eventually spawned the permanent agency UNCTAD. In this area, he claimed personal responsibility for persuading the head of the US delegation to the General Assembly to drop his opposition and embrace the initiative. Along with Paul Barton, Brown worked on early proposals for the conference, but when the row over his unauthorized travel erupted, Becu blocked him from attending the Preparatory Conference on Trade and Development in Geneva. Brown was up in arms and remonstrated with Becu: "It is inconceivable to me that we can plunge into the work of the Preparatory Committee of the coming UN World Trade Conference and not follow it through to the very end."99 The issue also highlighted the turf warfare that was ongoing between the New York office and Alfred Braunthal's 
economic research department in the ICFTU secretariat. Brown's claim was that the real initiative had come from him, whereas the input from the secretariat had been "pitifully inadequate." Excluded from the preparatory meeting, he protested that the ICFTU was being represented by a "faceless, uninformed delegation" whose members-Alfred Heyer and Heribert Maier-were ill equipped to deal with the subject. "The exchange of letters and proposals between the New York and Brussels offices of the ICFTU," he argued, "reveal what can only be called a state of bankruptcy in ... the secretariat." ${ }^{100}$

Brown was also frustrated by the failure of the ICFTU to act on his proposal to open a permanent office in the Ethiopian capital of Addis Ababa, where the Organization of African Unity was in the process of establishing itself as a vehicle for unifying the competing strands of pan-Africanism. This was where attempts would eventually be made to reconcile AATUF and those African centres that insisted on their right to affiliate to the ICFTU or the Christian international. Brown considered it essential for the ICFTU to have a continuing presence there. Such an office would clearly have provided an important field base for his African activities, but Becu's moves to restrict his foreign travel helped ensure that there would be no African sub-office for Brown. ${ }^{101}$

As relations between Omer Becu and George Meany went into terminal decline from late 1963 onward, Brown's open defiance of Becu increased across a range of issues. In March 1964, he wrote to the general secretary advising him of his refusal to distribute an ICFTU press release critical of a general strike in British Guiana waged as part of Cheddi Jagan's attempt to seize control of the labour movement for his ruling party. The press release was entitled "ICFTU Denounces Intimidation of British Guiana Sugar Workers," but Brown felt that its language was too mild and complained that while the word "denounce" appeared in the heading, the body of the text merely spoke of being "gravely disturbed" by Jagan's action. Brown demanded more red meat, and he remonstrated with Becu: "I regard the protest to Cheddi Jagan as a pitiful demonstration of political understanding and a feeble action.... There is a an utterly unwarranted assumption here that it is possible for an avowed Communist [i.e., Jagan] . . . enemy of free trade unionism to safeguard democratic freedoms." The release, he said loftily, "would only raise the most serious questions among informed people as to the ICFTU's comprehension of the crisis for free trade unionism in British Guiana." ${ }^{102}$

In Africa, Brown went about his business almost without reference to Becu, even while at times presuming to act on behalf of the ICFTU in matters of utmost importance. In June 1964 he held talks with Ugandan prime minister Milton Obote in an attempt to reach agreement on the disposal of the ICFTU college in Kampala that the government wanted closed down. Becu would later accuse Brown of having 
entered into negotiations without authorization. ${ }^{103}$ Likewise, on an unauthorized visit to Nigeria in autumn 1964, Brown met AFRO's newly appointed regional secretary Momodou Jallow and "agreed to work out a common programme" with him for the coming months, an arrangement clearly concluded on behalf of the AFL-CIO. ${ }^{104}$ Also in autumn 1964 Brown discussed with union leaders from Senegal and Tunisia how to help in paying off the debts of the African Trade Union Confederation (ATUC), with which the ICFTU had friendly relations. He talked of passing a sum of $\$ 100,000$ through a Geneva Bank on behalf of the ICFTU, though the organization had neither formal responsibility for ATUC nor budget for the assistance he proposed. ${ }^{105}$

During these days when he routinely disregarded the general secretary, Brown made a second visit to South Vietnam in June 1964. It followed a visit to the United States the previous month by Tran Quoc Buu, president of the CVT, as a guest of the AFL-CIO during which Brown accompanied him. The AFL-CIO arranged for Buu to meet President Lyndon Johnson at the White House, where he laid out plans already discussed with Brown and Lovestone for AFL-CIO-CVT cooperation. As part of this, Buu made the case for the CVT to have a central role in what would come to be known as "pacification" by creating "an almost para-military type of civilian organization to ... transform the indifferent and neutral mass of people into an active barrier against the communists."106

Taking as read President Johnson's favourable reaction, Brown impressed on Meany the need to follow up with the administration to guarantee support and for Buu to return as quickly as possible to Vietnam to ensure there was no objection from General Khanh, head of the military junta. The AFL-CIO would immediately begin to send personnel to Vietnam to lay the foundations for the program, with Brown himself among the first to visit the following month. ${ }^{107}$ There was no discussion of this with Becu, and the indications are that the project was arranged in conjunction with the intelligence services. ${ }^{108}$

In reports to the AFL-CIO during this period, Brown cruelly mocked Becu for being invisible or beyond reach, whether as a result of his incessant travel or because his frequent nervous ailments kept him away from work. In May-June 1964, he reported that in recent weeks the general secretary had been in New York, Tel Aviv, Athens, the French-Spanish border ("to meet the wrong kind of Spaniards"), and Stockholm. He joked:

The phantom is somewhere in the world and the latest report is Athens-of all places. If he is now meddling again with Makris, his psychological absenteeism takes on a most revolting physical presence! It is absolutely amazing that one calls Brussels - his home office-and one can almost feel the embarrassment at the other end of the line when one puts the now infamous question - "Is Omer there?" He is but he isn't and now even worse, he isn't but he is. ${ }^{109}$ 
His verbal attacks on Becu extended to the ICFTU secretariat, which he characterized as "a very mediocre and unrepresentative kind of staff" with "no one who can carry weight with either governmental or intergovernmental bodies." In June 1964, he wrote: "The organization is down to its lowest point of morale and there is an absence of any overall dynamic direction and organization. ... Documents reveal large accumulation of bits and pieces but no central guiding hand of leadership." Yet he still distinguished between the mediocre personnel and the ICFTU itself-a potentially worthwhile organization. ${ }^{110}$ Increasingly on his mind was the fact that Becu's term as general secretary was coming to an end; there would soon be talk of a succession. Although he himself had vacillated in the past over joining the ICFTU staff, he had never entirely abandoned the idea of filling the top post. Certainly he never conceded that anyone else was better qualified for the job.

Many people reading his vitriolic reports would have drawn the logical conclusion that the ICFTU was, from top to bottom, a lost cause and best abandoned. That surely was their long-term impact on George Meany. But Brown believed that he could continue to fire salvo after salvo of wounding criticism and still expect the organization to survive intact and be in a position to furnish him with an international stage on which to perform. That was his assumption when he told George Meany in June 1964: "If the present [ICFTU] situation is not changed very soon-and this means in one way or another a new leadership-there will be little hope at the next Congress in 1965 to save the situation."111 Five months later, in another knowing nudge, Meany was reminded of the absence on the scene of any credible successor to Becu, especially with the recent resignation of Stefan Nedzynski, and Brown reported that most people he talked with in Europe wanted to know what the Americans proposed to do about it. ${ }^{112}$

\section{Heading for the Amsterdam Congress}

As the ICFTU's 1965 congress in Amsterdam approached, the launch of the African-American Labour Centre (AALC) revived the vexed question of Brown's dual role, working for the ICFTU while undertaking activities on behalf of the AFL-CIO. Only relatively late in the negotiations with AID over the centre's shape and funding did Lovestone suggest that Brown discuss with Meany the obvious conflict of interest involved in Brown becoming executive director: "It is better to clear the matter thoroughly. ... I am not the only one who sees the need of such consideration. Others have posed the problem." ${ }^{113}$ Meany and Brown met in Geneva two weeks later to review the AALC project. Whatever passed between them on the undoubted conflict of interest, Brown clearly considered it insufficiently important to record in his report back to Lovestone. There was absolutely no doubt that Meany understood the 
AALC position to be a full-time job; Brown had told him quite specifically that he would be able to devote himself "full time," especially as the UN General Assembly was not in session. ${ }^{114}$

Sight of the official AALC press release announcing Irving Brown's appointment in September was the first confirmation Omer Becu had that Brown would be running the new institute. He had not been consulted about the project, nor was its launch discussed at the ICFTU executive board in November-December. On that occasion, Meany heaped insult on injury when he brought with him a cheque for the AFL-CIO contribution to the solidarity fund and, not for the first time, decided against handing it over. Brown described how "the general secretary ... presented a pitiful picture of a beaten, psychologically and possibly physically sick man." ${ }^{115} \mathrm{Becu}$ waited a couple of months before writing to Brown to protest at the obvious discourtesy of not discussing the AALC with him. ${ }^{116}$ Brown's response was simply to write back three weeks later affirming, without comment, that he accepted the statement of allegiance that all staff members of the ICFTU were bound by.

Becu had not previously risked challenging Brown's loyalty throughout his long months of disobedience by invoking the allegiance clause, doubting that the wording was sufficiently unambiguous to withstand a challenge. But now he proposed an amendment to the statement at the March 1965 ICFTU executive board, the effect of which was specifically to bar staff members from taking up other jobs or functions, whether paid or unpaid, without the written permission of the general secretary. The amendment was approved, with Meany dissenting. The AFL-CIO president pointed out that Brown was acting unpaid as head of the AALC, of which he himself was the chairman. The objectives of the centre were clear, and he defied anyone to show that they were in any way contrary to ICFTU policy. The charge of "incompatibility," he said, was simply a pretext to get rid of Brown, and he would not be a party to it. ${ }^{117}$

In follow-up correspondence with Becu, Meany asserted that hitherto there had been no confusion arising from Brown's holding two responsibilities and that he had never taken "instructions from any national or outside international organization which might interfere" with his duties. Moreover, Brown had put in far more hours for the ICFTU than a 100 percent commitment to the job required, and Meany suggested that his work for AALC would enhance his contribution to the ICFTU. As the amended statement gave the general secretary the right to authorize staff to hold additional positions, Meany therefore requested Becu to do so in this case. $\mathrm{He}$ signed off in breezy fashion: "Looking forward to hearing favourably from you on this matter." ${ }^{118}$

Persisting with the financial squeeze on the ICFTU, Meany concurrently won the backing of the AFL-CIO executive council to demand a full ICFTU accounting of all contributions made to the solidarity fund since 1961 (which he reckoned might 
amount to $\$ 3$ million) and the return of the AFL-CIO's pro rata share of unspent monies. At his regular press conference, Meany tossed out the suggestion that the AFL-CIO might quit the ICFTU, speaking of it as an organization that was "going downhill," a "real bureaucracy," and with a staff infiltrated by "fairies" (or "homosexuals," as the New York Times incorrectly reported him saying). ${ }^{119}$ His undiplomatic language disturbed even Jay Lovestone, who described his remarks as "an unfortunate occurrence" and commented that "in all good apartment houses the family laundry ... is not in the front parlour but only in the basement." At a meeting attended by Washington-based labour attachés, Lovestone also rowed back from Meany's casual suggestion of a possible American withdrawal from the international: there was no such intention. He did, however, express strong criticism of Geijer, Becu, and their colleagues in their capacities as officials of the ICFTU. ${ }^{120}$

Yet Meany's press statement, and especially his gratuitous reference to fairies within the secretariat, became a major issue at the mid-March meeting of the ICFTU executive board, two weeks later. The staff association had cabled Meany asking him to issue a public denial, but none was forthcoming. Meany now took the position that, as the issue was not on the board's agenda, he was not prepared to answer charges arising from a statement attributed to him by the New York Times. George Woodcock insisted that his position was "indefensible": a casual denial of the alleged statement at this stage, after it had been repeated and gone undenied for several days, was simply not enough. Meany eventually agreed to provide a written explanation and to meet with representatives of the staff association. ${ }^{121}$

Meany left the executive board meeting still defiant and immediately gave another press conference at which he talked in more lurid terms about "hidden incomes" being paid in addition to basic ICFTU salaries and of his determination to eliminate practices that were "certainly unethical if not something worse." He repeated his request for a full accounting, which he felt confident that the auditor was capable of providing. But he also upped his demand for a refund, now calling for it to be backdated not to 1961, as previously indicated, but to 1958, when the international solidarity fund was first launched. Meany followed up with a letter to Becu in which he again registered his dissatisfaction with the latest financial report provided by the general secretary. Exasperated, Becu maintained that he didn't know what Meany meant: nothing in the accounts was hidden. He also protested that Meany had offered no concrete evidence to support his general claim that, as an organization, the ICFTU was ineffective. Becu's pride was stung, and he quickly announced to the press that he intended to stand for a further term of office. ${ }^{22}$

Reporting back on the executive board meeting to his TUC colleagues, Woodcock expressed some sympathy for the AFL-CIO's wish to spend its money as it thought best but regretted that its self-justification "unnecessarily involved denigration of 
the ICFTU." At bottom, Woodcock concurred with the view, also held in Canadian labour circles, that Meany's demand for a refund sprang from an attitude that the ICFTU should function primarily as an anti-communist organization. That explained most of the sparring over ICFTU finances and Meany's strong hints about the misuse of funds. ${ }^{123}$

Meany's belligerence in the spring of 1965 had aroused widespread resentment, and this was still palpable as the date of the ICFTU's July congress approached. Arne Geijer wrote to tell Walter Reuther that "the situation of the ICFTU is serious" and that there was a "crisis in confidence." Writing from Bonn after talks with DGB chairman Ludwig Rosenberg, the Swedish labour attaché reported that Meany's behaviour had been counterproductive in Europe, his own view being that "irreparable damage" had been done to the ICFTU "by Meany's decision to bring out all of its differences in the public press." A week before the congress, Meany arranged a meeting with the ICFTU's travelling internal auditor, Ernst Smith, to discuss the financial accounts and told him that if, at its meeting in advance of the congress, the International Solidarity Fund Committee didn't agree to pay back the sum he demanded, the AFL-CIO "would be out of the ICFTU." ${ }^{124}$ Among affiliated centres, there was general despair at the state of the ICFTU, and few people viewed the future with optimism. Nevertheless, there was a strong sentiment among European affiliates not to see Becu hounded out of office so cruelly as a consequence of Meany's unremitting offensive. Yet Becu's health was failing-indeed, he took a further six weeks' sick leave in the period between the executive board meeting in March and the July congress-and it was hard to see how the organization would benefit from his re-election.

Despite clear signs that Meany's behaviour was alienating Europe's national trade union centres, Irving Brown convinced himself that the Americans could capture the leadership of the ICFTU if only they would apply themselves and orchestrate a vigorous campaign. In a strategy document drafted for Meany in the spring, he expressed genuine concern that the ICFTU was in deep crisis. But, unlike Meany, he was opposed to allowing the organization to collapse further. He urged the federation president to give the green light for a pre-congress campaign to galvanize those affiliates disillusioned with the existing leadership, to sweep Becu aside, and to take over the reins of the ICFTU. Indeed, he seemed ready to believe that he, personally, could play an important role in saving it—even leading it. Many would have considered him delusional, but he encouraged friends to talk up his leadership credentials in the months leading up to the congress, and a document emanating from North Africa that circulated in the early spring of 1965 advanced the case for Brown to replace Becu as general secretary. ${ }^{125}$

Lovestone followed up with an article for publication under Meany's name, which borrowed heavily from Irving Brown's strategy document-especially its focus on 
the core objective of fighting communism and the need for a dedicated department within the ICFTU to oversee this. It concluded that a "militant and effective" ICFTU was still needed, just as it was in 1949. In delivering the draft to Meany, Lovestone predicted that the article would immediately become the basis of discussion as to what the ICFTU has been and what it has to be in the future." ${ }^{126}$

However, even though he put his name to the article, which appeared in both the AFL-CIO News and the Free Trade Union News, and even though Irving Brown was upbeat about the positive reception he claimed the article was receiving internationally, in practice Meany evinced no real sign of enthusiasm for such an American-led campaign within the ICFTU. Years later, Stefan Nedzynski recalled that these attempts by Brown and Lovestone to influence Meany were inevitably doomed:

Meany was by that time convinced ... of the [ICFTU's] inherent ineffectiveness. ... He was no longer interested in reforming the ICFTU but wanted to settle his accounts with Becu and after that to reorganize AFL-CIO international activities on a unilateral [basis].... Brown's optimism about his chances of election to the [general secretary] post were an excruciating exercise in wishful thinking.... [Europeans] would have regarded it simply as scandalous for Meany to propose Brown as the next general secretary. Meany was realistic and knew that, but above all he was not interested in that business at all. ${ }^{127}$

Facing a threat of a pullout by the AFL-CIO if the rebate demanded by Meany were not paid, the solidarity fund committee agreed unanimously on the eve of the congress to refund $\$ 818,000$. But if the hope was thereby to reduce the level of acrimony, it was to no avail. ${ }^{128}$ George Meany approached the July congress, held in Amsterdam's Concertgebouw, with the almost cavalier attitude of one who cared little whether the ICFTU survived or perished. On the opening day, he gave a provocative interview to the Amsterdam social-democratic paper Het Parool in which he once again spoke witheringly of the management of ICFTU finances, saying that the organization resembled more a bank than a trade union body and instancing "clever accounting tricks" through which approximately two and a half million dollars were "hidden in funds with incorrect names" instead of being available to help unions in developing countries. ${ }^{129}$ Arne Geijer, about to retire as ICFTU president, was forced to explain to congress delegates that it all turned on the propriety of establishing reserves consisting of money that had been earmarked for projects that ended up not being pursued so that the funds could be used for other purposes in the future. Becu repeated his insistence that, as chair of the International Solidarity Fund Committee, Meany had regular access to the accounts and that if the financial situation was "news" to him, it should not have been. However, Meany remained combative, retracted none of his criticisms, and concluded his main conference 
address defiantly: "So that is our story, and if you like it, it is all right, if you do not, it is all right with me."130

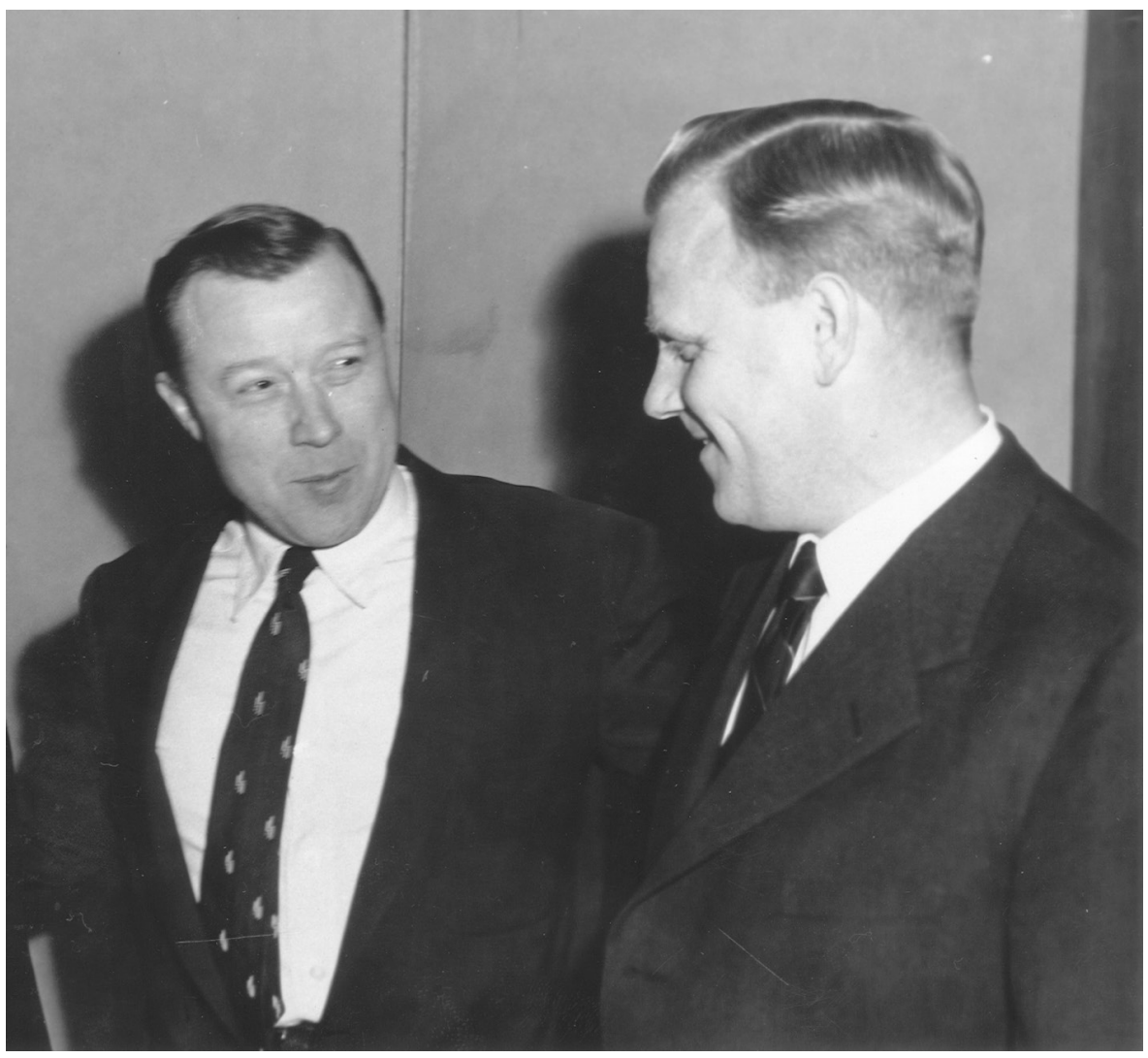

Figure 14. Walter Reuther (left) and Arne Geijer, ICFTU president, 1957-65. Reuther's closest ally in Europe, Geijer had little patience with Meany's belligerence, commenting that "Meany is not a man one can talk to. He is a man who likes to tell people what to do." Courtesy of Arbetarrörelsens arkiv och bibliotek, Stockholm.

The congress thus began in a state of uproar and continued in a climate soured by the position taken by the AFL-CIO president. Amsterdam 1965 was arguably the lowest point to date in the ICFTU's troubled history. Omer Becu was duly re-elected at the congress, though it was more a vote of pity than of confidence. His acceptance speech hinted at his eventual retirement and the possibility that he might not even serve a full term. Indeed, the ICFTU soon found itself again drifting aimlessly as Becu was forced to take increasing amounts of sick leave amid rumours that he had suffered a heart attack. 
Meany's standing in Europe was much diminished. A British diplomatic report spoke of the AFL-CIO president excelling himself at Amsterdam by his "impulsiveness, clumsiness and calculated offensiveness," which brought about the "total isolation of the AFL-CIO within the ICFTU." Geijer wrote to Becu regretting that "just one person" was responsible for Becu's difficulties, observing that, had it not been for Meany's "remarkable interview in the Het Parool" and a bullying move by the AFL-CIO to claim one of the executive board seats reserved for North Americans and traditionally filled by a Canadian delegate, the congress might have been considered a success. ${ }^{31}$ For his part, Lovestone made a point of checking on reportage in the Swedish labour press, which, he noted, was largely under the control of Geijer's LO, and wrote to Meany: "I have never read anything more scandalous, more dishonest, more scurrilous against the U.S., its foreign policy, its trade union movement and its leadership." ${ }^{132}$

Lovestone was also outraged that the DGB organ Welt der Arbeit described Meany as an "enfant terrible," with Ludwig Rosenberg quoted as saying that the AFL-CIO president was "too anti-Communist." Calling on the DGB to repudiate the journalism, Lovestone complained that it was "a vicious, hostile write-up unworthy of an organization ... which the AFL-CIO has always spared no effort to help." ${ }^{133}$ Lovestone linked the anti-American criticisms that followed the congress to more recent news that the TUC was planning to send a delegation to visit the Soviet trade union centre and that the FGTB congress had passed a resolution aiming at possible closer relations with the CGT and CGIL within the European Common Market. By the end of the year he was advising Meany:

I am more and more coming to the conclusion that the Amsterdam barrage against the Americans and particularly you was preconceived and carefully planned with an ulterior motive-the preliminary purpose being to reduce American influence in the ICFTU and to provoke us into non-participation in the ICFTU with a view to opening the doors to the Soviet Communists and their agents in Europe and elsewhere. ${ }^{34}$

Irving Brown, however, recognized that a large part of the problem was of the Americans' own making, citing especially their "shoddy performance" on ICFTU finances. He told his secretary that, in the wake of the Amsterdam congress, the position of the AFL-CIO was "far from what it used to be in terms of leadership and influence" in the international movement. During the congress he, personally, felt like "an outsider looking in at a traumatic experience à la Kafka." ${ }^{135}$

Still, the logic of Brown's analysis was that the ICFTU had to survive as a credible organization. At a minimum, it gave the Americans access to organized labour in parts of the world where otherwise they might not be welcome. It was necessary for 
the AFL-CIO to hang on as a member of the ICFTU and not pass up any opportunity to influence its future direction. What was needed was a more systematic application of the carrot and stick to achieve American ends-which, as in the past, would involve a constantly shifting mixture of programmatic criticism, denigration of personnel, offers of material support with strings attached, and efforts to feed in strategic thinking derived from the federation's distinctive world view. This had been the AFL-CIO's approach for most of the ICFTU's existence. Meany could be relied upon to wield the stick with demands for financial stringency. The task for Brown and Lovestone would be to counterbalance Meany's negative approach and endeavour to maintain a positive influence at the heart of the ICFTU.

Brown was under pressure from Becu to choose between the directorship of the AALC and his ICFTU post in New York. In August 1965, he notified the general secretary that he would be relinquishing his ICFTU position, but in a friendly gesture he suggested that the date could be by mutual agreement so as to guarantee a smooth transition. He also promised to do everything possible to establish cooperative relations between the ICFTU and the AALC. Becu reciprocated in kind, inviting Brown to continue in the post for as long as necessary while the search went on for an American to replace him. In the event, "as long as necessary" turned out to be eighteen months. In the meantime, Brown met Becu's request for a memorandum on the future work of the New York office and drafted a budget (which included a provision to increase his own salary). Becu expressed pleasure at Brown's efforts, and as Brown reported to Lovestone: "all love and kisses and all for cooperation." ${ }^{136}$

However, Becu was at this point physically and psychologically unable to handle the pressure of the job of general secretary. To compensate for his unreliability, Bruno Storti, the ICFTU's newly elected president, proposed to rearrange his own functions as general secretary of CISL and as a Christian Democrat deputy in the Italian legislature so as to be able to function in Brussels as a quasi- "executive president" for six months of the year, provided he had strong American support. But try as he might to woo the Americans, their backing wasn't forthcoming. ${ }^{137}$ A cable from the British Embassy in Washington to the Foreign Office summed up what was now becoming clear: "MEANY SAID TO BE NO LONGER INTERESTED IN INTERNATIONAL AFFAIRS. ACTING LIKE A SPOILED CHILD WHO CANNOT HAVE HIS WAY." ${ }^{138}$

Under concerted exhortation from Brown and Lovestone, the most Meany would do was submit the name of an AFL-CIO candidate-Morris Paladino, originally with the garment workers and latterly an official of ORIT and AIFLD_for assistant general secretary. But rather than see the offer of Paladino's services as a gesture of American support, Becu appears to have felt threatened by it. ${ }^{139}$ The ICFTU general secretary failed to keep an appointment in New York to interview Paladino and shortly afterward was again on protracted sick leave, from September to November 
1966. Meany then wrote in his capacity as chairman of the solidarity fund committee, laying down to members basic conditions for the AFL-CIO's continued backing for the fund. This involved a further restriction in the amount of activity supported by the fund-in effect, cuts worth some \$500,000, or almost one-third of the fund's existing outlay. Meany offered no commitment to maintain future AFL-CIO contributions, even at the reduced level, and warned that if the committee failed to operate within the limits he proposed, then "it would be finished" as far as the AFL-CIO was concerned. ${ }^{140}$

By this point, the ICFTU executive board had also had enough of Omer Becu and began to look for a replacement. In early January 1967, the general secretary tendered his resignation. It was an inglorious end to the career of a man in whom many had once placed high hopes. His leadership of the ICFTU had been undistinguished, but this was by no means all his fault. Becu was, in fact, the second ICFTU general secretary to have begun office as nominee of the AFL-CIO, only then to fall victim to a wounding American-led campaign against him.

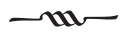

By the beginning of the 1960s, George Meany set little store by the ICFTU, despite the replacement of Jaap Oldenbroek as general secretary by the Americans' favourite, Omer Becu. The latter's welcome proposal to revise the modus operandi of the ICFTU and devolve to affiliated centres much of the responsibility for undertaking solidarity work overseas, provided it was done by agreement with the ICFTU, left Meany still aggrieved at Becu's failure to make good a promise to appoint Irving Brown to a position of influence in the ICFTU secretariat. Hostility to Brown among European affiliates proved too strong for Becu, who quickly realized that he could not deliver on his commitment to Meany. For the AFL-CIO president, the capacity to trust colleagues was fundamental: his inability to do so with Oldenbroek had doomed their relations, and the same factor now threatened to cripple his relations with Becu. It seems quite possible that, had Meany been able to win the backing of fellow leaders of the AFL-CIO in 1961, he would have led the federation out of the ICFTU. Even as chairman of its solidarity fund committee, with responsibility for strategic ICFTU spending decisions, his attitude toward the organization remained at best skeptical.

After Becu appeared to relent by giving Brown responsibility for UN affairsonly then to attempt to restrict his freedom of movement and manoeuvre-Meany's relations with the general secretary turned openly hostile. Meany demonstrated his capacity for infighting with Becu in brutal fashion from 1963 onward, and as Brown defied Becu, with Meany's full backing, the latter appeared to care little whether 
or not the ICFTU survived. What became clear was that the AFL-CIO would not relinquish the right to run its own programs abroad independently of the ICFTU. Irving Brown's increasing involvement in African labour affairs was testimony to that, although he would claim that he was only compensating for the ICFTU's failure to deliver on policies to which it was formally committed. The development of the Brown-Meany plan for a dedicated AFL-CIO labour institute for Africa modelled on the recently launched AIFLD, and similarly funded from the US government's aid budget, marked the big shift in American priorities as relations with the ICFTU went into terminal decline.

The first half of the 196os saw George Meany in his pomp in international affairs, a man evidently confident in his direction of travel and able to write his own script as he embarked on a new, expanded phase of activity through the three government-funded regional auxiliaries that he envisaged. This was also a period marked by a change in the chemistry between Lovestone and Brown and between the two of them and Meany. Lovestone disapproved of Brown's move to New York to take charge of the ICFTU's UN operation and also of the amount of time his former protégé now devoted to Africa. For Lovestone, Europe continued to be the main cockpit in the Cold War: Paris, not New York, was where Brown should be based. But Brown was less inclined than previously to defer to Lovestone, and their partnership would never be quite the same again.

Irving Brown also differed from Meany in his assessment of the ICFTU's potential, viewing it as capable of reform if only the AFL-CIO top leadership would devote more time to making the organization work. Yet Meany was largely deaf to Brown's argument. He was likewise unmoved by Lovestone's reservations about the AFL-CIO move to create the "auxiliary institutes," a development always likely to diminish the importance of the international affairs department and thereby Lovestone's own role. The signs were that Jay Lovestone's importance to George Meany as an advisor on international affairs was waning, even as he was confirmed as Mike Ross's successor as director of the international affairs department. The appointment of Meany's son-in-law, Ernie Lee, effectively as a gatekeeper to the president's office, was the most obvious indicator of that.

For Walter Reuther, the prospects for a new relationship between the AFL-CIO and the ICFTU under Becu soon palled as Meany's disenchantment with the ICFTU general secretary grew. Back in the late 1950 s and early 1960s, there had been much speculation within the AFL-CIO about a possible Reuther challenge to Meany for the presidency, but the UAW president's support among other union leaders had fallen away thereafter. He was unable to check Meany as he turned firmly against the ICFTU and began to restrict its funding. And it was against this background that Walter Reuther now forged ahead with the UAW's own ambitious international program. 



\section{Who Speaks for American Labour?}

The CIO approach to international affairs had differed from the AFL's from the early 1950s, and much of the continuing tension between the two organizations prior to the merger in 1955 was over international issues. It remained the situation even after the formation of the AFL-CIO: Walter Reuther's autoworkers disagreed with the way the federation prioritized the battle against communism over all other aims. The friction eased temporarily during the American-led campaign to replace Jaap Oldenbroek as ICFTU general secretary in 1959-60 over his handling of policy in Africa. However, as AFL-CIO relations with the ICFTU went into free fall from 1962 over the constraints Omer Becu attempted to place on Irving Brown's freedom to travel internationally, and with George Meany applying a tourniquet to solidarity fund spending - and especially vetoing further support for programs planned by the International Metalworkers' Federation and other trade secretariats-the UAW intensified its own international operations. These transcended the negative anti-communism of AFL-CIO international work that stood in the way of cooperation with less zealous sister organizations abroad. In contrast, they aimed to promote militant activity among free labour organizations in pursuit of economic improvements in the lives of trade unionists. Through its program, the UAW demonstrated an alternative approach to trade union international activity that found much favour overseas, and especially in Europe. As such, it was to lead to heightened friction between the autoworkers and the federation, and it would ultimately be an important factor in the former's subsequent disaffiliation from the AFL-CIO-with major consequences for the American role in international trade union affairs. 


\section{Seeking Influence in Foreign Affairs}

The internal politics of the AFL-CIO were willy-nilly a factor behind the deteriorating fortunes of Omer Becu and the ICFTU in the 196os. Clashes at leadership level between George Meany and Walter Reuther were recurrent, at times reflecting genuinely divergent policy positions, though just as often a product of personal rivalry stemming from Reuther's overweening ambition to replace Meany as AFL-CIO president and the latter's determination that he mustn't. National centres elsewhere could hardly ignore this contest within the ICFTU's largest affiliate and, by being drawn to identify with one or the other side, unavoidably helped project it onto the international stage.

Domestically, the struggle within the AFL-CIO's leadership was often represented as one between Reuther the "liberal" and Meany the "conservative business unionist," though Meany himself rejected the distinction and claimed that on basic trade union issues there was little to separate them. What Reuther characterized as Meany's conservative foot dragging was viewed more positively by other labour leaders-including former colleagues of Reuther in the CIO_-as a reflection of the AFL-CIO president's tactical skill in "bringing people along" and maintaining cohesion. In typical sardonic fashion, Mike Ross characterized the essential difference between Meany and Reuther as no more than that between a pessimist and an optimist. ${ }^{1}$

A better case can be made for the claim that their foreign policy differences were real and genuinely corrosive of personal relations. Meany was typecast as a belligerent, uncompromising cold warrior, whereas Reuther's anti-communism came with a measure of subtlety and willingness to explore ways of easing cold-war tensions. Though real, such differences had more to do with means than ends; both were committed anti-communists. The existence of such disagreement over how to pursue that common end brings into sharp relief the way those in Meany's camp regarded any "compromise" with communism as abhorrent and how Reuther recoiled from a rigid approach that regarded any tactical flexibility as the first stage in selling out to the forces of darkness.

They manoeuvred for tactical advantage in international affairs as much as in domestic policy issues. Reuther's visit to India in 1956 and his meetings with Soviet Deputy Premier Mikoyan and Party Secretary Khrushchev in 1959 had been in no small part exercises in image projection as an international statesman. In related vein, from the very start of the Kennedy administration, Reuther competed with Meany for the ear of the new president. It coincided with a period of intense speculation about the likelihood of a Reuther challenge to Meany's leadership at the AFL-CIO's 1961 convention and compounded their rivalry. 
Ahead of Kennedy's inauguration the two men vied for influence over presidential appointments, not least in the field of foreign affairs. ${ }^{2}$ Days after the presidential election in November 1960 a private strategy meeting was attended by Walter Reuther, his executive assistant and Kennedy insider Jack Conway, UAW general counsel Joe Rauh, and AFL-CIO general counsel Arthur Goldberg. Goldberg was Kennedy's main link to the labour movement and a leading candidate for high office in the administration. They agreed that Kennedy should be urged to offer George Meany the ambassadorship to Ireland or the Vatican - an honour they thought he, as a Catholic, would have difficulty refusing-so allowing Reuther to take over as AFL-CIO president. The meeting deputed Goldberg to relay this proposal to Kennedy. He duly went to see the president and at the meeting effectively staked his claim for the cabinet post of secretary of labour, but as Rauh ruefully recorded, it was doubtful that Kennedy ever heard the other components of the proposed deal. ${ }^{3}$

Kennedy's first appointments in the international field-Adlai Stevenson as UN ambassador, Chester Bowles as undersecretary of state, and G. Mennen Williams as assistant secretary of state-all chosen before the appointment of Dean Rusk as secretary of state-set alarm bells ringing for Jay Lovestone. The trio were to a man liberal Democrats with whom Reuther had close relations. That made their appointments all the more worrying for Lovestone, who feared that under the inexperienced figure of Dean Rusk, Bowles would be the real policy maker in the department. Indeed, Lovestone even speculated that the appointment of Bowles had been Stevenson's precondition for his own reluctant agreement to serve at the UN. As Lovestone saw it, the "double plays" would be from Stevenson to Bowles to Rusk. ${ }^{4}$

Chester Bowles was one of Kennedy's first appointments, but he was also one of the first members of the administration to lose his job, over his public criticism of the Bay of Pigs fiasco. At the first opportunity, Meany joined a campaign to have him replaced. Bowles had upset senior diplomatic staff with his support for new blood in foreign postings. In particular he had made an enemy of Loy Henderson, until recently the deputy undersecretary of state for administration and thus a key figure in advancing or retarding diplomatic careers, with whom Jay Lovestone had long benefited from ease of access and the ability to pitch for his favourites. In July 1961, Meany and Lovestone met with the secretary of labour, Arthur Goldberg, and lodged their complaint about Bowles. Lovestone described him as "an intrepid, petty factionalist working closely with Victor Reuther and in my opinion to the detriment of the best interests of the State and Labour Departments as well as the ICA [now being restyled as AID]." Seeing the danger to their ally, the Reuthers rallied to Bowles's defence and Victor Reuther lobbied attorney general Robert Kennedy and Arthur Goldberg to make the case for him. But his critics, including Meany, would claim his scalp, and shortly afterward Bowles was packed off as ambassador-at-large. ${ }^{5}$ 
In their meeting with Arthur Goldberg, Meany and Lovestone also took the opportunity to protest about other supposed "Reutherites" in government service. They included the labour attaché, David Burgess, who had accompanied Walter Reuther on his 1956 tour of India, but also, and more importantly, George Weaver, Goldberg's own hand-picked assistant secretary of labour for international affairs, who came from Jim Carey's International Union of Electrical Workers and had recently been suggested by Reuther as a candidate for ICFTU assistant general secretary. Weaver was another person to be denounced as "a scheming factionalist," his most recent offence being to cast aspersions on Herb Weiner, a Lovestone favourite within the labour attaché corps, by describing him as a "controversial" figure. Meany joined in the criticism of Weaver's attempt to undermine the labour attaché, and Lovestone's report to Irving Brown glowed at Meany's "fine job at the session with Arthur." 6

The highest-profile victim of the fallout from the Bay of Pigs episode was CIA director Allen Dulles. In this case it was the Reuthers who anticipated gaining a competitive advantage from his removal. Victor Reuther suggested to the British labour counsellor that a consequence of the housecleaning that would follow Dulles's replacement would probably be a move to curtail Irving Brown's activities in Africa. It was wishful thinking, and in reporting his conversation with Reuther, the labour counsellor observed that he, personally, had "seen no signs that Irving Brown will not continue his peregrinations in Africa, doling out largesse as and when he thinks fit."'

More directly than in the attacks on Reuther's allies in the Departments of State and Labour, Meany also tried to sideline the UAW president himself and so undermine his influence with the administration. A month after Meany's intervention against Bowles and Weaver, labour secretary Goldberg asked him to nominate trade union candidates for his department's labour advisory committee on international affairs. Meany failed to include Reuther's name among those proposed, and Goldberg sent the list back to Meany as unacceptable, noting that the UAW president was the single most active union leader in the field. ${ }^{8}$ In a still more decisive intervention, Meany opposed Reuther's nomination to the US delegation to the United Nations. This was a position that Meany himself had enjoyed since 1957, and Reuther hankered for similar recognition as a sign of parity with the AFL-CIO president. However, knowing that Meany would not give his approval, UN Ambassador Stevenson held up renewal of Meany's membership in the delegation, while broaching instead the idea that both Meany and Reuther should be appointed to positions as joint special advisors to the US delegation. Lovestone immediately saw it as a ploy to keep in play the idea that the AFL-CIO had a dual leadership and advised Meany to reject it:

Among some of Mr. Stevenson's cronies there is talk about ... being able to

... "harness Mr. Meany and Mr. Reuther to cooperate with each other in 
serving the nation under his guidance." Of course this is poppycock.... If [the Administration] was ready to risk being called a pro-Reuther Administration, people should know it.

Lovestone also went on to describe Arthur Goldberg's involvement in this initiative as "insolent" and likely to damage their relations with the secretary. Meany shared his sentiments and was happy to reject Stevenson's ploy. ${ }^{9}$

By 1962, a series of such reverses at Meany's hands within the AFL-CIO contributed to Reuther's decision to focus on what he could achieve independently through the UAW and the federation's Industrial Union Department, which he largely controlled. And with AFL-CIO relations with the ICFTU following the 1962 Berlin congress in free fall over the issue of Irving Brown's defiance of Omer Becu, it was now Reuther's intention to redouble the UAW's effort in the international sphereindependently of the AFL-CIO.

\section{The UAW's Free World Labour Defence Fund in Operation}

At its 1962 convention, the UAW voted to establish a \$3 million Free World Labour Defence Fund based on the interest earned by the union's $\$ 45$ million strike fund, planning to use it in a significantly enhanced program of international activities. It meant that the union would now be contributing 50 percent of the total funds spent by the American labour movement abroad. It reflected the importance the Reuther leadership attached to international solidarity, and especially the concept of "international fair labour standards" that it was promoting as a means of cross-border mobilization of labour in circumstances where multinational companies were beginning to make their presence felt around the globe with strategies of divide and rule. ${ }^{10}$

With no major domestic collective bargaining with Detroit's "big three" auto makers scheduled for the next three years, the decks were cleared for Walter Reuther to concentrate attention on international matters. ${ }^{11}$ In gearing up for this new phase of international work, Victor Reuther, who had previously combined the roles of international affairs director with oversight of the union's legislative-lobbying function in Washington, now concentrated exclusively on the former, supported by an enlarged staff.

The main beneficiary of the UAW's largesse would naturally be the International Metalworkers' Federation (IMF), especially after George Meany blocked further support from the ICFTU's International Solidarity Fund for IMF projects. The latter received $\$ 400,000$ of the first $\$ 500$, o0o disbursed by the UAW over the initial eighteen months of the fund's existence. By its example, the UAW hoped to encourage other leading affiliates of the IMF-particularly the German metalworkers led by the 
leftist Otto Brenner and the Swedish metalworkers among whom Arne Geijer was still a towering influence - to contribute generously toward a war chest for which a target of $\$ 1$ million was set. ${ }^{12}$

Much of this money was used by the IMF on programs for metalworkers in Latin America, Italy, and Japan. But there was also considerable independent expenditure abroad by the UAW under its own name, reflecting a keen awareness of its reputation as a "clean" union that did not operate as an agent of government and was not compromised by association with discredited elements in other countries. At the same time, Victor Reuther cautioned his colleagues against giving an impression that through their well-endowed treasury they expected to "run" the world labour movement from Detroit; the participation of other unions was necessary, and in the absence of a matching input from metalworking unions elsewhere, the UAW would scale back its financial support rather than assume disproportionate responsibility for international solidarity and appear to be buying allies. ${ }^{13}$

Among the first batch of grants made was a $\$ 10,000$ donation to the 100,000 striking metal and mining workers in Spain whose underground unions were waging an illegal strike against the Franco regime in 1962. ${ }^{14}$ The clandestine Spanish unions now coming to prominence were to be regular beneficiaries of assistance: a donation of $\$ 6,000$ covered the annual cost of maintaining a headquarters in Spain for the emerging triple alliance of social democratic, anarchist, and Christian trade unions, while $\$ 1,000$ was channelled to the Young Catholic Workers movement in Bilbao and Barcelona for leadership training. ${ }^{15}$

In 1963 , the autoworkers donated $\$ 25,000$ to striking French miners who were acting in defiance of a government back-to-work order. This was a union action of particular significance, since it was the first successful work stoppage of major proportions in the five years since Charles de Gaulle's return to power. The strike was seen as a blow struck for democracy amid current fears that France was drifting dangerously toward a form of strong-man rule. The UAW contributed $\$ 20$, ooo per annum of the $\$ 100,000$ now paid regularly by the AFL-CIO to the Histadrut-led Afro-Asian Institute. Combining with Germany's Friedrich-Ebert-Stiftung, the union donated $\$ 10,000$ to kick-start the work of a new ICFTU regional office in Beirut. The latter would henceforth serve as an information and documentation centre and distribution point for trade union literature in Arabic. UAW funding had been advanced after Jay Lovestone opposed the Beirut initiative as a waste of time. The Greek national trade union centre GSEE benefited from a \$6,00o UAW grant toward its press and education service, and the union also underwrote a \$25,000 loan to enable the Greek centre to hold its congress and officer elections in 1964 in circumstances where there was a possibility that the state would invoke its right under Greek law to nominate its choice of officers. ${ }^{16}$ 
Alongside such transactions numerous smaller amounts were awarded. $\$ 6,000$ was donated to the labour movement in Northern Rhodesia, divided equally between the national trade union centre and Kenneth Kaunda's United National Independence Party, toward the cost of a jeep for the former and the purchase of a printing press for the latter. As well, $\$ 2,500$ was voted for Defence and Aid, the Canon Collins fund for legal defence of South African nationalist opponents of apartheid, together with a $\$ 3,000$ grant to the Pan-African Congress Refugee Centre in Bechuanaland. For the benefit of IMF-affiliated unions, $\$ 5,000$ was allocated to finance an "International Labour Bookshelf" comprising between twenty-five and fifty essential titles. Funds were made available for translations of Walter Reuther's "Collected Works" - speeches and official statements-into French, Spanish, and Japanese. More ambitious was the proposal-subsequently dropped - to publish foreign language translations in Malay, Chinese, Bengali, Urdu, and Tamil. ${ }^{17}$

There was much more to the UAW program than writing out cheques for worthy causes; it also sought to involve the union's own membership. Reuther's idea was to harness the enthusiasm of local activists for whom "international affairs" was traditionally an esoteric subject to be handled by professionals. The union arranged for two hundred local union officers to travel to Berlin to experience at first hand the ICFTU congress in July 1962. Inventory was taken of foreign language skills and experience overseas of the UAW's local leadership, with plans then developed to train fifty such people to undertake short missions abroad on behalf of the union. Reflecting prevailing optimism about the work of the United Nations and the way it might help realize the UAW's "dynamic peace policy," the union instituted an annual four-day conference at the UN in New York, bringing together some three hundred local union activists in a bid to raise awareness of international questions and consider what American wage earners could do to help people in the developing world find democratic solutions to their problems. To stimulate rank-and-file interest in international affairs, the UAW arranged for bulk purchase and circulation of ICFTU literature. With a similar objective in view, it also entered into a joint publishing arrangement with the Foreign Policy Association to produce at a cost of $\$ 15,000$ pamphlet literature specifically for circulation at local union level. ${ }^{18}$

Walter Reuther had been a leading proponent of the Peace Corps, yet the UAW was disappointed that, as introduced by the Kennedy administration, the corps was largely closed to participation by blue-collar workers. The UAW leadership lobbied for the scheme to be extended to manual workers with an industrial background, and, by 1966-67, Peace Corps volunteers from blue-collar occupations sponsored by the UAW were operating in Guinea and Gambia. By this time, the UAW's community outreach unit had been incorporated as the Social, Technical and Educational Program (STEP), enabling it to access foundation grants and to contract with the 
government for AID projects. In conjunction with World Medical Relief, STEP collected and reconditioned medical equipment such as X-ray machines for use in mobile clinics supplied by the union to developing countries. ${ }^{19}$

At its height, the UAW's international program successfully tapped into a wellspring of idealism and creative energy. It had a fair claim to be the most ambitious effort in the field by any single American trade union, aiming to promote a new sense of direction and contrasting with the AFL-CIO's focus on bolstering whatever group of labour leaders appeared the strongest opponents of communism in a given location. Its significance was recognized by veteran American socialist Norman Thomas, who approached Walter Reuther ahead of the 1964 Democratic Party convention urging him to apply pressure for a more radical line in foreign policy, writing: "I understand the Lovestone-Meany policy would not be too different from Goldwater's. Our chance of getting anything like the policy we ought to have depends on the sort of labour you represent." ${ }^{20}$

\section{Reuther and the Italian Centre-Left}

The UAW's key strategic focus was to help the non-communist labour movement become a more effective representative of workers vis-à-vis employers, especially in situations where communist unions claimed a monopoly of militancy, even if the militancy operated only in the sphere of rhetoric. This UAW focus had a particular relevance for the IMF program of confronting multinational companies. Walter Reuther was the driving force behind the creation of IMF "world coordinating councils," which comprised national unions that represented a given multinational's workforce in different locations. These councils were to serve as the forum for union-employer engagement, with the hope that one day they might become agents for international collective bargaining. ${ }^{21}$

And in countries where communists did have a significant presence, the strategy required particular assistance to non-communist elements to prevent them from being dominated by political opponents setting the trade union agenda. It was this factor that drew the UAW leadership to focus heavily on Italy and Japan, where non-communist unions punched below their weight. ${ }^{22}$

During the Kennedy presidency, Walter Reuther was able to make common cause with like-minded members of the administration in a sustained campaign to realign Italian trade union and political forces on the centre-left-what Kennedy special assistant Arthur Schlesinger Jr. dubbed "Operation Nenni." ${ }^{23}$ This phase of activity initially saw the UAW contribute to a \$100,00o IMF campaign in 1962 in support of the Italian metalworkers attached to UIL (UILM) and CISL (FIM) in a key round of collective bargaining. It led to landmark reforms in the industrial relations system 
facilitating an articulated form of devolved plant-level bargaining that dovetailed with the IMF strategy for dealing with multinational firms.

The extended range of bargaining opened up the prospects in Italy for union action focusing on concrete economic goals rather than simply being an element in communist-directed national mobilization that often amounted to little more than political street theatre. ${ }^{24}$ The collective bargaining gains owed much to the fresh political climate that derived from a "turn to the left" in February 1962 with the formation of a Christian Democrat-led coalition supported for the first time in parliament by the Nenni socialists, who were now in the process of distancing themselves further from the communists. At the WFTU's latest congress in Moscow, the CGIL's socialists had taken a stand against their communist leadership's tendency to agree with WFTU policy proposals purely on the grounds that these had the endorsement of the Soviet bloc. ${ }^{25}$ This was the political context that the UAW and the IMF sought to exploit with attempts to extend the partial "turn to the left" into a full centre-left government.

The political forces working for and against such a further development were finely balanced. Nenni's socialists were divided over how far they dared go in moderating their traditional opposition to NATO and so exposing themselves to charges of "splitting" and of putting class solidarity at risk. In personal talks with Nenni in Italy in May 1961, Reuther encouraged the PSI leader to be bolder in distancing himself from the communists, while at the same time he urged the White House to change the US's long-standing policy in Italy and lend support to the centre-left. ${ }^{26} \mathrm{Nenni}$ was invited to the United States, ostensibly for a lecture tour but in reality for talks with the administration. Reuther was happy to be identified with this initiative, whereas George Meany wanted nothing to do with Nenni. ${ }^{27}$

Visiting Italy again in June 1962, the Reuther brothers had talks on the next phase of the IMF program for Italy at Nenni's home. Present at the meeting were the PSI leader, his party official responsible for trade union affairs, Giacomo Brodolini, and Piero Boni, the socialist joint-secretary of the CGIL's federation of metalworkers, Federazione impiegati operai metallurgici (FIOM). The specific focus of the meeting was the IMF's plan to provide shop steward training in courses that bridged union boundaries and increased the scope for centre-left politics. ${ }^{28}$ Back in the United States in August, the Reuthers reported to Arthur Schlesinger on the need for a change of labour attaché in Rome and the appointment of someone more sympathetic to the strategy of the UAW-IMF. Schlesinger arranged to accompany them and labour secretary Arthur Goldberg to the home of attorney general Robert Kennedy for a breakfast meeting, arising from which Walter and Victor Reuther were invited to a meeting of the National Security Council (NSC) to make the case for the State Department and the CIA to end their resistance to a centre-left government in Italy.29 Their chances of winning converts in the National Security Council were always slim 
given that George Meany strongly opposed their politicking in Italy. Significantly, labour secretary Goldberg stayed away from the NSC session, choosing not to be identified with the Reuthers in a situation where Meany was not present. In the event, their hopes were killed off by a leak to Lovestone's newspaper columnist friend, Victor Riesel, whose syndicated column reported misleadingly that the Reuthers had asked the NSC for a large sum of money to aid a merger between the communist and non-communist unions in Italy. Reuther's personal relations with Meany took a sharp turn for the worse over this episode, Meany accusing him of being deceitful and making "many mistakes" in Italy. ${ }^{30}$

As the general election in Italy approached in 1963, Walter Reuther returned for more talks with the party leaders of a would-be centre-left government and arranged with Nenni for the UAW and Jake Potofsky's clothing workers jointly to donate $\$ 32,000$ to the PSI's election fund..$^{31}$ Reuther believed that a successful outcome for the centre-left would have a significance extending beyond Italy by providing a model for other countries in Europe and Latin America. He wrote to Willy Brandt expressing the view that it would influence the German political climate following the retirement of "Der Alte" (Konrad Adenauer). He was concerned that US foreign policy was still ambiguous on the question of the centre-left, but through Schlesinger's influence, President Kennedy was nudged into appointing Averell Harriman as undersecretary of state, with a brief to take a firm grip on policy toward Italy. Harriman's appointment came too late to affect the outcome of the general election. A subsequent stalemate over the formation of a full centre-left government lasted many weeks and was only broken when President Kennedy himself visited Rome in the summer of 1963 and made clear through a personal meeting with Nenni that he favoured a government that would properly address the economic and social need of Italians. ${ }^{32}$

Nenni still needed to overcome opposition within his own party ranks and requested $\$ 90,000$ from the UAW to organize support ahead of the PSI congress in October 1963. No record of any financial transaction exists, but Victor Reuther wrote to the PSI's international secretary, Vittorelli, that he had asked IMF general secretary Adolphe Graedel to travel to Rome to meet him, Graedel being the key intermediary in unofficial financial transactions that passed through the IMF's Geneva office. ${ }^{33}$ At the congress, Nenni duly won support for entering the government. By the end of 1963 , he was deputy prime minister in a government led by Aldo Moro, with five other government posts held by PSI deputies. Meanwhile, in support of this development and to strengthen its factional base in the CGIL, the PSI planned for an ambitious training program for over six hundred socialist trade union activists in a series of two-week-long courses. The $\$ 126,000$ cost was to be covered jointly by the UAW, IG Metall, and the Austrian and Swedish metalworkers as prominent members of the IMF. ${ }^{34}$ 
The extent to which George Meany disapproved of these attempts at reconfiguring the Italian labour movement was evident from his reaction to a proposed groundbreaking joint visit to the United States in the spring of 1964 by Bruno Storti and Italo Viglianesi, the presidents of CISL and UIL, respectively. Both centres were affiliated with the ICFTU, but the AFL-CIO snubbed UIL by inviting only Storti to its executive council meeting. The two Italians planned to travel on State Department grants, but, fearful of offending Meany, the department now held back finance for Viglianesi. Angered at the sign that so little had changed in the AFL-CIO's approach to Italy since the 1950s, Victor Reuther wrote of his "shock" that the federation "still plays only one side of the street." Such behaviour had gone on too long, and he challenged his brother to react: "[we] owe it to our own integrity ... to inquire on what basis these kind of decisions are made." ${ }^{35}$

Hopes of fomenting a breakaway from the CGIL by its socialist membership came to the fore again in 1965 following a move by the leader of the socialist faction, Giovanni Mosca, to boycott the WFTU's Warsaw congress as part of a demand for factional autonomy within the CGIL and the right to associate internationally with whomever it chose. ${ }^{36}$ IMF general secretary Graedel asked Victor Reuther whether it would be possible to raise $\$ 500,000$ for such an initiative. The UAW international affairs director took the matter up with John Riley, an aide to US vice president Hubert Humphrey, who, Victor related to his brother, was "deeply involved" in the Italian situation and "in close contact with the Agency people who would have an interest." Riley suggested that Walter Reuther speak directly with President Johnson before any effort was made to contact CIA representatives, explaining: "If the President gives the green light then we can set up the other meetings to discuss specifics and details." Whether Reuther followed up this proposal is unclear, but further advice from the IMF headquarters was that a breakaway from the CGIL was not imminent and that there was no urgent need for financial assistance. ${ }^{37}$ Thereafter, talk among Reuther supporters of engineering a socialist split from the CGIL gave way to ideas for encouraging the reformist movement within the CGIL and hopes for gradually detaching the national centre itself from the WFTU - a project that became a central preoccupation of the international labour movement in the 1970s.

The widening divide between communists and socialists in the CGIL even aroused the interest of the AFL-CIO in exploring the overture from Mosca. Claiming to speak on Mosca's behalf, a British intelligence agent, Edward Scicluna, who was employed by FIAT, approached Jay Lovestone. Lovestone and Meany met Scicluna in New York and through him asked Mosca to supply a report on the WFTU congress. Lovestone also sounded out the possibility of Mosca paying a discreet visit to New York. But then Meany suddenly closed down this channel of communication on learning that the Italian was a signatory to the recent joint agreement between 
the CGIL and the French communist-led CGT to defy long-standing communist policy and seek consultative status with the European Common Market in Brussels. It appeared to vitiate Mosca's claim to be a rebel within the CGIL. In fact, the joint CGT-CGIL initiative amounted to a major revolt within the WFTU by its Italian and French affiliates, a dramatic signal of the growing estrangement of the CGIL from the Prague-based international body and an early sign of what would come to be known as Eurocommunism. A more flexible AFL-CIO leadership might have welcomed the development. ${ }^{38}$

Walter Reuther's determination to project himself as an important figure on the international political stage and his hope to involve American labour in discussions with leaders of the European centre-left more generally were evident from his catalytic role in what became known as the "Harpsund process," a series of meetings of leading labour figures held in Sweden. Between 1963 and 1965, Reuther was the driving force behind these gatherings at the Harpsund country residence of Swedish prime minister Tage Erlander that brought together Erlander, mayor of West Berlin Willy Brandt, Britain's Labour prime minister Harold Wilson, US vice president Hubert Humphrey, Danish prime minister Jens Krag, Norway's future socialist prime minister Trygve Bratelli, German social democrat leaders Erich Ollenhauer and Herbert Wehner, and leading trade unionists Arne Geijer, George Woodcock, Ludwig Rosenberg, and Konrad Nordahl of the Norwegian LO, for what amounted to brainstorming sessions. Discussions ranged over economic issues relating to growth, full employment and integration, disarmament, problems of developing countries, and technological change. A study group of economists was formed to develop plans for greater international monetary stability that UAW economist Nat Weinberg fondly hoped might lead to a new economic orthodoxy. Reuther and Humphrey considered it important to report back to President Kennedy on the results of the first conference.

However, the meetings promised more than they delivered. Reuther saw them as a clearing house for new thinking and a vehicle for liaison between politicians and intellectuals of the world's most important centre-left organizations. He was motivated by a desire to overcome the political isolation of American liberals in circumstances where other participants had in common their affiliation to the Socialist International. This proved to be a stumbling block; ahead of the US presidential election in 1964, Lyndon Johnson vetoed Hubert Humphrey's participation in the second scheduled Harpsund meeting with people so closely identified with the international. When the working party report on monetary stability was complete, Walter Reuther was also advised to omit his name from the document when it was suggested that it be submitted to the Socialist International for discussion. Beyond such issues, by 1965, with the British and German participants now in government and absorbed by the pressures of day-to-day decision making, the time for relaxed blue-skies thinking 
had passed and the Harpsund process came to an end. George Meany had been in no way involved, and there is no record of how he regarded these events. One can only speculate over his reaction to a project that absorbed so much of Walter Reuther's energy over a two-year period. ${ }^{39}$

\section{The Japanese Wage Research Center}

For American labour, even more challenging than the trade union situation in Italy was the problem of how to engage with organized labour in Japan, where the unions stood largely aloof from the international free trade union movement, with values and practices quite at odds with those of European and American labour. Faced with this, the UAW's approach was strategic in its attempt to address a number of interrelated factors: the fragmented nature of trade union organization overlaid by competing political loyalties; the strong anti-militarist and non-aligned sentiment of Japanese workers, which made them suspicious of Americans; the tame. company-dominated nature of unionism in much of private sector industry; and the specific competitive threat posed to the American automobile industry by Japanese car manufacturers benefiting from cheap labour costs that derived in part from an inscrutable wage system.

As in Italy, the UAW chose to work through the International Metalworkers' Federation, which first established a permanent office in Japan in 1957, very much at the urging of the Reuthers. Victor Reuther wrote: "I do think that the IMF might perhaps succeed where the ICFTU has failed, provided we do not fall into the same pitfall of insisting that our relationship with Japanese trade unionists be on political rather than economic and trade union issues." He criticized the AFL-CIO for being less concerned with the economic struggles of Japanese workers than with which of their union leaders were paying friendly visits to Moscow and Peking. The need was to avoid the mistake made by the AFL in France and Italy in refusing to work with any union infected by communism. ${ }^{40}$ The UAW was thus going against the grain of policy for Japan set by the AFL in the early 1950 os that had been at the heart of the fraught relations between the federation and the ICFTU.

Central to the divisions within Japanese labour was the antagonistic relationship between the Marxist-leaning centre, Sōhyō, and its much smaller rival, Zenrō Kaigi (the All-Japan Labour Union Conference). Sōhyō was a creature of the American occupation, established with the intention of excluding communist influence. However, it quickly fell under the leadership of Marxists of a fundamentalist stripe and subsequently refused to affiliate collectively to the ICFTU (though ten individual unions did affiliate) for fear of being identified with the Atlantic Alliance and thereby drawn into the war in Korea. ${ }^{41}$ Pursuing the politics of non-alignment and practising 
a brand of militancy that frequently bordered on the insurrectionary, Sōhyo routinely mixed together workaday industrial-economic grievances with a rhetorical anti-Americanism and anti-imperialism. As the world's largest and most significant non-aligned national trade union centre, it was inevitably viewed by the AFL as a threat to free trade unionism, whereas the ICFTU's refusal to deem it a "lost cause" and its continuing attempts to dialogue with the Sōhyō leadership had been high on the AFL's charge sheet of complaints against Oldenbroek, Jay Krane, and members of the ICFTU secretariat in Brussels. ${ }^{42}$

It was Sōhyō's ultra-militant tactics and its shunning of the ICFTU that led in 1954 to a breakaway by more moderate unions to form the rival centre, Zenrō. From the outset the latter enjoyed the moral and material backing of the AFL. FTUC representative Dick Deverall, its channel to the AFL, advised Lovestone: "I frankly think that the only thing that can be done is to give all aid possible to Zenrō and work increasingly to expose Sōhyō, to split what unions can be split and to try to make Zenrō the major centre." 43

The ICFTU also sympathized with Zenrō, but with four times the membership, Sōhyō was the bigger prize, and so the international shied away from the idea of collective affiliation of Zenrō for fear that it would permanently jeopardize the chance of drawing the larger body into the free trade union fold. Yet, through the late 1950s, Zenrō was backed wholeheartedly by the US embassy in Tokyo. The creation of the Japan Productivity Center in 1955 as a central part of the US aid program helped embed Zenrō's industrial moderation through a propaganda offensive that promoted a spirit of industrial partnership in pursuit of high levels of productivity. Sōhyō, in contrast, boycotted the productivity centre, leaving Zenrō as the prime beneficiary of an extensive program of study visits to the United States, which clearly established it as the "American centre." 44

For Sōhyō, with its penchant for insurrectionary tactics, the moment of truth arrived in 1960. A massive anti-militarist campaign involving direct action to oppose renewal of the US-Japan security treaty (formally, the Treaty of Mutual Cooperation and Security between the United States and Japan) ended in failure. Concurrently, amid scenes of extreme picket line violence, a year-long strike of coal miners at Mitsui's Miike mining complex ended in defeat and organizational collapse. ${ }^{45}$ As Sōhyō leaders began to rethink aspects of their ultra-militancy, the newly installed Kennedy administration also set out to recast US policy toward Japan, emphasizing in particular economic rather than military cooperation. Neither the quiescence of the American-backed Zenrō unions nor the often crude Marxism of Sōhyō appealed to the UAW. It was against this background of a changing climate in the world of Japanese labour and a new start to Japanese-American relations that the Reuthers set out to influence the direction of the trade union movement. ${ }^{46}$ 
The components of their approach were to redirect American attention to Sōhyō, help to deepen its dialogue with the ICFTU, and channel the centre's tradition of militancy more constructively into collective bargaining. Rather than pick sides in the contest between Sōhyō and Zenrō, the UAW hope was to promote unity between the competing organizations. As part of this, metalworking unions were to be encouraged into membership within the IMF especially, with a view to intensifying the relationship between American and Japanese autoworkers and helping the quiescent unions representing the latter to realize the benefits to be derived from a more focused militancy in collective bargaining. The Reuthers deplored the fact that Japan Productivity Center propaganda had conveyed the false idea that American unions spent most of their time collaborating with management to raise productivity, and set about changing this perception. ${ }^{47}$

The Kennedy administration's intention to reset US policy for Japan was signalled by the appointment as ambassador of Edwin O. Reischauer, a non-career diplomat who contended that the Eisenhower administration had failed in Japan because of the absence of dialogue with the political opposition and any attempt at "diplomacy in depth" with organizations like Sōhyō. ${ }^{48}$ To repair this damage, Reischauer introduced a new, extensive exchange program of trade union visits operated by the State Department under which Sōhyō would now receive equal treatment with Zenrō, while the former program under the aegis of the Japan Productivity Center that had favoured Zenrō would be phased out. Attorney general Robert Kennedy inaugurated the exchange program in a high-profile visit in February 1962. Twenty US union leaders were scheduled to make follow-up trips over the next two years, and the UAW made a pitch for most of these to be allocated to American affiliates of the IMF, since it had the most active program in Japan. Jim Carey, of the International Union of Electrical Workers, led the way as a guest at the May 1962 convention of the union's Japanese counterpart, Denki Rōren, and delivered a personal message from President Kennedy.49

Walter Reuther also planned a two-week visit in November 1962, for which meticulous preparations were made. Competing company unions in the Japanese car industry were pressed to come together and issue a joint invitation to him. The joint welcoming committee that was eventually formed lent the event the tone of a state visit, with Reuther travelling not simply as UAW president but also wearing his several other hats as vice president of the ICFTU, IMF, and AFL-CIO. Repeating the pattern of his visit to India six years earlier, reports of his movements in Japan dominated newspaper headlines as he worked hard to bring the country's mutually suspicious union leaders together. ${ }^{50}$

As part of the "Reischauer-Kennedy line," Washington and Tokyo had created a joint American-Japanese committee on trade and economic affairs that was intended 
to recast the relationship between the two countries as essentially economic rather than military, but the Japanese had declined a request to include in its remit the contentious issue of relative labour costs. This was to become a particular focus of Reuther's visit. He proposed the establishment of a Japanese wage research centre, supported by the international labour movement, whose aim would be to shine a light on the complexities of the Japanese wage structure, with its proliferation of company-based bonuses and consequent absence of any concept of a "going rate" crucial for comparing wages in collective bargaining. The expectation was that it would help give effect to the IMF policy of international fair labour standards in Japan, closing the wages gap with Europe in the first instance. The argument that Japanese real wages needed to rise resonated with Sōhyō propaganda, which maintained that low levels of remuneration were a product of Zenrō's docility.

A related objective of Reuther's visit was for his presence to act as a catalyst for metalworking unions to come together in a joint council through which they would affiliate to the IMF. More generally, he believed that the functional unity required for cooperation in launching the proposed wage research centre would help bridge the organizational divisions separating the co-sponsors of his visit, who included Sōhyō and Zenrō as well as two lesser centres. Before he left he succeeded in committing the metal unions to form a joint council and in having the national centres sign a joint statement of support for the concept of the wage centre. The New York Times reported that his visit was potentially one of the most important by an American in a decade..$^{51}$

A projected annual budget of $\$ 75,000$ was set for the wage research centre, the UAW idea being that the American, European, and Japanese trade unions should each contribute a third of this total and enable it to be staffed with suitably qualified professionals. The American contribution was to be shared equally by the UAW and the Reuther-controlled Industrial Union Department of the AFL-CIO. ${ }^{52}$

None of this activity had involved George Meany, and yet as the British labour counsellor shrewdly observed, the success or failure of the wage research centre was likely to depend more than anything on relations between Reuther and Meany. ${ }^{53}$ This point was well understood by Zenrō leaders, who had little enthusiasm for the project despite their formal support for it. From the outset they were keen to make common cause with Meany in obstructing progress.

In January 1963, Zenrō vice president Takeo Katayama led a delegation to the United States intent on persuading the AFL-CIO leadership that they had only signed up for the centre as a "diplomatic courtesy." Katayama expressed concern over Reuther's concept of the wage centre as a mechanism for promoting trade union unity, since Zenrō had no interest in a rapprochement with Sōhyō until such time as it was ready to jointly agree on a statement of opposition to communism. Since there was no chance of that happening, Zenrō had now submitted a new application 
to affiliate to the ICFTU. Katayama wanted to know from Meany whether Walter Reuther had been speaking for himself in Japan or for the AFL-CIO. Meany's answer was in the form of a joint statement reaffirming the AFL-CIO's strong rapport with Zenrō. ${ }^{54}$

Zenrō general secretary Haruo Wada followed up with a letter to Meany pointing out that the "committee to welcome Reuther," which had been now been converted into a preliminary consultative committee on the wage centre, was, in fact, only an unofficial preliminary committee. His hope was to slow down work on the centre, and he urged the AFL-CIO to become directly involved in the exercise. Meany agreed to go along with this, and shortly afterward arranged to contribute a token $\$ 500$ toward the centre's budget. It didn't amount to a sign of approval, but it gave Meany the right to express a view on the venture. Thereafter he played a helpful supporting role, whenever necessary serving up lines that enabled Wada to procrastinate..$^{55}$ In consequence, two more years were to elapse before the centre came into being, during which time, with strong backing from Meany, Zenrō pressed its case for affiliation to the ICFTU.

Zenrō's membership was expanding with the affiliation of a number of breakaway or "second unions" unions from Sōhyō. It was also in the process of merging with two smaller centres to form Dōmei Kaigi (the Japanese Confederation of Labour). Thus enlarged, it boasted that it was a more even match for Sōhyō, and its new application to affiliate collectively to the ICFTU was discussed at the executive board in March 1963. Writing in the Free Trade Union News, Wada repeated his argument against outside efforts to promote Japanese trade union reconciliation: "Any attempt at organizational unity between Sōhyō and Dōmei-Kaigi would merely confuse the true free trade unionists . . . without the advancement of the Dōmei-Kaigi there can be no progress or development of free trade unionism in Japan." ${ }^{6}$

Foot dragging on the part of the Zenrō leadership and bureaucratic obstructionism in conjunction with the AFL-CIO held back progress in establishing the wage research centre throughout 1963-64. Wada persisted in demanding to know in what capacity Reuther had been operating when in Japan-for whom did he speak? Meanwhile, in attempting to clarify the AFL-CIO's formal position, Ernie Lee only helped muddy the waters, writing to Wada: "It is important to reiterate and make clear ... that the AFL will cooperate with the project. However, the AFL-CIO does not sponsor ... nor will it undertake to participate." ${ }^{7}$

Walter Reuther challenged Meany over the purpose of Lee's letter at the AFL-CIO executive council in Miami in February 1964. Angrily, Meany confirmed that it had been sent on his specific instructions, telling Reuther: "Why should the AFL participate in this project because it was your idea and I feel no obligation to support it." Meany wanted no part of the wage centre, with its unstated purpose of bringing 
Zenrō/Dōmei-Kaigi and Sōhyō closer together, and he declined to allow AFL-CIO economist Nat Goldfinger to become involved in the centre's work as Reuther had planned. There was no question of the AFL-CIO agreeing to accept Sōhyō into membership in the ICFTU. An article by Harry Goldberg in the Free Trade Union News that same month made clear the official position. Sōhyōs line was considered to be little different from that of the communists: "to those inside Sōhyō . . it is necessary to make clear that the AFL-CIO rejects every neutralist equalization of the democratic ICFTU with the Communist WFTU.” Meany's main priority for Japan was to ensure a favourable decision on Zenrō/Domei Kaigi's application for affiliation to the ICFTU, and thereby its acceptance as the sole legitimate voice of Japanese labour. ${ }^{58}$

Indeed, George Meany's attendance at Dōmei's founding convention in November 1964 trumped all Reuther's efforts in Japan over the previous three years. The AFL-CIO regarded the Dōmei convention and the centre's subsequent admission to membership in the ICFTU as events of utmost significance; Meany's personal attendance was a clear demonstration of his priorities for Japanese labour. However, just prior to his departure for Tokyo, Lovestone obtained a leaked copy of a memo to US labour secretary Willard Wirtz from his assistant secretary for international affairs George Weaver, whom he and Meany had long regarded as persona non grata. The memorandum expressed the view that Meany's planned trip to the Dōmei convention was a mistake. His presence there would inhibit the labour exchange program, which had as an important aim the creation of a better understanding with Sōhyō. Weaver was thus against the trip and wanted the department to exert pressure against Meany's attendance in Tokyo. For Lovestone this was further damning evidence against Weaver. He wrote Meany that it shed light on "the operation of the pseudo left on an international scale." Weaver's memorandum was an insolent attempt to interfere in the US labour movement. "It is impossible for such a character to continue in so responsible an office ... . after the [presidential] election." 59

In fact, there was never any likelihood that Meany would be deterred from attending the convention. His son-in-law Ernie Lee was sent ahead to prepare the way and to arrange a meeting for Meany with the new prime minister, Sato. At the convention three senior vice presidents-David Dubinsky, James Suffridge, and George Harrison-accompanied Meany to underline the importance of the occasion.

While in Tokyo, Meany had a meeting with Sōhyō president Kaoru Ohta and general secretary Akira Iwai where there were sharp exchanges over Sōhyō's policy of "positive neutrality." Iwai angled for an invitation from the AFL-CIO to visit the United States-clearly an attempt to stay abreast of Dōmei, whose standing in the international labour movement was in the process of being significantly boosted. But Meany explained unconvincingly that there was no precedent for personal invitations 
of labour leaders from other countries; he was not about to bolster their prestige in that way. If the Sōhyō general secretary came to the United States, he would be treated politely, but the message was that he would need to come under his own aegis, not as an honoured guest. ${ }^{60}$

Iwai subsequently cabled Meany and invited him to that year's Sōhyō convention. A note by Ernie Lee to Meany's secretary accompanying the telegram said all that needed saying about the AFL-CIO attitude toward Sōhyō: "Jay believes that no reply should be made to Iwai's cable. But he feels that if President Meany desires to answer, the reply should be sharply and clearly 'No', stating that we should have nothing to do with Sōhyō in view of its cooperation with the Coms." ${ }^{11}$ The November 1964 meeting in Tokyo between Iwai and Meany proved to be the last between leaders of these two organizations for twelve years.

By the time the wage research centre was finally launched in the spring of 1965 , the conditions necessary for its effectiveness had already faded. There was certainly a continuing need to demystify Japanese wages and make them more open to comparisons. Indeed, employers were increasingly using sophisticated techniques of paternalistic management that left individual workers ever more dependent on a particular employer and at a collective disadvantage in wage bargaining. But having left behind the taste for extreme conflict of the 1950s, trade unionism was increasingly characterized by the dominance of tame, enterprise-based organizations under pressure to cooperate with employers. ${ }^{62}$ While Dōmei grew steadily in members and confidence, Sōhyō, whose militant tradition the Reuthers had hoped to harness in economic struggles, was losing members in the booming private sector, and its unions there were less able to provide the dynamic lead that the UAW had hoped for.

The wage research centre as devised by Reuther was a technocratic instrument intended to help push up relative wages; but loaded on top of this were unstated political objectives for the Japanese labour movement that proved beyond its power to deliver. As a going concern the centre lasted little more than two years. Even as it was still finding its feet in 1965, the US labour attaché, Louis Silverberg, reckoned that the Japanese trade unionists associated with it merely anticipated plodding along in stolid fashion without achieving much until the funds were finally exhausted. ${ }^{63}$ Indeed. that proved to be a fair prediction.

Al Epstein, the machinists' union economist brought in to be the Americans' technical advisor, was instructed by Lovestone not to attend the initial meeting of the steering committee on the grounds that the cost in time and money could not be justified. Sixteen months later, Dōmei's international director sounded out Lovestone over the inclination of his superiors to call for the closure of the centre; there was little doubting what his advice would be. In early 1968, Dōmei announced that 
it wanted to end its association with the project, and three months later the wage research centre was formally wound up.

It was revealing that, in his autobiography, Victor Reuther who had invested so much time in bringing the wage centre into being, devoted exactly one sentence to the exercise. Amid a general treatment of IMF activity he wrote, without further elaboration: "A basis was laid then for the founding in Japan of a Wage Research Centre." ${ }^{64}$

\section{The Dilemma over AIFLD}

Walter Reuther's interest in Latin America developed through the UAW's membership in the International Metalworkers' Federation. The growth of automobile assembly in Mexico from the mid-1950s first led the UAW to focus on its "backyard" below the Rio Grande. From 1957 onward, the union began to forge close links with the Mexican labour centre, Confederación de trabajadores de México, in the hope that its South American connections would subsequently extend to unions in Argentina, Brazil, and Chile, where the WFTU was active. The IMF first established a presence in Latin America that same year, and in 1959 Dan Benedict, a Reuther loyalist, was "loaned" to the IMF. Coming from the CIO's international affairs department, and following an unhappy spell on the AFL-CIO staff, where he was the object of Jay Lovestone's suspicion, he had most recently been education director for ORIT. Working for the IMF he was responsible for making initial contacts, distributing literature, and mounting training courses. It was difficult terrain; the trade secretariat's only affiliates were in Colombia, Uruguay, and Cuba, while a newly created Brazilian metal federation had recently voted against joining the IMF.65

Following Castro's seizure of power in January 1959, Benedict spent much of 1959-60 in Cuba, assessing the trade union situation for the IMF and seeking to retain the affiliation of the national metal union. Tainted by links with the Batista dictatorship, the old leadership of the Confederación de trabajadores de Cuba (CTC) had been ousted and replaced mainly by members of Castro's July 26 Movement. Walter Reuther looked to Benedict for advice on how to respond given the fierce battle that raged throughout 1959 within the trade unions between communists and the July 26 Movement. Reuther assessed Castro as an independent figure and retained hopes of keeping the CTC within the free trade union fold. ${ }^{66}$

However, in 1960, as Castro looked more and more to the Soviet Union for economic support, he drew closer to the Cuban communists and pressured the CTC's president, David Salvador, to include members of the communist party in its executive committee. It proved to be a turning point, and within months many of the non-communist leaders in the CTC, including David Salvador, found themselves ousted and, in some cases, in prison. The metalworkers' union, which had continued 
to pay dues to the IMF in spite of Castro's opposition to the free trade union movement, was forced to withdraw from the trade secretariat, leaving it with but two Latin American affiliates. The stage was now set for an intensification of the contest in the region between the free trade union movement and communist-leaning unions backed by Castro. ${ }^{67}$

With an expanded staff of organizers, the IMF geared up for a more concerted effort in the hemisphere, with Benedict appointed assistant general secretary in March 1961, the month that President Kennedy unveiled his proposed Alliance for Progress in Latin America. ${ }^{68}$ Through the alliance, the administration sought a new relationship with the US's neighbours to the south, aimed at countering the prevailing Hispanic perception of the "Yanqui" as an economic imperialist. Kennedy envisioned a program of social and economic reform in which the United States would work with democratic elements in Latin America to effect a transformation of society without that process being taken over by communists. Involving hemispheric cooperation between states, national planning, a new emphasis on public as opposed to private development initiatives, and the US promising $\$ 20$ billion in aid over ten years, the stated objective was no less than to lift the Latin American masses out of poverty, ignorance, and despair. The alternative was to risk the spread of Castroism. Launching the proposal, the new president spoke loftily of transforming the American continent into a vast crucible of revolutionary ideas, with political freedom an essential accompaniment to material progress.

The UAW-IMF project in Latin America tapped into this new spirit and, as in Italy and Japan, involved close collaboration between the Reuthers and Arthur Schlesinger Jr., Kennedy's assistant with responsibility for general oversight of the Alliance for Progress. ${ }^{69}$ By 1963, the IMF's budget for Latin America, at 550,000 Swiss francs, was double that for Japan, which had previously overtaken Italy as the main area of federation expenditure. A year later, the IMF claimed affiliates in eleven countries, with its membership up from the 8,00o of 1961 to half a million, and with the large metalworking unions of Brazil and Argentina as the main prize. These gains were made against a backdrop of keen differences within the US labour movement over how best to approach the development of the Latin American labour movement. ${ }^{70}$

The CIA's failed attempt to invade Cuba at the Bay of Pigs and topple Castro just four weeks after Kennedy unveiled his proposal for the Alliance for Progress immediately took the shine off the administration's high-minded project for Latin America, handing Castro a propaganda coup and hastening his declaration that Cuba was now "communist." The Reuthers reacted to the bungled invasion by calling for still more radical social and economic reforms in Latin America, with a distinct role for organized labour. Victor Reuther wrote to the president's special assistant in charge of formulating the Alliance for Progress: "Time gained by the Declaration 
of Bogota [Alliance for Progress] ran out on the Cuban beaches. ... The Castro-si, Yanqui-no sentiment has been strengthened . . the Alliance for Progress slogan must be energized politically by a shift to a democratic Alliance-for-Progressive-Action."

To assist Latin American trade unions, he urged the creation of a non-government foundation with federal funds that would work with the international trade secretariats, embrace the Peace Corps, and ensure that the unions functioned more effectively by training a cohort of professional and technical leaders. This thinking was incorporated into a UAW proposal to the ICA (soon to become AID) for government funding of trade secretariat programs. It didn't necessarily require an increase in the ICA budget for labour, currently running at \$2.7 million, but rather a change in priorities. The IMF budget for its Latin American office, Reuther pointed out, was currently a mere $\$ 50,000$, whereas by contrast the ICA had spent in excess of $\$ 1$ million the previous year on "labour tourism" alone-often ill-focused travel grants for Latin American trade unionists visiting the United States. What he was seeking would merely supplement in a "financially minor key" existing government labour programs. ${ }^{71}$

The UAW proposal for what it called a trade union "Council for Social Progress" was one of several approaches that were presented for consideration by the ICA/ AID over the next few months as the machinery of the Alliance for Progress, agreed at Punta del Este in August 1961, was assembled. The assistant secretary of labour, George Weaver (who was already the target of Jay Lovestone's hostility), argued for a similar approach, with a view to positioning the trade secretariats at the heart of the alliance. Noting that eight trade secretariats already had functioning Latin American operations and that in six of them the director of the regional office was an American trade unionist, Weaver's idea was that the secretariats, with a strong American input and supported by an increased number of well-qualified labour attachés possessing a genuine labour background, would constitute the basis of an altogether more dynamic labour program..$^{72}$

However, a rival trade union initiative with a different emphasis was already taking shape and would lead in 1962 to the creation of the American Institute for Free Labour Development (AIFLD). Its roots lay in a training scheme for Latin American trade unionists begun in 1958 by the Communication Workers of America (CWA) and the trade secretariat for postal and telecommunications workers, the PTTI. Sixteen trade unionists had been brought to the United States for three months' training, followed up by a nine-month internship in their home country paid for by the PTTI. CWA president Joe Beirne, a powerful voice on the AFL-CIO executive council who would later become chairman of its international affairs committee, hoped to extend the program. To this end, the University of Chicago's Union Research and Education Program (UREP) was contracted to elaborate a scheme, and, in August 
1960, UREP launched a proposal for the establishment of an institute that would train up to three hundred labour leaders annually using the CWA-PTTI model: three-month courses in the United States, followed by nine-month internships in Latin America. Initially, UREP envisaged the new body having a budget of $\$ 1$ million, with the money raised from foundations and government agencies. That same month, Beirne secured AFL-CIO agreement to appropriate $\$ 20$, 000 to pump-prime UREP's preliminary work. ${ }^{73}$

In May 1961, as the UAW's idea for a Council for Social Progress began to be refined, UREP invited a number of possible supporters, including Walter Reuther, to a meeting to form a Policy and Design Committee. Reuther didn't attend-he was in Rome for the IMF congress and to confer with leaders of the non-communist Italian left-but by August the understanding in UREP was that he had agreed to serve on the board of trustees of their proposed body, now being referred to as the American Institute for Free Labour Development. At this point alarm bells began to ring in the UAW as it became evident that prominent business leaders such as J. Peter Grace, of W. R. Grace and Company, and Charles Brinkerhoff, of Anaconda Mines, both with interests in Latin America, were also on the board..$^{74}$ This unusual arrangement was a product of George Meany's understanding that there would be more chance of government support for the scheme if employers were involved. Certainly Peter Grace took a keen interest from the start, submitting his own proposals for the new body at the initial meeting of the Policy and Design Committee in May. ${ }^{75}$

Ahead of a meeting of the board in October 1961 to elect the organization's officers, Victor Reuther warned his brother: "it is most unwise for the AFL-CIO (or you) to sit on a board with representatives of two companies as notoriously and historically anti-union as Grace and Anaconda." ${ }^{6}$ The UAW leader stayed away from the meeting at which Grace was elected president and Meany vice president. Grace and Meany were now the twin driving forces behind the project. In December 1961, Meany demanded that UREP's head, John McCollum, stand down as the project's executive director on grounds that he was thinking "too small." The budget now envisaged was $\$ 4$ million over five years, but McCollum's efforts to secure funding from private trusts had been largely unsuccessful. In contrast, Meany had his eyes on a much more bountiful source of income from the US aid budget.77

Meanwhile, by late 1961, the embryonic AIFLD and the UAW's proposed Council for Social Progress were in competition for government financial backing. According to Assistant Secretary Weaver's subsequent account, the UAW proposal won the support of attorney general Robert Kennedy and was then submitted to the president, who referred it to the State Department for final approval. But the AFL-CIO objected and lobbied hard for the AIFLD scheme as an alternative. Weaver related how, at a subsequent cabinet-level discussion, with Robert Kennedy urging support 
for the UAW version and Dean Rusk backing the AFL-CIO's, the president was loath to choose between the two labour organizations and so called in labour secretary Arthur Goldberg to decide between them. Goldberg understood all too well the realities of life in the AFL-CIO; it had one undisputed leader in the person of George Meany. He made it clear to the president that there was no alternative for him but to go along with Meany's preferred scheme or risk creating an impossible relationship with the only organization capable of speaking for the entire labour movement. Bizarrely, this outcome was not communicated to the UAW, whose representatives continued to attend meetings with administration officials on the proposed Council for Social Progress for some months afterward until it became clear that their efforts were going nowhere. ${ }^{78}$

In February 1962, Serafino Romualdi, the AFL-CIO's Latin American representative, was appointed AIFLD director pro tem in place of McCollum and would go on to become the institute's first executive director when it was formally constituted in June $1962 .{ }^{79}$ It may have been important to Meany-it certainly is of interest to historians of AIFLD-that Romualdi was not part of Jay Lovestone's circle and tended to avoid Lovestoneites in Latin America, though they shared the same brand of virulent anti-communism. ${ }^{80}$ Lovestone would express irritation that Romualdi kept him in the dark about Latin American developments, and he was never overly impressed with his colleague's performance..$^{81}$ The fact was that, through Romualdi, Meany had kept more direct control over Latin American activities than he managed to in areas supervised by Lovestone and Brown. Thus the appointment of the former Latin America representative as executive director of AIFLD was, arguably, Meany's way of ensuring that this new venture in international affairs remained firmly in his own hands. Contrary to received wisdom, Jay Lovestone was not "in" on the beginning of AIFLD and, indeed, was never enamoured of the AFL-CIO's approach to international affairs conducted through the three auxiliary institutes created in the 1960s.

Meany was able to announce in April 1962 that the Labour Advisory Committee of the Alliance for Progress (which he chaired) had recommended that AIFLD become the planning and executive arm for approved labour projects and that AID had agreed to this. AIFLD's formal launch coincided with its first training course held in Washington in June 1962. It was now effectively the semi-official labour wing of AID. It began life with a government grant of $\$ 350,000$, primarily for training. It was, Meany observed, the first time that the US government had made funds available directly to the US labour movement for overseas programs. ${ }^{82}$

As much as he would talk up the financial contribution to AIFLD from the labour movement and the smaller sum from business, the fact was that, with some 85 percent of its income from AID, AIFLD was overwhelmingly dependent on government 
money. Apart from the institute's training activities, a Social Projects Department was also created under the direction of William Doherty Jr., who, as PTTI representative for Latin America, had supervised the first CWA training course in 1958. The purpose of this department was to help with the formation of workers' cooperatives, housing schemes, and credit unions - all activities that were increasingly recognized in the free trade union movement as essential tools for development. They tended to be financed by loans negotiated by AIFLD and underwritten by the pension funds of US unions. ${ }^{83}$

The raw statistics of AIFLD activity in its first two years were impressive-some three hundred leaders trained in the United States by the end of 1964, national institutes established in ten countries for training at lower levels, and elsewhere training courses offered by the national union centres in eight more countries-enabling the institute to claim participation to one degree or another of 20,000 people during the first thirty months of its existence. In 1963, the Social Projects Division began its first workers' housing project in Mexico City with a loan of \$14 million, constructing three thousand dwellings for eighteen thousand trade unionists and their families. In 1964, plans existed for similar developments in a further seven countries. ${ }^{84}$

However, Victor Reuther viewed AIFLD with deep suspicion from the outset and fed a steady stream of criticism to Walter Reuther, all the time urging him to sever the UAW's formal link through his nominal membership on the board of trustees. He questioned the high proposed costings - $\$ 1$ million to be spent in the United States, with over half a million dollars on administrative salaries and other lavish outlays on furnishings and consultancies. In addition there was nepotism in appointments, with Romualdi's stepson, Jesse Friedman, and Bill Doherty Jnr., the son of Meany's old crony, postal workers' leader William Doherty Sr., on the payroll. Given that it was the only approved vehicle for government-backed labour programs in Latin America, Reuther considered it "very nearly a private, unregulated, and irresponsible monopoly," recommending that his brother request a report on AIFLD expenditure to the AFL-CIO executive council. The nature of its program would, he predicted, be a source of great tension between the AFL-CIO and the ICFTU and ITSs and would "boomerang in the hemisphere." ${ }_{5}$

In practice, hundreds of trade unionists from the region, having been on the US payroll of a project chaired by Peter Grace, would be vulnerable to accusations at home that they were "American agents." Moreover, Grace was not just any American employer; rather he represented Yankee imperialism at its worst and had antagonized many Peruvians through his identification with the notorious former dictator General Odria. On the eve of the launch of the institute, Victor Reuther drafted a letter for the UAW president to send to Meany expressing deep unease about the way AIFLD was shaping up. The letter was not sent, though it reflected the depth of 
Victor Reuther's feelings, especially concerning the presence on the board of Peter Grace and the institute's approach to the training of trade union leaders. ${ }^{86}$

There was no fundamental UAW disagreement with the AFL-CIO over the question of government finance for labour programs overseas. Victor Reuther was persuaded that essential tasks to be undertaken abroad were frequently beyond the financial means of labour and therefore needed the support of government. This was now recognized in West Germany, where the government-funded Friedrich-Ebert-Stiftung conducted extensive labour programs abroad on behalf of the DGB and SPD. Other national trade union centres would come to a similar view in later years, including the Scandinavians, Dutch, and Canadians. Nor did the Reuthers oppose all dealings with employers in organizing such programs. In planning their own unrealized Council for Social Progress, they were hoping for the encouragement of a number of "progressive employers"-Henry Ford II, Thomas J. Watson of IMB, and Henry Kaiser were all mentioned-but in the Reuther scheme there was no question of such people having a policy role and an input into the way training for trade unionists was conceived and delivered. What affiliate of the AFL-CIO, Victor Reuther asked, would invite employers to play an active role in training its future leaders, as AIFLD did for Latin American unions?

Between the UAW and AIFLD there were differences in detail over how and where training should be given, with the UAW opposed to the practice of bringing trainees to the United States to be enlightened by omniscient Americans. This, Victor Reuther claimed, would centralize the American effort in Latin America in the hands of people like Romualdi who were closely associated with ORIT, a body that was already widely discredited within the trade union world. The UAW preferred courses to be mounted on the spot, with trade unionists of various countries learning from one another about how to tackle their common problems. This was also the majority view of education officers of AFL-CIO affiliated unions. ${ }^{87}$

Apart from differences over where to locate training activities, AIFLD was distinct in the emphasis it gave to promoting "responsible" unionism operating in partnership with employers and government whose interests could be "harmonized in a joint equilibrium" with the help of "capable and responsible leadership." It reflected the sentiment then being assiduously promoted among industrial relations theorists and practitioners that labour-management conflict was passé and was being replaced by the notion of unions as corporate partners in national society. This was part of AIFLD's justification for according business leaders a high-profile role. As Joe Beirne, the institute's secretary-treasurer, explained: "If we are to export the concepts of our society, all of the elements of that society must be represented. The institute, therefore, had to find its support not only in labour, but the federal government, business management, and the professions as well." ${ }^{88}$ 
Indeed, partnership with business was not an incidental feature of AIFLD's approach but central and vigorously pursued by George Meany. It was evident in the way he and Bill Schnitzler, in a private meeting, eagerly wooed H. S. Woodbridge, president of the True Temper Corporation and a potential new member of the board of trustees. True Temper owned metal manufacturing establishments in Peru, where AIFLD was planning to open a labour institute. Extolling the virtues of American free enterprise, Meany explained to Woodbridge that if Latin America became socialist, the American system would be endangered, noting in passing that the socialism of the British labour movement failed to benefit workers as much as American free enterprise did. He conceded that AIFLD had its domestic opponents, and with the Reuthers in mind explained: "Not all ... labour leaders take this position. Such, nevertheless, are a minority ... whose noise is greater than its influence ... and is almost entirely from the mouth out." Such people were "not truly important" and were not going to stop the cooperation with business he hoped for. Schnitzler chipped in to reassure Woodbridge that the day would soon come when strikes as a tool of collective bargaining would no longer be needed. Meany concluded the meeting with comforting words about the current military junta in Peru, which, he said, had no militaristic intentions. Woodbridge then agreed to join the trustees. ${ }^{89}$

From late 1962, Grace led a concerted campaign to win US business support for AIFLD and to have two more businessmen appointed as trustees. He engaged Madison Avenue consultants who proposed that Meany should give a keynote speech to bodies such as the Chambers of Commerce and the Detroit Economic Club. The text of this suggested speech was to be circulated to five hundred corporate CEOs with a covering letter from a "distinguished American"-former President Eisenhower was the person he had in mind. Also proposed was the placing of AIFLD publicity material in business journals and "suburban papers in silk stocking districts." ${ }^{\circ \circ}$ Chase Mellon Jr., who served as financial secretary to the board of trustees, distributed to businessmen a letter signed by Peter Grace that raised the spectre of an "all-out offensive by Castro-Communism to subvert Latin America" and spoke of a counteroffensive involving the training of labour leaders in ways of "bringing about a more harmonious and productive relationship between labour and management." The letter boasted: "This is the first time that management and labour have voluntarily joined forces to launch and support an operation which recognizes the capitalistic and private enterprise system.".91

In a move arising from Grace's membership on the board of trustees, Victor Reuther ran a campaign against AIFLD, seeking out information on the labour relations record of Grace-owned firms and drawing his brother's attention to a copper miners' strike in Chile at Anaconda mines, whose president, Charles Brinkerhoff, was an AIFLD trustee. He obtained a copy of a pamphlet circulating in Chile written 
by a consultant, Alexander Lipsett, and presumed to have been commissioned by Anaconda. Calling for lower taxes and restraint in labour militancy, and advocating a form of company unionism, it was financed by AIFLD and contained a foreword written by Serafino Romualdi commending the author as "a staunch friend of labour." "[It] betrays all the things for which you have stood all your life," Victor Reuther told his brother. The good name of the UAW and Walter Reuther were being destroyed by the latter's continued silence over AIFLD, and though Victor understood his brother's caution and reluctance to jeopardize the AFL-CIO merger, he commented that "the merger is fragile indeed if it cannot withstand a clear decision between serving the interests of workers and being used as a company union tool for major corporations in their efforts to secure pliable unions." The AFL-CIO executive council was due to meet in six days, and he pressed his brother to act decisively. ${ }^{92}$ However, Walter Reuther chose to bite his tongue, though he did give specific instruction that no autoworkers' funds were to be used for investment in housing projects abroad and that UAW staff were not to engage in discussions with AIFLD about any activities without first consulting the international affairs department. "Our relations with the Grace-Meany Institute are very tenuous," recorded Victor Reuther. ${ }^{93}$

The situation changed radically on 1 April 1964, when a CIA-backed military coup in Brazil ousted President João Goulart, who was perceived to be sympathetic to the communist line and who supported a Latin American labour movement inclusive of both ICFTU and WFTU. For some months beforehand, AIFLD executive director Romualdi and Berent Friele, a business associate of Nelson Rockefeller and also a member of the AIFLD board of trustees, had been privy to the planning for the action. Confirmation of the important role played by AIFLD in this event came three months later when social projects director William Doherty gave a radio interview in which he boasted of the activities of institute interns in helping undermine a general strike called to defend President Goulart while supporting mass counter-demonstrations. "As a matter of fact, some of them [interns] were so active," Doherty explained, "that they became intimately involved in some of the clandestine operations of the revolution before it took place on April 1. What happened in Brazil on April 1 did not just happen-it was planned and planned months in advance." Circulating the transcript of the interview, Victor Reuther wrote indignantly: "I am horrified that all this is being done in the name of enabling a 'strong, free, virile trade union movement in Latin America.' With these kinds of friends, who needs enemies?... When you read the enclosed memo of developments in Brazil you will understand why, as a trade unionist, I feel a sense of revulsion." ${ }^{94}$

Communist-led labour organizations were now waking up to the existence of AIFLD and beginning to score effective propaganda points off it, as Victor Reuther had feared. He therefore intensified his efforts to persuade his brother to end his 
silence. Jack Lever, a CIO veteran who was working for AIFLD in Venezuela, was asked to write to the UAW leader with his impressions of the organization. Lever damned it with faint praise-it was a "playboy agency" whose leadership was not possessed of sufficient background to handle the task before it. Its housing operation-what he termed "the AFL-CIO's real estate department"-was big on self-promotion but poor on delivery; its labour banks existed for people too poor to save; its cooperatives were promoted by people with insufficient knowledge of the cooperative movement; and beneath all this was the suggestion that AIFLD opened itself up "cloak and dagger" operations. ${ }^{95}$

Finally, in early 1965, came damning new evidence of Grace's industrial relations practices in the United States that could no longer be ignored by Walter Reuther. At Airmold Products, a Grace Plastics Division plant in Tonawanda, New York, a UAW attempt to secure recognition under the National Labour Relations Act had been opposed by management. A leaflet circulated to workers entitled "Foreign Aid Plans-Union Style" asserted that "in a Grace plant no one needs a union partner in his pay envelope." And in highlighting the fact that the AFL-CIO spent 23 percent of income on its own "private foreign aid programme." the flyer advised workers to "ask the paid union organizer about this foreign aid plan of his AFL-CIO union from your pocket book." This was clearly a matter on which Reuther would have no option but to resign from the AIFLD trustees, and Victor Reuther drafted yet another letter for him to send to Meany. It reprised the reservations about the approach to training and the recent evidence from Brazil of "political activities far removed from the legitimate purposes of AIFLD." Yet it was still three months before Walter Reuther finally sent a letter of resignation, more restrained in tone than Victor's draft and confining itself to the core issue of Grace's anti-union behaviour at Airmold. ${ }^{96}$

There is little doubt that Reuther was extremely reluctant to open a rift with Meany, but developments generally in the labour movement were propelling him in that direction, and on this issue he really had no alternative but to take a stand on trade union principle. Increasingly the signs were that differences between George Meany and Walter Reuther would cause a rupture in the AFL-CIO. It was something that UAW president desperately wanted to avoid. Meany was now turned seventy, and Reuther clung to the hope that time might come to the rescue-but thoughts along those lines proved to be mere wishful thinking.

\section{Meany and Reuther at Odds Internationally: The Beginning of the End}

For a number of months following the 1965 ICFTU congress in Amsterdam, it was as though a truce had been signed by George Meany and Walter Reuther. In domestic policy, both men were close to President Lyndon Johnson and were enthusiasts for 
his "Great Society" program, which offered the labour movement scope for significant gains. In international affairs, Reuther's low-key resignation from the AIFLD board in September 1965 avoided public dispute. The ICFTU was in an advanced state of disarray, and though the two men viewed the causes and possible solutions differently, the UAW's continued primary focus on IMF programs abroad helped prevent open conflict in this area.

The burning international issue of the day, which increasingly dwarfed all others, was the war in Vietnam, but on this both Meany and Reuther were firm in their support for administration policy, even if Reuther's instincts were more dove-like. At the ICFTU congress, Reuther had used his influence to help prevent an acrimonious debate over the war. At home, it also proved possible for the two men to conciliate their different emphases on the war. At the December 1965 AFL-CIO convention, Reuther objected to the tone of a resolution drafted by Jay Lovestone that referred disparagingly to anti-war protesters as "a tiny but noisy minority" while pledging "unstinting support for all measures the Administration might deem necessary" to defeat "Communist aggression in Vietnam." Reuther failed to win support for a statement against further escalation of the war, but he secured Meany's agreement to tone down the language and to add words of praise for administration efforts to secure a negotiated peace. Meany's compromise clearly rankled with Lovestone. ${ }^{97}$

Yet if the UAW president was careful to keep the peace within the AFL-CIO, his brother Victor showed no such restraint, and his antipathy toward Jay Lovestone was as pronounced as ever. For one thing, he was seen to be exploring possible trade union contacts in the Soviet bloc. In March 1966, he approached ambassador-at-large Averell Harriman for help in establishing "unofficial ties" between American and Soviet trade unionists. He had plans to bring over union officials from the USSR through the agency of the Citizens' Exchange Corps, with itineraries already arranged for the visitors when they reached Washington and Detroit. Briefed by Jay Lovestone, labour columnist Victor Riesel revealed these details, and when Meany then protested, the State Department refused at the last minute to grant visas to the visitors. ${ }^{98}$ Three months later Victor Reuther led a party of over thirty members of Americans for Democratic Action on a trip to Poland. The UAW avoided publicizing this initiative, but again Victor Riesel obliged Lovestone by disclosing plans for the visit in his column. Riesel claimed that it was another attempt by Victor Reuther to arrange exchange visits with Soviet bloc trade unionists and speculated that Reuther was aiming to hold meetings with leaders of the Soviet AUCCTU while in Warsaw. ${ }^{99}$

While hoping to pave the way for UAW contacts with Soviet bloc unions, Victor Reuther was also intent on exposing ongoing links between the CIA and the AFL-CIO's international affairs department, focusing especially on Latin America. In the winter of 1965-66, a series of newspaper articles in the American press had 
already reported on intelligence operations in the labour field, some in connection with the April 1965 American-led military action in the Dominican Republic. Inquiries by Meany pointed to Victor Reuther being behind the stories, and he cautioned aides: "he is undercutting us." ${ }^{100}$ It is hard to understand why Reuther should want to draw attention to this highly sensitive subject at the precise moment he was sounding out Vice President Hubert Humphrey's office on the possibility of securing financing for an orchestrated split among CGIL members in Italy, and in the knowledge that such funding would need to come from the CIA. Evidently in his ongoing vendetta with Lovestone, the younger Reuther could not resist the opportunity for point scoring.

At the end of the UAW's convention at Long Beach in late May 1966, Victor went public in a press interview with the Los Angeles Times in which he claimed that the AFL-CIO's international affairs department was "involved" with the CIA and spent some $\$ 6$ million annually in Latin America alone. A substantial part of AFL-CIO international activities, he said, was not reported to the executive council, and some of its affiliates had permitted themselves to be used as cover for clandestine intelligence operations abroad. He cited a recent case where the food workers' trade secretariat, the International Union of Food and Allied Workers (IUF), had been forced to close down its entire Latin American operation after general secretary Juul Poulsen in Geneva discovered that at least eight people in Panama were posing as IUF representatives when the head office had no knowledge of their existence. These rogue "representatives" had been engaged by the AFL-CIO's inter-American representative, Andrew McLellan, who had previously worked for the IUF and still had a hand in its affairs in Latin America. ${ }^{101}$

Victor Reuther believed this was part of a wider pattern, suggesting that AFL-CIO international activities were a "vest-pocket" operation of Jay Lovestone, who had brought into the labour movement the habits and undercover techniques he had learned in the communist party. Yet so long as Meany had personal confidence in Lovestone, Reuther could see no hope for change in AFL-CIO foreign policy. He used the interview as an opportunity to draw attention to resolutions adopted at the UAW convention in favour of improved relations with communist China and increased trade with the Soviet bloc and warning against further escalation of the war in Vietnam-representing them as "major challenges" to the AFL-CIO. When asked whether these would provoke Jay Lovestone, he replied breezily: "I would hope so." ${ }^{102}$

In giving the interview to the Los Angeles Times, Victor Reuter had evidently "gone rogue," while intentionally raising the stakes in the UAW battle with the AFL-CIO. Meany telephoned Walter Reuther to complain, and the UAW president conceded that the interview had been a mistake; he said that his brother had been expressing 
a personal view and claimed not to agree with it. On that basis, Meany allowed the matter to rest. Of late his relations with Walter Reuther had been largely free of rancour: he had only recently returned to work after major hip surgery, and while in hospital he had been visited by Reuther, who spent a convivial few hours in amicable conversation with him. It would prove to be their last friendly meeting. ${ }^{103}$

The tone of their relationship was almost immediately to change as a consequence of dramatic events at the ILO in Geneva. Protesting the election of a Polish communist, Leon Chajn, as chairman of the international labour conference in June 1966, Rudy Faupl, who headed the US workers' delegation in Geneva, led an American walkout after putting in a phone call to Meany. A statement issued by the delegation maintained that Chajn's election "placed in serious jeopardy the continuance of the ILO as a tripartite body" The walkout risked undermining the Johnson administration's policy of "bridge-building" to the Soviet bloc, and immediately UN ambassador Arthur Goldberg, secretary of labour Willard Wirtz, and undersecretary of state George Ball spoke to Meany to urge caution. The following day, President Johnson invited Meany to see him and warned that although he personally was relaxed about the demonstration by the American workers' delegation, there could be no question of the United States quitting the ILO. ${ }^{104}$

Meany's public position on the 1966 walkout was that the decision had been Rudy Faupl's alone and that he, as AFL-CIO president, had merely concurred with Faupl's judgment. Yet the political reality was that no walkout would have taken place against the wishes of the president of the AFL-CIO, and it was widely understood in diplomatic circles that Meany was looking for a way of withdrawing from the ILO. On the basis of the formal constitutional relationship between himself and Faupl-under which Faupl represented the United States and not the AFL-CIO-Meany portrayed the walkout as a tactical decision by Faupl rather than a policy change by the AFL-CIO. $\mathrm{He}$ also denied that there had been any administration pressure not to walk out. ${ }^{105}$

No other trade union delegation had joined the American walkout, and there was a widespread view that the show of American truculence in Geneva had been counterproductive. It had damaged America's image and had helped ensure the election of the first ever representative from the USSR, P. T. Pimenov, to the Workers' Group of the ILO Governing Body. This was an outcome that the Americans had hoped to prevent. In the long run, Pimenov's election was likely to be a more significant breakthrough than Chajn's election to the conference chair; as Irving Brown wrote from Geneva: "If one cannot sit in a conference when the President is a Pole... how can one sit in a Governing Body when there is a Soviet 'workers' delegate'?" 106 However, it was the sequel to these events within the AFL-CIO that was to have the most lasting impact on the international labour movement. 
At the time of the walkout, UAW executive board members were attending the inaugural conference of the IMF's World Auto Council along with auto union delegates from a dozen countries-the culmination of a decade of endeavour by the UAW in the international field. The UAW delegates were much embarrassed to learn from the press about the ILO walkout, and Walter Reuther was urged to protest to Meany. He duly wrote, complaining that the action was "unwise, undemocratic, contrary to established AFL-CIO policy, and unauthorized by any AFL-CIO body with authority to change the policy," and he called on Meany to order the delegation back to the conference. He also sent a copy of his letter to the press, which featured it as evidence of a "major split" threatening the unity of the AFL-CIO. ${ }^{107}$

Unfortunately for Walter Reuther, Meany first learned the contents of his letter from the New York Times. His anger at this discourtesy was compounded by the fact that he and Reuther had been together at a meeting two days after the walkout and on that occasion the UAW leader made no reference to it. Meany replied, blasting Reuther for turning the ILO episode into a public dispute. His emphasis was not on the substance of Reuther's criticism but the way he had gone about airing it. In a passage that must surely have cut Reuther to the quick, he cautioned against harming the ICFTU, regretting such bad publicity at a time when its future "hung in the balance" and needed "the fullest possible support from American labour." Meany also announced the calling the following week of a special AFL-CIO executive council meeting to consider Reuther's criticisms. And with Victor Reuther's press conference allegations about AIFLD and the CIA still fresh in his mind, Meany was also intent on raising the younger Reuther's "slanderous attack" and "constant harassment." As Lovestone noted, it was a very effective response that made it difficult for Walter Reuther to win backing from any quarter. ${ }^{108}$ Matters were coming to a head.

\section{Bringing Foreign Policy Differences to a Head}

At the special executive council on 16 June 1966, Walter Reuther was very much on the defensive for having placed his criticisms of the AFL-CIO in the public arena. Meany gave him a dressing down and the UAW leader was forced to reassure the meeting that his observations on the walkout were meant to censure neither Meany nor Faupl. But on his wider criticism of AFL-CIO international policy generally he held firm; he expressed "deep concern" at the drift in international affairs and the fact that federation policy was neither positive nor constructive. The meeting voted by three to one to endorse the action taken by Faupl and Meany, but Reuther secured agreement to hold a further special meeting in November to review the whole range of AFL-CIO foreign policy, which he described as "rigid" and "frozen" and contrary to President Johnson's "bridge-building" approach to the Soviet Union. ${ }^{109}$ 
In the meantime, Victor Reuther's specific allegations about AIFLD and the CIA were slated for separate discussion at the regularly scheduled executive council meeting in August.

Privately, Victor Reuther claimed not to be worried by Meany's "statistical majority" in the executive council, comforted in the belief that those supporting his brother represented a larger share of total AFL-CIO membership. More importantly, he told the British labour counsellor: "While George may have the votes in the EC, he sure as hell won't get any votes in Europe." Victor saw this as the start of a major battle over foreign policy and wrote bullishly to Dan Benedict: "this is but the opening shot in what I am sure will eventually involve a broadside against many aspects of AFL-CIO policies in the international field." ${ }_{110}$

Within the AFL-CIO international affairs department there was equally a sense that a decisive confrontation was now in the offing, combined with an air of confidence over the eventual outcome. The AFL-CIO executive council had chosen to make no public statement over these internal differences that would dominate discussion in the coming months. Indeed, Walter Reuther was subsequently condemned for continuing to talk to the press about the issues involved. However, Jay Lovestone's views found their way into print via the syndicated column of labour correspondent Victor Riesel. Describing the UAW offensive as "open warfare," he predicted "a long hot summer." Echoing Lovestone's thinking, Riesel offered a scenario in which the outcome would be determined by whichever side had the best links to President Johnson: "Meany and the overwhelming bloc of U.S. labour chieftains will not retreat. ... The Reuthers will then tell the Meany majority to jump in the Potomac ... and then proceed on their own with the bridge-building. The big question is, however, 'Who will control the pontoon to the White House?'"11

Victor Reuther was preparing in depth for the executive council meeting in August. Throughout the summer he assigned his international affairs department staff to sleuthing work - what he dubbed "Operation August" - tracking down AIFLD representatives and taking statements from them. ${ }^{112}$ In late July, UAW general council Joe Rauh wrote privately to Walter Reuther on the outcome of this research:

Since I know you are mulling over the CIA matter, you are entitled to have this thought before you. We can demonstrate, all apart from George Meany's admissions to you personally [author's emphasis], that there is a massive CIA involvement in the foreign affairs operations of the AFL-CIO and vice versa. I am not suggesting the answers to the policy and political questions you have before you. But ... my personal assessment, based on what we have learned to date [is] that Vic's statement was mild indeed and that you can lead from strength not weakness. ${ }^{113}$ 
The UAW's detective work led to the production of a document claiming that, on the basis of evidence amassed, "it can be definitely affirmed without even a shadow of doubt that the AIFLD has from its inception been utilized as an active, intelligence gathering organization by the Central Intelligence Agency." Moreover, the presence of intelligence agents in the numbers that existed had inhibited the work of genuine AIFLD representatives performing legitimate tasks for labour. In consequence, it argued, AIFLD's record of achievement was poor, causing large numbers of staff to leave in frustration in the course of 1965-66. At an operational level, the document identified William Doherty, Romualdi's successor as director, as the chief culprit and called for his dismissal along with that of Secretary-Treasurer Joe Beirne. All covert activity needed to be brought to a halt, and the AIFLD board of directors reconstituted. ${ }^{114}$

However, the document never saw the light of day. Walter Reuther was coming under intense pressure from the Johnson administration to drop the allegations about the CIA and AIFLD. To this end Reuther had received telephone calls from Vice President Hubert Humphrey and Senator Robert Kennedy as well as Cord Meyer, successor to Tom Braden at the CIA with responsibility for international operations within the international trade union movement. Rauh's oblique reference to "Meany's personal admissions" to Walter Reuther about the CIA also related to the fact that the two men had met to discuss removing the item from the forthcoming executive council agenda. Indeed, as a result of the pressures being applied by the administration there were urgent behind-the-scenes talks within the AFL-CIO involving Meany, Reuther, and their respective assistants, Lane Kirkland and Jack Conway, over how to proceed at the August council meeting. And it was Reuther's firm belief that in a face-to-face meeting with Meany there had been agreement between them to drop the item in the interests of "national security."15

Yet when the executive council convened in August, as the first item AIFLD secretary-treasurer Joe Beirne insisted on introducing a detailed report denying that the institute was a tool of the CIA. Caught off guard once again, Reuther was forced onto the back foot, agreeing that it was wrong of his brother to raise the issue in public and accepting that Beirne was justified in feeling strongly about it. The majority then voted to commend the work of AIFLD and to reject the campaign of vilification. This time Joe Curran was the only other council member to vote with Reuther; even the normally supportive Jake Potofsky preferred to abstain.

It was far from the end of the debate about AFL-CIO links with the CIA; press disclosures implicating affiliated unions continued for several more months. ${ }^{116}$ The expose that proved to be the biggest bombshell came with Tom Braden's article for the Saturday Evening Post in May 1967, whose purpose was to put the CIA's side of the story and to counterbalance the moral outrage expressed over the disclosures 
of shady financing by various correspondents. As well as recalling the $\$ 50,000$ he passed to Walter Reuther in 1952 for use on trade union programs in Europe, Braden detailed the much larger sums the agency provided to Lovestone and Brown and the CIA's difficulty in keeping tabs on how it was spent. ${ }^{117}$ Meany immediately told a press conference that Braden's account was "a damned lie." "Neither the AFL during my term as secretary-treasurer and president nor the AFL-CIO has ever received any CIA money." (He carefully avoided any mention of the Free Trade Union Committee.) Again he absolved his international affairs director: "Lovestone had absolutely nothing to do with the CIA. ... I've talked to him many times, and I can tell you he does not have anything to do with this." The British labour counsellor reported that Meany now appeared to be one of the few people to believe that Brown and Lovestone were innocent of any connection with the CIA. ${ }^{118}$

However, for now the meeting of the AFL-CIO executive council in August 1966 had provided evidence of a further shift in the balance of power away from Reuther. The council went on to adopt a hawkish statement on the war in Vietnam that dropped the call for the negotiated settlement that Reuther had introduced at the $1965 \mathrm{AFL}-\mathrm{CIO}$ convention. It also condemned anti-war protesters for "aiding the Communist enemies of our country ... that is bearing the heaviest burdens in the defence of world peace and freedom." Reuther left the meeting before the statement was voted on and, in a letter to the press, disowned it as "intemperate, hysterical and jingoistic and unworthy of a policy statement of a free labour movement." ${ }^{19}$

In light of this outcome, Jay Lovestone now looked forward with confidence to the special session of the executive council in November requested by Reuther and meant to examine thoroughly the whole range of foreign policy positions adopted by the AFL-CIO. He was preparing for a final "showdown" and, in briefings with labour correspondent Victor Riesel, sought to represent Reuther as a frustrated man with overweening ambition in the international field whose multifaceted agenda was hard to fathom but was somehow tied up with undercover work. As a Victor Riesel column described it:

From the Congo to the Copacabana, from Mount Fuji to Mount Kenya, from Washington to Tunisia, Reuther's organizers trot the world. They supply films. They hand out movie projectors. They distribute literature in Arabic and Japanese. They run underground operations in Africa. They finance undercover activities in Spain. Still the rusty-haired leader of the ... [UAW] feels that the activities of his ... International Affairs Dept ... are too restricted by national AFL-CIO policies. ... Just what new policies Reuther wants haven't yet been made clear. Reuther's aims are intertwined with the auto union's covert and overt international activities. His International Affairs Dept . . is deep inside Spain. The auto union runs underground schools to train leaders 
for the illegal labour and youth movements. It helps to finance organization drives ... and it publishes anti-government newspapers ... in and out of Spain. This action parallels work in Africa ... with Zambia’s president Kenneth Kaunda, Tunisia's president Habib Bourguiba, Kenya’s ... Tom Mboya, and Dr Hastings Banda ... of Malawi. ... There are no objections from the Meany headquarters - so long as Reuther speaks for himself and his own union.... The Federation is hawkish on Vietnam-and says so frankly. The Reuthers are not-and say so frankly. And that's how they'll all talk to each other when the showdown comes. ${ }^{120}$

However, the showdown as envisaged by Lovestone was not to take place.

The heavy defeat he suffered at the August meeting of the executive council caused Walter Reuther to begin to wonder about the worth of the UAW's remaining a part of the AFL-CIO and to envision a future outside the federation. He was upset at Meany's "double cross" over the AIFLD-CIA agenda item and the fact that Beirne was allowed to speak to an item that had been withdrawn by agreement. How was it was possible, he mused, to do business with people who went back on their word given in a face-to-face meeting? ${ }^{121}$ In fact, the autoworkers' president was being forced into a position not of his choosing. As the British labour counsellor reported:

It is incredible how Walter Reuther allows himself to be led by the nose by his brother Victor. There is such intense enmity between Victor Reuther and Jay Lovestone that the former cannot resist any opportunity of sniping at the foreign policies of the AFL-CIO. While Walter obviously agrees with Victor he does not seem to know what to do about it. While Walter knows he cannot win a vote against Meany in the Executive Council, by doing things the wrong way he forfeits the sympathies of many others who otherwise agree with him. ${ }^{122}$

Over the coming weeks, in the autumn of 1966, the UAW president came to the conclusion that it was pointless to attend the special executive council meeting in November that he personally had requested, excusing himself on the last minute on the lame grounds of having a "prior engagement." His last reliable supporter on the executive council, Joe Curran, wired urging him to attend, but the appeal went unanswered. Yet, in spite of Reuther's absence Meany insisted on proceeding with the meeting. The council spent a whole day going through a thick file of foreign policy resolutions adopted since the 1955 merger, eventually endorsing them almost unanimously as positions that were "sound ... justified by events" and had "stood the test of time." ${ }^{123}$ For Meany, the simple fact was that all the AFL-CIO's international policies had been formally adopted in a constitutional manner. Reuther's larger point about the secretive manner in which Jay Lovestone ran the international operation and formulated policy went by default. 
In UAW circles, "independence" was now in the air. No dramatic steps followed immediately, although for the final quarter of 1966 the UAW paid its subscription to the AFL-CIO two months late-a warning shot across Meany's bow. Taking charge of strategy and evidently ensuring that his brother did not unduly influence the agenda, Walter Reuther's approach was to win support among the UAW membership for quitting the AFL-CIO by emphasizing the need for a more dynamic, socially progressive labour movement. And in doing so he emphasized that the focus needed to be on domestic issues. In a speech in November at the Wharton School, he described his differences with George Meany:

All the [press] emphasis has been on foreign policy. ... We do have differences.... I happen to support the Test Ban Agreement. I happen to think we ought to negotiate a settlement in Vietnam. I happen to disagree with walking out of the ILO conference. . . . But that is only a small part of the basic disagreement with this gentleman. Fundamentally, I disagreed because I believe that the American labour movement under his leadership is failing in the broad social responsibilities it has to the community of America. ${ }^{124}$

As ever, there was strong support abroad for Walter Reuther's international approach, though it was by no means clear that his favoured policies in the international arena would play better with UAW members than those of the AFL-CIO. Reuther therefore understood the need to place domestic disagreements at the forefront in his battle with Meany. The primary focus would then be on allegations of AFL-CIO complacency, adherence to the status quo, and lack of social vision and dynamic thrust. Yet the consequences for future American participation in the international free trade union movement of their disagreement over international policy would be far reaching.

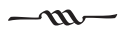

The UAW's international program in the 1960s aimed to demonstrate an approach significantly different from that of the AFL-CIO. It was by far the most ambitious single international program undertaken by any American union. It was also distinctive in the way it endeavoured to escape from the pattern of international trade union work as a field for professionals and to draw on the idealism and enthusiasm of the union's local leadership and rank and file as active agents in worker-to-worker contacts.

The Free World Labour Defence Fund provided assistance to non-communist, democratic unions abroad without the narrow anti-communist emphasis that the 
AFL-CIO brought to bear on its activities overseas. The focus was on support for labour organizations in their struggle for improved conditions. Learning the lessons that the UAW had absorbed in Europe in the early 1950s, a basic aim was to overcome crippling divisions between organizations that were, in many cases, the product of AFL-CIO practice of supporting only the most vocal opponents of communism.

Grant aid was dispensed in small amounts for one-off projects but also for major programs in which the International Metalworkers' Federation acted as the coordinating body. With UAW funding being offered as an incentive for metal unions elsewhere to emulate the Americans' commitment, the IMF would typically aim to draw in matching funds from other major affiliates-especially the German and Swedish metalworkers' unions.

The promotion of "world coordinating councils," which organized across national frontiers and within specific multinational corporations with the hope of becoming transnational negotiating bodies for their workers, was a core component of UAW strategy. In Japan, where labour movement divisions owed much to policies pursued by the AFL from the early 1950s, the autoworkers' objective was to help build unity within the framework of the IMF and to further overcome fragmentation of union groups by encouraging their joint participation in a wage research exercise aimed at unravelling the mysteries of a remuneration system that relied heavily on bonuses paid at the discretion of employers.

More ambitiously, the Reuthers aimed for a wider role on the political stageworking with figures in the Kennedy administration to help promote centre-left politics in Europe and Latin America, where previously the Eisenhower administration had favoured the conservative right and where the AFL-CIO had gone with flow of US policy. Walter Reuther played a catalytic role in bringing together leading European social democrats and American progressives for talks in the Harpsund conferences, which, at their most ambitious, aspired to create an international consensus around a new centre-left politics. Reuther's most concerted effort in that field was in Italy, where, in cooperation with partner unions in the IMF, an "opening to the left" was encouraged that eventually saw the Nenni socialists end their electoral pact with the communists and join a centre-left coalition government with the aim of breaking with the economic and social policies of conservative Christian Democracy.

The UAW programs in Italy and Japan directly challenged existing AFL-CIO policy and renewed friction between Reuther and Meany. In Latin America the UAW studiously avoided involvement in the work of AIFLD, compromised as it was by the formal role accorded to business interests on its board of trustees.

It was at Victor Reuther's initiative that the long-simmering differences between UAW and AFL-CIO in the international field were brought into the open in 1966 
with allegations of extensive CIA involvement in the work of AIFLD, thereby lending substance to other such disclosures by investigative reporters. The bitter public dispute with the AFL-CIO that began with this episode expanded across a range of policies domestic and international and launched the UAW on a course that would see them disaffiliate from the AFL-CIO within two years. 


\section{8}

\section{Toward an Independent Role}

Ever since the 1949 split in the World Federation of Trade Unions, free trade unionists were in no doubt that there should be no dealings with the WFTU. However, from the ICFTU's earliest days there had been little agreement on how to respond to persistent overtures from the Yugoslav trade unions that had been expelled from the WFTU yet were still communist-led. Should they be shunned, or was it wiser to maintain a line of contact to Yugoslavia and so avoid driving it back into the Soviet fold? The ICFTU's policy against contacts with communist organizations proposed by the AFL and adopted in 1955 was meant to clarify the position relating not just to this special case but also to contacts with all communist-controlled organizations. Exchange visits with the Soviet bloc were ruled out, and the ICFTU was to be notified of invitations received so that affiliates could be made fully aware of what the communists aimed to gain through such visits. Yet as a policy, it was never more than a statement of good intentions.

Regardless of whether or not national centres believed in the policy, they were rarely in a position to impose discipline on their own member unions. The ban on contacts also took no account of changes in the international climate. The Cold War had its moments of high tension-the crushing of the Berlin and Hungarian uprisings; the occasional standoff between American and Soviet military personnel at border crossings in Berlin; the Cuban missile crisis. But in between were periods when the post-Stalin "new look," the "spirit of Geneva," the "spirit of Camp David," or the undercurrent of reform permitted by Khrushchev provided the mood music for international relations. East-West dialogue at government level, the encouragement of cultural visits by civil society, and even the prospects for limited trade created an atmosphere in which Western labour centres could also make a case for accepting invitations to exchange visits aimed at developing a better understanding of the other 
side and contributing to an easing of tension. As this process intensified from the mid-196os, it opened up major divisions within the ICFTU that eventually led to the AFL-CIO quitting the fold.

\section{East-West Bridge Building}

In the aftermath of the Cuban missile crisis, with the establishment of the "hot line" between Moscow and Washington and both sides avoiding confrontational language, there was increasing scope for liberal voices to challenge the nostrums of the Cold War. Senator William Fulbright, chairman of the Senate Foreign Relations Committee, launched a wide-ranging critique of American foreign policy in spring 1964, arguing that it was based on "cherished myths." He challenged the belief that every communist state was an "unmitigated evil" and a "relentless enemy of the free world" and that the communist bloc was a monolith composed of governments that were no more than "organized conspiracies." By 1966, such views would lead to the Johnson administration adopting an official policy of "building bridges" to the Soviet bloc. ${ }^{1}$

George Meany was in total disagreement with the new thinking; communist states were "unmitigated evils" even if, owing to differences in size and resources, they were not all equally dangerous. If the USSR was currently less aggressive, he insisted that it was merely because of economic weakness and especially its current crisis in agriculture. America therefore needed to continue to build up its defences: "an arms race [did not] necessarily spell war." Meany criticized Fulbright for having nothing to say on the central problem of a divided Germany. In contrast, Frank Altschul, a prominent member of the business community and secretary of the Council on Foreign Relations, argued in a Free Trade Union News symposium that German reunification could only be achieved within a framework that addressed Soviet differences with the West. America, he insisted, had nothing to fear from a competitive struggle with the USSR when conducted within the framework of peaceful co-existence. ${ }^{2}$

In July 1964, clothing workers' president Jake Potofsky admitted in an interview that he saw "no harm in exchanging visits with the USSR," though he was not prepared to argue this publicly. Potofsky added that Lovestone was "living in the past" and writing speeches for Meany that were full of outdated "verbiage and old communist terms." Five months later, I. W. Abel, then secretary-treasurer of the steelworkers' union, who was philosophically close to the Reuthers, added to Lovestone's chagrin by accepting an invitation to the anniversary celebrations of the Bolshevik revolution at the Soviet embassy in Washington. He would soon be targeted by the embassy for an invitation to the USSR. ${ }^{3}$

While George Meany was profoundly irritated by this tendency for a few American unions to flirt with communists overseas, he was far more troubled by the pattern 
of European union visits to the Soviet bloc. Dependable allies in the battle against communism were thin on the ground; in practice, Jay Lovestone and Irving Brown could only look to André Bergeron, general secretary of Force ouvrière (FO) and Georg Leber, chairman of the DGB's building and construction workers' union, to hold the anti-communist line. Elsewhere in Europe there appeared to be a worrying lack of commitment in this area, and it would affect the way the AFL-CIO regarded the ICFTU in the years ahead.

André Bergeron took over the leadership of FO in 1963 in succession to Robert Bothereau. The change was a matter of some relief to Brown, who had come to regard Bothereau as too cautious an operator, too much his own man and reluctant to take his cue from the AFL-CIO. In contrast, Bergeron, the former printer, was a kindred spirit and one of the young Turks in whom Brown had placed much faith at the foundation of FO in 1948. Brown became his leading booster, informing Meany that with a young, dynamic leadership team around him and a clear, uncompromising position on communism, the feisty Bergeron was determined to invest FO with a new fighting spirit. Within weeks of his election, Bergeron was invited to the AFL-CIO's executive council, where he and Meany issued a joint statement on the importance of trans-Atlantic unity.

As a beneficiary of AFL-CIO largesse, Force ouvrière enjoyed an international standing out of all proportion to its domestic significance. Bergeron began to play a prominent role on the ICFTU executive board and, as a stern critic of Omer Becu's leadership, fed Brown insider reports of meetings that the latter, as a staff member, no longer attended. Yet his membership on the executive board was in a sense symbolic, representing, as former ITF general secretary Harold Lewis put it, a hope that France might one day be able to provide an affiliate that actually counted for something within the international. ${ }^{4}$

Force ouvrière's organizational weakness was readily apparent; Bergeron spent much of his first year in office grubbing for financial assistance from the AFL-CIO in the hope of receiving a $\$ 3$ million grant or cheap loan to purchase a new headquarters building that he claimed was a prerequisite for waging the anti-communist fight effectively. It was a sharp reminder of FO's client status vis-à-vis the Americans. Brown helped Bergeron draft his loan request to Meany and undertook to soften up the AFL-CIO president before presenting him with a translation of Bergeron's letter. He and Lovestone worked assiduously to persuade Meany to stump up the money, refusing to let the matter drop when the latter signalled that the AFL-CIO was not in the business of funding such real estate transactions. Meany declined to raise the issue in the AFL-CIO executive council and would go no further than to offer to guarantee a loan that FO would have to raise by its own devices. Yet this was of no help to FO since the interest payments on a commercial loan were beyond its means. ${ }^{5}$ Despite 
the dire warnings from Brown and Lovestone about the growth of sentiment for a popular front in France, it was a clear sign of George Meany's general disenchantment with European labour that he kept clear of any injection of finance into FO. Bergeron's value to the AFL-CIO would be less than Brown had originally hoped for.

A more substantial friend among European trade union leaders was the forty-two-year-old German construction workers' president and SPD deputy, Georg Leber, who had established himself as the leader of the "modernizing" wing of the DGB. Happy to discard the German labour movement's socialist, class-oriented ideology, he viewed free enterprise positively and agreed with the American emphasis on collective bargaining rather than political action as the main focus of union activity. He was a leading voice of pragmatic trade unionism within the DGB in the bitter struggle that broke out in 1962 over the government's proposed "emergency laws," which allowed constitutional rights to be breached in the event of a national emergency or uprising. The issue divided the labour movement between "modernizers" and those, led by the IG Metall chairman, Otto Brenner, who were wedded to a traditional socialist critique of capitalist society. Lovestone praised Leber's stand against the latter's "confusion, pacifism and fellow-traveller course." Spoken of widely as "the Americans' man" on the DGB executive board, Leber above all West German union leaders drew the most criticism from communist quarters while enjoying the support of the AFL-CIO. ${ }^{6}$

Unlike Bergeron, Leber needed no financial assistance from the AFL-CIO, but Meany was happy to extend moral support and agreed to address his union congress in Berlin in June 1963. Indeed, with President Kennedy visiting Berlin at the same time, Meany arranged for the president also to address the congress. In proposing their joint appearance, Lovestone predicted that it would "electrify the whole German labour movement ... and enhance the image of the Administration in Europe." Meany later accorded Leber red-carpet treatment when he made a return visit to Washington in 1965, laying on a dinner to which the late President Kennedy's brother Robert was invited as special guest. ${ }^{7}$

In their unrelenting hostility to communism, Bergeron and Leber stood out, but elsewhere in Europe, the ICFTU's formal policy of discouraging contacts with the Soviet bloc was increasingly being ignored. Sensing that CISL general secretary Bruno Storti was one of those beginning to shift his stance, Jay Lovestone wrote in 1964 asking him to clarify his position. It took all of ten months for Storti to respond. He claimed that Lovestone's letter had gone astray in his office, but now, eyeing the ICFTU presidency in succession to Geijer, he needed the support of the AFL-CIO and so replied cautiously that "dialogue [between East and West] is not superfluous. ... We believe in a relaxation... [but] it will not represent the giving up of ... values of democracy and freedom." 
However, the two European centres that caused the AFL-CIO leadership most concern were the British TUC and the German DGB. As far as Jay Lovestone was concerned, their behaviour would largely determine whether or not the principles underpinning the free trade union movement would survive.

Bit by bit between 1960 and 1966, the TUC reversed its position on contacts with communists overseas. Calls at the annual TUC conference for an end to the divide between the ICFTU and the WFTU, abandonment of the "cold-war mentality" in trade unionism, and for an extension of foreign visits to all countries were initially voted down, though over time the majority view shifted. George Woodcock, the TUC's largely apolitical general secretary, may have shared George Meany's lack of confidence in the ICFTU, but his assessment of the dynamics of the Cold War was quite different from Meany's, and he was central to the evolution of the TUC's thinking. For years he gave the impression of resisting the policy change while quietly but steadily helping to advance it. 9

By 1963 the TUC had abandoned any attempt to dissuade affiliates from liaising with unions in the Soviet bloc; it was for them to decide individually. That same year the TUC accepted an invitation from the Yugoslav Confederation of Trade Unions to exchange visits; ten senior union leaders became the first TUC party to visit a communist country since 1949. Privately Woodcock acknowledged that the TUC would ultimately be prepared to conduct exchanges with any trade union organization, be it in Spain or the USSR, provided that their meetings were devoid of "political" content and confined themselves to practical trade union matters. As in other European trade union centres, there was a revival of the mood of "1945" - when the idea of world trade union unity was in the air-though Kalmen Kaplansky, international director of the Canadian Labour Congress, reckoned that as yet it was still "only talk." ${ }^{10}$

However, in the immediate aftermath of the fractious Amsterdam congress of the ICFTU in 1965, the TUC accepted an invitation of the AUCCTU to visit the USSR the following summer on condition that the purpose of the visit would be solely to study the functions of Soviet trade unions and not to engage in political discussion. As Woodcock affirmed, the TUC couldn't conceive of a world where trade unions were indefinitely lined up against each other; a start had to be made somewhere to at least recognize the existence of the other side. ${ }^{11}$ The delegation that travelled to the Soviet Union in September 1966 was the first such TUC group to visit since the split in the WFTU. Symbolically, it was the most important development in re-establishing formal contacts with communist organizations since the formation of the ICFTU, a major contribution to the tide of détente that was now running high.

Yet, for Jay Lovestone, the visit was "a return to popular front tactics on a grand scale." The Soviet trade unions, he noted, were still an extended arm of the state and the communist party, and he pointed to the CPSU's March 1966 congress, where Party 
Secretary Brezhnev spoke in praise of the unions' newly enhanced role as "schools of Communism," and AUCCTU president Victor Grishin acknowledged that it was the responsibility of the party and its central committee to "formulate the tasks of the trade unions." ${ }^{12}$ Prompted by Lovestone, labour columnist Victor Riesel recorded that the TUC visitors to Moscow had been gullible and naïve. The KGB had supervised the trip; the British had been given red-carpet treatment and enjoyed some fine food, but their phones and hotel rooms had also been bugged, and he claimed that Meany now had access to US intelligence reports on the KGB's involvement. ${ }^{13}$

The DGB was more cautious in embarking on a program of visits to the Soviet bloc. More than most ICFTU affiliates, it had genuinely attempted to uphold the ICFTU's official policy and through the early 1960s had discouraged exchange visits to the Soviet bloc by its member unions. However, this line became increasingly difficult to maintain as Germans looked for ways of improving relations with their neighbours to the east. Voices calling for dialogue with the Soviet bloc grew louder, and in 1964 Walter Fabian, the editor of the DGB journal Gewerkschaftliche Monatschafte, wrote a personal article in support of such a policy. He was subsequently forced to resign his post, but there was an immediate campaign by the leaders of most DGB affiliates to have him reinstated. ${ }^{14}$

In spring 1964, as a party of young German trade unionists prepared to travel to Poland for a visit to Auschwitz in a gesture of atonement for Nazi war crimes, Ludwig Rosenberg highlighted the predicament faced by the DGB and called for a thorough review of ICFTU policy. The DGB had been loyal to the ICFTU but, as he explained, the German centre was also the one with the greatest stake in regularizing relations with the Soviet bloc. And unless it was free to engage directly with Eastern European countries, the DGB leadership risked losing control of these unofficial visits. ${ }^{15}$

Fearing that the DGB might unilaterally be preparing to drop its opposition to exchanges, Lovestone alerted Meany of the need to update ICFTU policy so as to reinforce the line against contacts with the communists. Given Omer Becu's diminishing authority, such divergent views made the issue too sensitive for the ICFTU to confront directly, and the opportunity to reassess the policy at the Amsterdam congress in July 1965 went begging. In the absence of the policy review it had called for, the DGB would now go its own way and align with the growing European interest in bridge building. In the wake of the Amsterdam congress, Irving Brown summed up the general picture: "The overwhelming opinion on Western Europe is moving ... in the direction of downgrading the danger of Russian Communism and upgrading not only the danger of Chinese Communism but what Europeans would call the super-giant policies of the U.S.A."16

By late 1965 the German labour movement had quietly embarked on exploratory exchanges with the Soviet bloc, initially through a visit by Heinz Kluncker, the young 
chairman of the public transport union, to a labour conference on health and safety in Prague. ${ }^{17}$ It was the first of several such low-key missions in 1965-66 that Kluncker undertook, acting as a stalking horse for the DGB. Concurrently Trud, the Soviet trade union paper, invited the editors of all West German trade union journals to visit the USSR, and in November 1965, DGB leaders attended a reception at the Soviet Embassy in Bonn celebrating the anniversary of the Russian Revolution. Lovestone advised Meany that such activities threatened to open the door to "wide penetration and subversion." There were divisions within the DGB leadership over the policy taking shape, with Rosenberg as chairman torn between the two camps. But Irving Brown's reading of the situation was that it was deteriorating seriously and unless the trend was soon reversed the consequences would be disastrous. Lovestone informed Meany: "Rosenberg, weakling that he is, is very panicky about the trend for acceptance of Soviet and satellite invitations on the part of his affiliates. He is not opposing it. He only wants to regulate the trend." In the absence of clear information on where this was leading, Meany now wrote directly to Rosenberg requesting an explanation. ${ }^{18}$

Rosenberg's reply-in a confidential letter he typed himself-explained that the policy was tentative and because of its sensitivity the DGB had deliberately kept the details from even the German foreign ministry. Representatives of German churches and political parties were beginning to visit the Soviet bloc with state backing, but the federal government had threatened to end support for this process if the trade unions didn't participate as well. The DGB resented such pressure but had decided to yield to government wishes. This was how he explained the secret diplomacy undertaken by Kluncker. The DGB would now wait until after its next congress in May 1966 before taking any decision on sending an official delegation to the Soviet bloc. Rosenberg was not personally committed to exchanges with the communists; arguments for and against were not black and white but appeared differently depending on whether viewed from Washington or Dusseldorf, and he protested: "No one is right to insist that their opinion is the only acceptable one."19

George Meany was intensely irritated by Rosenberg's special pleading and in a blistering reply rejected any suggestion that "liberalization" was taking place behind the Iron Curtain or that the unions of the Soviet bloc were in any sense "free" (the letter's angry tone is captured in its eighteen separate references to "so-called trade unions"). In developing countries, the knock-on effect of the example set by the DGB would also be damaging; inexperienced trade union leaders in Africa would find it hard to comprehend why they should refuse to deal with the East German trade unions offering them assistance when the unions of West Germany were themselves warming to contacts with the Soviet bloc. Moreover, the course being pursued by the DGB would give comfort to the WFTU in its present internal crisis by offering proof that its call for East-West rapprochement was sound and effective..$^{20}$ Meany's 
letter hinted at deep resentment over the German unions' lack of gratitude for past assistance from the Americans and closed on a bitter note that linked together criticism for German anti-Vietnam War protesters with those trade unionists who took their cue from Moscow in wanting to remove the US military shield in Germany: "I can assure you that if Moscow should, tomorrow, decide to revive its claims on West Berlin ... those who have been denouncing American involvement in Vietnam would demonstrate in support of Moscow's demand for the withdrawal of all American troops from Berlin." ${ }^{21}$ There was concern within the Bonn government at the deteriorating relations between the DGB and AFL-CIO and even talk of Chancellor Erhard inviting Meany to Germany to smooth matters. However, Lovestone advised against such a visit with the Christian Democrat leader, arguing that the "demagogues in the DGB" would use it against Meany just when "maximum AFL-CIO efforts are needed to prevent the pseudo-left from pushing it towards increasing rapport with Communist 'unions."' ${ }^{22}$ Rosenberg was himself alarmed at the rift that was opening up with the AFL-CIO and the possibility that the federation might not be represented at the DGB's congress in May 1966.

Only weeks before the congress was due to start, DGB international director Otto Kersten passed word through Irving Brown urging the AFL-CIO to send a fraternal delegate and thereby help Rosenberg face down his anti-American critics. Recognizing that it was out of the question for an AFL-CIO executive councillor to attend, Lovestone went himself and delivered a diplomatic statement in the forlorn hope that it would revive cooperation between the German and American labour movements and so offer encouragement to working people suffering under the yoke of Soviet bloc dictatorships. ${ }^{23}$ However, the congress voted to follow up the Kluncker initiative by supporting "information tours" to Eastern Europe. The stated intention was to obtain first-hand experience of the countries visited and overcome prejudices and misconceptions on both sides. In November 1966 an official DGB delegation left for an eleven-day visit to the USSR. The effect was to strain DGB-AFL-CIO relations for years to come. ${ }^{24}$

Ill feeling was compounded by what the AFL-CIO regarded as German labour's partial reporting of the internal American dispute between Meany and Reuther in the SPD's journal Vorwärts. When Georg Leber proposed to his fellow SPD leaders that the paper desist from unfriendly coverage, his plea was ignored. Lovestone pointed the finger specifically at party leader Willy Brandt and foreign affairs spokesman Herbert Wehner. Lovestone complained to the German labour attaché about similarly biased reporting in the DGB's paper Welt der Arbeit, and the German metal workers' journal Metall, deeming them guilty of "scandalous misrepresentations, misinformation and slanders." When later the German ambassador invited Lovestone to lunch to smooth matters over, he was promptly turned down. "Some people live in a fool's 
paradise," Lovestone fumed: "I am not thrilled by lunches with ambassadors. I have lived too long to be buttered up. We are in a fight and we are keeping an eye on all our opponents and those who serve and save our opponents," adding menacingly: "We will straighten out the accounts." 25

Hoping to repair the damage to relations with the AFL-CIO, Rosenberg invited George Meany to lead an AFL-CIO delegation to Germany to study "the trade union situation" and for talks about Vietnam. Irving Brown interpreted it as a positive gesture, the outcome of Georg Leber's pressure for "an exchange with 'our friends' rather than with the East." But Lovestone told Kuno Brandel, editor of the construction workers' journal and former colleague in the Communist Party (Opposition), that any such visit by the Americans would not be for social reasons- "only for a knock-down drag-out fight," and he wasn't sure that the AFL-CIO was ready for that at the moment. ${ }^{26}$ In fact, Meany responded with a tartly worded letter taking the DGB to task for adopting a factional stance on the internal AFL-CIO dispute with the UAW, complaining that "intervention by one ICFTU affiliate in the internal affairs of another national affiliate is anything but conducive to the unity and progress of the ICFTU" and demanding that this German behaviour cease. ${ }^{27}$

A further letter from Rosenberg failed to appease Meany, who complained angrily again about personalized attacks in the German labour press. Gewerkschaftliche Monatschafte, whose publisher Rosenberg was, had spoken of the AFL-CIO as "dominated by the seventy-two-year-old George Meany" who was "insensitive and unimaginative" and whose foreign policy "limits itself to a large extent to sterile anti-Communism of the Cold War ... which is to the right of Johnson-Rusk, of the Catholic Church and of more intelligent employer circles." A publication of the metalworkers', Der Gewerkschaftler, had speculated on the possible breakup of the AFL-CIO and suggested it would probably be "a good thing." Describing the comments as "unfounded, unwarranted and spiteful," Meany sent Rosenberg the text of a recent AFL-CIO executive council statement on the subject with a request that the DGB publicize it. Only when goodwill had been restored would the AFL-CIO be willing to send a delegation of senior vice presidents to Germany as requested. ${ }^{28}$

Yet barely a week later Lovestone learned that Rosenberg had circulated within the DGB literature from the UAW relating to its complaints against the AFL-CIO. Concurrently a joint press conference in Dusseldorf given by Rosenberg and V. I. Prokhorov, leader of a visiting delegation from the AUCCTU, announced a deepening of their program of reciprocal visits. But beyond this, the two leaders also spoke about the war in Vietnam, with Prokhorov carefully seizing the opportunity to identify with DGB opposition to "the dirty war." For them to be sharing a platform with the AUCCTU was bad enough, but to be united in opposition to a cause that the AFL-CIO leadership strongly supported was too much. A couple of 
weeks later Meany cabled Rosenberg cancelling the planned visit by the AFL-CIO vice presidents. ${ }^{29}$

\section{Brown in Africa: Launching the African-American Labour Centre, 1965-68}

George Meany's growing dissatisfaction at the way Western European trade union centres failed to stand up for free trade unionism with the same commitment that the Americans showed ruled out the likelihood of the AFL-CIO continuing to maintain an ongoing presence on the continent. It ensured that Irving Brown would devote most of his attention to Africa and the AALC. However, at Omer Becu's request, Brown continued to occupy the position of director of the ICFTU's New York office pending the appointment of a replacement. In effect he kept the job until early 1967 , a second string to his bow that allowed him freedom to travel and politic more widely.

The AALC began life just as the ICFTU was winding down its African program. Indeed, it was George Meany's intention that the AALC would largely replace the ICFTU in the region, flying the flag of anti-communism more effectively than the ICFTU's ill-starred regional body AFRO had managed to do. AFRO was "put on ice" at the Amsterdam congress, with formal control transferring to the Brussels secretariat. Even British diplomats, instinctively wary of the American interest in Africa, felt it appropriate to offer a cautious welcome to the AALC, though the British labour counsellor in Nigeria, a country soon to be the object of intense American efforts, opined that he had "no particular wish to have Irving Brown operating in his maladroit way in my parish." A quiet word with his counterpart in the US embassy in Lagos, he hoped, would "contribute to curbing Brown's less desirable activities." ${ }^{\circ}$

There was certainly scope for the Americans to counter Soviet and Chinese influence, and in that sense the notion advanced in the early 1960 s of Africa becoming the new front in the Cold War still resonated. However, free trade unionism as understood by Americans was hardly on the agenda, even among Africans who were anti-communist. Union organization independent of government was under pressure in these new one-party states. National centres were increasingly obliged to observe "positive neutrality" and so withdraw from the ICFTU, while the prioritization of development strategies required them to toe the government line in focusing on nation building rather than the interests of workers per se. It was hardly surprising that as he stepped down from the ICFTU presidency in 1965, Arne Geijer wondered whether there still existed anything that could be called a genuine free trade union movement in Africa. ${ }^{31}$

Avoiding publicity in the early stages of its program, with a small initial staff of six but a starting budget of slightly more than $\$ 1$ million (9o percent of it contributed by AID), the AALC adapted to the unpromising climate for free trade 
unionism by concentrating on assistance with training for vocational skills, the establishment of cooperative enterprise, and the provision of welfare schemes. This was to be the bread and butter of AALC activity, and it was soon the best-resourced union operation in Africa. ${ }^{32}$

By 1968, with total federal funding of $\$ 2.4$ million, a field staff of sixteen representatives or advisors, and around a hundred African trade unionists engaged as educators, the centre claimed to have programs of one sort or another in thirty-three countries. Of note were training colleges in the Congo/Zaire, Kenya, and Chad devoting much effort to equipping trade unionists with skills for commercial and secretarial work; a college in Ghana focusing on industrial relations with an emphasis on labour-management "peace"; a project for training in printing techniques at the Kenya Polytechnic; training for medical assistants in Tanzania as part of "village development"; mobile health clinics for workers in unionized firms in the Congo and Ghana; and even shower and toilet facilities for dockworkers in Lagos. ${ }^{33}$

While Irving Brown made favourable noises about cooperating closely with the ICFTU, the latter was largely kept in the dark about American intentions in Africa. The reality was that Brown's role in all this was essentially that of a roving deal maker, fronting the "sales drive" for assistance schemes but operating essentially at the political level. On a routine basis, he interfaced with presidents, prime ministers, and relevant cabinet ministers in the target countries. Reports home from Africa were peppered with references to high-level political contacts. Thus: "breakfast with [Ugandan] Prime Minister Obote and his Foreign Minister ... anxious for discussions about AALC ... most amiable meeting”; “just left Vice President Moi [of Kenya] ... excellent discussion-we have complete understanding which should lead to great possibilities ... this establishes a direct relationship with the highest offices in the country"; with Ghana's new Prime Minister Busia "signed a three-way AALC-GTUC-government of Ghana agreement" even before Busia's cabinet had been named; "spent some time with [Dahomey] President Maga and left him a memo"; in Tunisia for a meeting with Prime Minister Nouira: "This may lay the groundwork for an AALC office in Tunis"; and "long discussion with President Mobutu . . . very positive." 34

In early 1968, vice president Hubert Humphrey undertook a nine-nation tour of Africa and invited Irving Brown to accompany him. Brown made sure Humphrey met the important trade union leaders while, at the same time, the vice president's presence helped to raise the profile of the AALC. In Ethiopia, Humphrey was about to introduce the AALC director to Emperor Haile Selassie, Africa's pre-eminent statesman, but was cut short. Selassie told him he already knew Irving Brown very well. During the tour, the American ambassador to Kenya tried to persuade the vice president that Brown was persona non grata in Kenya and should be excluded from 
the party to visit the country. Humphrey disregarded the advice and later wrote telling George Meany how well Brown had been received in Nairobi, where the local press had actually given him a warmer welcome than the vice president himself. ${ }^{35}$

At its best, AALC technical assistance was considered to be of genuine benefit to the recipients. From British diplomats in West Africa there was grudging praise for its achievements. Despite British disdain for "Irving Brown and his methods," reports by the first secretary (Labour) in the British High Commission in Ghana recorded:

Whether the ICFTU or the British TUC like it or not, the Africans lap up help given by the AALC (most of it well-conceived and meeting real needs) so they must not be surprised if AALC spokesmen exercise influence in African trade union circles. In contrast, the Eastern Bloc achieve little by their aid programmes which consist almost entirely of scholarships to Bloc countries. ... The AALC has developed a presence in Africa ... and it has some first class chaps running its ventures. ${ }^{36}$

Yet, for Irving Brown, the specific focus of these vocational programs was of less interest than the opportunity it gave him to keep a finger on the pulse of African politics and, where possible, influence directly the politics of the labour movement. The hope was always one of shaping a pan-African movement oriented to the West, either created in opposition to AATUF (which hardly amounted to much) or by winning over elements in AATUF who could be encouraged to withdraw from the Soviet embrace.

The AALC planned its biggest effort in Nigeria, strategically important because of its rich natural resources. ${ }^{37}$ It had a proliferation of mainly small, in-house unions operating beneath organizationally weak but competing national centres, of which the two most important were the pro-Western United Labour Congress (ULC), affiliated to the ICFTU, and the Nigerian Trade Union Congress (NTUC), which traded on its support for "neutrality" while in reality being an outrider for the WFTU. With a reported membership of 300,000 (a figure that many doubted), the ULC claimed to be Nigeria's most powerful trade union centre; Brown's hope was to give substance to that claim..$^{38}$

An American-led ICFTU organizing campaign was launched with a proposed budget of $\$ 150,000$, 40 percent of it provided by the Americans. A British diplomatic note from Lagos observed: "The character of the 'confrontation' in Nigeria is changing from ICFTU versus Eastern bloc to America versus Eastern bloc." ${ }^{39}$ Brown insisted on firm American control of spending decisions, and over time that control was intensified. The Nigerians would have to submit to this approach or face the withdrawal of American backing. Brown emphasized that it meant "direct control of all operations through myself in cooperation with our representatives on the spot." The 
AALC would underwrite the cost of a small clerical and technical staff for the ULC headquarters, including "a confidential secretary (someone that we would furnish)." ${ }^{\circ}$

However, hopes for rapid progress were blighted when the political situation changed radically following a military coup in January 1966 and a counter-coup six months later. Nigeria would soon be propelled on the road to widespread ethnic violence and civil war over Biafra's quest for independence. Irving Brown sought to win favour with the new military government through a confidential memorandum sent to senior army officers, making a plea for the ULC to be accorded special status. The memorandum stressed the close link between the ULC and the AFL-CIO and suggested that the best way for the federal government in Nigeria to preserve national unity would be to enlist American support. The situation, he said, called for "extraordinary expenditures" to support "friendly forces" and proposed that the ULC be helped discreetly to strengthen its activities as the "sole, loyal and responsible trade union centre." The memorandum pointed out that the AFL-CIO and AALC were ready to do anything to help-as consultants, as investors, and as a force attempting to influence official American policy toward Nigeria. Brown concluded:

I should welcome an opportunity to meet with ... the head of your Government, to discuss discreetly and practically how we can work together towards common goals. I am sure that the leaders of the labour movement of America and especially its President, George Meany, are fully prepared to examine ... all means within our legitimate power to be of service in the great task to preserve Nigerian and therefore African unity. ${ }^{41}$

Yet the stumbling block for the AFL-CIO was that the Johnson administration was reluctant to become involved in the bloody Biafran conflict, which ran from 1967 to 1970. The ULC complained as AID appropriations were cut back. All Meany could do was to try to reassure its leaders that he shared Nigeria's disappointment that Washington had refused to sell it arms. ${ }^{42}$

\section{Building Pan-African Links: Ghana and Congo}

As scope for constructive work diminished in Nigeria, it opened up in the Congo and Ghana. Colonel Mobutu seized power in the Congo with American backing in November 1965 and imposed military rule. Two weeks later, a military coup in Ghana ousted Kwame Nkrumah, AATUF's main backer, forcing it to close its headquarters in Accra. Irving Brown now redirected AALC effort to forging links among African labour centres considered pro-Western, bidding thereby to challenge AATUF's claim to be the voice of pan-African labour. In this the Ghanaian and Congolese/Zairian trade unions became pivotal. 
The AALC was quickly on the scene in Accra, where Arnold Zack, an AALC contract worker from the CIA, was assigned to meet with Benjamin Bentum, who had been handed charge of the unions by the National Liberation Council. Bentum appealed for technical assistance from Western trade union centres generally but specifically requested $£ 14,000$ from Brown to enable him to fight an election that would confirm him as general secretary of the Ghana TUC. Jay Lovestone quickly notified Meany that he had obtained $\$ 10,000$ "out of the Berlin activities" to help build free trade unions in Ghana. ${ }^{43}$ In what was intended as a friendly gesture toward the AFL-CIO, Omer Becu-now in his final months in office-agreed that the Americans should take the lead in the new situation in Ghana, and in the following weeks, Brown shuttled between Brussels and Accra helping to coordinate the American-ICFTU effort, assisting with the recruitment of a head office staff for the Ghana TUC, equipped to conduct research, publicity and, to use Brown's portmanteau term, "cadre training." ${ }^{4}$

Working with Bentum, Irving Brown set out to extend AALC influence by encouraging a new pan-African initiative-"a moderate and genuine trade union set-up"-among independent trade union centres. By October 1966 Bentum was sounding out trade union opinion in Nigeria, Dahomey, and Togo, and over the next two months he signed joint communiqués with the centres in Togo and Ivory Coast espousing "true unity of African trade unions" and a commitment to work toward the formation of a provisional committee. Further Ghanaian delegations to the moderate states of west and central Africa were undertaken; the US labour attaché in Ivory Coast liaised with the Ghana TUC and his local AALC representative, and Bentum was invited to the United States as a guest of the AALC.

Claiming that support was spreading to countries such as Senegal and Kenya, Bentum made plans for a preliminary meeting of interested centres at the ILO's annual international labour conference in Geneva in June 1967. However, it came at a sensitive moment. The cost of convening the meeting and financing travel costs to Geneva for the twenty-one delegates was a substantial amount for the Ghana TUC to find. With Tom Braden's recent Saturday Evening Post article about CIA financing of American labour's foreign program resonating internationally, African delegates expressed misgivings about the source of funding for the event. They made a point of insisting on the right of non-intervention in African national affairs, while Bentum was forced to issue a statement denying AATUF claims that the conference being planned later for Accra was really a product of outside interference in African affairs. ${ }^{45}$

To what extent African sensitivity to possible American machinations worked against Bentum's project is a matter for guesswork, but his Accra conference, which followed three weeks later, was seen as a flop. The general impression was that the American "affair" with Bentum had led nowhere. Nonetheless, a perception that the 
Americans were playing a lone hand in these West African countries was a matter of concern in British government circles. When the British High Commission in Accra sought guidance from the Foreign Office in London on how to respond to these developments, it was advised:

It is important that in an area of common concern we should not work at cross purposes with the Americans... . [However,] it seems unlikely that the AALC, given its background, resources, present leadership and the increasing tendency of the AFL-CIO to go it alone, would wish to associate British trade unionism regularly with its activities; or that the TUC would be willing to be harnessed to them. ${ }^{46}$

Indeed, the go-it-alone approach served only to sow mistrust in the wider international labour movement.

Complementing Brown's activity in Ghana was a parallel effort in the Congo. The country had been in constant turmoil since Belgium suddenly granted it independence in 1960. However, it boasted a substantial trade union movement with upward of three quarters of a million supporters. Of three trade union centres, two-the Confédération des syndicats libres du Congo (CSLC) and the Fédération général du travail du Kongo-identified with the ICFTU, while the largest, the Union des travailleurs congolais affiliated to the Christian international, was reckoned by many to be the strongest democratic trade union organization in Africa.

Newly in power as military strong man, Colonel Mobutu faced armed revolts in 1966 and 1967 but defeated them with air support from the CIA. ${ }^{47}$ As he gained the upper hand in 1967 he set about political reconstruction under a new constitution that expanded and centralized state power, designating himself head of state, head of government, commander-in-chief of the armed forces, and "Father of the Nation." In May 1967 he dissolved all political organizations and established the Mouvement populaire de la révolution (MPR) as the only legal political party. In so doing, Mobutu brought key labour leaders into government, appointing them to the MPR's political bureau and granting them representation on a proposed tripartite government advisory body, the National Labour Council. Alphonse Kithima, the politically ambitious general secretary of the CSLC, became the MPR's director of policy, moving on within a matter of months to become Mobutu's minister of labour and, within a year, minister of education..$^{8}$

To ensure the Congo's continued membership in the western camp, the US government supported Mobutu with assistance in almost every aspect of life, and in this context Irving Brown also threw the full backing of the AALC behind the military-led government. The AALC wagon was hitched to the Mobutu regime, and over the next half-dozen years Brown's reports presented a positive picture of developments in 
the Congo. Whereas Belgian trade unionists offering assistance to their Congolese counterparts had been discouraged by the military government, there was no such restriction on the efforts of the Americans. An AALC representative, Paul Barrette, was deployed in the Congo from November 1966 and began a program of training for union branch secretaries, the first step toward the creation of an AALC training institute. ${ }^{49}$

By 1968, Brown was reporting that the AALC and AFL-CIO were "in great shape with the Congolese" - both the government and unions. The training institute in Kinshasa had become a reality and was "humming along" with over a hundred students taking vocational courses each day..$^{50}$ With Mobutu seen as the AALC's most reliable supporter, the following year planning began for a pan-African press service to be established in the country with a bilingual bulletin, Perspectives syndicales/ Labour Perspectives, sourced from American, European, and African union journals and serving all Africa. ${ }^{51}$

In the coming years, Brown's reports continued to portray a flourishing relationship with the Mobutu regime. Occasionally he would suggest that the situation left something to be desired: "There must be very soon some improvement ... for the people or else there may be some new explosions"; Alphonse Kithima "is doing a first class job as Minister of Education but appears to be getting too rich and comfortable"; "Mobutu has gone too far in an authoritarian direction and there may be some trouble for the unions." But such observations were typically mere asides, offered without elaboration. In general the more important message was that the Congo was "stable and secure." Toward the end of his tenure as director of the AALC, Brown was arranging for Mobutu to visit the AFL-CIO headquarters in 1973, telling George Meany that he had "had a long discussion with President Mobutu about the expansion of our relationship with them and that Mobutu's visit to America "would be very helpful for our entire work, not only in Zaire but in a good part of Africa where Mobutu's influence has been especially good in recent days."52

However, it was precisely because of his association with President Mobutu that Brown's parallel appointment as director of the ICFTU's New York office finally came to an abrupt end in 1967, thus restricting him for the most part to work in Africa for several more years. That same relationship had a decisive impact on the choice of a successor to Omer Becu then under consideration in Brussels. The crucial factor was that, as part of Mobutu's bid to impose his personal rule through the MPR, the various Congolese union centres were required to unify and subordinate themselves to ultimate direction by this single political party, and Irving Brown acted as a key agent in helping to force through the unification of the centres with the haste demanded by Mobutu. 
It was reported to the ICFTU that Brown had warned the Congolese unions that if they balked at unifying, they would be compelled by Mobutu to do so, and he made it clear that the AFL-CIO backed Mobutu. An earnest of the AALC's intentions was that training courses that Barrette had been offering to the separate union groups were now to be given to combined classes with immediate effect. ${ }^{53}$ Brown promised to reward the unions for their cooperation, and at the AFL-CIO convention in December 1967 he duly signed with their representative an agreement providing for the establishment in Kinshasa of the National Institute for Occupational Training, which offered vocational training, developmental work on cooperatives, and an American-run program of seminars for trade unionists.

Getting wind of Brown's activities, the ICFTU was concerned as to how far he was in league with the Mobutu regime and whether he was still trying to bring about a pan-African labour organization based on Ghana and the Congo. As the British labour attaché in Brussels noted: "ICFTU are concerned with Brown's activities in Kinshasa. They understand that he is active in some way in trying to bring about unity of the three trade union groups. They do not know what exactly he is doing, or what pressure he is applying, but they are mistrustful of him.".54

\section{Repercussions from the Congo: Ave Atque Vale Jef Rens}

Omer Becu was in the midst of a third extended period of sick leave in eighteen months in November 1966 when the ICFTU executive board meeting in Barbados decided that a successor needed to be appointed. Of the various names mentioned, two potential candidates stood out: Jeff Rens, until recently the widely respected deputy director-general of the ILO, whose roots were in the Belgian labour movement and was backed by the AFL-CIO; and Harm Buiter, the Dutch general secretary of the European Trade Union Secretariat, the coordinating body for national centres belonging to the European Communities (Economic, Euratom, and Coal and Steel), who was the preferred candidate of ICFTU president Bruno Storti.55 Under pressure to go, six weeks later Becu submitted his resignation on grounds of ill health. A special meeting of the executive board's inner subcommittee convened in mid-January 1967 judged that Rens had most support and should be appointed subject to confirmation by the full executive board meeting in March.

Rens's nomination came as a relief to the AFL-CIO leadership, whose faith in the ICFTU was ebbing away. Ahead of the Barbados meeting, Irving Brown had described the situation in the organization as "close to hopeless," warning that without a positive outcome (meaning the appointment of Rens) the outlook for the ICFTU as an important decision-making body was bleak. ${ }^{56}$ The Americans regarded Rens as a safe pair of hands who might be counted on to nurse the ICFTU through a 
difficult period. He was currently the part-time chairman of the Belgian government's National Council for Science Policy and agreed that prior to his formal appointment he would spend some time in the ICFTU headquarters to familiarize himself with the secretariat.

A parallel appointment that the Americans welcomed was the ICFTU's decision to hire Morris Paladino, currently deputy executive director of AIFLD, as assistant general secretary. It was the fulfilment of Becu's promise of 1960 to install in the Brussels secretariat an American who enjoyed George Meany's confidence. ${ }^{57}$ If the ICFTU were to have a future, much would depend on the effectiveness of Rens and Paladino working in partnership.

Paladino took up his post in Brussels in February 1967, but before the anticipated Rens-Paladino leadership team had a chance to establish itself, American hopes of a fresh start for the ICFTU were thrown into disarray as a consequence of the news recently received from the Congo. During his visits to the Brussels headquarters, Rens had learned of Brown's recent activities, and especially his pressuring of the Congolese Christian and secular union centres to amalgamate as part of Colonel Mobutu's program to incorporate them into his centralized system of government.

Rens protested to Meany about Brown's intervention, noting that it was not the first time he had heard of such behaviour by the American and that it ran counter to the kind of genuine international trade union policy he intended to favour if he were to become ICFTU general secretary. He requested an urgent meeting to discuss the matter with Meany before the executive board meeting in March, where confirmation of his appointment was expected. As he explained:

I would ... find it unacceptable if Irving Brown were to continue going around, invoking the power and the influence of the U.S. to impose his views to trade unionists of developing countries.... If he is allowed to continue in Africa and elsewhere the kind of operations ... under the official patronage of the American labour movement ... no ICFTU Secretary can succeed in his job. This [proposed meeting with Meany] I consider indispensable before entering in the new post. $^{58}$

Meany failed to respond to this or a second similar letter from Rens. In the absence of the assurances sought, the Belgian withdrew his candidacy one week before the executive board met to confirm his appointment. To spare all-round embarrassment, he withheld his real reason for withdrawing, inventing a fanciful story that the Belgian government had put pressure on him to work full time for the National Council for Science Policy. In a letter to the ICFTU, he described this account as "frank and full": "Above all do not think it was the difficulties inherent in this duty which disheartened me. I have never been afraid of difficulties." 59 Rens was nothing if not a diplomat. 


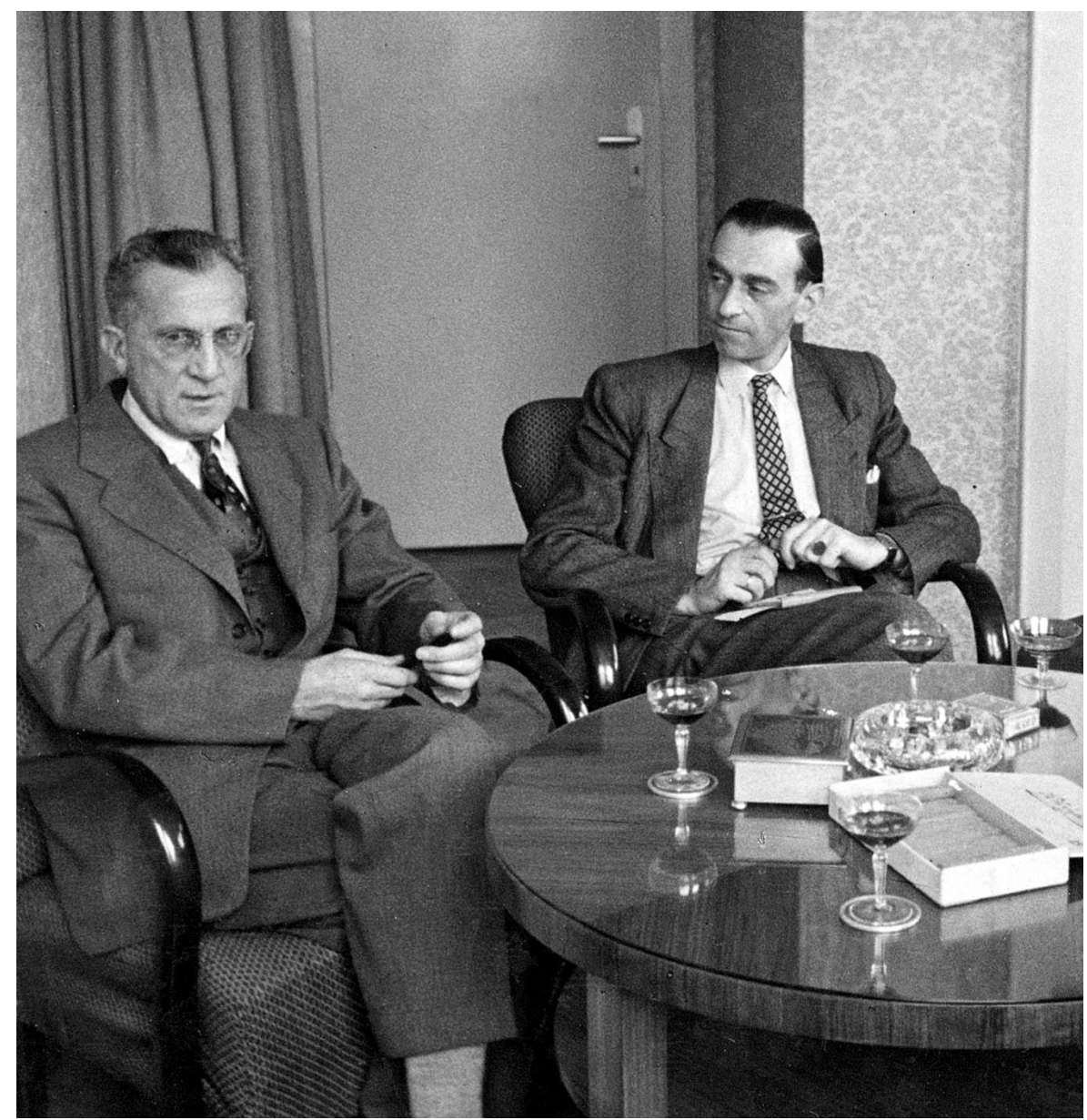

Figure 15. Jef Rens (left), with Ludwig Rosenberg, in 1951. At the time of Omer Becu's resignation, Rens was the Americans' preferred candidate for the position of ICFTU general secretary, but Brown's unconstrained activities in Africa persuaded him to turn down the job. Courtesy of AMSAB-Institute of Social History, Ghent. Copyright $\odot$ AdsD / Friedrich-Ebert-Stiftung.

President Bruno Storti asked the appointing subcommittee whether they wanted Rens to appear before them and elaborate further, but Meany was quick to spot the danger of dwelling on the subject and argued that a post-mortem would be pointless. With his concurrence, the European members of the subcommittee were asked to propose another candidate. ${ }^{60}$ Two days later, at a meeting between Irving Brown and Alfred Braunthal, the senior assistant general secretary, it was mutually agreed that Brown would vacate the post of ICFTU New York director, held pro tem since 
October $1965 .{ }^{61}$ No reason was given, but it was clearly a product of the criticisms made by Rens. What role Meany played in this decision other than to approve it is also unclear. His failure to respond to Rens's letters suggests that he felt no urgent need to placate the would-be general secretary; the signs were that the ICFTU was now peripheral to Meany's vision of what needed to be done in the international field. As the biggest contributor to ICFTU finances, the AFL-CIO still had a stake in the organization that needed to be safeguarded. But with Paladino at the heart of the Brussels secretariat, Meany doubtless considered the federation's interests to be adequately protected. In such circumstances it made sense to Meany for Brown to concentrate on work in Africa.

Evidently unaware of Rens's letters to Meany, Jay Lovestone viewed his withdrawal as a major setback that was now likely to lead to the appointment of a less qualified European as general secretary, as he wrote to Kuno Brandel:

I don't entertain any fond hope that the ICFTU can recover from this blow. All I can assure you is that if the Europeans prefer flirtations with Moscow to partnership with us ... I don't entertain any profound conviction that we can again rally American labour to save their necks as ... when we smashed the WFTU.

His big fear was that Harm Buiter, an ambitious Dutchman currently heading up the European Trade Union Secretariat, and with close links to the leadership of the International Metalworkers' Federation, would inevitably be the leading candidate to fill the vacant post. ${ }^{62}$

Bruno Storti had already sounded out Buiter as to his availability. Buiter confirmed his willingness to be a candidate but also submitted written "reservations." He stipulated that his nomination by the executive board would need to be unanimous or nearly unanimous, including the "definite agreement" of the large affiliates outside the six countries of the European Common Market. As general secretary he would insist on remuneration commensurate with the importance of the post. The ICFTU would also need to have a sufficiently large budget to fulfil its mission. Noting that the solidarity fund had just "undergone the American operation," he remarked tartly that he was not interested in heading up an organization "whose action is limited to sending telegrams of sympathy or of protest." Lastly, he insisted on "a blank cheque" to reorganize the secretariat, with what he called "the big fellows," accepting that there could be no special protection for their respective "favourites" among the staff. Buiter was not one to sell himself short; the phrasing of the letter captured well his self-regard and bluff style. And, importantly, his preconditions on finance and freedom to reorganize ICFTU personnel were directed particularly at the AFL-CIO. ${ }^{63}$ 
Storti kept the letter confidential, but in the summer months of 1967 Lovestone got wind of it and eventually managed to obtain a copy from a contact in Storti's office.

The European members of the appointing subcommittee authorized Storti to negotiate the terms on which Buiter might be engaged, with final confirmation of the appointment left to the full executive board meeting in October 1967. Sitting in on the subcommittee meeting as an observer was James Suffridge, attending as Meany's personal representative. He declined to participate in the discussion beyond telling the members that if they favoured Buiter, the AFL-CIO would go along with it. Earlier, in a private discussion with Storti, he had inquired whether any of the three current assistant general secretaries was qualified for promotion to the general secretaryship, clearly with a view to pressing the case for Morris Paladino. Storti responded that Paladino was "too new," and merely shrugged and smiled when Suffridge observed that Paladino did have thirty years' experience in the free trade union movement. The obvious conclusion, Suffridge later reported to Meany, was that no American was likely to be acceptable for the top job. ${ }^{64}$

Irving Brown made a point of being in Brussels when the proposal to nominate Buiter was being discussed, aiming to take the temperature of the organization. The following week he sent Meany a lengthy appraisal of where the ICFTU was heading, with advice on how to react. The burden of his letter was that the ICFTU was likely to become a more inward-looking, Eurocentric organization, with the British TUC exerting considerable influence. As such it was likely to shy away from tough policies toward totalitarian regimes and their labour organizations. With the ICFTU's interest in the developing countries likely to wane, Brown recommended that the AFL-CIO reinforce its independent work in Latin America, Africa, and Asia "while still offering to cooperate with and implement ICFTU decisions to coordinate more closely all its international activities with those of the national centres and the ITS."

To protect American interests within the ICFTU, Brown argued that it was important to reinforce Paladino's standing as assistant general secretary, ensuring that his "organizational and coordination responsibilities" were officially recognized and that he had sufficient means to function effectively. In other words, whatever cutbacks were imposed in other areas of ICFTU activity, Paladino's sphere of operations would need to be protected. Paladino also needed to be supported by the appointment of another assistant general secretary who shared the AFL-CIO world view-Brown's preferred candidate was Pierre Felce, the general secretary of Force ouvrière's transport workers' union. This proposed appointment, intended to increase the influence of FO within the ICFTU, was something Brown had already agreed to with André Bergeron. ${ }^{65}$

Brown signed off on an uncharacteristically diffident note: "I hope you don't mind these remarks which have been inspired by my recent trip." In fact, George Meany 
did mind. As Brown subsequently related to Stefan Nedzynski, at his next meeting with the AFL-CIO president in Washington Meany brandished the letter and asked him: "Irving, what is your job?" Perplexed, Brown replied: "AALC Director." “Then stick to it!" Meany barked, bringing the conversation to an abrupt close. ${ }^{66}$

It is possible that Brown had simply caught Meany on a bad day, though the latter's reaction seems to have been rooted in something deeper. He had received Brown's missive in the same week that Tom Braden's disclosures of CIA funding of FTUC activities in Europe were hitting the headlines, and it may be that he was annoyed at being forced to deny in public allegations that he knew were true. But the most plausible explanation is that Meany was no longer interested in receiving Brown's expert analyses of what was happening within the ICFTU or advice on how AFL-CIO strategy and tactics should be fine-tuned in response to the internal politics of the ICFTU. Meany's attitude toward the international was now firmly fixed and was not open to challenge. He had recently agreed to Brown's quitting his ICFTU post, to be replaced by Paul Barton, and in Paladino he had his own nominee in situ as ICFTU assistant general secretary-and presumably he felt that American interests were thereby sufficiently protected.

Whether or not Meany had intended to deflate Brown, that was evidently the effect of his sharp put-down. Nedzynski recalls a disconsolate Brown telling him about his meeting with Meany and the fact that he was now largely confined to fighting the threat of communism in the relative backwaters of Africa. After this experience, it would be a full eighteen months before the AALC director again wrote directly to Meany about ICFTU affairs.

Yet Irving Brown was still the man Lovestone relied on for sensitive missions. From time to time the AALC director would turn up in critical situations at locations far beyond his African bailiwick. One such instance was in early 1968 when he was sent to South Vietnam for two weeks immediately following the Tet Offensive. His mission was to give direction to the newly established Asian-American Free Labor Institute and to put the AFL-CIO's joint program with the Vietnamese Confederation of Labor (CVT) "on the map." Led by Tran Quoc Buu, the CVT was facing particular difficulties, with members imprisoned following a recent strike of power workers. Brown was tasked with negotiating their release in talks with the president, General Thieu, and the vice president, Air Marshall Ky. ${ }^{67}$ On another assignment a few months later, in the aftermath of the general strike that accompanied the "May Events" in France, Brown was sent to Paris to assess the prospects for a renewed program of assistance to the Force ouvrière unions..$^{68}$ In October of that same year, he was dispatched to Finland in an unsuccessful bid to prevent the imminent reunification of the Finnish trade unions as a result of which the pro-American Suomen Ammattijärjestö (SAJ), launched only eight years earlier, would soon be reabsorbed 
into the national centre, Suomen Ammattiliittojen Keskusjärjestö (SAK), in which communists still had a strong presence. ${ }^{69}$

Just as George Meany had brushed aside Irving Brown's latest advice on dealing with the ICFTU, he also closed his ears to Jay Lovestone's attempt to persuade him to oppose the appointment of Harm Buiter. Lovestone instinctively mistrusted Buiter because of his long-standing contacts with Otto Brenner, the leftist leader of the German metalworkers with close links to Walter Reuther. He spent the summer of 1967 intriguing in the hope of derailing the Dutchman's chances of being confirmed as ICFTU general secretary, his stance hardening when he became aware of the terms Buiter had set out for his appointment. Lovestone tried to embarrass Storti into making public the relevant letter with its "vicious anti-American touches," and he denounced the ICFTU president as a "Buiter ally" when he refused. He wrote to Paladino:

I think the worst mistake would be to assume that Buiter is already elected.

I have grave doubts whether the AFL-CIO will support this character. He is anti-American to the core. . . . President Storti can tell you much about it but he has chosen to keep quiet and to hide things in re this matter. ${ }^{\circ}$

Hoping to persuade Meany to renege on Suffridge's commitment to the Europeans that if Buiter was their choice, the Americans would accept it, Lovestone wrote to him emphasizing Buiter's "lack of qualification" and proposing deferment of any appointment until the next ICFTU congress scheduled for summer 1968 (later put back by twelve months) to allow for a renewed search for an alternative. He repeated the case made earlier by Brown for Pierre Felce to be supported as a candidate for assistant general secretary to prevent Paladino being isolated in the secretariat. ${ }^{71}$ Lovestone's support for Felce was reinforced when he learned that Buiter, alert to the danger that the Americans might succeed in foisting the Frenchman onto the ICFTU secretariat, had quizzed Felce critically about his pro-American line, making clear his disapproval and telling him accusingly: "You are the Americans' man."72

Lovestone reckoned to be making progress with Meany in his campaign against Buiter, claiming that his latest "categoric" position was to tell the Europeans: "Gentlemen: if you want him, you can have him but he will not have our confidence or support and we will not vote for him." If so, it was a step back from the commitment given by Suffridge, but Lovestone hoped to push Meany further into accepting the "absolute necessity" of voting against Buiter. He predicted that executive board would not favour a man "who sees the highest post in the labour movement in terms of maximum dollars and cents." Buiter, he argued, did not reveal "any genuine constructive interest in the international labour movement but discloses only a character on the make who only wants the dough. We don't buy this."73 
Yet all this was so much wishful thinking by Lovestone. Meany was aware that outside Europe, Buiter lacked strong support. But he was firmly backed by the more powerful European centres, and even André Bergeron was in his corner, loath to be isolated among other European labour leaders. ${ }^{74}$ As in his earlier dismissal of Irving Brown's offer of guidance, Meany simply ignored Lovestone's advice and stuck to his initial position as conveyed to the ICFTU by Suffridge. There was no point in opposing Buiter only to find the AFL-CIO without friends. Meany could-and would-deny the ICFTU the funds for anything more than basic activities. But his general attitude was that the AFL-CIO was now ready to go it alone in the developing world and that it was up to the ICFTU to demonstrate reasons why the Americans should invest much time and effort in a body that had disappointed time and again.

There had been talk within the AFL-CIO of Meany leading a powerful team of federation vice presidents to the crucial executive board meeting in October 1967, but he decided to drop out a couple of weeks before they were due to depart, leaving it to George Harrison and Joe Beirne to represent the AFL-CIO. Their instructions on the choice of general secretary were simply to abstain. It said something about Meany's changing relationship with Lovestone that the latter was not informed directly about this decision and only learned about it from the grapevine. He admitted that it made the situation "extremely difficult." Close observers were now beginning to sense a waning of Lovestone's influence. ${ }^{75}$

At the last minute, Lovestone was assigned to accompany Harrison and Beirne to the board meeting, and he clung to the hope that the vote might go against Buiter. Rumours that Buiter was mainly interested in a high salary and the right to travel first class had been assiduously spread around, and these weighed against him among some delegates. In the voting, the Americans dutifully abstained. Beirne told the meeting that the AFL-CIO was concerned at the lack of a general secretary over such a long period and wanted the post filled. "If Mr. Buiter could impartially carry out this task, as the AFL-CIO hoped, his organization would be the first to support him." As the only candidate, Buiter was then narrowly confirmed as general secretary with thirteen votes for, but with an embarrassing ten abstentions. ${ }^{76}$

Even then Lovestone was reluctant to accept it as the final word. Given the number of abstentions he insisted that Buiter could hardly claim a mandate, and he reported to Meany that the result had been influenced by Bruno Storti's threat to resign as president if Buiter were not accepted. Even those who voted for him saw him as a "temporary, makeshift candidate" whose re-election at the next congress could not be taken for granted. With much bitterness, his report then laid about the people at the helm in the ICFTU, whom it now served his interests once again to portray as implacable enemies: 
Storti ... is no friend of the AFL-CIO. He opposes our policies and supports Buiter because the latter is even more anti-American. In discussions with Europeans, Buiter speaks sharply against Meany and his "American entourage." Buiter is a Brenner man ... guided by Storti and Rosenberg, with the latter taking all his cues and orders from Brenner whose IMF is one of the most dangerous vehicles for eroding the principles and policies of the ICFTU. Buiter has ... opposed and so far succeeded in delaying the election of Felce as an assistant general secretary. ... Morris Paladino has been ... doing well. But without Felce, he is blocked and surrounded. Buiter will no doubt move carefully and not show his hand too crudely in dealings with Paladino. But Tulatz [AGS] and particularly Braunthal [AGS] are blocking him. Braunthal is crudely hostile in his attitude towards the AFL-CIO. . . Buiter will be much more cautious in his action. ... He will be careful ... but his basic position is with Brenner and Rosenberg. ${ }^{77}$

Almost certainly, Meany shared Lovestone's assessment of this cast of characters, but he was prepared to be patient and watch how Buiter performed. The new general secretary would have to operate within an ever-shrinking budget. The AFL-CIO had decided to make no further contributions to the solidarity fund until a thorough investigation of ICFTU finances had been conducted. And with Meany in the chair, the first meeting of the ICFTU finance committee since Buiter's appointment decided to close or cut back spending on regional offices, determined that staffing costs were unsustainable, and took no decision on new spending proposals. ${ }^{78}$ But the fundamental issue on which Buiter seemed likely to be judged was how he handled the problem of increasing East-West trade union contacts.

\section{The Committee on Contacts with Communists-and the Prague Spring}

National trade union centres were now rushing to catch up with a trend that had long been evident among their own affiliates. They no longer hid behind the argument that they couldn't stop their affiliates having friendly relations with Soviet bloc unions; instead, they were now themselves enthusiasts for exchanges. The trend was fed by the easing of tension between the United States and the USSR, most evident by 1967 in the steady progress being made in negotiating a nuclear non-proliferation treaty. At the same time, increasing political and economic liberalization, especially in Yugoslavia and to a lesser extent in Hungary and Romania, set a pattern for what would blossom in Czechoslovakia as the "Prague Spring" of 1968. Yet the AFL-CIO leadership doubted the substance of such developments. Lovestone declared the non-proliferation pact a "myth," while Meany voiced skepticism about the real 
meaning of "liberalization" and argued that, whatever the reality, it had not spread to the "pseudo unions" of the communist world.79

Among the ICFTU's European affiliates, the British, German, Scandinavian, Belgian, Dutch, and Italian were all conducting fraternal exchanges with the Soviet bloc. Further afield, the trade union centres in Australia and New Zealand were establishing regular contacts with their communist counterparts, as was Dōmei, the Japanese centre that the AFL-CIO had carefully nursed into existence only three years earlier. ${ }^{80}$ Even Italy's CISL, a godchild of the AFL and wholly dependent on the Americans for material assistance in its formative years, was working on new guidelines covering contacts with communists to take into account the fact that several of its affiliates simply refused to comply with the strict letter of ICFTU policy. The fact that its general secretary was Bruno Storti, who was also ICFTU president, was a source of particular resentment in the AFL-CIO. As Morris Paladino observed from his new vantage point in the ICFTU secretariat, there was such momentum behind the traffic in fraternal delegations that it was now hard to arrest: "Even those who are truly our friends and have supported our policy are now saying that perhaps we ought to get into the act and protect ourselves from the inside." ${ }^{{ }_{1}}$ Such widespread disregard for established ICFTU policy led him to speculate that disaffiliation by the AFL-CIO might not be far down the road.

In 1967, national trade union centres worldwide were invited to Moscow to participate in the fiftieth anniversary celebrations of the October Revolution. In Germany the casual manner in which the invitation was extended by the Soviets and initially accepted by the DGB -in the course of a press conference for an AUCCTU delegation visiting Dusseldorf-led Jay Lovestone's soulmate, Kuno Brandel, to protest to Ludwig Rosenberg about the absence of prior discussion of the implications within the DGB. Brandel deplored the prospect of German trade unionists celebrating in Moscow an event with such negative consequences for democracy in the USSR. In the event, the DGB decided against attending the fiftieth anniversary celebrations since it was a political event, but saw nothing wrong with being present at the AUCCTU congress some months later, since this was a trade union occasion. Brandel wrote again to Rosenberg challenging the distinction. ${ }^{82}$ As the editor of the construction union's journal and that union's officer responsible for East-West issues, Brandel felt entitled to go public with his criticisms, but when he published his correspondence with Rosenberg he was immediately dismissed. That he was being dismissed from Georg Leber's union added piquancy to the affair. Full of disdain, Lovestone remarked: "this rush to engage in exchanges and dialogue is worse in Germany where the behaviour of Rosenberg and his pals is increasingly obscene in kowtowing to the Kremlin." ${ }^{3}$

When the British TUC conference called in 1967 for talks between what it termed bona fide unions of the ICFTU and WFTU, Lovestone observed: "If the ICFTU or 
its affiliates accept the state company unions behind the Iron Curtain as genuine unions, then there is no basis for the ICFTU's existence or refusing to merge with ... the WFTU." Greece's GSEE had recently been expelled from the ICFTU following the "colonels' coup," but Lovestone noted that some dictatorships seemed more reprehensible than others and queried why this particular organization was not considered "kosher" whereas totalitarian state company unions in the Soviet bloc seemingly were. He warned darkly that the AFL-CIO "would be ready to be alone in its opposition to any policy which leads inevitably to the ICFTU committing suicide." ${ }^{84}$ Lovestone was personally opposed to the idea of AFL-CIO withdrawal from the ICFTU, but like Paladino, he was beginning to see the writing on the wall.

The arrival of a new general secretary made it an opportune time to address this growing problem, and the executive board meeting that confirmed Buiter's appointment also agreed to establish a committee to review the policy on "contacts with communists" and suggest a way forward. Besides the AFL-CIO, the move had the support of Force ouvrière and the Canadian Labour Congress. African and Asian representatives were ambivalent, but Lovestone felt confident they could be won over. Moreover, whereas at the board meeting George Woodcock had spoken against the proposal, he had then voted for it. This contradictory behaviour Lovestone saw as a reflection of Woodcock's unwillingness to fight the British communists on the domestic front. ${ }^{85}$

On the initiative of the AFL-CIO representatives, the committee's terms of reference were strengthened with the added requirement that it consider possible means of enforcing the agreed policy. Lovestone was appointed to the committee, viewing its work as the prelude to an inevitable "showdown." Reporting to Meany on the executive board discussion, he suggested that the future of the ICFTU depended in great measure on the judgment arrived at by this committee: "Outlook for the ICFTU? The question mark is big . . . unless the AFL-CIO engages just as vigorously in efforts to save the ICFTU [as before the breakup of the WFTU] there will be no ICFTU" He described his attitude as one of "restrained pessimism." 86

Yet, given the polarized views held by the more powerful national centres, it was hard to see the committee as more than a bureaucratic device to buy peace for a few more months. Some hoped it would come up with a formula consistent with "bridge building" that would legitimize their de facto disregard for existing policy. A diminishing number, including the Americans, stood by the policy, first enshrined in 1955 and reaffirmed numerous times since, favouring the suspension of all exchanges while the committee reviewed the matter. The AFL-CIO also urged the creation of an ICFTU department, such as had existed in the 1950s, dedicated to analyzing communist activities within the trade union field. ${ }^{87}$ Ideally it would help set the agenda for a more vigilant ICFTU. Intelligence reports revealed intermittent signs of labour 
unrest in the USSR and its satellites, and Lovestone believed that radio broadcasts beamed to the Soviet bloc reporting the achievements of American unions at home would have more a more beneficial effect than carefully chaperoned trade union tours could ever have.

Centres like the TUC and the DGB were hardly likely to shelve programs they were now committed to. Ludwig Rosenberg expressed resentment at attempts to put him "in the dock," insisting that due account had to be taken of changes in the world situation. The DGB line was that its initiative was essentially political, undertaken in line with German government policy in a bid to ease international tensions, without any risk of compromising the principles of the free trade union movement. With a different emphasis, the British presented their exchanges with the AUCCTU as a pursuit of common trade union interests.

General Secretary Woodcock argued that because TUC contacts with the Soviets did not lead to joint statements or the creation of organic links they posed no threat to free trade unionism. Soviet trade unions were responsible for the day-to-day protection of workers' interests, and Woodcock could see no harm in visitors studying the way they discharged their duties. ${ }^{88}$ Ahead of a planned visit by an AUCCTU delegation in 1968, the TUC's centenary year, he talked effusively of the "end of a difficult period ... now behind us" signalling "the fresh and positive way in which we regard each other." Anglo-Soviet trade union relations dealing with "the basic job of trade unions" were "normal." In words Lovestone found "significant and disturbing," Woodcock wrote in the British Communist Party newspaper:

You find that what you are engaged in is essentially the same object. For trade unions cannot help being trade unions. At one time there was a political barrier, but there is no political barrier now. . . I believe that both the World Federation of Trade Unions and the International Confederation of Free Trade Unions are beginning to understand the sterility of their original attitudes of sustaining political views against each other. ${ }^{89}$

Lovestone's idea was that the "committee on contacts" should proceed by reviewing the various charges made by the ICFTU over the years against "the communist so-called unions" - their subversive intent, their promotion of expansionist interests of Soviet imperialism, the suppression of free trade unions-and to consider whether these claims were valid. Of course, in his mind there was no doubting their validity, and he evidently envisaged the committee serving as a kind of teach-in to explain the Leninist conception of trade unionism for the benefit of its less savvy members..$^{90}$ National centres would be asked to submit written details of their meetings with communist organizations so that they could be centrally analyzed and then broadcast more generally for wider comment. As a consequence, it wasn't until June 
1968 that the committee convened for the first time with a working document for consideration. By now the "Prague Spring" had blossomed: Czechoslovakia's liberal reform movement opening up prospects for "socialism with a human face" with a liberalized economy, an end to censorship, and the introduction of press freedom. Here surely was a testing ground for the trade union visits program. With the prospects for success in Prague delicately balanced, the Czech reform movement's manifesto, 2000 Words, anticipated the moment of truth: "This spring has just ended and will never come back again. In the winter we shall know everything." ${ }^{11}$

Among Soviet satellites there was already intense disquiet that political reforms in Czechoslovakia might have a destabilizing effect in the Soviet bloc more generally. East Germany's communist leadership in particular was increasingly alarmed by the "contamination" effect of the Czech program and resentful of being isolated as West Germany's bridge building through trade missions and diplomatic ties with other Soviet bloc states specifically bypassed it. Heeding such concerns, the Soviet leadership began to warn the Czechs against any "subversive struggle against the socialist countries," which they stressed would not be permitted. The threat of military intervention was very much in the air.

Against this background, in June 1968, the two most significant trade union visitors to Moscow were Ludwig Rosenberg and Victor Reuther. As part of the DGB's expanding program of exchange visits, Rosenberg had been invited for talks with Alexander Shelepin, chairman of the AUCCTU. ${ }^{22}$ In a private meeting they agreed to intensify trade union contacts over technical issues on which there were no basic differences. But reflecting the elevated tension between the two Germanys, Rosenberg rejected the Soviet proposal that the DGB establish parallel contacts with its East German counterpart, the FDGB. Their talks were described as frank but friendly.

However, two days later, while he was still in the USSR, Rosenberg received word of new restrictions on cross-border travel by West German citizens to East Berlin, introduced in direct retaliation for Bonn's cold-shouldering of East Germany in its policy toward the Soviet bloc and its support for the Prague Spring. Rosenberg complained formally to Shelepin that there had been no mention of these restrictions in their meeting even though the policy clearly had prior Soviet approval. It revealed, he claimed, Shelepin's lack of genuine commitment to their dialogue. In a follow-up meeting with the Soviet deputy foreign minister, Rosenberg gave vent to his resentment and returned home early, refusing to attend a Soviet banquet in his honour. ${ }^{93}$ Was this evidence that such visits were a waste of time or did it, as the DGB would later claim, prove their value as an opportunity for forthright and constructive exchanges?

In Europe to attend the congress of the International Metalworkers' Federation and pay a subsequent visit to Prague, Victor Reuther also travelled on to Moscow and 
met Shelepin a matter of days after Rosenberg's departure. Aware of the sour note on which the DGB chairman's visit had ended, Reuther told Shelepin that nothing was more likely to destroy Soviet hopes for normal relations with the West than a revival of conflict over Berlin or a "Hungarian-type intervention" in Czechoslovakia. According to Reuther, the AUCCTU chairman assured him that Western press reports of threatened Soviet intervention in Czechoslovakia were without foundation. Comparing notes with Rosenberg afterward, Reuther wrote that he was in no position to say whether the USSR would refrain from hostile action over Berlin and Czechoslovakia, but overall he was comforted by the impression that the USSR was more concerned with the threat of Chinese aggression than the areas of tension existing in Europe. ${ }^{94}$

The ICFTU's committee on contacts finally convened a week later in June 1968. Among the dozen participants opinions were as divided as ever on matters of both substance and procedure. Existing policy was defended by André Bergeron, who questioned the assumption underlying the exchange programs: the communists had not changed their spots; Soviet trade unions were still instruments of the state, and he asked whether Shelepin was anything more than a police chief appointed by the Soviet government. From the opposite side, the DGB's international secretary, Otto Kersten, argued for the current prohibition on contacts to be replaced by a positive statement of ICFTU objectives to be pursued by engaging with the communists in "dialogue with confrontation" as practised by Rosenberg with Shelepin. ${ }^{95}$ Speaking for the TUC, international secretary Alan Hargreaves reflected British impatience with the whole debate. Whatever was decided by the committee, he insisted, many unions would continue to have contacts with the Soviet bloc and the TUC would be among them. He was opposed to any attempt by the ICFTU to generalize as to where or when exchanges were acceptable, insisting that each situation was specific and had to be treated on its merits. It was therefore futile for the ICFTU to try to establish ground rules and to hope to police them.

The committee agreed to press ahead with its plan for the secretariat to feed information to affiliates about developments in the communist world, while leaders of national centres would write discussion pieces for circulation and critical comment by others. The fond hope was that this quasi-academic exercise would produce a consensus in time for the congress twelve months hence. There was still disagreement over whether this debate should be conducted publicly or somehow kept from the outside world. Buiter, Lovestone, and Storti recognized that it would be virtually impossible to keep the debate private and that in any case an open discussion was the hallmark of a democratic organization. Bergeron and Hargreaves countered that there could be nothing worse than to be seen to disagree in public and so provide ammunition for use against them by their enemies. The final decision-that the 
secretariat lead and moderate the debate and that it be conducted with sensitivity to the concerns of the latter group-had an unconvincing ring to it.

Lovestone's contribution in the committee was emollient, doubtless reflecting his judgment that the AFL-CIO could not win in the existing climate. He made no reference to the AFL-CIO's earlier insistence on seeking ways of enforcing a policy on contacts. And although he revived his long-harboured proposal for the ICFTU to establish a department dedicated to monitoring communist activities, he let the matter drop when Buiter responded that such a role was already performed by the secretariat. By arguing the need to be "firm on principles and flexible on tactics," without specifying precisely what principles he had in mind, Lovestone came across as the epitome of sweet reasonableness; no one could argue with such advice. His concern seemed to be to avoid any provocative gesture and, playing for time, to ensure that the committee remained in being. Given increasing speculation that the AFL-CIO might leave the ICFTU, and his personal preference that it shouldn't, stringing the committee's work out seemed his best option. ${ }^{96}$

Less than two months later, on 21 August, the armies of five Warsaw Pact countries crossed into Czechoslovakia to put an end to the reforms introduced in the Prague Spring. With tanks on the streets of Prague, the case for dialogue with the Soviet bloc suddenly looked quite different. It gave fresh heart to Jay Lovestone, and with a strong sense of vindication, he wrote at once to George Meany:

The price of crow tripled this morning. So many people in line to eat it. I speak, of course, of our doves who now have to swallow the Russian invasion of Czechoslovakia.... I am afraid that the AFL-CIO with all its "dogmatic rigidity" is right again.... The bridge-builders will have to discard their blueprints and think of building bridges to the people ... who really want freedom.... I wonder how the Woodcocks and Rosenbergs will feel ... [and Victor] Reuther, who boasted that he is responsible for Brezhnev not invading Czechoslovakia, will have to shed even this responsibility.

His disdain was not only for these named trade unionists. Also mentioned were American critics of AFL-CIO foreign policy and support for the Vietnam War: J. K. Galbraith, Senator Wayne Morse, and "Senator Halfbright," whom Lovestone had been watching on television as their faces "lengthened and sorrowed": "They all were on the defensive. They all admitted that the doves will have to eat some crow."97

The invasion had stopped the Czech reform movement in its tracks. But within the international trade union movement it was not necessarily clear that the proponents of dialogue with communists had misread the prospects for finding common ground. The fact was that the WFTU had immediately denounced the invasion and offered moral support to the Czech trade unions. In this, the influence of the communist-led 
French CGT and Italian CGIL had weighed heavily. Two weeks after the invasion, the entire CGIL leadership refused an invitation by Shelepin to attend a meeting with trade union officers from the invading countries in protest at the action of the Warsaw Pact.

Among ICFTU affiliates, current plans for exchange visits were immediately put on hold. The TUC quickly withdrew its invitation to the AUCCTU to visit Britain and voted instead to send a delegation to Czechoslovakia in a show of support. DGB unions informed trade unionists from the USSR, Bulgaria, and Hungary who had been due to visit Germany that they were no longer welcome. However, Lovestone correctly surmised that such bans on contacts would be only temporary and the centres would soon be looking for a chance to reinstate visits. Indeed, Ludwig Rosenberg, who before the invasion had invited Shelepin to visit Germany despite the sour outcome of his recent trip to Moscow, refused to concede that the contacts program had been misconceived and argued that those who held such a view were playing into the hands of warmongers. ${ }^{98}$

A conference on Czechoslovakia convened jointly by the ICFTU and international trade secretariats promptly issued a statement condemning the invasion and agreed there could be no contacts with the five countries involved. But there was no suggestion of terminating the dialogue with unions in Yugoslavia and Romania, where the invasion had been opposed. ${ }^{99}$ The conference endorsed Otto Kersten's argument that liberalization in Czechoslovakia prior to the occupation was proof that trade union contacts were necessary to encourage reforms and even revolts in communist parties. Hardly surprisingly, in light of the way the WFTU had responded to the Czech crisis, a majority also rejected Bergeron's argument that the WFTU should now be exposed for its hypocrisy and a serious campaign waged against communist-dominated unions in Western Europe. ${ }^{100}$ Dining with Lovestone a month later, Buiter tried to persuade him that the issue of contacts with communists could be resolved if only the Americans were less rigid and prepared to close their eyes and ears to what the DGB was doing. Lovestone reported to Meany his response:

Told him point blank that the lesson of Czechoslovakia is so important that we cannot possibly play possum with the consequences and with the need for undelayed effective preparations to counteract Soviet aggression and subversion against democratic institutions and values-particularly in re subversion of the free trade union movement. ${ }^{101}$

The majority view at the conference on Czechoslovakia became the dominant line adopted in the committee on contacts when it reconvened in November 1968. Most members were now in favour of exchanges with the Soviet bloc in the appropriate circumstances. The ban currently in force would be lifted in due course. Along with 
Bergeron, only the Histadrut and ULC (Nigeria) delegates argued "the AFL-CIO line," and only Bergeron voted for it. The DGB was in the process of planning an exchange with the Yugoslav unions; Kersten described them as "real unions," and argued that: "we must find a solution for the Yugoslav trade unions to bring them back into the international labour movement." ${ }^{102}$ Within a year the German centre would reinstate visits with all Soviet bloc countries except East Germany.

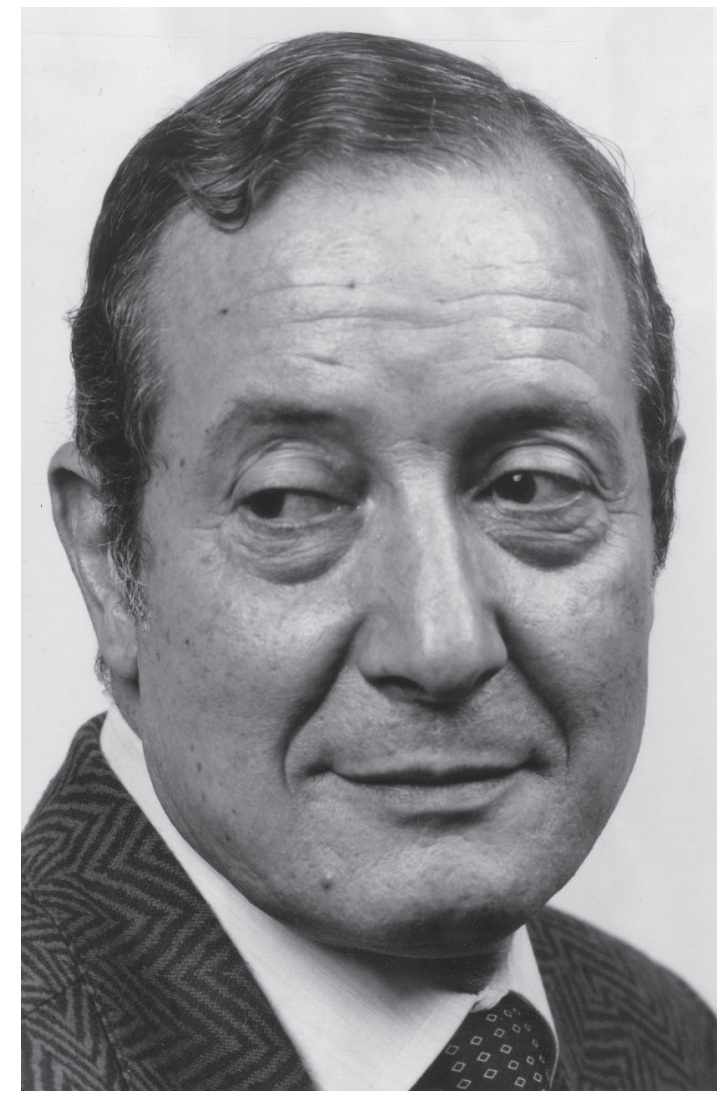

Figure 16. Bruno Storti, general secretary of CISL, 1958-76, and ICFTU president, 196572. Though CISL was originally established under pressure from the AFL, its increasing openness, during the 1960 s, to contacts with communist-led unions at home and abroad doomed Storti's hope of being able to act as an honest broker in ICFTU efforts to retain the AFL-CIO as an affiliate. Courtesy of the International Institute of Social History, Amsterdam. Copyright @ Nico Naeff.

ICFTU president Bruno Storti agreed with the need to revise the existing policy and allow contacts with countries that "moved towards improving civil liberties." He 
also put in a special word for the CGIL, making the point that its firm opposition to the invasion of Czechoslovakia merited a change in the ICFTU's attitude regarding this Italian centre. Harm Buiter joined him in conceding that ICFTU policy was no longer valid; in view of the role the CGT and the CGIL were playing within the European Economic Community (EEC), he wondered how long it would remain practical to prevent their reintegration with the unions of Western Europe. Morris Paladino filed a brief report on the proceedings with George Meany. He signed off: "Finita la commedia!" It might have been an epitaph to the AFL-CIO's nineteen years' membership in the ICFTU, now coming to a close. ${ }^{103}$

Passing through Paris, a forlorn Irving Brown, in semi-isolation in Africa, noted the growing sentiment within European labour for a common front: "I think the time has come to realize that we are not only in a similar situation to 1945 but worse in that there is no active participating [AFL-CIO] force here in Europe to unite those groups and individuals ready to resist this new trend." He urged Lovestone to tackle Meany and see "whether we cannot get a new approach going from our side which in fact would not be new since it would return to what we have done successfully for so many years." ${ }^{104}$ But for now, and for as long as Meany regarded European labour as pretty much a lost cause, the active role in Europe that Brown yearned for was closed to him.

The ICFTU committee on contacts finally recommended that the 1955 policy of opposition be dropped, a decision that was undoubtedly more easily reached in the absence of an American representative. Jay Lovestone had been ordered to boycott its meetings, not over this issue, but in protest at the way Harm Buiter had handled an application by the now independent UAW to affiliate separately to the ICFTU. For the time being, it would be this issue rather than the question of exchanges with communist organizations that would take centre stage. Indeed, the latest twist in the Reuther-Meany saga was to provide the immediate cause of the final rupture between the AFL-CIO and the ICFTU.

\section{UAW Bids for Separate Affiliation to the ICFTU}

The serious rift that had opened up in 1966 between George Meany and Walter Reuther moved into high gear in 1967 when the UAW began to issue a series of lengthy "administrative letters" to its membership and the wider labour movement expounding the case for root-and-branch reform of the AFL-CIO. However, the federation declined to engage in debate about their content. It was prepared to consider a reasoned complaint but not what it described as "a kaleidoscope of ever-changing allegations and demands, expressed through press releases, public speeches or circular letters."105 
In February 1967, Reuther upped the ante by announcing that the UAW had instructed him to resign from the AFL-CIO executive council and other UAW representatives to withdraw from subordinate bodies of the federation. He declined an offer by David Dubinsky to mediate his differences with Meany, telling him he didn't have time. The scent of disaffiliation was in the air. Two months later a special UAW convention adopted a list of proposals for reform to be presented to the AFL-CIO convention in December 1967. But no sooner had the UAW submitted the list in November for inclusion in the convention agenda than Reuther notified Meany that, because of collective bargaining commitments, the UAW would not be represented at the convention. He asked for consideration of the proposals to be deferred until a later date. Meany accused Reuther of avoiding — and not for the first time-a debate with fellow union leaders that he had originally demanded. ${ }^{106}$

Reuther saw himself waging a battle for the soul of the American labour movement, telling fellow UAW officers:

If the labour movement ... is not a dynamic force that is challenging the status quo, where the status quo is unacceptable, where the status quo denies millions of Americans that measure of justice to which they are entitled, then the labour movement is nothing more than an extension of the business community.... That is precisely what the labour movement is becoming - an extension of the business community... I I believe this very sincerely, that the AFL-CIO structurally is historically obsolete. It has little to do with America today. ${ }^{107}$

Many in the labour movement sympathized at a general level but were unconvinced that a civil war was worth the candle. From the outset, Reuther was unable to dispel the impression that his main motivation was personal ambition to replace Meany as president. The head of the public relations firm retained by the UAW advised Victor Reuther that the union was facing a major public relations problem; "out on a limb without even the support of usual friends," Walter Reuther appeared "restless, ambitious" and prepared to do a "wrecking job," while Meany came across as "patient, long-suffering" and trying to keep the issues "in family."108

Failure to be represented at the AFL-CIO convention increased speculation that the UAW would soon quit the federation. Lovestone was telling people that its leaders had already written Reuther off. Harm Buiter now weighed up the implications for the ICFTU. Reuther had informed him that he intended to be present at the next executive board meeting in summer 1968, and Buiter worried over what might happen if Reuther turned up having already withdrawn his union from the AFL-CIO. He held his seat on the board as a nominee of the AFL-CIO, not in a personal capacity, and would automatically lose it if the UAW disaffiliated. Buiter had visions of 
an ugly scene, with the domestic American conflict injected into the heart of ICFTU deliberations. ${ }^{109}$

In March, the UAW requested a special AFL-CIO convention to be held in December 1968, following the US presidential election, to consider its reform proposals, indicating its intention to withdraw if this were not granted. ${ }^{110}$ Meany was now out of patience. The AFL-CIO executive council quickly rejected this ultimatum but offered to convene a special convention as soon as possible-even within the next thirty days-on two provisos: that the UAW commit itself to attend and that it agree to be bound by whatever decisions were reached. The UAW rejected the second of these conditions as a violation of the concept of voluntary association. By the end of March, Victor Reuther was speaking of the union's withdrawal from the AFL-CIO as "inevitable." The UAW convention in May decided to pay its AFL-CIO fees into an escrow account until its terms for a special convention had been met. ${ }^{111}$ The federation treated the decision as tantamount to withdrawal, and when the 15 May deadline for paying the fees passed the UAW was automatically suspended from membership. George Meany spoke regretfully of "a one-sided barrage" from the UAW over the previous two years. Asked by the press what chances there were of reconciliation, he responded with perplexity: "I haven't any idea. I don't know what the quarrel is about." On 1 July, the UAW officers wrote formally to disaffiliate. Meany accused them of a transparent attempt to engineer a withdrawal that had long been planned; they had demonstrated an unwillingness to "live in constructive harmony within an organization."

However, by this point, the dispute was no longer confined to the Americans; the question of the UAW's status within the ICFTU was now at issue. In late May, when the UAW was suspended from the federation but still affiliated, Walter Reuther had what he maintained was a "chance encounter" with Harm Buiter and Bruno Storti in Rome while returning home from an IMF meeting in Turin. There he raised with them his hope of continuing the UAW's affiliation to the ICFTU as an independent centre. His idea was that the UAW would pay its dues directly and that he would retain his executive board seat. Buiter and Storti advised him that "continuing membership" was not an option and that the UAW would have to reapply for membership. Nonetheless, Reuther subsequently wrote seeking membership on the terms he had outlined, and Buiter accepted a cheque from him for $\$ 18,750$ - the first instalment of UAW dues backdated to February and to be held in escrow until membership was formalized. ${ }^{113}$

Crucially, Buiter failed to notify the ICFTU executive board of his meeting with Reuther in Rome or of the fact that, in advance of a successful application for reaffiliation, he had accepted from the UAW a backdated payment of dues. Reuther always maintained that the meeting in Rome had been a chance occurrence, but when Meany learned of it he interpreted it as a case of the ICFTU general secretary 
deliberately "soliciting" an application from a delinquent member of the AFL-CIO. His suspicions aroused, Meany had no difficulty in construing subsequent actions by Buiter as part of a conscious attempt to favour the UAW over the AFL-CIO. The autoworkers' bid for membership in the ICFTU was a saga that would run for the next eighteen months, during which time Harm Buiter joined Walter Reuther in AFL-CIO demonology and gradually replaced the UAW president as arch-villain as the plot unfolded.

Walter Reuther was duly replaced as an ICFTU executive board member by steelworkers' president I. W Abel in July 1968. Only at that point did the UAW president accept the need to apply for affiliation anew. However, even before the application was submitted, Buiter wrote privately to Meany urging him not to oppose the autoworkers' bid for membership. Opposition by the federation, he observed, might "neutralize the good will which in the present conflict is on the side of the AFL-CIO." And if, on the strength of formal opposition by the federation, the executive board went on to reject the application, Buiter pointed out the likelihood of the UAW appealing to the congress in 1969, something that would damage the image the ICFTU as a unified world trade union body. It was clear that the ICFTU general secretary also assumed that such an appeal would be upheld by the congress. Meany interpreted the letter as a gratuitous insult. He was being told that by exercising its constitutional right to object, the AFL-CIO would bring itself into bad odour internationally: "our image was not too good in Europe and if we objected to the affiliation we might lose this goodwill."114 Again, the existence of this letter from Buiter was not disclosed to the ICFTU executive board until nine months later when the general secretary came under sharp criticism for sending an unauthorized communication that expressed only his personal views.

Disregarding Buiter's request, Meany registered the AFL-CIO's formal objection to the UAW application in September 1968. The ICFTU constitution provided for a single affiliate per country, though the rule had been bent on many occasions, and the United Mineworkers of America had always belonged to the international as an independent affiliate. However, for the AFL-CIO president, it was no longer a case of opposing a simple application from the UAW. The latter was now in the process of forming a new federation-the Alliance for Labor Action-with the teamsters, who had been expelled from the AFL-CIO a decade earlier for corruption. And this unlikely alliance now threatened to become a rival centre to the AFL-CIO. ${ }^{115}$

Calculating that the ICFTU executive board would be stalemated, and anticipating a possible acrimonious confrontation if asked to decide on the UAW application at its November 1968 meeting and that the final decision would then have to be made by the July 1969 congress, Buiter looked for a way of avoiding a protracted standoff. To this end, he flew to Washington for a meeting with Meany and the AFL-CIO 
international affairs committee in October. He predicted a deadlock in the executive board - "six for, six against and sixteen on the pot"-and attempted again to convince them that they would be wise to drop their opposition to the application, since support for Reuther would eventually result in the congress approving it.

The Americans reasonably disputed the right of the congress to rule on a matter constitutionally reserved for the executive board, but Buiter angered them with the observation that he was expressing the view of "our European friends" and that Bruno Storti, who would chair the congress, would rule that it was entitled to adjudicate. The members of the international affairs committee were further antagonized when Buiter revealed for the first time his intention to travel on from Washington to Detroit for discussions with Reuther. Having failed to persuade them to reconsider their objection, his hope in Detroit was to obtain Reuther's agreement that consideration of the application should be deferred until just prior to the 1969 congress. Reuther was accommodating: it was the one positive achievement of Buiter's trip. As with his earlier dealings with Reuther and Meany, Buiter kept the ICFTU executive board in the dark about his visit to America. With admirable understatement, he later admitted that his meeting with the AFL-CIO in Washington "had not been a complete success." 116

\section{AFL-CIO Heads Toward the Exit}

On 8 November 1968, two weeks before the ICFTU executive board was due to meet, Meany wrote to Buiter stating that what was at stake was not only the UAW application but the very integrity of the AFL-CIO and all other national centres that might face a breakaway movement. The ICFTU should be standing firmly behind the American centre in face of attacks by "a secessionist union in alliance with an expelled union." In these circumstances dual affiliation of the UAW to the ICFTU was "unthinkable and indefensible." The ICFTU needed to (a) declare its full support for the AFL-CIO and (b) condemn the divisive tactics of the UAW. "We do not believe," Meany wrote, "that either question before the Board should warrant or require an argument, defence or debate by any AFL-CIO spokesman." The federation would therefore watch with interest the outcome of the board meeting but would not attend. ${ }^{117}$ The ball was decidedly in the ICFTU's court.

Strenuous efforts were made by the ICFTU to find a way out of the dilemma. Hoping to avoid exacerbating the internal American struggle, the executive board eventually settled on a formulation that it would "take no further action on the UAW application." For the Scandinavians, Arne Geijer opposed this non-decision as unconstitutional; the board had an obligation to deliver a ruling on the application one way or another. But the meaning of "taking no further action" was itself open to conflicting interpretations. Did it leave open the possibility of reopening 
the discussion at a further meeting? And, if not, did it allow for final appeal to the congress? Firmly in the AFL-CIO's corner, the British TUC considered that the formulation settled the matter once and for all; the Canadians agreed: "it was tabled, definitely tabled." But others had voted for it as a delaying mechanism that would allow future consideration of this or a subsequent application. And while Arne Geijer reckoned that Meany was the one with most cause to be satisfied with the form of words adopted, the AFL-CIO leadership was in fact deeply unhappy that the matter had not been conclusively disposed of; the two points made in Meany's letter of 8 November-explicit support for the AFL-CIO combined with condemnation of the UAW - had still not been addressed. ${ }^{118}$

Ernie Lee was detailed to lay out the options for and against staying in the ICFTU. Backed by International Affairs Committee Chairman Joe Beirne, Meany favoured withdrawal from the ICFTU, but they lacked majority support in the executive council. Nevertheless, Meany notified Buiter that the AFL-CIO would now "take no part whatsoever in any activities of the ICFTU until this matter is finally disposed of." Nothing short of an explicit rejection of the UAW and a measure of humble pie from the ICFTU would satisfy. Failing that, the executive council, due to meet again on 17 February 1969, might decide to make the withdrawal permanent. ${ }^{119}$ To Walter Reuther, it was but a further example of Meany behaving in typical arrogant fashion. As he wrote to Geijer: "He is trying to blackmail the ICFTU with respect to the UAW's application for affiliation. If the ICFTU yields to this ... I believe it will do serious damage to its credentials and credibility in the eyes of workers throughout the world."120

How would the international labour movement react to this development? The AFL-CIO announcement was hardly a surprise; Meany had long been in favour of quitting and was now forcing the issue by making demands that would be difficult for the ICFTU to meet. Some reckoned that if Meany followed through and withdrew permanently, it might be the ICFTU's salvation. The UAW had substantial support overseas, and there was much wishful thinking that, if it were affiliated, it would be able to make good the shortfall caused by the loss of fee income from the AFL-CIO, especially if joined by the teamsters, its new partner in the Alliance for Labor Action. There was speculation that the AFL-CIO's departure would make it possible for the ICFTU to be re-energized, perhaps by amalgamating with the former Christian international (now renamed the World Confederation of Labour) and also attracting into membership the labour centres from Czechoslovakia and Yugoslavia. ${ }^{121}$

IMF general secretary Adolphe Graedel, however, genuinely feared the possibility that the AFL-CIO might make an effort to "raid" several of the international trade secretariats-including eventually the IMF-and create "puppet structures under total American domination" modelled on the way Jim Suffridge's retail clerks' union 
had exercised influence in the clerical-technical trade secretariat, FIET. Signalling a possible interest in this area, there were already rumours of Meany bringing pressure on the International Transport Workers' Federation to refuse membership to the teamsters. ${ }^{122}$

There was certainly much support in Europe for Reuther's cause. Yet Morris Paladino doubted its firmness under pressure, reporting to Meany his view that the Europeans lacked fight, with many simply wanting to save face. Buiter talked defiantly of a mood for "going it alone," but Paladino's assessment was that, with the exception of the Swedes, his judgment was wrong: Europeans would be willing to reject the UAW application if this could be done without appearing to cave in. Referring with disdain to his superior's activities-"the manoeuvring of the jerk here"-Paladino suggested that, despite bold talk, the general secretary was losing support and becoming rattled. "Buiter is in a corner and is panicky. He is beginning to get the feeling that he will be sacrificed. Europeans don't want to put him on the chopping board but will if they have to." In light of this assessment, the looming possibility that the AFL-CIO would decide to pull out as early as 17 February was regrettable. Paladino wrote Lovestone: "it is a shame because the Europeans are ready to support him [Meany]." ${ }^{123}$

Paladino's optimism derived mainly from his close association with the TUC's international secretary, Alan Hargreaves, through whom he gained a clear understanding of the British reaction to the possibility of withdrawal by the Americans. The British instinct was to row back from the dangerous position in which the ICFTU now found itself. The TUC was in no doubt that the UAW application had to be rejected, chiefly on grounds that the AFL-CIO was America's acknowledged trade union centre and without its membership the ICFTU's claim to have global support would be hollow. It followed that solidarity had to be extended to the federation as a sister organization facing an external threat.

Serving out the final months of his term as TUC general secretary, George Woodcock made what would be his final contribution on the international scene and flew to Washington in early February 1969 to see Meany. He explained that the TUC fully supported the federation but could not join in a vendetta against the UAW. However, it was during their talks that Woodcock learned for the first time of Buiter's confidential letter to Meany the previous June urging no opposition to the UAW and of his unreported mission to meet the AFL-CIO international affairs committee in October, followed by his rendezvous with Reuther in Detroit. This put a new light on the ICFTU's handling of the UAW application. As Hargreaves reported to Ernie Lee, Woodcock came back "all steamed up" over Buiter's duplicity. A joint meeting of the ICFTU executive board's most important committees had been called for February 
to recommend a response to Meany's latest letter, and Woodcock was determined that the ICFTU must now try to meet the AFL-CIO's demands. ${ }^{124}$

Woodcock laid out his position for Victor Reuther when the two met in London the day after his return from Washington. He confirmed his full support for the AFL-CIO in its rejection of the UAW claim for membership, refusing to accept that the UAW had the right to speak for American labour at the highest level. But he had also assured Reuther that the TUC would not seek to prevent the UAW operating internationally as part of the IMF. Woodcock volunteered that he would not be in the least surprised if the AFL-CIO still pulled out, regardless of any change of heart by the ICFTU. Reuther was irked by the TUC leader's "rather lofty detached and somewhat pontifical mood," which he attributed to the fact that he was within sight of retirement. For his part, Reuther told him that "we [the UAW] would be around for awhile ... whatever the ICFTU did." In fact, Woodcock acknowledged that any decision by the executive board was likely to be challenged at the ICFTU congress in July, and that was where the Reuthers now expected the matter to be decided. Victor Reuther was planning a world tour during which he would hold meetings with heads of national trade union centres to line up the support of congress delegates-and he and his brother were confident of winning. ${ }^{125}$

For different reasons, the DGB was also now worried by the consequences of UAW persistence in seeking ICFTU membership. Aware of how fraught relations already were with the AFL-CIO as a consequence of German participation in bridge building with the East, Ludwig Rosenberg shrank from the prospect of being identified as the principal cause of the federation's disaffiliating. He had therefore decided to support Meany's demands. The DGB was also concerned to safeguard its position as the exclusive representative of German labour within the ICFTU and was wary of establishing a precedent that might open the door to parallel affiliation by the separate clerical workers' centre, the Deutsche Angestellten-Gewerkschaft. In early January 1969, Ludwig Rosenberg and IG Metall chairman Otto Brenner both wrote to Walter Reuther pointing out the German dilemma and asking whether the UAW would be prepared to withdraw its application so as not to pose problems for them. ${ }^{126}$ "Withdrawal" in this context appeared to be another term for "deferring" the application until a more opportune time. On that understanding, Buiter also privately supported the idea that the UAW should withdraw its application. For a brief period, Europeans anticipated that the UAW would indeed heed the DGB request, thus resolving, at least temporarily, the ICFTU's problem with the AFL-CIO. ${ }^{127}$

However, the Reuthers saw no reason to give up on their application. To stiffen German resolve, Victor Reuther accepted an invitation to attend a session of the DGB executive board held on the eve of the ICFTU's executive board meeting. As he later reported, the Germans appeared confused over the rules for independent affiliation, 
and he spent time explaining to the meeting the circumstances under which no fewer than twenty-seven organizations already held independent affiliation to the ICFTU, as the UAW was now seeking. He surmised that the DGB confusion was an affectation to mask their lack of toughness in the face of the AFL-CIO's hardball tactics. He was certainly conscious that Rosenberg seemed all too inclined to gloss his weak advocacy of the UAW cause by blaming the TUC for being such a vigorous supporter of the AFL-CIO.

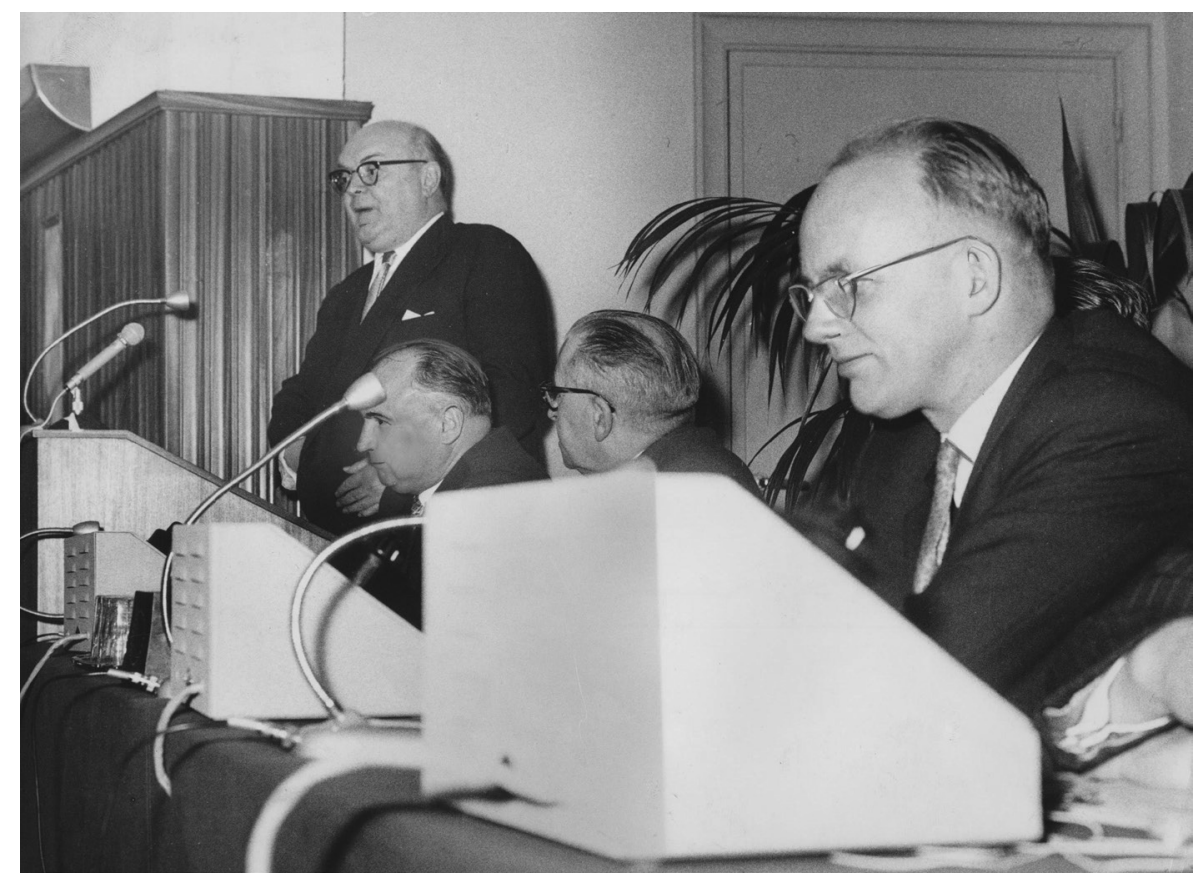

Figure 17. Harm Buiter, general secretary of the ICFTU, 1967-71 (right), at a January 1961 conference of the European Trade Union Secretariat, listening to Paul-Henri Spaak (left). Seated next to Spaak is the FGTB's Louis Major and, beside him, Willi Richter. The AFL-CIO refused to support Buiter's candidacy for the position of general secretary, and his backing for the independent affiliation of the UAW to the ICFTU prompted George Meany's decision to lead the AFL-CIO out of the international body. Courtesy of AMSAB-Institute of Social History, Ghent. Copyright $\odot$ Keystone (Switzerland).

Although Reuther spoke German, he chose to address the DGB executive board in English, remarking in his report back that the Germans tended to pay particular attention to Meany whenever he spoke in English. It was a form of shock therapy. He reminded them of the way the AFL-CIO had frequently meddled in German labour affairs and of Meany's secret meetings with Konrad Adenauer when he was 
chancellor, pointing out as well that only recently Jay Lovestone had met Chancellor Kiesinger without a German labour leader being present. At the conclusion of the meeting, his impression was that a majority supported the UAW case and wanted its application to stand. However, the episode had given Victor Reuther his first inkling that not all the UAW's traditional allies would remain firm in face of prolonged pressure from the AFL-CIO. ${ }^{128}$

The crucial joint meeting of the ICFTU subcommittee and finance and general purposes committee met with Ludwig Rosenberg in the chair. Some objected to the peremptory tone of Meany's latest letter. In particular, Georges Debunne, of the Belgian FGTB, spoke bitterly of the AFL-CIO's bullying approach in international affairs, citing as an example Irving Brown's role in aiding Mobutu in the Congo and insisting that the Belgians would not be browbeaten into rejecting the UAW application.

Yet it was Woodcock's detailed account of his meeting with Meany that proved most compelling. He insisted that the latter's various complaints against Buiter were "entirely reasonable," and he criticized the "irresponsible anti-AFL-CIO views" expressed by people who were motivated by a sense of grievance against the Americans. It was not a sensible way to proceed against an organization that was universally recognized as the representative of American labour. When he proposed that the UAW should be formally condemned, Rosenberg blocked the motion, and a fierce row took place over latter's chairmanship. However, the meeting finally agreed on a response to the AFL-CIO's latest letter that accepted the federation's "unchallengeable right" to be recognized as the national trade union centre in the United States, denied the UAW's claims to speak for any but a minority of trade unionists, and thus rejected its application for independent affiliation. But the narrowness of the vote-five "for," three "against," and one abstention-was hardly a ringing endorsement of the AFL-CIO position. And when Rosenberg reported back to the DGB he conceded that he had cast his vote for the motion, very much in the expectation that the AFL-CIO would still withdraw and leave the door open to UAW membership. ${ }^{129}$

The committees' recommendation was communicated to the AFL-CIO informally, but before there was time to send an official letter, Meany announced to a press conference that the federation intended to disaffiliate. No new reasons were given, but the narrowness of the vote in favour of the statement and Rosenberg's cynical reasons for giving his support-Lovestone declared that it amounted to "bad faith"clearly tipped the balance of opinion within the AFL-CIO executive council when it met. When the roll call vote was taken, the decision was all but unanimous; only Jake Potofsky abstained, while David Dubinsky's discomfort was evident from his answer- "present"-when his name was called.

Though supported by the overwhelming majority, the decision to quit was essentially Meany's. Jay Lovestone had argued against this course of action throughout. 
Indeed, the British labour counsellor saw the AFL-CIO's decision as a blow to Lovestone's position and self-esteem. Irving Brown shared Lovestone's dismay; it was, he wrote, "a wrong decision ... bad in terms of timing and substance. Our friends-esp. Bergeron-are in disarray." But Meany had been entirely firm in his purpose and determination. Out of patience with the ICFTU, for two years leading up to the decision he had steered a clear course, avoiding the tactical niceties proposed by Lovestone and Brown, which were mostly designed to keep the pot stirred while maintaining the AFL-CIO's affiliation. That had been their modus operandi for much of the previous twenty years, but Meany had now called time on it. ${ }^{130}$

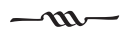

The ICFTU was of steadily diminishing relevance in Meany's scheme of things, and during the 1960 s the AFL-CIO's international effort was increasingly made through the regional auxiliary bodies, AIFLD, the AALC, and later the Asian-American Free Labor Institute. From mid-decade, the federation's grievances were compounded by growing differences over the fundamental issue of free trade union relations with the communist bloc and the ICFTU's ineffective policing of its own policy. In the spirit of the Johnson administration's "bridge building" with the USSR, important ICFTU affiliates were showing interest in making contacts with Soviet bloc unions. Whether this was, as the TUC maintained, an exercise in sharing practical experiences out of a mutual concern to improve trade union performance or, in the case of the DGB, to support in the trade union field the foreign policy of the government in Bonn, for the AFL-CIO leadership fraternization with government-controlled "trade unions" of the Soviet bloc involved selling out a fundamental principle of free trade unionism.

A more authoritative figure than Omer Becu as general secretary might have managed to paper over these differences. Certainly, Harm Buiter never had much chance of achieving such a feat. From early on in his term of office, Buiter was embroiled in the growing conflict between the UAW and the AFL-CIO, and behaving-as Meany had reason to believe-in partisan fashion. Where Buiter was concerned, Meany kept his own counsel, ignoring Jay Lovestone's argument that Buiter's appointment should be flatly opposed and disinclined to listen to Irving Brown's advice on how to "work around" the new general secretary. However tough their talk about the ICFTU, Lovestone and Brown drew a line at any suggestion of quitting the organization, whereas for Meany it was still very much an option. He was ready to give Harm Buiter enough rope to hang himself.

The ICFTU's review of its policy on dialogue with Soviet bloc unions took place against the backdrop of Czechoslovakia's "Prague Spring," which provided a litmus 
test for the question at hand. Was the liberalization of Soviet bloc economies and democratization of their trade unions ever a serious possibility, to be encouraged by exchange visits and constructive dialogue such as that attempted by Ludwig Rosenberg and Victor Reuther with Alexander Shelepin? For the AFL-CIO, the brutal suppression of the Prague Spring made it abundantly clear: trade union dialogue with the communists would always be futile. Yet the ICFTU chose to draw a different lesson: the Czech experience demonstrated that contacts had helped create a climate in which the Prague Spring emerged, and the WFTU's open opposition to the Warsaw Pact invasion was an indication that it was at least possible to do business with some of that body's affiliated members. Permanently putting up the shutters against further contacts was not the way forward.

Jay Lovestone wrote of the "contemptuous disregard" for existing ICFTU policy, with the suggestion that the chasm between the two sides was now unbridgeable. ${ }^{131} \mathrm{But}$ the AFL-CIO was no longer present at ICFTU committee meetings to register formal opposition to the new position on contacts. The federation was already engaged in a boycott after the ICFTU executive board failed to stand foursquare behind the AFL-CIO in its dispute with Reuther's autoworkers. While ICFTU affiliates were at sixes and sevens in attempts to concert a position on this issue, George Meany acted decisively in permanently withdrawing the AFL-CIO from the ICFTU, even before full deliberations could take place within his own executive council. What had been threatened on and off for well over a decade had now come to pass. Henceforth, the AFL-CIO would plough its own international furrow. 



\section{9}

\section{Au Revoir Becomes Adieu}

Few people could have been entirely surprised by the AFL-CIO decision to withdraw from membership in the ICFTU, yet the announcement still left the organization in turmoil. It wasn't a clear-cut break; the federation intended to continue its membership in ORIT, the hemispheric regional body for Latin America and the Caribbean, with which the AFL-CIO had a separate historical relationship. The matter couldn't be left in this unsatisfactory state, and other national centres felt obliged to retrieve the situation, especially with new leadership at the helm in the TUC and DGB. George Woodcock had made his final contribution to ICFTU policy discussion in February 1969 and was now replaced by the avuncular figure of Victor Feather, highly experienced as a "backroom boy" at the TUC and with whom George Meany already had a warm rapport. Ludwig Rosenberg, who had contributed significantly to the American decision to withdraw, was also in his final few months as DGB chairman. His place at meetings was increasingly taken by his eventual successor, Heinz-Oskar Vetter, who was little known in the wider German labour movement, let alone internationally. ${ }^{1}$ The AFL-CIO had its own interest in engaging in further talks, all the more so when it discovered that it could exert at least as much leverage outside the ICFTU as it did when a full member.

The result was that over the next eighteen months the principal leaders of the ICFTU and the AFL-CIO engaged in a delicate and protracted dialogue-cum-negotiation that involved four face-to-face sessions and saw the ICFTU deliberating the issue on more than half a dozen occasions at meetings of its executive board, finance, and general purposes committee, and "negotiating team"- with the "good offices" of labour attachés in Brussels, Bonn, Washington, and London on regular call throughout. The ICFTU looked to entice the AFL-CIO back into the fold and fondly imagined it might even be able to help restore unity to the American labour movement. For its 
part, the AFL-CIO had three objectives. It was determined to establish Harm Buiter's personal responsibility for the recent breakdown in trust. It was bent on ensuring that the UAW would have no chance of being admitted to ICFTU membership as an independent body, now or in the future. Thirdly, it aimed to discover whether, following the recent salutary shock to its system, the ICFTU was capable of substantial reform of policy and practice. Bit by bit, the AFL-CIO secured its objective on the first two points-George Meany all but ended Buiter's trade union career and comprehensively outmanoeuvred Walter Reuther and the UAW over their aim to affiliate to the ICFTU. But over the ICFTU's attitude toward contacts with communists the dialogue finally ran into the sand, leaving the AFL-CIO outside the free trade union movement's largest grouping of labour organizations.

\section{At Odds over the Americans' Departure}

The ICFTU executive board meeting in March 1969 considered a response to the AFL-CIO's announced withdrawal. It decided to write to George Meany, appealing to the AFL-CIO to reconsider its position while reaffirming the ICFTU's recognition of the federation as the unchallenged representative of the majority of American workers. But it made no reference to the UAW, and in AFL-CIO eyes this amounted to a dilution of its previous position, which had at least stated that the autoworkers could only be recognized as speaking for a minority of trade unionists. As the TUC's Vic Feather argued, it would clearly be unacceptable to the federation.

The ICFTU was divided over the issue. A few-most notably the TUC and Force ouvrière-were ready to make almost any concession to induce the AFL-CIO to return. By contrast, Georges Debunne of the Belgian FGTB reckoned that the latest letter to Meany lacked dignity with its "appeal" to the AFL-CIO. Along with Arne Geijer of the Swedish LO, Debunne was willing to risk closing the door permanently to the AFL-CIO in the interests of securing the affiliation of the UAW. The belief was that the UAW would help revitalize the ICFTU while at the same time securing the financial viability of the organization, which now faced the prospect of a 17 percent loss of fee income as a consequence of the AFL-CIO's departure. The Reuthers encouraged this thinking, insisting that the UAW's Free World Labour Defence Fund had "more than sufficient resources ... to guarantee the surmounting of any such emergency."

Supporters of the UAW were heartened by the ICFTU's latest communication. Valerio Agostinone, UIL's international director, wrote to Victor Reuther: "UIL is satisfied the compromise leaves prospects for UAW unaffected." There was a new feistiness in the DGB following Rosenberg's earlier vacillation over whether or not to throw his weight behind the UAW application. The mood now favoured a 
reconsideration of the autoworkers' case, an attitude shared by the Dutch, Belgians, Canadians, and the handful of Japanese affiliates belonging to Sōhyō. A DGB statement drafted by international secretary Otto Kersten for the benefit of labour attachés rejected as baseless all the charges used by the AFL-CIO to justify disaffiliation. His advice to Victor Reuther was that the UAW should submit a new application so as to thwart the manoeuvres of any "constitutional technicians" who might argue that the original application had lapsed or ceased to be valid. Walter Reuther duly followed the advice and resubmitted the UAW application. Kersten also urged Reuther to make sure that he was on hand in Brussels on the opening day of the congress scheduled for July in order to present his case. ${ }^{3}$

DGB publicity director Walter Fritze expressed the confident view that the ICFTU congress would admit the UAW "with more or less certainty." In the opinion of Welt der Arbeit, the ICFTU would be strengthened by the AFL-CIO's withdrawal, observing that the ICFTU's "sin" was simply to have recognized Walter Reuther's right, like any good trade unionist, to disagree with George Meany. And while Jay Lovestone complained to Georg Leber about Welt der Arbeit's continued distorted reporting of AFL-CIO affairs, Ludwig Rosenberg was quoted in Der Spiegel as saying that the Americans' withdrawal would not create a lot of sadness. When the DGB wrote inviting the AFL-CIO to send a representative to its congress in May, Meany sent a curt reply to Rosenberg saying it would not be possible. ${ }^{4}$

Informed that Otto Kersten had been asking around Brussels what the AFL-CIO wanted by way of reconciliation, Lovestone offered an unequivocal answer, writing to the US labour attaché in Bonn: "He [Kersten] knows very well . . . the UAW ... must be excluded from membership.... Buiter ... must be dropped. And ... a Commission should be appointed to reorganize the entire ICFTU, its methods of work, its leadership and even its kind of leadership." ${ }^{5}$ Whether or not the AFL-CIO rejoined, it was considered worth keeping up the pressure on the ICFTU to make these changes. And for this purpose it helped that it maintained a toehold in the organization through Morris Paladino's position as assistant general secretary.

At the executive board meeting in March, Buiter had come under some pressure to account for his behaviour in connection with the UAW application. There was a growing recognition on the ICFTU side that he had been guilty of some serious errors of judgment. Yet the general secretary was determined to fight back, denying that he was the cause of the AFL-CIO's decision to withdraw and arguing that he was simply the whipping boy. With the departure of the Americans, he was keen to ease Paladino out of his post, but Meany instructed his man not to resign. ${ }^{6}$ Paladino claimed to see behind Buiter's bluster and reported that his position was becoming precarious. 
H.B. now has a situation in the Secretariat ... of his own making. He is very well aware that, should the Federation return, he will have to go, or at best, submit to an arrangement which will seriously curtail his authority. On the other hand, having failed miserably to fulfil his boast that he would have my resignation before the [board] meeting, my continuous presence and participation in ICFTU events serves as a daily reminder that he is losing face with his European friends.

Paladino suggested that the AFL-CIO test the balance of power within the ICFTU by inviting a small group over to the United States for talks, while making Buiter's exclusion from the party a condition of receiving them. Their reaction would reveal which group in the ICFTU had the upper hand. ${ }^{\text {? }}$

Although he was out in the cold and forced to watch from the sidelines, Irving Brown understood better than Paladino the European mindset on the need to protect the general secretary. Meany had previously claimed the scalps of Oldenbroek and Becu, but he wasn't going to have his way again. Though noting that the British and Italians in CISL were among those willing to appease the AFL-CIO, he recognized that there was no likelihood that even they would support a move to oust Buiter. Indeed, he suspected that Buiter might even be strengthened rather than weakened. Lovestone too was convinced that the AFL-CIO now faced a sterner task, advising Meany that the forces determined to admit the UAW into membership and make the rupture with the AFL-CIO irreparable were much stronger than appeared on the surface. He considered the latest ICFTU communication "a bad step backward ... insulting in its contents and manner ... [that] will only serve to deepen the breach. ... As of now, I can see no sign of reconciliation."

\section{Keeping the AFL-CIO Sweet}

Any further attempt by the ICFTU to accommodate the AFL-CIO would require some minimal indication from the federation that it might still consider returning, but the AFL-CIO executive council was unlikely to meet to discuss relations with the ICFTU before May. On the ICFTU side there was vague talk of President Bruno Storti writing to sound out Meany on his latest position, but it remained mere talk, and Rosenberg concluded that the ICFTU had done all it could. In these circumstances, Vic Feather made it his personal business to keep channels of communication open. Through the US labour attaché in Brussels, Harry Pollack, it was suggested to Lovestone that a signal from Meany to Feather might break the logjam. Feather was duly informed that Meany would be receptive to an overture, and he now patiently embarked on a long-term initiative to keep open the door to eventual AFL-CIO reaffiliation. ${ }^{9}$ 
The key members of the ICFTU's finance and general purposes committee met privately in Brussels on 7 May and agreed that Storti should write to Meany to propose an informal meeting in Geneva in June during the annual ILO conference. Paladino was instructed to let Meany know that he could expect a letter from Storti. However, the ICFTU president preferred to delay until after the AFL-CIO executive council had divulged its latest thinking..$^{10}$ To avoid any loss of momentum, Feather again took the initiative and contacted Meany directly, expressing the hope that he would agree to a meeting. On the following day he heard back from Meany that AFL-CIO representatives would be available to attend such an event. The AFL-CIO executive council confirmed as much a week later. Its meeting had before it a long, detailed narrative statement on the events leading up to withdrawal that was sharply critical of Buiter and the ICFTU, and to this it added a final paragraph stating the AFL-CIO's willingness to engage in talks aimed at the restoration of "free world labour unity." Such discussions were to be conducted "in the light of the reasons which led to our withdrawal," the implication being that there would be a minute raking over of recent insults and slights. But at least the two sides would be talking to one another. Victor Reuther's assumption was that the elimination of Harm Buiter would be the concession demanded by the AFL-CIO, though he still doubted that their wish would be met: "It is ... not certain that the ICFTU would go this far toward committing hara-kiri."

At the same time as securing AFL-CIO agreement to engage in further dialogue, at the ICFTU's finance and general purposes committee Feather had also won support for a proposal to notify the UAW that its application for independent affiliation would be considered at the executive board's first meeting following the congress. It was the first step toward ensuring that nothing at the congress disturbed the proposed dialogue with the AFL-CIO. Indeed, what was emerging among figures like Feather, Storti, and Bergeron was an understanding of the need to prevent, at all costs, an open debate on the UAW application at the congress. It was part of a subtle change in the atmosphere, offering the AFL-CIO hope that continuing dialogue might produce dividends. ${ }^{12}$

The exploratory meeting between senior AFL-CIO and ICFTU representatives took place in Geneva on 17 June. Buiter had wanted a formal agenda structured to elicit from the Americans their terms for re-entry. According to Morris Paladino, the general secretary also boasted of an agreement among the Europeans that they would maintain a united front by avoiding private meetings with George Meany. But Paladino and the TUC international secretary, Alan Hargreaves, ensured that in the days beforehand Meany met with most of the people on the ICFTU side one-to-one on a private basis, including several private talks with Vic Feather. A private lunch between Meany, Feather, and the new DGB chairman, Heinz-Oskar Vetter, immediately before 
the start of the meeting proper confirmed an understanding that it would proceed without preconditions by either side.

Meany was accompanied by newly appointed secretary-treasurer, Lane Kirkland, and Jake Potofsky. Interestingly, Lovestone was not included in the party and was plainly upset at being omitted. ${ }^{13}$ In Geneva, supporters of the UAW cause were depleted by the absence of Arne Geijer and Georges Debunne, neither of them considering it worth devoting time to wooing George Meany. Ludwig Rosenberg, who was also broadly sympathetic to the UAW despite his wavering some months earlier, was also missing, replaced by his recently elected successor, Vetter, an unknown quantity who made no contribution in the meeting.

With the self-assurance of a veteran whose experience in international affairs far exceeded that of any of his counterparts on the ICFTU side, George Meany dominated the proceedings, speaking for an hour and a half without notes. It was all about Buiter's mishandling of the UAW application. In substance there was nothing new; the charges had already been made in the detailed statement by the AFL-CIO executive council a month earlier. He pulled no punches, accusing Buiter of acting "as a champion of the UAW against the AFL-CIO" and waging a six-month campaign on their behalf, while failing to report crucial episodes to the ICFTU executive board. He was scathing about the official narrative account of the entire affair that Buiter had recently prepared for the ICFTU_-"about as complete a falsehood as I have seen on a piece of paper." Buiter was under instructions not to respond to such personal criticism, and it passed unchallenged. It was an exercise in allowing Meany to let off steam; the ICFTU side listened in respectful silence, hoping not to queer the pitch for a possible change of heart by the Americans. It was painfully clear that the ICFTU side were in the role of supplicants while Meany posed as the aggrieved elder statesman needing to be mollified.

Having heard him out, Feather, who led the discussions for the ICFTU, hoped to steer Meany toward agreement to meet again and focus more constructively on the future. The TUC leader strained to create an atmosphere of mutual trust when he broached the idea of having a smaller ICFTU group meet him as an informal body. Meany offered to withdraw while the ICFTU side talked over the options, but Feather insisted that he stay: "I do not look at this as two sides. I view it as a family." Storti went even further and appeared to conceive of the body as a task force to which Meany would belong rather than being the spokesman for the other side. It was left to Meany to point out politely that he couldn't be a member of their committee.

Likewise the discussion tiptoed around whether Buiter, as the controversial figure at the centre of problem, needed to be involved in the talks. Storti was evidently doubtful and suggested that it didn't have to be an official committee. But if the ICFTU side were fishing for Meany to say whether or not Buiter's inclusion would be 
welcome, they were to be disappointed. He handed the ball back to them, observing: "I don't think you should ask me what kind of committee you should have. I think this is up to you." Solicitously, Meany was then asked whether he would agree to the proposal for a further meeting. "We would not object," was his deadpan response. "I understand you say you will not object-but would you welcome it?" Feather probed unctuously, attempting to elicit a glimmer of enthusiasm. "We are ready to talk to anybody at any time," was all Meany would say. ${ }^{14}$ For the ICFTU, Storti was keen to meet again soon, even before the following month's ICFTU congress, but Meany indicated that he was in no rush. If the ICFTU was the more eager party it was because it faced financial difficulties. In that respect, there was every reason for the AFL-CIO to string the process out.

Paladino reported the meeting as a complete victory for Meany, telling Lovestone, "He was magnificent," and that his performance was "devastating." By the same token it was a humiliation for Buiter:

How he took it I don't know, and he looked pathetic sitting there alone after the end of the meeting.... There is no question left that the purpose of the committee meetings will be to find a formula to "clip" HB's wings.... HB is now boiling over ... threatening that he will never accept any reduction in his authority. However, if he acts as usual, the old \$ sign will make him more rational. Besides, he is not man enough to resign.

There was reason for the AFL-CIO to be pleased. It was in the driver's seat, and the ICFTU was being forced on the defensive over the performance of its general secretary. In the process, the issue of the UAW's possible affiliation was also slipping into the background. Lovestone now believed there was a "reasonably good chance" that unity within the ICFTU would be restored. ${ }^{15}$

However, six weeks later, on the eve of the ICFTU congress, when the executive board received a report of the Geneva meeting, there was much concern at the sharpness of Meany's ad hominem criticism of Buiter and the fact that this had gone unanswered. It was acknowledged that Buiter had made mistakes, but most speakers gave him their backing; if his scalp was the price of the AFL-CIO's return to the fold, it was unacceptable. Buiter remained defiant; the AFL-CIO allegations against him were a collection of "half truths and inaccuracies." Georges Debunne, who had stayed away from Geneva, argued that after agreeing to have contact with the Americans, it was disappointing that the ICFTU had heard nothing more from the AFL-CIO than a repetition of points that had already been publicized in an official statement.

With more first-hand experience of dealing with Meany than anyone else present, Arne Geijer believed there was nothing the executive board could do to convince 
the AFL-CIO to come back. He was critical of the fact that the Geneva meeting had been held at all and of the decision reached there to continue such "fruitless conversations." While the AFL-CIO was insistent in demanding full loyalty from the ICFTU, he noted that there was never any talk of the loyalty that the AFL-CIO owed to the ICFTU. ${ }^{16}$ Vic Feather, who was increasingly setting the tone, remained optimistic that the AFL-CIO's withdrawal was not final but negotiable. He envisaged a future meeting with the AFL-CIO focusing on how to overcome the domestic rift in the American labour movement. A small committee-the "ICFTU Five"-was named to conduct these talks. Apart from Storti and Buiter, the other three-Feather, Vetter, and Andries Kloos of the Dutch NVV-were all newcomers at this level. ${ }^{17}$

The board discussed a proposed statement on the future dialogue that included an expression of complete confidence in Buiter. It became the subject of an animated debate, with the TUC refusing to endorse the statement insofar as it referred to Buiter's handling of the UAW application: it was important to avoid wording that gave specific offence to the AFL-CIO. However, the British were in a minority, and Rosenberg, attending the executive board for the last time, stated clearly that in his shoes he would have acted exactly as Buiter had done. The resolution finally passed noted that Buiter had given a full explanation in answer to AFL-CIO allegations and that the executive board approved his efforts aimed at restoring unity within the ICFTU. The last clause affirmed "in order to eliminate any confusion ... its full confidence in its general secretary." In this form the resolution was adopted unanimously. ${ }^{18}$

If Vic Feather had been forced to go along with the majority in circling the wagons around Harm Buiter, he was more successful in neutralizing the issue of the UAW application. When the ICFTU congress opened in July, President Bruno Storti was formally authorized to announce at the start of proceedings that the incoming executive board would consider the UAW application after the congress; thus it would not appear on the agenda. Along with a mere two paragraphs in the general secretary's report to the congress briefly summarizing the steps leading to the AFL-CIO's withdrawal, this was the only reference to the momentous events of the previous months. Victor Reuther, who had visited twenty national trade union centres in twenty-five days prior to the congress to line up support and was confident of winning a comfortable majority if the application were put to a vote, was disgusted to discover that the UAW's best chance of securing affiliation had now been closed off. He attended the first day of the congress as an observer but walked out when it was clear there would be no chance for him to make the UAW case. Complaining that the ICFTU was "completely paralyzed" by the disaffiliation of the AFL-CIO, he told a British labour correspondent: "The British TUC ... are granting to George Meany, an organization not now holding membership in the ICFTU, veto power over who shall be considered eligible for membership."19 
George Meany remained unhappy with the congress's noncommittal statement on the AFL-CIO withdrawal, and even more so with the executive board resolution recording confidence in Harm Buiter. It was a setback to hopes for the ICFTUAFL-CIO dialogue, and clearly there was a need to repair the damage. Passing through London, US undersecretary of labour Phil Delaney suggested to Vic Feather that he speak with Meany to explain the circumstances under which the resolution had been drafted and so soften the impact. ${ }^{20}$ André Bergeron wrote to Lovestone apologizing for the wording while explaining that an earlier draft had been much worse and that he had only voted for the final version because the TUC representatives were ready to support it and he didn't want to embarrass them. ${ }^{21}$ Prior to the congress, DGB chairman Vetter had also written to Meany half acknowledging that "possible maladroitness" and "mistakes in attitude" on the ICFTU side had contributed to the present situation, but he suggested that "condemning each other morally" was unhelpful in the joint exercise on which they were now embarked. ${ }^{22}$

AFL-CIO international affairs committee chairman Joe Beirne had an opportunity while in Berlin that summer to talk more with Vetter about the issue, telling him bluntly that he couldn't see anything constructive coming from joint meetings if Buiter participated. Some way would have to be found to circumvent the general secretary. Indeed, the "status, influence and standing of Buiter in the ICFTU" was, he believed, one of the major topics the talks would have to cover. According to Beirne, Vetter was now willing to take a firmer line. The German told him that he would have no hesitation in asking for Buiter's resignation if any of Meany's accusations-which Buiter denied-proved to be true. Equally, Vetter attempted to put some distance between himself and Ludwig Rosenberg by telling Beirne that he did not feel personally tied to any of the "manoeuvres, manipulations or activities" of his predecessor. The new DGB leader was keen to start off on good terms with Meany, admitting that he knew very little about the international labour movement and modestly conceding that he had much to learn. "Open, frank yet quite naïve" was how Beirne summed him up for Meany. ${ }^{23}$

Beirne obtained a more authoritative account of the general attitude of the ICFTU's European affiliates from Vic Feather when they met in London in July. As he reported to Meany:

The Europeans "desperately wanted" the AFL-CIO to return and would do almost anything to ensure that result... The one thing they could not do, because it is engrained in the European tradition, was to outrightly fire Buiter after he had been just re-elected. ... In the European view the AFL-CIO has struck out two Secretary-Generals and by tradition within their own movement a third cannot go down the same path. 
Still, like Vetter, Feather believed that some way could be found to reduce the general secretary's authority. ${ }^{24}$

Meany wrote to Feather shortly afterward to inform him that the AFL-CIO executive council had nominated their own representatives for the next round of talks. But he noted that the portents were not good in the aftermath of an interview that Buiter had recently given to the Dutch NVV journal. In it Buiter had implied that the AFL-CIO's activities in Latin America were basically undertaken on behalf of the US government. Meany wrote: "The tone is obviously wrong and suggests the ICFTU will not have the AFL-CIO back under any conditions." ${ }^{25}$

Striving to keep the matter low-key, Feather responded that he would have a quiet word with Buiter about the press interview. Three days later he reported back to Meany via the US labour attaché in London, saying that Buiter was understood to be in line for a high position in the Dutch government and "may well disappear on his own as an obstacle to AFL-CIO-ICFTU rapprochement." And with that, Feather hoped to leave it. With good fortune, the problem might just take care of itself. In any event, the problem surrounding Buiter had now been extensively discussed in private, and no one was in any doubt about the need to keep him on a tight rein. Feather clearly hoped it might be possible to move on to a more constructive plane when the two sides met for talks, now scheduled to take place in New York in October $1969 .{ }^{26}$ Passing on to his brother the rumour of a possible job move by Buiter, Victor Reuther observed bitterly: "If Buiter accepts another post, the capitulation to the AFL will have become complete."27

\section{Dialogue in New York}

Vic Feather's hope that the meeting in New York on 27 October would focus on the future was to prove in vain. Meany opened by complaining that the ICFTU statement to the congress on the American withdrawal contained nothing that got to the nub of the problem - the unacceptable behaviour of the general secretary. So once again he rehearsed at length his version of events as previously expounded in Geneva. "It all boils down to a question of integrity," he said, noting that in Geneva he had heard nothing from Buiter. "The part he played is almost beyond belief. How can we live with this sort of situation ... if we can't trust the office in Brussels."

It was finally time for Harm Buiter to defend himself before Meany. Justifying his actions, the general secretary challenged Meany's interpretation of his motivation. In essence he argued that if Meany would only accept the truth of his claim that the May 1968 meeting in Rome where Walter Reuther first proposed "continuing affiliation" by an independent UAW was a chance meeting-a claim supported by Geijer and Storti, who were also present-the charge that he was conspiring behind the back 
of the AFL-CIO would lose its foundation. Yet a new admission by Buiter-elicited under questioning by Joe Beirne-that he still held the UAW cheque for $\$ 18,750$ to cover dues, seventeen months after it was originally handed over and nearly a year since it was decided to take "no further action" on the application, seemed to support Meany's allegation that he was working hard behind the scenes to ensure the success of the UAW bid.

For the first time Buiter showed a hint of contrition. Of the private and confidential letter to Meany in June 1968 that had caused such offence, he said it had never crossed his mind that the contents could be taken as an insult: "if it is, I regret it." As an apology, it wasn't very heartfelt. He claimed that at that time he had no idea that there was such discontent within the AFL-CIO over the likelihood of a UAW application for membership. It required Beirne to remind him that only a few weeks after Buiter's letter to Meany, he and fellow executive board member Max Greenburg had met with the general secretary specifically to warn that his behaviour was leading to a head-on collision. They told him: "no more shenanigans." On his abortive trip to Washington in the hope of preventing a confrontation at the November 1968 executive board meeting, Buiter admitted: "My reasoning perhaps was wrong.... I learned there was a possibility the applicants would try to appear before the ... meeting.... I saw the spectacle of Walter Reuther in the corridor and I felt the row would start right away." Altogether it was a most uncomfortable session for the general secretary, but it had a cathartic effect, even if the slate had yet to be wiped clean.

At length, exhaustion set in and even Meany ran out of steam, admitting, "I have nothing to add at this time." They adjourned and reconvened the next day. The sticking point was still the AFL-CIO's insistence that its letter eleven months earlier calling on the ICFTU to support the federation fully in the conflict with the UAW and to specifically reject the UAW application for affiliation had not been answered to its satisfaction. Feather was anxious to know if the two points in that letter were all that now divided them. Meany confirmed this. All the AFL-CIO concerns leading to withdrawal had been aired, he said. "We feel it is now up to the ICFTU executive board to take whatever necessary steps they want to take." But what would come after that? They had discussed all the points leading immediately to the AFL-CIO withdrawal, but were these the only points needing to be agreed on before the Americans would return to the fold? The ICFTU side hoped so, though Meany's body language suggested otherwise. As the chronicler of ICFTU fortunes, John Windmuller, noted, the AFL-CIO had begun to realize that its leverage on issues still to be resolved was greater outside than inside the ICFTU. ${ }^{28}$

In fact, as Morris Paladino noted privately, the meeting had simply identified the first steps the ICFTU needed to take to attract the AFL-CIO back into the fold. Meany had told the "ICFTU Five" that he would be prepared to meet again; but what 
would be on the agenda? The ICFTU team had travelled a long way to New York to give Meany another opportunity to let off steam and denounce the ICFTU general secretary, but once again they now found themselves scrabbling for the merest concession from the AFL-CIO. Feather asked what precisely the Americans might want to discuss next time. "I would not care to indicate," said Meany evasively. "We would certainly want to talk about the whole structure of the ICFTU-its policies and plans-beyond that I don't want to discuss." Feather tried another angle: "I don't want to press the point but would it follow that there was a reluctance to leave the ICFTU?" Meany simply ignored the question. A mere observer at the meeting, Jay Lovestone later commented dismissively: "The strongest fellow in the negotiating committee was Feather, and Feather was as strong as a feather." ${ }^{29}$

The ICFTU would need to go back to the drawing board and again try to come up with an acceptable response to Meany's original letter before the two sides met again. This time it would have to deal with the UAW application for affiliation. The ICFTU Five met in Dusseldorf ahead of the October 1969 executive board to map the way forward. ${ }^{\circ}$ Vic Feather argued that the reply needed above all to make clear that the UAW application was firmly rejected and that the ICFTU had no intention of recognizing any American organization other than the AFL-CIO. He reasoned that it shouldn't be seen merely as a bid to placate the AFL-CIO; affiliating the recognized national centre was the principled approach. Buiter disagreed, suggesting that such a proposal might antagonize the executive board given that the ICFTU was suffering financially, its morale sapped as a consequence of an AFL-CIO policy that seemed to amount to a strategy of "rule or ruin."

Others worried about being left "holding the bag" if they pulled up the drawbridge to the UAW only to find that the AFL-CIO still wasn't prepared to rejoin. They were disturbed at the Americans' unwillingness to "trade" on their return to the ICFTU fold. If they could be sure of the AFL-CIO's readiness to reaffiliate, there seemed little doubt that they would recommend meeting Meany's demands. However, executive board members would not want to eat crow if it was uncertain that the AFL-CIO would rejoin. Split between these two positions, the group simply decided to report the nature of the discussion in New York and hand the matter back to the board's finance and general purposes committee for one last attempt at formulating a response. ${ }^{31}$

When the ICFTU executive board met the following week and its finance and general purposes committee addressed Meany's letter, the mood had shifted. Georges Debunne was not present for this exercise, and Arne Geijer stayed away from the board altogether, having advised Reuther: "It is hopeless because our friends have not got the guts to stand up, and I am going to disassociate myself." ${ }^{22}$ In their absence the finance committee was unanimous in proposing to reject the UAW application, and 
the full executive board subsequently ratified the decision amid a growing sentiment for "putting our house in order." Debunne and Dalla Chiesa of UIL were alone in criticizing the "lack of dignity" involved in having to submit to AFL-CIO "preconditions." As Paladino reported to Meany, the board had finally grasped "the realities of the situation."

Yet there was still disagreement over the agenda for the next round of talks with the AFL-CIO. How wide ranging should they be when there was no assurance that the Americans would return? Buiter warned of the constitutional impropriety of entering into discussions with a non-affiliate on the future of the ICFTU. To avoid this, he suggested that the wording of the reply must specify that talks would only take place within the constitutional framework of the ICFTU. This became the focus of intense debate, with the British representatives fiercely opposed to Buiter for introducing "a false issue" that would only "complicate matters." The TUC finally had its way; the resolution adopted aimed to answer Meany's letter along the lines the Americans demanded. Expressing the hope that this spurning of the UAW would enable the reunification of the free trade union movement, the ICFTU letter to the AFL-CIO looked forward to "the continuation of our dialogue."

As Paladino noted, the ICFTU's latest position was a product of the TUC's sticking to its guns to the very end. ${ }^{33} \mathrm{He}$ informed Meany that executive board members were relieved to have finally and unequivocally dealt with the issue, having expressed to him their hope that the letter to be sent to the AFL-CIO would be interpreted as a "correction of past errors." The rejection of the UAW's application was, he maintained, never in doubt; even the two abstainers, Debunne and Dalla Chiesa, made no specific reference to their support for the UAW, registering their abstention on the grounds that the resolution went too far in satisfying the AFL-CIO. With justification, Paladino's report to Meany concluded: "the case of the AFL-CIO has clearly triumphed." ${ }^{4}$

The UAW had been outmanoeuvred, largely as a result of the AFL-CIO's continuing influence within the international labour movement. One-time editor of the UAW paper, Frank Winn, who had been close to Walter Reuther since the 1930s, grasped a key dimension of what had happened, commenting that the only time the UAW president ever underestimated an adversary was in his judgment of George Meany. ${ }^{35}$

Walter Reuther reported the ICFTU decision to his UAW executive board with evident disgust. It was, he said, the first time the ICFTU had denied the right of an applicant to come before it for a personal hearing. The UAW had received little support, deserted by former friends. The Canadians had reversed their position since the previous spring and had gone along with the prevailing logic, saying: "We have to clear the decks for the return of the AFL-CIO. If that means condemning the UAW, then so be it." Even the FGTB and UIL representatives, its stalwart supporters in previous meetings, only abstained on the vote-and then principally over the issue of 
whether there should be further open-ended discussions with the AFL. "How do you live with people and have any self-respect or any sense of integrity if this is the way you are used?" Reuther asked. Arne Geijer had told him he intended to have nothing more to do with the organization whose president he had been for eight years. Walter Reuther now had little option but to follow suit: "If this is the way the ICFTU is going to be, then it is not worth our effort. ... We therefore ought to intensify our work ... with the IMF." It was always sad to see an organization commit self-immolation, Victor Reuther observed, but that was exactly what the ICFTU was doing. ${ }^{36}$

\section{Dialogue in Bal Harbour}

It was less than eighteen months since the Warsaw Pact forces had invaded Czechoslovakia, but already the ICFTU's European affiliates were resuming their contacts with the unions of the Soviet bloc. The DGB congress had decided on this course in May 1969. In September 1969, following Victor Feather's first annual conference as TUC general secretary, Jay Lovestone pointed out to George Meany that the combined weight of the engineers' union led by Hugh Scanlon and Jack Jones's transport workers' union, two mainstays of British trade unionism's "broad left," had been decisive in overturning existing TUC policy and calling for the resumption of East-West contacts. At the same time Lovestone informed Meany that at the German metalworkers' congress, the Soviet ambassador to West Germany, no less, had been guest of honour. ${ }^{37}$

More worrying still, Poland's trade union centre had written to Western European unions floating the idea of a trade union conference on "international security", while a counterproposal by some ICFTU affiliates had been to hold an East-West European trade union conference under ILO auspices. For the first time, as part of Ostpolitik, there were now DGB plans to establish contacts with the East German trade union centre, the FDGB. And Heinz-Oskar Vetter had been to Moscow in December 1969 with a DGB delegation to discuss future exchanges with Alexander Shelepin. What was envisaged were German-Soviet exchanges by national and sub-national union bodies and newspaper editors along with cultural programs organized by the two centres. The AUCCTU agreed to visit West Germany in May 1970. The talks were reported as very amicable, with Welt der Arbeit effusive over the fact that Shelepin had agreed to attend a banquet with Vetter at the West German Embassy. The discussions had also been notable for the fact that Shelepin had provocatively questioned the appropriateness of the DGB's inclusion of a West Berliner in its delegation; the Soviet Union did not recognize West Berlin as part of the Federal Republic. ${ }^{38}$

Whether or not the AFL-CIO really would have seen fit to rejoin the ICFTU without these developments must be moot, but three weeks before the ICFTU Five 
and the AFL-CIO team were due to resume their dialogue in Miami in early February 1970, Jay Lovestone wrote that, but for the recent meeting between Vetter and Shelepin, the AFL-CIO would probably be back in the ICFTU. But now the omens for that dialogue were not promising. ${ }^{39}$

Heinz-Oskar Vetter travelled to Bal Harbour ahead of his ICFTU Five colleagues and spent a few days acclimatizing on the fringes of the federation's leisurely winter executive council session before his colleagues arrived. Updating them, he enthused that the atmosphere was good and that Meany had been personally friendly, though he had no idea what his plans were for the meeting. He thought the Americans might be interested in discussing ways of strengthening the executive board and its committees - the focus being to curb Buiter's powers - though he sensed that they were not proposing his removal. Vetter also had the impression that the Americans just might want to discuss East-West policy. How right he was.

As the meeting started, Meany declared himself satisfied with the ICFTU's rejection of the UAW application. That matter was now closed. Feather then hoped to steer the discussion in the direction of more general policy issues, but straight away Meany launched into his next major sticking point-the issue of East-West contacts. Immediately a chill descended on the meeting. Feather interjected that the ICFTU's affiliates, just like the AFL-CIO, must be free to make their own policy. Meany replied in belligerent tone: "I can give you an answer very clearly-we don't want to be in an organization where affiliates exercise their rights and form alliances with totalitarian governments-I can tell you right now we will not be-not be-associated with people who exercise that right."

The remarks were directed very much at Vetter. Alluding to his recent friendly talks with Shelepin, Meany snapped: "I don't want someone calling Shelepin 'Brother Shelepin' and then calling me 'Brother Meany." He was particularly upset that Shelepin had queried the participation in the DGB's Moscow delegation of a West Berliner. And he mocked the German interest in "co-existence", a subject that, he noted, the Hungarians in 1956 and the Czechs in 1968 knew all about.

Speaking in earnest, Vetter defended his recent meeting in Moscow, whose aim was to lessen international tension. It was also intended to forestall criticisms by West German communists that the DGB was not doing enough to end the division of Germany. He pointed out that the DGB had already shown principle by declining a Soviet invitation to join in the celebrations of Lenin's centenary and the May Day celebrations where rockets and military hardware were paraded. But he was prepared to discuss trade union matters with the AUCCTU, and given that the Soviet organization planned a return delegation in May, he suggested that this item now be taken off the present agenda. By May, when the AUCCTU had paid their visit, the prospects for lowering tension would be clarified; if the signs were no longer 
promising for improvements in international relations, the DGB would end its talks with the Russians. Vetter became indignant when Beirne asked sarcastically whether it might take another Soviet invasion or even a war to clarify the picture for him. Meany then agreed to drop the topic from the current agenda.

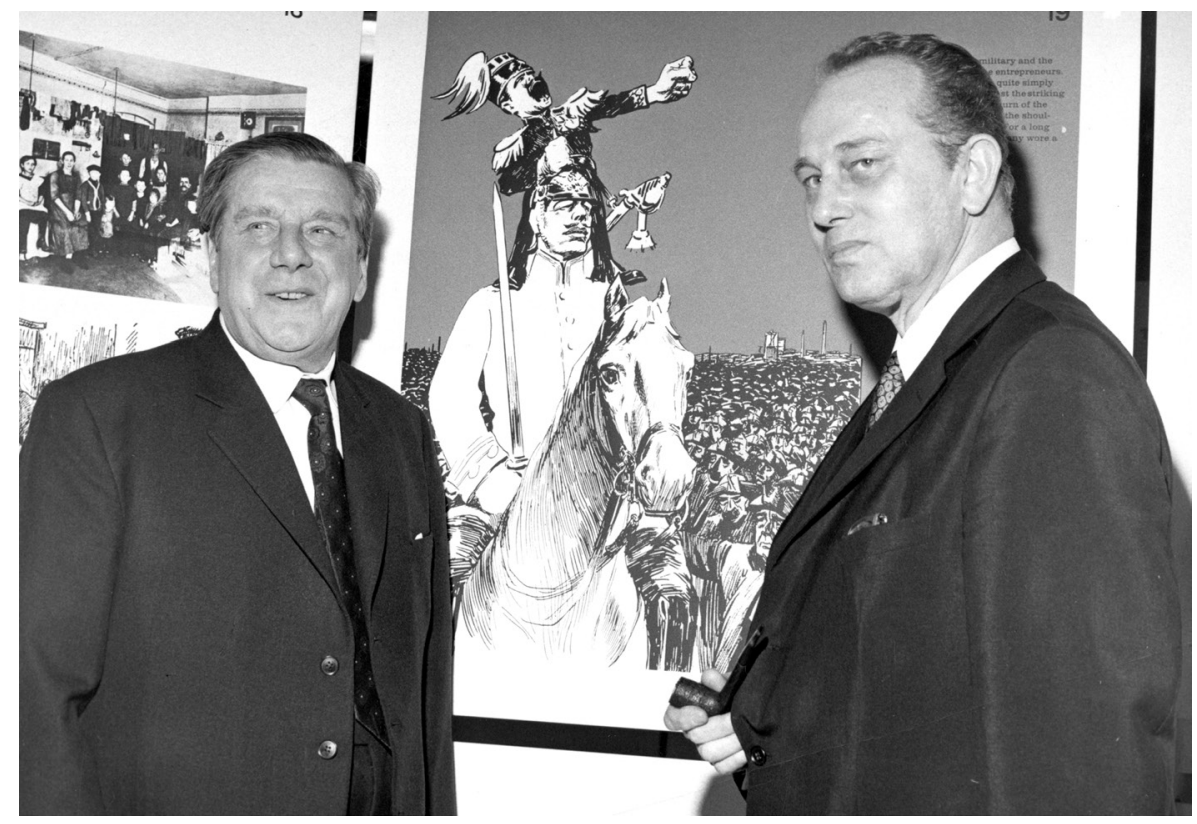

Figure 18. Vic Feather, general secretary of the TUC, 1969-73 (left), with Heinz-Oskar Vetter, DGB chairman, 1969-82. Feather led the campaign to keep the AFL-CIO affiliated to the ICFTU, whereas Vetter's contacts with the Soviet trade unions in the cause of détente helped to doom that campaign. Courtesy of TUC Library Collections, London Metropolitan University.

There were signs of growing irritation all round. Vetter complained that the stalemate that now existed between them would only demoralize their friends and give comfort to their enemies. Meany retorted that the current impasse was very much a product of the Germans meeting with the Soviets; DGB policy had changed in recent times. Vetter countered that the Americans had advance notice of the DGB's planned visit to Moscow, as they had sent observers to the latest DGB congress. "Nonsense," snapped Meany; there had been no official AFL-CIO representative there. Had Vetter mentioned at their October meeting in New York his plans for going to Moscow, the ICFTU could have heard the AFL-CIO response there and then. For many years, Meany said, the problem of visits had been at a 
lower level and could be dismissed as instances of people looking for a "free trip." But more recently it had been a case of the head of the DGB going to Moscow, and he added: "If there is a mutual interest between the DGB and the so-called unions of the Soviet bloc then there can't be much of a mutual interest between the DGB and ourselves." Vetter asked whether the East-West contacts were the main reason for the AFL-CIO remaining disaffiliated. Meany answered bluntly. "I think we have made our position clear. If these contacts are to develop we do not want to be in the same organization with the DGB." Seeing how badly the talks were going, Feather intervened to move adjournment. And when they reconvened briefly the following morning, he expressed the view that a continuation of the discussion would be "less than useful at this stage." Morosely, he intoned: "I consider it [East-West policy] . . . a very negative phase of our discussions." ${ }^{40}$ The meeting ended with only a tentative agreement to meet sometime again in 1970.

This latest round of talks had failed miserably, and the ICFTU side left it to the AFL-CIO to decide whether they felt it worthwhile to call a further meeting. It was evident that Beirne and Meany had no intention of rejoining the ICFTU. Discussion within the AFL-CIO leadership was now over whether to bother with a further meeting; the strategic options were between suggesting ad hoc get-togethers from time to time, or alternatively simply "leaking" word of their deep dissatisfaction through Morris Paladino and so bringing the process to an end forthwith. ${ }^{41}$

Informed of the stalemate, Victor Reuther's verdict was that the ICFTU leadership had set out to appease an organization that had never shown any concern for the international labour movement but had given priority to its own national and chauvinistic interests, and for what? The TUC's single-minded strategy of paving the way for the AFL-CIO's return, it seemed, had achieved nothing other than to permanently exclude the UAW from the ICFTU. ${ }^{42}$

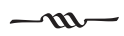

One more gathering was convened in Geneva in June 1970, on the fringes of the International Labour Conference. Meany didn't attend, the AFL-CIO being represented solely by Joe Beirne and Lane Kirkland. There was now a different climate: Walter Reuther had died in a plane crash a month earlier, and the UAW's expensive program of international activities financed from the interest on its strike fund was brought to a speedy end, with the union about to embark on a titanic two-month strike against General Motors that would see its strike fund drained and the UAW effectively mortgaged to the teamsters' union. A distinct era in American labour's involvement in international labour affairs was coming to an end. 
This time the exchanges between ICFTU and AFL-CIO were sharper and colder, with no sense that a meeting of minds was even a remote possibility. Buiter stated that the ICFTU was unable to accommodate the AFL-CIO further. Beirne responded that it wasn't only DGB behaviour that concerned the Americans but the failure of purpose in the ICFTU and the apparent lessening of concern for human rights. Vetter observed that the AFL-CIO hadn't cited the DGB's actions previously as the reason for its disaffiliation, but Kirkland went beyond that now, stating that the Americans no longer regarded the ICFTU as a useful channel for promoting trade unionism worldwide.

The ICFTU Five pointed out that the organization was engaged in a wide range of activities that were eminently suitable topics for constructive discussion, but Beirne was dismissive, claiming that the organization was currently virtually inactive in many essential areas. The AFL-CIO had broken with the ICFTU, he explained, simply because its key affiliates gave insufficient support to the fundamental purposes of the ICFTU as they and the Americans had understood them in the past. Bringing the exchange to a close, Lane Kirkland had the last word, telling the ICFTU representatives that the discussion had provided no grounds for hope that the AFL-CIO would reaffiliate at an early date. It was time to say goodbye. ${ }^{43}$ 


\section{0}

\section{Conclusion \\ The "Cold War" Within the Cold War}

The years examined here began with the bulk of the international labour movement seeking worldwide unity within the World Federation of Trade Unions, with the strategic goal of securing a genuine role at the decision-making table and an authoritative voice in shaping the architecture of postwar international economic relations. They ended with a growing number of unions affiliated to the International Confederation of Free Trade Unions, engaging in contacts with Soviet bloc labour bodies in the context of East-West détente. The years in between saw the hardest phases of Cold War politics, affecting social, economic, cultural, and military relationships. At the start and at the end, however, the one unchanging element was the AFL/AFL-CIO refusal to join in the process. Courting isolation, its preference was to stand apart from the main representative body of organized workers.

One thread running through this study is the concept of "free trade unionism," the label adopted by the ICFTU's founders to distinguish themselves from the WFTU. Never precisely defined, it was as much aspiration as description, a pointer to a preferred form of trade unionism, but it was still susceptible to different interpretations and thus to disagreements. Nevertheless, it provides a prism through which to view issues that were often contentious in labour circles. Free trade unionism was rooted in a conviction that workers had an inalienable right to form trade unions as the natural expression of their interests. Axiomatic was the belief that these should be self-governing worker organizations under the control of their members and entitled, if they so chose, to federate with other similar bodies. For free trade unionism to thrive, a democratic polity and pluralism in social organizations was essential. 
Free trade unionism for the AFL was a long-standing and fundamental principle, born of hostility to the Bolshevik revolution and the unwavering opposition to continuing efforts by communists deploying Leninist tactics to gain a toehold in the US labour movement. Bitter experience gained from "united front" tactics and campaigns of "entryism" taught the lesson that communists only took would-be partners by the hand the better to take them by the throat. The AFL therefore believed there was no such thing as a partnership of equals with communists in which different groups respected the integrity and independence of the other; the basic rule was thus to have no truck with them. In the context of totalitarian communist regimes, trade unions were seen essentially as agents of the state to be totally opposed. The AFL believed that help should be given, where feasible, to workers in communist countries who challenged their communist party's monopoly of representational rights. The principle was also applied by the AFL to unions in fascist and authoritarian countries, notably Franco's Spain and Argentina under Perón, though over time there would, in practice, be less concrete opposition to unsavoury, authoritarian regimes in Latin America or, indeed, in post-colonial Africa.

How free trade union principles were to be drafted into the ICFTU constitution was subject to fierce debate at its foundation. Memories of this founding disagreement lingered long and injected for years to come a bitter edge into relations between those who had been involved. The AFL had wanted an explicit statement that trade unions should be free from control by political parties, government, employers, or the church, but facing opposition from the British TUC, the Americans settled for a formulation more attuned to union practices in Western countries where organic union links with a labour or socialist party existed. The AFL, however, secured a compensating constitutional reference to trade unions as "bargaining agents" - a corrective to the European trade unions' greater reliance on legislative gains to be sought and achieved through their political partners.

By the time of the formation of the ICFTU in 1949, early hopes for a peacetime world based on a continuation of the wartime big power alliance had given way to one polarized between East and West, with both sides heavily armed. Since the WFTU's foundation, the international labour movement had witnessed divisions, not unity, paralleling the harsh realities of the developing Cold War. But it was not simply a case of the Cold War impacting on the labour movement; the AFL was itself an important protagonist in the birth of the Cold War. Its efforts in France, Germany, Greece, and Italy were of fundamental importance in shaping the labour movements in those countries and in steering a significant portion of trade unions into the Western camp. The AFL gave strategically important assistance to French and Italian trade unionists who were already resisting the increasing communist domination of the CGT and 
the CGIL in pursuit of a shifting sectarian political line. The Americans considered that they were simply striking a blow for the principle of free trade unionism.

The ICFTU, formed in 1949 and to which most Western union centres belonged, symbolized a rejection of the way the WFTU had served as a pawn of the communist bloc in opposing Marshall aid. At the outset, the one clear policy of the ICFTU in terms of external relations was to distrust the WFTU and to reject its determined pursuit of contacts and dialogue: there would be no relations between ICFTU and WFTU. How to deal with other bodies in the communist orbit remained to be determined.

The ICFTU was a component of the Western bloc. Testament to that was the appointment in 1951 of a trade union-approved representative in the NATO secretariat as liaison to the ICFTU. ${ }^{1}$ It was an arrangement that backfired on the ICFTU when it failed to recruit into membership Japan's largest trade union centre, Sōhyō, which feared Japanese embroilment in the Korean War. Denials that the ICFTU supported either rearmament or the Korean War cut no ice with the Japanese, but they did serve to fuel early AFL doubts about the ICFTU's wholehearted commitment to waging the Cold War. The AFL remained the most stalwart trade union champion of NATO and, indeed, of a close organizational link with the NATO secretariat.

In this climate, the AFL opted to continue its separate program of international labour relations by focusing its work and its funding on the "independent activities" developed by its Free Trade Union Committee since 1945. The AFL also kept a watchful eye on the ICFTU leadership, criticizing from within any perceived backsliding by the ICFTU secretariat and other affiliates in their opposition to communism. The AFL's justification for its continuing go-it-alone international program was that American unions had a special role to fulfil, and a unique competency. As Irving Brown put it, the ICFTU could not and would not do what the AFL could and must do.

The AFL's Free Trade Union Committee aimed to strengthen the anti-communist capability of Force ouvrière and CISL, its client centres in France and Italy, and explored ways of extending the anti-communist crusade behind the Iron Curtain; but it looked askance at developments within the ICFTU when affiliates accepted invitations from the non-aligned (though still communist) Yugoslav trade union centre to its congresses. The AFL was outspokenly opposed when there were signs from time to time that international trade secretariats might be willing to entertain membership by a communist-led union. Yet such choices by self-governing bodies were entirely defensible under the rubric of self-governing "free trade unionism." The problem for labour was that whereas "unity" remained a deeply held value, a Holy Grail for international unionism, for the AFL the battle against communism took precedence. 
Questions that were of an essentially administrative nature, such as whether or not to admit into membership in the ICFTU the Australian Workers' Union, the Unione italiana del lavoro, or the Japanese centre Zenrō, were judged by the AFL according to perceptions of the likely impact on the way the latter had chosen to fight communism in these countries and on the particular impacts on anti-communist alliances that it had already forged. The recommendation of the ICFTU's first exploratory mission to Asia to base the regional organization in Singapore was evaluated by Jay Lovestone entirely in terms of what it meant for the fight against communism in Asia should the ICFTU locate its subsidiary body in a British colony. His hostile reaction, based in part on his mistrust of the British TUC, led to a breach with General Secretary Oldenbroek that was never healed. The failure of ICFTU affiliates to take a firm position in opposition to the Soviet Union's application to take its seat at the ILO-an agency of the United Nations to which the USSR was perfectly entitled to belong, even though trade unions in that country were simply instruments of the state-was judged as a sign of the lack of firm anti-communist resolve within the ICFTU. And for the AFL, the appointment of an ICFTU director of organizing became a test of whether or not the person chosen would prioritize organizing for the anti-communist struggle. In practice, it became a question of whether or not the job should be handed to the AFL's Irving Brown.

In 1955, following a proposal by the AFL, the ICFTU stance on free trade unionism was clarified with a policy that ruled out contacts with all communist organizations. Yet just as its affiliated national centres were often powerless to stop their own unions from having such relations with communists, so also the ICFTU had no means of enforcing its new policy: free trade unionism did not sit easily with the idea of any central body imposing top-down discipline. A typical argument of those unions that did not comply was that while they fully endorsed the ICFTU constitution, their policy had to be adapted to the practical needs of the situation at hand.

As the cold-war climate eased from the mid-1950s, and with the Soviet Union proclaiming a "new look," East-West dialogue led to the introduction of cultural exchanges and a parallel increase in the number of invitations to Western unions to visit communist organizations behind the Iron Curtain. Willing takers there were, mostly hoping to learn at first hand what communist societies looked like, and in turn keen to share their Western understanding of trade union principles. The trend in "trade union tourism" continued into the 196os, growing stronger when President Johnson's administration became focused on "building bridges" to the East and the West German government began to shape Ostpolitik as a way of regularizing relations with its eastern neighbours.

Differences there undoubtedly were between ICFTU affiliates on the advisability of such visits. Honest attempts at dialogue were criticized by anti-communist 
hard-liners as an unnecessary lowering of the guard that would naively serve the purposes of communist propagandists. Absent the central power of the ICFTU to impose a "disciplined line," the situation called for diplomatic skill and a plentiful supply of pragmatism and goodwill. Here the role of the AFL-led FTUC invites examination. In staffing the FTUC, the AFL chose to fight fire with fire, deploying former communists to take on present-day communist opponents. As FTUC director, Jay Lovestone maintained that only those who had experienced the communist movement from within could ever be reliable anti-communists. Thus he hired ex-Lovestoneites Irving Brown and Harry Goldberg, with other personal allies from Communist Party (Opposition) days in supporting roles. To critics it was the application of "communism in reverse."

The particularly close relationship between Lovestone and Brown was a key feature of FTUC work. They were obsessive in their pursuit of "the project" and in the way they buoyed up one another's commitment, sharing the same sense of impending doom at the perceived international drift toward communism. Prone to dramatize events, and with the self-image of lonely warriors fighting valiantly against the heaviest of odds, they maintained a subtext in their reports to the AFL leadership of their indispensability: they alone understood the nature of the communist threat and the way to defeat it.

Reflecting this passionate anti-communist mindset, the correspondence between Lovestone and Brown often described colleagues within the ICFTU disparagingly as ineffectual or as liabilities: some were viewed as knaves, others as fools, but either way they were the subject of ad hominem criticisms and wounding personal put-downs. Their opinions were hardly a secret and over time could only have a negative influence on the way senior AFL-CIO officers perceived the ICFTU, implicitly raising the question of whether continued American membership in such a body was worthwhile.

Within the wider international labour movement the Lovestone-Brown style often exacerbated already strained relations. Speaking at a conference of the Industrial and Labour Relations Association in the 1950s, Lovestone informed his audience in characteristically dismissive terms that "the ICFTU wakes up sometimes when we kick it in the shins. The ICFTU lacks the drive, force, vitamins. It is asleep, but sleep is not an occupation. It's a disease." Walter Reuther, the president of the United Auto Workers and a sharp critic of the AFL-CIO's approach to the problem of communism, deplored this ongoing "cold war" against the ICFTU. As the respected American labour media correspondent Jack Herling commented, the substantive issues over which opinions on international matters differed were not nearly so divisive as the tactics deployed and the personal animosities thereby generated. ${ }^{2}$

Yet if Lovestone and Brown inflamed relations with other trade union centres, they were doing so with the tacit consent of AFL-CIO president George Meany and 
after he, personally, had set the tone. Indeed, Meany stoutly defended Lovestone and Brown against "the hatchet job" on them he believed Walter Reuther was engaged in. As early as 1951, it was Meany who turned a deaf ear to the private plea by TUC general secretary Vincent Tewson that he intervene to end Lovestone's scope for publishing for overseas consumption tendentious statements that casually insulted sister organizations. Meany's low regard for the ICFTU as led by Jaap Oldenbroek was evident from the earliest days, first reflected in the prolonged AFL boycott in 1952 and subsequently in a continuing skirmish over the finance needed by the ICFTU to operate effectively. And by abetting Irving Brown in his calculated defiance of Oldenbroek's successor, Omer Becu, Meany undermined and eventually destroyed his one-time ally's authority as general secretary. Meany's failure in 1967 to respond to Jef Rens's request that Brown cease aiding Colonel Mobutu's strong-arm centralization of the Congolese trade unions finally robbed the ICFTU of the prospect of appointing a widely respected general secretary.

Despite Meany's public image as an irascible, cigar-chomping union boss, those close to him considered that his effectiveness as a leader derived from his characteristic personal decency and sense of principle, seeing in him a man who was essentially humble and even inclined to shyness. Yet it was a different, belligerent Meany who tended to appear on the international stage. To Stefan Nedzynski, who dealt with him at close quarters as ICFTU assistant general secretary, he seemed to be always angry.

Meany was never in doubt that his trenchant criticisms of the ICFTU and fellow leaders of certain national affiliates were fully justified. The ICFTU lacked his sense of urgency at the threat posed by communism. He saw this issue in moral terms: communism was a conspiracy against freedom that needed to be fought everywhere. Yet on this, as with other matters, Meany found Jaap Oldenbroek intransigent and prone to arrogance. The TUC's Vincent Tewson also irritated Meany with his overly cautious approach to fighting communism and belief that the ICFTU's general effectiveness would be reduced if it were tagged with the cold-warrior label.

Anti-colonialism, a key item on the ICFTU's agenda, was closely linked to the anti-communist struggle inasmuch as the continuation of the colonial system was likely to play into the hands of communists operating inside third world nationalist movements. Here the AFL-CIO had an exemplary record-in both supporting movements for national independence and in strongly criticizing the way the US government indulged foot dragging by European colonial powers averse to a speedy process of decolonization. The AFL-CIO was often unfairly accused of following US government foreign policy. In fact, the accusation could with more justification be levelled against European unions with organic links to a party in government-especially when engaged in the administration of colonialism. Meany could fairly argue that the British TUC operated according to double standards. It expected loyalty to 
the ICFTU from others, while being determined to retain for itself a proprietorial interest in trade union affairs in British colonial territories, with a program equivalent to the AFL's "independent activities" that were so disapproved of when practised by the FTUC. For the AFL-CIO, the close relationship between Oldenbroek and Tewson evoked memories of European domination of the pre-war international labour movement and especially the way leaders of the TUC and the now defunct International Federation of Trade Unions were the axis on which the movement had operated. It was an imperial British arrangement that the AFL had been determined would not be repeated in the ICFTU.

The perception that the ICFTU was too much influenced in its approach to Africa by its European affiliates with colonial interests caused Walter Reuther to overcome personal differences with Meany and join forces in opposing the way ICFTU policy was implemented in Africa and in forcing Oldenbroek from office. The AFL-CIO's preference for playing a lone hand in Africa through the African-American Labour Centre in the 1960s was in part a reaction against the lingering colonial instincts of some European trade union centres. It was also a factor behind the close relationship that Irving Brown developed with Colonel Mobutu in the Congo.

Despite the common interest of George Meany and Walter Reuther in replacing Jaap Oldenbroek, there was recurring friction within the AFL-CIO between the two men over international affairs. For some, this was portrayed as no more than a manifestation of Reuther's ambition to succeed Meany as AFL-CIO president, yet the significant, substantive differences between them over foreign policy cannot be brushed aside. As the British labour attaché in Washington noted in 1960, the mere fact that Reuther had a high profile internationally and was admired by trade unionists in other countries grated with the AFL-CIO president. Meany accused Reuther of trying to diminish his standing around the world. He particularly resented the fact that the TUC kept in close contact with the UAW president, and he considered that, through his activities overseas, Reuther made it easier for the British to play off one section of the US labour movement against the other. It made Meany all the keener to assert his primacy in the international field.

International trade union relations highlighted the different emphases Meany and Reuther drew from the concept of free trade unionism. These were captured in the slogans they coined, mostly for use against one another. The FTUC was criticized for its "negative anti-communism," which fed labour's "cold war" within the Cold War. In turn, Reuther was mocked by Lovestone as the naïve proponent of "belly communism," his view that an assault on poverty and hunger in the Third World, and primary attention to increasing workers' living standards in the West, was the best defence against the spread of communism. Reuther's slogan, "neither Standard Oil nor Stalin," never expressed Meany's approach to international trade unionism. 
In contrast with the AFL's activities, the CIO program conducted by Victor Reuther in Europe in the early 1950 os had at its core the aim of improving negotiated terms and conditions at work by assisting French and Italian non-communists in their industrial struggle against employers. The ambitious program launched by the UAW in the 1960s and financed by the interest earned on its strike fund largely fitted the same mould. The sums involved were significant, and in 1967 alone, when the UAW's departure from the AFL-CIO appeared increasingly likely, Jay Lovestone calculated that the union had spent close to $\$ 1$ million on international affairs. ${ }^{3}$ The UAW program was unique in attempting to carve out a genuine role for union members at the base-something almost universally lacking in the conduct of international policy by organized labour everywhere, whether or not they subscribed to some notion of free trade unionism. The UAW's suspicion of the American Institute for Free Labour Development (AIFLD), the AFL-CIO's flagship regional agency in Latin America, and especially the formal role it accorded to employers, also pointed to a fault line between competing emphases within free trade unionism, suggesting for some a boundary line beyond which the concept began to lose all meaning.

No less anti-communist than Meany, Reuther differed with him in believing that it was worth engaging with communist opponents-as with Soviet leaders Mikoyan and Khrushchev, to confront them at the level of ideas, or with Tito, to obtain a first-hand view of how much scope there might be for dialogue with the Yugoslavs. Victor Reuther's meeting with AUCCTU leader Alexander Shelepin during the Prague Spring was no attempt to cozy up to the Soviet trade unions but rather to impress on a ranking member of the Politburo the UAW's support for the liberalizing Czech metal workers' union, which it continued to assist even after the country's attempt at liberal reform was crushed when Warsaw Pact tanks rolled into Czechoslovakia.

In the years covered by this study, American trade unions began to rely significantly on finance from government sources for their international work. Some came directly from the Central Intelligence Agency, some via government aid agencies from counterpart funds "owned" by the CIA, and later, more commonly, from the Agency for International Development under its own auspices in support of the AFL-CIO's regional institutes and for disbursement to selected international trade secretariats. Labour leaders justified the practice on grounds that their communist opponents were even more generously funded from Soviet government sources.

The fact that the CIO was also clearly in receipt of CIA funding in the early 1950s, if on a smaller scale, became a serious source of friction between the AFL and CIO in their years of organizational rivalry before they merged in 1955. The unconvincing claim made by Walter and Victor Reuther was that they understood 
the money to come from counterpart funds of the aid agency, which were voted publicly by Congress for programs that included international activities conducted by the labour movement. Even so, union accounts failed to record these sums, and the union leadership was clearly conscious that attempts to procure aid agency funds for programs administered by the ICFTU necessarily involved deceit.

Funding from the CIA was channelled secretly and avoided public scrutiny. The membership in whose name it was spent was kept entirely in the dark and received no accounting. While for many years there was no general awareness of the source of funding, Irving Brown especially earned a reputation overseas as a moneybags and because of that came to be viewed with suspicion. There was too much of a tendency to "buy" the support of fellow trade unionists. In France, Force ouvrière's dependency on AFL subsidies was long-standing, and even as it failed to grow in membership Irving Brown felt a continuing need to talk up its prospects, so much personal credibility had he invested in the organization. Over time, the word "free" liberally attached to trade union bodies that were artificially funded opened up the whole concept of free trade unionism to criticism.

The issue of CIA funding - denied for so long-proved difficult for the AFL-CIO to live down, and doubtless accounts for delays in opening up its files on international affairs. The practice is clearly impossible to square with the precepts of free trade unionism, except by persuasive definition, arguing in circular fashion that its use by unions in the struggle against Soviet communism-where unions, by definition, were not free-must have been in the cause of free trade unionism. Apologists have suggested that the real problem derived from the secrecy surrounding the arrangement and, optimistically, that the controversy could have been diffused had there been openness about the source of funding. ${ }^{4}$ Others point out that the collaboration between organized labour and the CIA's forerunner, the OSS, during the war against Nazism was never regarded as a source of embarrassment. Therefore, they argue against different values being applied in the battle against Soviet communism. That would appear to have been George Meany's attitude, given the way people with apparent intelligence backgrounds found work in sensitive areas with the AFL-CIO, whether they were formally on the books or not. Yet notwithstanding such cases, it is necessary to recognize that the AFL-CIO's links with the world of intelligence in no way paralleled the situation in the Soviet Union, where the head of the AUCCTU was the former head of the KGB!

Only in the second half of the 1960 s did the facts relating to secret funding surface, when they became an important issue in the developing conflict between the UAW and the AFL-CIO. That conflict led in turn to the autoworkers' disaffiliation from the AFL-CIO and its subsequent attempt to rejoin the ICFTU as an independent centre. This was the proximate cause of the AFL-CIO withdrawal from the ICFTU in 1969. 
It was a reflection of the fall in the AFL-CIO's international standing that a number of European affiliates responded with equanimity at the prospect of its departure. They were upbeat at the prospect of the UAW taking its place as an altogether more congenial American partner.

There was now disillusionment on both sides of a growing divide within the ICFTU, with serious consequences for international trade union cohesiveness. For years, with ever-lower expectations of the ICFTU, the Meany-led AFL-CIO had been gearing up to work abroad through its three regional institutes. Equally frustrated at the continuing impasse within the ICFTU, the Europeans had also started to turn inward, focusing on their particular regional concerns and beginning to think in terms of a new Europe-wide international body_what finally emerged in 1973 as the European Trade Union Confederation (ETUC). Within a few years this development would highlight serious differences of attitude toward free trade unionism among Europeans themselves.

Although the AFL-CIO identified the German DGB and the British TUC as the chief culprits in defying ICFTU policy through their contacts with the USSR, and thereby undermining the principle of free trade unionism, there were important differences in motivation between Europe's two leading national centres. The DGB was acting in support of the West German government's Ostpolitik and claimed to be engaging in diplomacy rather than seeking institutional links. The Germans did not dispute the essential difference between free trade union practices and those in the Soviet bloc. But equally they understood the case for making every possible effort to help reduce tensions and divisions due to the Cold War.

In contrast, and as judged by the public musings of its general secretary, George Woodcock, the TUC no longer regarded the gap between itself and unions in the Soviet bloc as unbridgeable, nor the organizational split between the ICFTU and WFTU as in the best interests of union members. Woodcock argued that in an imperfect world free trade unions had no choice but to deal with communist organizations that "represented," however inadequately, workers in totalitarian countries. He was no ideologue, and was not proposing any dramatic new initiative; the cautious expression of his views was doubtless intended primarily to mollify an increasingly vocal British trade union left, among which a communist-supporting minority was the most cohesive component. Yet this emerging TUC position logically implied a wholesale rejection of free trade unionism as understood by the AFL-CIO. Indeed, it could imply rejecting the rationale behind the ICFTU's existence.

Had it remained within the ICFTU, would there have been scope for the AFL-CIO to exploit such Anglo-German differences? To some ICFTU affiliates, the Americans' unbending refusal to deal with Soviet bloc unions may have come to sound like a one-note refrain, but in its well-founded belief that there could be no common 
purpose with the communists on the essentials of trade unionism, the AFL-CIO was certainly not alone.

Yet there was another dimension to this situation, less focused on general hopes for détente and reflecting more immediately the quotidian concerns of trade unions in pursuit of their members' interests. The late 1960 s witnessed an increase in unrest among workers on both sides of the Atlantic that translated into a new pattern of militant trade union behaviour - the frequently cited "blue-collar blues" in the United States-and would characterize industrial relations in many Western countries in the 1970s. It reflected both a generational change in trade union leadership and an increasing self-confidence among workers following a sustained period of full employment. It also coincided with organized labour's first experience of the disruptive power of multinational corporations and a new awareness of the urgent need for greater transnational union cooperation as a countervailing force.

The renewed quest for trade union unity placed in the spotlight centres such as Italy's CGIL and Japan's Sōhyō, to take two prominent examples. Both were powerful organizations yet firmly outside the ICFTU fold. Their estrangement from the ICFTU raised the question of whether their potential value as allies in cross-border industrial campaigns should take precedence over such political litmus tests as their stance on the virtues of NATO, or the desirability of the US-Japanese peace treaty under which American military bases existed in Japan.

In the case of the CGIL, the "hot autumn" of 1969 and the imperative need for national union unity in Italy had already induced moves to federate with the Christian Democrat and Social Democrat-led centres from which it had been separated since the early days of the Cold War. And if trade unionists from these two non-communist Italian centres could see their way to cooperating with the CGIL, the case for union bodies elsewhere to reconsider their attitude toward the "communist" CGIL in the interests of international solidarity was surely no less compelling. In the face of AFL-CIO warnings against entanglement with communists, many labour movement activists of the time might simply reflect that the communists they were aware of were more often than not highly committed and even self-sacrificing trade unionists rather than fifth columnists in an international conspiracy. In the climate of late 1960 s and 1970 radicalism, there was also a tendency among some to take at face value the WFTU propaganda-its rhetorical militancy was aimed exclusively at a Western audience - and in some quarters it was accepted as a sign that the WFTU was simply a more full-blooded trade union body than the stolid ICFTU.

The forum within which such issues were debated was the European Trade Union Confederation launched in 1973. For many of its founding members-all of them ICFTU affiliates-its primary focus was to be on labour's concerns within the EEC. However, the British TUC and the Nordic trade unions envisaged a wider 
ETUC role in Europe, extending beyond the EEC, and the prospect that it would be open to Eastern European centres joining one day, thereby healing the breach caused by the 1949 schism in the WFTU. To this end, the British-playing hardball as much as the AFL-CIO had ever done within the ICFTU_insisted successfully that the emotive word "free" be removed from the suggested name of the new organization: there would be no letter "F" in the ETUC. In short order, the CGIL became the first communist-led organization to be admitted to membership. The ETUC was demonstrably not to be a "free" trade union body in the sense that the AFL-CIO understood the term. In further pursuit of the same strategy, the British and Nordics were also the driving force behind a series of biennial East-West trade union conferences of European labour organizations through the 1970s aiming to deepen understanding between participants from blocs that were now, so the argument went, increasingly obsolete.

How these initiatives played out in detail is necessarily the subject matter of another volume. Suffice to say that where purely European issues were concerned, the AFL-CIO was mostly no more than a disapproving onlooker. By this point it is doubtful that it could have intervened with any effect: the drift in Europe toward accommodation with Soviet bloc unions simply had to run its course. Time alone would reveal whether Western European labour movements would gain much from such a project. It meant that for the duration of the 1970s, with trade union militancy at a postwar peak, but with organizational strength threatened by an upward trend in unemployment as the long boom ended, the international labour movement based in the West was subject to a major division.

Acting largely alone in these circumstances, the AFL-CIO redoubled its effort in defending its vision of free trade unionism within the International Labour Organization, the one major international forum open to it. This was where it considered labour's real cold-war battle had to be fought by holding up to international criticism the abuse of workers' rights in the Soviet bloc. And as a result, it was to be the AFL-CIO that proved best placed to provide an international lead in support of Poland's Solidarność in the 1980s. The launch of this body in 1980 presented Soviet communism with its biggest and-as events proved-its most decisive trade union challenge. Tellingly, the official Soviet bloc labour bodies so assiduously courted by Western European unions offered no help to the new Polish free trade union movement.

At this remove in time, it can be difficult to grasp the full meaning of the passionate conflicts that characterized the international trade union movement in the years of the Cold War. It is perhaps even more difficult to imagine a world where that movement played such a significant role in the relations between the dominant forces. In 1949, Walter Schevenels had predicted that the AFL would have 
little to offer European trade unions but money. That was always too sweeping an indictment. When the AFL ventured abroad in 1945, it did so armed with a simple but powerful message about the basic difference between free trade unionism and the "state unionism" version allowed under communism. And in the 1980s, it was this free union vision that Polish and other Eastern European workers found most appealing-with catastrophic consequences for the legitimacy and functioning of an entire communist regime. 



\section{Abbreviations Used in Notes}

Becu papers (ICFTU)

Omer Becu Papers, International Trade Union Confederation (ITUC, formerly ICFTU), Brussels, Belgium

Benedict papers

Daniel Benedict Fonds, R12411-O-3-E, Accession 2003-0832, Library and Archives Canada, Ottawa, Canada

Burati papers

Valery Burati Papers, 1932-76, Accession LPo01351, Archives of Labor and

Urban Affairs, Walter P. Reuther Library, Wayne State University, Detroit, MI, United States

CIO Secretary-Treasurer records

CIO Office of the Secretary-Treasurer Records, 1935-60, Accession LRooo185, Archives of Labor and Urban Affairs, Walter P. Reuther Library, Wayne State University, Detroit, MI, United States

CIO Washington Office records

CIO Washington Office Records, 1950-56, Accession LRoo0548, Archives of Labor and Urban Affairs, Walter P. Reuther Library, Wayne State University, Detroit, MI, United States

CLC Archives

Canadian Labour Congress Fonds, Library and Archives Canada, Ottawa, Canada

Cormier and Eaton papers

Frank Cormier and William Eaton Papers, Accession LPoo1099, Archives of Labor and Urban Affairs, Walter P. Reuther Library, Wayne State University, Detroit, MI, United States

Dubinsky records

ILGWU, David Dubinsky, President's Records, 1932-66, Collection 5780/o02, Kheel Center for Labor-Management Documentation and Archives, Martin P. Catherwood Library, Cornell University, Ithaca, NY, United States 
Geijer personal papers

Arne Geijer Personal Papers, Arbetarrörelsens arkiv och bibliotek, Stockholm Germer papers

Adolph Germer Papers, 1898-1966, U.S. Mss. 125A, State Historical Society of Wisconsin, Madison, WI, United States

GMMA

George Meany Memorial AFL-CIO Archives, University of Maryland, College Park, MD, United States

IAD Brown files

AFL-CIO International Affairs Department, Irving Brown Files, 1943-89, RG18-004, George Meany Memorial AFL-CIO Archives, University of Maryland, College Park, MD, United States

IAD Country files, 1945-71

AFL-CIO International Affairs Department Records, International Affairs Department, Country Files, 1945-71, RG18-001, George Meany Memorial AFL-CIO Archives, University of Maryland, College Park, MD, United States IAD Country files, 1969-81

AFL-CIO International Affairs Department Records, International Affairs Department, Country Files, 1969-81, RG18-010, George Meany Memorial AFL-CIO Archives, University of Maryland, College Park, MD, United States

IAD Lovestone files

AFL-CIO International Affairs Department, Jay Lovestone Files, 1939-74, RG18-003, George Meany Memorial AFL-CIO Archives, University of Maryland, College Park, MD, United States

IAD Ross files

CIO International Affairs Department, Director's Files, Michael Ross, 1920-63, RG18-002, George Meany Memorial AFL-CIO Archives, University of Maryland, College Park, Maryland, MD, United States

ICFTU Archives

ICFTU/ITUC Archives, International Institute for Social History, Amsterdam, Netherlands

Kemsley papers

William and Ann Kemsley Papers, 1943-61, Accession LPooo943, Archives of Labor and Urban Affairs, Walter P. Reuther Library, Wayne State University, Detroit, MI, United States 
Krane papers

Jay B. Krane Papers, 1943-61, Accession LPooo614, Archives of Labor and

Urban Affairs, Walter P. Reuther Library, Wayne State University, Detroit, MI, United States

LAB 13

Ministry of Labour and Successors, Records of the International Labour Division and Overseas Department, Registered Files, 1923-1997, National Archives, Kew, Surrey, United Kingdom

LAC

Library and Archives Canada, Ottawa, Canada

Lovestone papers (Cornell)

Jay Lovestone Papers, 1929-83, Collection 6036/o28, Kheel Center for

Labor-Management Documentation and Archives, Martin P. Catherwood Library, Cornell University, Ithaca, NY, United States

Lovestone papers (Hoover)

Jay Lovestone Papers, 1904-1989, Collection 75091, Hoover Institution, Stanford University, Stanford, CA, United States

Meany files, $1940-80$

AFL-CIO Office of the President, George Meany Files, 1940-80, RG1-038, George Meany Memorial AFL-CIO Archives, University of Maryland, College Park, MD, United States

Meany files, 1947-60

AFL-CIO Office of the President, President's Files, George Meany, 1947-60, RG1-027, George Meany Memorial AFL-CIO Archives, University of Maryland, College Park, MD, United States

Rebhan records, $1965-80$

UAW International Affairs Department, Herman Rebhan Records, 1965-80, Accession LRooo488_HR, Archives of Labor and Urban Affairs, Walter P.

Reuther Library, Wayne State University, Detroit, MI, United States

Reuther-Carliner records, 1955-63

UAW International Affairs Department, Washington Office, Victor Reuther and Lewis Carliner Records, 1955-63, Accession LRoo2254, Archives of Labor and Urban Affairs, Walter P. Reuther Library, Wayne State University, Detroit, MI, United States 
Reuther-Carliner records, 1962-68

UAW International Affairs Department, Victor Reuther and Lewis Carliner Records, 1962-68, Accession LRooo488_VRLC, Archives of Labor and Urban Affairs, Walter P. Reuther Library, Wayne State University, Detroit, MI, United States

Reuther-Rebhan records, 1968-72

UAW International Affairs Department, Victor Reuther and Herman Rebhan Records, 1968-72, LRooo488_VRHR, Archives of Labor and Urban Affairs, Walter P. Reuther Library, Wayne State University, Detroit, MI, United States

Schevenels papers

Walter Schevenels Papers, 1901-86, Collection 77056, Hoover Institution, Stanford University, Stanford, CA, United States

Thorne files

American Federation of Labor Records 1888-1955, Series 8, Files of Research Director, 1935-52, correspondence of Miss Florence Thorne, State Historical Society of Wisconsin, Madison, WI, United States

TUC Archives

Trades Union Congress, 1846-2006, Modern Records Centre, University Library, University of Warwick, Coventry, United Kingdom

Victor Reuther papers

Victor G. Reuther Papers, 1890-1980, Accession LPooooo2_VGR, Archives of Labor and Urban Affairs, Walter P. Reuther Library, Wayne State University, Detroit, MI, United States

Zimmerman papers

Charles S. Zimmerman Papers, 1920-58, Collection 5780/014, Kheel Center for Labor-Management Documentation and Archives, Martin P. Catherwood Library, Cornell University, Ithaca, NY, United States 


\section{Notes}

\section{Chapter 1: Facing the Future}

1. Report of 75th Annual Trades Union Congress (Blackpool, 1945), 353-56; Daily Worker, 13 September 1945 .

2. Daily Worker, 13 September 1945.

3. Walter Schevenels, Forty-Five Years: International Federation of Trade Unions, 1901-1945, 333.

4. Geert Van Goethem, The Amsterdam International: The World of the International Federation of Trade Unions (IFTU), 1913-45, 179-82. Sir Walter Citrine (1887-1983) was apprenticed as an electrician in his native Liverpool, where he became district secretary of the electricians' union in 1914, rising to the position of national president in 1918. He joined the TUC in 1924 and was promoted to general secretary the following year. In the wake of the 1926 general strike, he and Ernest Bevin collaborated to centralize control of the TUC as it developed a partnership role with governments. In 1935, he became one of the first British trade union leaders to be knighted. Abandoning the IFTU in 1945, he was elected as the WFTU's founding president, but he held office for less than a year before resigning from his trade union positions to head up Britain's newly nationalized electrical power industry in 1946. He was staunchly anti-communist and was clear about his criticism of Soviet communism when he first approached the AFL to join the ICFTU in the 1930s.

5. Peter Weiler, British Labour and the Cold War, 64, citing the minutes of the February 1942 meeting of the Anglo-Soviet Trade Union Committee.

6. Speaking at the New York Central Trades and Labour Council on 5 April 1945, Meany refused to be party to the "rigging of international labour machinery to be used as ... the chocolate coating of any ideology among people who would choke if they knew the consequences of what they were swallowing." Joseph C. Goulden, Meany, 125. For detailed accounts of the trade union diplomacy leading to the formation of the WFTU, see Van Goethem, The Amsterdam International, chaps. 7, 9; Schevenels, Forty-Five Years, chaps. 7-8; Lewis Lorwin, The International Labour Movement, chap. 19; Philip Taft, Defending Freedom: American Labour and Foreign Affairs, chap. 3; Peter Weiler, British Labour and the Cold War, 55-69.

7. William Green (1873-1952) was a miner from Ohio who was elected AFL president on the death of Sam Gompers in 1924, largely through the influence of John L. Lewis, president 
of the United Mine Workers of America. Although Green edged out Matthew Woll for the presidential post, in matters of international affairs he deferred to Woll and later to Meany as well, when the latter became AFL secretary-treasurer. Indeed, on the whole, Green played little role in this area.

8. Report of 75th Annual Trades Union Congress, 366-68, 402.

9. Weiler, British Labour and the Cold War, 69; Lincoln Evans to David Dubinsky, 19 January 1949, IAD Brown files, box 29, file 6.

10. Van Goethem, The Amsterdam International, 258n159; Schevenels, Forty-Five Years, 344.

11. Schevenels, Forty-Five Years, 346-49; Walter Citrine, Two Careers, 219, 224.

12. The Labor League for Human Rights operated until the end of 1946, when it was wound up and its remaining funds $(\$ 1,674)$ transferred to the FTUC. The FTUC continued for some years afterward to use letterhead, which gave the impression that it was still a subsidiary part of the league when in fact the league was defunct. Minutes of LLHR Administrative Committee, meeting, 13 December 1946, Dubinsky records, box 78, file 3 a.

13. Charles Zimmerman (1896-1983) emigrated from Russia aged thirteen and by the age of sixteen was an ILGWU member and president of his local shop. In 1923, he became a leader of the powerful Local 22 but was removed two years later as a result of his membership in the Communist Party. He was expelled from the party in 1929, at the same time as Lovestone, and, in 1933, ran again successfully for the presidency of Local 22, which subsequently provided a base for Lovestone's career in the labour movement. In 1934, Zimmerman was elected an ILGWU vice president and played a prominent role in the AFL's international solidarity activities. He was an important figure in the Jewish Labor Committee (JLC), whose president he became in 1969. On retirement in 1972, he was elected co-chairman of Social Democrats, USA.

David Dubinsky (1892-1982) worked as a baker in his native Poland, where he became an assistant secretary of the Jewish Bund at the age of fourteen. Arrested for strike activity, he escaped from a labour camp and made his way to the United States in 1911. He worked in the garment industry and, as a member of the ILGWU, rose from local president to vice president in 1922 and then to international president in 1932. He helped launch the CIO but subsequently opted for the ILGWU to remain in the AFL. As the garment workers' president and a close ally of George Meany, he was one of the most powerful trade union figures both nationally and internationally until his retirement in 1966.

14. Ted Morgan, A Covert Life: Jay Lovestone, Communist, Anti-Communist, and Spymaster; Jay Lovestone, "Labour's Stake in Democracy: American Labour Looks Ahead," 1940, Dubinsky records, box 262, file 4c.

15. Dubinsky to Henry Allen Moe, 16 October 1940, Dubinsky records, box 262, file 4c.

16. Lovestone to Ernesto Cuneo, 24 June 1940, cited in Van Goethem, The Amsterdam International, 186; A. E. Jolis, "The OSS and the Labour Movement: How European Trade Unionists Operated Behind German Lines," New Leader, 13 August 1946.

17. FBI Report, 31 December 1943, cited in Morgan, A Covert Life, 226. During the 1950s, J. H. (Jaap) Oldenbroek, of the ICFTU, would point out in private that Lovestone's activities often damaged the free trade union movement but never seemed to result in outcomes 
disadvantageous to the communists. Author interview with William Kemsley, 18 April 1987. Michael (Mike) Ross, a former Communist Party member who became Lovestone's boss in the AFL-CIO, used to wonder whether Lovestone had ever really left the Communist Party. Author interview with Rosy Ruane, 14 January 1995.

18. Morgan, A Covert Life, 141.

19. Matthew Woll (1880-1956) emigrated from Luxembourg as a child and began work as a photo engraver in 1895. He became his union's president in 1906 and, as an AFL vice president from 1919, was a close colleague of the president, Samuel Gompers. Though his ambitions to succeed Gompers were thwarted, Woll remained a powerful influence behind President William Green and took a special interest in international affairs. As successor to Green from 1952, Meany had to work hard to wrest control of international affairs from Woll. Bob Reynolds, "Choosing the 2nd President of the AFL: Ephemeral Correspondence That Survived," draft note prepared for the AFL-CIO Archives at the University of Maryland, sent by Reynolds to author, 25 July 2018.

20. Catherine Collomp, “The Jewish Labor Committee, American Labor, and the Rescue of European Socialists, 1934-41," 127-28. Although ALCIA initially embraced AFL and CIO personnel, participation by CIO figures ceased after the conference came under attack by the American Communist Party, which accused it of being "counter-revolutionary" and "anti-Soviet."

21. Varian Fry, "How to Help the Free and Democratic Labour Movements in Liberated Europe," April 1945, Dubinsky records, box 173, file 3b.

22. Fry to Dubinsky, 20 August 1945, Dubinsky records, box 173, file 3b. Fry envisaged a publication jointly produced by the AFL and ALCIA, with AFL staff contributing domestic news from the American labour movement, while ALCIA staff would handle the "international" content. But organizationally, ALCIA was already in difficulties. Meany had resigned from its board of directors as a consequence of policy disagreements, the budget was overspent, staff were being laid off, and Fry's suggested budget of \$50,00o for the overseas publication (which would need to come from the AFL's Free Trade Union Fund) looked like a desperate bid to keep ALCIA afloat. Fry to ALCIA executive board members, 12 September 1945, Dubinsky records, box 173, file 3a.

23. Information about Brown's period in the FEA and intended move into the US Office of Military Government comes from the author's interviews with Newman Jeffrey, Morris Weisz, and Alan Strachan, 28 August 1986. See also Paul Porter, "Conflict Within American Military Government Concerning the Revival of German Trade Unions," 7-14, Paul R. Porter Papers, Group I, Harry S. Truman Presidential Library and Museum, Independence, MO.

24. "Irving Brown, AALC Founder Remembered," AALC Reporter Supplement, n.d. [1988], IAD Brown files, box 9, file 11: Irving Brown, Condolences.

25. Author telephone interview with Kaare Sandegren, 16 September 2002. Haakon Lie's doubts about claims that Brown had been in Norway during the war were expressed in a conversation he had with Kaare Sandegren, who, in the 1970s, was the secretary of international affairs for the Landsorganisasjonen i Norge (the Norwegian trade 
union centre). Lie's doubts are of particular significance as he was an early leader of the Norwegian anti-Nazi resistance, from 1940 onward. Forced to flee the country in 1941, he then took charge of propaganda for the exiled Norwegian labour movement, based in London. However, Kaare Sandegren also relates that, in talks of his own with Irving Brown in 1975, the latter gave him to believe that he did indeed spend time in occupied Norway during the war. Separately, Brown also hinted to his deputy and eventual successor as AFL-CIO representative in Europe, Jim Baker, that he had been in France during the war-in Normandy and Paris-where he had had contact with the CGT. He was careful to tell Baker that, while he had worked with the OSS, he had never worked for them. Jim Baker to author, 12 June and 21 June 2002.

26. Ben Rathbun, The Point Man: Irving Brown and the Deadly Post-1945 Struggle for Europe and Africa, 91-95, 169-70. Rathbun claims that Brown was able to reach Oslo via Sweden and met Norwegian partisans, including Willy Brandt, that he conducted a session on rail sabotage in Norway, travelled on to Copenhagen for a meeting with officials of the International Transport Workers' Federation, and was then flown back to Paris in an OSS plane for meetings with "the anti-CGT members of Force Ouvrière."

27. Brown answered one interviewer's innocent question about his relatives by saying that yes, he did have a family "which includes a wife and grown-up children." It was partly true but hardly very helpful. In fact, he was then divorced and had married for a second time, with one child from his first marriage. Brown to Norbert Anderson, 8 September 1978, IAD Brown files, box 33 , file 7 .

\section{Chapter 2: Building Labour's Anti-Communist Opposition in Europe}

1. Brown to Abraham Bluestein, 2 November 1945, Thorne files, box 16, file: International Labour Relations Committee.

2. Ted Morgan, A Covert Life: Jay Lovestone, Communist, Anti-Communist, and Spymaster, 147-48. Whether, given a change in the international climate and the relations between the big powers, they might choose to abandon their studied moderation and mount a revolutionary challenge could only be a matter for conjecture. In fact an article under the name of Jacques Duclos, number two in the Parti communiste français (PCF), and published in Cahiers du communisme in April 1945 had attacked the idea that the class struggle was no longer relevant in the postwar years. In America such a view had already led the Communist Party to dissolve itself on the assumption that its adherents should now join all-party coalitions. The significance of this PCF pronouncement went largely unnoticed at the time, but the article to which Duclos had attached his name was in fact simply a translation of one that had already appeared in the Bulletin of the Central Committee of the Soviet Communist Party. In reality the French communists were on notice from Moscow that political and industrial moderation was only a temporary tactic.

3. In return, the AFL backed Caffery in the face of concerted moves to have him replaced as ambassador. Meany and Dubinsky spoke on his behalf at a meeting with President 
Truman in March 1947 and wrote to Secretary of State Marshall. Brown to Lovestone, 17 February and 23 April 1947, IAD Lovestone files, box 11, file 7; Brown to Lovestone, 26 December 1947, IAD Brown files, box 29, file 3.

4. Lovestone's doubts about the reliability of State Department personnel extended to the very top. When General George Marshall succeeded James Byrnes as secretary of state, Lovestone believed that the tendency to appease communism would increase. Likewise, he mistrusted Dean Acheson, assistant secretary of state, who was close to Alger Hiss, and never forgot that in 1945 the Daily Worker had praised Acheson as one of the most forward-looking men in the department. "Pro-Soviet Personnel in State Department," Thorne files, box 2, file: Communism; Ted Morgan, “The Grey Eminence” (typescript, n.d.), 420; Lovestone to Brown, 9 January 1947, IAD Lovestone files, box 11, file 8; Lovestone to Woll, 27 January 1947, IAD Lovestone files, box 64, file 26. Acheson replied to the AFL request that Murphy be attached to the office of the secretary of state by saying that Murphy had many other responsibilities and couldn't be spared for this work. He suggested another name, but the person proposed lacked the particular talents that the AFL required. Minutes of International Affairs Committee meeting, 7 April 1949, Thorne files, box 17, file: International Labour Relations Committee.

5. "Four Day Period Observations: France, 18 November 1945," section of letter from Irving Brown to Abraham Bluestein, 18 December, 1945, Thorne files, box 16, file: International Labour Relations Committee; Zimmerman cable to Dubinsky, 19 November 1945, Dubinsky records, box 34, file 3; Bert (Jolis) to Lovestone, 13 November 1945, Lovestone papers (Hoover), box 391, file: OSS, 1945. Even in the days immediately prior to Brown's arrival in Paris, it was evident that Lovestone was in discussion with Jolis and Raymond Murphy of EUR-X Department about the use of funds to assist French socialists.

Léon Jouhaux (1879-1954) began his working life in a match factory and became minute secretary of his local union branch at the age of sixteen. After losing his job following a strike, he served as CGT local union representative from 1906. Elected in 1909 as CGT general secretary, a post he held until 1947, he played a central role in international affairs before 1914-campaigning against the looming prospect of war, attending the Versailles Peace Conference in 1919, and helping launch the ILO. He was one of the founders of the IFTU and was active in the League of Nations as a member of its Economic Advisory Council. During World War II, he was imprisoned by the Vichy regime and then deported to Germany, where he spent two years in Buchenwald. He returned to the general secretaryship of the CGT after the war until 1947, when he reluctantly led the breakaway to form Force ouvrière, becoming its first president, 1948-54. He was awarded the Nobel Peace Prize in 1951.

6. Brown to Bluestein, 27 November 1945, Lovestone papers (Hoover), box 355, file: Irving Brown, 1939-45; Brown to Bluestein, 29 November 1945, Thorne files, box 16, file: International Labour Relations Committee. Robert Bothereau (1901-85) was a metalworker who joined the CGT in 1919 and worked in its confederal office under Jouhaux from 1932. During the war, he was part of the CGT underground. He became a leading figure in the group formed around Résistance ouvrière out of which grew the 
breakaway centre, Force ouvrière, which he founded jointly with Jouhaux and led as general secretary, 1948-63. His relations with Brown were mostly cordial, though the latter regarded him as a stolid, uninspiring figure and was pleased when he retired.

7. Brown to Bluestein, 2 December 1945, Lovestone papers (Hoover), box 355, file: Irving Brown, 1939-45; Brown to Woll, 5 December and 10 December 1945, Thorne files, box 16, file: International Labour Relations Committee; Brown to Woll, 14 December 1945, Zimmerman papers, box 11, file 5 .

8. Brown to Woll, 28 December 1945 and 1 January 1946, Thorne files, box 16, file: International Labour Relations Committee; Brown to Woll, 21 January 1946, and Brown to Bluestein, 27 February 1946, Zimmerman papers, box 21, file 1; Brown to Lovestone, 25 February 1948, IAD Brown files, box 29, file 4.

9. Zimmerman to Brown, 11 January 1946, Dubinsky records, box 11, file 16.

10. George S. Wheeler, Who Split Germany? Wall Street and the West German Trade Union Leaders, pt. 11, 25-39; Paul Porter, "Conflict Within American Military Government Concerning the Revival of German Trade Unions," 7-14, Paul R. Porter Papers, Group I, Harry S. Truman Presidential Library and Museum, Independence, MO.

11. McSherry subsequently claimed that undercover communists in the Manpower Division had used and deceived him. However, in 1954, when Senator Joseph McCarthy got wind of these events and sought details to support possible charges that General Eisenhower and General Clay had harboured communists in US Office of Military Government, he failed to come up with the evidence and did not pursue the case. Porter, "Conflict Within American Military Government Concerning the Revival of German Trade Unions."

12. Wheeler clung to his job for almost two more years but left of his own accord in November 1947 when it became evident that all hope for an American-Soviet agreement over Germany had disappeared. Maintaining that the "right wing social democrats" who were being allowed to take over leadership of the trade unions were simply people who "preferred Nazis to communists," he went to live in Czechoslovakia and remained there for thirty years. To suggestions that this revealed his pro-Soviet sympathies, he pointed out that the Czechoslovakia he moved to was still a socialist country under Benes. Wheeler, Who Split Germany?; Wheeler to author, 17 June 1986.

13. Brown to Woll, 22 February 1946, Zimmerman papers, box 21, file 1; Irving Brown, "Report on Germany," American Federationist, May 1946, 32. Hillman's biographer gives an altogether different impression of this visit, describing how, in the three weeks the WFTU delegation were in Germany they spent much time with trade unionists on the factory floor and in works councils. He argues that Hillman himself was assiduous and meticulous in exploring the situation, voracious in gathering data from trade unionists, and a dogged interrogator of military officials. Steven Fraser, Labour Will Rule: Sidney Hillman and the Rise of American Labour, 555.

14. Brown to Woll, 17 February and 22 February 1946, Zimmerman papers, box 21, file 1.

15. Brown to Woll, 20 May 1946, and Leon Dennen to Zimmerman, 27 April 1946, Zimmerman papers, box 21, file 1 .

16. Brown to Meany, 17 June 1947, IAD Brown files, box 29, file 2. 
17. Brown to Woll, 20 August 1946, Zimmerman papers, box 21, file 1. Doubtless the secretary of state, a conservative southern Democrat with an anti-union track record, was more impressed with Brown's anti-communism than his pro-union advocacy.

18. Brown to Bluestein, 27 February 1946, Zimmerman papers, box 21, file 1; Brown to Zimmerman, 14 March 1946, Dubinsky records, box 11, file 16.

19. Zimmerman to Dubinsky, 12 April 1946, Dubinsky records, box 7, file 3.

20. Brown later recalled that the strike was the occasion of Benoit Frachon's first public attack on him. Brown to Lovestone, 5 April 1952, IAD Lovestone files, box 11, file 15.

21. Brown to Woll, 10 August 1946, Zimmerman papers, box 21, file 1.

22. Brown to Woll, 20 May 1946, Zimmerman papers, box 21, file 1; G. M. Lamming, "Report on LO Conference," 14 September 1946, LAB 13/596: WFTU: General File.

23. Brown to Woll, 22 March 1946, Zimmerman papers, box 21, file 1.

24. Brown to Woll, 24 May 1946, Zimmerman papers, box 21, file 1.

25. Abramovitch to Dubinsky, 9 June 1946, Dubinsky records, box 173, file 3a. The considerable disparity between the projected cost of Brown's scheme and that proposed by Abramovitch suggests that there was as yet no common idea of what the FTUC would be able to afford.

26. Brown to Woll, December 1946, Zimmerman papers, box 21, file 1.

27. Jay Lovestone, “The Frantic Mr. Franchon," Free Trade Union News, December 1946.

28. Apart from a number of right-wing members of the TUC General Council such as steel union leader Lincoln Evans, he had in mind in particular Herbert Tracy, the TUC's press officer, and Edgar Harries of the international department, whose unofficial briefings had kept him informed of internal TUC politics.

29. Volney D. Hurd, "AFL Drops Paris Bureau Plan," Christian Science Monitor, 3 January 1947.

30. Daniel Yergin, The Shattered Peace: The Origins of the Cold War and the National Security State, 275.

31. Lovestone to Brown, 24 June 1947, and Brown to Lovestone, July 1947, IAD Lovestone files, box 11 , file 7 .

32. Brown to Lovestone, 23 April 1947, IAD Lovestone files, box 11, file 7.

33. Lovestone to Brown, 8 March 1948, IAD Lovestone files, box 11, file 9.

34. Lovestone to Brown, 13 January and 31 January 1947, IAD Lovestone files, box 11, file 8; Brown to Lovestone, 17 February 1947, IAD Lovestone files, box 11, file 7.

35. Brown to Lovestone, 4-17 December 1946, and Lovestone to Brown, 6 January 1947, IAD Lovestone files, box 11, file 8 .

36. Brown to Lovestone, 20 March, 1 April 1947, and Lovestone to Brown, 28 March 1947, IAD Lovestone files, box 11, file 8; Brown to Lovestone, 17 May 1947, IAD Lovestone files, box 11, file 7.

37. Lovestone to Brown, 13 January 1947, IAD Lovestone files, box 11, file 8; Brown to Lovestone, 17 February and 7 April 1947, IAD Lovestone files, box 11, file 7; Irving Brown, "The Crisis in Greece: What Are the Tasks of American Labour?" Free Trade Union News, May 1947.

38. Lovestone to Brown, 28 March and 23 May 1947, IAD Lovestone files, box 11, files 7 and 8. 
39. Brown to Lovestone, 7 April 1947, IAD Lovestone files, box 11, file 7.

40. Bevin to Marshall, 6 May 1947, FO 80o/468. Hubert Gee, Bevin's special advisor on international labour matters at the Foreign Office, was convinced that Brown was wrongheaded in believing that the now-discarded GSEE executive committee was "communist." He wrote that it indicated "an inability to see the situation in its proper perspective, which is really frightening when one considers the influence which Mr. Brown is in a position to exercise." H. G. (Hubert) Gee to Mr. Veysey, 10 May 1947, LAB 13/656.

41. Brown to Lovestone, 17 May 1947, IAD Lovestone files, box 11, file 7; Brown to Watt, 18 June 1947, and Irving Brown, "Confidential Report on Greece, France and England," 7 July 1947, Thorne files, box 17, file: International Labour Relations Committee.

42. "Report by Irving Brown on the Greek Labour Convention," 10 April 1948, IAD Lovestone files, box 11, file 9; Lovestone to Brown, 17 May 1947, IAD Lovestone files, box 11, file 7.

43. Peter Weiler, British Labour and the Cold War, 346; Lovestone to Brown, 13 July 1949, IAD Lovestone files, box 11, file 10; minutes of International Labour Relations Committee meeting, 13 July 1949, and of FTUC meeting, 13 October 1949, Thorne files, box 17, file: International Labour Relations Committee.

44. Weiler, British Labour and the Cold War, 164. Reflecting on the difficulties experienced by the British in the international labour field in these years, Denis Healey, then the British Labour Party's international secretary, recalled that Lovestone and Brown strove to mobilize the European labour movement against local communist parties and the USSR, often with little regard to the facts of the local situation. Yet, strongly supported with money and diplomatic assistance by the Truman administration, they were often able to exert more influence in Europe than the British Labour Party or the TUC. This was certainly the case in Greece in 1947. Denis Healey, The Time of My Life, 95.

45. Diary, 15 November 1946, Germer papers, box 25. There is no hint or suggestion anywhere in AFL or FTUC records that sums remotely of this order were actually available to the AFL. Minutes of FTUC meeting, 2 July 1947, IAD Lovestone files, box 35, file 29; Lovestone to Brown, 28 July 1947, IAD Lovestone files, box 11, file 7.

46. Brown to Lovestone, 2 September 1947, IAD Lovestone files, box 11, file 7.

47. Brown to Lovestone, 8 January 1948, IAD Lovestone files, box 11, file 9; Lovestone, "Report on Germany," [August?] 1948, Dubinsky records, box 262, file 4b. Under the leadership of Ernst Scharnowski, UGO would soon establish an Ostburo through which trade unionists, supported by the CIA, engaged in intelligence-gathering activities in the Eastern zone. Brown to Lovestone, 9 December 1950, Lovestone papers (Hoover), box 283, file: Irving Brown, 1951.

48. Brown to Lovestone, 7 April and 23 April 1947, IAD Lovestone files, box 11, file 7.

49. Twenty-five years later, Lovestone revelled in the memory of Schumacher's visit: his admiration for him was unbounded. Lovestone to Fritz Heine, 5 January 1971, IAD Country files, 1969-80, box 3, file 21.

50. Louis Edinger, Kurt Schumacher: A Study in Personality and Political Behaviour, 172-73. Brown underscored his belief in Schumacher some months later in arranging for the AFL's American Federationist to publish an article by the SPD leader, translated from the 
German by his wife, Lillie. The article was controversial in AFL terms in that it reaffirmed support for the Marshall Plan but insisted that German workers wanted to see "socialist results" and were "not willing to fight for capitalism." Kurt Schumacher, "A German Democrat Speaks."

51. Brown to Lovestone, 17 February and 23 April 1947, and Lovestone to Brown, 23 May 1947, IAD Lovestone files, box 11, file 7. Production of the French edition was expected to cost an additional $\$ 1,500$ per month.

52. Brown to Lovestone, 17 May 1947, IAD Lovestone files, box 11, file 7; Irving Brown, "Confidential Report on Greece, France and England," 7 July 1947, Thorne files, box 17, file: International Labour Relations Committee; Brown to Lovestone, 7 August 1947, Lovestone papers (Hoover), box 698, file: Irving Brown.

53. W. E. Davis, report no. 121, 30 September 1947, LAB 13/246.

54. Brown to Lovestone, 19 December 1947, Lovestone papers (Hoover), box 698, file: Irving Brown. For an account of the strikes, see Val R. Lorwin, The French Labor Movement, $120-25$.

55. Brown to Lovestone, 28 December 1947, IAD Brown files, box 29, file 3. Force ouvrière's founding congress voted 3:1 to seek affiliation to the WFTU, but the application was rejected.

56. Brown to Zimmerman, 16 December 1947, Dubinsky records, box 14, file 5; Brown to Lovestone, 17 December 1947, Lovestone papers (Hoover), box 698, file: Irving Brown.

57. Brown to Lovestone, 12 February 1948, and Lovestone to Brown, 17 May and 9 June 1948 , IAD Lovestone files, box 11, file 9. Lovestone notified Brown that "Ray" had assured him that the $\$ 10,000$ requested for the one hundred typewriters "would be given you very soon."

58. Lovestone to Lillie Brown, 31 August 1948, IAD Lovestone files, box 11, file 9.

59. Brown to Lovestone, 16 October 1948, IAD Brown files, box 29, file 5.

6o. US Embassy, Paris, telegram to State Department, 24 October 1948, U.S. Department of State, RG 59, Central Decimal Files, 1910-1963, 851.5045/10-2748. Brown's sources informed him that the CGT had a total of $\$ 350,000$ to finance the strike activity. Brown to Lovestone, 6 October 1948, IAD Lovestone files, box 11, file 9.

61. Brown to Lovestone, 15 May 1948, IAD Lovestone files, box 11, file 9.

62. "Sacha Volman, Grey or Red Eminence: Idealist, Adventurer or Marxist," n.d., Lovestone papers (Hoover), box 583, file: Volman. Sacha Volman (1923-2001) appears to have spent his entire adult life in the shadowy world of secret intelligence. He admitted to working for British and American intelligence while in Romania after the war, but he had also been an informant for the Soviet Union. His sudden departure from the country thus became necessary when the latter realized that he was playing a double game. Although he was fluent in several languages, his soft delivery and conspiratorial manner led wags to observe that he was incomprehensible in any of them. On first arriving in the West, he claimed to be representing Constantin Titel Petrescu, the veteran president of the Social Democratic Party of Romania, and, with Brown's help, he unsuccessfully sought recognition by the Committee of the International Socialist Conference (COMISCO) as that party's sole 
representative outside Romania. Serban Voinea, "Note on Sacha Volman," 14 July 1958, Benedict papers, box 54, file: Business Correspondence 1 and 2.

By 1951, as ICFTUE secretary, Volman was benefiting from CIA finance through its front, the National Committee for a Free Europe. It was when he was sent to New York in 1952 to liaise with the committee that Lovestone first became aware that Volman enjoyed independent links to the CIA, discovering that his fare to the United States had been paid by the agency-what Lovestone referred to drily as the "Joint Distribution Committee." Thoroughly disenchanted, Lovestone wrote Brown: "It is one big mess-never should have got involved. He is a nice boy who should go to school and not play with matches." Lovestone to Brown, 26 March 1952, IAD Lovestone files, box 11, file 15.

In the mid-1950s, Volman switched his field of activity to Latin America when it appeared that an important way to fight communism in that region was to bring home to trade unionists the lessons of life under Eastern European communism. Initially based at the Institute of International Labor Research in New York, he became by turns a confidant of social democrat politicians José Figueres Ferrer, president of Costa Rica, and Juan Bosch, president of the Dominican Republic. Volman to Hans Gottfurcht, 2 May 1956, and Volman to Brown, 29 April 1957, IAD Lovestone files, box 12, file 9; Volman to Benedict, 23 April 1957, and Volman to Arturo Jauregui Hurtado, 22 June 1955, Benedict papers, box 54, file: Business Correspondence 1 and 2, and box 101, file: untitled. See also Patrick J. Iber, “'Who Will Impose Democracy?': Sacha Volman and the Contradictions of CIA Support for the Anticommunist Left in Latin America." Volman was alleged to have hosted the meeting of mostly Cuban exiles in 1976 at which the assassination in Washington of Salvador Allende's former foreign minister, Orlando Letelier, was planned. Much about his life remains obscure-even his age was disputed-and to most people he was simply a mystery man. When he died in the Dominican Republic, a local newspaper paid tribute to him under the appropriate heading "Sacha el misterioso." Georgie Anne Geyer, "Sacha Volman: Classic Original and Latin American Legend," Universal Press Syndicate, 16 March 2001; Jean-Guy Allard, "CIA Patented the Crimes of Posada and Bosch in Bonao," Granma internacional, 21 June 2007, reprinted by the National Committee to Free the Cuban Five, http://www.freethefive.org/usTerrorism/USTerrBonao62107.htm.

63. Brown to Lovestone, 16 October 1948, IAD Brown files, box 29, file 5; Lovestone to Woll, 19 July 1948, IAD Lovestone files, box 65, file 2; Lovestone to Brown, 20 October 1948, IAD Lovestone files, box 11, file 9; Lovestone to Brown, 27 December 1948, IAD Lovestone files, box 11, file 11; minutes of ICFTUE meeting, 31 December 1948, IAD Lovestone files, box 35 , file 25 .

64. Minutes of International Labour Relations Committee meeting, 19 October 1948, Thorne files, box 17, file: International Labour Relations Committee.

65. To relieve pressure on FTUC finances, the cost of Brown's rent was borne by the AFL from the outset. Brown to Lovestone, 13 March, 20 March, and 28 March 1947, and Lovestone to Brown, 28 March 1947, IAD Lovestone files, box 11, file 8.

66. Lovestone to Brown, 2 June 1947, IAD Lovestone files, box 11, file 7. 
67. Lovestone to Brown, 11 March 1947, and Brown to Lovestone, 13 March 1947, IAD Lovestone files, box 11, file 8 .

68. Hannah Haskel to Brown, 13 May 1948, and Lovestone to Brown, 17 May 1948, IAD Lovestone files, box 11, file 9; Brown to Haskel, 19 May 1948, IAD Brown files, box 29, file 4; Lovestone to Brown, 12 and 20 October 1948, IAD Lovestone files, box 11, file 9.

69. Lovestone to Brown, 31 July 1947, IAD Lovestone files, box 11, file 7.

70. Brown to Lovestone, 23 April 1947, IAD Lovestone files, box 11, file 7. As a thrusting twenty-six-year-old member of the American delegation to the Paris Peace Conference in 1919, Bullitt had been sent to Moscow to explore with Bolshevik leaders the possibilities for peace between the Allies and the new Soviet government. He met Lenin, formed a favourable view of him, and reported back to the Paris conference on the possibilities for a deal. However, sensing that Lenin saw Bullitt as a "useful idiot," American and British leaders at the conference declined to act on his report. Bullitt was shattered by the experience, but during his subsequent years as America's first ambassador to the USSR from 1934, he became a fervent anti-communist. Margaret Macmillan, Peacemakers, 86-89. Brown to Lovestone, July 1947 and Lovestone to Brown, 28 July 1947, IAD Lovestone files, box 11, file 7; Lovestone to Brown, 12 January 1948, IAD Lovestone files, box 11, file 9. The coded reference to sums of money as "books," "anthologies," "poems," and "pages" was a new departure that was adhered to throughout the period during which the FTUC came to rely on funding from intelligence sources.

71. Lovestone to Brown, 23 December 1947, IAD Brown files, box 29, file 3; minutes of FTUC meeting, 11 December 1947, IAD Lovestone files, box 35, file 29.

72. Lovestone to Brown, 12 January 1948, IAD Lovestone files, box 11, file 9.

73. Lovestone to Brown, 6 April 1948, IAD Brown files, box 29, file 4.

74. Lovestone to Brown, 25 May 1948, IAD Brown files, box 29, file 5; Lovestone to Woll, 25 May 1948, IAD Lovestone files, box 65, file 1; Lovestone to Rutz, 24 June 1948, IAD Brown files, box 29, file 10; minutes of International Labour Relations Committee meeting, 9 September 1948, Thorne files, box 17, file: International Labour Relations Committee.

75. Lovestone to Brown, 20 October 1948, IAD Lovestone files, box 11, file 9.

76. Winthrop Aldrich to Donovan, 10 December 1948, Lovestone papers (Hoover), box 291, file: Donovan 1951; FTUC Contributions 1948, IAD Lovestone files, box 73, file 4.

77. Lovestone had met Forrestal when accompanying Kurt Schumacher to a meeting of the National Security Council during his 1947 visit to the United States. Lovestone to Fritz Heine, 5 January 1971, IAD Country files, 1969-80, box 3, file 21.

78. Morgan, A Covert Life, chap. 14.

79. Woll to Wisner, 10 December 1948, cited in Morgan, A Covert Life, 197.

80. Anthony Carew, "The American Labour Movement in Fizzland: The Free Trade Union Committee and the CIA."

81. Denis MacShane, International Labour and the Origins of the Cold War, 122; W. E. Davis, "World Federation of Trade Unions," report no. 50, 26 February 1946, and telegrams from Sir M. [Maurice] Peterson, British Embassy Moscow, to Foreign Office, 15 June, 17 June, and 30 June 1946, LAB 13/569: WFTU: General File. 
82. Brown to Lovestone, 27 December 1946, IAD Lovestone files, box 11, file 7; Brown to Woll, n.d. [December?] 1946, Zimmerman papers, box 21, file 1. J. H. Oldenbroek (1897-1970) had been employed in the labour movement since leaving school, beginning in 1915 when he joined the head office of the Dutch trade union centre NVV. There he began to learn about the international trade union movement at the feet of General Secretary Edo Fimmen, a man now largely forgotten but who was destined to become a towering figure in the world of trade unionism in the interwar years. When Fimmen became general secretary of the IFTU in 1919, Oldenbroek moved with him as administrative secretary, and then again accompanied Fimmen when he took on the general secretaryship of the ITF in 1921, working as office manager and interpreter. He was appointed assistant general secretary under Fimmen in 1937 and became de facto general secretary when Fimmen died in 1942. Based in London during the war, Oldenbroek was drawn into the world of secret intelligence and even entered into a written contract with the labour desk of the OSS to engage in covert ITF activities in enemy-occupied countries. (The full English text of this agreement, "ITF-OSS Agreement Dated 20 October 1942," appears in a Flemish typescript of Becu's unpublished "Memoirs," n.d., 182-85; I am grateful to John Vanderveken for supplying a copy of these pages. See also Bob Reinalda, "ITF Cooperation with American Intelligence, 1942-1944," esp. n. 606.) In 1946, Oldenbroek was confirmed as ITF general secretary in his own right, and, during a period when he was closely identified with the Americans, he was strategically the most important European trade union opponent of the WFTU. Following election as the ICFTU's first general secretary in 1949, his good relations with Brown and Lovestone would soon deteriorate in spectacular fashion.

83. Brown to Harvey Brown, 13 January 1947, IAD Lovestone files, box 11, file 8; MacShane, International Labour and the Origins of the Cold War, 76; Free Trade Union News, November 1947.

84. Lovestone to Woll, 31 January 1947, IAD Lovestone files, box 64, file 27; Lovestone to Brown, 1 April and 30 April 1947, IAD Lovestone files, box 11, files 7-8. Although the AFL and ITF combined to block incorporation of the trade secretariats within the WFTU, their motives were not identical. For the AFL, the main objective was to undermine the WFTU, an organization that was likely to end up dominated by communists. For the ITF, the battle was mostly about preserving its autonomy. As Harold Lewis, a former general secretary of the ITF, notes: "The ITF ... would have taken the same stand on the WFTU issue if 'integration' had come without a trace of communist presence or influence." Lewis to author, 3 October 2007. See also Harold Lewis, “The International Transport Workers' Federation (ITF), 1945-65: An Organizational and Political Anatomy," 212, where he argues persuasively: "There might have been a 'cloak and dagger' air to some of Oldenbroek's ... dealings with the American Federation of Labor, but he had declared his determination to defend the ITF's independence from the outset. Single-minded and relentless as he was, Oldenbroek would have used the AFL every bit as much as it thought it was using him." 
85. Brown to Ilg, 8 January 1948, IAD Brown files, box 1, file 10; Brown to Lovestone, 15 February, 21 March, 10 April, and 26 April 1948, IAD Lovestone files, box 11, file 9; Oldenbroek to Brown, 21 August 1948, and Brown to Oldenbroek, 23 August 1948, IAD Brown files, box 32, file 3; Brown to Lovestone, 16 October 1948, IAD Brown files, box 29, file 5. Brown's close dealings with the ITF also opened up prospects for taking the ideological fight into Eastern Europe. Herman Kaufken, who represented workers on the inland waterway system in Europe, including people whose work took them into the Soviet zone of Germany, offered to provide Brown with a network of contacts able to supply information on conditions there. Brown requested additional funding from Lovestone to support Kaufken, but Lovestone turned him down and told him simply to use his judgment (and existing funds) in rendering moderate assistance. Still, Lovestone was soon able to report that an underground network was in place and ready for an active campaign. Earlier, in January 1947, Brown had proposed that he be permitted to make a trip to Poland and Hungary to assess what was happening in the labour movement, but Lovestone was concerned for his safety and vetoed the idea as too risky. Brown to Lovestone, 17 February 1947, IAD Lovestone files, box 11, file 7; minutes of FTUC meeting, 21 March 1947, IAD Lovestone files, box 35, file 29; Lovestone to Brown, 28 March 1947, IAD Lovestone files, box 11, file 8; Irving Brown, "Confidential," 10 November 1947, and minutes of International Labour Relations Committee meeting, 11 November 1947, Thorne files, box 17, file: International Labour Relations Committee.

86. Brown to Ilg, 8 January 1948, IAD Brown files, box 1, file 10; Brown to Lovestone, 15 February, 21 March, 10 April, and 26 April 1948, IAD Lovestone papers, box 11, file 9; Oldenbroek to Brown, 21 August 1948, and Brown to Oldenbroek, 23 August 1948, IAD Brown files, box 32, file 3; Brown to Lovestone, 16 October 1948, IAD Brown files, box 29, file 5. In the 1960s, Zander himself would play a significant role in harnessing the Public Services International, as Bolle's organization had now become, to CIA operations in Latin America.

87. Lovestone to Brown, 2 June, 28 July, and 31 July 1947, IAD Lovestone files, box 11, file 7; Brown to Lovestone, 18 June 1947, Lovestone papers (Hoover), box 698, file: Irving Brown.

88. Irving Brown, "Confidential," 10 November 1947, Thorne files, box 17, file: International Labour Relations Committee.

89. "Workers of the World" and "World Trade Unions: Relations with the American Federation,” Times (London), 17 November 1947; “TUC Asked to U.S. Talks: Drive Against Communists," Daily Telegraph, 17 November 1947.

90. Walter Galenson to Zimmerman, 29 November 1947, Dubinsky records, box 14, file 5; Brown to Lovestone, 17 December 1947, Lovestone papers (Hoover), box 698, file: Irving Brown.

91. Brown to Lovestone, 13 March, 7 April, and 23 April 1947, IAD Lovestone files, box 11, file 8.

92. Secretary of State to Ambassador, Washington, 24 December 1947, FO 371/62784, National Archives, Kew.

93. Brown to Lovestone, 25 December 1947, IAD Lovestone files, box 11, file 7; Brown to Lovestone, 26 December 1947, IAD Brown files, box 29, file 3 . 
94. Secretary of State to Ambassador, Washington, 24 December 1947, FO 371/62784, National Archives, Kew.

95. Secretary of State to Ambassador, Washington, 19 February 1948, FO 371/71806, National Archives, Kew.

96. Lovestone to Brown, 20 February 1948, IAD Lovestone files, box 11, file 9.

97. Brown to Lovestone, 25 February 1948, IAD Brown files, box 29, file 4.

98. Brown to Lovestone, n.d. [November] 1947, IAD Lovestone files, box 11, file 7.

99. Kennan to Lovett, 30 June 1948, Records of the Policy Planning Staff, cited in Eric Thomas Chester, Covert Network: Progressives, the International Rescue Committee, and the CIA, 26-27. Number one on Kennan's list was Frank Wisner, who eventually landed the job.

100. Brown to Lovestone, 5 May 1948, IAD Lovestone files, box 11, file 9.

101. Lovestone to Dubinsky, 12 May 1948, IAD Lovestone files, box 33, file 5; Lovestone to Lillie Brown, 10 June 1948, IAD Lovestone files, box 11, file 9.

102. Brown to Lovestone, 21 March, and Lovestone to Brown, 26 March 1948, IAD Lovestone files, box 11, file 9. In practical terms, the ERP Conference led to the creation of the ERP-Trade Union Advisory Committee (TUAC), which eventually evolved into the OECD-TUAC.

103. Brown to Lovestone, 21 March 1948, IAD Lovestone files, box 11, file 9; New York Times, 10 March 1948. In general, there was a marked absence of overt anti-communist sentiment at the European Recovery Program Trade Union Conference in London, all the more remarkable given contemporary events in the world. In the wake of the communist coup in Czechoslovakia, the alleged suicide of Czech foreign minister Jan Masaryk occurred while the conference was in session; the Finnish government was, at that moment, under intense Soviet pressure to enter into a Pact of Friendship; the Hungarian and Czech socialist parties were facing imminent expulsion from COMISCO for bowing to pressure to merge with the communists; and, only two days before the ERP conference opened, the Soviet ambassador in London had formally protested the illegality of recent decisions at the London Six-Power Conference, whose purpose had been to lay the basis for a permanent partition of Germany. For detailed treatment of the complex TUC manoeuvring that enabled the WFTU to remain in business for nine more months, see Anthony Carew, Labour Under the Marshall Plan: The Politics of Productivity and the Marketing of Management Science, chap. 5.

Sir Vincent Tewson (1898-1981) started work in Yorkshire as an office boy in the head office of the dyers' and bleachers' union. Following military service in World War I, he returned to the union with responsibility for negotiating piece rates. He joined the TUC after the 1926 general strike and was in charge of its organization department. As a loyal lieutenant of Walter Citrine, he became assistant general secretary in 1931, eventually succeeding Citrine in 1946 . He was a capable administrator with a meticulous concern for detail (his finickiness led Lovestone to dub him "the pompous clerk"), but he was more cautious and hesitant than Citrine and personified the lack of drive that Meany saw in the British and European unions more generally. He was ICFTU president, 
1951-53, and through his close collaboration with Jaap Oldenbroek was arguably the most influential member of the ICFTU executive board up to his retirement in 1960.

104. European Recovery Programme: Report of the Second International Trade Union Conference (London, 29-30 July 1948); Lovestone to Brown, 21 February 1948, IAD Lovestone files, box 11, file 9 .

105. Brown to Lovestone, 1 July 1948, IAD Lovestone files, box 11, file 9. A couple of months later, a barbed comment about the TUC leadership made by Brown at a private dinner in London caused Tewson to "hit the roof" when word got back to TUC headquarters. The upset felt was conveyed informally to David Dubinsky, and Lovestone was compelled to write and tell Brown to cool it-his lack of diplomacy was having a negative effect on AFL-TUC fraternal relations. Lovestone to Brown, 20 October 1948, IAD Lovestone files, box 11, file 9 .

106. Krane to Cope, 1 December 1948, Krane papers, box 1, file 2; Diary, 16-17 December 1948, Krane papers, box 1 file 4. Jay Krane was assistant to Elmer Cope, the CIO's nominee as WFTU assistant general secretary. He was a witness to many private conversations of European trade union leaders and kept a detailed diary. He was a particularly close observer of Walter Schevenels.

\section{Chapter 3: For Multilateralism or "Independent Activities"?}

1. New York Herald Tribune, 11 January 1949.

2. Elmer Cope, "An Interim Programme of Activities for the CIO in Europe," 17 February 1949, CIO Secretary-Treasurer records, box 115, file: WFTU Correspondence.

3. "Confidential Memorandum About Walter Schevenels," 18 November 1948, and Lovestone to Brown, 18 January 1949, IAD Brown files, box 29, file 6. The dossier was the work of Jiri Stolz and was a scurrilous attack on Schevenels's character. Yet Schevenels readily admitted that where the WFTU was concerned he played both sides of the fence. As he told Jay Krane, within the federation he had done all he could to strengthen it and steer it away from trouble. Meanwhile, outside the WFTU he had made every effort to undermine the organization. He had no qualms of conscience about such behaviour. Krane to Cope, 14 December 1948, Jay Krane papers, box 1, file 4.

Walter Schevenels (1894-1966) had worked as a toolmaker in Antwerp before becoming a full-time official of the Belgian socialist metalworkers' union. From 1929 to 1945, he was assistant general secretary and then general secretary of the International Federation of Trade Unions (IFTU), where he worked closely with its president, Walter Citrine. He was appointed assistant general secretary of the WFTU from 1946 to 1949. Having failed to become the general secretary of the ICFTU when it was founded in 1949, he served as the secretary of its European Regional Organization until his death in 1966.

4. Minutes of ERP-Trade Union Advisory Committee meeting, Berne, 22 January 1949, and Brown to Lovestone, 24 January and 1 February 1949, IAD Lovestone files, box 11, file 11; Tewson to Bill Green, 28 January 1949, Schevenels papers, box 1, file: AFL Controversy. 
5. Brown to Lovestone, 16 January 1949, IAD Lovestone files, box 11, file 11. Brown believed that Jim Carey of the CIO, with his close links to Secretary of State Dean Acheson, was behind this.

6. Bevin to Dubinsky, 14 February 1949, Dubinsky records, box 7, file 3. Foreign Office officials were alert to the potential seriousness of the rift over the Schevenels affair and judged that Brown's "excursions into international trade union activities were a real menace." Their recommendation was that Bevin suggest to Secretary of State Acheson or even to President Truman that someone "talk a little sense into the AFL." But Bevin's preference was to write to Dubinsky. H. G. (Hubert) Gee to Secretary of State, 26 January, 4 February, and 7 February 1949, LAB 13/600: Break-up of WFTU.

7. Brown to Lovestone, 24 January 1949, and Lovestone to Brown, 3 February and 15 February 1949, IAD Lovestone files, box 11, file 11; "AFL Opposes Schevenels in TUAC Post," Free Trade Union News, March 1949.

8. Cope to Ross, 13 March 1949, IAD Ross files, box 10, file 23; Brown to Lovestone, 31 May 1949, and Lovestone to Brown, 1 August 1949, IAD Lovestone files, box 11, file 11; George Lichtblau, "Internationalism and the World Federation of Trade Unions" (typescript, 1949), 76; FTUC Financial Accounts, June-July 1949, IAD Lovestone files, box 73, file 4. During his trip to India, Brown met Prime Minister Nehru and recommended to Lovestone that he be invited to the AFL's 1949 convention. Lovestone commented: "No one in Washington ... is awake to the overwhelming import of what has happened in China... They cannot see the organic connection between a street corner in Berlin, the Bund in Shanghai and the critical conditions in Calcutta." But the situation could be saved "provided we play a true and politically progressive policy in countries like Indo China, Burma, Ceylon, Siam and Indonesia. ... Here is the big task for American labour." Lovestone to Brown, 7 June 1949, IAD Lovestone files, box 11, file 10.

9. "Statement by AFL International Relations Committee," 7 April 1949, and minutes of TUC International Committee meeting, 26 April 1949, TUC Archives, MSS 292/901/15. Despite these assurances, for much of the next decade relations between the AFL and TUC within the ICFTU were conducted in an atmosphere that was often strained, each regarding the other as seeking pre-eminence. The affairs of an international organization should never be narrowed down to an account of how just two of its members related to one another, but in the case of the ICFTU a central dynamic of the organization cannot be adequately conveyed without dwelling on the suspicions the AFL and the TUC had of one another.

10. Lillie Brown to Lovestone, 13 July 1949, IAD Lovestone files, box 11, file 10; Berger to Dubinsky, 26 August 1949, Dubinsky records, box 248, file 8c.

11. It would be an oversimplification to reduce the situation to a simple contest between Brown and Tewson or the AFL versus the TUC. In such meetings, the TUC did in fact often reflect the values of the smaller, social democratic centres of the Benelux and the Nordic countries, while the AFL saw itself as the champion of those national bodies that did not share the social democratic perspective of most Europeans.

12. The AFL had already organized a hemispheric grouping, the Confederación interamericana de trabajadores, and Brown's initial line was that this should become a 
directly affiliated, self-governing regional body within the international. As such, it would naturally add greatly to the influence of the AFL.

13. Brown to Lovestone, 30 July 1949, Lovestone papers (Hoover), box 355, file: Irving Brown, 1949-53; Lovestone to Brown, 2 August 1949, IAD Lovestone files, box 11, file 10; Ross and Krane, "Summary of Meeting of the Trade Union Preparatory Committee, London, 21-23 September 1949," CIO Secretary-Treasurer records, box 123, file: ICFTU.

14. The then British labour counsellor in Washington, Archie Gordon, subscribed to a different version, claiming that the TUC had favoured Oldenbroek for the post from an early date but had refrained from publicizing the fact for fear that the AFL would then oppose him out of spite. It played its cards close to its chest until it was too late for the AFL to do other than follow the TUC's lead. Lovestone to Brown, 6 December 1951, Lovestone papers (Hoover), box 283, file: Irving Brown, 1951. I have found no evidence to support this interpretation. Less wedded to Oldenbroek, the CIO went along with his candidacy simply for the sake of harmony. Within a few years it found itself in the ironic position of defending him against AFL attacks when the latter turned violently against him.

15. Walter Reuther remarks at CIO International Affairs Committee, 7 January 1954, CIO Washington Office records, box 56, file 10; Lovestone to Meany, 13 March 1955, Lovestone papers (Hoover), box 705, file: George Meany.

16. Brown to Lovestone, 30 July 1949, Lovestone papers (Hoover), box 355, file: Irving Brown, 1949-53; Ross and Krane, "Summary of Meeting," CIO Secretary-Treasurer records, box 123, file: ICFTU; Diary, 10 January 1950, Krane papers, box 1, file 4, reporting a conversation between David Lasser and David Dubinsky. Lovestone was in full agreement with Brown on the need to continue independent activities, though he warned that the British would gain support "on a demagogic basis if we allow them to put us in the position of placing the Communist issue in a negative sense." Lovestone to Brown, 2 August 1949, IAD Lovestone files, box 11, file 10.

17. Under George Meany's presidency, the AFL's Latin American operation would continue to be a closed book as far as Lovestone was concerned-a situation that extended into the 1960 s and 1970s, when AIFLD was the key American organization.

18. Lovestone to Brown, 23 May 1950, and Brown to Lovestone, 30 May 1950, IAD Lovestone files, box 11, file 12.

19. Cope to Ross, 27 March 1950, IAD Ross files, box 10, file 25.

20. Along with general AFL claims that European trade unions lacked dynamism, it was routine for them also to be criticized for their unimaginative approach to public relations. The ICFTU's director of publicity who incurred so much AFL criticism was John Riddell. Lovestone harboured suspicions of Riddell on grounds that he had once worked in Moscow and was married to a Polish woman, though Brown tried to reassure him that there was little to worry about on that score. Lovestone to Brown, 16 October 1952, and "Irving Brown Report," 22 October 1952, IAD Brown files, box 11, file 14. That Riddell was English and a nominee of the TUC was sufficient reason for mistrust. 
21. On this occasion, Brown's powers of persuasion proved inadequate. Oldenbroek decided to appoint Phil Delaney, the AFL's representative at the ILO, to the seat without first consulting Dubinsky and Woll. Such lack of consultation and the appointment of a "technician" rather than a ranking union leader-Woll had wanted the seat for himselfcaused such offence that he and Dubinsky both tendered their resignation as consultants, thereby opening up another front in what had, by this time, become an undeclared FTUC war on the ICFTU general secretary. Lovestone to Oldenbroek, 17 January 1950 and 31 January 1950, IAD Lovestone files, box 52, file 20; Brown to Lovestone, 16 November 1950, and Lovestone to Brown, 21 March 1951, Lovestone papers (Hoover), box 283, file: Irving Brown, 1951. This matter would fester for many months, and Lovestone wrote of his "creeping feeling that the AFL is sort of being taken for granted by the dominant leaders. ... The reaction to such lack of consideration is becoming more marked." Lovestone to Brown, 2 April 1951, Lovestone papers (Hoover), box 283, file: Irving Brown, 1951.

22. Brown to Lovestone, 23 December 1949, IAD Brown files, box 29 file 8; George Meany, “The ICFTU in Session," Free Trade Union News, August 1950; Cope to Ross, 27 March 1950, IAD Ross files, box 10, file 25.

23. Brown to Lovestone, 19 February 1950, and Lovestone to Brown, 28 February 1950, IAD Lovestone files, box 11, file 13 .

24. Lovestone to Brown, 29 June 1950, IAD Lovestone files, box 11, file 12. In fact, Lovestone doubted that the State Department itself really understood what was at stake in Korea. America was not just fighting the North Koreans, but also the Chinese and behind them the Russians. He summed up the danger in simplistic terms: "If we lose Korea, we lose Asia. If we lose Asia, Europe is automatically lost." Lovestone to Brown, 4 December 1950, IAD Lovestone files, box 11, file 12.

25. Brown to Lovestone, 8 July 1950, IAD Lovestone files, box 11, file 12; Brown to Meany, 16 August 1950, Meany files, 1947-6o, box 56, file 21.

26. Jay Krane (1923-61) had worked for UNRRA before a two-year stint in the CIO's Paris office, 1948-50. With horn-rimmed glasses and bow tie, he resembled a young college lecturer. He joined the ICFTU in 1950 and, in 1956, became assistant to Charles Millard as director of regional affairs. At that time, Brown supported his appointment: Krane, he reckoned, would be an "objective and hardworking secretary... He is honest enough not to act as a factional CIO man." Brown to Lovestone, 19 June 1950, IAD Lovestone files, box 11, file 12. On leaving the ICFTU in 1961 following a vicious battle to oust Oldenbroek and his closest associates, Krane was briefly director of international affairs of the AFL-CIO's Industrial Union Department.

Always a controversial figure, Richard Deverall (1911-80) was active in the Association of Catholic Trade Unionists before appointment to the UAW education department, 1940-42. After war service, he worked in the labour education branch during the American military administration of Japan. From 1949 to 1956, he served as the FTUC's Asia representative in India and Japan. He worked as assistant to the assistant general secretary of the ICFTU from 1956 to 1959 and thereafter was employed in the AFL-CIO education department on his return to the United States. 
27. Lovestone to Brown, 17 April 1950, IAD Lovestone files, box 11, file 13; Lovestone to Brown, 12 May 1950, and Brown to Lovestone, 19 June 1950, IAD Lovestone files, box 11, file 12; Oldenbroek to Lovestone, 19 May 1950 and 19 June 1950, and Lovestone to Oldenbroek, 22 June 1950, IAD Lovestone files, box 52, file 20. Woll stated that the idea for an FTUC office in Tokyo came from Secretary of Defence James Forrestal. Minutes of International Labour Relations Committee meeting, 7 April 1949, Thorne files, box 17, file: International Labour Relations Committee. Deverall's reputation for informing on "communists" dated back to wartime when he worked for the UAW in Detroit. Richard Deverall to Federal Bureau of Investigation, “Re: United Auto Workers-CIO," 3 August 1943, Victor Reuther papers, box 5, file 19. On learning of Deverall's appointment by the FTUC, the former chief of SCAP's labour division, Theodore Cohen, wrote: "I think it would be tragic if the sole qualification of any representative the AFL may send there were to be [a] loud but negative anti-communist." Cohen to Lovestone, 26 July 1949, Lovestone papers (Hoover), box 296, file: Japan.

28. According to Lovestone's secretary, General MacArthur personally granted Deverall special permission to enter Japan with the ICFTU party, but this was "sabotaged" by his military government staff. Ann Larkin to Oldenbroek, 26 July 1950, IAD Lovestone files, box 52, file 20; Burati to Oldenbroek, 9 May 1950, Burati papers, box 2, file 8; Burati to Phil Delaney, 5 June 1950, IAD Country files, 1945-71, box 27, file 7: Burati to Potofsky, 12 June 1950, Burati papers, box 1, file 12; Burati to Oldenbroek, 29 June 1950, Burati papers, box 2, file 8; Ko Ono, "Subject: ICFTU Delegation," 20 July 1950, Burati papers, box 2, file 8. Lovestone would hound Burati in subsequent years, vetoing his attempts to secure government posts in the labour field. The fact that Burati had groomed Minoru Takano for the general secretaryship of Sōhyō rebounded against him after Takano swung to the left in the early 1950s. For Lovestone, this was ex post facto proof of Burati's political unreliability. Yet Burati had in fact been a major architect of the military government's 1949-50 campaign against communism in the trade unions, which, in the hands of Japanese employers, snowballed into the infamous "Red Purge." Burati to Victor Reuther, 1 September 1955, Benedict papers, box 86, file: Business and Personal Correspondence, 1952-58.

29. Lovestone to Oldenbroek, 11 August 1950, IAD Lovestone files, box 52, file 20; Lovestone to Brown, 5 September 1950, IAD Lovestone files, box 11, file 12; Lovestone to Brown, 2 April 1951, Lovestone papers (Hoover), box 283, file: Irving Brown, 1951.

30. Oldenbroek to Lovestone, 21 August 1950, and Lovestone to Oldenbroek, 7 May 1951, IAD Lovestone files, box 52, file 20; Lovestone to Brown, 2 April 1951, Lovestone papers (Hoover), box 283, file: Irving Brown, 1951.

31. Deverall also complained to Lovestone that in Taiwan, Krane had indulged in loose talk about FTUC support for the clandestine Free China Labour League, which was financed by US intelligence. Lovestone concluded: "If Mr. Krane worked under orders of Russia he could not have done as much damage to us." Lovestone to Brown, 8 August 1950, and 5 September 1950, IAD Lovestone files, box 11, file 12. Eighteen months on, an editorial in the ICFTU's Free Labour World written by Krane, which contained critical references to 
anti-communist American senators McCarran and McCarthy, led Lovestone to comment: "I still think that Jay Krane has connections with the Communists and their fellow travellers." “The Dignity of the Free World," Free Labour World (March 1952); Lovestone to Brown, 7 April 1952, IAD Lovestone files, box 11, file 15.

32. Among AFL figures with a low opinion of Deverall was Jim Killen, vice president of the pulp and sulphite workers, who had been his boss in the labour division of the military government in Japan and went on to have a stellar career as labour attaché. In 1956, Meany pressured Oldenbroek to find a job for Deverall in Brussels when FTUC activities in Asia were winding down. Almost certainly Meany was relieved to be rid of him: the problem was now one for the ICFTU to deal with.

33. Oldenbroek's earlier links with the AFL had been very close, and he came to realize that this needed to change. In the summer of 1950, he had been subject to sharp criticism from within his own Dutch national trade union centre, NVV, for being too subservient to the American point of view. Critics cited loans received from the Americans to cover administrative expenses and his ownership of an American car, in the purchase of which Irving Brown had acted as intermediary. The NVV leadership felt strongly enough to raise these matters with ICFTU president Paul Finet. A. Greenhough to Turner, 12 July 1950, LAB 13/632: ICFTU General File, 1949-52. Oldenbroek was astute enough to realize that he could not afford to let such impressions take firm hold.

34. Minutes of FTUC meeting, 31 October 1950, IAD Lovestone files, box 35, file 29; FTUC Circular 27, October 1950, Thorne files, box 14, file: FTUC.

35. Tension between Woll and Meany was assumed to be over the future of the FTUC. There were persistent rumours that it might be closed down now that the AFL had been successful in helping to split the WFTU. Phil Delaney, the AFL's ILO representative, had been telling people in Washington that Brown himself favoured such a development, and the latter's transfer to the AFL staff in 1950 had fuelled a belief that the FTUC's days might be numbered. Cope to Ross, 17 March 1950, IAD Ross files, box 10, file 25; Lovestone to Brown, 8 May 1950, IAD Lovestone files, box 11, file 12.

36. Tewson to Meany, 13 March 1951, and Meany to Tewson, 23 March 1951, Meany files, 1940-80, box 59, file 14 .

37. Brown to Lovestone, 14 December 1951, Lovestone papers (Hoover), box 355, file: Irving Brown, 1949-53. It seems that Tewson also made known his feelings about the role of the FTUC to other AFL leaders. Consequently, Meany anticipated criticism by members of the executive council at its meeting in Florida in February 1952. To forestall this, he secured prior agreement in the FTUC that Dubinsky and Woll would close ranks with him if any attempt were made at the council meeting to criticize Lovestone and Brown. Lovestone to Brown, 7 January 1952, IAD Lovestone files, box 11, file 16.

38. Brown to Green, 2 August 1951, Lovestone papers (Hoover), box 283, file: Irving Brown, 1951; minutes of ICFTU Executive Board meeting, 12 July 1951, ICFTU Archives, folder 10: CIO World Affairs Bulletin, vol. 1, no. 1 (October 1951); Lovestone to Meany, 9 November 1951, Meany files, 1947-6o, box 56, file 1. Increasingly, Lovestone was inclined to view Oldenbroek as an honorary Englishman. It marked quite a change: "phooey" had been his 
response in 1949 to Swedish suggestions that Oldenbroek was "too pro-British." Lovestone to Brown, 9 May 1949, Lovestone papers (Hoover), box 698, file: Irving Brown.

39. Brown to Green, 2 August 1951, Lovestone papers (Hoover), box 283, file: Irving Brown, 1951. The Economist had criticized the AFL for elevating the anti-communist struggle above all else and for maintaining independent regional offices. The Economist, 21 July 1951. Writing in response, Woll disputed the argument that his organization was out of line with other national centres. Matthew Woll, "The International Role of the AFL: Reply to the London Economist," Free Trade Union News, October 1951. A few months earlier the labour correspondent of the Times of London had also chided the AFL for continuing its independent programs. "World Trade Unions: Two Internationals in Opposition," Times (London), 14 December 1951.

40. A. Gordon to C. F. Heron, 29 October 1951, and Heron to Gordon, 23 November 1951, LAB 13/632: ICFTU: General File.

41. Meany's suggestion that Tewson couldn't count reflected the tenor of the meeting: there were only sixteen voting members present, and in each of the three votes taken the split was identical—nine for, five against, and two abstentions, with Tewson and Oldenbroek both among those voting "for." In asking for a roll call vote, Meany was doubtless also showing his displeasure with the two abstainers, Robert Bothereau, of FO, and Farhat Hached, of Tunisia's UGTT, both of whose organizations were highly dependent on AFL assistance.

42. Agenda item 5: "General Secretary Report," and minutes of ICFTU Executive Board meeting, 26-30 November 1951, ICFTU Archives, folder 11; Lovestone to Brown, 29 November 1951, Lovestone papers (Hoover), box 283, file: Irving Brown, 1951; Brown to Lovestone, 22 December 1951, Lovestone papers (Hoover), box 355, file: Irving Brown, 1949-53.

43. Lovestone to Brown, 5 January and 23 January 1952, IAD Lovestone files, box 11, file 16. 44. Brown to Lovestone, 2 December 1951, Lovestone papers (Hoover), box 355, file: Irving Brown, 1949-53; Lovestone to Brown, 6 December 1951, Lovestone papers (Hoover), box 283, file: Irving Brown, 1951. On the recurrent criticisms of lack of dynamism in the ICFTU and its affiliates, see Lovestone to Brown, 2 April 1951, Lovestone papers (Hoover), box 283, file: Irving Brown, 1951; Brown to Lovestone, 14 December 1951, Lovestone papers (Hoover), box 355, file: Irving Brown, 1949-53; Brown to Meany, 30 June 1952, Meany files, 1947-6o, box 57 , file 21.

45. Ann Larkin to Brown, 2 April 1952, IAD Lovestone files, box 11, file 15.

46. Brown to Green, 28 April 1952, Meany files, 1947-60, box 57, file 21; Lovestone to Meany, 30 April 1952, Meany files, 1947-6o, box 56, file 1; Lovestone to Brown, 8 May 1952, IAD Lovestone files, box 11, file 15. "Bevanites"-practitioners of "Bevanism"-were parliamentary followers of British Labour politician Aneurin Bevan and reflected the main strand of left-wing Labour thinking in the 1950s. They included many who were attracted to CND and were critical of NATO. As an organized group, Bevanites were ranged against the right-wing Gaitskellites in Labour's ideological debates of that time.

47. Brown to Lovestone, 3 April 1952, IAD Lovestone files, box 11, file 15. 
48. Brown to Green, 28 April 1952, Meany files, 1947-6o, box 57, file 21. There is no indication as to whether Green took his interest in the job seriously or acted on his letter.

49. Green to ICFTU affiliates, 2 May 1952, CLC Archives, MG28 I 103, vol. 257, LAC.

50. Lovestone to Brown, 26 May 1952, IAD Lovestone files, box 11, file 15.

51. AFL International Labour Relations Committee Meeting, 18 June 1952, Thorne files, box 17, file: International Labour Relations Committee.

52. Lovestone to Brown, 13 October 1952, IAD Brown files, box 29, file 14; Lovestone to Brown, 16 October and 21 October 1952, IAD Lovestone files, box 11, file 14.

53. Brown to Lovestone, 13 May 1952, IAD Lovestone files, box 11, file 15; Brown to Meany, 30 June 1952 and 21 October 1952, Meany files, 1947-60, box 57, file 21.

54. Several of the issues that had exercised the Americans were resolved or were overtaken by events by the time the executive board met in New York. Over the following six months, the outstanding ones were referred to ICFTU committees, and by July 1953, eighteen months after the row first erupted, the outstanding ones were reported "resolved." Minutes of ICFTU Executive Board meeting, 1-5 December 1952, ICFTU Archives, folder 21; Lovestone to Brown, 16 October 1952, IAD Lovestone files, box 11, file 14; agenda item 6: "Report of the Emergency Committee on the Circular Letter from the AFL Dated 2 May 1952, Addressed to All ICFTU Affiliated Organizations," ICFTU Executive Board meeting, Stockholm, 1-2 July 1953, ICFTU Archives, folder 22; Brown to Lovestone, 13 March 1953, IAD Brown files, box 30 , file 15 .

55. The program in support of the FCLL cost almost $\$ 100,000$ in just over two years. The league's agents, trained in Formosa, were intended to provide leadership to an estimated 450,000 anti-communist guerrillas operating in largely spontaneous fashion on the Chinese mainland. In a disastrous development, CIA funding was suspended in 1950 and several FCLL members, who were thus stranded in southern China, were rounded up and executed. More than anything else, Lovestone's experience of this failed operation undermined his confidence in joint activities undertaken with the CIA. Lovestone to Etter, 6 October 1950, IAD Lovestone files, box 35, file 14; Lovestone to Brown, 26 October 1950, IAD Lovestone files, box 11, file 12; Lovestone to Brown, 23 February 1951, Lovestone papers (Hoover), box 283, file: Irving Brown, 1951; Etter to Lovestone, 9 May 1951, Lovestone papers (Hoover), box 368, file: Willis Etter, 1942-52; Anthony Carew, “The American Labour Movement in Fizzland: The Free Trade Union Committee and the CIA," 27.

56. Harry Goldberg was the son of a founding member of the ILGWU. He taught philosophy at New York College and led a Lovestoneite faction in the teachers' union. Within the Communist Party (Opposition) his nom de guerre was "Jim Cork." A snappy dresser, classically trained pianist, and sometime music critic for a paper, he cut an unlikely figure as an international representative of a trade union. In Indonesia, he ran a training program aimed at non-communist trade unionists intended to steer them away from their neutralist, "third force" political orientation. In the two years 1951-52, \$30,000 of CIA money was channelled into this effort. Suffering from ill health and exhaustion, Goldberg returned to the United States and was subsequently redeployed as FTUC representative in Italy. Goldberg to Lovestone, 29 September 1951, and Goldberg, "Report from Indonesia," 
12 November 1951, IAD Brown files, box 29, file 11; Lovestone to Sam Berger, 31 March 1952, IAD Lovestone files, box 10, file 11; Lovestone to Brown, 26 May 1952, IAD Lovestone files, box 11, file 15; Carew, "The American Labour Movement in Fizzland."

57. Lovestone to Offie, 13 March 1950, Lovestone papers (Hoover), box 310, file: Carmel Offie; Eliezer Liebenstein, "Israel and Its International Ties," Free Trade Union News, September 1950.

58. Lovestone to Brown, 28 February 1950 and 10 July 1950, IAD Lovestone files, box 11, file 13. Lovestone to Offie, 15 January 1951, Lovestone papers (Hoover), box 310, file: Carmel Offie. Lovestone informed Brown: "On November 17th we sent the funds to Mr. Meany for shipment of the books to Australia.... We have already received work [sic] from Australia and New Zealand that they have gotten notification of the arrival of the books." Lovestone to Brown, 27 December 1950, IAD Lovestone files, box 11, file 12.

59. For FTUC annual accounts, Lovestone papers (Hoover), box 403, file: Free Trade Union Committee; box 416, Financial Documents, 1954-58; and box 417, file: Free Trade Union News; Carew, “The American Labour Movement in Fizzland," 25-42. Paul Sakwa, who worked on the French desk of the CIA's Western European division during 1951-54, confirms Philipsborn's role as Brown's paymaster. Author interview with Paul Sakwa, 18 September 1995.

6o. Burton Hersch, The Old Boys: The American Elite and the Origins of the CIA, 320.

61. Lovestone to Dubinsky, 3 January 1949, IAD Lovestone files, box 33, file 3 . In the thinly disguised code used by Lovestone in correspondence when discussing CIA-financed transactions, a "volume" was $\$ 1,000$ and there were associated references to "books" and "libraries." Lovestone liked playing with words, couldn't resist a pun, and when specific countries were involved he would often change the allusion, with financial help referred to as "pottery" in Italy; "perfume" in France; "sausages" in Germany, "lumber" in Finland, and "glassware" in Czechoslovakia.

62. Lovestone to Brown, 21 January and 26 January 1949, IAD Lovestone files, box 11, file 11.

63. Brown to Lovestone, 6 March 1950, IAD Lovestone files, box 33, file 6.

64. Brown to Lovestone, 8 February and 15 February 1949, IAD Lovestone files, box 11, file 11.

65. Brown to Lovestone, 31 October 1949, IAD Lovestone files, box 11, file 10; Brown "Report on Finland," October 1949, IAD Brown files, box 10, file 5; "Finnish Report: Visit of Mr. Irving Brown," 25 October 1949, LAB 13/656: USA-AFL General File, 1947-54. In the late 1960s and early 1970s, Leskinen was successively minister of trade and industry and foreign minister.

66. "Memorandum Aku Sumu and Olavi Lindblom," 4 May 1950, Lovestone papers (Hoover), box 310, file: Carmel Offie; Brown to Lovestone, 19 June 1950, IAD Lovestone files, box 11, file 12; Lovestone to Brown, 30 June 1950, IAD Brown files, box 29, file 10.

67. Ann Larkin to Brown, 26 February 1951, and Lovestone to Brown, 13 March 1951, Lovestone papers (Hoover), box 283, file: Irving Brown, 1951; Ann Larkin to Lillie Brown, 5 March 1951, IAD Brown files, box 29, file 11. Ann Larkin (Stolte) was Lovestone's secretary.

68. Brown to Lovestone, 1 April 1951, Lovestone papers (Hoover), box 283, file: Irving Brown, 1951. 
69. Lovestone to Brown, 4 April 1951, Lovestone papers (Hoover), box 283 file: Irving Brown, 1951.

70. Lovestone to Brown, 26 May 1951, Lovestone papers (Hoover), box 283, file: Irving Brown, 1951; Arvo Tuominen, "Finnish Unionists Again Beat Back Soviet Seizure," Free Trade Union News, October 1951; Mijo Majander, Demokratiaa dollareilla.

71. Brown to Lovestone, 2 January 1949, IAD Lovestone files, box 11, file 11. The idea of training an elite force, schooled in Leninist tactics and capable of challenging communist trade unionists on their own turf, was recurrent in Brown's thinking. In 1954, in Italy, he hoped to establish a school for such purposes at FIAT's Turin plant with the backing of the firm's management and the US embassy in Rome. FIAT was willing to contribute financially, but the embassy declined to match its contribution. Untitled document ("The major fortress of communism in Italy ...”), June 1954, IAD Brown files, box 12, file 20.

72. Pierre Ferri-Pisani (1901-63), a native of Marseille, became leader of the seamen's union in 1927 and later the city's socialist deputy mayor. His wartime role in the resistance led to his arrest in 1943 and imprisonment in Buchenwald. After the war, unable to re-establish leadership of the socialist party in Marseille, which was now under the control of Gaston Defferre, he focused on trade union work and identified with Robert Bothereau and the group around Résistance ouvrière. Following Force ouvrière's breakaway from the CGT, he became secretary of the small FO maritime union in Marseille. As head of the CIAfinanced Mediterranean Committee, he led the anti-communist campaign for control of the Marseille waterfront and other Mediterranean ports in the early 1950s. When this source of money dried up in the mid-1950s, he drifted from prominence. He committed suicide in 1963.

73. Alexander Werth, France: 1940-1955, 442.

74. For a colourful account of the Marseille waterfront scene at this time, see Alfred W. McCoy, The Politics of Heroin: CIA Complicity in the Global Drug Trade, which describes the Guerini family's involvement in drug trafficking. His treatment of their role in labour events is less reliable. The development of secretive cadre organizations in the French labour movement at this time in the struggle with communism chimed perfectly with advice given by the ECA chief of mission in France, David Bruce, who had been head of OSS wartime activities in Europe. At a May 1950 meeting of the ECA's Labor Information staff in Paris, he advocated the use of black propaganda to "sabotage" the communist effort. Anthony Carew, Labour Under the Marshall Plan: The Politics of Productivity and the Marketing of Management Science, 126-27.

75. "Report of AFL Representative in Europe for July 1949-July 1950," IAD Lovestone files, box 11, file 12 .

76. In an industry with an estimated 38,000 union members, 25,000 of them belonging to the CGT, the FO union's optimistic claim was to have around 5,00o. Harold Lewis, "The International Transport Workers' Federation (ITF), 1945-65: An Organizational and Political Anatomy," 281. I am grateful to Harold Lewis for many insights into ITF policy and field activities during this period and also for generous help in making sense of the 
complexity of international trade union developments more generally in the postwar period.

77. Lovestone to Bergeron, 2 May 1967, Lovestone papers (Cornell), box 1, file 17; Alfred Pacini and Dominique Pons, Docker à Marseille, 86.

78. A detailed account of the events in Naples was provided by the ITF's Fred Strauss. Strauss to Becu, "Confidential Report on Italian Trip, 1-5 September 1950," International Transport Workers' Federation, 1896-2012, MSS 159/1-18, Modern Records Centre, University Library, University of Warwick, Coventry, UK. The founding of the Mediterranean Committee revealed the tenuous nature of its link with the International Transport Workers' Federation. An international conference of European dockers and transport workers was planned for Naples immediately following the foundation, and for months Jay Lovestone had been working to mobilize the support of AFL transport union leaders with a view to a strong American delegation being present at the conference. His hope was that, while they were in Europe, the Americans would participate in anti-communist rallies as part of an offensive to "drive the Russian rats out of their piers." However, at a late stage, the ITF leaders became alarmed and vetoed American participation, fearful that the operation was drifting too far away from their control. In fact, this was never in any real sense an ITF-led exercise. When challenged over the chaotic conference arrangements, Brown announced that the Americans had the wherewithal to launch the Mediterranean Committee on their own if necessary, insisting: "We don't like red tape: we act." Indeed, three months earlier Lovestone had notified him that the CIA had instructed their man in Rome to "make the ITF transaction," and FTUC accounts duly recorded an "ITF loan" of $\$ 2,800$ to cover the cost of the conference. The ITF leadership was reminded of its ill-judged sponsorship of the committee at its 1952 congress when none other than Force ouvrière's railway union secretary wondered aloud about the committee's source of financing. Lovestone to Carmel Offie, 9 March 1950, Lovestone papers (Hoover), box 310, file: Carmel Offie; Lovestone to Brown, 7 June 1950, IAD Lovestone files, box 11, file 12; Lewis, “The International Transport Workers' Federation (ITF) 1945-65," 261-65 and 281-82.

79. As a trade union journal, Air-Terre-Mer was a much more substantial affair than anything the ITF was capable of producing.

8o. Lewis, “The International Transport Workers' Federation (ITF) 1945-65," 266.

81. Irving Brown, "Mediterranean Vigilance Committee in Action," Free Trade Union News, September 1951.

82. Brown to Lovestone, 22 December 1950, IAD Lovestone files, box 11, file 12; Brown to Lovestone, 9 January 1951, Lovestone papers (Hoover), box 283, file: Irving Brown, 1951. Brown first met Eisenhower in 1951 when, as NATO Supreme Commander, he had invited Brown to accompany him while travelling between Frankfurt and Paris. The following year at a meeting with Oldenbroek at NATO headquarters, Eisenhower told the ICFTU leader that everything he knew about labour and its international problems came from Irving Brown: "We think he is pretty good." Brown to Lovestone, 26 January 1951, Lovestone papers (Hoover), box 355, file: Irving Brown, 1949-53; Brown to Lovestone, 
25 February 1951, Lovestone papers (Hoover), box 283, file: Irving Brown, 1951; Brown to Lovestone, 19 January 1952, IAD Lovestone files, box 11, file 16.

83. See Daniele Ganser, NATO's Secret Armies: Operation GLADIO and Terrorism in Western Europe.

84. Air-Terre-Mer could truthfully point out, for example, that the Soviets had also shipped war materials from Gdynia to Albania, initially for use by insurgents in Greece and then available for a possible attack on the dissident communist regime in Yugoslavia. All this was a necessary corrective to Soviet attempts to claim the moral high ground with its "peace campaigning," which helped foster a growing mood of neutralism in Western Europe.

85. Brown to Lovestone, 30 May 1950, IAD Lovestone files, box 11, file 12; Brown to Lovestone, 9 December 1950, 25 February 1951, 1 and 25 April 1951, Lovestone papers (Hoover), box 283, file: Irving Brown, 1951; Brown to Lovestone, 21 May 1951, Lovestone papers (Hoover), box 355, file: Irving Brown, 1949-53. The Turkish trade unionists who visited the AFL were financed by a $\$ 6,000$ grant from the Rockefeller Foundation.

86. Lewis, “The International Transport Workers' Federation (ITF), 1945-65," 278.

87. Leon Dale, untitled document, 31 March 1953, IAD Brown files, box 14, file 6; Dale to Giornelli, 13 January 1953, IAD Brown files, box 13, file 2. Dale also reported in the same document a meeting with "Philips" (John Philipsborn, the CIA officer based in the Paris embassy under cover of assistant labour attaché) in which they discussed in some detail the need for "new offices" for the Mediterranean Committee. "Philips" complained to Dale about the present lack of organization within the committee and planned to write a special report on it. Leon Dale's appointment to Paris as CIA assistant to Brown lasted from February 1951 to September 1953. Strangely, for one whose role was clearly meant to be secret, Dale appears to have been lax in inviting the curiosity of others. In November 1951, at the CISL congress in Naples, he stood in for Brown as the formally accredited AFL fraternal delegate. His fraternal address, quoting Karl Marx on workers having "nothing to lose but their chains," won him loud applause. This aroused the interest of Joe Curran, president of the CIO's National Maritime Union, who was also attending the congress as the CIO's fraternal delegate and demanded to know what Dale was doing there. I lavori e gli atti: le congresso nationale (Naples: CISL, November 1951), 32-36; Leon Dale, "Report on CISL Congress in Naples, November 1951," IAD Brown files, box 14, file 6; Lovestone to Brown, 21 November 1951, Lovestone papers (Hoover) box 283, file: Irving Brown, 1951. The US embassy in Rome seemed more sensitive to the incongruity of a CIA operative delivering a fraternal address to a foreign trade union gathering: labour attaché Tom Lane blocked official release of Dale's speech and its favourable reference to Karl Marx.

88. Giornelli to Brown, 6 June 1953, IAD Brown files, box 13, file 2; Brown to Lovestone, 6 December 1954, IAD Lovestone files, box 12, file 1; Brown to Meany, 23 June 1955, IAD Lovestone files, box 41, file 3 .

89. Dubinsky's financial support for Le Populaire was long-standing, though assistance was withheld for a period in 1949-50 when socialist party (SFIO) members were divided over the hard-line policing of strikes introduced, with AFL backing, by socialist interior 
minister Jules Moch. When, as a consequence, Moch lost his seat on the party's ruling body, Dubinsky temporarily stopped funding the paper. Brown considered this action folly and had to work hard to persuade Dubinsky and Lovestone to reintroduce the subsidy. To improve the chances, he urged the editor of Le Populaire to present a more favourable image of America in its reporting. Late in 1950, Dubinsky relented and promised a further injection of $\$ 60$,ooo while at the same time advising that the publication be separated from the SFIO and turned into a general paper of liberal opinion. Brown to Lovestone, 23 October 1950, IAD Lovestone files, box 11, file 12. The subsidy was still in place at the end of 1952 when Le Populaire was seeking to having it increased to $\$ 4,000$ a month (1.3 million francs). Robert Blum to Dubinsky, 28 August and 27 November 1952, Dubinsky records, box 255, file 4a.

90. Carmel Offie to Lovestone, 12 January 1951, Lovestone to Brown, 17 January 1951, and Lovestone to Offie, 30 April 1951, Lovestone papers (Hoover), box 310, file: Carmel Offie.

91. Rousset was one of the first people to draw public attention to widespread use of labour camps in the Soviet Union, for which the communist party demonized him. The FTUC's subsidy to Franc-Tireur covered the period during which Rousset successfully defended himself in a court case over charges of defamation brought by the communist journal Les Lettres françaises. Rousset broke with Sartre over the issue of the labour camps. The AFL took a keen interest in the Rassemblement democratique revolutionaire, sending greetings to its congress in April 1949 and assisting a number of Americans to attend alongside people like Camus, Sartre, Ignazio Silone, and Carlo Levi. But Lovestone was critical of the congress's hesitation in making an all-out condemnation of totalitarian communism. He wrote to Altman that no good purpose was served by having Trotskyites, vegetarian pacifists, anarchists, and "other nuts" on the platform. Lovestone to Altman, 11 May 1949, IAD Lovestone files, box 35, file 13.

92. Lovestone to Brown, 26 October, 17 November 1950, and Brown to Lovestone, 30 November 1950, IAD Lovestone files, box 11, file 12; Lovestone to Offie, 15 March 1951, Lovestone papers (Hoover), box 310, file: Carmel Offie.

93. Leon Dale, untitled document, 24 March 1951 ("On March 24, 1951 I had a conversation with Marzet and Clouzet ..."), IAD Brown files, box 14, file 6.

94. Brown to Lovestone, 23 October 1950, and Lovestone to Brown, 17 November 1950, IAD Lovestone files, box 11, file 12; Peter Coleman, The Liberal Conspiracy: The Congress for Cultural Freedom and the Struggle for the Mind of Postwar Europe, 46, 51.

95. Coleman, The Liberal Conspiracy, 35. Brown's association with the CCF was essentially on an individual basis; as an organization the AFL was only peripherally involved. From the CCF's earliest days Lovestone urged Brown to restrict the amount of time he devoted to its affairs, a view increasingly shared by the FTUC leadership. Lovestone to Brown, 26 March 1951, Lovestone papers (Hoover), box 283, file: Irving Brown, 1951. Brown didn’t include himself among the intellectuals and was amused by their lack of worldly wisdom, but he certainly understood the propaganda value of having film stars associated with the congress. He took Gary Cooper with him to a CCF conference in Berlin in 1953 and urged Lovestone: "Keep after this Hollywood business because it is the biggest thing we can 
do. ... If we can have them on our side ... it will be one of the biggest blows against the communists in Europe." Brown to Lovestone, 30 October 1951, Lovestone papers (Hoover), box 283, file: Irving Brown, 1951; Jeffrey Meyers, Gary Cooper: An American Hero, 265.

Having urged American action on the cultural front in India following his May 1949 visit, Brown was actively involved in extending CCF organization into the subcontinent in 1951. During this phase the extent to which the CIA regarded the FTUC as part of its apparatus became apparent. A request was made by US Ambassador Loy Henderson via EUR-X’s Raymond Murphy that the local FTUC representative, Mohan Das, be assigned to Delhi for six weeks in the early spring of 1951 to assist with preparation for the founding conference of the CCF's section in India. However, Lovestone rejected the request, reminding people: "We are still a trade union movement." Raymond Murphy to Lovestone, 19 February 1951, IAD Lovestone files, box 51, file 6; Lovestone to Lillie Brown, 19 February 1951, Lovestone papers (Hoover), box 283, file: Irving Brown, 1951.

96. Josselson to Brown, 9 October 1956, and Brown to Lovestone, 13 October 1956, IAD Lovestone files, box 12, file 7; Frances Stonor Saunders, Who Paid the Piper: The CIA and the Cultural Cold War, 99-100. See also Hugh Wilford, The Mighty Wurlitzer: How the CIA Played America; Giles Scott-Smith, The Politics of Apolitical Culture: The Congress for Cultural Freedom and the Political Economy of American Hegemony, 1945-1955.

97. Donald Robinson, “Mr. Brown vs. Generalissimo Stalin,” Reader's Digest (September 1952), 116.

98. Brown to Lovestone, 15 November 1951, and Lovestone to Brown, 21 November 1951, Lovestone papers (Hoover), box 283, file: Irving Brown, 1951. In 1952, Lovestone discovered that a piece of intelligence from Profous, which he had been assured was meant exclusively for the FTUC, had actually been shared with others in the Czech exile group. This amounted to "double dealing," and nobody worked for long with Lovestone if they also reported to someone else. He was also annoyed that Profous had attended a Conference of the Free Peoples of Europe in Düsseldorf along with some politically dubious exiles from the Ukraine and Russia who, Lovestone insisted, "are no damn good despite . . . being lavishly financed by the Fizzmaniacs." All this spelled the end of the road for the relationship with their prize Czech contact: "I am sorry to see Profous go wrong," wrote Lovestone. "We rather liked him. ... But I think he has finished himself. As far as I am concerned support for his special project is out of the window." Lovestone to Brown, 11 July 1952, IAD Brown files, box 29, file 14. Profous was eventually brought over to the United States in 1953 to work for the National Committee for Free Europe.

99. Zygmunt Kratko, "Irving Brown, alias 'Bronzovy'-American Secret Service Agent," World Trade Union Movement, April 1953; "Who Is Irving Brown?” Trud, 11 September 1953. 100. The NCFE described itself as a "group of private citizens drawn together to carry out direct action to strengthen man's most valuable possession-freedom." In fact, it was created by the CIA and had an annual budget of $\$ 8$ million.

101. It was for the purpose of arguing the counterclaim on behalf of the Paris group that Sacha Volman was sent to New York in 1952. See also Quenby Olmsted Hughes, "In 
the Interest of Democracy": The Rise and Fall of the Early Cold War Alliance Between the American Federation of Labor and the Central Intelligence Agency, chap. 6.

102. C. D. Jackson to Royall Tyler, 18 September 1951, Lovestone papers (Hoover), box 355, file: Irving Brown, 1949-53; Dennen to Lovestone, 29 October 1951, IAD Lovestone files, box 26, file 9. Leon (Denenberg) Dennen (1908-74) was born in New York but brought up in the Ukraine, where his father worked as a journalist. Returning to the United States, he became education director of ILGWU Local 60 and managing editor of the Jewish Labor Committee's journal. After the war, he represented the Jewish Labor Committee in Turkey and on the International Rescue and Relief Committee. At the time of his appointment to the NCFE, he was foreign correspondent for the Scripps-owned Newspaper Enterprise Association in Europe.

103. Phenix to Augustine, 19 September 1951, Lovestone papers (Hoover), box 355, file: Irving Brown, 1949-53; Lovestone to Dennen, 3 October 1951 and 7 November 1951, IAD Lovestone files, box 26, file 9; Brown to Lovestone, 30 October 1951, Lovestone papers (Hoover), box 283, file: Irving Brown, 1951; Dennen to Lovestone, February 1952, IAD Lovestone files, box 11, file 15 .

104. Lovestone to Brown, 12 October 1951, Lovestone papers (Hoover), box 283, file: Irving Brown, 1951; Jackson to Brown, 15 January 1952, and Brown to Jackson, 22 January 1952, IAD Lovestone files, box 11, file 16; Brown to Jackson, 14 May 1952, IAD Brown files, box 31, file 4; Woll to Jackson, 31 October 1951, Lovestone papers (Hoover), box 355, file: Irving Brown, 1949-53; Lovestone to Meany, 21 December 1951, Meany files, 1947-60, box 56, file 1. Jackson was also president of the CIA's dummy Farfield Foundation, which took over from the FTUC as the main conduit for funding the Congress for Cultural Freedom. After losing his job with the NCFE, Henry Kirsch was appointed as FTUC representative in Turkey. He resurfaced again briefly in the mid-196os as an "AFL-CIO" representative in Saigon.

105. Draft letter, Woll to Admiral H. B. Miller, 16 April 1952, Lovestone papers (Hoover), box 382, file: NCFE, 1952; Lovestone to Dubinsky, 17 April 1952, Lovestone papers (Hoover), box 305, file: David Dubinsky; Lovestone to Brown, 8 May 1952, IAD Lovestone files, box 11, file 15 .

106. Lovestone to Brown, 8 May 1952, IAD Lovestone files, box 11, file 15.

107. Brown to Lovestone, 26 April and 5 May 1948, IAD Lovestone files, box 11, file 9: Ronald Filippelli, American Labour and Postwar Italy, 1943-1953: A Study of Cold War Politics, 153.

108. Dunn to Acting Secretary of State, 21 September 1948, Department of State, RG 59, Central Decimal Files, 1910-1963, 865.5043, National Archives, Washington, DC.

109. Counterpart funds consisted of payments by participating governments for goods and services received under Marshall aid. They were held in the currency of the particular country for use there-but only with the approval of the ECA. A part of the funds was also reserved for use by the CIA on unvouchered programs. The first significant use of such funds for labour programs was in Italy in support of the LCGIL, where expenditures would rise to some \$3 million per year by 1951. Lane to Brown, 17 December 1948 , IAD Brown files, box 1, file 11; Rome Embassy to State Department, 15 January 1949, 
Department of State, RG 59, Central Decimal Files, 1910-1963, 840.50 Recov; untitled document (" 1 . The Corporation expressed a desire to work closely with the worker

..”), n.d. [1951?], Lovestone papers (Hoover), box 381, file: Monk, 1951. This document, making the claim of a $\$ 3$ million annual subvention to the Christian Democrat trade unions, appears to have been prepared by Carmel Offie as a briefing for Lovestone prior to a meeting with CIA Director Walter Bedell Smith in April 1951.

110. Filippelli, American Labour and Postwar Italy, 153.

111. Lovestone to Brown, 15 June and 21 June 1949, IAD Lovestone files, box 11, file 10.

112. Dubinsky to Harriman, July 1949, Dubinsky records, box 255, file 3b; minutes of AFL International Affairs Committee meeting, 27 October 1949, Thorne files, box 17, file: International Labour Relations Committee.

113. Lovestone to Brown, 15 June 1949, Brown to Lovestone, 21 July 1949, and Lovestone to Brown, 1 August 1949, IAD Lovestone files, box 11, file 10.

114. Filippelli, American Labour and Postwar Italy, 165.

115. Ibid., 161, 165, 185-86; minutes of AFL International Affairs Committee meeting, 27 October 1949, Thorne files, box 17, file: International Labour Relations Committee.

116. Lovestone to Lillie Brown, 2 May 1950, IAD Lovestone files, box 11, file 12.

117. Filippelli, American Labour and Postwar Italy, 189; Brown to Lovestone, 1 April 1951, Lovestone papers (Hoover), box 283, file: Irving Brown, 1951; Lovestone to Brown, 16 May 1950, IAD Lovestone files, box 11, file 12.

\section{Chapter 4: The AFL and CIO Abroad}

1. Anthony Carew, "The American Labour Movement in Fizzland: The Free Trade Union Committee and the CIA." Lovestone discovered that alongside the FTUC operation in Finland, the CIA also had quite separate contact with the Finnish trade unions through the Norwegian labour leader Haakon Lie. Soon, and without the AFL being informed, the $\mathrm{CIO}$ would also have a finger in that pie. He was concerned when Arthur Koestler revealed to him inside knowledge of FTUC activities that could only have come from the CIA. Later, when the agency deployed Leon Dale as assistant to Irving Brown in Paris to help him with the administration of his budget, Lovestone was alarmed to discover that a journalist on Reader's Digest was aware of Dale's position and that as a result rumours were circulating about this new mystery man in Paris. At the same time, German railway union leader Hans Jahn, who had a CIA-supported network of contacts in the Eastern zone for distributing copies of his paper, Die Kleine Tribune, complained to Brown that in the absence of his regular contact, George Silver, the agency had sent a complete stranger to liaise with him over activities in the East. Jahn demanded from Brown "an unequivocal statement" that the CIA middleman would merely be used for passing money, with all policy questions still settled directly between himself and Brown. As far as he was concerned, the project was a trade union one and, failing clarification that this was still the case, Jahn favoured having the whole operation being taken over by the ITF in London. 
Brown to Lovestone, 16 November and 9 December 1950, Lovestone papers (Hoover), box 283, file: Irving Brown, 1951; Lovestone to Brown, 26 December 1950, IAD Lovestone files, box 11, file 12; Jahn to Brown, 1 August 1951, Lovestone papers (Hoover), box 355, file: Irving Brown, 1949-53.

2. Lovestone to Brown, 19 January 1952, IAD Lovestone files, box 11, file 16.

3. "Memorandum," 24 November 1950, Lovestone papers (Hoover), box 528, file: Carmel Offie. Carmel Offie (1909-72) was a career foreign service officer who had earlier worked in the State Department as assistant to Frank Wisner, with responsibility for East European refugee affairs. When Wisner became head of the Office of Policy Coordination (OPC) in 1948 (which was absorbed into the CIA in 1951), Offie assumed responsibility for liaison between the FTUC and OPC/CIA, becoming Lovestone's most valuable contact in intelligence circles. After Senator McCarthy began to investigate him as a security threat on the grounds that he was a known homosexual-he had been arrested in 1943 for loitering near the men's room in Washington's Lafayette Park, only escaping prosecution through the intercession of senior State Department officials-he was formally placed on the payroll of the FTUC in June 1950 in order to spare the OPC's embarrassment, though the intelligence service continued to fund his salary. In Lovestone-Brown correspondence, he was referred to as "the Monk" (on the basis of his first name, which summoned to mind the Carmelite order). Within the CIA, he remained a controversial figure, and from the moment he joined the FTUC the FBI placed him under investigation. This also led to the tightening of FBI surveillance of Lovestone: his phone began to be tapped, and, in January 1951, J. Edgar Hoover urged that "a very thorough and searching investigation of Lovestone should be made." Ted Morgan, A Covert Life: Jay Lovestone, Communist, AntiCommunist, and Spymaster, 226, 230.

4. For the origin of the secret arrangement that allowed the CIA to access counterpart funds as agreed between Averell Harriman, Frank Wisner, and Richard Bissell of the ECA, see Tim Weiner, Legacy of Ashes: The History of the CIA, 40.

5. Lovestone was still apt to refer to the CIO as the "American section" of the (longdisbanded) Red International of Labour Unions.

6. "Memorandum," 24 November 1950, Lovestone papers (Hoover), box 528, file: Carmel Offie.

7. In a telephone conversation with former OSS chief General Donovan that was bugged by the FBI, Lovestone said that if the CIA remained obdurate, he would enlist the support of Senator Pat McCarran, chairman of the Senate Internal Security Committee. An undated letter from Senator McCarran to Bedell Smith indicates that Lovestone did contact him for help. It referred to the deteriorating relationship between the FTUC and CIA, identified the "great harm to security" and the "irreparable damage to labour" at home and abroad caused by the CIO having access to counterpart funds, and spoke of "many complaints, some of them very bitter ... reaching my office" over the failures of the CIA's work with Eastern European refugee trade unionists. The FBI sent a memo to Bedell Smith describing Lovestone as "a proficient con-man capable of intrigue and assuming any role ... the type of operative relied upon by Russia to assume an inactive 
and anti-Communist role for a number of years.... This informant's opinion [is] that Lovestone is still a Communist and a very dangerous individual." Morgan, A Covert Life, 230; Lovestone memo to Bedell Smith ("My dear General,"), n.d., Lovestone papers (Hoover), box 381, file: Monk, 1951.

8. Brown to Lovestone, 30 November 1950, Lovestone to Brown, 1 December, 4 December, and 26 December 1950, IAD Lovestone files, box 11, file 12.

9. Woll to C. D. Jackson, 31 October 1951, Lovestone papers (Hoover), box 355, file: Irving Brown, 1949-53; Lovestone to Meany, 21 December 1951, Meany files, 1947-60, box 56, file 1.

10. Lovestone to Brown, 27 December 1950, IAD Lovestone files, box 11, file 12; Brown to Lovestone, 9 December 1950, 9 January, and 22 January 1951, and Lovestone to Brown, 26 March 1951, Lovestone papers (Hoover), box 283, file: Irving Brown, 1951; Brown to Lovestone, 22 December 1950, IAD Lovestone files, box 11, file 12.

11. David Dubinsky and A. H. Raskin, David Dubinsky: A Life with Labor, 261. Written twenty-five years after the event, Dubinsky's account of the meeting with Bedell Smith was self-serving and intended to suggest that the AFL link with the CIA was just a brief, passing affair. It was no such thing. He, personally, would have brought it to an end, but he couldn't get Meany to agree.

12. Lovestone to Berger, 18 May 1951, Lovestone papers (Hoover), box 283, file: Sam Berger. S. D. (Sam) Berger (1911-80), with his long-standing links with Harriman, was a highly significant figure in postwar international labour relations. From 1942, he worked with Harriman in London on lend-lease. Having established contacts with senior figures in the British labour movement, he was appointed labour attaché in London in 1945 and was reunited with Harriman when the latter returned as ambassador to Britain in 1946. He was given a clear remit to help break up the WFTU and in this capacity collaborated closely with Irving Brown. It was through Berger and Harriman that Brown obtained his introduction to Secretary of State Byrnes in 1946. In London, Berger arranged discreet meetings for the ambassador with British labour figures at his apartment, and for this he was attacked at the British Communist Party congress in 1948. In 1947, partly at the suggestion of Ernest Bevin, he was sent to Greece as US labour attaché for six months and again worked with Brown in helping to reconstitute the GSEE free from communism. He rejoined Harriman at the Truman White House in 1950, where the latter's position was special advisor responsible for interfacing between the departments of State and Defence.

From the White House, Berger acted as the liaison man between the CIA and FTUC from 1950 to 1953, featuring in Lovestone's correspondence under the name "the Prophet." In that position, he also played a key role in drafting the anti-communist strategy for use in Japan, which was adopted by Eisenhower's Psychological Strategy Board as resolution NSC 125/6 in June 1953. That same year he was appointed labour attaché to Japan, but he soon fell from grace when Vice President Nixon, on a visit to Japan, believed that he had been "set up" after he found himself dealing with a "communist" trade union official at a meeting that Berger had arranged. Berger was recalled after only fourteen months and was subject to internal investigation until 1956 over his labour contacts. (This coincided with a period during which Lovestone himself was also under congressional and FBI 
investigation as a suspected closet communist.) Berger was so concerned at the threat to his career that he destroyed his papers: thus, despite his importance, there exists no "Berger collection." Eventually, with his name cleared, Berger was appointed ambassador to South Korea, 1961-64. His hopes of serving as deputy chief of mission in London following the election of Harold Wilson's Labour government in 1964 were disappointed, though he did become deputy ambassador to Ellsworth Bunker in South Vietnam from 1968 to 1972. Graenum Berger, A Not So Silent Envoy: A Biography of Ambassador Samuel David Berger, 72, 88-89, 92-94.

13. With an Ivy League background, Tom Braden (1917-2009) had worked for the OSS during the war. Back in civilian life, he maintained his intelligence contacts while serving as executive secretary of the Museum of Modern Art, where he became an advocate of the view that official support for abstract expressionism would serve America well in waging the cultural side of the Cold War. In 1949, he joined the American Committee for a United Europe, a CIA front, before moving to become assistant to CIA Deputy Director Allen Dulles in 1950 and later director of the agency's International Organizations Division. Donovan to Lovestone, 29 July 1949, IAD Lovestone files, box 33, file 2; Frances Stonor Saunders, Who Paid the Piper: The CIA and the Cultural Cold War, 259.

14. In the course of the struggle in the auto industry between the AFL and CIO in 1937, Lovestone had famously met Walter Reuther at the Woodward Hotel in Detroit and attempted to make a deal under which he offered to shift his loyalty from Homer Martin and to back Reuther for the union presidency if the latter would break with the communists. Offered a twenty-point program of peace terms, Reuther replied that he could accept 95 percent of it but would not openly fight the communists. He didn't support them, but he wouldn't fight them. It wasn't acceptable to Lovestone, and they parted company with the seeds of lasting bitterness sown. Anthony Carew, Walter Reuther, 25-26.

15. European Recovery Programme: Report of the Second International Trade Union Conference (London, 29-30 July 1948), 26-28; "Interview with Jay Lovestone," 30 May 1968, Cormier and Eaton papers, box 2, file 26.

16. Lovestone to Brown, 21 December 1951, Meany files, 1947-6o, box 56, file 1, in which Lovestone reports of Mike Ross telling him that he was critical of "big shots" like Victor and was glad that he was not a big shot himself. The fact that Victor Reuther owed his position to his brother was at times a source of resentment among union colleagues. Because of his sizable ego, many people found him arrogant and self-regarding. Yet his personal record of service in the early years of the union gave him standing on his own merits, and though he was always Walter's loyal assistant, he remained his own man.

17. On the debate over the treatment of European workers under the Marshall Plan, see Anthony Carew, Labour Under the Marshall Plan: The Politics of Productivity and the Marketing of Management Science, chaps. 6, 8, and 9.

18. Milton Katz and CIO international affairs committee chairman, Jake Potofsky, had been in discussion about appointing Reuther, with Katz keen to know what would be the AFL's reaction. Potofsky told him there would be no problem—on that he had David Dubinsky's 
assurance. As well as being less comfortable with the CIA link than his FTUC colleagues, Dubinsky was also more open to cooperation with the CIO abroad. With his personal preeminence as American labour representative on the continent apparently under threat as a consequence of Reuther's presence, Brown's relations with Katz were soured for several months until the latter denied ever making Reuther a job offer. Brown to Lovestone, 3 March 1951, IAD Brown files, box 29, file 11.

19. Jack Carney, "Further Report from England," 27 August 1951, Lovestone papers (Hoover), box 285, file: Jack Carney, 1951.

20. Charles Levinson (1920-97) was a Canadian who had worked briefly on the staff of the Canadian Department of Labour before undertaking postgraduate studies in the late 1940s, during which time he assisted Val Lorwin on his important study of French trade unionism. In 1950, he went to work in the special media section of the ECA's Labor Information Division in Paris, from where Victor Reuther hired him as assistant in the CIO's Paris office. Some suspected that he had a communist past in Canada, although the Canadian Congress of Labour's secretary-treasurer, Pat Conroy, had vetted him before he was proposed for the position on Reuther's staff. However, Levinson's politics would return as an issue when the CIO office in Paris later encountered general criticism not only from the AFL but also from anti-Reuther sections of the CIO. Levinson transferred to the staff of the IMF in 1954, when the CIO closed its Paris office. In the early 1960s, he was disappointed at Reuther's failure to support him for promotion as assistant general secretary within the IMF, and, in 1964, Levinson quit his job to become general secretary of the International Factory Workers' Federation, a moribund organization that he converted into the dynamic International Chemical Workers' Federation. At the head of this organization until 1983, Levinson adopted the UAW approach to relations with multinational companies, which involved the creation of "world coordinating councils," and became the leading publicist for the notion of transnational collective bargaining in the 1970 .

21. "Report of CIO Committee to Europe to CIO Committee on International Affairs," March 1951, IAD Ross files, box 7, file 20.

22. Lovestone to Brown, 4 April 1951, Lovestone papers (Hoover), box 283, file: Irving Brown, 1951; Lovestone to Meany, 27 June 1951, Meany files, 1947-60, box 56, file 1. Name-calling apart, Lovestone was sure that the CIO represented "a deadly menace" and that Victor Reuther, as representative of the "pseudo lefts," was the most "demagogic" and "dangerous" of the lot. Brown, too, would sometimes dismiss Reuther as an ingenue, though the seriousness with which he viewed the latter's presence in Paris was better reflected in the transfer of his own office back from Brussels to Paris, so as to be on hand to counter the CIO's initiatives.

23. Untitled document by Irving Brown, 9 January 1952, IAD Brown files, box 10, file 10. Brown even suggested the membership of his proposed SPD-DGB committee-it was to consist of Schumacher's close SPD allies, Fritz Heine and Alfred Nau, DGB international specialist Ludwig Rosenberg, and Kuno Brandel, editor of IG Metall's journal and a former member of the Communist Party (Opposition) and staunch ally of Lovestone. 
24. Brown to Lovestone, 13 May 1952, and Lovestone to Brown, 16 May 1952, IAD Lovestone files, box 11, file 15; Lovestone to Brown, 2 March 1953, IAD Brown files, box 29, file 13.

25. Untitled document by Irving Brown, 9 January 1952, IAD Brown files, box 10, file 10; Lovestone to Brown, 23 April 1952, IAD Lovestone files, box 11, file 15. As part of this exercise, Irving Brown was passing 250,00o lire (\$400) a month to Ignazio Silone to fund a letter-writing program to communist party members. Brown to Silone, 18 April 1952, IAD Brown files, box 13 , file 13 .

26. Brown to Lovestone, 2 August 1952, IAD Lovestone files, box 11, file 14. Dockers' leader Paolo Giornelli proposed a small monthly budget of $\$ 500$ to $\$ 750$ for activities in Trieste. Giornelli to Dale, 1 January 1953, IAD Brown files, box 13, file 2.

27 . By the early 196os, the CFTC left would come to dominate the confederation and end its confessional link with the Church.

28. Lovestone to Brown, 13 March 1951 and 24 May 1951, Lovestone papers (Hoover), box 283, file: Irving Brown, 1951. Lovestone was present at the meeting between Dubinsky and Reuther and objected to the approach being discussed.

29. "Irving Brown Report," 25 April 1951, Meany files, 1947-60, box 57, file 21. Commenting on Reuther's bid for parity of treatment with Brown in the dispensing of government funds, Lovestone wrote Sam Berger: "Victor Reuther might be a very nice guy .... But to put [him] and Irving Brown on a par in carrying on the frontal struggle against totalitarian Communism and its machinations ... is enough, as Stalin said, to make a horse laugh.” Lovestone to Berger, 18 May 1951, Lovestone papers (Hoover), box 283, file: Sam Berger.

30. Lovestone to Brown, 30 April 1951, Lovestone papers (Hoover), box 283, file: Irving Brown, 1951. Arthur Goldberg, the wartime head of the OSS's Labor Division, was now legal counsel to the CIO. He would later serve as secretary of labour and UN ambassador during the Kennedy and Johnson presidencies before being appointed to the US Supreme Court.

31. A quiet, thoughtful figure, H. S. (Mike) Ross (1898-63) was the CIO's first director of international affairs, a post he had held since 1945. Born in England, he served in the British army in World War I and was gassed on the Western Front, leaving him with a chronic chest complaint that remained with him for the rest of his life. He joined the British Communist Party in the late 1920s and worked in Moscow in 1931-32 as an editor in the Foreign Section of the State Publishing House. Having abandoned his communism, he emigrated to the United States in 1933 and became a naturalized citizen in 1941. Prior to joining the CIO, he had been employed in the Public Works Administration and then as a researcher for the La Follette Committee before becoming research director for the Marine and Shipbuilding Workers in 1942. In the merged AFL-CIO he became director of international affairs in 1957, with Lovestone as his assistant, and held the post until his death.

32. Jacob (Jake) Potofsky (1894-1979) succeeded Sidney Hillman as president of the Amalgamated Clothing Workers in 1946 and had been chairman of the CIO's international affairs committee since 1950. He was one of the most senior figures in the CIO and also a close ally of Walter Reuther. Following the CIO merger with the AFL in 1955, he was 
elected joint chairman of its international affairs committee but resigned in 1957, finding it impossible to work in harness with his co-chairman, George Meany.

33. Braden to Ross, 21 June 1951. I am grateful to Frances Stonor Saunders for this reference.

34. Lovestone to Meany, 21 July 1951, Meany files, 1947-60, box 56, file 1. That it was Mike Ross rather than Reuther who was dealing with Braden is of interest. Like Dubinsky, in later years Victor Reuther would seek to minimize his contacts with the CIA, claiming that his attempts to secure government financial backing for labour projects overseas was restricted to the ECA, a different matter from dealing with the CIA. He also maintained that if the CIO had been cooperating with the CIA, it was through Mike Ross, and he and Ross never saw eye to eye. When Lovestone dined with Ross in New York in 1951 after attending a meeting of the Council for Foreign Relations, he reported the latter as saying he was critical of "big shots like Victor and he was glad he was not a big shot himself." Lovestone to Brown, 21 December 1951, Meany files, 1947-60, box 56, file 1. Lovestone was later heartened to learn that the agency had not been overly impressed by the BellancaSalla mission. Apart from useful work among the dockers of Genoa, they had also made contact with a person purporting to represent socialist leader Pietro Nenni. He told them that the PSI leadership was unhappy in its alliance with the communist party and was looking for some financial inducement to make a break. Bellanca to Potofsky, 2 July 1951, and Potofsky to Dulles, 10 July 1951, IAD Ross files, box 10, file 10. Hearing the intelligence, and suspecting that the CIA was being taken for a ride, Allen Dulles chose to disregard the request for money. Lovestone gloated at the outcome, telling Brown that "Mr. Fizzlander is now keenly disappointed over his ever having come into partnership with Victor and company" and predicting that "the Victor Boys will find themselves out on a limb." Lovestone to Brown, 7 November and 29 November 1951, Lovestone papers (Hoover), box 283, file: Irving Brown, 1951.

35. Olavi Lindblom, Pitkalla Palkilla, 182. I am indebted to Kari Tapiola for this reference and for help with background information on these events.

36. Lovestone to Brown, 9 November and 21 November 1951, Lovestone papers (Hoover), box 283, file: Irving Brown, 1951.

37. Lindblom to Victor Reuther, 10 January 1952, Lovestone papers (Hoover), box 305, file: Finland. It is of interest that a copy of this letter from Lindblom to Reuther, with its highly sensitive contents, found its way into Lovestone's files.

38. Lovestone to Meany, 17 June 1951, Meany files, 1947-6o, box 56, file 1; Brown to Lovestone, 1 November 1951, Lovestone papers (Hoover), box 283, file: Irving Brown, 1951; Reuther to Ambassador Dunn, 13 December 1951, IAD Ross files, box 16, file 1.

39. Reuther to Becu, 4 December 1951, Lovestone papers (Hoover), box 355, file: Irving Brown, 1949-53.

40. Brown to Lovestone, 25 February 1951, Lovestone papers (Hoover), box 283, file: Irving Brown, 1951.

41. Minutes of CIO International Affairs Committee meeting, 1 November 1951, IAD Ross files, box 7 , file 20 . 
42. Lovestone to Brown, 21 December 1951, Lovestone papers (Hoover), box 283, file: Irving Brown, 1951.

43. Lovestone to Brown, 19 January 1952, IAD Lovestone files, box 11, file 16; Lovestone to Brown, 21 January 1953, Meany files, 1947-60, box 56, file 16.

44. At the end of 1951, the ICFTU's total income for what was termed "solidarity activity" amounted to only $\$ 190,000-$ far less than the combined sums then being discussed in TUC and CIO circles. And, for the whole of 1952, only a further $\$ 276,000$ was contributed to the RAF by all ICFTU affiliates combined.

45. Lovestone to Brown, 21 January 1953, Meany files, 1947-6o, box 56, file 16. It would take three more years before Meany finally agreed that it was time for Lane to be removed. This followed his obstructive role in 1954 in blocking a proposal by Irving Brown for an anti-communist training school based at the FIAT plant in Turin. Even then, it required the combined efforts of Allen Dulles, Tom Braden, Assistant Secretary of State Robert Murphy, and FOA administrator Harold Stassen to convince Meany that the time was right. Not least of the arguments against keeping Lane on was the scope for anti-American propaganda that he afforded the Italian communists. As Irving Brown observed to Meany: "The latter can gleefully point out that there are no Russian government officials walking around the premises of the CGIL while there is an American official as large as life not only walking around the CISL premises but acting as though he were the landlord." Offie to Brown, 30 August, 10 December 1954, and 14 January 1955, IAD Brown files, box 32, file 2; Brown to Meany, 18 December 1954, Meany files, 1947-60, box 57, file 23.

46. Lovestone to Brown, 19 January 1952, IAD Lovestone files, box 11, file 16. It was of interest that Time magazine carried a profile of Brown to coincide with his March 1952 visit to Washington. It lionized him as "one of the Americans that [European] Communists know best-and hate most." It also drew an unflattering comparison between Brown and Victor Reuther, quoting the latter's observation that "Europeans are tired of little men who run around with little black bags." Editorially on Brown's side, Time noted that "with far greater experience, Brown finds Reuther naïve" and recorded with approval that the previous week he had been in Washington "filling his little black bag with plans for a lot more anti-Communist deviltry." It was a teasing reference to the literal truth-that Brown had been there on CIA business. Only a handful of people would have known the purpose of the visit, but they certainly included C. D. Jackson, on leave from his post as managing director of Time-Life International, currently president of the CIA's National Committee for Free Europe, and soon to become President Eisenhower's personal advisor on psychological warfare and the White House's liaison between the CIA and the Pentagon. “The Most Dangerous Man," Time, 17 March 1952.

47. Lovestone to Berger, 18 March 1952, IAD Lovestone files, box 10, file 11.

48. Lovestone to Brown, 23 January 1952, IAD Lovestone files, box 11, file 16.

49. "Memorandum on the Need for Strengthening Free Trade Unionism in France," 17 December 1951, IAD Brown files, box 22, file 18; "Report on Propaganda in France and Italy," ICFTU Emergency Committee, 17-19 March 1952, ICFTU Archives, folder 15a. 
50. For a discussion of the pilot plant program in France and Italy, see Carew, Labour Under the Marshall Plan, chap. 10.

51. Brown to Lovestone, 19 January 1952, IAD Lovestone files, box 11, file 16; Brown to Lovestone, 3 April 1952, IAD Lovestone files, box 11, file 15.

52. Brown to Lovestone, 19 January 1952, Brown to Hayes, 22 January 1952, and Lovestone to Brown, 23 January 1952, IAD Lovestone files, box 11, file 16; Lovestone to Brown, 7 April 1952, IAD Lovestone files, box 11, file 15; Brown to Lovestone, 12 April 1952, IAD Brown files, box 23, file 4; Lovestone to Brown, 8 May 1952, IAD Lovestone files, box 11, file 15; Brown to Lovestone, 13 May 1952, IAD Lovestone files, box 11, file 15. Indeed, there were signs that steelworkers' union officials were attempting to make life difficult for Reuther, reviving rumours that Charles Levinson had a communist past. The steelworkers' vice president, Alan Haywood, and the union's Canadian director, Charles Millard, were again questioning his political reliability. Victor reacted impatiently, sick of all the "unnecessary vetting" and the expectation that people be pure. Millard to Haywood, 13 December 1952, and Reuther to Ross, 14 December 1952, IAD Ross files, box 16, file 1.

53. Leon Dale to Volonté, 18 November 1952, and Brown to Volonté, 18 December 1952, IAD Brown files, box 12, file 21. Why, given the generous American financial support to CISL, Pastore could not fund Volonté himself was a mystery to Lovestone. On financial support for the social democrats within CISL, which took the form of assistance to Alberto Simonini's paper Giustizia, see Dale to Lovestone, 29 April 1952, Lovestone papers (Hoover), box 362, file: Leon Dale, 1952; Brown to Lovestone, 13 May 1952, and Lovestone to Brown, 16 May 1952, IAD Lovestone files, box 11, file 15; G. Mariotti to Brown, 25 November 1952, IAD Brown files, box 26, file 10.

54. Le Figaro, 23 September 1952; Levinson to Reuther, 6 November 1952, CIO Washington Office records, box 64, file 18 .

55. Point 8 of an untitled, undated document of 1951 drafted by Offie as a working paper for Dubinsky prior to the April 1951 meeting with Bedell Smith, Lovestone papers (Hoover), box 381, file: Monk, 1951; Brown to Lovestone, 2 December 1951, Lovestone papers (Hoover), box 355, file: Irving Brown, 1949-53; Irving Brown, "Report on Meeting of the Interim Committee for the Regional Activities Fund," 29 October 1951, IAD Brown files, box 11, file 16 .

56. "Suggestions for Work to Be Done in the Lyon Cultural Area," AFL International Affairs Committee, 12 March 1952, Thorne files, box 17, file: International Labour Relations Committee. Tronchet, a former anarcho-syndicalist but by now a fierce anti-Stalinist member of the Swiss Socialist Party, had recently visited the United States by invitation of the US embassy. He remained a close ally of Brown for the next thirty years, and the school he ran in Geneva would become the location for Brown's annual "exchange of views" with trade union delegations, mostly from Africa and Asia, attending the annual ILO Conference. Luc Van Dongen, "Brother Tronchet: A Swiss Trade Union Leader Within the U.S. Sphere of Influence," in Luc Van Dongen, Stéphanie Roulin, and Giles Scott-Smith, eds., Transnational Anti-Communism and the Cold War: Agents, Activities and Networks, 50-63. 
57. Golden to Sender, 4 January 1952, IAD Brown files, box 23, file 4; Lovestone to Brown, 6 December 1951, Lovestone papers (Hoover), box 283, file: Irving Brown, 1951; Irving Brown, "Report on the Meeting of the Interim Committee for the Regional Activities Fund," 29 October 1951, IAD Brown files, box 11, file 16; Woll to Florence Thorne, 7 April 1952, Thorne files, box 8, file: Ford Foundation; Thorne to Woll, 15 April 1952, Thorne files, box 17, file: International Labour Relations Committee.

58. Lovestone to Brown, 19 January 1952, IAD Lovestone files, box 11, file 16.

59. Assistant Director of Supply (MSA) to Golden, 27 May 1952, Casserini to Reuther, 5 May 1952, Guaranty Trust Co. to Golden, 27 May 1952, and Oldenbroek to Reuther, 12 June 1952, Clinton S. Golden papers, box 5, file 12, Special Collections Library, Penn State University, State College, PA; Oldenbroek to Brown, 5 August 1952, IAD Brown files, box 32, file 4.

6o. Brown to Lovestone, 12 August 1952, IAD Lovestone files, box 11, file 14. The MSA also gave technical support for the courses by handling photographic, film, radio, and press relations at La Brevière.

61. Tom Braden, “I’m Glad the CIA Is Immoral," Saturday Evening Post, 20 May 1967. Braden's account of the CIA funding and the explanations that Walter and Victor Reuther were forced to make in consequence do not tally, and all lack dates and precise details. Braden claimed that he gave the money in 1952 in response to a request from Victor Reuther. Having seen a leaked copy of Braden's article before publication, Victor Reuther prepared a draft statement, which made no mention of the $\$ 50,000$. He stated that he had been introduced to Braden by Ross in 1951, shortly after being appointed CIO representative to Europe, and had the impression Braden was with the State Department or a Marshall Plan agency. They discussed the CIO program for Europe, but Reuther denied making a request for funds then or subsequently. His statement went on to describe being contacted in Paris in the late summer of 1952 by Charles Thayer, who was with the CIA under the cover of "political officer" at the US embassy, and asked him to call in for a talk with Braden. On this occasion, Braden surprised Reuther by telling him that he was responsible for supplying some of the CIO's operating budget and that he had been funding the AFL for years and would like to establish a similar arrangement with the CIO if Reuther would agree to serve as a CIA agent. In his statement, Reuther claims to have rejected the proposal and to have reported the approach to CIO President Phil Murray. Victor Reuther to Joseph Walsh, 4 May 1967, Victor Reuther papers, box 17 file 30.

Separately, Walter Reuther issued a press statement admitting that the UAW "did reluctantly agree on one occasion to ... transmit government funds" for use in Europe to supplement the inadequate funds of the American trade unions and that his action had been approved by President Phil Murray. In his autobiography nine years later, Victor Reuther stated that in "carrying out the request to transmit financial assistance," he acted with "unjustified innocence" as to the source, repeating his belief at the time that Braden was with the State Department or MSA and that funds from such sources were acceptable as they had been publicly voted and were being used for purposes intended by Congress. Victor Reuther, The Brothers Reuther, 424-26. He also told Walter Reuther's biographer that the $\$ 50,000$ was not handed to his brother personally and that it was only later that 
Walter realized the funds were from the CIA. Victor Reuther to William Eaton, 15 June 1970, Victor Reuther papers, box 70, file 28.

From all this it seems clear that, in June 1952, Jay Lovestone was justified in claiming that Victor Reuther had access to substantial funds from non-union sources, though whether it was as much as $\$ 20,000$ per month, as he alleged, is unclear. Lovestone to Berger, 9 June 1952, IAD Lovestone files, box 10, file 11. In the one previous documented link between the CIO and the CIA, relating to Frank Bellanca's exploratory mission to Genoa in 1951, the contacts were between Ross and Braden. On that occasion, Victor Reuther was mentioned only in passing in a Braden letter to Ross suggesting that he be alerted to the need for secrecy. It was always Victor Reuther's contention that the CIA's real contact with the CIO was Michael Ross. Author interview with Victor Reuther, 27 August 1986. I have found no other hard evidence of the Reuthers dealing directly with the CIA, although in 1966, when the IMF was hoping to encourage non-communists to split away from the Italian CGIL, Victor Reuther talked to John Riley, a staffer in Vice President Hubert Humphrey's office responsible for liaison with the CIA, and was advised that the best way to canvass support from that quarter would be for Walter Reuther to have a prior meeting with President Johnson. Whether the advice was followed is not known. See the discussion in chapter 7 , in the section headed "Reuther and the Italian Centre-Left."

62. Bill Kemsley to author, 9 August 1986. Unravelling the threads of these sub rosa payments and their provenance-Marshall Plan counterpart, Ford Foundation, CIA—can only be a matter of educated guesswork from this distance, but the source of funds for all three was often the same.

63. Brown to Lovestone, 13 October 1952, Lovestone papers (Hoover), box 316, file: ICFTU; Benoit Frachon, “Corrupteurs sans visa," L'Humanité, 6 November 1952; Brown to Meany, 10 January 1953, Meany files, 1947-60, box 57, file 22; Samuel H. Barnes, “The Politics of French Christian Labour”; Brown to A. Hayes, 24 May 1953, Meany files, 1947-6o, box 57, file 22; minutes of CIO International Affairs Committee meeting, 18 March 1953, IAD Ross files, box 7 , file 22 .

64. Victor Reuther to Walter Reuther, 22 January 1953, Victor Reuther papers, box 9, file 21.

65. Faupl called for the negotiations over the contract to be conducted publicly, but as Kemsley pointed out in private correspondence: "This we could not afford so a deal was made that he would keep his mouth shut on the thing and the IMF people would hold off any action until Vic and Walt [Reuther] got back to the States. They would then talk to Hayes [IAM President] and, if they can convince Hayes, Faupl will go along." Kemsley to Bill Friedland, 15 February, 30 April, 8 June, 30 June, and 25 July 1953, Kemsley papers, box 2, files 7-8.

Bill Kemsley (1908-90) joined the UAW in Detroit in 1937, became a member of the Reuther faction, and was close to Walter and Victor. He served briefly in Germany on the staff of the US Office of Military Government's Manpower Division in 1945. After the war, he was the CIO's director of education for Michigan before being again recruited into government service on the staff of the labour education department of the Mutual Security Agency (later the Foreign Operations Administration) in Paris in 1952. The 
ICFTU appointed him its representative to the United Nations in New York in 1954, a post he held until 1961, when he resigned following the ouster of Oldenbroek and severed his employment with the labour movement.

66. Victor Reuther to Ross, 7 May 1954, CIO Washington Office records, box 74, file 22; minutes of CIO International Affairs Committee meeting, 18 March 1953, IAD Ross files, box 7 , file 22 .

67. Back in 1948, AFL president Bill Green had identified Reuther as the CIO leader most likely to promote unity. Frank Cormier and William J. Eaton, Reuther, 315. CIO president Philip Murray seems not to have regarded Meany in a similar light, reputedly describing him as "some kind of loud-mouth bum from New York. ... I don't want to have anything to do with him." Robert H. Zieger, The CIO, 1935-1955, 472.

68. "Meany Would Quit to Aid Labour Unity," New York Times, 8 December 1952; Goulden, Meany, 184-85.

69. Irving Brown recognized that many Europeans hoped that the CIO would come to dominate a merged American federation and thus take the lead in international affairs, with Lovestone ousted from the scene. "Report from Irving Brown," 3 November 1954, Meany files, 1947-60, box 57, file 23. At other times, Brown's impression was that Jaap Oldenbroek was fearful that the loss of the $\mathrm{CIO}$ as an independent voice would rob him of vital American support on which, together with British and German backing, he had counted to secure a majority against AFL disruption. Brown to Lovestone, 2 December 1954, Lovestone papers (Hoover), box 698, file: Irving Brown. There was a similar perception in Britain, where some feared that the TUC might lose influence as the numerical weight of the Americans increased, with the $\mathrm{CIO}$ voice muted. "Strengthening U.S. Labour's Voice," Times (London), 11 February 1955.

70. Walter Reuther to Oldenbroek, 18 September 1953, CIO Secretary-Treasurer records, box 123, file: ICFTU General Correspondence.

71. Minutes of CIO International Affairs Committee meeting, 7 January 1954, CIO Washington Office records, box 56, file 11; Victor Reuther to Ross, 1 December 1953, CIO Washington Office records, box 74, file 21. At the time, Hans Gottfurcht was the sole assistant general secretary.

72. Remarks by Carey to CIO Executive Board, Cleveland, 12 November 1953, CIO SecretaryTreasurer records, box 124, file: ICFTU Miscellaneous; Carey to Oldenbroek, 29 October 1953, CIO Secretary-Treasurer records, box 123, file: ICFTU General Correspondence. James Carey (1911-73) started work in a Philadelphia radio manufacturing plant in 1929 where, aged twenty-two, he helped establish a small union of radio workers. In 1934, he was engaged as a general organizer for the AFL and, in 1936, took his union into the new United Electrical Workers, becoming its first president. With the split in the AFL, Carey became secretary-treasurer of the CIO in 1938, a position he held until 1955. Influenced by Catholic social teaching, he opposed the communists within the UE and, as a consequence, was defeated as president in 1941. When the UE was expelled from the CIO in 1949, he helped launch the International Union of Electrical Workers in opposition. From the earliest postwar days, he played a prominent role in international 
affairs, helping to launch the WFTU, dealing with the Soviet trade unions at close quarters on three missions to the USSR, and then leading the campaign to disaffiliate from the WFTU in 1949 and form the ICFTU. He was a close colleague of Walter Reuther but had a particularly strained relationship with George Meany.

73. Minutes of FTUC meeting, 14 October 1953, IAD Lovestone files, box 35, file 24.

74. Lovestone to Brown, 14 April and 30 April 1953, IAD Lovestone files, box 11, file 18; Lovestone to Woll, 12 May 1953, IAD Lovestone files, box 65, file 5; Lovestone to Kirsch, 28 May 1953, IAD Brown files, box 29, file 13. Dubinsky reduced financial and other material support, billing the committee retrospectively for expenditure on postage and telegrams over the previous two years while removing from the union's books Lovestone's secretary, Ann (Larkin) Stolte, whose salary it had covered. Dubinsky's subsidy to the FTUC was worth $\$ 15,000$ a year, and the sum now reclaimed for postage alone amounted to $\$ 6,000$. Lovestone was up in arms, complaining about being treated as "everyone's janitor," railing at Dubinsky's "deflationary practices," and telling Irving Brown that "if the present trends continue, you can look for a marked shrinkage of AFL activities" and that "I will be compelled to recommend curtailment of our publications as well as representation." But Dubinsky persisted, and Lovestone warned that "if things keep up the way they are going, I doubt whether I will continue with the work after the AFL convention." The treasury was low, and Lovestone began to economize by axing Henry Kirsch from his recently created post as representative in Turkey.

75. Lovestone to Brown, 5 November and 6 November 1953, IAD Brown files, box 29, file 16; Brown to Lovestone, 26 November 1953, IAD Lovestone files, box 11, file 19; Lovestone to Brown, 30 November 1953, IAD Brown files, box 29, file 16.

76. Minutes of CIO International Affairs Committee meeting, 7 January 1954, CIO Washington Office records, box 56, file 11.

77. Lovestone to Brown, 27 October 1953, IAD Brown files, box 29, file 16.

78. Brown to Meany, 4 November 1953, Meany files, 1947-60, box 57, file 22; Lovestone to J. Godson, 19 October 1953, IAD Brown files, box 29, file 16.

79. Omer Becu (1902-82) occupies a central place in our history from this point on. As a Belgian merchant seaman, he had gone into exile in 1940 and spent much of the war in New York representing the ITF, during which time he formed strong relations with the AFL. In 1944, he undertook a mission for the OSS behind enemy lines in North Africa and Italy in support of anti-fascist trade unionists. He succeeded Oldenbroek as ITF general secretary in 1950 and, while holding this post, also became the ICFTU's third president at its 1953 congress. Becu was very much the AFL's candidate for the post; the federation was the architect of a necessary constitutional change agreed on by the congress specifically to allow Becu to run for the presidency since he wasn't a member of the executive board. Subsequently, he became the AFL-CIO's favourite to succeed Oldenbroek as ICFTU general secretary and eventually acceded to this position in 1960, holding it until his resignation in 1967 . 
80. Minutes of AFL International Affairs Committee meeting, 14 November 1953, IAD Brown files, box 29, file 16; Brown to Lovestone, 26 November 1953, IAD Lovestone files, box 11, file 19.

81. Minutes of CIO International Affairs Committee meeting, 7 January 1954, CIO Washington Office records, box 56, file 11.

82. Archie Robinson, George Meany and His Times, 169.

83. "Union Policy on Communism," Times (London), 2 July 1953.

84. "Trade Unionist Stresses Conflicting Views," Times (London), 6 July 1953.

85. AFL News-Reporter, 17 July 1953, 3.

86. “The Great Debate: Anglo-American Relations" (parts 1 and 2), Free Trade Union News, December 1954-January 1955.

87. “Report from Irving Brown," 23 May 1953, Meany files, 1947-60, box 56, file 2. A senior figure in Force ouvrière, André Lafond was a railway trade unionist who became the FO national secretary in charge of international affairs. He was extremely close to Brown, though they differed over the question of the European Defence Community and later more seriously over Lafond's support for French government policy in Algeria and his backing for de Gaulle in 1957.

88. Untitled document (“The major fortress of Communism in Italy ... ”), June 1954, IAD Brown files, box 12, file 20; J. E. Jacobs, "Memorandum of Conversation: FIAT's Efforts to Combat Communist Labour Domination," 28 July 1954, and "Memorandum: Gist of a Proposed Letter from FIAT to the Ambassador Concerning FIAT's Efforts to Combat Communist Domination of Its Labour Force," 24 August 1954; draft letter, Professor Valletta to Ambassador Luce, 6 September 1954, cited in Maria Eleonora Guasconi, L'Altra faccia della medaglia: Guerra psicologica e diplomazia sindacale nelle relazioni Italia-Stati Uniti durante la prima fase della guerra fredda (1947-55), 131.

89. Lovestone to Rutz, 16 March 1954, Meany files, 1947-6o, box 56, file 18.

90. Walter Freitag and Albin Karl to Victor Reuther, 22 October 1953, CIO Washington Office records, box 74, file 20; Reuther to Freitag and Karl, 11 November 1953, CIO Washington Office records, box 69, file 16 .

91. Lovestone to Woll, 20 April 1953, IAD Lovestone files, box 65, file 5; Lovestone to Brown, 3 August 1953, IAD Brown files, box 29, file 13; "Meany Hits Attacks on German Labour," Free Trade Union News, November 1953.

92. Lovestone to F. Heine, 19 November 1953, Meany files, 1940-80, box 59, file 26.

93. Brown to Lovestone, 24 March 1954, IAD Lovestone files, box 12, file 2.

94. "AFL in Arms Plea to German Unions," New York Times, 8 February 1955.

95. Lovestone to "Dear Friend" [Dubinsky], 7 March 1955, and Lovestone to Meany, 13 March 1955, Lovestone papers (Hoover), box 705, file: George Meany.

96. Brown to Lovestone, 29 December 1953, Lovestone papers (Hoover), box 355, file: Irving Brown, 1949-53. Laconic, unassertive, and without personal ambition, Ross lacked the drive and energy of either Victor Reuther or Irving Brown. But for people who recoiled from the Reuther-Brown rivalry, he was a safe pair of hands. John Boughton, "From Comintern to the Council on Foreign Relations: The Ideological Journey of Michael Ross." 
97. Brown to Lovestone, 26 November 1953, IAD Lovestone files, box 11, file 19; Brown to Lovestone, 29 December 1953, Lovestone papers (Hoover), box 355, file: Irving Brown, 1949-53; Lovestone to Brown, 30 November 1953, IAD Brown files, box 29, file 16; "Report from Irving Brown,” 3 November 1954, Meany files, 1947-60, box 57, file 23. George (Phil) Delaney (1909-72) was appointed AFL international representative in 1948 and served as US worker delegate at the ILO. Uncomfortable with the tensions in the international affairs department of the AFL-CIO, he became the Department of Labor's special assistant for international labour affairs in 1959 and, in 1964, transferred within the federal government to become director of the Office of Labor Affairs in AID, where he remained until 1970.

98. Brown to Lovestone, 5 April 1954, IAD Lovestone files, box 12, file 1.

99. Irving Brown, “Report on ICFTU Executive Board," May 1954, IAD Lovestone files, box 12, file 1.

100. Kemsley to Gottfurcht, 4 May 1953, Kemsley papers, box 2, file 16.

101. Gottfurcht to Kemsley, 8 June 1954 and 12 February 1955, Kemsley papers, box 2, file 16.

102. A. E. (Art) Lyon (1900-1976) was a railway worker who became president of the Brotherhood of Railroad Signalmen in 1934. In 1945, he was appointed executive secretary of the Railway Labour Executives' Association (RLEA), a lobbying body that existed to represent the interests of US railwaymen at government and industry levels. At the urging of the AFL as well as US government foreign and security officials, Lyon negotiated the affiliation of the RLEA with the ITF in 1946, bringing in 700,00o railway members, a figure rising to over one million ten years later. Representing one of its most powerful affiliates, Lyon served on the ITF executive committee until 1962. Self-effacing and taciturn, he rarely spoke at governing body meetings but kept meticulous notes. Harold Lewis, a personal assistant to the ITF general secretary from 1956 to 1966 and responsible for the minutes, recalled that Lyon always made clear that his priority, to the exclusion of anything else on the ITF's agenda, was unqualified opposition to communist activities and influence in the international trade union movement.

103. Meany to Brown, 19 July 1955, Meany files, 1947-60, box 56, file 5; Lovestone to Brown, 1 August 1955, IAD Lovestone files, box 41, file 3.

104. Brown to Meany, 9 June 1954, and Irving Brown, "Report on ICFTU Executive Board 24-29 May 1954," IAD Lovestone files, box 12, file 1.

105. Victor Reuther to Ross, 7 May 1954, CIO Washington Office records, box 74, file 22; Ross to Victor Reuther, 31 May 1954, CIO Secretary-Treasurer records, box 133, file: IAD M. Ross 1953-54.

106. Brown to Lovestone, 26 November 1953, IAD Lovestone files, box 11, file 19; Brown to Lovestone, 10 July 1953, IAD Brown files, box 29, file 17; Lovestone to Brown, 30 November 1953, 14 July 1954, IAD Brown files, box 29, files 16-17. James Angleton, who had formerly been the liaison officer between the CIA and the FBI, was now the agency's head of counterintelligence. He and Lovestone were kindred spirits and became firm friends. They shared an obsession with the threat posed by "communist" enemies, real and imagined, and were intent on collecting every possible shred of evidence 
against them. Interestingly, it was George Meany's discovery that this secret funding arrangement with Angleton was still in existence in 1974-long after all AFL-CIO ties with the intelligence community were supposed to have been severed-that led him to "retire" Lovestone. Morgan, A Covert Life, 276, 350-51.

107. Pegler deployed a scattergun approach: among other things, he claimed that Brown had been responsible for imposing the system of co-determination in Germany to deliver control of industry to "socialist union bosses," and he saw something particularly dangerous in the fact that Lovestone had been allowed to lecture at the Army War College. Lovestone concluded that Pegler was being briefed by people in the CIA hostile to the overseas work of the FTUC. Articles by Pegler appearing in the New York Journal-American were: "Plans to Sift Dubinsky's Union Activities in Europe," 9 November 1951; "More About Activities of U.S. Unions in Europe," 15 November 1951; "Paris Communist Paper Discusses 'Arrogant Valet," 31 December 1951; "More About AFL 'Envoys' Contacting Europe Labour," 3 January 1952; "An Exchange of Letters with Envoy Irving Brown," 16 January 1952; "Fair Enough," 26 March 1952; "Praise of Irving Brown in the Readers Digest," 12 October 1952; "Red Lectures to Army," 21 February 1954; "More About Activities of Lovestone and Brown," 8 April 1954. Pegler's articles led Lovestone to draft an untitled and undated document-most probably intended for the director of the CIA - that began: "Inestimable damage has been done to the Free Trade Union Committee, AFL, both here and abroad, as well as to the interests of the United States by recent attacks of Pegler, inspired by CIA officials, according to Pegler's own written and oral statements; not to mention injury to various personalities associated with the FTUC." Lovestone went on to threaten to end the existing relationship between the FTUC and "CIA representatives, cut-outs, and other persons controlled by the CIA" unless a more satisfactory modus operandi could be agreed upon. Lovestone papers (Hoover), box 403, file: FTUC.

Spencer Miller joined the fray in late 1953, alleging that Brown had used $\$ 30,000$ of CIA money to buy gold on the black market in Greece. The White House was also drawn into the affair, and President Eisenhower's chief of staff asked J. Edgar Hoover for an opinion on Lovestone. The FBI director responded that he was "a rather sinister character" conducting intelligence work within the labour movement for the CIA and whose abandonment of communism he had "always doubted." Miller gave testimony to the House Un-American Activities Committee and the Senate Internal Security Committee, while Senator Joseph McCarthy began to probe the roles of Lovestone and Carmel Offie. With no evidence to substantiate these allegations, McCarthy's assistant, Roy Cohn, told Lovestone in May 1954 that they had no interest in causing him further trouble. The FBI settled for keeping Lovestone under surveillance. Morgan, A Covert Life, 234-43.

108. L'Affaire Dides, as it became known, gripped Paris for several weeks before the official inquiry exonerated Mitterand. Behind it was a strong hint of an attempt to discredit the Mendès France government amid suggestions that the recently concluded war in Indochina had been lost through "treason" in the ranks of government. Brown feared 
that the arrest of Dides was part of a wider move by Mitterand to expose American links to the police's extra-legal anti-communist work. Interestingly, just before the scandal broke, Brown had come into possession of a verbatim report of the communist party's political committee that he had forwarded to Lovestone. Admitting to being "insecure and keyed up," he lay low for a week in Paris and then sought safety across the German border. From Munich, he sent Lovestone's secretary, Ann Stolte, a close friend and confidante, a handwritten letter setting down his "most troublesome thoughts and suspicions" for the record. Of the Dides affair, he wrote: "It is more important than the mere revelation of espionage. ... Mitterand originally attempted to move against the so-called American reseau in France (this was obviously to be directed against myself and all the other anti-communists who have been ... supporting the Americans).... In going after Dides ... it was expected to uncover how he was being financed by and working for the Americans-and if possible by chance yours truly.... They would certainly like to pin a lot on me but there is no chance. I have been around. I have seen people. I have talked." Nonetheless, clearly troubled, he asked her to "become the living recorder of my deepest anxieties about France and whither we are drifting. ... Keep records of these love notes for me in NY." "From Irving," 21 October 1954, Meany files, 1947-60, box 57 , file 23 .

109. Jack Carney (1887-1956) was born in Dublin. He became a close associate of Irish republican trade union leader James Larkin, with whom he moved to Chicago following the 1916 Easter Rising in Dublin. In Chicago, he became the editor of the Irish Worker and later of the Duluth-based Socialist Party paper Truth. He was a founding member of the Workers' Party of America, where he first met Lovestone. Imprisoned briefly in 1922 for criminal syndicalism, he subsequently returned to Ireland. After 1945, he worked as a journalist in London and in 1951 began submitting regular reports to Lovestone.

Klaus Dohrn (1909-79) was an Austrian journalist who fled Nazism and during the war joined the German emigration in the United States, where he met Lovestone. After 1945, he settled in Switzerland and worked as a special reporter for C. D. Jackson, editor-in-chief of Henry Luce's Time-Life publications. He enjoyed direct access to the highest levels of the West German foreign ministry during the Adenauer years and acted as a conduit between Adenauer and Lovestone. As a Catholic, he was well connected to the Vatican, but he also enjoyed good contacts with sometime Austrian chancellor Bruno Kreisky.

John Bruegel was a London-based Czech refugee who combined journalism with freelance translating work for the Socialist International, the Labour Party and the TUC. He took over from Jack Carney in 1957 and for the next twenty years, as a by-product of his regular translating work, he was able to supply Lovestone with confidential labour movement documentation. Bruegel's daughter, who became a leading figure in Jews for Justice in Palestine, severed relations with him when she discovered that he was in the pay of the CIA.

Mohan Das began work for the FTUC in India in the late 1940s and was subsequently employed in a similar capacity in the 1960 s by the Brotherhood of 
Railroad and Steamship Clerks. Throughout, he reported regularly to Lovestone on India's labour affairs. It was Das whom the US ambassador wanted Lovestone to second to the Congress for Cultural Freedom when the Indian section of that body was being established in 1951.

By and large, the tittle-tattle content of the "JX reports" emanating from these stringers was hardly earth-shaking. Of greater possible significance was the so-called HTLINGUAL program launched by Angleton in December 1955, which ran for the next eighteen years. Under this, with a base at La Guardia airport, Angleton arranged to have correspondence of targeted individuals opened and photocopied. The information gleaned was shared with Lovestone. Over the period some 215,820 pieces of correspondence were opened. In the 1970s, the Church Committee heard evidence that most of this was "worthless." Whatever the truth, the operation indulged Lovestone's taste for the clandestine. Morgan, A Covert Life, 245-46, 252-53; Michael Holzman, James Jesus Angleton: The CIA and the Craft of Counter-Intelligence, chap. 9.

110. "Statement for Meeting of AFL and CIO International Affairs Committee," 25 February 1955, CIO Washington Office records, box 56, file 17; "Confidential Notes on Joint Meeting Between Representatives of the CIO-AFL International Affairs Committees," 25 February, 1955, CIO Secretary-Treasurer records, box 129, file: IAD Correspondence 1955; minutes of FTUC meeting, 16 April 1955, IAD Brown files, box 29, file 16; Lovestone to Brown, 18 April 1955, Lovestone papers (Hoover), box 698, file: Irving Brown.

111. Brown to Lovestone, 22 April 1955, IAD Lovestone files, box 12, file 4; Lovestone to Meany, 13 March 1955, Lovestone papers (Hoover), box 705, file: George Meany; Brown to Lovestone, 2 December 1954, Lovestone papers (Hoover), box 698, file: Irving Brown.

112. Brown to Meany, 19 March 1955, Meany files, 1947-60, box 57, file 24; Lovestone to Brown, 18 April 1955, Lovestone papers (Hoover), box 698, file: Irving Brown.

113. Meany to Brown, 7 July 1955, IAD Lovestone files, box 12, file 4 .

114. "Confidential: American Labour and the ICFTU," n.d., CIO Secretary-Treasurer records, box 124, file: ICFTU Vienna meeting May 1955 Correspondence.

115. Victor Reuther to Ross, 14 June 1955, CIO Washington Office records, box 74, file 26.

116. Victor Reuther to Bill Gausmann, 29 July 1955, Kemsley papers, box 2, file 13.

117. Lovestone to Brown, 7 July 1955, IAD Lovestone files, box 12, file 4.

118. Gausmann to Victor Reuther, August 1955, Kemsley papers, box 2, file 13; Ted Morgan, "The Grey Eminence" (typescript, n.d.), 861-62.

119. "Suggested Programme for Strengthening the ICFTU," 28 April 1955, CIO Washington Office records, box 69, file 25 .

120. Lovestone to Meany, 1 August 1955, and "Report from France," 30 August 1955, Meany files, $1947-60$, box 56 , file 6 .

121. "Memorandum of Meeting with Phil Delaney," 10 October 1955, Meany files, 1947-60, box 56 , file 7 .

122. Morgan, "Grey Eminence," 864; Kemsley to Gausmann, 27 November 1955, Kemsley papers, box 2, file 13 .

123. Brown to Lovestone, 3 November 1955, IAD Lovestone files, box 12, file 4. 
124. Untitled note, Lovestone to Meany, 9 December 1955, Meany files, 1947-6o, box 56, file 8.

125. "ICFTU Executive Board Meeting Incidents," n.d. [December] 1955, Meany files, $1947-60$, box 56 , file 8 .

\section{Chapter 5: A Wedding Without a Honeymoon}

1. Lovestone to Brown, 11 January 1956, IAD Lovestone files, box 12, file 6; Lovestone to Brown, n.d. [February] 1956, Lovestone papers (Hoover), box 355, file: Irving Brown, 1954-56; Ross to Brown, 19 February 1956, IAD Brown files, box 33, file 13; Dan Benedict to Victor Reuther, 20 February 1956, Reuther-Carliner records, 1955-63, box 83, file 24. The merger had brought together two quite different organizations, and between them they had yet to establish basic administrative practices. The AFL's international "department"an operation barely justifying the name-had a loose structure with no fixed pattern of procedures. It was quite unlike the $\mathrm{CIO}$ equivalent, where systems were clearly laid down. Prior to the merger, Meany had hoped to preserve the AFL ethos, and Lovestone approved of this since it made for greater informal control and allowed him and his vest-pocket organization, the FTUC, more room to manoeuvre. The international affairs committees of the two centres also differed greatly in their modi operandi. AFL committee meetings followed a very loose agenda, and minutes were sketchy or non-existent. For the CIO committee, verbatim transcripts of proceedings were kept and policy making was thus more transparent. Rosy Ruane to author, 2 January 2004. Rosy Ruane worked as secretary to both Mike Ross and Jay Lovestone and was employed in the CIO and then AFL-CIO international affairs department for thirty years.

2. Lovestone to Brown, 29 February 1956, IAD Lovestone files, box 12, file 6; Lovestone to Brown, 6 March 1956, Brown to Lovestone, 7 March 1956, and Lovestone to Brown, 15 March 1957, IAD Lovestone files, box 12, file 10; Brown to Meany, 1 March 1956, enclosing "Memorandum on the Possible Reorientation of the ICFTU," n.d., Meany files, 1947-60, box 56, file 10. In hoping to land the directorship in charge of organizing, Brown had been quietly canvassing potential backers. But among European centres, Force ouvrière was the only one willing to endorse him. He claimed that Robert Bothereau believed him to be the best candidate, while Ferri-Pisani, now a fading star, supplied a testimonial deploring a perceived softening of the ICFTU's stand on communism and urging Meany and company to take the initiative and force through Brown's appointment. The Chinese Federation of Labour in Taiwan was also on his side, and word from Latin America was that the Cuban Confederation of Labor, led by Eusebio Mujal, who had made his peace with the Batista dictatorship, also favoured him. Otherwise, Brown's support was hard to identify, and he was reduced to appealing to Meany's anti-British instincts by forwarding to him a report from Dick Deverall stating that the ICFTU secretariat was full of Britons.

3. Ross to Brown, 19 February 1956, IAD Brown files, box 33, file 13; Joseph C. Goulden, Meany, 276; Lovestone to Brown, n.d. [February] 1956, Lovestone papers (Hoover), box 355, file: Irving Brown, 1954-56. 
4. Lovestone to Brown, 29 February and 6 March 1956, IAD Lovestone files, box 12, file 6. Lovestone's own letterhead reflected an even more cavalier approach to the recent merger-with "CIO" crudely typed in alongside the "AFL" logo on notepaper originally printed for the now-defunct Labor League for Human Rights.

5. Victor Reuther to Walter Reuther, 6 February 1956, Reuther-Carliner records, 1955-63, box 83 , file 24 .

6. Returning as "the hero of Geneva," the president was guardedly optimistic about the prospects for peace in what came to be known as his "Spirit of Geneva Speech." President Dwight D. Eisenhower, "Address at the Annual Convention of the American Bar Association," Philadelphia, 24 August 1955; “Statement on Big Four Meeting," CIO Executive Board, July 1955, box 4; untitled document (“The Geneva Summit ...”), n.d., IAD Brown files, box 12, file 4; Lovestone to "Dear Friend," 22 July 1955, Lovestone papers (Hoover), box 701, file: Dulles.

7. Lovestone to Brown, 29 February 1956, n.d. [February] 1956, and 15 March 1956, IAD Lovestone files, box 12, file 10.

8. Goulden, Meany, 272; David Burgess, Fighting for Social Justice: The Life Story of David Burgess, 112; Mohan Das, "Report from India," 23 December 1955, Meany files, 1947-60, box 56, file 8; Tripathi to Meany, 14 December 1955, 14 March 1956, and Meany to Tripathi, 4 February 1956, ICFTU Archives, folder 359d; Ross to Brown, 27 February 1956, IAD Brown files, box 33, file 11; "Nehru Says Pacts Encircle Indians," New York Times, 30 March 1956; "Mission to India," New York Times, 3 April 1956; George Meany, "Criticism of Nehru," New York Times, 13 April 1956.

9. Walter Reuther to J. F. Dulles, 23 March 1956, and Lovestone, "Memorandum on UAW President Walter P. Reuther's Letter to Secretary of State John Foster Dulles, Dated 23 March 1956," n.d., IAD Brown files, box 12, file 9; Stanley Levey, "Reuther Disputes Meany India Talk," New York Times, 29 March 1956.

10. "Walter Reuther Statement on Arrival in Delhi, 4 April 1956," Reuther-Carliner records, 1955-63, box 105, file 13. During his travels around India, Reuther was accompanied by labour attaché David Burgess, who calculated that he made 118 speeches in eleven days. Burgess, Fighting for Social Justice, 113; Walter P. Reuther, "India, the United States, and the Free World: Address Before the Indian Council on World Affairs," New Delhi, 5 April 1956, in Henry M. Christman, ed., America's Labor Statesman Speaks Out: Walter P. Reuther, Selected Papers, 108-20.

11. Lovestone to Brown, 23 April 1956, IAD Lovestone files, box 12, file 6 .

12. The Free Trade Union News gave extensive space to the issue from April to August 1956. In September, it reported a sharp exchange between Meany and Nehru over the highly symbolic censoring in India of an award-winning film, With These Hands, made by the ILGWU, that dealt with the union's battle with the communists. The film had been circulating in India for five years, but recently the Board of Censors had insisted on cuts of detrimental remarks about the USSR contained in the film and about the battle with the communists in the ILGWU in the 1920s. Burgess to Victor Reuther, 15 June 1956, ReutherCarliner records, box 104, file 28. 
13. Goulden, Meany, 273-75.

14. Lovestone, "Confidential," 3 May 1956, IAD Lovestone files, box 12, file 9; Lovestone to Brown, 9 March and 24 April 1956, IAD Lovestone files, box 12, file 6.

15. Charles Millard (1896-1978) had been suggested for the job of ICFTU director of organization some months earlier by Bill Kemsley, based in the ICFTU's New York office, and the Reuthers had quickly backed his candidacy. He was a labour official of considerable experience who had been an organizer of the unemployed during the Depression and then headed the autoworkers' organizing drive in Canada in the 1930 s before becoming the head of the CIO in Canada (which helped to organize the Canadian Congress of Labour, founded in 1940) and subsequently the leading figure in the steel union. A lay preacher as well as a democratic socialist, he had also served two terms in the Ontario provincial legislature as a representative of the Co-operative Commonwealth Federation. In the 1940s, he had been regarded as the most powerful trade union figure in Canada. Representing the Canadian Congress of Labour, he was recognized as one of the more energetic members of the ICFTU's Regional Activities Fund Committee from 1951 to 1954. With an ICFTU loyalist like him in the post, the director of organization would not be someone to shackle or undermine Oldenbroek, as originally envisaged by Lovestone, but someone who would work to expand the essential role of the ICFTU. Anthony Carew, "Charles Millard, a Canadian in the International Labour Movement: A Case Study of the ICFTU, 1955-61."

16. A memorandum drafted by Dubinsky seems to have been the only written record of what was agreed to. "Memorandum," transmitted to Lovestone by Dubinsky's secretary Hanna Haskel, 8 November 1956, IAD Lovestone files, box 33, file 9; Kemsley to Oldenbroek, 24 June 1956, ICFTU Archives, folder 1121: Personal Correspondence of J. H. Oldenbroek; Millard to Geddes, 13 June 1956, United Steelworkers of America, Canadian Division fonds, MG28 I 103, vol. 34, LAC.

17. Lovestone to M. A. Khatib, 8 June 1956, Lovestone papers (Hoover), box 367, file: David Dubinsky, 1956-70; Lovestone to Deverall, 19 June 1956, IAD Lovestone files, box 12, file 9.

18. To ensure there was no doubting where he stood, Millard also disassociated his Canadian steelworkers' union from Meany's criticisms of Nehru. Millard to Oldenbroek, 3 January and 27 February 1956, ICFTU Archives, folder 1121: Personal Correspondence of J. H. Oldenbroek.

19. Lovestone to Deverall, 19 June 1956, and "Letter from Irving Brown," 19 June 1956, IAD Lovestone files, box 12, file 7; Lovestone to Freitag, 19 June 1956, Lovestone papers (Hoover), box 369, file: Walter Freitag, 1956.

20. Deverall to Meany, 3 June 1956, Meany files, 1947-6o, box 56, file 11. Deverall's ICFTU post had been demanded by Meany following the winding up of the FTUC program in Asia.

21. "Letter from Irving Brown," 19 June 1956, IAD Lovestone files, box 12, file 7.

22. Lovestone to Meany, 19 June 1956, Lovestone papers (Hoover), box 379, file: George Meany, 1950-59.

23. Lovestone to Brown, 26 June 1956, IAD Lovestone files, box 12, file 6. 
24. Ibid.; Meany to Oldenbroek and Becu, 25 June 1956, CLC Archives, MG28 I 103, vol. 257, file 14 .

25. Minutes of ICFTU Executive Board meeting, 2-7 July 1956, ICFTU Archives, folder 60; Irving Brown, "Report on ICFTU Executive Board Meeting, 2-7 July 1956," Meany files, 1947-60, box 56, file 12; Gausmann to Kemsley, 18 July 1956, Kemsley papers, box 2, file 14.

26. Irving Brown, "Report on ICFTU Executive Board Meeting 2-7 July 1956," Meany files, 1947-60, box 56, file 12; Brown to Lovestone, 2 July 1956, Lovestone papers (Hoover), box 355, file: Irving Brown, 1954-56; “Letter from Irving Brown," 7 July 1956, IAD Lovestone files, box 12, file 7; Lovestone to Brown, 26 July 1956, IAD Lovestone files, box 12, file 6.

27. Walter Reuther to Potofsky, 20 July 1956, Reuther-Carliner records, 1956-62, box 83, file 25.

28. Millard to Krane, 10 September 1956, Krane papers, box 17, file 32.

29. Millard to Krane, 28 September 1956, Krane papers, box 17, file 32; agenda item 10: "Report by Director of Organizing," ICFTU Executive Board meeting, 26-30 November 1956, ICFTU Archives, folder 62; Schnitzler to Oldenbroek, 19 August 1957, ICFTU Archives, folder 1121: Personal Correspondence of J. H. Oldenbroek.

30. Lovestone to Brown, 13 August 1956, IAD Lovestone files, box 12, file 6.

31. The solidarity fund for Poland was initially characterized as an extension of the ICFTU's "Berlin Committee Fund," which had financed activities in the Soviet zone following the 1953 Berlin uprising. As a member of the Berlin Committee, Irving Brown cabled asking the AFL-CIO to respond to the appeal. Among other things, he was concerned about his reputation among the Eastern European exiles belonging to the ICFTUE who were then cooperating with the CIA's sensitive "redefection" program to the Soviet bloc. But Meany was unenthusiastic and irritated by Reuther's decision that the AFL-CIO's Industrial Union Department under his direction would itself contribute $\$ 50,000$ to the appeal for Poland regardless of Meany's reaction. Lovestone supported Meany and told Brown: "I will not give any assist. ... I don't trust Oldenbroek and co. with any finance for a Solidarity Fund," adding that such funds were "rackets," from which the Polish workers were unlikely to benefit. His reaction also reflected concern over factional disputes among the ICFTUE leadership and especially the fact that the organization's $\$ 50,000$ budget from the NCFEnow secretly channelled through the ICFTU but not recorded in its books-left it, as Brown said, "pretty much an instrument in the hands of the bureaucracy in Brussels." "Projected Exile Trade Unionist Budget for Remainder of Fiscal Year 1955-56," IAD Brown files, box 39, file 14; Volman to Brown, 13 September 1956, IAD Brown files, box 39, file 14; Brown to Ross, 18 October 1957, IAD Brown files, box 33, file 13.

32. Lovestone to Dubinsky, 24 May 1956, IAD Lovestone files, box 33, file 10; Lovestone to Brown, 30 July, 4 September, and 17 September 1956, IAD Lovestone files, box 12, file 6. Payments to the FTUC by the CIA almost halved between 1955 and 1956, when they amounted to only $\$ 25,239$. By 1957 , the only foreign activities being financed by the committee were in India $(\$ 3,950)$, Italy $(\$ 13,000)$, and Macao $(\$ 4,161)$. Lovestone papers (Hoover), box 417, file: Free Trade Union News.

33. Lovestone to Hannah Haskel, 24 April 1956, IAD Lovestone files, box 33, file 10; Lovestone, “Memorandum," 24 September 1956, Meany files, 1947-6o, box 56, file 14. 
34. One of the factors in the dispute between Meany and Potofsky was the Industrial Union Department's decision to upstage Meany with its donation to the solidarity fund for Poland. John Herling, "Meany-Reuther Rift?” Washington Daily News, 12 February 1957; W. H. Braine to A. Greenhough, 4 February 1957, LAB 13/1270; Goulden, Meany, 268-69.

35. Lovestone to "Dear Friend" [Dulles], 22 July and 19 September 1955, Lovestone papers (Hoover), box 701, file: Dulles; Lovestone to Meany, 1 August 1955, Meany files, 1947-60, box 56, file 6; Lovestone to Meany, 17 March 1958, Meany files, 1947-6o, box 57, file 1.

36. Brown to Meany, 23 January 1956, including "Report from France," 24 January 1956, Meany files, 1947-6o, box 56, file 9. It is unclear whether Brown's secrecy regarding the unnamed personnel meant that their commitment to the DGB-related project was uncertain or, perhaps, that he was afraid of their names leaking out to unsympathetic members of the international affairs staff in Washington.

37. Brown, "Memorandum on DGB Congress at Hamburg" (1-6 October 1956), n.d., IAD Brown files, box 12, file 7; Lovestone to Brown, 11 October 1956, IAD Brown files, box 12, file 6; Brown to Lovestone, 8 October 1957, IAD Brown files, box 12, file 11.

38. Willi Richter soon joined forces with leaders of other national trade union centres who called for the shutting down of the FTUC, and he complained vocally to Meany on a number of occasions about the way articles by Lovestone in the Free Trade Union News failed to reflect fairly the DGB point of view in international affairs. Richter to Meany, 23 May 1958, IAD Country files, 1945-71, box 2, file 9.

Willi Richter (1894-1972) was a skilled engineer who joined the metalworkers union in 1913 and worked for the city of Frankfurt, where he became a prominent trade unionist before losing his job under Nazism. He re-emerged as a leading trade union figure in the American zone in the late 1940 s and was a full-time officer of the DGB from 1949 and an SPD deputy in the Bundestag, 1950-57. He was DGB chairman from 1956 to 1962.

39. "Recollections and Appreciation of Adenauer," 1967, Lovestone papers (Cornell), box 3 , file 51; Victor Reuther to Walter Reuther, 28 November 1956, Reuther-Carliner records, 1955-63, box 2, file 3 .

40. Lovestone to Meany, 5 June 1957, Meany files, 1947-6o, box 56, file 21.

41. Der Spiegel, 11 September 1957.

42. Brown to Meany, 23 January 1956, Irving Brown, "Report from France," 2 February 1956, and "Letter from Irving Brown," 16 February 1956, Meany files, 1947-6o, box 56, file 9.

43. Brown to Lovestone, 15 April 1956, IAD Lovestone files, box 12, file 8; agenda item 11: "The Social and General Situation in Algeria and Its Repercussions on North African Labour as a Whole," minutes of ICFTU Sub-Committee meeting, 9-11 April 1956, ICFTU Archives, folder 53; "M. Lacoste confirme à L'Internationale syndicale libre son opposition à l'entrée en Algérie de M. Irving Brown," Le Monde, 13-14 May 1956. Brown's support for UGTA over the more broadly based Union des syndicats des travailleurs algériens, with its stronger commitment to basic trade union aims, is interesting and was evidently based on the hope that the former would prove to be more nationalist than communist in the long run. Mathilde von Bülow, "Irving Brown and ICFTU Labour Diplomacy During Algeria’s Struggle for Independence 1954-62," 221-24. 
44. Meany to Guy Mollet, 14 June 1956, cited in Ben Rathbun, The Point Man: Irving Brown and the Deadly Post-1945 Struggle for Europe and Africa, 291.

45. Brown to Lovestone, 19 June 1956, IAD Lovestone files, box 12, file 7; Brown to Meany, 2 July and 27 July 1956, Meany files, 1947-6o, box 56, file 12.

46. Lovestone to Brown, 26 June 1956, IAD Lovestone files, box 12, file 6. In fact, Victor Reuther did speak out on behalf of Brown when the recomposition of the Algerian delegation was being debated. He told the ICFTU executive board that as the ICFTU had asked Brown to perform a task, they now had a moral obligation to support him. Irving Brown, "Report on ICFTU Executive Board Meeting 2-7 July 1956," Meany files, 1947-60, box 56 , file 12 .

47. Harry Goldberg, Report 5656 from Italy, 19 May 1956, Meany files, 1947-60, box 56, file 11; Lillie [Brown] to Lovestone, 22 June 1957, IAD Lovestone files, box 12, file 2. Delaney passed on the details of the meeting between the ambassador and the foreign minister to Bill Kemsley, based in the ICFTU's New York office. Kemsley to Krane, 9 February 1958, Kemsley papers, box 3, file 7 .

48. "Letter from Irving Brown," 29 August 1958, IAD Brown files, box 7, file 17.

49. Levinson to Victor Reuther, 11 February and 10 March 1959, Reuther-Carliner records, 1955-63, box 120, file 2. Gaullist Prime Minister Michel Debré offered Lafond the post of minister of labour in 1959 on condition that Bothereau endorse the appointment, but Bothereau refused.

50. Kemsley to Krane, 28 January 1959, Reuther-Carliner records, 1955-63, box 124, file 11.

51. "Irving Brown Report," 17 May 1957, Meany files, 1947-6o, box 57, file 25.

52. Lovestone to Meany, 4 September and 10 September 1956, Meany files, 1947-60, box 56, file 14; “Irving Brown Report," 17 May 1957, Meany files, 1947-6o, box 57, file 25; Harry Goldberg, report nos. 5572, 5651, and 5671, from Italy, 3 October 1955, 3 May 1956, and 4 July 1956, Meany files, 1947-6o, box 56, files 7, 11, and 12.

53. Barny Taylor to Victor Reuther, 31 July 1956, Victor Reuther papers, box 34, file 25; Gausmann to Victor Reuther, 7 January 1957, Reuther-Carliner records, 1955-63, box 95, file 20.

54. Adolphe Graedel to Walter Reuther, 4 April 1957 and 13 May 1957, Victor Reuther papers, box 43, file 19; Italo Viglianesi, "Programme for the Training of Union Leaders and Productivity Training," 7 October 1958, Victor Reuther papers, box 36, file 19.

55. Brown to Meany, 3 June 1957, IAD Lovestone files, box 12, file 12.

56. Victor Reuther to Schevenels, 29 August 1957, Reuther-Carliner records, 1955-63, box 3, file 9.

57. "Memorandum" (unsigned: Fotis Makris?), 28 June 1957, Benedict papers, box 54, file 3 , Business Correspondence, 1954-57; "Letter from Irving Brown," 21 May 1957, Lovestone papers (Hoover), box 356, file: Irving Brown, 1957.

58. "Letter from Irving Brown," 12 October 1958, Meany files, 1947-60, box 57, file 3.

59. Hugh Wilford, The CIA, the British Left and the Cold War: Calling the Tune? 244-45. Lovestone had advised Brown to steer Bill Schnitzler away from Brussels in the first instance, thereby dramatizing the fact that the ICFTU headquarters was being 
cold-shouldered. At the same time, he suggested that Dick Deverall, recently installed in his new position as special assistant in the ICFTU secretariat, should be invited to join Schnitzler's party in London for the irritant effect it would have on the TUC: "Sir Vincent would probably get cross-eyed and might smoke his pipe from the wrong end. Watch me weep!" Before returning to the United States, Schnitzler did call in at the ICFTU head office, taking the opportunity to tell Jaap Oldenbroek and Jay Krane that it was they who were on trial and not the FTUC or Irving Brown. Lovestone to Brown, 24 August, 14 September, and 17 September 1956, IAD Lovestone files, box 12, file 6; "Report from Irving Brown," 3 October 1956, Meany files, 1947-60, box 56, file 15.

6o. Ben Rathbun, interview with Irving Brown, 5 April 1983, cited in Rathbun, The Point Man, 281,306 . No sum of $\$ 350,000$ appears in the FTUC accounts, and the figure was certainly beyond the means of the AFL. In July 1952, Brown had a meeting in London with General William Donovan, former head of the OSS and still a presence in intelligence circles, to discuss the Tunisian situation. Lovestone to Brown, 16 July 1952, IAD Brown files, box 29, file 14. According to Rathbun's account, the French foreign ministry complained to US ambassador David Bruce about Brown's activities in Tunisia. The ambassador went through the motions and called him in to read out the French complaints. Brown responded that he was acting as a private citizen, not an agent of the US government, and it was therefore of no concern to the embassy. The two men then sat down and had a friendly chat about other matters.

61. In December 1954, Lovestone invited Tayeb Bouazza to New York and supplied him with funds to set up a Committee for the Establishment and Development of Free Trade Unions in Morocco, which later gave rise to the Union marocaine du travail (UMT), with the economist Mahjoub Ben Seddik as general secretary. Ted Morgan, A Covert Life: Jay Lovestone, Communist, Anti-Communist, and Spymaster, 256.

62. "Union Aide to Prod U.S.: Brown Pledges Drive to Back North African Nationals," New York Times, 22 November 1956. "We have to give them certain types of military assistance to enable them to maintain order at home," Lovestone wrote James Angleton. Morgan, $A$ Covert Life, 256.

63. In answer to African calls within the ICFTU for the continent to be treated as a single entity with the creation of a regional trade union organization, Louis Major, of the Belgian FGTB, argued that such talk was meaningless as the territories differed so much. The Force ouvrière line was to reject any suggestion that it stand aside in favour of purely African unions. TUC general secretary Vincent Tewson maintained that much of the talk of "colonialism" was outdated; trade union rights existed in British territories, and the need was to focus on building unions patiently from the bottom up. This involved a time frame that plainly did not satisfy the Africans-or Americans. Minutes of ICFTU Executive Board meeting, 12-16 December 1955, ICFTU Archives, folders 44-55.

64. Krane to Kemsley, 10 August and 24 November 1956 and 2 January 1957, Kemsley papers, box 3, file 2; Victor Reuther to Walter Reuther, 10 September 1957, Reuther-Carliner records, 1955-63, box 3, file 10. Tom Mboya (1930-69) worked as a sanitary inspector for Nairobi City Council and became chair of its staff association, which later evolved 
into the Kenya Local Government Workers' Union, affiliated to the Kenya Federation of Labour (KFL). Mboya became KFL general secretary in 1953, at a time when political parties were banned under the Mau Mau emergency. He used the KFL as a platform for the independence movement, which he led during the imprisonment of Jomo Kenyatta. In 1955-56, he studied at Ruskin College, Oxford. In 1958, he was elected chairman of the All-African Peoples' Conference and, in 1960, helped found the Kenya African National Union, whose first general secretary he became. He remained KFL general secretary until 1963 but was already heavily involved in national politics as a member of the legislative assembly and negotiator at the Lancaster House independence talks in London. In the run-up to independence he served as minister of labour, and was later minister for justice and minister for economic planning. A potential successor to Kenyatta as president, he was assassinated in 1969 .

65. Although not on the list of scheduled speakers at the ICFTU's regional conference, Schnitzler ignored a specific request of chairman John Tettegah to limit his contribution to five minutes, speaking for much longer than anyone else. FO delegate Marcel Babeu protested that it ill became "fleeting guests" to attack other countries and, by implication, another ICFTU affiliate, when those same guests made no contribution to the Regional Activities Fund that had enabled the conference to take place. "Letter from Irving Brown," 22 January 1957, Lovestone papers (Hoover), box 356, file: Irving Brown, 1957; "Draft Address for William Schnitzler-Accra ICFTU Conference," Meany files, 1947-6o, box 56, file 17; Krane to Millard, 22 January 1957, Kemsley papers, box 3, file 4; "Resolutions and Statements Adopted by the First African Regional Conference of the ICFTU," TUC Archives, MSS 292/919.66/1: General Correspondence re the African Regional Bodies, ICFTU, 1952-57.

66. "Report to the President on the Vice President's Visit to Africa, 5 April 1957," Foreign Relations of the United States, 1955-1957, Africa, vol. 18; "Letter from Irving Brown," 9 April 1957, Meany files, 1947-60, box 56, file 19; "Letter from Irving Brown," 21 May 1957, Lovestone papers (Hoover), box 356, file: Irving Brown, 1957; Lovestone to Meany, 5 April 1957, Meany files, 1947-6o, box 56, file 19.

67. "Report from Irving Brown," 7 September 1956, and "Letter from Irving Brown," 8-15 September 1956, Meany files 1947-6o, box 56, file 14.

68. Lovestone to Meany, 10 September 1956, Meany files, 1947-6o, box 56, file 14.

69. Lovestone to Brown, 28 September 1956, IAD Lovestone files, box 12, file 6.

70. Meany to Oldenbroek, 23 October 1956, and "Proposals for Action, Respectfully Submitted by the AFL-CIO to the ICFTU Executive Board Meeting, 26-30 November 1956," Meany files, 1947-60, box 56, file 15 .

71. James Carey to Meany, 28 November 1956, Reuther-Carliner records, 1955-63, box 83, file 25.

72. Krane to Kemsley, 14 November 1956, Kemsley papers, box 3, file 2.

73. Minutes of ICFTU Executive Board meeting, 26-30 November 1956, ICFTU Archives, folder 63; Krane to Kemsley, 2 January 1957, Kemsley papers, box 3, file 2; Irving Brown 
telegram transmitted by Lovestone to Meany, 1 December 1956, and handwritten note from Brown to Lovestone, n.d., Meany files, 1947-6o, box 56, file 16.

74. Lovestone to Meany, 22 March and 11 April 1957, Meany files, 1947-6o, box 56, files 18-19; note from Lovestone, n.d. [June?] 1957, Meany files, 1947-6o, box 56, file 21; Victor Reuther to Gausmann, 21 December 1956, Reuther-Carliner records, 1955-63, box 2, file 6; Victor Reuther to Potofsky, 9 January 1957, Victor Reuther papers, box 53, file 11; Deverall to Meany, 28 April 1957, Meany files, 1947-6o, box 56, file 19.

75. "Dissensions in International Workers Organization," Times (London), 18 March 1957.

76. Lovestone to Meany, 22 March 1957, Meany files, 1947-6o, box 56, file 18.

77. George Meany, "Conflicts of Policy," Times (London), 12 April 1957. Meany wrote in the wake of a recent sharp exchange between Brown and Tewson over British obstruction of trade unions in Cyprus. Brown had been in the colony to take stock of the situation soon after the guerrilla fighting began and had reported on how, in a wholly discreditable episode, Vincent Tewson had colluded in a British government manoeuvre to grant union leader Michael Pissas freedom from prison, where he was being held without trial, provided he would agree to go into voluntary exile. Brown to Meany, 15 March 1957, Meany files, 1947-60, box 56, file 18; Tewson to Oldenbroek, 14 August 1956, ICFTU Archives, folder 1121: Personal Correspondence of J. H. Oldenbroek.

78. Walter Reuther to Meany, 11 January 1957, Victor Reuther papers, box 53, file 11; John Herling, "Meany-Reuther Rift?” Washington Daily News, 12 February 1957; W. H. Braine to A. Greenhough, 4 February 1957, LAB 13/1270.

79. Kemsley to Friedland, Gausmann and Krane, 23 March 1957, Kemsley papers, box 3, file 3; “Confidential B" [Krane to Ted Barber], 27 February 1957, Krane papers, box 17, file 8.

8o. Kemsley to Gausmann, 24 February 1957, Kemsley papers, box 2, file 14. Shortly after his appointment as director, Ross confessed to Brown that Meany had assigned an AFLCIO representative to a project in Singapore without consulting him and that he had no knowledge of the federation's plans or program for the upcoming ICFTU congress. He told Brown: "At the moment am feeling more empty than ever." Ross to Brown, 3 April 1957, IAD Brown files, box 33, file 13 .

81. Hugh Chevins, "Inquiry into World Trade Union Dropped: U.S. Caused Offence," Daily Telegraph, 18 June 1957; Brown to Meany, 18 May 1957, Meany files, 1947-6o, box 56, file 20. The teamster corruption case focused unwelcome international attention on the seamier side of American trade unionism. In a report to Meany in March, Brown noted a marked increase in anti-Americanism in Europe and also observed that the teamster scandal had provided much ammunition for US labour's enemies abroad. Indeed, Meany felt it necessary to write to the German magazine Der Spiegel to refute a charge that the corrupt behaviour of the teamster president, Dave Beck, had its roots in the form of business unionism developed by AFL founding president Samuel Gompers. Rejecting this allegation, Meany claimed that, through his misbehaviour, Beck had actually betrayed "Gompersism." George Morris, "World of Labour: Meany's Letter to Germany on Gompersism and Beckism," Daily Worker, 1 July and 3 July 1957 (published in two parts). 82. Schnitzler to Oldenbroek, 12 June 1957, Meany files, 1947-60, box 56, file 21. 
83. Lovestone to Meany, "Report Number 1," 7 July 1957, Meany files, 1947-60, box 56, file 22. Omer Becu had tendered his resignation as ICFTU president the previous year, claiming pressure of work, but really to test the water for a possible challenge for the general secretaryship at the Tunis congress. He was subsequently persuaded to stay in the post until the 1957 congress, on the basis that there needed to be continuity in the dangerous period following the crushing of the Hungarian uprising in November 1956. At that point, he dissembled in insisting that there was no friction between himself and Oldenbroek. Having previously seen Becu as an international leader on whom they could pin their hopes, Lovestone and Brown were disillusioned by his contortions in shying away from a challenge for the ICFTU general secretaryship and by his unwillingness to be candid about his differences with Oldenbroek. Lovestone to Brown, 4 September 1956, IAD Lovestone files, box 12, file 6; minutes of ICFTU Executive Board meeting, 26-30 November 1956, ICFTU Archives, folder 65; Brown to Lovestone, 3 December 1956, Meany files, 1947-6o, box 57 , file 24 .

Lovestone wrote: "I have arrived at the conclusion that Becu is a very strong man over a cup of coffee in a restaurant which isn't very well lit. I can understand his withdrawing his resignation, but why he should have hid his reasons for it, is beyond me." Lovestone to Brown, 7 December 1956, IAD Lovestone files, box 12, file 6. Brown was even more critical of Becu: "He lacks forcefulness and directness. His handling of his personal resignation has reduced him in size because no one is fooled about his 'good' reasons as distinct from his 'real' reasons for resigning. This is a damaging blow to whatever Becu could have done to take away the leadership and policy-making powers from Oldenbroek and Tewson. Whether he stays or not, Becu has become a sort of lame duck." "Irving Brown Report," 17 May 1957, and Brown to Meany, 18 May 1957, Meany files, 1947-6o, box 56, file 20.

84. Victor Reuther to Walter Reuther, 7 July 1957, Reuther-Carliner records, 1955-63, box 3, file 7. Arne Geijer (1910-79) was president of the Swedish national trade union centre Landsorganisationen i Sverige (LO) from 1956 to 1973. A metalworker by trade, he had previously been for over ten years the general secretary and then president of the metalworkers' union. He combined his trade union role with the duties of a social democratic deputy in the Swedish parliament. His presidency of the ICFTU ran from 1957 to 1965 . A man of few words but considerable presence, he became the public face of the powerful Swedish labour movement throughout the high point of that country's successful tripartite system of industrial relations from the 1950s to the 1970s. He was, and remained throughout, Walter Reuther's closest European ally.

85. Lovestone to Meany, "Report Number 1," 7 July 1957, Meany files, 1947-6o, box 56, file 22.

86. “U.S. Labour Rift Apparent Abroad," New York Times, 20 October 1957; Goulden, Meany, 277.

87. Victor Reuther to Gausmann, 27 August 1958, Reuther-Carliner records, 1955-63, box 4, file 15; Victor Reuther to Schevenels, 29 August 1957, Reuther-Carliner records, 1955-63, box 3, file 9; Victor Reuther to Krane, 18 April 1957, Reuther-Carliner records, 1955-63, box 2, file 21; Victor Reuther to Krane, 4 September 1957, Reuther-Carliner records, 1955-63, box 3, file 10; Victor Reuther to George Weaver, 9 September 1957, Reuther-Carliner 
records, 1955-63, box 3, file 10. With the Reuther campaign to remove Joe Godson as London attaché on the point of succeeding, Lovestone noted that "GM [George Meany] simply will not and cannot get involved in any assignment of government personnel," while admitting coyly: "I am not supposed to be, but I do get myself involved." Lovestone to Brown, 6 October 1958, IAD Brown files, box 29, file 18.

88. Stanley Levey, "Labour Reshapes Foreign Policies," New York Times, 9 December 1957; A. M. Morgan, “U.S.A. Labour Review for the Year Ended 31 December 1957," LAB 13/1215.

89. "Letter from Irving Brown," 14 October 1957, Meany files, 1947-6o, box 56, file 23.

90. Brown to Lovestone, 7 January 1957, Lovestone papers (Hoover), box 355, file: Irving Brown, 1954-56; “Letter from Irving Brown," 24 September 1958, IAD Lovestone files, box 12, file 13 .

91. Handwritten letter from Lovestone to Meany, n.d. [December 1957], Lovestone papers (Hoover), box 379, file: George Meany.

92. Victor Reuther to Gausmann, 17 December 1957, Reuther-Carliner records, 1955-63, box 3, file 18; Walter Reuther to Oldenbroek, 16 December 1957, ICFTU Archives, folder 1121: Personal Correspondence of J. H. Oldenbroek.

93. However, within a few short months Brown was bemoaning George Harrison's performance as fraternal delegate at the TUC annual conference, reporting that he had spoken approvingly of Walter Reuther in conversation with British labour leaders while falling for Vincent Tewson's clever suggestion that he leave out the more controversial anti-colonial passages of his speech so as not to prompt a walkout by the conference delegates. "Letter from Irving Brown," 15 September 1958, and Lovestone to Brown, 19 September 1958, Lovestone papers (Hoover), box 356, file: Irving Brown, 1958.

94. Lovestone to Deverall, 12 December and 31 December 1957, Victor Reuther papers, box 31, file 7. The Free Trade Union Committee's operations were now ended, but the committee's bank account remained active until at least 1961 and was used to make payments to Lovestone's network of reporters, ostensibly for material supplied to the Free Trade Union News, seemingly from funds channelled by James Angleton through the "Gompers Library." See Lovestone papers (Hoover), box 343, file: FTUC Financial Documents, 1961. In listing the members of the AFL-CIO's international affairs staff, the GMMA records Lovestone as the director of the Free Trade Union Committee from 1949 to 1963. "Descriptive Inventory, RG 18-oo1: International Affairs Department, Country Files, 1945-71," p. 6, GMMA.

95. Krane to Kemsley, 17 December and 29 December 1957, Kemsley papers, box 3, file 6.

96. H. F. B. Fane to A. Greenhough, 8 June 1956, LAB 13/1218; A. M. Morgan to Wilson, 13 December 1957, LAB 13/1270.

97. Lovestone to Meany, 10 November 1958, Meany files, 1947-60, box 57, file 3; "Memorandum of Interview: Discussion with Mr. Walter Reuther, AFL-CIO, 7 May 1959," TUC Archives, MSS 292/973/16: Trade Unions, U.S., 1959-60.

98. Lovestone to Brown, 8 September 1958, IAD Lovestone files, box 12, file 13. 
99. On his East African trip, Randolph delivered in person the AFL-CIO's $\$ 35$, ooo grant for the KFL headquarters building to Mboya. Schnitzler to Mboya, 28 May 1957, IAD Country files, 1945-71, box 11, file 4 .

10o. For Springer's account of her brief but eventful involvement in the training program, see Yevette Richards, Maida Springer: Pan-Africanist and International Labor Leader, chap. 6. Evidence of intense opposition from the British Colonial Office and the TUC to the original AFL-CIO program is to be found in "Proposed Contacts Between American Trade Union Movement and African Trade Unionists, 1957-58," LAB 13/1271. Victor Reuther informed his brother that the State Department was alarmed at the damage Springer's African trip might do to Anglo-American relations and that Assistant Secretary of State Robert Murphy had tried to get Meany to delay the mission. Victor Reuther to Walter Reuther, 9 October 1957, Reuther-Carliner records, 1955-63, box 3, file 12.

Maida Springer (1910-2005) had been education director in her ILGWU local and later business agent. She studied at Ruskin College, Oxford, in 1951-52 and, in 1959, was invited by Golda Meir to spend a year in Israel assisting with a program for a vocational training school for African women. She provided lodgings for Tom Mboya on his first visit to the United States and shortly after attended the ICFTU's first African Regional Conference in Accra. From 1960 to 1966, she worked for the AFL-CIO International Affairs department.

101. Brown to Meany, 9 November 1957, Lovestone papers (Hoover), box 355, file: Irving Brown, 1954-56; Millard to Tewson, 19 November 1957, Kemsley papers, box 3, file 15; minutes of TUC International Committee meetings, 26 November and 17 December 1957 and 22 April 1958; minutes of TUC Commonwealth Advisory Committee meetings, 5 February, 2 April, and 16 July 1958; minutes of TUC General Council meeting, 26 February 1958, TUC Archives, MSS 292D/901; Millard to Tewson, 22 May 1958, TUC Archives, MSS 292/901/145; minutes of AFL-CIO International Affairs Committee meeting, 14 March 1958, IAD Brown files, box 33, file 14; Gausmann to Victor Reuther, 28 June 1959, Reuther-Carliner records, 1955-63, box 95, file 23.

102. “Confidential Report from Irving Brown," 1 March 1958, Meany files, 1947-60, box 57, file 1.

103. "Report of General Secretaries' Conference Held at Arusha, 15 February 1958," Lovestone papers (Hoover), box 379, file: Tom Mboya, 1958-63.

104. Mboya to Meany, 11 March 1958, Lovestone papers (Hoover), box 379, file: Tom Mboya, 1958-63.

105. Mboya to Meany, 15 May, 4 June, and 27 November 1958, IAD Country files, 1945-71, box 11, file 4. Replying positively to one such financial appeal, Mike Ross wrote guardedly of the criticism heaped on the AFL-CIO following the original contentious donation of \$35,00o but explained: "We are pursuing every possibility.... It probably would not be advisable to have much publicity around this matter. ... You will be notified as soon as possible, and I know that we can rely on your discretion in this matter." Ross to Mboya, 17 December 1958, IAD Brown files, box 33, file 14. A further \$21,00o was later paid to the KFL without fuss or publicity. Harold Jack to Riggs National Bank, Washington, 18 February 1960, IAD Country files, 1945-71, box 11, file 5 . 
106. Mboya to George McCray, 6 February 1958, IAD Country files, 1945-71, box 11, file 4; Mboya to A. Philip Randolph, 30 January 1959, IAD Brown files, box 7, file 18.

107. The WFTU had only three affiliates in Africa, whereas the ICFTU had fourteen. Communist support for "neutrality" - meaning, in trade union terms, withdrawal from non-African organizations-was clearly intended to damage the ICFTU more than the WFTU. For an interesting treatment of "neutralism" in African trade unions, see John C. Stoner, "We Will Follow a Nationalist Policy; but We Will Never Be Neutral': American Labour and Neutralism in Cold War Africa, 1957-1962."

108. Irving Brown, "Report on the Accra Conference," 9 December 1958, and Brown to Meany, 24 December 1958, enclosing "Report on All-African People’s Congress, 5-14 December 1958," IAD Brown files, box 7, file 17; Maida Springer, “Observations of the AAPC Held in Accra and Its Trade Union Implications, 1-13 December 1958," and George F. McCray, "Observations on the AAPC at Accra, 8-13 December 1958," IAD Country files 1945-71, box 14, file 14; Brown to Lovestone, 26 December 1958, Lovestone papers (Hoover), box 356, file: Irving Brown, 1958; Brown to Lovestone, 7 January 1959, Meany files, 1947-60, box 57 , file 4 .

109. John Tettegah to Brown, 19 March 1959, IAD Brown files, box 7, file 18.

110. Brown to Meany, 24 December 1958, and Brown to Ross, 26 December 1958, IAD Brown files, box 7 , file 17 .

111. Brown to Lovestone, 24 December 1958, IAD Brown files, box 7, file 17; Lovestone to Meany, 22 December 1958, Meany files, 1947-60, box 57, file 3.

112. Meany to Oldenbroek, 9 January 1959, and Oldenbroek to Meany, 21 January 1959, CLC Archives, reel H-180; "Statement by the AFL-CIO Executive Council on Africa," 20 February 1959, TUC Archives, MSS 292/901/15.

113. As the leader of the black trade unions in francophone West Africa, Sékou Touré doubted the AFL-CIOs commitment. He had complained to Brown on many occasions that "Americans are always there after the battle is won in order to feather their own nest. While the fight for freedom is on [they] are the absentees." Irving Brown, untitled commentary on Africa, 11 February 1961, IAD Brown files, box 8, file 2.

114. David Goldsworthy, Tom Mboya: The Man Kenya Wanted to Forget, 116-19. Mboya urged more dynamism to override TUC fears of African nationalism. Reuther's erstwhile American critics such as Maida Springer, who laid the abandonment of the AFL-CIO's Africa training program at his door, viewed his change of heart with wry amusement. Lovestone commented sarcastically: "Nobody reminded our 'saintly' brother that this was a [new] line for him and that he owed it to himself as well as to us to explain why he changed his old position." Richards, Maida Springer, 193.

Victor Reuther's first reaction to the idea of sending black American organizers to Africa had been to oppose it on the grounds that American chances of being able to influence the policies of European governments in Africa through their trade union centres would be very limited if the AFL-CIO were to resume a freewheeling role. But a few months later a highly critical commentary on the TUC policy in Africa prepared by the UAW noted the British tendency to disregard the economic, social, and political 
problems faced in Africa and to explain the weakness of its labour movement almost exclusively in terms of the personal shortcomings of its leaders. The TUC said nothing about the obstacles presented by colonialism and the absence of progressive labour legislation. Victor Reuther to Walter Reuther, 12 February 1959, Reuther-Carliner records, 1955-63, box 5, file 3; "Notes on TUC Memorandum on African Trade Unions," Reuther-Carliner records, 1955-63, box 95, file 28. Mboya kept up his flow of complaints about the ICFTU to the Reuthers, protesting to Victor two months later that the Brussels secretariat had prevented the KFL from purchasing a motor vehicle. Mboya to Victor Reuther, 4 July 1959, forwarded to Walter Reuther, 13 July 1959, Reuther-Carliner records, 1955-63, box 5, file 11; Gausmann to Victor Reuther, 26 October 1959, Reuther-Carliner records, 1955-63, box 95, file 23 .

115. Goldsworthy, Tom Mboya, 152, 156, 161-62; Tettegah to Mboya, 14 December 1960, IAD Country files, 1945-71, box 10, file 20. Mboya was increasingly the object of a whispering campaign that he was a tool of the Americans and a traitor to pan-Africanism. Following the ICFTU congress in December 1959, a document purporting to be an annexe to a British government cabinet paper began to circulate in Africa. It reviewed the ICFTU's activities in Africa in terms of rival schemes by the British and US government to take control of African trade unionism in the post-colonial world. The document represented Mboya as an unscrupulous tool of the Americans whose main motivation was pecuniary gain. The British insisted that the document was a forgery, while Mboya answered it at length and claimed it was the work of Gogo Nzeribe, a Nigerian communist trade union leader. Seven years later, during the war in Biafra, Nzeribe was murdered while in the custody of the Nigerian military government. In 1969, Mboya himself was assassinated in Nairobi. "Annexe to Cabinet Paper on Policy in Africa," 12 December 1959, and Hood to Feather, 30 November 1960, "Dependent Territories: Assistance, ICFTU and America," TUC Archives, MSS 292/932/551; Gogo Nzeribe, The Great Conspiracy Against Africa, NTUC, December 1960; Tom Mboya, "No Conflict of Loyalties: Tom Mboya Replies to the Ghana Times," Free Labour World (May 1960): 185-87.

II6. Reuther to Geijer, 26 May I959, Victor Reuther papers, box 26, file 6.

II7. Lovestone to Meany, II June I959, IAD Lovestone files, box 69, file 26; Brown to Lovestone, 5 June 1959, Lovestone papers (Hoover), box 356, file: Irving Brown, 1959.

II8. Brown cable to Lovestone, 3 July I959, IAD Lovestone files, box I2, file I5; Geijer to Walter Reuther, 6 July I959, Birger Viklund personal papers, Arbetarrörelsens arkiv och bibliotek, Stockholm.

II9. Reuther to Geijer, 22 July I959, Victor Reuther papers, box 26, file II.

120. Kemsley to Adamczyk, 4 February 1959, Kemsley papers, box 2(1); "Memorandum of Conversation at Luncheon with Soviet Deputy Premier A. I. Mikoyan, 6 January 1959," Reuther-Carliner records, 1955-63, box 100, file 7; John Herling, "U.S. Labour vs. Mikoyan"; Frank Cormier and William J. Eaton, Reuther, 362-63.

121. "Khrushchev and the American Unions," The Freedom Fund, April 1960, ReutherCarliner records, 1955-63, box 100, file 8; Trud, 29 October 1959; Cormier and Eaton, Reuther, 363-67. 
122. Brown to Lovestone, 10 October 1959, Lovestone papers (Hoover), box 356, file: Irving Brown, 1959; Brown to J. M. Aguirre, 26 November 1959, IAD Brown files, box 23, file 11.

123. Brown to Lovestone, 27 July and 10 October 1959, Lovestone papers (Hoover), box 356, file: Irving Brown, 1959.

124. It is of interest that in the same year that Adenauer honoured Meany and Lovestone, Willy Brandt's choice of guest speaker at the SPD's May Day rally in Berlin was Walter Reuther. Anthony Carew, Walter Reuther, 97-98. For the Reuthers' view of the Adenauer-Brandt rivalry and how it impinged on them, see Victor Reuther, The Brothers Reuther, 347.

125. ICFTU Report of Sixth World Congress, Brussels, 3-11 December 1959 (Brussels: ICFTU, 1960), 259, 372-73, 431-33, 435.

126. The resolution for the appointment of the ad hoc committee was introduced by Geijer and seconded by Walter Reuther. ICFTU Report of the Sixth World Congress, 525-39; Times (London), 7 December 1959. A strong supporter of Oldenbroek, Bill Kemsley would refer to this as "Reuther's dirty job." Earlier in the congress he had tried to persuade Reuther against forcing the resolution through, but the UAW leader rounded on him and told him that so long as he kept his nose clean and stopped meddling in ICFTU politics, he would continue to have a job. This was the end of Kemsley's long association with Walter Reuther; within a year he had resigned from the ICFTU in disillusionment. Author interview with William Kemsley, 19 April 1987. Also in disagreement with American tactics, Vincent Tewson asked rhetorically what the ICFTU's reaction would have been had it been a case of Soviet trade unions bringing heavy-handed pressure to get rid of Louis Saillant as general secretary of the WFTU. Tewson to Geijer, 15 June 1959, Birger Viklund personal papers, Arbetarrörelsens arkiv och bibliotek, Stockholm.

127. Geijer to Walter Reuther, 8 January 1960, and Walter Reuther to Geijer, 7 January 1960, Geijer personal papers, box 54; Walter Reuther to Becu, 28 January 1960, Becu papers (ICFTU); Walter Reuther to Geijer, 28 January and 15 February 1960, Reuther-Carliner records, 1955-63, box 123, file 12; Geijer to Walter Reuther, 3 March 1960, ReutherCarliner records, 1955-63, box 123, file 12.

True to type, Becu appeared to waver for a few weeks in April-May 1960. He told colleagues in the International Transport Workers' Federation that he did not envisage leaving the organization and even proposed that its head office be moved to Brussels. His motivation was never clear. Was he hoping for a more congenial location in his native Belgium as the price for staying with the ITF? Did he then perhaps envisage combining the general secretaryship of the ITF and the ICFTU, as his predecessor, Edo Fimmen, had done in the 1920s? Or was he manufacturing an artificial dispute with his ITF colleagues and thereby creating an excuse for leaving an organization to which he was emotionally committed? Harold Lewis, "The International Transport Workers' Federation (ITF) 1945-65," 62-65. The latter seems the more plausible explanation and ties in better with his reasoning in his letter of resignation on 12 May 1960. The unfortunate manner of his leaving the ITF, and the fact that he also went back on his long-standing commitment not to challenge Oldenbroek for the leadership of the ICFTU 
while the latter held the post, played badly in Europe, with negative consequences for him during his early months as ICFTU general secretary.

128. Agenda item 12: "Recommendations of the Ad Hoc Committee," minutes of ICFTU Executive Board meeting, 27 June-2 July 1960, ICFTU Archives, folder 103a. Noting that copies of Geijer's report were collected up at the end of the meeting and destroyed, Millard described it as the worst document he had ever seen and commented that the manner in which Oldenbroek was treated had no place in a democratic movement. Millard to Kemsley, 5 July 1960, Kemsley papers, box 3, file 17.

129. Irving Brown, untitled report ("On Tuesday, June 28, a closed session of the Executive Board ...”), n.d., Meany files, 1947-6o, box 58, file 2.

130. Ibid.; minutes of ICFTU Executive Board meeting, 27 June-1 July 1960, ICFTU Archives, folder 103a.

131. Along with Oldenbroek, Millard, and Krane, other key figures also left the ICFTU around this time, providing further scope for a fresh start. Alois Adamczyk, whose direction of the ICFTU department responsible for monitoring Eastern Europe and developments under communism more generally had never impressed Lovestone, died in 1959; Bill Kemsley was soon to quit as director of its New York office, while Assistant General Secretary Hans Gottfurcht retired.

132. Lovestone to Brown, 11 July 1960, Lovestone papers (Hoover), box 356, file: Irving Brown, 1960. The British labour counsellor in Washington actually believed that Lovestone would have preferred Oldenbroek to survive- "for nuisance value" - so as to have a scapegoat when Lovestone himself failed. Kemsley to Krane, 29 May 1960, Kemsley papers, box 3, file 11 .

\section{Chapter 6: Into the 1960s}

1. The phrase "the year of Africa" was coined by UN under-secretary Ralph Bunche with reference to the "explosive rapidity" with which Africans were emerging from colonialism. Paul Hoffmann, "Bunche Says '6o Is Year of Africa,'” New York Times, 16 February 1960.

2. Press statement by Senator John F. Kennedy, 1 December 1960. Cited in John C. Stoner, "Anti-communism, Anti-colonialism, and African Labor: The AFL-CIO in Africa, 19551975," 228; "Khrushchev Lauds Anti-Colonial Fight," New York Times, 28 December 1960.

3. Lovestone to Brown, 5 January and 26 January 1959, IAD Brown files, box 29, file 18; P. Lavon to Meany, 10 April 1960, IAD Country files, 1945-71, box 10, file 11; Meany to J. Avrech, 6 June 1960, IAD Country files, 1945-71, box 10, file 8; "A Labour School Opens in Israel," New York Times, 19 October 1960; Meany to Avrech, 23 November 1960, Avrech to Meany, 28 December 1960, and Meany to Avrech, 12 January 1961, IAD Lovestone files, box 10 , file 8 .

4. Springer to Meany, 13 January 1959, IAD Country files, 1945-71, box 14, file 14.

5. Brown to Lovestone, 23 January 1960, Lovestone papers (Hoover), box 356, file: Irving Brown, 1960. 
6. Transmittal slip, Springer to Rosy Ruane, June 1960, IAD Country files, 1945-71, box 10, file 8.

7. Ross to Brown, 30 October 1959, IAD Brown files, box 30, file 18.

8. Brown to Meany, 12 May 1960, Meany files, 1947-60, box 57, file 9; Brown to Lovestone, 2 June 1960, Lovestone papers (Hoover), box 356, file: Irving Brown, 1960; Irving Brown, "Confidential," 7 July 1960, IAD Brown files, box 1, file 21.

9. Five months later, Mboya reminded Brown that "the airlines have been after me." Mboya to Brown, 4 November 1960, IAD Brown files, box 30, file 11.

10. David Goldsworthy, Tom Mboya: The Man Kenya Wanted to Forget, 146-47, 150-52, 160; Brown to Ross, 13 January 1962, Lovestone papers (Hoover), box 356, file: Irving Brown, 1961-63; Brown to Ross, 7 November 1960, IAD Brown files, box 33, file 19; Mboya to Becu, 30 November 1960, IAD Brown files, box 30, file 11; Goldsworthy, Tom Mboya, 158.

11. "Letter from Irving Brown," 30 July 1960, Lovestone papers (Hoover), box 356, file: Irving Brown, 1960; Becu to Meany, 8 February 1961, IAD Brown files, box 23, file 12; Brown to Ross, 7 November 1960, and enclosing untitled report dated 5 November 1960, IAD Brown files, box 33, file 19; Yevette Richards, Maida Springer: Pan-Africanist and International Labor Leader, 212. During the visit, Brown met Lumumba’s former press secretary, Serge Michel, and agreed to try to arrange for publication in the United States of a series of articles he was writing on the deposed prime minister. But he met strong resistance from Lovestone, who disagreed with his positive assessment of Lumumba, writing waspishly that, while he wouldn't call him "a direct agent of Moscow," he knew "much better and stronger people who were." Lovestone to Brown, 18 November 196o, Lovestone papers (Hoover), box 356, file: Irving Brown, 1960. At the time of the visit, Lumumba was still at large. He was later arrested and in January 1962 murdered by Belgian troops before CIA plans to assassinate him could be put into effect.

12. "Letter from Irving Brown," 16 October 1960, IAD Lovestone files, box 12, file 17.

13. Krane to Millard, May 1961, Krane papers, box 14, file 18; Brown to Ross, 18 October 1960, IAD Brown files, box 33, file 18; Richards, Maida Springer, 216-21, 226-33; Springer, "Summary of Six Weeks in Africa, 21 September-6 November 1960," 14 November 1960, IAD Country files, 1945-71, box 14, file 3; T. H. Mothibe, "Zimbabwe: African Working Class Nationalism, 1957-63," 178; Brown to Ross, 14 June 1961, IAD Brown files, box 33, file 21.

From the moment that the Southern Rhodesian Trade Union Congress affiliated to the ICFTU, Nkomo and Mugabe opposed Jamela, seeing membership in the ICFTU as a challenge to their concept of pan-Africanism and at odds with the correct relationship of the trade unions to the nationalist party, the Zimbabwe African People's Union. The fact that Brown was Jamela's patron, and especially the practice whereby AFL-CIO financial assistance was paid to Jamela personally (funds over which he retained tight control), were matters that aroused understandable suspicion in SRTUC circles. Jamela also insisted that the SRTUC should exercise autonomy, remaining independent of the nationalist movement. In consequence, he was portrayed as a "sell-out," and he and his family were eventually in physical danger. Ultimately, his intransigence led to his expulsion from the Zimbabwe African People's Union, following which the ICFTU decided to end material 
support for the trade union centre and to redirect it to the party. Timothy Scarnecchia, The Urban Roots of Democracy and Political Violence in Zimbabwe: Harare and Highfield, 1960-1964, 101-24.

14. Lewis to author, 23 July 1998.

15. Brown to Lovestone, 6 July 1960, Lovestone papers (Hoover), box 698, file: Irving Brown. Lovestone was in full agreement that Brown would be unwise to accept the bureaucratic role of assistant general secretary. A month earlier, when Oldenbroek's future as general secretary was still unresolved, Lovestone had warned: "Whether Oldenbroek, Shodenbroek or Geiger will be Gen Sec, I think your mobility and effectiveness would be destroyed if you became part of a so-called bureaucratic team with Mapara, Pateet and Vic Feather." (The three named were all rumoured to be possible candidates for such appointment.) Lovestone to Brown, 6 June 1960, IAD Brown files, box 29, file 20.

16. Lovestone to Brown, 11 July 1960, Lovestone papers (Hoover), box 356, file: Irving Brown, 1960.

17. Becu to Geijer, 13 September 1960, Geijer personal papers, box 14; Reuther to Becu, 22 November 1960, Becu papers (ICFTU); Krane to Victor Reuther, 17 January 1961, Victor Reuther papers, box 51, file 15. George Weaver and Rudy Faupl were both to play significant roles in international labour affairs, though not as ICFTU assistant general secretaries.

George L. P. Weaver (1912-95) began work as a redcap in Chicago. In 1940, he became assistant to CIO secretary-treasurer Jim Carey. Within the merged AFL-CIO he was responsible for civil rights. In 1958, he rejoined Carey in the electrical workers union as assistant to the president. During the Kennedy and Johnson administrations, he was appointed assistant secretary of labour for international affairs and, as such, was chairman of the ILO's governing body in 1968. In 1969, he joined the staff of the ILO and worked as special assistant to the director-general. Over the prospect of going to work for the ICFTU in 1960, he told the British labour counsellor that as a black trade unionist he would not want to get involved in the "African situation" as long as Lovestone and Brown were riding high in the AFL-CIO. A. M. Morgan to A. G. Wallis, 16 February 1960, LAB 13/1459. Equally, Lovestone was hardly likely to accept Weaver as the ICFTU's "American Assistant General Secretary," regarding him as a "scheming factionalist." Lovestone to Brown, 18 July 1961, Lovestone papers (Hoover), box 356, file: Irving Brown, 1961-63.

Rudy Faupl (1908-81) emigrated from Hungary and joined the machinists' union in Milwaukee in the late 1920s. He was appointed organizer with the Wisconsin State Federation of Labour in 1936. By the 1950s, he was responsible within the machinists for international affairs and, from 1957 to 1972 , served as the US worker delegate to the ILO. Quietly effective as a conciliator, he was trusted by people from both former wings of the movement and generally regarded as a safe pair of hands.

18. Brown to Ross, 15 November 1960, IAD Brown files, box 33, file 18.

19. Brown to Meany, 29 September 1960, Meany files, 1947-60, box 58, file 2.

20. Brown to Ross and Lovestone, 14 November 1960, Meany files, 1947-60, box 58, file 2. 
21. Irving Brown, "Report on ICFTU Executive Board"” 7 December 1960, IAD Lovestone files, box 12, file 17; agenda item 3a: "Structure of the ICFTU Secretariat," item 4a: "Tasks of the ICFTU and Its Affiliates," item 4b: "Relations Between the ICFTU and Its Regional Organizations," and item 4c: "Relations Between ICFTU and ITS," minutes of ICFTU Executive Board meeting, 28 November-2 December 1960, ICFTU Archives, folder 103a.

22. Ross to Lovestone, 6 December 1960, Lovestone papers (Hoover), box 542, file: Michael Ross; Krane to Victor Reuther, 10 December 1960, Reuther-Carliner records, 1955-63, box 123, file 13; Millard to Eileen and Bert, 29 November-3 December 1960, Margot Thompson fonds, MG31 B 28, vol. 2, file: C. H. Millard, 1956-61, LAC; Victor Reuther to Walter Reuther, 16 December 1960, Victor Reuther papers, box 26, file 25; Victor Reuther to Geijer and Becu, 6 January 1961, Geijer personal papers, box 58; "Personal Notes Dictated by Walter Reuther," 8 March 1961, Victor Reuther papers, box 31, file 11; H. F. B. Fane to A. J. S. James, 15 December 1960, LAB 13/146o.

23. AFL-CIO News, 10 December 1960; Becu to Geijer, 12 December 1960, Geijer personal papers, box 14; Geijer to Walter Reuther, 15 December 1960, Geijer personal papers, box 54; Lovestone to Brown, 13 December 1960, IAD Lovestone files, box 12, file 17; Ross cable to Brown, 21 December 1960, and Ross to Brown, 22 December 1960, IAD Brown files, box 33, file 19; Victor Reuther to Geijer and Becu, 6 January 1961, Geijer personal papers, box 58; Meany to Reuther, 25 January 1961, IAD Brown files, box 33, file 21; "Personal Notes Dictated by Walter Reuther," 8 March 1961, Victor Reuther papers, box 31, file 11.

24. Lovestone to Brown, 23 January 1961, IAD Lovestone files, box 13, file 1; Ross to Brown, 23 January and 27 January 1961, IAD Brown files, box 33, file 20; "Personal Notes Dictated by Walter Reuther," 8 March 1961, Victor Reuther papers, box 31, file 11.

25. "AFL-CIO and the ICFTU," 4 March 1961, Geijer personal papers, box 58.

26. Walter Reuther to Meany, 14 February 1961, Becu papers (ICFTU); Ross to Brown, 27 January 1961, IAD Brown files, box 33, file 20; Walter Reuther to Meany, 2 March 1961, Becu papers (ICFTU); "Personal Notes Dictated by Walter Reuther," 8 March 1961, Victor Reuther papers, box 31, file 11; Walter Reuther to Meany, 8 March 1961, Becu papers (ICFTU); Meany to Becu, 9 March 1961, Geijer personal papers, box 58.

27. Brown to Becu, 30 January 1961, IAD Lovestone files, box 13, file 1.

28. Brown to Ross, 8 February 1961, IAD Brown files, box 33, file 20.

29. Ibid.

30. "Notes on Africa by Irving Brown," 19 February 1961, IAD Brown files, box 7, file 12; Irving Brown, "ICFTU 21st Executive Board Meeting," 18 March 1961, IAD Brown files, box 23, file 3.

31. Brown to Ross, 8 February 1961, IAD Brown files, box 33, file 20; Brown to Ross, 14 March 1961, IAD Brown files, box 8, file 2.

32. Irving Brown, "ICFTU 21st Executive Board Meeting," 18 March 1961, IAD Brown files, box 23, file 3; Becu to Lovestone, 8 February 1961, IAD Lovestone files, box 41, file 12.

33. Brown to Meany, 19 June 1961, IAD Lovestone files, box 13, file 1; Brown to Ross, 14 June 1961, IAD Brown files, box 33, file 21. 
34. George Woodcock (1904-79) started work as a cotton weaver in Lancashire at the age of twelve. In his mid-twenties, he won a trade union scholarship to Ruskin College, Oxford, and later obtained a degree from Oxford University. Following two years as a civil servant, in 1936 he joined the TUC as head of its economics department and, in 1947, was promoted to assistant general secretary. Aloof and deeply intellectual, he was prone to treat union meetings as though they were seminars, causing puzzlement among delegates at one TUC annual conference when he famously posed the question: "What are we here for?" "Memorandum of Interview: Discussion with Mr. Walter Reuther, AFL-CIO, 7 May 1959," TUC Archives, MSS 292/973/16.

35. Woodcock was, for example, disturbed over the $\$ 60,000$ allocated from the solidarity fund to build the ICFTU College in Kampala. Minutes of joint meeting of TUC International Committee and TUC Commonwealth Advisory Committee, 9 March 1959, TUC Archives, MSS 292/901/15; Woodcock to Oldenbroek, 23 April 1959, TUC Archives, MSS 292/919.66/2. Victor Reuther was concerned at the new general secretary's attitude toward the ICFTU and urged his brother to stop over in London for a talk with him on his next visit to Europe, telling him: "There is a danger that Woodcock may develop a disinterest in the ICFTU because of the new AFL-CIO tensions and the net effect of this would be to further erode the ICFTU position." Six months later, Victor Reuther declared himself "very disturbed" about the TUC's continuing negative attitude as reflected in its wish to abolish the solidarity fund. Victor Reuther to Walter Reuther, 25 January 1961, Reuther-Carliner records, 1955-63, box 6, file 18, and 8 August 1961, Reuther-Carliner records, 1955-63, box 7 , file 3 .

36. Minutes of ICFTU Executive Board meeting, 28 November-2 December 1960, ICFTU Archives, folder 104a.

37. Ross to Lovestone, 6 December 1960, Lovestone papers (Hoover), box 542, file: Michael Ross. The sum included $\$ 75,000$ that the Americans had earmarked for Nigeria, the purpose of which Becu queried, since no such sum had been requested by the Nigerian unions. Becu to Meany, 8 February 1961, IAD Brown files, box 23, file 12.

38. Minutes of ICFTU Executive Board meeting, 13-16 March 1961, ICFTU Archives, folder 105a; minutes of ICFTU Executive Board meeting, 30 October-2 November 1961, ICFTU Archives, folder 106a; Nedzynski to author, 15 April 1999. Stefan Nedzynski (1919-2008) was born in Poznan and served three years in a labour camp following the Soviet invasion of Poland in 1939. On release, he joined the Polish army, fighting in the Middle East and Italy. Refusing to be repatriated after the war, he completed his university studies in Britain and worked for the Post Office Engineering Union before moving to the economics department of the ICFTU in the early 1950s. In 1958, he joined the Postal, Telegraph and Telephone International (PTTI) and rose to assistant general secretary. Becu recruited him to the ICFTU in 1961, and he worked for three years as assistant general secretary responsible for organizing, before rejoining the PTTI in 1964 as general secretary. He was proposed as a candidate for ICFTU general secretary when Becu retired but was vetoed by George Woodcock on grounds that he had already quit jobs with the ICFTU twice before. Staunchly anti-communist, he instinctively sympathized with many 
positions adopted by the AFL-CIO in the Cold War but found working with George Meany difficult. In retirement, he represented Solidarność (Solidarity) overseas.

39. Brown to Lovestone, 8 June 1961, IAD Lovestone files, box 13, file 1; Brown to Ross, 14 June 1961, IAD Brown files, box 33, file 21; Brown to Meany, 19 June 1961, IAD Lovestone files, box 13, file 1; Ross to Brown, 21 June 1961, IAD Brown files, box 33, file 20.

40. "Statement to the Executive Board by the General Secretary of the ICFTU on the AATUF [Conference] Held in Casablanca," 26 June 1961, IAD Country files, 1945-71, box 14, file 15; "Africa: The Casablanca Trade Union Conference": "Statement by N.O. Eshiett" and "Comments by Ahmed Tlili," Free Trade Union News, June 1961. Becu wrote to Geijer: "I have ... no hesitation in saying that the Casablanca Conference was [a] hundred per cent political in character and worse than that, there was a real indication that it was communist inspired." Becu to Geijer, 4 July 1961, Geijer personal papers, box 17; Stefan Nedzynski, "My Days with International Trade Union Movement" (typescript, 1992), 88-89; Nedzynski to author, 20 October 2004.

41. Irving Brown, untitled report, 6 October 1961, Lovestone papers (Hoover), box 356, file: Irving Brown, 1961-63. Jay Lovestone was unhappy with Brown's "unorthodox" approach in believing that he could control Ben Seddik and so act as a restraining influence on AATUF. He had never wavered from his original opinion, formed in the mid-1950s, that Seddik was wholly untrustworthy. He was therefore against giving him any help. By all means try to win him over, but Brown needed to remember that Seddik "uses the ICFTU" and is "the leader of an African group urging a break with the ICFTU." Lovestone to Brown, 18 July 1961, Lovestone papers (Hoover), box 356, file: Irving Brown, 1961-63. Yet Brown never completely lost faith in Ben Seddik, telling Lovestone: “There is an outside chance that he will make an important turn in the pan-African movement. If our people remain united, there is a real possible split on the issue of disaffiliation and related issues." Brown to Lovestone, 24 December 1963, Lovestone papers (Cornell), box 1, file 26. David Brombart, who was present at the 1961 Casablanca conference as an observer and later worked as Brown's assistant in the AALC, disputes Lovestone's assessment of Ben Seddik. Brombart shared Brown's view that Seddik was a nationalist, not a communist, and notes that under his presidency of AATUF over the next decade there was no signed agreement with the WFTU. This was the litmus test for Brown's strategy. Brombart to author, 2 September 2015 .

42. Brown to Ross, 10 August and 15 August 1961, IAD Brown files, box 33, file 20.

43. "Letter from Irving Brown," 8 June 1961, Lovestone papers (Hoover), box 356, file: Irving Brown, 1961-63. For Brown's nuanced assessment of the situation in Africa at this time, see his undated report on the Casablanca conference sent to Lovestone on June 2, 1961. Brown, “Pan-African Trade Union Congress, Casablanca, 25-29 May 1961," IAD Lovestone files, box 13, file 1.

44. Brown to Lovestone, 24 June and 11 August 1961, Lovestone papers (Hoover), box 356, file: Irving Brown, 1961-63; Brown to Ross 14 July 1961, IAD Lovestone files, box 13, file 1. 45. In Nedzynski’s view, they weren't. Nedzynski to author, 11 April and 28 July 2004. 
46. Becu to Meany, 28 September 1962, Lovestone papers (Hoover), box 353, file: Omer Becu 1960-65; H. F. B. Fane to A. G. Wallis, 31 January 1962, LAB 13/1615.

47. Becu to Walter Reuther, 19 September 1962, Reuther-Carliner records, 1955-63, box 124, file 16; Lovestone to Brown, 9 October 1961, Lovestone papers (Hoover), box 356, file: Irving Brown, 1961-63.

48. Lovestone to Brown, 9 October 1961, Lovestone papers (Hoover), box 356, file: Irving Brown, 1961-63.

49. Brown to Lovestone, 7 November 1961, Lovestone papers (Hoover), box 356, file: Irving Brown, 1961-63.

50. Brown's four-day visit in November 1961 came at a time when the CVT was struggling to survive. Once favoured by the Diem government, it was now subject to repression by this increasingly authoritarian regime. A frequent contributor to the Free Trade Union News, Phan Quang Dan, was imprisoned, and Tran Quoc Buu, president of the CVT, was also considered to be at risk. Brown's presence signalled American support for both of them. His report on the trip noted both the recent successes of the Viet Cong in identifying with the masses and, in contrast, the corruption and ineffectiveness of the Diem government. Tran Quoc Buu greatly impressed him, and it was in connection with Brown's talk of a "total fight against a total enemy" that the latter suggested a paramilitary role for the CVT, going beyond labour's traditional social and political role. Intriguingly, he also wrote that Buu might be considered "in terms of any possible reshuffling of the political control of the government." Irving Brown, "Report on Vietnam Trip," 17-21 November 1961, cited in Edmund Wehrle, “'Reprehensible Repercussions': The AFL-CIO, Free Trade Unionism, and the Vietnam War, 1947-75," 165-69. See also Edmund F Wehrle, Between a River and a Mountain: The AFL-CIO and the Vietnam War. Wehrle provides the most detailed account of AFL-CIO activities in Vietnam. Brown's 1961 trip can be seen as the real beginning of a continuing attempt by the AFL-CIO to influence the political course in South Vietnam via the CVT. As we shall see, the scope for such activity increased with the overthrow of Diem in 1963 and the expanding US military involvement in Vietnam from 1964.

51. Becu to Meany, 28 September 1963 , Becu papers (ICFTU). It was all so characteristic of Becu's indecisiveness and his tendency, when in a tight spot, to try to play both sides of the fence.

52. Becu's occasional, unexplained illnesses dated back to his ITF days. In the ICFTU, where they became more frequent and disabling, people tended to refer to Becu's "migraines," but Harold Lewis, who worked with him at the ITF, considers they may have been more symptomatic of a "nervous breakdown." Lewis to author, 3 December 2009.

53. H. F. B. Fane to A. G. Wallis, 17 November 1961, LAB 13/1514.

54. Brown to Lovestone, 7 November 1961, Lovestone papers (Hoover), box 356, file: Irving Brown, 1961-63; Brown to Becu, 27 December 1961, IAD Brown files, box 23, file 12; Brown to Lovestone, 8 January 1962, IAD Lovestone files, box 13, file 1.

55. Brown to Lovestone, 8 January 1962, and minutes of joint meeting of ICFTU International Solidarity Fund Committee and ICFTU Finance Sub-Committee, 18-19 January 1962, IAD Brown files, box 24, file 18 . 
56. Brown to Lovestone, 14 January 1962, Lovestone papers (Hoover), box 356, file: Irving Brown, 1961-63; Brown to Ross, 27 December 1961, Lovestone papers (Hoover), box 356, file: Irving Brown, 1961-63; “Re: Conversation with George Meany," n.d. [February? 1962], IAD Brown files, box 33, file 17.

57. Unsigned, untitled memorandum, 27 January 1962, IAD Lovestone files, box 13, file 1. Formerly associated with the hatters union, Braunthal had worked in the ICFTU secretariat for ten years and was keen to return to the United States.

58. Brown to Ross, 30 January 1962, IAD Brown files, box 33, file 22; Brown to Meany, 5 February 1962, IAD Lovestone files, box 13, file 1.

59. Lovestone to Meany, 8 February 1962, Lovestone papers (Hoover), box 379, file: George Meany 1960-69.

6o. Becu to Brown, 24 March 1962, IAD Lovestone files, box 13, file 1; Brown to Meany, 26 March 1962, IAD Brown files, box 8, file 3; Brown to Lovestone, 27 March 1962, IAD Lovestone files, box 13, file 1 .

61. ICFTU Report of Seventh World Congress, Berlin, 5-13 July 1962 (Brussels: ICFTU, 1962), 21; Nedzynski, "My Days with International Trade Union Movement," 68.

62. Minutes of ICFTU Executive Board meeting, Berlin, 12 July 1962, ICFTU Archives, folder 107; Brown to Meany, 23 July 1962, Lovestone papers (Hoover), box 356, file: Irving Brown, 1961-63. The TUC delegation that took exception to Brown's travels was by no means made up of people with an anti-American bias. Apart from Frank Cousins, the other six elected members were all from the mainstream or right wing of the movement. Brown gave no particular reason for the planned African trip other than that various African leaders had invited him. Becu to Meany, 28 September 1962, Lovestone papers (Hoover), box 353, file: Omer Becu, 1960-65. On the question of his entitlement to travel to Africa, he was supported by Becu's deputy, Stefan Nedzynski, who reminded the general secretary of a recent conversation when Brown talked of the need to keep up his interest in Africa. On that occasion, Becu had responded by instructing Nedzynski to cooperate with him in such situations. But Becu gave Nedzynski short shrift, and as the latter recalled: "Becu coldly told me to mind my own business and not to get involved in something that was of no concern to me." Nedzynski to author, 2 December 2003; Nedzynski, "My Days with International Trade Union Movement," 94.

63. Brown to Becu, 28 July 1962, IAD Brown files, box 7, file 12; Brown to Meany, 24 August 1962, Lovestone papers (Hoover), box 353, file: Becu 1960-65.

64. Brown to Lovestone, 16 December 1962, and Brown to Meany, 19 December 1962, Lovestone papers (Cornell), box 1, file 23.

65. Brown to Meany, 24 August 1962, Lovestone papers (Hoover), box 353, file: Omer Becu, 1960-65.

66. Meany to Becu, 30 August 1962, Becu to Meany, 28 September 1962, and Meany cable to Becu, 4 October 1962, Lovestone papers (Hoover), box 353, file: Omer Becu, 1960-65; Mboya to Meany, 27 September 1962, IAD Country files, 1945-71, box 11, file 5 . In Brown's correspondence files on this topic (IAD Brown files, box 7, file 12), there is a single page, undated and apparently from a longer letter to him, possibly from Mboya, which reads: 
"The only way to save the situation in Africa now is not through the ICFTU as such, but through dedicated democrats and fighters like yourself and a few others; the programme henceforth should increasingly place emphasis on direct relations between the national centres in Africa and their counterparts like the AFL-CIO. To use the ICFTU organ now is to refuse to recognize the need for a change in tactics.... By all means we shall defend the ICFTU and affiliation to it, but by itself alone it will not be enough.”

67. Lovestone to Brown, 31 October 1962, IAD Lovestone files, box 13, file 1.

68. Brown to Lovestone, 21 November 1962, Lovestone papers (Hoover), box 356, file: Irving Brown, 1961-63; H. F. B. Fane to A. G. Wallis, 8 December 1962, LAB 13/1615. Revealing a remarkable capacity to remain above the fray, Ross wondered why Becu put up with being hammered from left and right, first by the AFL-CIO and then the TUC. Why, he pondered, didn't he just tell Meany and Woodcock to get together and reach an understanding so that he and the ICFTU could get on with their job?

69. Lovestone to Brown, 17 December 1962, IAD Lovestone files, box 13, file 1.

70. Brown to Becu, 12 January 1963, Becu papers (ICFTU); Brown to Lovestone, 6 January 1963, Lovestone papers (Hoover), box 356, file: Irving Brown, 1961-63.

71. Brown to Lovestone, 16 December 1962, and Brown to Meany, 19 December 1962, Lovestone papers (Cornell), box 1, file 23 .

72. Untitled document, 10 January 1963, Lovestone papers (Cornell), box 3, file 25 .

73. H. F. B. Fane to A. G. Read, 15 September 1964, LAB 13/2015. Following military service in the US Marines, Ernie Lee had gained limited experience of trade unionism from working in the South American regional office of the International Federation of Commercial, Clerical and Technical Employees in Lima. Ironically, Lovestone had been behind Lee's hiring by the AFL-CIO, suggesting it to Meany in an attempt to curry favour. It reflected his manipulative side, and he did it without consulting Ross, who was his boss. Ross's secretary, Rosy Ruane, recalled that on learning of Lee's appointment, Ross had thrown up his hands in horror. He then told her to "teach him [Lee] the job." She duly gave up her Thanksgiving weekend to do so. A few days later, she saw his paycheque and noted that it was double her salary. "A girl remembers such a thing," she mused thirty-three years later. After Lovestone had succeeded Ross and grew frustrated with Lee, she would tease him, telling him he only had himself to blame for suggesting that Lee be hired in the first place. Author interview with Rosy Ruane, 14 January 1995.

74. Brown to Meany, 19 December 1962, Lovestone papers (Cornell), box 1, file 23.

75. Irving Brown, "Memorandum for the Record: Meeting with President Meany," 7 February 1963, IAD Brown files, box 18, file 8; The Scope and Distribution of United States Military and Economic Assistance Programs: Report to the President of the United States from The Committee To Strengthen the Security of the Free World (Washington, 1963).

76. By including in his resolution this reference to a role for employers, he was replicating the practice adopted in AIFLD. Untitled draft (“A new chapter has been opening up ...”), n.d. [1963?], IAD Brown files, box 1, file 23.

77. Brown to Lovestone, 29 June 1964, Lovestone papers (Hoover), box 356, file: Irving Brown, $1964-65$. 
78. Lovestone to Brown, 7 August 1964, Lovestone papers (Cornell), box 1, file 29.

79. Lovestone to Victor Reuther, 24 April 1964, Reuther-Carliner records, 1962-68, box 27, file 15.

8o. Irving Brown memorandum: "Possible Projects for Proposed Afro-American Labour Centre," 11 August 1964, Lovestone papers (Cornell), box 1, file 29. In 1963, when the idea of the AALC was first discussed, Ernie Lee seemed to assume that he would become director and had even hired a representative, Rowland P. Pollard, to work in North Africa. Pollard quit his job after a few months.

81. John P. Windmuller, "Leadership and Administration in the ICFTU: A New Phase of Development," 150-55, 167, 169; Victor Reuther to Windmuller, 11 March 1963, ReutherCarliner records, 1962-68, box 1, file 10.

82. Minutes of joint meeting of ICFTU International Solidarity Fund Committee and ICFTU Finance Sub-Committee, 14-15 January 1963, ICFTU Archives, folders 879-84; Nedzynski, "My Days with International Trade Union Movement," 94; Nedzynski to author, 8 August 2004.

83. The IMF had received $\$ 30,000$ from the International Solidarity Fund toward important organizing work among Latin American metalworkers in 1961, and this was now beginning to pay dividends. But Meany closed the door to any further assistance.

84. Irving Brown, "Memorandum for the Record: Meeting with President Meany," 7 February 1963, IAD Brown files, box 18, file 8. A prime example of how Meany and Brown differed over the ICFTU arose six weeks after the launch of the AALC when the ICFTU executive board appointed a working party to review its work in Africa, which most now accepted had been a failure. Among the topics to be considered by the working party was a revised approach that would prioritize such things as vocational training, the promotion of worker cooperatives, housing schemes, and other tools of economic development that the AALC had recently agreed were central to its own approach. Brown regarded the move by the ICFTU as a positive development and, recognizing that it still had a vital role as a clearing house and coordinating centre for devolved solidarity activities in Africa, urged Meany to insist on a seat for the AFL-CIO on the working party beside the three members already appointed-George Woodcock, Donald MacDonald, of the CLC, and Ludwig Rosenberg, of the DGB. But Meany wasn't interested and declined his advice. When the African unions also requested a seat on the working party, Meany opposed their demand as pointless. And when Tunisia’s Ahmed Tlili remonstrated with Meany for being so negative, the AFL-CIO president rounded on him and told him angrily that he didn't give a damn for the working party, nor did he consider the ICFTU up to handling problems in Africa. He added: "If things have to be done and money spent in Africa, then I can tell you we are not going to do it through the ICFTU. I'll give it to Irving Brown to do it." Irving Brown, "Some Private Notes on the ICFTU Executive Board Meeting, 30 November-3 December 1964," IAD Brown files, box 18, file 8; agenda item 4a: "Africa," minutes of ICFTU Executive Board meeting, 30 November-3 December 1964, ICFTU Archives, folder 127.

85. Nedzynski, "My Days with International Trade Union Movement," 94-95. 
86. Walter Reuther to Geijer, 24 January 1963, Reuther-Carliner records, 1962-68, box 6o, file 5; Victor Reuther to Walter Reuther, 18 January 1963, Reuther-Carliner records, 1962-68, box 1, file 4; Becu to Walter Reuther, 8 February and 19 February 1963, Becu papers (ICFTU); Victor Reuther to Walter Reuther, 1 October 1963, Reuther-Carliner records, 1962-68, box, file 4; Walter Reuther to Geijer, 15 August 1963, Geijer personal papers, box 65.

87. Nedzynski to author, 11 July 2004, 9 December 2004.

88. “WPR Notes for George Meany file," 22 March 1963, Victor Reuther papers, box 31, file 11.

89. Becu to Brown, 28 January, 29 July, and 10 August 1964, ICFTU Archives, folder 5067.

9o. Becu to Brown, 10 May 1963, Lovestone papers (Cornell), box 1, file 24; Becu to Brown, 21 May 1963, Lovestone papers (Hoover), box 353, file: Omer Becu, 1960-65; Brown to Becu, 31 May 1963, Lovestone papers (Cornell), box 1, file 24.

91. Windmuller, "Leadership and Administration," 151.

92. Becu to Brown, 10 May 1963, Lovestone papers (Cornell), box 1, file 24; Kalmen Kaplansky, "Observations on Certain Aspects of International Labour Activities," 9 January 1964, CLC Archives, reel $\mathrm{H}-193$.

93. It was in the course of these visits that Brown first made the acquaintance of Nana Mahomo, an official of the Pan-African Congress in exile. In the 1980 s he was hired by the AALC to take charge of training South African trade union leaders, and as such played a significant part in shaping AFL-CIO policy toward South Africa in the final years of apartheid.

94. Meany to Ross, 13 August 1963, Meany files, 1940-80, box 6o, file 19; Brown to Lovestone, 29 July 1963, Lovestone papers (Cornell), box 1, file 25; Brown cable to Meany, 5 August 1963, Lovestone papers (Hoover), box 356, file: Irving Brown, 1961-63.

95. Nedzynski, "My Days with International Trade Union Movement," 95.

96. Minutes of International Solidarity Fund Committee meetings, 5-6 December 1963 and 3-4 December 1964, ICFTU Archives, folders 112 and 127; agenda item 7: "Conclusions of 19th and 2oth International Solidarity Fund Committee Meetings on the Future of the International Solidarity Fund," minutes of ICFTU Executive Board meeting, 2-4 March 1964, ICFTU Archives, folder 119; Irving Brown, "Some Private Notes on the ICFTU Executive Board Meeting, 30 November-3 December 1964," IAD Brown files, box 18, file 8; Nedzynski, "My Days with International Trade Union Movement," 95; Nedzynski to author, 15 April 1999 and 12 August 2004.

97. Nedzynski to Becu, 12 September 1964, Becu papers (ICFTU); Nedzynski to author, 12 August 2004; Brown to Lovestone, 20 June 1964, Lovestone papers (Hoover), box 356, file: Irving Brown, 1964-65.

98. Irving Brown, "Report of First Year of the Reorganized Activity of the ICFTU New York Office," 31 May 1963, Lovestone papers (Cornell), box 1, file 24; "Code for Political Prisoners," New York Times, 6 October 1962; Irving Brown, "Memorandum for the Record: Meeting with President Meany," 7 February 1963, IAD Brown files, box 18, file 8.

99. Brown to Becu, 31 May 1963, Lovestone papers (Cornell), box 1, file 24.

10o. Untitled report on ICFTU Executive Board, n.d. [March 1963], IAD Lovestone files, box 41 , file 16 . 
101. Ibid. African trade union centres belonging to the ICFTU and Christian IFCTU who were not attracted by the neutralism of AATUF formed the African Trade Union Confederation (ATUC) in 1962 as an expression of pan-Africanism that was still open to organizational links with international bodies outside Africa. It merged with AATUF to form the Organization of African Trade Union Unity in 1973.

102. Brown to Becu, 13 March 1964, Lovestone papers (Cornell), box 1, file 27.

103. "Re: ICFTU College in Kampala, Uganda, June 1964," undated memorandum on telephone conversation with Irving Brown from Brussels, Belgium, Lovestone papers (Cornell), box 1, file 28; Becu to Brown, 8 June 1965, IAD Brown files, box 8, file 6.

104. Irving Brown memorandum, "Executive Board Meeting of the ICFTU, Brussels, 30 November-3 December 1964," IAD Brown files, box 18, file 8.

105. Irving Brown memorandum, "ATUC", 5 October 1964, IAD Brown files, box 18, file 8. Stefan Nedzynski, who had responsibility for ICFTU liaison with ATUC up to his resignation three weeks prior to this meeting, considered Brown's dealings here hard to credit and "a pipe dream." Nedzynski to author, 8 August 2004.

106. Buu to President Johnson, 20 May 1964, IAD Brown files, box 39, file 27; Tran Quoc Buu, "Social Progress Key to Victory in Vietnam," Free Trade Union News, June 1964.

107. Brown told Meany: "This entire programme will involve a certain amount of financial aid ... In light of the tremendous amounts spent on the military, it seems ... that there should be no difficulty in getting sufficient amounts." He was thinking in terms of $\$ 10,000$ a month in the first instance, with the amount possibly reducing to zero within two years. This was obviously money that was expected to come mainly from non-trade union sources. Brown pointed out that initially it would require a contribution from the AFL-CIO, "augmented from other sources" but always funnelled through the AFLCIO-CTV Joint Committee. Brown to Meany, 1 June 1964, and Brown to Lovestone, 20 June 1964, Lovestone papers (Hoover), box 356, file: Irving Brown, 1964-65. Five weeks later Brown wrote to Lovestone about his flying visit to Saigon. He had met Jim Killen, AID director in South Vietnam and former vice president of the pulp and paperworkers' union, who was ready to make "all sorts of financial provisions in a proper way so that there would be very little burden on us.... In view of the tremendous amount of money being spent in Vietnam, almost \$2 million a day, I don't think that anyone can begrudge us a very, very small percentage." Brown to Lovestone, 4 August 1964, Lovestone papers (Hoover), box 356, file: Irving Brown, 1964-65.

108. H. F. B. Fane to A. G. Read, 27 July 1964, LAB 13/2012. The AFL-CIO experienced initial difficulties in staffing the Vietnamese operation. Henry Kirsch, a former staff member of the National Committee for a Free Europe and veteran of FTUC fieldwork in the early 1950s, and Thomas Altaffer, who first appeared on the scene in 1963 working in the AFL-CIO's Paris office after Irving Brown had transferred to the ICFTU, were sent to Saigon in 1965. However, Kirsch objected to having to work with Altaffer, pointing out to Meany that he had "previously been identified as a CIA man," with the result that "the effort to provide direct AFL-CIO assistance to the CVT was subject to the suspicions of the CIA and U.S. government involvement." Kirsch to Meany, n.d., IAD Lovestone files, 
file 63(12). Altaffer was almost certainly with the CIA and had been very anxious that his name not be publicized at a press conference called in Saigon. Earlier Lovestone had considered him for a position with the AALC when that body was first being planned but came to the conclusion that he lacked "seasoning." Lovestone to Brown, 11 June 1964, Lovestone papers (Hoover), box 356, file: Irving Brown, 1964-65. A few months after his short-lived partnership with Kirsch, Altaffer disappeared from the scene, and AFL-CIO files contain no further trace of him.

109. Brown to Lovestone, 1 June and 11 June 1964, Lovestone papers (Hoover), box 356, file: Irving Brown, 1964-65. Meany would complain to Geijer of Becu's indecisiveness, the weakness of his programs, and the fact that he was absent from his office so often, either travelling abroad or on sick leave. Geijer's response was to tell Meany that it was he who bore responsibility for Becu's deep insecurity, citing the issue of Brown's dual role, which Meany condoned. "Meany is a not a man one can talk to. He is a man who likes to tell people what to do," Geijer later told a press conference. A report of the press conference is contained in an untitled document marked "Limited Use," dated 15 January 1965 and evidently prepared by the Embassy of the United States, Stockholm, possibly by its labour attaché, J. Kaukonen. See also J. Kaukonen to State Department, 20 January 1965, Meany files, 1940-80, box 62, file 8; "Differences of Opinion Within ICFTU," Landsorganisationen i Sverige, Information to Foreign Countries, series 3, no. 3 (March 1965), Arbetarrörelsens arkiv och bibliotek, Stockholm.

110. Irving Brown, untitled report on ICFTU Executive Board, n.d. [March 1964], IAD Lovestone files, box 41, file 16; Irving Brown memorandum for Meany, "Notes on 21st ISFC Geneva Meeting, 18-19 June," 17 June 1964, Lovestone papers (Cornell), box 1, file 27.

111. Brown memorandum for Meany, "Notes on 21st ISFC Geneva Meeting, 18-19 June," 17 June 1964, Lovestone papers (Cornell), box 1, file 27.

112. Irving Brown, "Some Private Notes on the ICFTU Executive Board Meeting, 30 November-3 December 1964," Irving Brown memorandum for George Meany, "Executive Board Meeting of the ICFTU, Brussels, 30 November-3 December 1964," IAD Brown files, box 18 , file 8 .

113. Lovestone to Brown, 11 June 1964, Lovestone papers (Hoover), box 356, file: Irving Brown, 1964-65.

114. Brown to Lovestone, 23 June 1964, Lovestone papers (Cornell), box 1, file 28.

115. Irving Brown, "Some Private Notes on the Executive Board Meeting, 30 November-3 December 1964," IAD Brown files, box 18, file 8.

116. Becu to Brown, 18 December 1964, Becu papers (ICFTU).

117. Minutes of ICFTU Executive Board meeting, 15-16 March 1965, ICFTU Archives, folder 127.

118. Becu to Brown, 25 March 1965, Geijer personal papers, box 25; Meany to Becu, 29 April 1965, Becu papers (ICFTU).

119. Meany to Becu, 1 March 1965, IAD Lovestone files, box 41, file 19; "AFL-CIO May Stop Funds to World Trade Union Group," New York Times, 3 March 1965.

120. Lovestone to Brown, 4 March 1965, Lovestone papers (Hoover), box 356, file: Irving Brown, 1964-65; H. F. B. Fane to A. G. Read, “The AFL-CIO and the ICFTU," 25 March 
1965, LAB 13/2015. What bothered Lovestone was not so much fairies as "communists," and over the next two years he persisted in the view that there were still some of those on the ICFTU staff. J. J. Watson to J. Oates, 8 November 1967, LAB 13/2432.

121. Minutes of ICFTU Executive Board meeting, 15-16 March 1965, ICFTU Archives, folder 127; Kalmen Kaplansky memorandum for Claude Jodoin, "Report on 36th Executive Board of ICFTU," CLC Archives, reel H-194; “Crisis in World Trade Unions After U.S. Threat to Leave," Times (London), 15 March 1965. Meany's explanation was that, when he said "fairies," he wasn't referring to homosexuals but to "ineffectual sort[s] of people," his disingenuous claim being that this was what the term meant in America and Ireland, where his forebears came from. Becu grudgingly accepted this but still noted that he would be upset if he were called a "fairy." "International Trade Unions Under Fire," Times (London), 17 March 1965; "At the Bottom of the Garden," The Economist, 20 March 1965.

122. Kalmen Kaplansky memorandum for Claude Jodoin, "Report on 36th Executive Board of ICFTU," CLC Archives, reel H-194; “International Trade Unions Under Fire," Times (London), 17 March 1965; Meany to Becu, 25 March 1965, Becu papers (ICFTU); Becu to Arturo Jauregui, 25 March 1965, Lovestone papers (Cornell), box 3, file 40.

123. Minutes of TUC International Committee meeting, 23 March 1965, TUC Archives, MSS 292D/901; Kalmen Kaplansky to Donald MacDonald, June 1965, CLC Archives, reel H-436.

124. Geijer to Walter Reuther, 28 April 1965, Geijer personal papers, box 40; Vidkun Ulriksson (Swedish labour attaché in Bonn) to Geijer, 18 May 1965, Geijer personal papers, box 72; "Memorandum of Discussion Between Mr. G. Meany and Mr. E. Smith on Wednesday, 30 June 1965," and "AFL-CIO Application for Refund of Unspent Allocations," Becu papers (ICFTU). Ernst Smith was a middle-ranking official of a small British trade union whose occasional work for the ICFTU involved conducting an internal audit of the accounts of its overseas offices and reporting back to the ICFTU finance officer. It is not clear whether Meany considered him a whistle-blower or merely reckoned that a well-publicized meeting with the auditor would help to dramatize his accusations of financial malpractice. According to Stefan Nedzynski (who, until six months earlier, had been an assistant general secretary), Smith was not held in high regard as an auditor and was not taken seriously within the ICFTU, although he was recognized within the organization as a troublemaker. He also noted that Smith seemed to relish the chance to parlay himself into high-level ICFTU policy discussions alongside "big league" players like Meany and Brown, trading on items of information gleaned on his travels. Nedzynski to author, 5 November 2003.

125. Irving Brown memorandum to George Meany, "The ICFTU and Its Future," n.d. [April 1965?], and "Memorandum on the Leadership of the ICFTU Secretariat," n.d. [1965], IAD Brown files, box 9, file 14. The author of the last document is unknown, though it was evidently the work of someone based in North Africa who had an interest in the region's trade unions. It referred favourably to supporters of Irving Brown in UGTA and UMT and went on to float the possibility of a joint ICFTU election slate comprising the Tunisian trade union leader Ahmed Tlili for president and Irving Brown for general secretary. Interestingly, it was written in idiomatic English, suggesting that it could 
have been the work an American. It remains an intriguing possibility that the author was Rowland P. Pollard, who appeared mysteriously as an "AFL-CIO representative" in Algeria in 1964, having evidently been hired by Ernie Lee. After writing a few reports from the field and contributing a news item on the work of CARE in Algeria for the May 1964 issue of the Free Trade Union News, Pollard soon disappeared from the AFL-CIO books, leaving little trace and with hardly anyone in the federation even aware of his existence. ICFTU assistant general secretary Stefan Nedzynski, who devoted much time to North Africa in that period, claimed never to have heard of Pollard, and yet it seems inconceivable that he would not have been aware of a bona fide AFL-CIO representative working in Algeria. Commenting on the contents of a 1964 report that Pollard had sent to Irving Brown from Algeria, Nedzynski noted that its remarks on the trade union situation were factually incorrect and that the author was "probably not a trade unionist." "I would not be surprised if it turned out that he worked for intelligence" was Nedzynski's judgment. Nedzynski to author, 17 January 2005.

126. Lovestone to Meany, 24 May 1965, Meany files, 1940-80, box 6o, file 20; George Meany, "The ICFTU: Estimate and Perspective," AFL-CIO News, 12 June 1965, as well as Free Trade Union News, June 1965.

127. Irving Brown, "Memorandum for Record," 22 June 1965, Brown files, box 8, file 6; Nedzynski to author, 9 December 2004.

128. Kaplansky to Jodoin, 23 July 1965, CLC Archives, reel 436.

129. "IVVV Schiet te Kort," Het Parool, 7 July 1965. Lovestone's biographer quotes Meany as saying in Amsterdam: "I have been in Brussels and looked at the books, but the money is not satisfactorily accounted for." Ted Morgan, A Covert Life: Jay Lovestone, Communist, Anti-Communist, and Spymaster, 322.

130. "Notes Concerning Mr. G. Meany's Statement in Het Parool," n.d. [July 1965], Becu papers (ICFTU); ICFTU Report of the Eighth World Congress, Amsterdam, 7-15 July 1965 (Brussels: ICFTU, 1962), 505-27.

131. "Isolation of the AFL-CIO in the Congress, Amsterdam, 7-15 July 1965," LAB 13/2015; Geijer to Becu, 18 August 1965, Becu papers (ICFTU). Bill Mahoney, director of the Canadian section of the United Steelworkers, wrote to the union's American international president, I. W. Abel, to complain that "Meany ran the [North American] delegation this time as a one-man show." He went on to say: "It is my view, and I know it was shared by a substantial part of the delegations to the World Congress, that Meany presented a horrible and totally incorrect picture of the attitude of the American labour movement toward other unions in the world." Mahoney to Abel, 23 July 1965, United Steelworkers of America, Canadian Division fonds, MG28 I 268, vol. 33, file 9.

132. Lovestone to Meany, 17 August 1965, Lovestone papers (Hoover), box 379, file: George Meany, 1960-69. Mischievously, in his letter, Lovestone also sought to associate Walter Reuther with the criticisms prevailing in the Swedish labour press. Reuther and his family had recently vacationed in Sweden with the Geijers. "Forgive me," Lovestone wrote Meany, "I don't mean the entire leadership. One man is excluded very definitely from the criticism." 
133. "Auch die heißen Eisen wurden mutig angefaßt," Welt der Arbeit, 16 July 1965; Lovestone to Georg Leber, 21 July 1965, IAD Country files, 1945-71, box 2, file 15. Lovestone continued to vent his spleen the next day when he cancelled the AFL-CIO subscription to the German Tribune, which provided a digest of news from West Germany. Lovestone to German Tribune, 22 July 1965, IAD Country files, 1945-71, box 2, file 15.

134. Brown to Lovestone, 11 November 1965, Lovestone papers (Hoover), box 356, file: Irving Brown, 1964-65; Bergeron to Lovestone, 29 December 1965, IAD Country files, 1945-71, box 2, file 5; Lovestone to Meany, 31 December 1965, Lovestone papers (Cornell), box 3 , file 40 .

135. Brown to Naomi Spatz, 22 July 1965, IAD Brown files, box 1, file 27; "Memorandum for the Record," unsigned [Irving Brown], [July] 1965, IAD Brown files, box 8, file 6.

136. Becu to Brown, 28 July 1965, IAD Lovestone files, box 41, file 19; Brown to Becu, 27 August 1965, Lovestone papers (Hoover), box 353, file: Omer Becu, 1960-65; Brown to Lovestone, 1 October 1965, Lovestone papers (Cornell), box 1, file 31; Brown to Meany, 8 October 1965, and Brown to Becu, 28 October 1965, IAD Brown files, box 8, file 6; Brown to Lovestone, 9 April 1966, Lovestone papers (Hoover), box 356, file: Irving Brown, $1966-67$.

137. "Memorandum for the Record," unsigned [Irving Brown], [July] 1965, IAD Brown files, box 8, file 6. Storti attended the AFL-CIO convention in December 1965, hoping to elicit a more cooperative response from Meany. Brown urged that, while in the United States, Storti be given plenty of time alone with Meany and that Lovestone impress on the AFL-CIO president the need to be more than simply passive: "There is a chance to do something if anyone is still interested in the ICFTU." Irving Brown, untitled document ("After one week in Europe ..."), 8 November 1965, and Brown to Lovestone, 9 November 1965, Lovestone papers (Hoover), box 356, file: Irving Brown, 1964-65.

138. British Embassy, Washington, telegram no. 427 to Foreign Office, 3 February 1966, LAB $13 / 2432$.

139. Author interview with John Vanderveken, 21 April 1995.

140. Minutes of ICFTU Sub-Committee meeting, 21 November 1966, Reuther-Carliner records, 1962-68, box 59, file 4 .

\section{Chapter 7: Who Speaks for American Labour?}

1. A. M. Morgan to A. G. Wallis, 12 February 1960, LAB 13/1459.

2. Reuther was absent from the infamous ICFTU executive board meeting in November 1960, where Meany rounded on Becu for failing to deliver the staffing appointments expected of him. The UAW leader judged that it was more important for him to remain in the United States as President-Elect Kennedy deliberated over appointments to his administration. Indeed, Reuther had already spent several days as a guest in the Kennedy family home on Cape Cod, at Hyannis Port, where he reckoned he had won Kennedy's support for the idea of the Peace Corps. Anthony Carew, Walter Reuther, 101. 
3. Author interview with Joseph Rauh, 7 July 1987.

4. Lovestone to Brown, 13 December 1960, IAD Lovestone files, box 12, file 17. That same week, Victor Reuther was a guest of mayor Willy Brandt in Berlin, where he gave a press interview to the Hannover Telegraf. George Meany's reaction to this interview spoke volumes about the competition for influence then bubbling up between the two camps. In the interview, the younger Reuther presented himself as an intimate of the president-elect, telling the paper that the Reuthers' relations with the White House were "even closer than those we had with Truman and Roosevelt" and indicating that he knew exactly Kennedy's mind on how to handle the Berlin crisis. His remarks received wide international publicity and clearly needled Meany, who read them while in Europe for the ICFTU executive board meeting. He forwarded the text to Kennedy's brother Robert with a sarcastic covering note: "Dear Bob, I thought you might be interested, and perhaps even amused, by the interview given by a spokesman for the new Administration." Meany to Robert Kennedy, 6 December 1960, Meany files, 1940-80, box 66, file 3 .

5. Lovestone to Brown, 18 July 1961, Lovestone papers (Hoover), box 356, file: Irving Brown, 1961-63; Victor Reuther to Walter Reuther, 28 July 1961, Reuther-Carliner records, 1955-63, box 7 , file 1 .

6. Lovestone to Brown, 18 July 1961, Lovestone papers (Hoover), box 356, file: Irving Brown, 1961-63.

7. H. F. B. Fane to A. G. Wallis, two letters of 24 May 1961, LAB 13/1513.

8. "Dictated by WPR," 14 August 1961, Victor Reuther papers, box 31, file 11.

9. Adlai Stevenson to Meany, 7 September 1961, Meany files, 1940-80, box 53, file 19; Lovestone to Virginia Tehas, 13 September 1961, Lovestone papers (Hoover), box 389, file: Virginia Tehas, 1956-74; Joseph C. Goulden, Meany, 304. It plainly rankled with Reuther that he had been rebuffed, and in an aide-mémoire written shortly after Kennedy's assassination, he recorded that in their last private conversation, a matter of days before the president's death, Kennedy had finally agreed to his appointment to the UN delegation in 1964, having concluded that Meany was wrong to veto him. "Dictated by WPR," 20 February 1964, Victor Reuther papers, box 31, file 11.

10. Victor Reuther to Harry Pollack, 24 May 1962, Reuther-Carliner records, 1955-63, box 7 , file 25; Walter Reuther to Leo Cherns, 14 May 1963, Reuther-Carliner records, 1962-68, box 1, file 21; Nat Weinberg to Walter Reuther, 25 January 1962, Reuther-Carliner records, 1955-63, box 66, file 22. Not all delegates to the UAW convention agreed with the use of interest from the strike fund for international programs. This was something Reuther would later have to take on board when a split between the UAW and the AFL-CIO loomed as a reality and he had to persuade members of the case for withdrawing from the AFL-CIO mainly in terms of domestic disagreements rather than differences over foreign policy.

11. Victor Reuther to Claudio Rocchi, 12 October 1961, Reuther-Carliner records, 1955-63, box 7, file 10 . 
12. "Victor Reuther Statement to IMF Executive Committee, Oslo, 7-10 August 1962," Reuther-Carliner records, 1955-63, box 115, file 24; Victor Reuther to Walter Reuther, 17 July 1963, Reuther-Carliner records, 1962-68, box 1, file 28.

13. "Discussion of Agenda for UAW International Free World Labour Defence Fund Programme with UAW Department Heads," Reuther-Carliner records, 1955-63, box 10, file 8; Victor Reuther to Miles Galvin, 18 February 1963, Reuther-Carliner records, 1962-68, box 1 , file 7 .

14. Since 1959, the IMF had enjoyed some success in Spain in encouraging the formation of a broad alliance of metalworkers embracing all except the communists. Levinson to Victor Reuther, 9 June 1959, Reuther-Carliner records, 1955-63, box 120, file 3.The 1962 action marked a new phase of anti-Franco agitation, and in 1962, through meetings between Victor Reuther and Ed Murrow, the head of the U.S. Information Service, the UAW was beginning to press the Kennedy administration for a favourable American response.

15. "UAW Donates $\$ 10,000$ to Spanish Strikers in Struggle for Political Freedom," Labour News from the United States, June 1962; Victor Reuther to Alberto Uriarte, 5 June 1962, Reuther-Carliner records, 1955-63, box 7, file 26; Victor Reuther to Gonzalez Malo and Miguel Ortiz, 19 May 1964, Reuther-Carliner records, 1962-68, box 2(33).

16. Draft press release, 3 April 1963, Reuther-Carliner records, 1962-68, box 1, file 13; Walter Reuther to Aaron Becker, 10 April 1963, Reuther-Carliner records, 1962-68, box 1, file 14; Walter Reuther to Becu, 18 May 1964, Reuther-Carliner records, 1962-68, box 2, file 33; Herbert Wehner to Victor Reuther, 24 July 1964, Reuther-Carliner records, 1962-68, box 3, file 5; Victor Reuther to Alfred Nau, 10 August 1964, Reuther-Carliner records, 1962-68, box 3, file 8; Walter Reuther to Makris, 18 May 1964, Reuther-Carliner records, 1962-68, box 2, file 33; Victor Reuther to Walter Reuther, 24 June 1964, Reuther-Carliner records, 1962-68, box 3, file 2. The UAW grant and loan to the Greek national trade union centre GSEE was strongly criticized by Irving Brown, who warned Meany to have no truck with a confidential proposal by Becu that the ICFTU should pass Reuther's money to the Greeks. Brown to Lovestone, 26 January, 11 June, and 22 June 1964, and Lovestone to Brown, 11 June 1964, Lovestone papers (Hoover), box 356, file: Irving Brown, 1964-65.

17. Victor Reuther to C. Chakulya, 6 June 1964, Reuther-Carliner records, 1962-68, box 3, file 3; Walter Reuther to Canon Collins, 1 May 1963, Reuther-Carliner records, 1962-68, box 34, file 20; Victor Reuther to Fritz Heine, 27 June 1963, Reuther-Carliner records, 1962-68, box 1, file 26; Victor Reuther to Anthony Steele, 8 June 1964, Reuther-Carliner records, 1962-68, box 2, file 36; Victor Reuther to Walter Reuther, 7 July 1964, Reuther-Carliner records, 1962-68, box 3, file 4; Carliner to Victor Reuther, 7 August 1963, Reuther-Carliner records, 1962-68, box 3, file 27.

18. Victor Reuther to Geijer, 31 January 1962, Reuther-Carliner records, 1955-63, box 9, file 25; UAW questionnaire, September 1962, Reuther-Carliner records, 1955-63, box 7, file 32; Victor Reuther to Graedel, 12 November 1962, Reuther-Carliner records, 1955-63, box 7, file 37; Walter Reuther to Mennen Williams, 20 November 1962, Reuther-Carliner records, 1955-63, box 10, file 23; Victor Reuther to Walter Reuther, 8 April 1963, ReutherCarliner records, 1962-68, box 1, file 14; Victor Reuther to Walter Reuther, 21 January 1964, 
Reuther-Carliner records, 1962-68, file 2, box 18; Jim Crellin, "UAW Will Pioneer with World Auto Union Parley Here," Detroit News, 1 December 1966; Lewis Carliner, “The Dispute That Never Was," 608.

19. Victor Reuther to Sargent Shriver, 10 November 1964, Reuther-Carliner records, 1962-68, box 3, file 18; Saville R. Davis, "Organized Labour Steps Up International Programmes," Christian Science Monitor, 16 January 1966; "UAW Overseas Role Is Stressed," Detroit News, 23 March 1967; Patrick J. Owns, “UAW’s Peace Corps Gets Back in Action,” Detroit Free Press, 18 March 1967.

20. Victor Reuther to Irving Bluestone, 13 March 1964, Reuther-Carliner records, 1962-68, box 2, file 24; Norman Thomas to Walter Reuther, 17 July 1964, Reuther-Carliner records, $1962-68$, box 18 , file 3 .

21. The concept of world coordinating councils had been germinating in the automobile industry since 1956. Such councils were established on a firm basis in 1964 and, in 1968, at the height of the UAW conflict with the AFL-CIO, began to aim for the coordination of collective bargaining strategies across national frontiers. Walter Reuther, "Mobilize the Unions Against Super Corporations," Tribune, 6 June 1969. In 1967, seeking to encourage the extension of the concept to other industries, the UAW arranged for a grant of $\$ 20,000$ to the International Chemical Workers' Federation, under the leadership of Charles Levinson, to support the organization's activities in Latin America, after Levinson adopted the UAW model of world coordinating councils for organizing the oil and chemical industries. As a further show of support, the UAW also affiliated to the International Chemical Workers' Federation. Minutes of IMF Executive Council meeting, Vienna, 23-28 November 1964, Reuther-Carliner records, 1962-68, box 51, file 6; Victor Reuther to Walter Reuther, 7 June 1967, Reuther-Carliner records, 1962-68, box 38, file 20.

22. A key consideration in Italy for the UAW leadership was that, among organized metalworkers, the combined membership of FIM (CISL) and UILM (UIL), together with the non-communist membership of FIOM (CGIL), more than matched the size of the majority communist bloc in FIOM.

23. See "JFK, la Nuova Frontiera e il centro-sinistra italiano," a special issue of Critica sociale (no. 5/6) published in November 20I3, on the fiftieth anniversary of Kennedy's death, including Schlesinger's article, "Kennedy, Pietro Nenni e la svolta progressista: Il racconto di Schlesinger." Reuther belonged to a network formed by Schlesinger in April 1962 under the name of the International Study Group on Freedom and Democracy (ISG). Schlesinger steered this body from his office in the White House, with the help of a European secretariat in Bologna led by Fabio Luca Cavazza. Cavazza was editor of the intellectual journal Il Mulino and was well connected in the State Department and to members of the National Security Council. The ISG aimed to bring together figures from the American centre-left with their European counterparts - politicians such as Ugo La Malfa, Erich Ollenhauer, Giuseppe Saragat, Hugh Gaitskell, and Anthony Crosland. Schlesinger consulted Walter Reuther about his project from the outset; the UAW donated $\$ 2,500$ by way of seed corn, and Victor Reuther served on the ISG advisory council. Former Socialist International official Adolph Sturmthal, who occasionally advised 
Reuther on international labour issues and was involved in the early stages of setting up the ISG, warned Reuther about the inadvisability of the group hiring a former CIA officer, Dana B. Durand, to work in the secretariat in Washington. This may have deterred the Reuthers from playing a more vigorous role in the organization, though their personal links with Schlesinger remained strong. Arthur M. Schlesinger Jr., A Thousand Days: John F. Kennedy in the White House, 263-64; "Proposal for a Worldwide Democratic Initiative," 29 December 196I, Reuther-Carliner records, I955-63, box 40, file 23; Dana Durand to Victor Reuther, 27 June 1962, Reuther-Carliner records, 1955-63, box 96, file II; Adolph Sturmthal to Victor Reuther, 5 July I962, Reuther-Carliner records, I955-63, box 40, file 23; Sturmthal to Williams, 4 May I962, Reuther-Carliner records, I955-63, box 40, file 22; Sturmthal to Walter Reuther, I3 March 1963, and to Victor Reuther, 22 October 1963, Reuther-Carliner records, 1962-68, box I8, file I; Victor Reuther to Durand, II October I963, Reuther-Carliner records, I962-68, box II, file I3; Victor Reuther to Durand, 3 November 1963, Reuther-Carliner records, I962-68, box 3, file I7.

24. Arnold Steinbach to Carliner, 23 April 1963, Reuther-Carliner records, 1962-68, box 37, file 17 .

25. Walter Reuther to Bruno Storti, 6 June 1962, Reuther-Carliner records, 1955-63, box 10, file 8; Victor Reuther, "Memorandum to UAW Officers, Executive Board Members and Education-Citizenship Staff," 6 March 1962, Reuther-Carliner records, 1955-63, box 10, file 1.

26. Walter Reuther to Italo Viglianesi, 6 June 1961, Reuther-Carliner records, 1955-63, box 6, file 27; Victor Reuther to Val Agostinone, 24 May 1961, Reuther-Carliner records, 1955-63, box 6, file 25; Victor Reuther to Corrado de Luca, 4 August 1961, Reuther-Carliner records, 1955-63, box 7, file 2; Schlesinger, A Thousand Days, 749.

27. On a recent trip to Italy, Harry Goldberg, of the AFL-CIO international affairs department, had been taken aback on being told by Fr. Mario Reina, Pope Paul VI's onetime trouble-shooter on labour issues, that the pontiff personally supported the turn to the left and was absolutely in favour of Nenni joining a centre-left government. Goldberg also reported his concern at signs that a new generation of militants in CISL were attempting to compete with the CGIL "on class terms" as an instrument of workers' struggle. Harry Goldberg, "Meetings with Rev. Mario Reina of Italy," 18 September 1962, IAD Country files, 1945-71, box 5, file 9.

28. Before the Reuthers travelled to Italy, Arthur Schlesinger arranged for them to brief Assistant Secretary of State Foy Kohler. Victor Reuther to Graedel, 14 March 1962, Reuther-Carliner records, 1955-63, box 7, file 19; Victor Reuther to Paolo Vittorelli, 18 June 1962, and Victor Reuther to Giacomo Brodolini, 29 June 1962, Reuther-Carliner records, 1955-63, box 7, file 27; Item 6d "Italy," IMF Central Committee, 8 August 1962, Oslo, Reuther-Carliner records, 1955-63, box 114, file 10.

29. Victor Reuther, The Brothers Reuther, 352. There could be no doubting the built-in resistance to a change in policy among embassy staff. Ambassador Frederick Reinhardt had complained to President Kennedy about Schlesinger's "meddling” in Italian affairs. Military attaché Vernon Walters (a future deputy director of the CIA) had actually recommended military intervention if necessary to block the formation of the centre-left 
government. Arthur M. Schlesinger Jr., “The Kennedy Administration and the CentreLeft," 188. In calling for a change of attitude toward the Italian socialists, Walter Reuther was able to cite the most recent formulation of PSI policy on neutralism as furnished by international secretary Paolo Vittorelli and the meaning this had for NATO. It boiled down to an ingenious statement that, while the PSI retained its commitment to neutralism, it accepted that this could not be pursued on a unilateral basis, since to do so would increase rather than ease international tension. In effect, the differences between East and West had to be settled first before Italian neutralism became operational. Vittorelli to Walter Reuther, 21 July 1962, Reuther-Carliner records, 1955-63, box 96, file 11.

30. Victor Reuther, The Brothers Reuther, 352; author interview with Victor Reuther, 6 July 1987; Victor Riesel, “What's Behind Meany-Reuther Split?” New York Mirror, 24 October 1962; “Note for George Meany Files," 14 August 1962, Victor Reuther papers, box 31, file 11.

31. Victor Reuther to Vittorelli, 10 April 1963, Reuther-Carliner records, 1962-68, box 1, file 14; Victor Reuther to Frank Rosenblum, 18 June 1963, and Victor Reuther to Brodolini, 18 June 1963, Reuther-Carliner records, 1962-68, box 1, file 25.

32. Victor Reuther to Viglianesi, 20 February 1963, Reuther-Carliner records, 1962-68, box 1, file 8; Walter Reuther to Willy Brandt, 3 April 1963, Victor Reuther papers, box 27, file 26; Victor Reuther to Nicolo Pistelli, 27 March 1963, Reuther-Carliner records, 1962-68, box 35, file 17; Schlesinger, $A$ Thousand Days, 751.

33. The financial request came via Fabio Luca Cavazza. Cavazza to Victor Reuther, 12 July 1963, Reuther-Carliner records, 1962-68, box 35, file 20; Victor Reuther to Vittorelli, 2 October 1963, Reuther-Carliner records, 1962-68, box 2, file 4; Victor Reuther to Cavazza, 9 October 1963, Reuther-Carliner records, 1962-68, box 2, file 5. Adolphe Graedel (190280) was general secretary of the Swiss Watchmakers' and Metalworkers' Union (1945-55) and succeeded Konrad Ilg as IMF general secretary from 1955 to 1970 . He was close to Victor Reuther during these years of spectacular membership growth.

34. Victor Reuther to Walter Reuther, 12 February 1964, Reuther-Carliner records, 1962-68, box 2, file 19; Dan Benedict to Victor Reuther, 22 April 1964, Reuther-Carliner records, 1962-68, box 35, file 23; Victor Reuther to Benedict, 28 April 1964, Reuther-Carliner records, 1962-68, box 2, file 31.

35. Victor Reuther to Walter Reuther, 12 February 1964, Reuther-Carliner records, 1962-68, box 2, file 19; Victor Reuther to Walter Reuther, 13 May 1964, Reuther-Carliner records, 1962-68, box 2(32).

36. Giovanni Mosca (1927-2000) was a member of CGIL's farm labourers' union and later metalworkers' union. He was a leader of the PSI in Milan (1961-64) and, as such, helped form the city's first centre-left administration in 1961. As leader of CGIL's socialist faction, he served as assistant general secretary from 1964 to 1972 . Between 1963 and 1979, he was a socialist deputy in the Italian parliament.

37. Victor Reuther to Walter Reuther, 7 April 1966, Victor Reuther papers, box 36, file 25.

38. Lovestone to Meany, 31 December 1965, Lovestone papers (Cornell), box 3, file 40; Edward Scicluna to Lovestone, 12 October 1965, IAD Country files, 1945-71, box 5, file 11; Scicluna to Lovestone, 21 December 1965, IAD Country files, 1945-71, box 5, file 10; Scicluna 
to Lovestone, 12 January 1966, IAD Country files, 1945-71, box 5, file 11; Lovestone to Scicluna, 28 October 1965 and 5 January 1966, IAD Country files, 1945-71, box 5, file 11; Harry Goldberg, "Italian Trade Union Situation," 10 January 1966, IAD Country files, 1945-71, box 5, file 11.

39. Willy Brandt to author, 20 August 1985; Walter Reuther, "Note: Follow Thru Per Conversation with Willy Brandt," 11 July 1962, UAW President's Office: Walter P. Reuther Records, box 463, file 5; Brandt to Walter Reuther, 7 January 1963, Victor Reuther papers, box 27, file 24; Victor Reuther to Brandt, 15 January 1963, Reuther-Carliner records, 1962-68, box 1, file 3; Walter Reuther to Brandt, 29 January 1963, Victor Reuther papers, box 27, file 24; Victor Reuther to Walter Reuther, 29 March 1963, Reuther-Carliner records, 1962-68, box 1, file 3; Harold Wilson to Walter Reuther, 29 August 1963, Victor Reuther papers, box 35, box 11; Willy Brandt to Walter Reuther, 15 July 1963, Victor Reuther papers, box 27, file 28; Walter Reuther to Tage Erlander, 22 July 1963, Victor Reuther papers, box 28, file 1; Weinberg to Walter Reuther, 21 July 1965, Weinberg papers, box 19, file: Chronological File, July-December 1965.

40. Minutes of IMF Central Committee meeting, Lugano, 16-20 September 1957, ReutherCarliner records, 1955-63, box 112, file 7; Joe Miyazawa to Graedel, 8 May 1956, Reuther-Carliner records, 1955-63, box 106, file 11; Victor Reuther to Walter Reuther, 22 July 1958, Reuther-Carliner records, 1955-63, box 8, file 5 .

41. Although Sōhyō's leadership was generically Marxist rather than communist, about a quarter of its membership were reckoned to be under communist discipline. Sōhyō leaders were often close to Chinese communists whose claim to be "non-aligned" was taken on faith.

42. Lovestone to Meany, 25 March 1953, Meany files, 1947-60, box 56, file 2; Lovestone to Meany, n.d. [October? 1956], Meany files, 1947-6o, box 56, file 15.

43. Deverall to Lovestone, 11 September 1956, Meany files, 1947-6o, box 56, file 14.

44. Between 1955 and 1961, under the Japan Productivity Centre's program, 856 Japanese trade unionists visited the United States, of whom 55 percent were from Zenrō unions and only 20 percent from Sōhyō affiliates. Koji Nakakita, "Incorporating Japanese Labour into the Free World: Cold War Diplomacy and Economic Interdependence, 1949-64," 207, 211.

45. Edwin O. Reischauer, My Life Between Japan and America, 239; Akira Iwai to Walter Reuther, 28 May 1960, Reuther-Carliner records, 1955-63, box 106, file 21; Ernest Jones, secretary of the Miners' International Federation, "Report to the International Solidarity Fund Committee, 13-14 June 1960," ICFTU Archives, folder 193a; Haruo Wada cable to Meany, 20 June 1960, and Wada to Meany, 22 June 1960, IAD Country files, 1945-71, box 27, file 12; Lovestone to Meany, 20 June 1960, IAD Lovestone files, box 49, file 14.

46. Jay Lovestone saw no sign of any real change in Sōhyōs approach and advised Meany that it was still "the most dangerous enemy of democracy in the Far East alongside the Chinese Commie outfit." Lovestone to Meany, 31 October 1960, IAD Lovestone files, box 49, file 14. The recently retired labour attaché in Tokyo, Ed Skagen, a member of the machinists' union, disagreed, observing: "We cannot take the stand that Sōhyō leadership is completely dominated by the Communist Party as we will eventually defeat our purposes. 
We must adopt a position of helpful neutrality and let them work out their own answers to their own problems." Ed Skagen, "What's Behind the Tokyo Riots," The Machinist, 7 July 1960; Skagen to Lovestone, 28 July 1960, Meany files, 1947-60, box 57, file 9.

47. Victor Reuther to Dick Kelly, 25 March 1958, Reuther-Carliner records, 1955-63, box 3, file 28; Victor Reuther to Walter Reuther, February 1958, Victor Reuther papers, box 25, file 15; Victor Reuther to Walter Reuther, 22 July 1958, Reuther-Carliner records, 1955-63, box 8, file 5.

48. Reischauer, My Life Between Japan and America, 161-71.

49. Asahi Shinbun, 7 July 1962; Carliner to Victor Reuther, 7 March 1962, Reuther-Carliner records, 1955-63, box 10, file 1; Victor Reuther to Ross, 29 May 1962, Reuther-Carliner records, 1955-63, box 7, file 25; Victor Reuther to Arthur Goldberg, 31 May 1962, ReutherCarliner records, 1955-63, box 106, file 31.

50. Ambassador, Tokyo, to Department of State, "Formation of Federation of Automobile Workers Unions," 19 February 1962, Reuther-Carliner records, 1955-63, box 108, file 1; Becu to Walter Reuther, 1 August 1962, IAD Country files, 1945-71, box 28, file 8; Victor Reuther to Carliner, 11 July 1962, Reuther-Carliner records, 1955-63, box 10, file 12.

51. "Joint Statement by Japanese Joint Trade Union Sponsoring Committee and UAW," 24 November 1962, Reuther-Carliner records, 1955-63, box 108, file 7; Pollack to Ross, 25 November 1962, IAD Country files, 1945-71, box 28, file 8; A. M. Rosenthal, "Japan Is Stirred by Reuther Visit: Union Unity and Better Pay Seen as Possible Results," New York Times, 2 December 1962; Victor Reuther to Robert Kennedy, 10 January 1963, ReutherCarliner records, 1962-68, box 1, file 3 .

52. Victor Reuther to Becu, 27 March 1963, and Victor Reuther to Harald Simon, 28 March 1963, Reuther-Carliner records, 1962-68, box 1, file 12.

53. H. F. B. Fane to Department, 18 December 1962, LAB 13/1615.

54. "Memorandum of Discussion with Takeo Katayama at University of Illinois, 15 January 1963" 7 February 1963, Reuther-Carliner records, 1962-68, box 44, file 23; Victor Reuther to Walter Reuther, 14 January 1963, Reuther-Carliner records, 1962-68, box 1, file 1; Victor Reuther to Walter Reuther, 12 February 1963, Reuther-Carliner records, 1962-68, box 1, file 3.

55. Haruo Wada to Meany, 8 April 1963, and Meany to Wada, 2 May 1963, IAD Country files, 1945-71, box 29, file 4. Haruo Wada (1919-99) began work as a qualified mate in the Japanese merchant marine in 1939. In 1945, he joined the All Japan Seamen's Union, becoming an organizer in 1948. He participated in the formation of Sōhyō in 1950 and was appointed a permanent secretary. Opposed to the leftward drift under Minoru Takano, he was a central figure in the AFL-backed breakaway that led to the formation of Zenrō in 1954, becoming its first general secretary. With Zenrō's absorption into Dōmei in 1964, he was elected vice president. As a member of the Democratic Socialist Party, he served as a deputy in the lower house of the Diet from 1969 to 1972 and in the upper house from 1974 to 1979.

56. Haruo Wada, "Free Trade Unionism in Japan: Retrospect and Prospect," Free Trade Union News, June 1963. 
57. Wada to Meany, 4 June and 4 September 1963, IAD Country files, 1945-71, box 27, file 13; Wada to Walter Reuther, 9 January 1964, and Ernest Lee to Wada, 23 January 1964, IAD Country files, 1945-71, box 29, file 4.

58. Harry Goldberg, "The World Through the Eyes of Sōhyō," Free Trade Union News, February 1964; Meany cable to Becu, 28 February 1964, IAD Country files, 1945-71, box 27, file 15 .

59. Lovestone to Meany, 15 October 1964, Lovestone papers (Hoover), box 379, file: George Meany, 1960-69.

6o. Katsumi Yakabe, "Reaction to Meany's Visit to Japan," Nikkan Kogyo Shimbun, 20 November 1964.

61. Akira Iwai cable to Meany, 12 July 1965, IAD Country files, 1945-71, box 27, file 14.

62. Victor Reuther was appalled at the extent to which the Japanese trade unionists he talked to still accepted uncritically the employers' argument that their firms' trading position was precarious and so were uneasy about demanding higher wages. Victor Reuther to Weinberg, 4 April 1963, Reuther-Carliner records, 1962-68, box 1, file 13.

63. Stanley Greenspan to Victor Reuther, 13 December 1965, Reuther-Carliner records, 1962-68, box 47, file 2.

64. Rosy [Ruane] to Ernie [Lee], 13 January 1966, Lovestone to Ethel Epstein, 18 January 1966, and Epstein to Wada, 11 February 1966, IAD Country files, 1945-71, box 29, file 5; Epstein to Lovestone, 15 March 1967, Kihata to Lovestone, 11 April 1967, and Lovestone to Kihata, 20 April 1967, IAD Country files, 1945-71, box 28, file 1; Shogo Ohki to Victor Reuther, 20 February 1968, Victor Reuther papers, box 40, file 6; Victor Reuther, The Brothers Reuther, 406.

65. Victor Reuther to Walter Reuther, 28 November 1956, Reuther-Carliner records, 1955-63, box 2, file 3; Victor Reuther to Walter Reuther, 25 February 1957, Reuther-Carliner records, 1955-63, box 2, file 14; Victor Reuther to Walter Reuther, 22 July 1958, Reuther-Carliner records, 1955-63, box 4, file 9; Levinson to Graedel, 15 February 1957, Reuther-Carliner records, 1955-63, box 2, file 13; Charles Levinson, "Report on the Trade Union Situation and Scope for IMF Action in Latin America," submitted to the meeting of the IMF Central Committee, Lugano, 16-20 September 1957, Reuther-Carliner records, 1955-63, box 112, file 7; author interview with Dan Benedict, 29 July 1998.

66. Walter Reuther to Benedict, 23 July 1959, Victor Reuther papers, box 26, file 11.

67. Dan Benedict, “Cuba: Hopes and Fears in Latin America," July 1961, Victor Reuther papers, box 41, file 15.

68. Victor Reuther to Graedel, 3 November 1960, Reuther-Carliner records, 1955-63, box 6, file 12; Victor Reuther to Graedel, 6 January 1961, Reuther-Carliner records, 1955-63, box 6, file 16; Dan Benedict, "Report to the IMF General Secretary on Inter-American Activities, 1 March-31 July 1961," Reuther-Carliner records, 1955-63, box 120, file 10.

69. Schlesinger, A Thousand Days, 152, 175-76, 182-85.

70. Victor Reuther to Ted Moscoso, 15 June 1962, Reuther-Carliner records, 1955-63, box 68, file 8; Victor Reuther to Walter Reuther, 20 December 1962, Reuther-Carliner records, 1955-63, box 10, file 27; Victor Reuther to Walter Reuther, 20 May 1964, Reuther-Carliner records, 1962-68, box 2, file 33 . 
71. Victor Reuther to Richard Goodwin, "Towards a Community of Democratic American States," 4 May 1961, Reuther-Carliner records, 1955-63, box 61, file 22; "A Labour Programme for Latin America," n.d. [May 1961?], Reuther-Carliner records, 1955-63, box 52, file 27; "On the Need for an Agency Capable of Undertaking Projects in the Labour Field on ICA Contracts," 6 May 1961, Reuther-Carliner records, 1955-63, box 9, file 7.

72. Weaver to Goldberg, "A Programme for Labour Action in Latin America," 24 May 1961, Reuther-Carliner records, 1955-63, box 52, file 27.

73. "A Proposal for a Comprehensive Educational Programme for Leaders of South American Trade Unions," 17 August 1960, Meany files, 1947-6o, box 56, file 27; John McCollum to Walter Reuther, 17 October 1961, Reuther-Carliner records, 1955-63, box 20, file 8. In the summer of 1961, the AFL-CIO Executive Council voted a further \$13,00o to see the UREP project through until the end of the year. Minutes of AIFLD Board of Trustees meeting, 11 October 1961, Meany files, 1940-80, box 57, file 1.

74. At the time, there was confusion in Reuther's immediate office as to how he had become involved with AIFLD: he couldn't recall an invitation to the initial May 1961 meeting. Otha Brown to Victor Reuther, 24 May 1961, Reuther-Carliner records, 1955-63, box 20, file 8.

75. J. Peter Grace, “It's Not Too Late in Latin America," Minutes of AIFLD Board of Trustees meeting, 11 October 1961, Meany files 1940-80, box 57, file 1. Even if one accepts the legitimacy of a role for employers in this trade union institute, the choice of Grace was hard to comprehend. As president of W. R. Grace, Peter Grace had interests in shipping, sugar growing and refining, paper manufacture, food processing, paint making, banking, and insurance throughout Latin America and was also a director of Kennecott Copper. He was on the political right and was a supporter of the journal Human Events, which shared publishing facilities with the John Birch Society. Irving Bluestone to Victor Reuther, 16 October 1962, Reuther-Carliner records, 1955-63, box 10, file 20. Besides Grace and Brinkerhoff, other business leaders who became members of the board of trustees included Juan Trippe of Pan American Airlines, Robert C. Hill, of Merck and Co., and H. S Woodbridge, of True Temper Corporation. In 1966, AIFLD's director, Bill Doherty, informed the British labour counsellor in Washington that there were fifty US corporations "contributing" to AIFLD operations. H. F. B. Fane to J. Oates, 30 March 1966, LAB 13/2432.

Jack Otero, who hailed from the railroad clerks' union and was serving as Latin American representative of the International Transport Workers' Federation in the early 1960s, was puzzled by the decision to have Grace on the AIFLD board and raised the issue with BRAC's president, George Harrison, only to be cautioned against questioning Meany's decision. Harrison told him: "Meany is looking at the big picture, Jack, and you are not even inside the museum door." Otero got the message and kept his mouth shut. Otero to author, 24 June 2015. Born in Cuba, Joaquin (Jack) Otero (1934-2016) emigrated in 1954 to the United States, where he joined BRAC, the railway clerks' union. Following his six-year stint as ITF representative in Latin America, he returned to BRAC in 1967 and was, for twenty-two years, an international vice president. He was later assistant secretary 
of labour during the Clinton administration and chief US government negotiator of the NAFTA Labour Supplemental Agreement.

76. Draft letter, Victor Reuther to Walter Reuther, n.d. [September-October 1961], ReutherCarliner records, 1955-63, box 20, file 8 .

77. McCollum to Board of Trustees of AIFLD, 8 January 1962, and Meany to Grace, 22 February 1962, Meany files, 1940-80, box 57, file 1.

78. This account of how the government had come down in favour of AIFLD was recounted three years later by George Weaver to Victor Reuther's deputy, Louis Carliner. Carliner to Walter Reuther, "Kennedy Decision to Support American Institute for Free Labour Development and to Disapprove UAW Proposals for a Council for Social Progress," 10 October 1964, Reuther-Carliner records, 1962-68, box 4, file 4. Even after the formal launch of AIFLD in June 1962, Victor Reuther was still discussing with his brother how to bring the Council for Social Progress into existence. Victor Reuther aide-mémoire, 12 June 1962, Reuther-Carliner records, 1955-63, box 63, file 18 .

79. Serafino Romualdi (1900-1967) fled Italian fascism in 1923 and worked in New York as a publicist for the ILGWU. During World War II, he was a staff member of Nelson Rockefeller's Office of the Coordinator of Latin American Affairs. In the final year of the war, he transferred to the OSS and was sent to Italy by Adolphe Berle (who later devised the intelligence dimension of the Alliance for Progress). He acted as technical advisor to Luigi Antonini on his important Anglo-American trade union mission to Italy and, with OSS permission, handled the distribution of funds intended for the Italian labour movement from the Italian-American Labor Council. After the war, David Dubinsky sent him to Latin America as representative of the Free Trade Union Committee. He transferred to the AFL staff in 1948 and thereafter spent most of his working life in Latin America, in effect as Meany's personal emissary. He was ubiquitous as the American "ambassador" to labour and a "fixer" among "presidents and peons" of often unsavoury, authoritarian regimes. Following the CIA-backed ouster of President Árbenz in Guatemala, the new military strong man, Colonel Armas, thanked AFL officials for their "clear-cut, anti-communist stand" and referred to the invaluable services of Romualdi. AFL News-Reporter, 13 August 1954. Romualdi became very close to the discredited, Batista-supporting Cuban labour leader, Eusebio Mujal, and helped arrange for him to be resettled in the United States after he fled Cuba in 1959. The new pro-Castro leadership of the Cuban CTC made it a precondition of their remaining in ORIT that Romualdi be excluded from its councils. Their already bad relations with the AFL-CIO became worse when it emerged that Romualdi was assisting Mujal and his supporters in exile to gain recognition in international labour circles. Serafino Romualdi, Presidents and Peons, chap. 2; Benedict to Meyer Bernstein, 20 June 1961, Reuther-Carliner records, 1955-63, box 120, file 8; Victor Reuther to Walter Reuther, 22 June 1961, Reuther-Carliner records, 1955-63, box 6 , file 27.

8o. At the end of his career, Romualdi was prepared to share a platform with such a person as the extreme right-winger Fred C. Schwarz of the Christian Anti-Communism Crusade. 
Victor Reuther to Walter Reuther, 22 June 1964, Reuther-Carliner records, 1962-68, box 3, file 2.

81. According to Lovestone's secretary, Rosy Ruane, he tried but failed to dominate Romualdi. Author interview with Rosy Ruane, 14 January 1995. Lovestone complained to Irving Brown: "Romualdi may be in the same building ... but I hear less from him than even from Castro," and "Latin American work is the weakest part of our international affairs situation and you know how weak that means." Lovestone to Brown, 11 July 1960 and 15 May 1961, Lovestone papers (Hoover), box 356, file: Irving Brown, 1960. Interestingly, Romualdi's long and detailed autobiography makes only three passing references to Lovestone and none to Irving Brown.

82. Minutes of AIFLD Board of Trustees meeting, 4 April 1962, Meany files, 1940-80, box 57, file 1; minutes of Labour Advisory Committee for Alliance for Progress meeting, 15 August 1962, Meany files, 1940-80, box 57, file 5. Meany's awareness that he now had this assured source of funding for overseas work coincided exactly with the breakdown in relations between Omer Becu and Irving Brown over the latter's foreign travel and was doubtless a factor behind the AFL-CIO president's instructions to Brown to defy Becu. Soon Meany and Brown would start planning for the African version of AIFLD in the shape of the AALC

83. Romualdi, Presidents and Peons, 426-28.

84. Minutes of AIFLD Board of Trustees meeting, 10 March 1965, Victor Reuther papers, box 11, file 24.

85. Draft, Victor Reuther to Walter Reuther, "American Institute for Free Trade Union Development," n.d. [September-October? 1961], Reuther-Carliner records, 1955-63, box 20, file 8; draft letter, Walter Reuther to Meany, 31 May 1962, Reuther-Carliner records, 1955-63, box 20, file 11; Victor Reuther to Walter Reuther, 17 October 1962, ReutherCarliner records, 1955-63, box 10, file 20. Along with these close family appointments, Meany's son-in-law, Ernie Lee, would soon be seated among the AIFLD trustees.

86. Victor Reuther to Walter Reuther, 1 June 1962, Reuther-Carliner records, 1955-63, box 20, file 11; draft letter, Walter Reuther to Meany, 31 May 1962, Reuther-Carliner records, 1955-63, box 20, file 11 .

87. Draft letter, Victor Reuther to Walter Reuther, 26 April 1962, Reuther-Carliner records, 1955-63, box 10, file 5; Victor Reuther to Robert Johnston, 19 March 1962, Reuther-Carliner records, 1955-63, box 7, file 20; "Confidential: Notes for Discussion with U.S. Metal Unions," 30 August 1963, Reuther-Carliner records, 1962-68, box 58, file 1.

88. "Opening Remarks by Serafino Romualdi: AIFLD Inauguration of First Course," 19 June 1962, Meany files, 1940-80, box 57, file 7; Romualdi, Presidents and Peons, 419.

89. "Conference: Meany, Schnitzler, H. S. Woodbridge, Held in Mr. Meany’s Office in Washington, DC, on Thursday, 27 December 1962," Meany files, 1940-80, box 57, file 5.

90. Norman L. Wolfson, "American Institute for Free Labour Development: A Public Relations Memorandum," February 1963, Meany files, 1940-80, box 57, file 11.

91. Draft letter from Peter Grace, 11 June 1963. The original idea had been for the letter to be signed by both Grace and Meany, but Chase Mellon's suggestion was that a letter solely 
from Grace would seem to businessmen to be more "personal." Chase Mellon to Bill Schnitzler, 11 June 1963, Meany files, 1940-80, box 57, file 6.

92. Victor Reuther to Walter Reuther, 2 November 1962, Reuther-Carliner records, 1955-63, box 3, file 36; Victor Reuther to Walter Reuther, 8 November 1962, Reuther-Carliner records, 1955-63, box 3, file 37 .

93. Victor Reuther to Bluestone, 7 November 1963, Reuther-Carliner records, 1962-68, box 2, file 11.

94. Labour News Conference, Mutual Broadcasting System, "Building Free Trade Unionism in Latin America, Guest: William C Doherty," 12 July 1964, Reuther-Carliner records, 1962-68, box 6, file 9; Romualdi, Presidents and Peons, 289, 291; Victor Reuther to Walter Reuther, 29 July 1964, Reuther-Carliner records, 1962-68, box 6, file 9; Victor Reuther to Joe Keenan, 31 March 1965, Victor Reuther papers, box 11, file 24. On the eve of the coup in Brazil, the US ambassador wrote to Secretary of State Rusk that, in addition to the planned secret delivery of arms of non-US origin, "We are meanwhile undertaking complementary measures ... to help strengthen resistance forces. These include covert support for prodemocracy street rallies ... encouragement of democratic and anti-communist sentiments ... in friendly labour and student groups." State Department Top Secret Cable from Rio de Janeiro, 27 March 1964, National Security Archives, Washington, DC; "Report on Brazil” prepared by AFL-CIO International Affairs Department, 4 May 1964, Meany files, 1940-80, box 68, file 25. The US military attaché in Rio at the time of the coup was Vernon Walters, who, earlier in the decade, had recommended military action in Italy to prevent the advent of a centre-left government.

Bill Doherty Jr. (1926-2011), who was the son of Meany's close friend and former letter carriers' union president Bill Doherty Sr., worked in the regional activities department of the ICFTU (1952-55) before becoming inter-American representative of the PTTI (1955-62) based in Mexico City and Rio de Janeiro. He was the first director of AIFLD's social projects department (1962-64) and then succeeded Serafino Romualdi as executive director (1965-96).

95. Jack Lever to Walter Reuther, 14 January 1965, and "Latin American Development," 8 February 1965, Victor Reuther papers, box 15, file 25. Jack Otero, who was based in Brazil as ITF Latin American representative at the time, argues that the charge that AIFLD was a "cloak and dagger" operation was overstated and that most AIFLD operatives were more like "Keystone Kops" when it came to political operations. Otero to author, 24 June 2015.

96. Draft letter, WPR to Meany, 11 June 1965, and Walter Reuther to Meany, 9 September 1965, Victor Reuther papers, box 11, file 25 .

97. Irked by Reuther's performance at the convention, Lovestone attempted to persuade Meany that remarks Reuther had made afterward on television criticizing both the sclerotic membership of the AFL-CIO executive council and the recent large pay increase voted for Meany were part of a concerted anti-Meany campaign. In future years, Lovestone liked to pretend that he had conceded nothing of substance following Reuther's call for a dilution of the resolution's militaristic language. Lovestone to Meany, 
31 December 1965, Lovestone papers (Cornell), box 3, file 40; Goulden, Meany, 355-56, $375-76$.

98. "Victor Reuther's Request for Governor Harriman's Help in Facilitating Unofficial Contacts with Soviet Trade Unionists, 15 March 1966," Averell Harriman Papers, cited in Edmund Wehrle, "Reprehensible Repercussions: The AFL-CIO, Free Trade Unionism, and the Vietnam War, 1947-75," 218; Victor Riesel, "Victor Reuther's Trip to Moscow Called Open to Searing Criticism," Flint Journal, 27 June 1966. A year earlier, the UAW had invited the leader of the Yugoslav trade union centre, Svetozar Vukmanović-Tempo, to visit its Detroit headquarters during a ten-day tour of the United States. The UAW was keen to keep the event low-key, insisting that he travel at his own expense and that the meeting be informal. Victor Reuther also took care to ask the Department of Labor to assume responsibility for booking his travel and accommodation. However, the visit served to break the ice and led eventually to regular exchanges with the Yugoslavs. They began in 1969, following a visit by Walter Reuther to Belgrade in November 1968 for talks with President Tito. Reuther took advantage of his personal contact with Tito to call for the release from prison of the dissident Mihajlo Mihajlov. Carliner to Assistant Secretary Weaver, 15 December 1964, Reuther-Carliner records, 1962-68, box 4, file 5; Victor Reuther to Walter Reuther, 21 January 1969, and Walter Reuther to Petrovic, January 1969, UAW Reuther-Carliner records, 1962-68, box 40, file 9; Victor Reuther to Ivar Noren, 2 March 1971, Benedict papers, box 30, file: IMF.

99. Riesel, "Victor Reuther's Trip to Moscow Called Open to Searing Criticism," Flint Journal, 27 June 1966.

100. Articles by Dan Kurzman, Washington Post, 30-31 December 1965 and 1-2 January 1966; Goulden, Meany, 377-78.

101. Harry Bernstein, "AFL-CIO Unit Accused of 'Snooping' Abroad," Los Angeles Times, 22 May 1966; Goulden, Meany, 377-78. Andrew McLellan (1911-82) was raised in Scotland and emigrated to Canada and then the United States following the 1926 general strike. In 1934, he joined the meat cutters' union in California. Following military service in the war, he worked for the Texas Federation of Labour from 1947 until he was assigned by the IUF to Central America, based in Honduras. He transferred to the AFL staff as assistant to Serafino Romualdi in 1960 and succeeded him as inter-American representative from 1962. Meanwhile, he continued to act as an IUF consultant until 1965, with effective control of its finance and appointments in Latin America. On these matters, the Geneva headquarters was kept largely in the dark.

In 1963, General Secretary Poulsen was angered to learn that at the IUF's Third Latin American Conference two of the participants had listed their affiliation as "United States Army." A pattern was evident in which the most intense phases of IUF activity in the region happened to coincide with moments of political crisis such as the military coups in Brazil and Bolivia in 1964 and the US-led military intervention in the Dominican Republic in 1965. Poulsen came to realize that IUF policy in Latin America was, in fact, AFL-CIO policy and simply reflected US interests. Under McLellan's influence, the IUF had failed to project a native, homegrown form of trade unionism 
attractive to Latin American workers and in consequence failed to win new affiliates and expand membership. Poulsen estimated that the IUF would have needed the dues income from over half a million members to cover the costs being incurred by the secretariat in Latin America-whereas actual membership was no more than 4,10o. In announcing the closing down of the Latin American operation in 1965 for the good of the wider organization, Poulsen said he was unable to confirm or deny the existence of links to the CIA or whether funds originated from other US government agencies. He left it to the AFL-CIO to answer that question. Poulsen to IUF Managing Committee, 3 April 1967, "Conc: Problems of the IUF Regional Activities [Principles, Goals, Performance and Finance]," document in author's possession; Sigvard Nyström and Peter Rütters, History of the IUF, 279-82. The IUF case illustrated what Victor Reuther believed was taking place more broadly in Latin America in conjunction with AIFLD. In the wake of the IUF scandal, by the spring of 1966 most international trade secretariats had withdrawn from Latin America.

102. Details of the IUF affair had been slow to filter out, and Reuther was slapped down when he first tried to raise it in a meeting of directors of international affairs from various US unions convened by Lovestone in the AFL-CIO headquarters. Reuther also complained to Lovestone that at such meetings called by Lovestone, there were typically almost as many representatives from US government agencies in attendance as from AFL-CIOaffiliated unions. Victor Reuther to Lovestone, 18 March 1966, Victor Reuther papers, box 30, file 31; Lovestone to Meany, 15 April 1966, IAD Lovestone files, box 49, file 15.

Despite Lovestone's attempt to block open discussion of the IUF case, a few months later an article in New Politics, written pseudonymously by Dan Gallin of the IUF, provided a damning review of AFL-CIO international activity. It confirmed Reuther's account of events in the IUF and drew attention to similar experiences in other trade secretariats. David Langley [Dan Gallin], "Colonization of the International Trade Union Movement." Gallin described how, some years earlier, the Swiss general secretary of the PTTI had been dismissed when he enquired how much money was being spent in Latin America (the CWA's Joe Beirne was then the president of the PTTI). The International Federation of Petroleum and Chemical Workers, with a dues income of a mere $\$ 80,000$, still managed to employ two dozen officials at American salaries and maintain offices in various parts of the world, funded by a CIA front.

Between 1960 and 1964, the Latin American operation of the public service trade secretariat, Public Services International, had similarly been hijacked by its US affiliate, AFSCME, undertaking to finance activities and staff with grants amounting to some $\$ 100,000$ a year from CIA-front organizations. None of this was known to Public Services International general secretary Paul Tofahrn in London until AFSCME's new general secretary, Jerry Wurf, quietly closed down the Washington-based operation. An analogous situation prevailed in the clerical and technical workers' international trade secretariat (IFCCTE, later FIET), whose president, James Suffridge, was also president of the retail clerks' union. Much of the cost of staff and offices maintained worldwide by the IFCCTE came from Suffridge's union. On becoming aware of the wider pattern 
of American "colonization" of the trade secretariats, IFCCTE general secretary Erich Kissel approached Tofahrn for advice. Tofahrn told him to make a clean breast of what he knew and close down the operation: "You must put an end to free enterprise under the IFCCTE flag ... chèvre choutisme [trying to reconcile the irreconcilable] inspired by camaraderie will not pay." Kissel subsequently closed down the organization's Lima office, whose staff had been instructed by Suffridge to take instructions only from him in Washington. Jerry Wurf to Paul Tofahrn, 18 September 1964, and Tofahrn to Howard McCabe, 22 September 1964 and 27 June 1965; minutes of Public Services International Executive Committee meeting, 13-14 April 1967; "Comment on an Article in the Sunday Times, 16 April 1967," Public Services International press release, 17 April 1967; Tofahrn to Kissel, 29 March 1967: all documents in author's possession; "Victor Reuther Dictated Notes from Israel," 16 February 1969, Victor Reuther papers, box 39, file 12.

103. Goulden, Meany, 377-78, 385; Archie Robinson, George Meany and His Times, 252; Frank Cormier and William J. Eaton, Reuther, 414.

104. Goulden, Meany, 379-80; H. F. B. Fane to J. Oates, 6 June 1966, LAB 13/2432. The walkout of the US workers' delegation in Geneva in 1966 represented an escalation of US labour's opposition to recent developments within the ILO. At a meeting of its governing body the previous year, Meany had instructed Faupl to fight hard to reverse a decision made under the rules to allocate additional seats to Soviet bloc representatives on certain committees after they had failed to win them in open elections. Unable to alter the results, Faupl flew back to the United States for a specially convened AFL-CIO executive council meeting where Meany secured approval to take the issue up "at the highest level" within the administration. He duly met Secretary of State Rusk and Secretary of Labour Wirtz and warned them that if the drift away from tripartism continued and there was not better coordination at the ILO between the US government and workers' delegations, the AFL-CIO would refuse to nominate worker representatives to the annual international labour conference. In more alarmist terms, Meany told the press that the AFL-CIO might pull out of the ILO. "On Strike Against the World," New York Times, 12 April 1965.

Reporting on these events, Victor Reuther noted that Faupl had received little support for his position from other labour delegates at the ILO and that he overreacted, apparently under instructions from Meany. Reuther agreed with the prevailing sentiment in Europe that it was morally indefensible to pursue a "cold-war strategy" on the technical issue of committee membership: "It appears that the logic of the AFL-CIO position is that we should not only withdraw from the ICFTU but also the ILO and, I suppose, eventually from the human race." Victor Reuther to Walter Reuther, 6 April 1965 and 12 April 1965, Victor Reuther papers, box 28, file 6. Yet AFL-CIO fears over the dilution of the much-prized tripartism of the ILO were long-standing, and the perception was that the problem was growing. Moreover, Assistant Secretary of Labour George Weaver, long a Meany antagonist, appeared willing to make concessions in this area, and the omens for 1966 were not good. Following the 1965 international labour conference, the AFL-CIO's Bert Seidman reported that a "critical situation" now existed 
whose outcome would determine whether the ILO was "worth saving." Bert Seidman, "ILO at the Crossroads," Free Trade Union News, August 1965.

105. Goulden, Meany, 379-80. Evidence to the contrary comes from the British labour counsellor, Brian Fane, who was in Meany's secretary's office waiting to see the president just as news of Chajn's election came through from Geneva. Meany's secretary told him then that Faupl had been "instructed" to withdraw the delegation and that she thought that its members would now pack their bags and come home. It came as little surprise to Fane, who, for over six months, had been advising the British government that Meany was looking for a way of quitting the ILO. That was also the perception of his American counterpart, the US labour attaché in London. H. F. B. Fane to J. Oates, 3 January and 6 June 1966, LAB 13/2432.

The same de facto line of command between Meany and Faupl had been evident the previous year in the dispute over the allocation of ILO committee seats. On that occasion, as Lovestone noted, Faupl was instructed to fight for a reversal of the decision and, in the event of failure, to leave in protest. Two weeks after the June 1966 walkout, Fane dined alone with Meany and reported back to London his impression that the AFL-CIO president's real target in this episode was not Chajn so much as ILO director general David Morse for having lobbied actively on behalf of Chajn and being ready to give special consideration to the recruitment of ILO staff from the Soviet bloc. Meany stressed how communists always succeeded in taking over any organization in which they were active. He also insisted that he had no need of Jay Lovestone to tell him about communists, assuring Fane that he had known all about them long before he met Lovestone. Indeed, Fane noted how Lovestone was privately against the ILO walkout. H. F. B. Fane to J. Oates, 20 June 1966, LAB 13/2432.

106. P. A. G. Westlake to J. Oates, 29 June 1966, LAB 13/2432; Brown to Lovestone, 11 June 1966, Lovestone papers (Hoover), box 356, file: Irving Brown, 1966-67.

107. New York Times, 11 June 1966; Cormier and Eaton, Reuther, 415.

108. Meany to Walter Reuther, 10 June 1966, IAD Lovestone files, box 49, file 15; Lovestone to Brown, 14 June 1966, Lovestone papers (Cornell), box 1, file 32.

109. Goulden, Meany, 383-85. Although Reuther was in a clear minority in the executive council, there was support for him in the press, with the New York Times devoting two editorials to the ILO issue. Describing the walkout as a "self-defeating boycott," it observed: "Building walls instead of bridges seems to be the AFL-CIO's idea of how to arrive at One World." The paper approved of Reuther's protest, which had brought in its train the prospect of a more open debate on the wisdom of Meany's "adamantine stand" against any East-West rapprochement in the labour field. "Labour's Foreign Policy," New York Times, 14 June 1966, and “U.S. Labour's Iron Curtain," New York Times, 20 June 1966. "Bridge building" was a policy initiative of the Johnson administration launched in spring 1966 with the aim of reducing cold-war tensions by means of a series of modest steps leading toward peaceful coexistence and settlement of the division of Germany and Europe. 
110. H. F. B. Fane to J. Oates, 20 June 1966, LAB 13/2432; Victor Reuther to Benedict, 20 June 1966, Benedict papers, box 17, file: Personal, Victor Reuther.

111. Riesel, "Victor Reuther's Trip to Moscow Called Open to Searing Criticism," Flint Journal, 27 June 1966."

112. See, for example, interviews with Herbert Kemmsies, former AIFLD project manager for Brazil, and Frank Elorriaga on his training by the CIA. Victor Reuther papers, box 11, file 29, and box 73, file 27 .

113. Joseph Rauh to Walter Reuther, 22 July 1966, Victor Reuther papers, box 17, file 20.

114. "The AIFLD: An Evaluation of Future Prospects in the Light of Its Record to Date," 15 August 1966, Victor Reuther papers, box 11, file 26. Lovestone had advance information that such a document was likely to be produced in pamphlet form and issued on the eve of the executive council meeting. A Riesel column disclosed that the UAW was working in conjunction with a "prolific writer" to produce the document. Victor Riesel, "Around the Labour World," La Prensa, 12 August 1966. The document was unsigned and is likely to have been the handiwork of Scott Runkle, a Washington-based publicity agent who was engaged from time to time to promote some of the UAW's more ambitious projects. It bore no reference to the UAW, and it is quite likely that it was simply a draft awaiting further refinement.

115. Cormier and Eaton, Reuther, 415-16; Goulden, Meany, 385; Jack Conway, interview with Alice Hoffman, 23 May 1979, AFL-CIO Oral History Project, GMMA.

116. At Victor Reuther's prompting, in February 1967, Drew Pearson and Jack Anderson claimed in the Washington Post that the CIA had ploughed vast sums into the labour movement, none of which was spent without Lovestone's approval. Drew Pearson and Jack Anderson, “CIA Figures in Reuther-Meany Rift," Washington Post, 24 February 1967.

117. Thomas W. Braden, "I'm Glad the CIA Is 'Immoral." See chapter 4 in this volume for Braden's dealings with the AFL and CIO in the early 1950 .

118. Stanley Levey, “CIA Money and Labour: Whom Do You Believe?” Washington Daily News, 9 May 1967; AFL-CIO News, 13 May 1967. Lovestone and Brown kept a low profile, saying they wouldn't dignify Braden's accusations with a reply. Lovestone contented himself with private letters to friendly labour leaders around the world in which he diverted the focus to the late Pierre Ferri-Pisani, to whom Braden had alluded in connection with Irving Brown's use of CIA money to "pay off his strong arm squads" in the Marseille docks. Acting as the outraged guardian of Ferri-Pisani's honour, Lovestone wrote: "Every once in a while, you run into an argument or diatribe against Ferri-Pisani as a gangster, tough type, who made trouble in Marseille. Once and for all, I want to nail this slander and lie: Ferri-Pisani was a heroic figure. He spent three years of his life in [Buchenwald]. He is no café resistance figure. He suffered for it. ... He fought the Communists and they couldn't stop the food getting in.... This is one of the brightest episodes in our effort to help European labour." Lovestone to André Bergeron, 2 May 1967, Lovestone papers (Cornell), box 1, file 17. The same letter was sent to many of Lovestone's contacts overseas. The British labour counsellor met Lovestone a matter of days after Braden's revelations surfaced and reported that "he looked me straight in the 
eye and said that he had never taken a penny of CIA funds; that neither he nor any of his staff had ever acted on behalf of the CIA." J. J. Watson to G. Foggon, 9 May 1967, LAB $13 / 2465$.

119. J. J. Watson to J. Oates, 9 September 1966, LAB 13/2432; "For Peace and Freedom in Vietnam," AFL-CIO August 1966; Kevin Boyle, The UAW and the Heyday of American Liberalism, 1945-1968, 220; Goulden, Meany, 385-87.

120. Victor Riesel, "Reuther's Pressing Global Agitation," Detroit Free Press, 25 October 1966.

121. Reuther's close aide, Jack Conway, claimed that ahead of the executive council meeting in question, he had checked with Meany's assistant, Lane Kirkland, about whether Reuther and Meany had reached agreement on this subject. Kirkland, he said, had confirmed as much. Kirkland's later version was that there had been talks but no agreement. Conway's perception was that this was the point at which Reuther began to focus on an eventual exit from the AFL-CIO. Goulden, Meany, 385, 387.

122. H. F. B. Fane to J. Oates, 20 June 1966, LAB 13/2432. The unintended way in which international issues came to shape the Reuther-Meany conflict was hinted at in a letter from Scott Runkle to Victor Reuther enthusing over the fact that Meany and Lovestone were being pilloried in the press. He wrote that "though the CIA business is an unplanned aspect of the UAW's quasi separation, it could be a powerful element in support of your position." Runkle to Victor Reuther, 27 February 1967, Reuther-Carliner records, 1962-68, box 17, file 6.

123. Goulden, Meany, 385-88. For the special executive council meeting, Lovestone had initially prepared a summary of the AFL-CIO's international work since the merger, with a focus almost entirely on the federation's anti-communist activities. Shrewdly, Meany recognized that such emphasis would leave them wide open to Reuther criticism that the AFL-CIO approach was entirely negative, reflecting "insufficient concern for the needs of the 'struggling masses' - and all that jazz." Lovestone was sent away to redraft it and include references to policies in the field of development, support for the United Nations, liberation movements, disarmament, and opposition to right-wing dictators. Meany to Lovestone, 25 October 1966, Meany files, 1940-80, box 61, file 11. After the meeting, Joe Curran told the press of his disgust that Reuther had "sold us down the river" by not attending. Regarding Reuther's absence, Meany managed a tone of weary insouciance: "That's his privilege. We're a free institution. There's no compulsory attendance." Patrick Owens, "Reuther Loses an Ally in Foreign Policy Row," Detroit Free Press, 15 November 1966.

124. Goulden, Meany, 388; J. J. Watson to J. Oates, 8 December 1966, LAB 13/2465.

\section{Chapter 8: Toward an Independent Role}

1. Frank Costigliola, "Lyndon B. Johnson, Germany, and 'the End of the Cold War," 193-200.

2. George Meany, "A Return to Appeasement," Free Trade Union News, May 1964; "Statement of George Meany on Nuclear Test Ban Treaty, 27 August 1963, Before Senate Committee 
on Foreign Relations," Lovestone papers (Cornell), box 3, file 31; "Has Communism Abandoned Its Drive for World Domination?” Free Trade Union News, August 1964. In January 1965, while attending the funeral of Winston Churchill in London, ambassador-atlarge Averell Harriman discussed with TUC general secretary George Woodcock the issue of trade with communist countries and expressed support for long-term credits and a broadening of cultural exchanges to include organizations such as trade unions. Lovestone fumed: "I am at a loss to understand what business it was of Harriman's to engage in such conferences with trade union leaders—and for such purposes." Lovestone to Meany, 29 January 1965, Lovestone papers (Hoover), box 379, file: George Meany, 1960-69.

3. Jacob Potofsky, interview with Neil Gold, 6 July 1964, Amalgamated Clothing Workers of America Records, Collection 5619, box 188, folders 1-3, Kheel Center for LaborManagement Documentation and Archives, Martin P. Catherwood Library, Cornell University, Ithaca, NY; Lovestone to Meany, 5 November 1965, Lovestone papers (Cornell), box 3 , file 45 .

4. Brown to Meany, 26 November 1963, and Brown to Lovestone, 24 December 1963, Lovestone papers (Cornell), box 1, file 26; Lovestone to Bergeron, 26 January 1964, IAD Country Files, 1945-71, box 2, file 5; Brown to Lovestone, 26 January 1964, Lovestone papers (Hoover), box 356, file: Irving Brown, 1964-65; Free Trade Union News, March 1964; Harold Lewis to author, February 2011. André Bergeron (1922-2014) worked as a printer and participated in the 1936 strikes that brought the Popular Front to power. He was forced to leave France during the war and worked in Austria. In 1946, he became secretary of the CGT printers' union in the Belfort region, identifying with the Force ouvrière faction. After the split from the CGT in 1948, he was secretary of FO's regional printers' union and, from 1950, a member of FO's national executive committee. He was elected FO general secretary in 1963 and held the post until 1989, during which time he was the AFL-CIO's most vocal ally within the ICFTU.

5. Bergeron to Meany, 8 June and 24 June 1964, IAD Country files, 1945-71, box 2, file 5; "Letter from Irving Brown," 20 June 1964, Lovestone papers (Cornell), box 1, file 27; Lovestone to Meany, 7 August 1964, Lovestone papers (Cornell), box 3, file 35.

6. Lovestone to Brown, 31 October 1962, IAD Lovestone files, box 13, file 1. The "emergency laws" were required by the Allies as a condition for transferring full sovereignty to the Federal Republic. They were resisted for years by youth and labour groups and were only finally passed in 1968. Georg Leber (1920-2012) served in the Luftwaffe during the war and, in 1945, became a bricklayer before being appointed as a regional official of the building workers' union in 1949. He became vice chairman of the union in 1955 and then served as chairman from 1957 to 1966 . As a member of the SPD, he was elected to the Bundestag in 1957. From 1966, he served as minister of transportation in the Grand Coalition and was minister of defence (1972-78) under chancellors Willy Brandt and Helmut Schmidt.

Otto Brenner (1907-72) was born in Hannover and worked as an electrician before losing his job under the Nazis. In 1931, he joined the Socialist Workers Party in opposition to the SPD and, in 1935, was sentenced to two years' imprisonment. After the war, he 
became a district secretary in IG Metall while also serving as an SPD member of the state legislature. A militant leader of the campaigns for codetermination and against rearmament, he was labelled by Lovestone as "the worst opponent we have in the DGB." Lovestone to Meany, 23 March 1955, Lovestone papers (Hoover), box 705, file: George Meany. In 1952, he became vice chairman of IG Metall and then chairman in 1956, a position he held until 1972. In 1961, he was elected president of the IMF, in which capacity he worked closely with Walter Reuther.

7. "Memorandum on German Building Workers Convention, 22-29 June 1963," Lovestone papers (Cornell), box 3 , file 30 . The construction workers' congress in 1963 was held in the Benjamin Franklin Halle, which had been built in 1957 as a gift of the United States to the City of Berlin. As Kennedy prepared to speak, Meany handed him a scribbled note containing a quotation from Benjamin Franklin that formed an inscription on the wall of the building: "This is my home; this is where I belong, where freedom is." The president prefaced his remarks with the quotation and thus set the tone for his celebrated "Ich bin ein Berliner" address later that day outside the city hall. For that speech, Ted Morgan credits Lovestone with responsibility for feeding Kennedy the line "I too am a Berliner"-a departure from the prepared script—which Kennedy jotted down phonetically in Mayor Willy Brandt's office minutes before speaking. However, the president was unable to pronounce the German for "too" [auch] and so chose to keep it simple. Kennedy's improvisation lent the speech a cold-war tone that had not originally been intended. It clearly disturbed Brandt, who was expecting something more low-key and constructive. Ted Morgan, A Covert Life: Jay Lovestone, Communist, Anti-Communist, and Spymaster, 334; Frederick Taylor, The Berlin Wall: 13 August 1961-9 November 1989, 337-40; Robert Kennedy to Meany, 11 May 1965, Meany files, 1940-80, box 64, file 4. Lovestone's cultivation of Leber would assure the AFL-CIO of an ally of special influence within the Brandt-led government in 1972, when the construction union leader became minister of defence of the Federal Republic.

8. Lovestone to Storti, 16 May 1964, and Storti to Lovestone, 18 March 1965, IAD Country files, 1945-71, box 5, file 10; Lovestone to Meany, 4 March 1965, Lovestone papers (Hoover), box 379, file: George Meany, 1960-69. Bruno Storti (1913-94) was a law graduate and active member of the Catholic workers' movement when he became a national secretary of CGIL's civil service union after the war. With the 1948 split in the Italian labour movement, he became a deputy confederal secretary of LCGIL in 1948 and then confederal secretary of CISL, its successor, in 1950. In 1954, he became an assistant general secretary of CISL and, in 1959, succeeded Giulio Pastore as general secretary, a post he held until retirement in 1977. In 1959, he was elected to the Italian legislature as Christian Democrat deputy for Rome. Between 1965 and 1972, he served as ICFTU president in succession to Arne Geijer. His growing openness to dialogue with the Soviet bloc in the 1960 s caused him to lose favour with the AFL-CIO and was an important factor in the latter's decision to quit the ICFTU in 1969.

9. Lovestone to Brown, 25 April 1961, IAD Lovestone files, box 13, file 1. Woodcock pointedly refused to condemn what Meany always referred to as the "so called" unions of the Soviet 
bloc: "I make no qualitative judgement about the two [union types].... The time may come when we will all grow up ... when we might find a basis for common action and understanding which I agree is the basis of trade union unity." Report of 94th Annual Trades Union Congress (Blackpool, 1962), 393.

10. Kalmen Kaplansky to Claude Jodoin, 25 February 1964, CLC Archives, reel H-193.

11. Brown to Lovestone, 11 November 1965, Lovestone papers (Hoover), box 356, file: Irving Brown, 1964-65; minutes of TUC International Committee meeting, 25 May 1965, TUC Archives, MSS 292D/901.

12. Jay Lovestone, "No Free Trade Union Exchanges with State Company Unions," Free Trade Union News, May 1966. To make clear where the AFL-CIO stood with regard to the British labour movement, Lovestone recommended to Meany that they should provide a dinner with full red-carpet treatment for British deputy prime minister George Brown, who was due to visit Washington shortly. Brown, a committed anti-communist, was famous for having publicly insulted Nikita Khrushchev ten years earlier when the Soviet leader, on a visit to Britain, was addressing a dinner in the House of Commons given by leaders of the Labour Party. A former official of the British transport workers' union, Brown was a leading rival of Prime Minister Harold Wilson and, as Lovestone noted, "a vigorous friend" of the AFL-CIO. Honouring him with a formal dinner would, Lovestone argued, "strengthen his stand in the Labour Party and the TUC against pseudo lefts and phony liberals." Lovestone to Meany, 2 September 1966, IAD Lovestone files, box 49, file 15.

13. Lovestone, "No Free Trade Union Exchanges with State Company Unions"; Victor Riesel, "Inside Labour: George Meany Learns of Newest Soviet Espionage Operation Against Labour," syndicated column, 26 October 1966.

14. Kuno Brandel to Lovestone, 3 May 1964, and Lovestone to Meany, 7 May 1964, Lovestone papers (Hoover), box 379, file: George Meany, 1960-69.

15. Minutes of ICFTU Executive Board meeting, 2-4 March 1964, ICFTU Archives, folder 119; Jay Lovestone, "Memorandum on German Developments," 20 July 1964, Lovestone papers (Cornell), box 3, file 35. Ludwig Rosenberg (1903-77) became a full-time officer of the federation of clerical workers at the age of twenty-five. In 1933, he fled from the Nazis and lived in England, finding employment in the British Foreign Office during the war. He became international secretary of the DGB in 1949 and was a delegate at the founding conference of the ICFTU. He took charge of the economic department in 1954 and, in 1959, became DGB vice chairman. Elected chairman in 1962, he led the organization until retirement in 1969. Erudite, but with a tendency to arrogance, as DBG chairman he became an increasingly acerbic critic of AFL-CIO international policy, his personal dislike for Meany being fully reciprocated by the federation president.

16. Lovestone to Meany, 30 November 1964, Lovestone papers (Hoover), box 379, file: George Meany, 1960-69; agenda item 10: "Communist Tactics on the International Trade Union Scene," minutes of ICFTU Executive Board meeting, 30 November-3 December 1964, ICFTU Archives, folder 120; Brown to Lovestone, 4 January 1966, Lovestone papers (Cornell), box 1, file 13 .

17. Jones to J. Oates, 20 April 1966, LAB 13/2432. 
18. Lovestone to Meany, 18 October 1965, Lovestone papers (Cornell), box 3, file 40; Lovestone to Meany, 5 November 1965, Lovestone papers (Cornell), box 3, file 45; Meany to Ludwig Rosenberg, 30 November 1965, IAD Country files, 1945-71, box 3, file 13.

19. Rosenberg to Meany, 15 December 1965, IAD Country files, 1945-71, box 3, file 13.

20. The WFTU had lost its Chinese affiliate, and the French and Italian affiliates were in open revolt against its blanket opposition to the EEC.

21. Meany to Rosenberg, 13 January 1966, IAD Country files, 1945-71, box 3, file 13.

22. Lovestone to Lee, 22 January 1966, IAD Country files, 1945-71, box 2, file 16.

23. Brown to Lovestone, 9 April 1966, Lovestone papers (Hoover), box 356, file: Irving Brown, 1966-67; Lovestone to Brown, 12 April 1966, Lovestone papers (Cornell), box 1, file 32; “George Meany Message to DGB Convention," Berlin, 3 May 1966, Meany files, 1940-8o, box 66 , file 4 . Lovestone combined his congress appearance with a personal visit to Konrad Adenauer for the purpose of calming the ex-chancellor's worries over US policy in Vietnam. After seeing him, Adenauer wrote appreciatively to Meany: "I was very glad that Mr. Lovestone was sent to clear up doubts . . . about the attitude of the U.S. . . I believe that your wisdom, understanding and vision will render great service ... in the field of inter-American and German foreign policy. We will need your advice and experience more than ever." Adenauer to Meany, 24 May 1966, IAD Lovestone files, box 49, file 15.

24. "DGB Meet Acts on Emergency Law, East-West Relations," Free Trade Union News, May 1966.

25. Lovestone to Meany, 7 November 1966, IAD Lovestone files, box 49, file 15 . Willy Brandt was treated coolly when he was next in Washington in the winter of 1967, AFLCIO leaders making no effort to extend hospitality. To his old friend and editor of the construction workers' journal, Kuno Brandel, Lovestone wrote: "It will be a very long time before I get myself involved in sticking my neck out for the DGB or the SPD. . . No matter what our German colleagues, who have behaved in the most indecent manner towards us, do, we will stand by our basic policies." Lovestone to Brandel, 17 March 1967, Lovestone papers (Cornell), box 1, file 20.

26. Aide-mémoire, n.d. [April 1967], IAD Brown files, box 1, file 27; Lovestone to Brandel, 16 May and 18 May 1967; IAD Country files, 1945-71, box 2, file 17.

27. Meany to Rosenberg, 16 May 1967, IAD Country files, 1945-71, box 2, file 17.

28. Meany to Rosenberg, 7 June 1967, IAD Country files, 1945-71, box 3, file 13. Dealing with this controversy in Welt der Arbeit, the head of the DGB's press department, Walter Fritze, said that while the paper was willing to publish any comments received from the AFL$\mathrm{CIO}$, Rosenberg was not prepared to prevent publication of any material simply because Meany did not approve of it; the DGB did not practise censorship. Welt der Arbeit, 2 August 1967.

29. Lovestone to Elly Borochowitz, 16 June 1967, Lovestone papers (Cornell), box 1, file 18; "Summary of Letter by Brandel to Rosenberg, 23 June 1967," Meany files, 1940-8o, box 63, file 22; Meany cable to Rosenberg, 7 July 1967, IAD Country files, 1945-71, box 3, file 13.

30. "Report on Activities, Supplement III, The ICFTU Regional Organization: Its Present Situation and Positive Proposals for the Future," n.d., and minutes of ICFTU Executive 
Board meeting, 5-11 July 1965, ICFTU Archives, folder 131; J. E. D. Slater to A. G. Read, 31 March 1965, LAB 13/2012.

31. J. Kaukonen to State Department, 20 January 1965, Meany files, 1940-80, box 62, file 8 .

32. "The Trade Union Situation in Africa," statement issued by the AFL-CIO Executive Council, 1 March 1965. Brown wrote in June 1965: "I found very little criticism and a rising recognition of these new types of international trade union action.” Irving Brown, "Memorandum for the Record," 22 June 1965, Brown files, box 8, file 6.

33. Brown to Lovestone, 14 August 1966, Lovestone papers (Hoover), box 356, file: Irving Brown, 1966-67; Irving Brown, "African-American Labour Centre at Work," Free Trade Union News, August 1967; "Centre Afro-Américain du Travail en Action," presentation to Pan-African Cooperative Conference, n.d. [1967], IAD Brown files, box 2, file 1; Irving Brown, "Notes on Trip to Africa, 28 November-16 December 1968," 10 December 1968, Lovestone papers (Cornell), box 1, file 37; Brown to Lovestone, 18 April 1970, Lovestone papers (Hoover), box 357, file: Irving Brown, 1970; "Ethiopian Labour Centre Built with AFL-CIO Help," Free Trade Union News, May 1970; Emily Hoyt, "Five Years of AfricanAmerican Labour Centre-Record of Achievement," Free Trade Union News, August 1970, and Brown to Lovestone, 15 December 1970, Lovestone papers (Hoover), box 357, file: Irving Brown, 1970.

34. Asked by the Foreign Office for an update on what the ICFTU knew about AALC operations, the British labour attaché in Brussels wrote: "In practice ... nobody has the remotest idea of what [Brown] is really doing or seeking at any given time.... He is a man who operates in the shadows and the half-lights, pulling strings behind the scenes, pursuing his own purposes in all sorts of mysterious ways, intriguing, deceiving if necessary, and is generally the type of person it is almost impossible to tie down ... a law unto himself.' R. O. Barritt to G. Foggon, 24 January 1966, LAB 13/2012. For Brown's high-level contacts in Africa, see Irving Brown, "Memorandum for the Record," 22 June 1965, IAD Brown files, box 8, file 6; Brown to Lovestone, 1 September 1969, Lovestone papers (Cornell), box 1, file 39; Brown to Lovestone, 7 September 1969, Lovestone papers (Hoover), box 356, file: Irving Brown, 1968-69; Brown to Lovestone, 15 December 1970, Lovestone papers (Hoover), box 357, file: Irving Brown, 1970; Brown to Meany, 29 December 1970, IAD Brown files, box 8, file 6; Brown to Meany, 18 September 1973, Meany files, 1940-80, box 61, file 11 .

35. Donald Robinson, untitled draft ("In the African city of Nairobi ..."), Lovestone papers (Cornell), box 1, file 28; Hubert Humphrey to Meany, 12 January 1968, Victor Reuther papers, box 30, file 28; Ben Rathbun, The Point Man: Irving Brown and the Deadly Post1945 Struggle for Europe and Africa, 323.

36. J. E. D. Slater to J. Oates, 7 November 1967, 23 July 1968, LAB 13/2244.

37. Irving Brown, "Memorandum for the Record," 22 June 1965, IAD Brown files, box 8, file 6.

38. Wogu Ananaba, The Trade Union Movement in Nigeria, 277; J. E. D. Slater, "[Report on] United Labour Congress, Nigeria," 21 June 1965, LAB 13/1972. 
39. Irving Brown, "Memorandum for the Record," 22 June 1965, IAD Brown files, box 8, file 6; W. J. Vose to J. Oates, 14 January 1966, LAB 13/2012; minutes of ICFTU International Solidarity Fund Committee meeting, 4 February 1966, ICFTU Archives, folder 135.

40. Irving Brown, "Report on Nigeria," 1 February 1966, and Meany to Brown, 27 January 1966, Lovestone papers (Hoover), box 514, file: George Meany, 1966; Brown to Lovestone, 28 January 1966, IAD Brown files, box 7, file 12; Lovestone to Meany, 7 February 1966, IAD Lovestone files, box 49, file 15 .

41. Irving Brown, "Confidential Memorandum," 21 April 1967, Lovestone papers (Cornell), box 1 , file 34 .

42. Brown to Lovestone, 14 October 1968, Lovestone papers (Hoover), box 356, file: Irving Brown, 1968-69; H. P. Adebola to Meany, 25 August 1967, LAB 13/2578; Meany to Adebola, 26 September 1967, Lovestone papers (Cornell), box 1, file 11.

43. Arnold Zack, From A to Z: A Memoir by Arnold Zack, 156-60. The funds acquired by Lovestone for the union election in Ghana were presumably from a dormant account originally set up for covert work in Berlin. Lovestone to Meany, 25 April 1966, IAD Lovestone files, box 49, file 15; Lovestone to Brown, 12 April 1966, Lovestone papers (Cornell), box 1, file 32. Benjamin Bentum had been the leader of Ghana's forestry workers before taking a ministerial post in Nkrumah's government. He was one of the few Ghana TUC leaders who were not ardent followers of the Nkrumah line and was better known as a moderate who, on a visit to China in 1963 , had controversially refused to subscribe to a joint statement on the evils of American "imperialism."

44. Brown to Lovestone, 14 August 1966, Lovestone papers (Hoover), box 356, file: Irving Brown, 1966-67.

45. J. E. D. Slater to J. Oates, 3 February 1967, LAB 13/2244; Irving Brown, "Report on African-American Labour Centre Conference with African Representatives to Annual ILO Conference," 20 June 1967, IAD Country files, 1945-71, box 1, folder 27. At one of a series of three AALC seminars planned as a follow-up to the meeting in Geneva and held in Kampala in February 1968, Don Taylor-an invited speaker who was an official of the Canadian steelworkers-was warmly received when he told the African trade union participants that the AFL-CIO should divest itself of government financial backing for the AALC. Taylor argued that the labour centre threatened the independence of both the AFL-CIO and the recipient African labour movements and was, indeed, a potential source of embarrassment to the US government itself. Reporting to his superiors in Canada, he noted that these remarks didn't seem to upset the AALC's deputy director, who was in attendance, although the US embassy people present "looked a bit uncomfortable." His message home was that the Canadians could, in concert with like-minded national labour movements, play a significant part in "putting a damper on the AALC's adventures and helping to provide alternative and more respectable forms of . . . trade union assistance." Don Taylor to Bill Mahoney, "My Visit to Uganda in Connection with the Afro-American Labour Centre Seminar," 16 February 1968, United Steelworkers of America, Canadian National Office fonds, MG28 I 268, vol. 33(9), LAC. 
46. J. E. D. Slater to J. Oates, 7 November 1967, 20 May 1968, LAB 13/2244; “The Position and Prospects of Pan-African Trade Unionism at the Beginning of 1968," Intel 3, Foreign Office and Commonwealth Office to Certain Missions, 14 February 1968, LAB 13/2244.

47. As an army officer, Joseph Mobutu (1930-97) was responsible for removing from office elected Prime Minister Lumumba in 1960. He was also implicated in Lumumba's murder the following year, by which time he already enjoyed close links with the CIA. Promoted to army chief of staff, it was from this position that he seized power in 1965 and embarked on a campaign to impose personal rule. His regime was marked by corruption, brutality, and violations of human rights. The political party that he created, the MRP, was the only legal political organization between 1967 and 1990. Throughout the same period, all independent trade unions were illegal. He was forced out of office in 1997, the year he died.

48. It was through the National Labour Council that the practice of "obligatory civic work" was introduced by Mobutu in the 1970s, evolving over time into a system of forced labour.

49. J. E. D. Slater to R. O. Barritt, 31 March 1967, LAB 13/2012. Brown's generally sympathetic reporting of Mobutu's regime contrasts with the withering assessment of British ambassador Sir John Cotton. He described Mobutu's rule as "comparing unfavourably with other similar dictatorships" in terms of repression and Mobutu himself as "quite unfit to govern," though likely to enjoy continued American support because of Washington's fear of a left-wing alternative. Cotton to Foreign and Commonwealth Office, 22 August 1967, FCO 38/126, and Cotton to Stewart, 20 August 1968, FCO 25/55, National Archives, Kew.

50. Brown to Lovestone, 10 August 1968, Lovestone papers (Cornell), box 1, file 34.

51. “Agenda, Paris, 14-15 January 1972-Exchange of Views," IAD Brown files, box 2, file 5.

52. Ibid.; Irving Brown, "Notes on Trip to Africa," 1 September 1969, Lovestone papers (Cornell), box 1, file 39; Brown to Meany, 18 September 1973, Meany files, 1940-80, box 61, file 11. Much appreciated by Brown was Mobutu's "courageous stand against the Arabs" in the lead-up to the Yom Kippur War in 1973.

53. Jef Rens to Meany, 3 March 1967, IAD Brown files, box 1, file 23; J. E. D. Slater to R. O. Barritt, 31 March 1967, LAB 13/2011.

54. R. O. Barritt to Labour Department, 10 March 1967, and Barritt to Slater, 14 April 1967, LAB 13/2011.

55. Rens had previously been an assistant general secretary of the Belgian FGTB. Prior to his recent retirement from the ILO, he had enjoyed vigorous support from the AFL-CIO in battles with his superior, ILO director general David Morse, over the latter's attempts to restructure the ILO and better accommodate the member states from the Soviet bloc.

56. Brown to Lovestone, 22 October 1966, Lovestone papers (Hoover), box 356, file: Irving Brown, 1966-67; agenda item 3: "Resignation of the General Secretary and proposals for the appointment of an Acting General Secretary," minutes of ICFTU Sub-Committee meeting, 13-14 January 1967, ICFTU Archives, folder 376; minutes of ICFTU Extraordinary Executive Board meeting, 14-15 March 1967, ICFTU Archives, folder 143; Walter Reuther to Rens, 19 January 1967, Reuther-Carliner records, 1962-68, box 59, file 26.

57. Agenda item 4: "Duties of the New Assistant General Secretary," minutes of ICFTU SubCommittee meeting, 13-14 January 1967, ICFTU Archives, folder 376. Morris Paladino 
(1920-91) had been a member of the garment workers' union when he was posted to Latin America in 1960. There he worked as a lecturer for the AFL-CIO in Brazil, as director of organization and later assistant general secretary for ORIT, and then, from 1964, as deputy executive director of AIFLD in charge of planning and administration. Meany insisted that at the ICFTU he be given charge of the department of organization, which was responsible for relations with international trade secretariats, and work in the emerging field of vocational training and cooperative enterprise. Following the AFL-CIO withdrawal from the ICFTU, he became the director of the Asian-American Free Labor Institute.

58. Rens to Meany, 3 March 1967, IAD Brown files, box 1, file 23. Victor Reuther suspected that Rens was also alarmed at the recurrent allegations of CIA financing of AFL-CIO activities abroad. Victor Reuther to Walter Reuther, 18 April 1967, Reuther-Carliner records, 1962-68, box 59, file 26 .

59. "Message from Mr. Jef Rens to All the Members of the Sub-Committee," 14 March 1967, IAD Lovestone files, box 42, file 6.

6o. Minutes of ICFTU Sub-Committee meeting, 14 March 1967, ICFTU Archives, folder 376; minutes of ICFTU Extraordinary Executive Board meeting, 14-15 March 1967, ICFTU Archives, folder 143 .

61. Alfred Braunthal wrote to Brown on 24 March confirming the agreement that Brown would vacate the post of ICFTU New York director, to take effect from 15 April. (His reference to their meeting having taken place on 16 April is clearly an error.) Braunthal noted that Brown was to be replaced in the New York office by his deputy, Paul Barton, and that George Meany had agreed to this. Alfred Braunthal to Brown, 24 March 1967, IAD Lovestone files, box 42, file 6 .

62. Lovestone to Kuno Brandel, 17 March 1967, Lovestone papers (Cornell), box 1, file 20. As a student during the war, Harm Buiter (1922-2011) had been active in the Dutch resistance. After completing university, he worked for the Dutch metalworkers (NVV) before appointment in 1956 as general secretary of the European Trade Union Secretariat, which represented the unions of the European Communities (Coal and Steel, Economic, and Euratom). In that capacity he worked closely with the leftist German metalworkers' leader, Otto Brenner, the president of the IMF. It was indeed Buiter who won over Brenner to support for the Common Market, introducing him to Jean Monnet and interpreting for the two men at their first meeting. A casualty of Meany's bruising battle with the ICFTU that led to the AFL-CIO's withdrawal in 1969, Buiter resigned as ICFTU general secretary in 1971 to become the mayor of Groningen.

63. Buiter to Storti, 15 November 1966, IAD Lovestone files, box 42, file 3.

64. James A Suffridge, "Memorandum of Activities Representing President Meany and AFLCIO, Brussels, Belgium, 15-21 May 1967," IAD Lovestone files, box 41, file 21.

65. Brown to Meany, 23 May 1967, IAD Brown files, box 8, file 8. Pierre Felce had been a close supporter of Ferri-Pisani within Force ouvrière. He was regarded as a moderate among the traditional socialists who formed the core of FO's membership and, as a member of the French Chapter of the Atlantic Institute, was committed to French membership in 
NATO. Irving Brown advised: "This would be the time to go all out for the FO and not cut down as is being done." "Suggested Procedure re Election of General Secretary," n.d. [August 1967?], Lovestone papers (Cornell), box 3, file 46; "Letter from Irving Brown," 6 June 1967, Lovestone papers (Hoover), box 356, file: Irving Brown, 1966-67; Lovestone to Meany, 7 June 1967, Meany files, 1940-80, box 64, file 15.

66. Author interview with Stefan Nedzynski, 11 November 1995; Nedzynski to author, 17 June 2005.

67. Apart from talks with Thieu and Ky, Brown also had discussions with the infamous chief of national police, General Nguyen Ngoc Loan, who two weeks earlier gained worldwide notoriety when, in front of TV cameras, he executed a captured Viet Cong officer in the street with a pistol shot to the brain. With the CVT leadership, Brown reviewed the scope for material assistance to repair the organization's headquarters, which had been targeted by the Viet Cong during the Tet Offensive. In these talks, he encouraged Buu to involve the CVT more in the political process, The following year, Buu formed the farmer-worker party, the Cong Nong, in an attempt to inject a reformist element into South Vietnamese politics. It was in the hope that this American-backed initiative would pay long-term dividends that Meany remained a supporter of the US military intervention for as long as he did. Fernand Audie to Lovestone, 16 March 1968, IAD Country files, 1945-71, box 31, file 6; Brown to Lovestone, 14 March 1968, Lovestone papers (Hoover), box 356, file: Irving Brown, 1968-69; Gwenn R. Boardman, "CVT-Force for Social Progress in Vietnam," Free Trade Union News, September 1968; Edmund Wehrle, "Reprehensible Repercussions: The AFL-CIO, Free Trade Unionism, and the Vietnam War, 1947-75," 279-80.

68. Brown reported on the scope for Force ouvrière to develop further as a "responsible and efficient trade union movement" and to serve as "an essential stabilizer" in French society. As ever, he talked up FO's prospects. He envisaged a two-year organizing drive that would require him to spend more time in France. His idea was to involve the group around the former communist, August Lecoeur (now an FO member), and his publication, $\mathrm{La}$ Nation socialiste, and focus on winning over disillusioned CGT cadres in metalworking and construction. Noting that the Soviet trade unions had announced a grant of $\$ 300,000$ for the CGT, Brown proposed that the international free trade unions be asked to raise $\$ 1$ million so as to finance the work of up to fifty organizers. Bergeron was subsequently brought over for the AFL-CIO executive council meeting that discussed the proposal. The $\$ 5,000$ per month that the federation actually voted for FO, and for only six months, was a pittance alongside Brown's big talk of a $\$ 1$ million fund. This eye-catching figure may simply have reflected his tendency to "think big," but it is possible that his report to Lovestone was also intended for influential friends outside the trade union movement. Irving Brown, "Report and Proposal on France and Labour," 9 July 1968, and Brown to Lovestone, 30 August 1968, IAD Brown files, box 17, file 14; Brown to Lovestone, 24 July 1968, Lovestone papers (Hoover), box 356, file: Irving Brown, 1968-69; Joe Beirne, "ICFTU Meeting, Brussels, 3-5 July 1968," IAD Lovestone files, box 41, file 21.

69. Attempts at healing the rift between SAK and SAJ had been in train for some time and were backed by mainstream leaders of the Finnish trade unions and social democratic 
party who believed they were capable of containing the communist minority in SAK. Brown was unconvinced and lent his support to SAJ president Jaako Rantanen's opposition to "premature unification." He recommended giving financial assistance and reported to Lovestone: "They will need much more resources to carry on the fight. ... The amounts [are] very high." In the event, the merger was agreed and was completed by June 1969. What funding was requested by Rantanen or provided by Brown during this process is unknown. It was a highly sensitive subject: the SAJ was dogged by allegations that it had previously received CIA funding. Evidence suggests that financial help from American unions was reaching favoured recipients within the merged SAK well into the 1970 . Brown to Lovestone, 1 October 1968, Lovestone papers (Cornell), box 1, file 35; Brown to Lovestone, 2 October 1968, Lovestone papers (Hoover), box 356, file: Irving Brown, 1968-69; Brown to J. C. Turner, 16 September 1977, IAD Brown files, box 5, file 3.

70. Lovestone to Paladino, 4 August and 25 August 1967, Lovestone papers (Hoover), box 383, file: Morris Paladino, 1967-74.

71. Harold Lewis, then with the ITF and later its general secretary, notes that, at the time, Felce's national union was affiliated to the ITF with a membership of 2,250-down from the already insignificant total of 7,000 of 1952. He remarks that the FO transport workers-indeed Force ouvrière itself- "had a standing in the international movement out of all proportion to their domestic significance ... acting out the fiction that they really did have members and influence and were not mere cyphers." In this context, Lewis regarded the support for Felce shown by Lovestone and Brown- "clearly intelligent, in many ways very well informed, hard nosed" - as "an unfathomable paradox." Lewis to author, 9 January 2005.

72. Lovestone to Meany, 6 June 1967, Lovestone papers (Cornell), box 3, file 46; Jay Lovestone, "Report on the ICFTU Executive Board, 4-5 October 1967, 12 October 1967," IAD Lovestone files, box 42 , file 6.

73. Lovestone to Paladino, 25 August 1967, Lovestone papers (Hoover), box 383, file: Morris Paladino, 1967-74; Lovestone to Harry Goldberg, 11 September 1967, Lovestone papers (Cornell), box 2, file 10. On his appointment, Buiter's salary was worth 25 percent more than Becu had received. Lovestone calculated that, with other supplements, his remuneration would amount to 45 to 50 percent above that of Becu. He had also negotiated a unique provision for severance pay under which he would receive a year's salary plus one month's salary per year of service if congress or the executive board terminated his contract before retirement age. Minutes of ICFTU Executive Board meeting, 4-6 October 1967, ICFTU Archives, folder 145.

74. Brown cable to Lovestone, 11 September 1967, and "Letter from Irving Brown," 12 September 1967, Lovestone papers (Cornell), box 1, file 33.

75. Lovestone to Goldberg, 15 September and 29 September 1967, Lovestone papers (Cornell), box 2, file 10; Lovestone to Brown, 21 September 1967, Lovestone papers (Cornell), box 1, file 33. The apparent diminution of Lovestone's influence was a theme that recurred around this time in the reports of the British labour counsellor in Washington, who noted 
that Lovestone, approaching his sixty-eighth birthday, was also beginning to look old and tired. H. F. B. Fane to J. Oates, 30 March 1966, LAB 13/2432.

76. Minutes of ICFTU Executive Board meeting, 4-6 October 1967, ICFTU Archives, folder 149.

77. Jay Lovestone, "Report on ICFTU Executive Board Meeting, 4-6 October 1967-Brussels, Belgium," 12 October 1967, IAD Lovestone files, box 42, file 6. Paul Barton (Jiř́ Veltruský), a member of Brown's staff in the ICFTU's New York office, who had recently succeeded him as director, joined in Lovestone's campaign to undermine Buiter, his boss, barely a month after the latter's confirmation in office. He sent a confidential briefing paper to Meany attacking the general secretary and his Brussels staff in the same scurrilous terms in which Irving Brown had once routinely attacked Becu. His observations ranged widely over the style and substance of Buiter's leadership, talking of a "paralysing crisis" in the secretariat and the general secretary's "alarming" tendency to work through a "personal clique" of incompetents while employing "delaying tactics" in handling the burning issue of trade union contacts with Eastern Europe. His main point was that Buiter was vulnerable and could be defeated at the next congress. To achieve his "elimination," Barton suggested that, as the staff member responsible for administration at the upcoming ICFTU World Economic Conference that would precede the next congress, he was in a position to use the conference as a launch pad for a challenge to the general secretary. It would provide an opportunity for any rival to Buiter to demonstrate his competence, and Barton would ensure that the person had ample scope to showcase his talents. Paul Barton, "Confidential-ICFTU," November 1967, IAD Lovestone files, box 42, file 6. This was a remarkable document for a member of the ICFTU staff to send to a vice president of the organization, dealing as it did with the alleged personal and professional defects of the recently appointed general secretary. Meany could have put an immediate stop to such mischief but chose not to, just as he had done nothing to rein in Irving Brown's earlier efforts to undermine Jaap Oldenbroek and Omer Becu. Indeed, he was soon to hire Barton as an AFL-CIO representative working in the Paris office.

78. "Report of ICFTU Finance Sub-Committee, 10-11 January 1968," ICFTU Archives, folder 149; Lovestone to Brandel, 22 January 1968, Lovestone papers (Cornell), box 1, file 20.

79. There could be no doubting the Soviet effort to liberalize industry. Under the 1965 "Liberman reforms," "capitalist" material incentives had been adopted that aimed at more efficient production. Liberman's importance was recognized in the United States when, on 12 February 1965, he became the only Soviet economist ever to make it to the front cover of Time magazine. The AFL-CIO leadership was quite right that liberalization among trade unions lagged far behind. But rather than accept this as justification for shunning them à la Meany, people like Charles Levinson, general secretary of the International Chemical Workers' Federation, argued that it was imperative to engage with Soviet bloc unions over the dumping of low-priced goods on Western markets and the transfer, by multinational firms, of plant to the Soviet bloc to capitalize on lower labour costs, both of them products of communist collaboration with Western capitalism that had been encouraged by the Liberman reforms. Charles Levinson, "East-West Trade and Union Contacts: An Increasingly Irrelevant Controversy for Trade Unions," International 
Federation of Chemical and General Workers' Unions, Geneva, 1968, Reuther-Carliner records, 1962-68, box 38 , file 25 . Levinson sent a copy of this discussion document to Victor Reuther on 6 August 1968.

8o. It was the developing contacts between these three trade union centres and the Soviet bloc that lent urgency to the work of the Asian-American Free Labor Institute, which was modelled on AIFLD and the AALC. Shortly after the opening of the institute's field office in Saigon in 1968, Ernie Lee wrote that if these Asian-Pacific centres "do not hold back, we are in deeper water." He suggested that Lovestone make a trip to Tokyo in one final attempt to reason with them and "then push the [independent] regional activities as hard as possible." Lee to Lovestone, 19 April 1968, Meany files, 1940-80, box 64, file 1.

81. Paladino to Lovestone, 31 July 1967, Lovestone papers (Hoover), box 383, file: Morris Paladino, 1967-74.

82. Welt der Arbeit, 23 June 1967; "Summary of Letter by Kuno Brandel to Rosenberg, 23 June 1967," Meany files, 1940-80, box 63, file 22.

83. Lovestone to Goldberg, 15 September and 29 September 1967, Lovestone papers (Cornell), box 2, file 10. As the architects of the government's incipient Ostpolitik, the SPD members of the Grand Coalition, Willy Brandt and Herbert Wehner, were already under a cloud. Lovestone deemed them "anti-American." For a time, Georg Leber, now a minister in the coalition government, also found himself out of favour with the AFL-CIO. Lovestone to Brandel, 22 January 1968, Lovestone papers (Cornell), box 1, file 20; Lovestone to Leber, 21 March 1968, IAD Country files, 1945-71, box 2, file 17.

84. Lovestone to Paladino, 4 August 1967, Lovestone papers (Hoover), box 383, file: Morris Paladino, 1967-74.

85. J. J. Watson to J. Oates, 8 November 1967, LAB 13/2465; Jay Lovestone, "Report on ICFTU Executive Board Meeting, 4-6 October 1967, Brussels, Belgium," 12 October 1967, IAD Lovestone files, box 42, file 6. Lovestone commented: “This dangerous [TUC] policy has already led to the likelihood of the Communists taking over the second biggest affiliate [Amalgamated Engineering Union] and, together with Frank Cousins's Transport Union [Britain's biggest] changing the entire face and course of the TUC."

86. Jay Lovestone, "Report on ICFTU Executive Board Meeting, 4-6 October 1967," IAD Lovestone files, box 42 , file 6 .

87. The director of the original department was Alois Adamczyk, the exiled Polish trade union leader who had previously led the New York-based faction within the ICFTUE. However, Lovestone never trusted him, and under his leadership the department failed to operate with the vigour and purpose that the AFL-CIO had hoped for. With Adamczyk's death in 1959, the operation fell into abeyance.

88. "Relations Between Free Trade Unions and Communist-Controlled Trade Union Organizations," minutes of ICFTU Executive Board meeting, 4-6 October 1967, ReutherCarliner records, 1962-68, box 59, file 1.

89. George Woodcock, "Blackpool TUC Will Welcome Soviet Delegates," Morning Star, 24 July 1968; Lovestone to Bergeron, 7 August 1968, IAD Country files, 1945-71, box 2, file 7. 
90. "Relations Between Free Trade Unions and Communist-Controlled Trade Union Organizations," minutes of ICFTU Executive Board meeting, 4-6 October 1967, ReutherCarliner records, 1962-68, box 59, file 1. Lovestone was supremely confident in his ability to dominate any discussion on this topic. He had for some time been trying unsuccessfully to lure European trade union leaders into writing articles for the Free Trade Union News justifying their approach to contacts with Soviet bloc organizations. It was a matter of frustration that no one took up his offer, thereby denying him the chance to publish an accompanying demolition of their naïve offerings. Lovestone to Paladino, 4 August 1967, Lovestone papers (Hoover), box 383, file: Morris Paladino, 1967-74.

91. "The Manifesto That Angered the Soviet Leadership," Manchester Guardian Weekly, 18 July 1968.

92. Alexander Shelepin (1918-94) had recently been appointed to the AUCCTU post, an intriguing move since he was previously responsible for the KGB. For some years he was a rising star in Soviet politics-first secretary of the Komsomol (1952-58), then head of the KGB (1958-61), and then, in 1961, deputy premier under Khrushchev, in whose ouster, it has been alleged, he was complicit. As KGB head, he ordered the killing of a Ukrainian nationalist leader, Stepan Bandera, in Munich in 1959 and was unable to make a scheduled visit to the DGB in the early 1970 s for fear of being arrested in connection with this. Shelepin also signed the indictment of the U-2 pilot, Francis Gary Powers, who was shot down over Soviet territory in 1960. From 1964 to 1975, he was a member of the Politburo and, as the youngest such member, had ambitions to replace Party secretary Leonid Brezhnev.

93. “Ludwig Rosenberg's Moscow Talks," Die Quelle, July-August 1968, IAD Country files, 1945-71, box 2, file 17; Jay Lovestone, "Rosenberg's Mission to Moscow," 17 June 1968, IAD Country files, 1945-71, box 3, file 13 .

94. Victor Reuther to Rosenberg, 11 July 1968, Victor Reuther papers, box 35, file 3.

95. Raised in East Germany, Otto Kersten (1928-82) was sentenced in 1953 to fifteen years' forced labour for involvement in the social-democratic opposition to the communist regime. Released early, in 1960 he went to work for Harm Buiter on the staff of the European Trade Union Secretariat. He became head of the DGB's international department in 1965 and, in 1972, succeeded Buiter as ICFTU general secretary.

96. Jay Lovestone, “[Report on] East-West Committee Meeting, Friday, 28 June 1968," IAD Lovestone files, box 41, file 21. In a lengthy discussion document on East-West visits in August 1968, Charles Levinson, general secretary of the International Chemical Workers' Federation, expressed a view increasingly heard in ICFTU circles that the AFL-CIO seemed headed for isolation, adding that this was not entirely unwelcome. Levinson, "East-West Trade and Union Contacts: An Increasingly Irrelevant Controversy for Trade Unions."

97. Lovestone to Meany, 21 August 1968, Lovestone papers (Hoover), box 379, file: George Meany, 1960-69.

98. Lovestone to Dale Good, 3 September 1968, Lovestone papers (Cornell), box 2, file 16; Lovestone to Joseph Godson, 9 September 1968, Lovestone papers (Cornell), box 2, file 6 . 
99. Irving Brown warned Lovestone of this latest tendency to distinguish between Soviet bloc communist countries that did invade and those that didn't invade, creating a basis for continued friendly relations and eventual discussions of unity with the latter. Brown to Lovestone, 14 October 1968, Lovestone papers (Hoover), box 356, file: Irving Brown, 1968-69.

10o. Lovestone pooh-poohed Kersten's argument, dismissing him as "the little petty bureaucrat." Lovestone to Good, 13 September 1968, Lovestone papers (Cornell), box 2, file 16; agenda item 8: “Czechoslovakia," ICFTU Executive Board meeting, 20-22 November 1968, ICFTU Archives, folder 152.

101. Paladino to Meany, 10 September 1968, Lovestone papers (Hoover), box 359, file: Harm Buiter, 1967-70; Lovestone memorandum, "Conference with Buiter, 17 October 1968, Madison Hotel Restaurant, Montpelier," 18 October 1968, Meany files, 1940-80, box 61, file 16.

102. Within a year the UAW was also working on plans to include the Yugoslav unions in a three-way project with itself and the Swedish metalworkers, focusing on assistance to unions in the developing world. Victor Reuther to Walter Reuther, 16 September 1969, Reuther-Rebhan records, 1968-72, box 30, file 7.

103. Agenda item 9: "Report of Second Meeting of Committee on Relations Between Free Trade Unions and Communist-Controlled Trade Union Organizations," minutes of ICFTU Executive Board meeting, 20-22 November 1968, ICFTU Archives, folder 152; Morris Paladino, "[Report on] Meeting of East-West Committee, 19 November 1968," Meany files, 1940-80, box 61, file 7.

104. Brown to Lovestone, 14 October 1968, Lovestone papers (Hoover), box 356, file: Irving Brown, 1968-69.

105. It was a measure of the bad blood between the UAW and the AFL-CIO that although copies of the administrative letters were widely distributed, no copies were sent to the AFL-CIO per se. Frank Cormier and William J. Eaton, Reuther, 417.

106. Ibid., 416-17; Nelson Lichtenstein, The Most Dangerous Man in Detroit, 409; Joseph C. Goulden, Meany, 390-93.

107. Minutes of a special session of the UAW International Executive Board, 1-2 March 1968, UAW Region 9a, box 24, cited in Kevin Boyle, The UAW and the Heyday of American Liberalism 1945-68, 237.

108. Scott Runkle to Victor Reuther, 27 February 1967, Reuther-Carliner records, 1962-68, box 17, file 6. Bill Mahoney, head of the Canadian section of the steelworkers' union and thus one who might be expected to empathize with Reuther, later admitted to Meany that the UAW president's behaviour had been "alien to democratic traditions." He noted that few Americans or Canadians understood what Reuther was up to and that he was thus not surprised that trade unionists elsewhere were inclined to be puzzled. Mahoney to Meany, 12 December 1968, Meany files, 1940-80, box 61, file 6.

109. Lovestone to Brandel, 22 January 1968, Lovestone papers (Cornell), box 1, file 20; Lovestone to Meany, 17 January 1968, Meany files, 1940-80, box 64, file 1. 
110. A White House aide told President Johnson: "Walter is playing seven card stud, high-low, with Mr. Meany, the last card coming face down on election day." Boyle, The UAW and the Heyday of American Liberalism, 237.

111. Reuther to Levinson, 27 March 1968, Rebhan records, 1965-8o, box 4, file 16; "Relations with the AFL-CIO," Resolution of the 21st Constitutional Convention of the UAW, 4 May 1968, Rebhan records, $1965-80$, box 8 , file 3 .

112. “Transcript of President George Meany's Press Conference, Executive Council Meeting, Washington, DC, 13 May 1968," and Reuther, Mazey, Woodcock, and Greathouse to Meany, 1 July 1968, Victor Reuther papers, box 11, file 11. In the battle to sway outside opinion, the AFL-CIO gained considerably with its closely argued statement To Clear the Record: AFL-CIO Executive Council Report on the Disaffiliation of the UAW, which was issued in April 1969 and translated into four languages. Prepared by Meany's executive assistant, Lane Kirkland, who was about to move up to the post of secretary-treasurer, it served as a powerful refutation of the UAW's criticism of the AFL-CIO leadership. The document pointed up factual errors in Reuther's "administrative letters" and highlighted his erratic behaviour in the lead-up to the UAW's disaffiliation from the AFL-CIO. And, of crucial importance, its argument went completely unanswered. Walter Reuther's executive assistant, Irving Bluestone, was tasked with drafting a response, and he produced a list of headings around which a rebuttal might be framed. But there was no follow-up. Bluestone to Walter Reuther, 21 May 1969, and Bluestone memorandum, "Items for Possible Response," 17 May 1971, Victor Reuther papers, box 33, file 6; author interview with Irving Bluestone, 17 June 1987. Thus the long-running Reuther-Meany struggle concluded with the federation having the last word and very much holding the upper hand. It is impossible to judge with any precision the effect that the AFL-CIO statement had internationally, but it is reasonable to assume that union leaders abroad who subsequently adjusted their view did so, at least in part, in light of this document.

113. Walter Reuther to Storti and Buiter, 23 May 1968, Reuther-Carliner records, 1962-68, box 59 , file 8 .

114. Untitled transcript of ICFTU-AFL-CIO meeting, Monday, 27 October 1969, New York City, IAD Lovestone files, box 42, file 1. The goodwill toward the AFL-CIO in Europe was already in short supply. Following the ICFTU's Amsterdam congress in 1965, Meany had been out of favour among large numbers of European trade unionists, and since then the AFL-CIO backing for the Vietnam War had become a particular cause of disagreement. In 1968, William Gillen was the latest AFL-CIO fraternal delegate at the British TUC conference to experience a frosty reception. He wrote personally to Meany: "If there is a soul in Great Britain who supports our position in Vietnam, I didn't encounter him: I'm reasonably sure he wasn't at the TUC congress. Last year, I was in Japan and found a similar reaction. Right or wrong, hawk, dove or chicken, our position on that issue is getting awfully lonesome in the world." Gillen to Meany, 25 November 1968, IAD Country files, 1945-71, box 4, file 3. The next year, Les Dennis, president of the railroad clerks, was also booed and jeered during his fraternal address to the TUC conference. 
Dennis to Meany, "Special Report," 8 September 1969, Lovestone papers (Hoover), box 379, file: George Meany, 1960-69.

115. Lovestone to Meany, 27 May 1968, Lovestone papers (Hoover), box 379, file: George Meany, 1960-69.

116. Following the meeting with the AFL-CIO, Buiter and Lovestone dined alone. Their conversation ranged widely, with Buiter mentioning at one stage the depth of Arne Geijer's "hatred of and bitterness toward the Americans-especially Meany" and noting that Geijer's views carried much weight with the Germans. From Lovestone's account of the conversation, it sounded rather as though Buiter understood how much trouble he was now in with Meany and was seeking to deflect some of the hostility onto Geijer. Agenda item 3: "Reports of Special Joint Meetings of the ICFTU Sub-Committee and the Finance and General Purposes Committee," minutes of ICFTU Executive Board meeting, 12-14 March 1969, ICFTU Archives, folder 158; author interview with Harm Buiter, 2 July 1995; Lovestone memorandum, "Conference with Buiter, 17 October 1968, Madison Hotel Restaurant, Montpelier," 18 October 1968, Meany files, 1940-80, box 61, file 16.

117. Meany to Buiter, 8 November 1968, ICFTU Archives, folder 152.

118. Geijer to Walter Reuther, 16 December 1968, Rebhan records, 1965-80, box 4, file 3 .

119. Lee to Lovestone, 22 November 1968, IAD Lovestone files, box 41, file 21; Meany to Buiter, 16 December 1968, cited in agenda item 9: "Chronological Account of Developments Leading Up to and Following the Application for Direct ICFTU Affiliation of the UAW, Appendix VI," prepared for the meeting of the ICFTU Executive Board, 30 June-1 July 1969, ICFTU Archives, folder 158. Meany subsequently told a briefing meeting for foreign labour attachés that his initial anger at the executive board's decision intensified when he read the minutes of the meeting and realized that Buiter had not reported all the salient details. He emphasized that the withdrawal had been caused neither by the UAW application as such nor by the issue of East-West contacts. It was a direct consequence of Buiter's unprincipled behaviour. J. J. Watson to Miss E. R. Ryland, 11 April 1969, LAB $13 / 2674$.

120. Walter Reuther to Geijer, 16 January 1969, Victor Reuther papers, box 28, file 15 .

121. Meany's relations with the Christian grouping in Latin America, Confederación latinoamericana de sindical cristiana (CLASC), were notoriously bad, and, in October 1968, Buiter had incurred the wrath of the AFL-CIO by floating the idea of unification with the World Confederation of Labour. In contrast, the UAW had managed to maintain a rapport with CLASC and had recently helped to finance a visit of its leaders to the United States for the purpose of building bridges. Lovestone to Meany, 14 October 1968, Lovestone papers (Hoover), box 379, file: George Meany, 1960-69; Victor Reuther, "Visit of CLASC Delegation from Latin America to the U.S.," 1 October 1968, ReutherRebhan records, 1968-72, box 24, file 16; Victor Reuther to Harold Gibbons, 18 July 1969, Reuther-Rebhan records, 1968-72, box 1, file 9.

122. Benedict to Victor Reuther, 19 December 1968, Victor Reuther papers, box 53, file 22; Victor Reuther, "Dictated Notes from London," 7 February 1969, Victor Reuther papers, box 35, file 23. Within the ITF, Frank Cousins was touting the idea of admitting the 
teamsters, and the Reuthers voiced strong support. Victor Reuther to Jack Jones, 12 January 1970, Victor Reuther papers, box 35, file 20.

123. Paladino to Meany, 21 January 1969, and "Notes on Telephone Conversation [LovestonePaladino], 22 January 1969," Meany files 1940-80, box 61, file 7 .

124. Lee to Meany, 7 February 1969, IAD Lovestone files, box 49, file 16; "Joint Meeting of the Sub-Committee and the Finance and General Purposes Committee of the ICFTU, 11 February 1969," report submitted to the meeting of the TUC International Committee, 25 February 1969, TUC Archives, MSS 292D/901.

125. Victor Reuther, "Dictated Notes from London," 7 February 1969. Reuther dined that same evening with Frank Cousins and Jack Jones, the former and current general secretaries of the British transport workers' union, and formed the clear impression that while they sympathized with the UAW, on this issue they were not willing to challenge George Woodcock or his successor, Vic Feather, who became TUC acting general secretary that month. Jack Jones to Victor Reuther, 21 March 1969, Reuther-Rebhan records, 1968-72, box 29, file 4 .

126. Rosenberg to Walter Reuther, 9 January 1969, Otto Brenner to Walter Reuther, 2 January 1969, and Victor Reuther to Brenner, 16 January 1969, Victor Reuther papers, box 35, file 9.

127. Paladino to Meany, 21 January 1969, "Notes on Telephone Conversation, 22 January 1969," and Ernie [Lee] to Virginia [Tehas], 31 January 1969, Meany files, 1940-8o, box 61, file 7.

128. Victor Reuther, "Dictated Notes from Dusseldorf," 10 February 1969, Victor Reuther papers, box 35, file 10. A further sign of support for the UAW melting away came when, on the same mission, Reuther travelled to Rome to see Bruno Storti. The CISL general secretary was conveniently "unavailable" and palmed Reuther off to his assistants. Ernie [Lee] to Virginia [Tehas], 31 January 1969, Meany files, 1940-80, box 61, file 7.

129. "Joint Meeting of the Sub-Committee and the Finance and General Purposes Committee of the ICFTU, 11 February 1969," report submitted to the meeting of the TUC International Committee, 25 February 1969, TUC Archives, MSS 292D/901; Rosenberg memorandum to the DGB Executive Council, "Recommendations of the ICFTU SubCommittee to the Executive Board Regarding the UAW Application for Affiliation to the ICFTU," 13 February 1969, IAD Brown files, box 5, file 6. That Buiter was also one of the five in favour of the motion would hardly have impressed Meany; it merely served to underline how slim the majority was.

130. Meany to Buiter, 22 February 1968, cited in agenda item 9: "Chronological Account of Developments Leading Up to and Following the Application for Direct ICFTU Affiliation of the UAW, Appendix VIII," prepared for the meeting of the ICFTU Executive Board, 30 June-1 July 1969, ICFTU Archives, folder 158; Brown to Lovestone, 28 February 1969, Lovestone papers (Hoover), box 356, file: Irving Brown, 1968-69; J. J. Watson to A. M. Morgan, 24 July 1969, LAB 13/2674.

131. Jay Lovestone, “The Chasm Is Unbridgeable," Free Trade Union News, February 1969. 


\section{Chapter 9: Au Revoir Becomes Adieu}

1. Victor Feather (1908-76) worked as a retail clerk and was a member of the shop assistants' union before being appointed as assistant in the TUC's department of organization at the age of twenty-nine. He remained with the TUC for the rest of his working life, rising slowly through the bureaucracy until he was appointed general secretary in 1969, just four years before his retirement. Though new to the ICFTU executive board, he had considerable previous experience of international trade unionism, having been sent on a wartime delegation to the USSR and, in 1945, to Germany and Greece to advise on the re-establishment of democratic trade unions. He had also been on ICFTU missions to Japan and the Far East. At the TUC, he became the acknowledged expert on communist activities within the British labour movement. Although he was firmly anti-communist, his first press interview after replacing Woodcock was, ironically, with the Soviet trade union journal Trud_-"Shelepin's sheet," as Lovestone termed it. Bemused by this, the latter commented to Meany, "The ways of the British are hard to explain." Lovestone to Meany, 6 February 1969, IAD Lovestone files, box 49, file 16. Having played a leading part in the failed bid to entice the AFL-CIO to return to the ICFTU, Feather spent his remaining years as general secretary warily overseeing the deepening relationship between the TUC and the unions of the Soviet bloc.

Heinz-Oskar Vetter (1917-90) worked as a locksmith in the coal mining industry before serving in the Luftwaffe throughout the war. Returning to civilian life, he became a full-time official of the miners' union in 1952, a member of its executive board in 1960, and assistant chairman in 1964, with responsibility for its international links. A lastminute candidate for the DGB post in 1969, after the front-runner suddenly withdrew, he was barely known outside his own union at the time of the election, which saw a full one-third of the congress delegates abstain. Lovestone suggested to Meany that although Vetter might be an improvement on Rosenberg (whom Meany heartily detested), he was essentially a weak figure who would not seek to dominate the leaders of the DGB's powerful national unions. Lovestone to Meany, 2 June 1969, IAD Lovestone files, box 49, file 16. In fact, Vetter was to have a significant influence in the international field.

2. Minutes of ICFTU Executive Board meeting, 12 March 1969, ICFTU Archives, folder 158; "Meeting of ICFTU Executive Board, Brussels, 12-14 March 1969," report submitted to the meeting of the TUC International Committee, 25 March 1969, TUC Archives, MSS 292D/901; untitled record of telephone conversation, Harry Pollack and Dan Goott, 12 March 1969, Meany files, 1940-80, box 61, file 7; John Herling's Labour Letter, 26 July 1969.

3. Val Agostinone to Victor Reuther, 18 March 1969, Rebhan records, 1965-80, box 8, file 37; Otto Kersten, "Letter to All German Labour Attachés," 24 February 1969, Lovestone papers (Hoover), box 474, file: AFL-CIO; Welt der Arbeit, 28 February 1969; Kersten to Victor Reuther, 19 March 1969, Reuther-Rebhan records, 1968-72, box 28, file 6.

4. Walter Fritze, "Not in Danger," Welt der Arbeit, 21 March 1969; Der Spiegel, 3 March 1969; Lovestone to Leber, 14 January 1969, IAD Country Files, 1945-71, box 3, file 2; Meany to Rosenberg, 1 May 1969, IAD Country files, 1945-71, box 3, file 14. Irv Lippé, the US labour 
attaché in Brussels, was sensitive to AFL-CIO displeasure at the treatment of the issue in Europe's labour press and admitted to Victor Reuther that he felt under pressure from federation headquarters to self-censor his reports so as to match up with AFL-CIO views. Victor Reuther, "Dictated Notes from Europe," n.d. [1969], Victor Reuther papers, box 34, file 28 .

5. Lovestone to Dale Good, 21 March 1969, Lovestone papers (Cornell), box 2, file 16.

6. J. J. Watson to Miss E. R. Rylands, 11 April 1969, LAB 13/2674.

7. Initially, Paladino described his relations with Buiter in the headquarters as "an armed truce, with staff in the middle worrying about their scalps and not willing to take bets." Discussions between the two men had become "table-pounding arguments." But later he argued to Lovestone: "I can do more good by trying to influence HB . . . rather than have stand-up fights on every issue." Irritated by Lovestone’s carping criticism, he protested: “I can do with less taunting." "Notes on Telephone Conversation (Lovestone-Paladino), 22 January 1969," Meany files, 1940-80, box 61, file 7; Paladino to Meany, 23 March 1969, and Paladino to Lovestone, 11 August 1968, Lovestone papers (Hoover), box 383, file: Morris Paladino, 1967-74. Harm Buiter recalled that although Paladino had been appointed to keep an eye him, they still managed to deal with each other in a friendly manner. This once led Paladino to joke that it spelled danger for both of them. Author interview with Harm Buiter, 2 July 1995.

8. Lovestone to Dale Good, 21 March 1969, Lovestone papers (Cornell), box 2, file 16; Lovestone to Meany, 28 February 1969, Meany files, 1940-80, box 61, file 7; Brown to Lovestone, 28 February 1969, Lovestone papers (Hoover), box 356, file: Irving Brown, 1968-69.

9. “Letter from Harry Pollack," 29 April 1969, Meany files, 1940-80, box 64, file 2.

10. Lee to Meany, n.d. [8 May 1969], reporting telephone call from Paladino, Meany files, 1940-80, box 61, file 7 .

11. Victor Reuther to Executive Board members, 3 June 1969, Reuther-Rebhan records, 1968-72, box 40, file 22. Buiter had recently told Paladino that although he understood he was part of the problem, everyone, including the TUC, had assured him that he would not be sacrificed. Lee to Meany, n.d., Meany files, 1940-80, box 61, file 7.

12. Section G, International, para. 253, "Relations with the AFL-CIO," Annual Report of the Trades Union Congress (Portsmouth, 1969), 340-41; Lee to Meany, 8 May 1969, Meany files, 1940-80, box 61, file 7; "Appendix XI: Chronological Account," in “The AFL-CIO and the ICFTU: Statement by the AFL-CIO Executive Council, Washington, 14 May 1969," and Burton Bendiner cable to Victor Reuther, 18 June 1969, Reuther-Rebhan records, 1968-72, box 40, file 13. Contributing to this changing mood was the AFL-CIO's document To Clear the Record: AFL-CIO Executive Council Report on the Disaffiliation of the UAW, along with the resulting perception in the international labour movement that Meany did have genuine grounds for complaint about the way the UAW application had been handled.

13. Lane Kirkland (1922-99) joined the U.S. Merchant Marine in 1939, aged seventeen and, as a member of the International Organization of Masters, Mates, and Pilots, rose to the rank of chief mate during the war. After the war, and following university studies 
at Georgetown University, he joined the AFL in 1948 as a member of the research department. He was to remain with the federation for the rest of his working life, apart from a two-year break as research director of the Union of Operating Engineers (195860 ). During the 1960s, he was executive assistant to George Meany before being appointed secretary-treasurer in 1969. On his appointment, the British labour counsellor sensed that Meany was keen to involve him in international affairs in a way that his predecessor, Bill Schnitzler, never had been. The labour counsellor also saw this as a possible sign of Lovestone's waning influence. Lovestone was not an intimate of Kirkland's and was noncommittal when asked about his reaction to Kirkland's elevation. J. J. Watson to A. M. Morgan, 24 July 1969, LAB 13/2674. Kirkland succeeded Meany as AFL-CIO president in 1979 and served in that position until his retirement in 1995.

14. In his subsequent account to the committee, Feather claimed that Meany "welcomed" the suggestion. But the Americans transcript of the meeting recorded nothing so upbeat. Untitled transcript ("Storti . . reviewed the past"), 17 June 1969, Meany files, 1940-80, box 61, file 8; "Joint Meeting of the ICFTU Sub-Committee and the Finance and General Purposes Committee, and Meeting with AFL-CIO Representatives, Geneva, 17 June 1969," report submitted to the meeting of the TUC International Committee, 24 June 1969, TUC Archives, MSS 292D/901.

15. Paladino to Lovestone, 18 June 1969, Lovestone papers (Hoover), box 383, file: Morris Paladino, 1967-74; Lovestone to Edward Scicluna, 9 July 1969, IAD Country files, 1945-71, box 5 , file 11 .

16. On Geijer's insistence on reciprocal loyalty, see Geijer to Walter Reuther, 16 December 1968, Rebhan records, 1965-80, box 4, file 23.

17. Feather had been acting general secretary for only four months, Vetter had been in his post for two months, and Kloos of the Dutch NVV was not a titular member of the executive board but was substituting for Debunne, who was scornful of the exercise and chose not to attend. Apart from Buiter and possibly Kloos, none was known as a strong supporter of the UAW bid for affiliation. The "ICFTU Five" were also hobbled to some extent as Bruno Storti became preoccupied with the "hot autumn" of trade union militancy in Italy. Indeed, in August he paid a secret visit to Meany (the Italian Embassy in Washington was under strict instructions not to make known his presence in the city) to discuss CISL's need for American help as he faced increasing internal pressure for unity with the CGIL. Arguably, in such circumstances he was in no position to take a firm line with Meany in the talks over ICFTU reaffiliation.

18. There had been a fierce row in the executive board when Donald MacDonald of the CLC argued that Buiter might feel forced to resign if he were not supported. For the TUC, Fred Hayday countered that this was to put unfair pressure on board members. Agenda item 9: "Report of the Special Joint Meeting of the ICFTU Sub-Committee and the Finance and General Purposes Committee (Geneva, 17 June 1969)," minutes of ICFTU Executive Board meeting, 30 June-1 July 1969, ICFTU Archives, folder 160.

19. ICFTU Report of the Ninth World Congress, Brussels, 2-8 July 1969 (Brussels: ICFTU, 1969), 15-16, 328. On Victor Reuther's globetrotting and bid to line up international support 
for the UAW application, see his reports in Victor Reuther papers, box 33, file 32; Victor Reuther to Fay, 9 July 1969, Reuther-Rebhan records, 1968-72, box 28, file 10.

20. J. J. Watson to A. M. Morgan, 24 July 1969, LAB 13/2674.

21. Bergeron to Lovestone, 1 August 1969, IAD Country files, 1945-71, box 2, file 7.

22. Vetter to Meany, 27 June 1969, IAD Country files, 1945-71, box 3, file 2.

23. Joe Beirne to Meany, 5 August 1969, Meany files, 1940-80, box 61, file 7 . Vetter's weakness within the DGB was reflected in his lack of control over his own press. Despite his emollient tone in letters to Meany, Welt der Arbeit was still uncompromising in its approach to the AFL-CIO, commenting with respect to the Geneva meeting: "As much as Vetter wants a return of the AFL-CIO, he is not prepared to make any concessions to the Americans." It also went on to insist that, in matters of aid to developing countries, the ICFTU must be given freedom to operate "without being influenced by government interests and power politics motives." Walter Fritze, "ICFTU at the Crossroads," Welt der Arbeit, 18 July 1969. In the wake of these comments, the hapless Vetter wrote apologetically to Meany explaining that it was difficult to control what the labour press said. He enclosed a piece he had written about the ICFTU congress in which he praised an article written by Meany and talked of his personal commitment to reaching a settlement with the AFL-CIO. Vetter to Meany, 4 August 1969, IAD Country files, 1945-71, box 3, file 14.

24. Beirne to Meany, 5 August 1969, Meany files, 1940-80, box 61, file 7 .

25. Meany to Feather, 11 August 1969, Meany files, 1940-80, box 61, file 6.

26. Text of cable from London Embassy to State Department, n.d. [24 August?] 1969, Meany files, 1940-80, box 59, file 12 .

27. Victor Reuther to Walter Reuther, 26 August 1969, Victor Reuther papers, box 28, file 16.

28. Untitled transcript of ICFTU-AFL-CIO meeting, Monday, 27 October 1969, New York City, IAD Lovestone files, box 42, file 1; John Windmuller, "Internationalism in Eclipse: The ICFTU After Two Decades," 522.

29. Untitled transcript of ICFTU-AFL-CIO meeting, Monday, 27 October 1969, New York City, IAD Lovestone files, box 42, file 1; Paladino to Lovestone, 14 November 1969, Lovestone papers (Hoover), box 383, file: Morris Paladino, 1967-74; Lovestone to Joseph Godson, 14 November 1969, Lovestone papers (Cornell), box 2, file 6.

30. The "Five" were now down to four. Italy's "hot autumn" of 1969 kept Storti at home, and he missed the follow-up talks with the AFL-CIO.

31. Paladino to Meany, 14 November 1969, Lovestone papers (Hoover), box 383, file: Morris Paladino, 1967-74; "Relations with the AFL-CIO: Report of a Meeting of ICFTU Representatives, Dusseldorf, 16 November 1969," TUC International Committee, 20 November 1969, TUC Archives, MSS 292D/901.

32. Victor Reuther said that the rejection of the UAW application was a sign of the collapse of confidence in the ICFTU on the part of affiliates, telling the UAW executive board: "What is really happening is the major organizations are really deserting the ICFTU. They just don't care about it any more because they have for years now been ignoring major policy statements which Meany has insisted that the ICFTU adopt, but which are totally unrealistic ... so each national centre goes ahead and does what it damn well pleases 
anyway." Minutes of UAW International Executive Board meeting, 17 December 1969, Reuther-Rebhan records, 1968-72, box 40, file 23.

33. He gave the greatest credit to the TUC's international secretary, Alan Hargreaves, for his tenacity in both the Finance and General Purposes Committee and on the executive board in opposing Buiter and neutralizing Debunne, "who can be a devastating rabblerouser." A reflection of the woolly thinking among some was Vetter's behaviour in voting in favour while simultaneously demanding assurances that the AFL-CIO would return without further discussions of the internal affairs of the ICFTU and yet believing that the federation would, in any case, opt to stay outside. According to Lovestone, Vetter was of the view that the AFL-CIO preferred to remain independent since it believed the Third World was full of communists and therefore needed to work alone in the field. Lovestone to Good, 5 December 1969, Lovestone papers (Cornell), box 2, file 17.

34. Lee to Meany, 26 November 1969, Meany files, 1940-8o, box 61, file 8; Paladino to Meany, 2 December 1969, IAD Lovestone files, box 42, file 1; agenda item 6: "Relations with the AFL-CIO," and item 14: "UAW Application for Affiliation," ICFTU Executive Board meeting, 26-28 November 1969, ICFTU Archives, folder 162.

35. Author interview with Frank Winn, 20 April 1987.

36. Minutes of UAW International Executive Board meeting, 17 December 1969, ReutherRebhan records, 1968-72, box 40, file 23.

37. Lovestone to Meany, 8 September 1969, Lovestone papers (Hoover), box 379, file: George Meany, 1960-69.

38. "Vetter Views Future USSR-FRG Trade Union Relations," Moscow Radio, 8 December 1969; Welt der Arbeit, 12 December 1969; Heinz-Oskar Vetter, "Labour's East Policy," New York Herald Tribune, 30 January 1970; Vetter to Lovestone, 20 January 1970, and Kersten to Lovestone, 5 February 1970, IAD Country files, 1945-71, box 3, file 14.

39. Lovestone to Godson, 22 January 1970, Lovestone papers (Cornell), box 2, file 6. Jay Lovestone took issue when the US labour attaché in Bonn suggested that international secretary Otto Kersten was the person responsible for the drift of DGB policy. Lovestone argued that it went much deeper than that and reflected the weight of SPD ideology on Vetter's thinking, describing him as someone "whose heart and mind and dictates are elsewhere ... consciously or otherwise serving others." In his judgment, the DGB chairman was incapable of playing a positive, independent role in facilitating free-world labour reunification. Lovestone to Good, 8 August 1969, Lovestone papers (Cornell), box 2 , file 17 .

40. Untitled transcript of ICFTU-AFL-CIO meeting, 15 February 1970, Meany files, 1940-80, box 61, file 9; "Relations Between the AFL-CIO and the ICFTU, Meeting in Miami, 15-16 February 1970," report submitted to the meeting of the TUC International Committee, 24 February 1970, TUC Archives, MSS 292D/901.

41. Beirne to Meany, 25 March 1970, Meany files, 1940-80, box 61, file 9.

42. Victor Reuther to Mapara, 23 February 1970, Reuther-Rebhan records, 1968-72, box 1, file 19.

43. "Meeting of Representatives of the AFL-CIO and of the ICFTU, Geneva, 25 June 1970," TUC International Committee, 21 July 1970, TUC Archives, MSS 292D/901. 


\section{Chapter 10}

1. The person appointed, Ted Thompson, had a wartime background in British military intelligence and postwar employment on the staff of the International Socialist Conference. Immediately prior to his appointment, he worked as a publicity officer for the ICFTU. Denis Healey to Kenneth Younger, 19 March 1951 and Healey to Thompson, 19 and 29 March 1951. Papers in the private collection of Victor E. Thorpe.

2. Jack Herling, Washington Daily News, 24 January 1957.

3. Lovestone to Meany, 27 May 1968, Lovestone papers (Hoover), box 379, file: George Meany, 1960-69.

4. Morris Weisz, former labour attaché, official in the Marshall Plan, and driving force behind the Foreign Affairs Oral History Project, has suggested on various occasions that the problem was the secrecy surrounding the CIA funding of union programs, not the CIA funding per se. See Morris Weisz, interviewed by Melbourne Spector, 30 July 1990, Frontline Diplomacy: The Foreign Affairs Oral History Collection of the Association for Diplomatic Studies and Training, Manuscript Division, Library of Congress, Washington, DC; a transcript is available at https://adst.org/oral-history/oral-history-interviews/\#gsc.tab=o. 



\section{Bibliography}

\section{Primary Sources}

\section{Manuscript Collections}

Arbetarrörelesens arkiv och bibliotek, Stockholm, Sweden

Arne Geijer Personal Papers

Birger Viklund Personal Papers

Archives of Labor and Urban Affairs, Walter P. Reuther Library, Wayne State University,

Detroit, MI, United States

CIO Office of the Secretary-Treasurer Records, 1935-60, Accession LRooo185

CIO Washington Office Records, 1950-56, Accession LRooo548

UAW International Affairs Department, Herman Rebhan Records, 1965-80, Accession LRooo488_HR

UAW International Affairs Department, Victor Reuther and Lewis Carliner Records, 1962-68, Accession LRooo488_VRLC

UAW International Affairs Department, Victor Reuther and Herman Rebhan Records, 1968-72, Accession LRooo488_VRHR

UAW International Affairs Department, Washington Office, Victor Reuther and Lewis Carliner Records, 1955-63, Accession LRoo2254

UAW President's Office, Walter P. Reuther Records, 1933-70, Accession LRooo261

Valery Burati Papers, 1932-76, Accession LPoo1351

James B. Carey Papers, Accession LPoo1474

Frank Cormier and William Eaton Papers, Accession LPoo1099

William C. Gausmann Papers, 1942-77, Accession LPooo901

William and Ann Kemsley Papers, 1943-61, Accession LPooo943

Jay B. Krane Papers, 1948-61, Accession LPooo614

Victor G. Reuther Papers, 1890-1980, Accession LPooooo2_VGR

Nat Weinberg Papers, 1931-85, Accession LPooo108

George Meany Memorial AFL-CIO Archives, University of Maryland, College Park, MD,

United States

Office of the President Records

Office of the President, George Meany Files, 1940-80, RG1-038

Office of the President, President's Files, George Meany, 1947-6o, RG1-027

International Affairs Department Records

CIO International Affairs Department, Director's Files, Michael Ross, 1920-63,

RG18-002

International Affairs Department, Country Files, 1945-71, RG18-0o1

International Affairs Department, Country Files, 1969-81, RG18-010

International Affairs Department, Irving Brown Files, 1943-89, RG18-004

International Affairs Department, Jay Lovestone Files, 1939-74, RG18-o03 
Hoover Institution, Stanford University, Stanford, CA, United States

Jay Lovestone Papers, 1904-1989, Collection 75091

Walter Schevenels Papers, 1901-86, Collection 77056

International Institute for Social History, Amsterdam, Netherlands

ICFTU Archives

International Trade Union Confederation (ITUC, formerly ICFTU), Brussels, Belgium Omer Becu Papers

Kheel Center for Labor-Management Documentation and Archives, Martin P. Catherwood Library, Cornell University, Ithaca, NY, United States

ILGWU, David Dubinsky, President's Records, 1932-66, Collection 5780/002

Jay Lovestone Papers, 1929-83, Collection 6036/028

Charles S. Zimmerman Papers, 1920-58, Collection 5780/014

Library and Archives Canada, Ottawa, Canada

Daniel Benedict fonds, R12411-O-3-E, Accession 2003-0832

Canadian Labour Congress fonds, MG28 I 103 and Microfilm Reels H-18o, H-193, and H-194

Kalmen Kaplansky fonds, MG30 A 53

Margot Thompson fonds, MG 31 B 28

United Steelworkers of America, Canadian Division fonds, MG28 I 103

United Steelworkers of America, Canadian National Office fonds, MG28 I 268

Modern Records Centre, University Library, University of Warwick, Coventry, United

Kingdom

International Transport Workers' Federation, 1896-2012, MSS 159

Trades Union Congress Archives, 1846-2006, MSS 292, International Files (900-999)

National Archives, Kew, Surrey, United Kingdom

Ministry of Labour and Successors, Records of the International Labour Division and Overseas Department, Registered Files, 1923-1997, Collection LAB 13

Special Collections Library, Penn State University, State College, PA, United States

Clinton S. Golden Papers, 1858-1961, Collection HCLA 1565

State Historical Society of Wisconsin, Madison, WI, United States

Adolph Germer Papers, 1898-1966, U.S. Mss. 125A

American Federation of Labour Records, 1888-1955, Series 8, Files of Research Director, 1935-52, correspondence of Miss Florence Thorne

\section{Personal Interviews}

Fabrizia Baduel Glorioso, 29 March 2006, Rome

James Baker and John Vanderveken, 29 October 2013, Brussels

Daniel Benedict, 29 July 1998, Ottawa

Irving Bluestone, 17 June 1987, 2 August 1988, Detroit

Harm Buiter, 2 July 1995, Groningen

Sir Peter Carr, 14 March 2013, Newcastle upon Tyne

Albert Carthy, 29, October 1983, Thaxted, Essex

Nelson Cruikshank, 11 September 1982, Washington, DC

André Dewil, 27 May 1997, Brussels

Thomas Donahue, 16 July 2012, Silver Spring, MD

480 Bibliography 
Sven Fockstedt, 7 April 1997, Stockholm

George Foggon, 16 June 1983, London

Charles Ford, 24 February 1996, Enfield, Middlesex

Douglas Fraser, 1 June 1987, Detroit

Kalmen Kaplansky, 17 April 1993, Ottawa

Joseph D. Keenan, 12 September 1982, Washington, DC

William Kemsley, 18-21 April 1987, Bellows Falls, VT

Lane Kirkland, 10 July 1996, Washington, DC

Ernest Lee and Herbert Weiner, 19 December 1995, Silver Spring, MD

Harold Lewis, 18 April 2011, Cobham, Surrey

Heribert Maier, 12 November 1995, Geneva

Joseph Morris, 7 September 1995, Victoria, BC

Lionel Murray, 13 February 1997, London

Stefan Nedzynski, 11 November 1995, Geneva

Marjorie Nicholson, 13 April 1983, 8 July 1993, St. Albans, Hertfordshire

Jack Otero, 25 July 2012, Washington, DC

Paul R. Porter, 24 November 1982, Birmingham

Joseph L. Rauh, 7 July 1987, Washington, DC

Victor Reuther, 16 July 1982, 27 August 1986, 6 July 1987, 13 September 1995, Washington, DC

Irving Richter, 10 September 1982, Washington, DC

Rosemary Ruane, 14 January 1995, 16 September 1995, 13 July 1996, Washington, DC

Paul Sakwa, 18 September 1995, Washington, DC

Kaare Sandegren, 16 September 2002 and 7 October 2005, telephone interviews

Virginia Tehas, 17 September 1995, telephone interview

John Vanderveken, 21 April 1995, Brussels

Birger Viklund, 8 April 1997, Stockholm, and 10 October 1997, telephone interview

Morris Weisz, Newman Jeffrey, and Alan Strachan, 28 August 1996, Washington, DC

Frank Winn, 20 April 1987, Bellows Falls, VT

Leonard Woodcock, 1 August 1988, Ann Arbor, MI

\section{Other Interviews}

Irving Brown, interviewed by Frank Sullivan, October 1979, Paris. AFL-CIO Oral History Project, 1978-1980, George Meany Center for Labor Studies. International Affairs Department, Irving Brown Files, 1943-89, RG18-004, box 5, file 5. George Meany Memorial AFL-CIO Archives, University of Maryland, College Park, MD, United States.

Jack Conway, interviewed by Alice Hoffman, 23 May 1979, Silver Spring, MD. AFL-CIO Oral History Project, George Meany Center for Labor Studies. George Meany Memorial AFLCIO Archives, University of Maryland, College Park, MD, United States.

Jacob Potofsky, interviewed by Neil Gold, 6 July 1964. Amalgamated Clothing Workers of America Records, Collection 5619, box 188, folders 1-3. Kheel Center for LaborManagement Documentation and Archives, Martin P. Catherwood Library, Cornell University, Ithaca, NY, United States.

Jay Lovestone, interviewed by Ed Finn, 30 August 1978, New York. Collection 6036/o23, box 1. Kheel Center for Labor-Management Documentation and Archives, Martin P. Catherwood Library, Cornell University, Ithaca, New York. 
Sir Vincent Tewson, interviewed by Åke Wedin, n.d. [1970?]. Åke Wedin collection,

Arbetarrörelsens arkiv och bibliotek, Stockholm.

Morris Weisz, interviewed by Melbourne Spector, 30 July 1990. Frontline Diplomacy: The Foreign Affairs Oral History Collection of the Association for Diplomatic Studies and Training. Manuscript Division, Library of Congress, Washington, DC.

\section{Typescripts}

Lichtblau, George. "Internationalism and the World Federation of Trade Unions." 1949. George Meany Memorial AFL-CIO Archives, University of Maryland, College Park, MD.

Morgan, Ted. “The Grey Eminence.” N.d. Archives of Labor and Urban Affairs, Walter P. Reuther Library, Wayne State University, Detroit, MI.

Nedzynski, Stefan. "My Days with International Trade Union Movement." 1992. International Transport Workers' Federation, 1896-2012, Miscellaneous Items, c. 1975-2007, MSS 159/7/2, Modern Records Centre, University Library, University of Warwick, Coventry, UK.

\section{Secondary Sources}

\section{Publications}

Agyeman, Opoku. The Failure of Grassroots Pan-Africanism: The Case of the All-African Trade Union Federation. Lanham, MD: Lexington Books, 2003.

Aldrich, Richard J. "OSS, CIA and European Unity: The American Committee on United Europe, 1948-6o." Diplomacy and Statecraft 8 (March 1997): 184-227.

Alexander, Robert J. “International Labor Groups in the Americas." Labor Law Journal 13, no. 7 (July 1962): 507-15.

_ . "Labor and Inter-American Relations." Annals of the American Academy of Political and Social Science 334 (March 1961): 41-53.

Ananaba, Wogu. The Trade Union Movement in Africa: Promise and Performance. London: Hurst, 1979.

- The Trade Union Movement in Nigeria. London: Hurst, 1969.

Anderson, David. Histories of the Hanged: Britain's Dirty War in Kenya and the End of Empire. London: Weidenfeld and Nicolson, 2005.

Anderson, Terry H. The United States, Great Britain, and the Cold War, 1944-1947. Columbia: University of Missouri Press, 1981.

Angster, Julia. “'Safe by Democracy': American Hegemony and the 'Westernization' of West German Labor." Amerikiastudien / American Studies 46, no. 4 (2001): 557-72.

Barnes, Samuel H. “The Politics of French Christian Labour." Journal of Politics 21, no. 1 (February 1959): 105-22.

Barnes, Trevor. "The Secret Cold War: The CIA and American Foreign Policy in Europe, 1946-1956." Parts 1 and 2. Historical Journal 24, no. 2 (June 1981): 399-415, and 25, no. 3 (September 1982): 649-70.

Bendt, Heinz. One World, One Voice, Solidarity: The International Trade Secretariats. Bonn: Friedrich-Ebert-Stiftung, 1996. 
Berg, Elliot J. “The External Impact on Trade Unions in Developing Countries: The Record in Africa." Proceedings of the Sixteenth Annual Meeting of the Industrial Relations Research Association (1963): 89-101.

Berger, Graenum. A Not So Silent Envoy: A Biography of Ambassador Samuel David Berger. New York: John Washburn Bleeker Hampton, 1992.

Berger, Henry W. “American Labor Overseas: Lovestone, Meany, and State." The Nation, 16 January 1967.

Berner, Wolfgang. "The Italian Left, 1944-1978: Patterns of Cooperation, Conflict, and Compromise." In The European Left: Italy, France and Spain, edited by William E. Griffith, 13-47. Lexington, MA: Lexington Books, 1979.

Birchall, Ian H. Workers Against the Monolith: Communist Parties Since 1943. London: Pluto, 1974.

Boughton, John. "From Comintern to the Council on Foreign Relations: The Ideological Journey of Michael Ross." Labor History 48, no. 1 (February 2007): 49-72.

Boyle, Kevin. The UAW and the Heyday of American Liberalism, 1945-1968. Ithaca, NY: Cornell University Press, 1995.

Braden, Thomas W. "I'm Glad the CIA Is 'Immoral.” Saturday Evening Post, 20 May 1967.

Braunthal, Gerard. "West German Trade Unions and Disarmament." Political Science Quarterly 73 (March 1958): 82-99.

Bretton, Henry L. "The German Social Democratic Party and the International Situation." American Political Science Review 47, no. 4 (December 1953): 980-96.

Brown, Irving. "Report on Germany." American Federationist, May 1946.

Buhle, Paul. Taking Care of Business: Samuel Gompers, George Meany, Lane Kirkland and the Tragedy of American Labor. New York: Monthly Review Press, 1999.

Bullock, Alan. Life and Times of Ernest Bevin: Foreign Secretary, 1945-51. London: Heinemann, 1983.

Burgess, David. Fighting for Social Justice: The Life Story of David Burgess. Detroit: Wayne State University Press, 2000.

Busch, Gary K. The Political Role of International Trade Unions. London: Macmillan, 1983.

Carew, Anthony. "The American Labour Movement in Fizzland: The Free Trade Union Committee and the CIA." Labor History 39, no. 1 (February 1998): 25-42.

—. "Charles Millard, a Canadian in the International Labour Movement: A Case Study of the ICFTU, 1955-61." Labour / Le Travail 37 (Spring 1996): 121-48.

_ "Conflict Within the ICFTU: Anti-Communism and Anti-Colonialism in the 1950s." International Review of Social History 41 (1996): 147-81.

_. "Il fallimento dell'unità sindacale internazionale: La Federazione sindacale mondiale, 1945-1949." In Le scissioni sindacali: Italia e Europa, edited by Maurizio Antonioli, Myriam Bergamaschi, and Federico Romero, 15-25. Pisa: BFS, 1999.

- Labour Under the Marshall Plan: The Politics of Productivity and the Marketing of Management Science. Manchester: Manchester University Press, 1987.

- "The Politics of Productivity and the Politics of Anti-Communism: American and European Labour in the Cold War." In The Cultural Cold War in Western Europe, 1945-1960, edited by Giles Scott-Smith and Hans Krabbendam, 73-91. London: Frank Cass, 2003.

. "Striden om en oberoende internationalism: den fria fackföreningsrörelsens inre och

yttre fiender." Arbetarhistoria 109-110, nos. 1-2 (2004): 38-55. 
—. "The Trades Union Congress in the International Labour Movement." In British Trade Unions and Industrial Politics, vol. 1, The Post-war Compromise, 1945-64, edited by Alan Campbell, Nina Fishman, and John McIlroy, 145-67. Aldershot, UK: Ashgate, 2000.

- Walter Reuther. Manchester: Manchester University Press, 1993.

Carew, Anthony, Michel Dreyfus, Geert Van Goethem, Rebecca Gumbrell-McCormick, and Marcel van der Linden, ed., The International Confederation of Free Trade Unions. Bern: Peter Lang, 2000.

Carlile, Lonny E. "Sōhyō Versus Dōmei: Competing Labour Movement Strategies in the Era of High Growth in Japan." Japan Forum 6, no. 2 (October 1994).

Carliner, Lewis. “The Dispute That Never Was." Labor History 12, no. 4 (1971): 605-13.

Carr, Peter D. It Occurred to Me: Or, How Did I Get Here? Victoria, BC: Trafford Publishing, 2004.

Chester, Eric Thomas. Covert Network: Progressives, the International Rescue Committee, and the CIA. Armonk, NY: M. E. Sharpe, 1995.

Christman, Henry M., ed. America's Labor Statesman Speaks Out: Walter P. Reuther, Selected Papers. New York: Pyramid Books, 1964.

Citrine, Walter. In Russia Now. London: Hale, 1942.

- Two Careers. London: Hutchinson, 1967.

Cochran, Bert. Labor and Communism: The Conflict That Shaped American Unions. Princeton, NJ: Princeton University Press, 1977.

Cohen, Barry. "The CIA and African Trade Unions." In Dirty Work 2: The CIA in Africa, edited by Ellen Ray, William Schaap, Karl van Meter, and Louis Wolf, 70-79. London: Zed Press, 1980.

Cohen, Robin. Labour and Politics in Nigeria, 1945-71. London: Heinemann, 1974.

Coleman, Peter. The Liberal Conspiracy: The Congress for Cultural Freedom and the Struggle for the Mind of Postwar Europe. New York: Free Press, 1989.

Collomp, Catherine. "The Jewish Labor Committee, American Labor, and the Rescue of European Socialists, 1934-41." International Labor and Working-Class History 68 (Fall 2005): $112-33$.

Cooper, Frederick. Decolonization and African Society: The Labour Question in French and British Africa. Cambridge: Cambridge University Press, 1996.

Cormier, Frank, and William J. Eaton. Reuther. Englewood Cliffs, NJ: Prentice-Hall, 1970.

Costigliola, Frank. "Lyndon B. Johnson, Germany, and 'the End of the Cold War."' In Lyndon Johnson Confronts the World: American Foreign Policy, 1963-1968, edited by Warren I. Cohen and Nancy Bernkopf Tucker, 173-210. Cambridge: Cambridge University Press, 1994.

Cronin, James E. The World the Cold War Made: Order, Chaos, and the Return of History. New York: Routledge, 1996.

Dale, Leon Andrew. Marxism and French Labor. New York: Vantage, 1956.

D'Attorre, Pier Paolo. ERP Aid and the Politics of Productivity in Italy During the 1950 s.

Florence: European University Institute, 1985.

Davies, D. I. “The Politics of the TUC's Colonial Policy.” Political Quarterly 35, no. 1 (January 1964): 23-34.

Davies, Ioan. African Trade Unions. London: Penguin, 1966. 
Debouzy, Marianne. “Le mouvement syndical américain: une 'politique de puissance.” In Syndicalisme: dimensions internationales, edited by Guillaume Devin, 333-58. La GarenneColombes, France: Erasme, 1990.

Delanoue, Paul. "La CGT et les syndicats de l'Afrique noire de colonization française, de la Deuxième Guerre mondiale aux indépendences." Le Mouvement social 122 (January-March 1983): 103-21.

Del Pero, Mario. "The United States and 'Psychological Warfare' in Italy, 1948-55." Journal of American History 87, no. 4 (March 2001): 1304-34.

Devinatz, Victor G. "A Cold War Thaw in the International Working Class Movement? The World Federation of Trade Unions and the International Confederation of Free Trade Unions, 1967-77." Science and Society 77, no. 3 (July 2013): 342-71.

Dickson, David A. United States Foreign Policy Towards Sub-Saharan Africa: Change, Continuity and Constraint. Lanham, MD: University Press of America, 1985.

Dreyfus, Michel, Gérard Gautron, and Jean-Louis Robert, eds. La naissance de Force ouvrière: Autour de Robert Bothereau. Rennes: Presses Universitaires de Rennes, 2003.

Drummond, Gordon D. The German Social Democrats in Opposition 1949-60: The Case Against Rearmament. Norman: University of Oklahoma Press, 1982.

Dubinsky, David, and A. H. Raskin. David Dubinsky: A Life with Labor. New York: Simon and Schuster, 1977.

Dubofsky, Melvyn. “American Labour and Foreign Policy." Monthly Review (June 1971).

Edinger, Louis. Kurt Schumacher: A Study in Personality and Political Behaviour. Stanford, CA: Stanford University Press, 1965.

Eisenberg, Carolyn. Drawing the Line: The American Decision to Divide Germany, 1944-1949. Cambridge: Cambridge University Press, 1996.

—. "Working Class Politics and the Cold War: American Intervention in the German Labour Movement, 1945-49.” Diplomatic History 7, no. 4 (October 1983): 283-306.

Epstein, Leon D. Britain: Uneasy Ally. Chicago: University of Chicago Press, 1954.

Faenza, Roberto, and Marco Fini. Gli Americani in Italia. Milan: Fetrinelli, 1976.

Fifield, Russell H. "The Five Principles of Peaceful Co-existence." American Journal of International Law 52, no. 3 (July 1958): 504-10.

Filippelli, Ronald. American Labor and Postwar Italy, 1943-1953: A Study of Cold War Politics. Stanford, CA: Stanford University Press, 1989.

Fischer, Georges. "Syndicats et décolonization." Présence africaine 34-35 (October 1960January 1961): 17-60.

Fleming, R. D. The Cold War and Its Origins, vol. 1. London: Allen and Unwin, 1961.

Fletcher, Richard. "How CIA Money Took the Teeth Out of British Socialism." In Dirty Work: The CIA in Western Europe, edited by Philip Agee and Louis Wolf, 188-200. London: Zed Press, 1978.

Fraser, Stephen. Labor Will Rule: Sidney Hillman and the Rise of American Labor. New York: Free Press, 1991.

Gaddis, John Lewis. The Long Peace: Inquiries into the Origins of the Cold War. Oxford: Oxford University Press, 1989.

Gannon, Francis X. Joseph D. Keenan: Labor's Ambassador in War and Peace. Lanham, MD: University Press of America, 1984. 
Ganser, Daniele. NATO's Secret Armies: Operation GLADIO and Terrorism in Western Europe. London: Frank Cass, 2005.

Godfrey, E. Drexel. The Fate of the French Non-Communist Left. Garden City, NY: Doubleday, 1955.

Godson, Roy. "The AFL Foreign Policy Making Process from the End of World War II to the Merger." Labor History 16 (Summer 1975): 325-37.

- American Labor and European Politics. New York: Crane Russack, 1976.

Goldberg, Arthur J. AFL-CIO: Labor United. New York: McGraw-Hill, 1956.

Goldsworthy, David. Tom Mboya: The Man Kenya Wanted to Forget. London: Heinemann, 1982.

Gordon, Andrew. The Wages of Affluence: Labor and Management in Postwar Japan.

Cambridge, MA: Harvard University Press, 1998.

Gould, Jean, and Lorena Hickok. Walter Reuther: Labor's Rugged Individualist. New York:

Dodd Mead, 1972.

Goulden, Joseph C. Meany. New York: Atheneum, 1972.

Graf, William D. The German Left Since 1945. Cambridge, UK: Oleander Press, 1976.

Griffith, Robert, and Athen Theoharis. The Spectre: Original Essays on the Cold War and the Origins of McCarthyism. New York: Franklin Watts, 1974.

Grose, Peter. Gentleman Spy: The Life of Allen Dulles. Boston: Houghton Mifflin, 1994.

Guasconi, Maria Eleonora. L’altra faccia della medaglia: Guerra psicologica e diplomazia sindacale nelle relazioni Italia-Stati Uniti durante la prima fase della guerra fredda, 19471955. Soveria Mannelli, Italy: Rubbettino, 1999.

Hamilton, Richard F. Affluence and the French Worker in the Fourth Republic. Princeton, NJ: Princeton University Press, 1967.

Harrod, Jeffrey. Trade Union Foreign Policy: A Study of British and American Union Activities. Garden City, NY: Doubleday, 1972.

Healey, Denis. The Time of My Life. London: Penguin, 1989.

Heaps, David. "Union Participation in Foreign Policy Programmes." Industrial and Labor Relations Review 9 (October 1955): 100-108.

Herling, John. "U.S. Labour vs. Mikoyan.” New Leader, 2 February 1959.

Hero, Alfred O., and Emil Starr. The Reuther-Meany Foreign Policy Dispute. Dobbs Ferry, NY: Oceana, 1970.

Hersch, Burton. The Old Boys: The American Elite and the Origins of the CIA. New York: Scribners, 1992.

Hirsch, Fred, and Richard Fletcher. The CIA and the Labour Movement. Nottingham, UK: Spokesman, 1977.

Holzman, Michael. James Jesus Angleton: The CIA and the Craft of Counter-Intelligence. Amherst: University of Massachusetts Press, 2008.

Hopwood, Derek. Habib Bourguiba of Tunisia: The Tragedy of Longevity. London: St. Martin's Press, 1992.

Horowitz, Daniel L. The Italian Labor Movement. Cambridge, MA: Harvard University Press, 1963.

Howe, Irving, and B. J. Widdick. The UAW and Walter Reuther. New York: Random House, 1949. Hughes, Quenby Olmsted. "In the Interest of Democracy": The Rise and Fall of the Early Cold War Alliance Between the American Federation of Labor and the Central Intelligence Agency. Oxford: Peter Lang, 2011. 
Iber, Patrick J. “'Who Will Impose Democracy?': Sacha Volman and the Contradictions of CIA Support for the Anticommunist Left in Latin America." Diplomatic History 37, no. 5 (November 2013): 995-1028.

Jack, Homer A. "Ideological Conflicts: Russia and the West, Cairo vs. Accra." Africa Today 6, no. 1 (1959): 11-17.

Jankowski, Paul. Communism and Collaboration: Simon Sabiani and Politics in Marseille, 1919-1944. New Haven, CT: Yale University Press, 1989.

Jecchinis, Christos. Trade Unionism in Greece: A Study in Political Paternalism. Chicago: Roosevelt University, Labor Education Division, 1967.

Jenkins, Mark. Bevanism, Labour's High Tide: The Cold War and the Democratic Mass Movement. Nottingham, UK: Spokesman, 1979.

Jolis, A. E. “The OSS and the Labor Movement: How European Trade Unionists Operated Behind German Lines." New Leader, 31 August 1946.

Josephson, Matthew. Sidney Hillman. Garden City, NY: Doubleday, 1952.

Kantrowitz, Jack. "L'influence américaine sur Force Ouvrière: Myth ou réalité?" Revue française de science politique 28 (1978): 717-38.

Keeran, Roger. The Communist Party and the Auto Workers' Union. Bloomington: Indiana University Press, 1980.

Kelly, Sean. America's Tyrant: The CIA and Mobutu of Zaire. Lanham, MD: American University Press, 1993.

Kendall, Walter. The Labour Movement in Europe. London: Allen Lane, 1975.

Kerper, Michael. The International Ideology of U.S. Labour, 1941-1975. Gothenburg: University of Gothenberg, 1976.

Kerr, Clark. "The Trade Union Movement and the Redistribution of Power in Post-War Germany." Quarterly Journal of Economics 68, no. 4 (1954): 535-64.

Kofas, Jon V. "U.S. Foreign Policy and the World Federation of Trade Unions, 1944-48." Diplomatic History 26, no. 1 (Winter 2002): 21-60.

Koscielski, Frank. Divided Loyalties: American Unions and the Vietnam War. London: Routlege, 2015 .

Kratko, Zygmunt. “Irving Brown, alias 'Bronzovy'-American Secret Service Agent.” World Trade Union Movement, April 1953.

Lacroix-Riz, Annie. “Autour d'Irving Brown: l'AFL, le Free Trade Union Committee, le Département d'État et la scission syndicale française (1944-1947).” Le Mouvement sociale 151 (April-June 1990): 79-118.

Lange, Peter, George Ross, and Maurizio Vannicelli. Unions, Change and Crisis: French and Italian Union Strategy and the Political Economy, 1945-1980. London: Allen and Unwin, 1982.

Langley, David. [Dan Gallin]. "The Colonization of the International Trade Union Movement." New Politics 5, no. 1 (Winter 1966): 52-56.

LaPalombara, Joseph. The Italian Labor Movement: Problems and Prospects. Ithaca, NY: Cornell University Press, 1957.

—. "Trade Union Education as an Anti-Communist Weapon in Italy." Southwestern Social Science Quarterly 37 (June 1956): 29-42.

Lens, Sidney, "Labor Lieutenants and the Cold War." New Politics 7 (Summer 1968): 47-57.

Levenstein, Harvey A. Communism, Anticommunism, and the CIO. Westport, CT: Greenwood Press, 1981. 
Lewis, Harold. "Smoke, Mirrors and Spooks: The International Transport Workers' Federation Vigilance Committees, 1949-1953." Historical Studies in Industrial Relations 17 (Spring 2004): 45-73.

Lichtblau, George E. "The Communist Labor Offensive in Former Colonial Countries." Industrial and Labor Relations Review 15, no. 3 (April 1962): 376-401.

—. "Current Trends in the International Labour Scene." Yearbook of World Affairs (1963): 195-218.

—. "The Dilemma of the ICFTU." Africa Report 10, no. 6 (June 1965): 18-19.

_ . "The World Federation of Trade Unions." Social Research 25, no. 1 (Spring 1958): 1-36.

Lichtenstein, Nelson. "The Communist Experience in American Trade Unions." Industrial Relations 19, no. 2 (Spring 1980): 119-30.

- A Contest of Ideas: Capital, Politics, and Labor. Urbana: University of Illinois Press, 2013.

- The Most Dangerous Man in Detroit: Walter Reuther and the Fate of American Labor.

New York: Basic Books, 1995.

Lindblom, Olavi. Pitkällä palkilla. Helsinki: Tammi, 1981.

Link, Werner. The Contribution of Trade Unions and Businessmen to German-American Relations, 1945-1975. Bloomington, IN: Institute of German Studies, 1978.

Logue, John. Toward a Theory of Trade Union Internationalism. Gothenberg: University of Gothenberg, 1980.

Lorwin, Lewis L. The International Labor Movement: History, Policies, Outlook. New York: Harper and Brothers, 1953.

Lorwin, Val R. The French Labor Movement. Cambridge, MA: Harvard University Press, 1954.

Loth, Wilfried. Overcoming the Cold War: A History of Détente, 1950-1991. Translated by

Robert F. Hogg. Basingstoke, UK: Palgrave, 2002.

Luff, Jennifer. Commonsense Anti-Communism: Labor and Civil Liberties Between the World Wars. Chapel Hill: University of North Carolina Press, 2012.

MacMillan, Margaret. Peacemakers: The Paris Conference of 1919 and Its Attempt to End War. London: John Murray, 2001.

MacShane, Denis. International Labour and the Origins of the Cold War. Oxford: Clarendon Press, 1992.

Majander, Mijo. Demokratiaa dollareilla. Keuruu, Finland: Otava, 2007.

Martens, George. “Unity Eludes Africa’s Trade Unions." Industrial Relations Journal 16, no. 1 (Winter 1985): 85-97.

McCarthy, Patrick. ed. Italy Since 1945. Oxford: Oxford University Press, 2000.

McCoy, Alfred W. The Politics of Heroin: CIA Complicity in the Global Drug Trade. Brooklyn: Lawrence Hill Books, 1991.

McCreary, Edward A. The Americanization of Europe. Garden City, NY: Doubleday, 1964.

McIlroy, John. "Léon Jouhaux, Louis Saillant and the National and International in Transnational Trade Unionism.” Labor History 54, no. 5 (December 2013): 554-76.

McMahon, Robert J. "U.S. Policy Toward South East Asia and Tibet During the Early Cold

War." Journal of Cold War Studies 8, no. 3 (Summer 2006): 131-44.

Meany, George. The Last Five Years. Washington, DC: American Federation of Labor, 1951.

Meyer, Cord. Facing Reality: From World Federalism to the CIA. New York: Harper Brothers, 1980.

Meyers, Jeffrey. Gary Cooper: An American Hero. New York: Harper Collins, 1998. 
Migone, G. G. "Stati Uniti, FIAT e repressione antioperaia negli anni cinquanta." Rivista di storia contemporanea 3, no. 2 (April 1974): 232-81.

Morgan, Ted. A Covert Life: Jay Lovestone, Communist, Anti-Communist, and Spymaster. New York: Random House, 1999.

- Reds: McCarthyism in Twentieth-Century America. New York: Random House, 2003.

Morris, George. The CIA and American Labor: The Subversion of the AFL-CIO's Foreign Policy. New York: International Publishers, 1967.

Mothibe, T. H. “Zimbabwe: African Working Class Nationalism, 1957-1963." Zambezia 23, no. 2 (1996): 157-80.

Nakakita, Koji. "Incorporating Japanese Labour into the Free World: Cold War Diplomacy and Economic Interdependence, 1949-64." Labor History 49, no. 2 (May 2008): 199-222.

Nakamura, Kenji. “Twenty Years of Sōhyōo” Jiyu Magazine, May 1970.

Neufeld, Maurice F. “The Italian Labour Movement in 1956: The Structure of Crisis." Annals of the American Academy of Political and Social Science 310, no. 1 (March 1957): 75-86.

- Italy: School for Awakening Countries. Westport, CT: Greenwood Press, 1974.

Nicholson, Marjorie. The TUC Overseas: The Roots of Policy. London: Allen and Unwin, 1986.

Niethammer, Lutz. "Structural Reform and a Compact for Growth: Conditions for a United Labor Movement in Western Europe After the Collapse of Fascism.” In The Origins of the Cold War in Contemporary Europe, edited by Charles Maier, 201-43. New York: New Viewpoints, 1978.

Nuti, Leopoldo. "Commitment to NATO and Domestic Politics: The Italian Case and Some Comparative Remarks." Contemporary European History 7, no. 3 (November 1998): 361-77.

_ . "The Italian 'Stay Behind' Network—the Origins of 'Operation Gladio." Journal of Strategic Studies 30, no. 6 (November 2007): 955-80.

—. "The United States, Italy, and the Opening to the Left, 1953-63." Journal of Cold War Studies 4, no. 3 (Summer 2002): 36-55.

Nyström, Sigvard, and Peter Rütters. History of the IUF. Bonn: Friedrich-Ebert-Stiftung, 1989.

Pacini, Alfred, and Dominique Pons. Docker à Marseille. Paris: Payot, 1996.

Parmet, Robert D. The Master of Seventh Avenue: David Dubinsky and the American Labor Movement. New York: New York University Press, 2005.

Peck, Winslow. "The AFL-CIA." In Uncloaking the CIA, edited by Howard Frazier, 226-65. New York: Free Press, 1978.

—. "CIA Target: Labour." Counterspy 2, no. 1 (Fall 1974): 25-44.

Phillips, Paul. “The German Trade Union Movement Under American Occupation.” Science and Society 14, no. 4 (Fall 1950): 289-306.

Pomian, John, ed. Joseph Retinger: Memoirs of an Eminence Grise. Brighton: Sussex University Press, 1972.

Posner, Charles. Reflections on the Revolution in France:1968. London: Penguin, 1970.

Powers, Richard Gid. Not Without Honor: The History of American Anticommunism. New York: Free Press, 1995.

Prittie, Terence. Willy Brandt: Portrait of a Statesman. London: Weidenfeld and Nicolson, 1974.

Radosh, Ronald. American Labor and United States Foreign Policy: The Unions from Gompers to Lovestone. New York: Random House, 1969.

Rajak, Svetovar. "No Bargaining Chips, No Spheres of Interest: The Yugoslav Origins of ColdWar Non-alignment." Journal of Cold War Studies 16, no. 1 (Winter 2014): 146-79. 
Rathbun, Ben. The Point Man: Irving Brown and the Deadly Post-1945 Struggle for Europe and Africa. London: Minerva Press, 1996.

Reinalda, Bob. "ITF Cooperation with American Intelligence, 1942-1944." In The International Transport Workers' Federation, 1914-1945: The Edo Fimmen Era, edited by Bob Reinalda, 224-38 Amsterdam: IISG, 1997.

Reischauer, Edwin O. My Life Between Japan and America. New York: Harper and Row, 1986.

Reuther, Victor. The Brothers Reuther. Boston: Houghton Mifflin, 1976.

Rice-Maximin, Edward. "The United States and the French Left, 1945-49: The View from the State Department." Journal of Contemporary History 19 (1984): 729-47.

Richards, Yevette. Maida Springer: Pan-Africanist and International Labor Leader. Pittsburgh, PA: University of Pittsburgh Press, 2000.

Riste, Olav. “Stay Behind': A Clandestine Cold War Phenomenon." Journal of Cold War Studies 16, no. 4 (Fall 20014): 35-59.

Roberts, B. C. Labour in the Tropical Territories of the Commonwealth. Durham, NC: Duke University Press, 1964.

Robinson, Archie. George Meany and His Times. New York: Simon and Schuster, 1981.

Robinson, Donald. “Mr. Brown vs. Generalissimo Stalin.” Reader's Digest, September 1952.

Rodríguez García, Magaly. Liberal Workers of the World, Unite? The ICFTU and the Defence of Labour Liberalism in Europe and Latin America, 1949-1969. Bern: Peter Lang, 2010.

Romero, Federico. The United States and the European Trade Union Movement, 1944-1951.

Chapel Hill: University of North Carolina Press, 1992.

Romualdi, Serafino. Presidents and Peons. New York: Funk and Wagnalls, 1967.

Ross, George. Workers and Communists in France: From Popular Front to Eurocommunism.

Berkeley and Los Angeles: University of California Press, 1982.

Sassoon, Donald. One Hundred Years of Socialism: The West European Left in the Twentieth Century. London: Fontana, 1996.

- The Strategy of the Italian Communist Party. London: Pinter, 1981.

Scarnecchia, Timothy. The Urban Roots of Democracy and Political Violence in Zimbabwe:

Harare and Highfield, 1960-1964. Rochester, NY: University of Rochester Press, 2008.

Schevenels, Walter. Forty-Five Years: International Federation of Trade Unions, 1901-1945.

Brussels: International Federation of Trade Unions, 1956.

Schlesinger, Arthur M., Jr. "Kennedy, Pietro Nenni e la svolta progressista: Il racconto di Schlesinger." Critica sociale, special issue, "JFK, la Nuova Frontiera e il centro-sinistra italiano," no. 5/6 (November 2013): 14-15.

- "The Kennedy Administration and the Centre-Left." In Italian Socialism: Between

Politics and History, edited by Spencer M. Di Scala, 183-91. Amherst: University of

Massacshusetts Press, 1996.

- A Thousand Days: John F. Kennedy in the White House. Boston: Houghton Mifflin, 1965.

Schoenberg, Howard. “American Labor's Cold War in Japan.” Diplomatic History 3 (1979):

249-72.

Schonberger, Howard B. Aftermath of War: Americans and the Remaking of Japan. Kent, OH:

Kent State University Press, 1989.

Schumacher, Kurt. “A German Democrat Speaks.” American Federationist, April 1948.

Schwarz, Hans-Peter. Konrad Adenauer: A German Politician and Statesman in a Period of

War, Revolution and Reconstruction, vol. 2, The Statesman, 1952-67. Translated by Geoffrey

Penney. Providence: Berghahn Books, 1997.

490 Bibliography 
Scott-Smith, Giles. The Politics of Apolitical Culture: The Congress for Cultural Freedom and the Political Economy of American Hegemony, 1945-1955. London: Routledge, 2001.

Shadegg, Stephen. Clare Boothe Luce: A Biography. New York: Simon and Shuster, 1970.

Short, Suzanna. Laurie Short: A Political Life. Sydney: Allen and Unwin, 1992.

Smith, R. Harris. OSS: The Secret History of America's First Central Intelligence Agency.

Berkeley and Los Angeles: University of California Press, 1972.

Spalding, Hobart A. "U.S. Labour Intervention in Latin America: The Case of the American Institute for Free Labour Development." In Trade Unions and the New Industrialization of the Third World, edited by Roger Southall, 259-86. London: Zed Press, 1988.

Steinbach, Arnold. "Regional Organizations of International Labour." Annals of the American Academy of Political and Social Science 310, no. 1 (March 1957): 12-20.

Stoner, John C. "'We Will Follow a Nationalist Policy; but We Will Never Be Neutral': American Labour and Neutralism in Cold War Africa, 1957-1962." In American Labor's Global Ambassadors: The International History of the AFL-CIO During the Cold War, edited by Robert Anthony Waters and Geert Van Goethem, 237-51. New York: Palgrave Macmillan, 2013.

Stonor Saunders, Frances. Who Paid the Piper: The CIA and the Cultural Cold War. London: Granta, 1999.

Stromquist, Shelton, ed. Labor's Cold War: Local Politics in a Global Context. Urbana: University of Illinois Press, 2008.

Sturmthal, Adolph, and James Scoville, eds. The International Labor Movement in Transition. Urbana: University of Illinois Press, 1973.

Taft, Philip. Defending Freedom: American Labor and Foreign Affairs. Los Angeles: Nash, 1973. Taylor, Frederick. The Berlin Wall: 13 August 1961-9 November 1989. London: Bloomsbury, 2006.

Thomas, Martin. "Defending a Lost Cause? France and the United States Vision of French North Africa, 1945-1956." Diplomatic History 26, no. 2 (2002): 215-47.

. Fight or Flight: Britain, France, and Their Roads from Empire. Oxford: Oxford University Press, 2014.

—_. "France Accused: French North Africa Before the UN, 1952-62." Contemporary European History 10, no. 1 (2001): 91-121.

—. "Innocent Abroad? Decolonization and U.S. Engagement with French West Africa, 1945-56." Journal of Imperial and Commonwealth History 36, no. 1 (2008): 47-73.

Thompson, Willie. The Communist Movement Since 1945. Oxford: Blackwell, 1998.

Thomson, Don, and Rodney Larson. Where Were You, Brother? An Account of Trade Union Imperialism. London: War on Want, 1978.

The Trade Unions and NATO. 2nd ed. Paris: North American Treaty Organization, Information Division, 1957.

Twenty Years ICFTU. Brussels: International Confederation of Free Trade Unions, 1969. van der Beugel, Ernst H. From Marshall Aid to Atlantic Partnership: European Integration as a Concern of American Foreign Policy. Amsterdam: Elsevier, 1966.

van der Pijl, Kees. The Making of an Atlantic Ruling Class. London: Verso, 1984. van Dongen, Luc, Stéphanie Roulin, and Giles Scott-Smith, eds. Transnational Anti-

Communism and the Cold War: Agents, Activities and Networks. Basingstoke, UK: Palgrave Macmillan, 2014. 
Van Goethem, Geert. The Amsterdam International: The World of the International Federation of Trade Unions (IFTU), 1913-1945. Aldershot, UK: Ashgate, 2006.

von Bülow, Mathilde. "Irving Brown and ICFTU Labor Diplomacy During Algeria’s Struggle for Independence, 1954-62." In American Labor's Global Ambassadors: The International History of the AFL-CIO During the Cold War, edited by Robert Anthony Waters and Geert Van Goethem, 217-36. New York: Palgrave Macmillan, 2013.

Warner, Michael. "Origins of the Congress for Cultural Freedom, 1949-50." Studies in Intelligence 38, no. 5 (Summer 1995): 89-98.

Waters, Robert Anthony, and Geert Van Goethem, eds. American Labor's Global Ambassadors: The International History of the AFL-CIO During the Cold War. New York: Palgrave Macmillan, 2013.

Wedin, Åke. International Trade Union Solidarity: ICFTU, 1957-1965. Stockholm: Prisma and Landsorganisationen i Sverige, 1974.

Wehrle, Edmund F. Between a River and a Mountain: The AFL-CIO and the Vietnam War. Ann Arbor: University of Michigan Press, 2005.

Weiler, Peter. British Labour and the Cold War. Stanford, CA: Stanford University Press, 1988.

—. Ernest Bevin. Manchester: Manchester University Press, 1993.

—. "The United States, International Labour and the Cold War: The Breakup of the World Federation of Trade Unions." Diplomatic History 5, no. 1 (Winter 1981): 1-22.

Weiner, Tim. Legacy of Ashes: The History of the CIA. London: Penguin, 2008.

Werth, Alexander. De Gaulle: A Political Biography. London, Pelican 1965. . France, 1940-1955. London: Robert Hale, 1956.

Wheeler, George S. Who Split Germany? Wall Street and the West German Trade Union Leaders. Berlin: Tribüne, 1962.

Widick, B. J. Labor Today: The Triumphs and Failures of Unionism and the United States. Boston: Houghton Mifflin, 1964.

Wilford, Hugh. The CIA, the British Left and the Cold War: Calling the Tune? London: Frank Cass, 2003.

- The Mighty Wurlitzer: How the CIA Played America. Cambridge, MA: Harvard University Press, 2008.

Willets, Peter. The Non-aligned Movement: The Origins of a Third World Alliance. London: Pinter, 1978.

Windmiller, Marshall. "America's Relations with India: A Re-appraisal." Far Eastern Survey 25, no. 3 (March 1956): 33-38.

Windmuller, John P. American Labor and the International Labor Movement, 1940 to 1953. Ithaca, NY: New York State School of Industrial and Labor Relations, 1954.

- "Cohesion and Disunity in the ICFTU: The 1965 Amsterdam Congress." Industrial and Labor Relations Review 19, no. 3 (April 1966): 348-67.

- "Czechoslovakia and the Communist Union Model." British Journal of Industrial Relations 9, no. 1 (March 1971): 33-54.

_. "External Influences on Labour Organizations in Underdeveloped Countries." Industrial and Labor Relations Review 16, no. 4 (July 1963): 559-73.

—. "The Foreign Policy Conflict in American Labour." Political Science Quarterly 82, no. 2 (June 1967): 205-34. 
"ICFTU After Ten Years: Problems and Prospects." Industrial and Labor Relations

Review 14, no. 2 (January 1961): 257-72.

"Internationalism in Eclipse: The ICFTU After Two Decades." Industrial and Labor

Relations Review 23, no. 4 (July 1970): 510-27.

. "Leadership and Administration in the ICFTU: A New Phase of Development." British

Journal of Industrial Relations 1, no. 3 (October 1963): 147-69.

. "The Stockholm Congress of the ICFTU." Industrial and Labor Relations Review 7, no.

3 (April 1954): 434-43.

. “The Vienna ICFTU Congress." Industrial and Labor Relations Review 9, no. 2 (1956):

268-79.

Woolf, S. J., ed. The Rebirth of Italy, 1943-50. London: Longman, 1982.

Yergin, Daniel. The Shattered Peace: The Origins of the Cold War and the National Security

State. London: Penguin, 1977.

Zack, Arnold. From A to Z: A Memoir by Arnold Zack. N.p.: Lulu, 2007.

Zieger, Robert H. The CIO, 1935-1955. Chapel Hill: University of North Carolina Press, 1995.

\section{Theses and Conference Papers}

Angster, Julia S. "The Westernization of the German Labor Movement: Cultural Transfer and Transnational Network Politics in the 1940s and 1950s." Paper presented at the conference of the German Historical Institute, "The American Impact on Western Europe: Americanization and Westernization in Transatlantic Perspective," Washington, DC, 25-27 March 1999. http://webdoc.sub.gwdg.de/ebook/p/2005/ghi_12/www.ghi-dc.org/conpotweb/ westernpapers/angster.pdf.

Carew, Anthony. "Ideology and International Trade Unionism." Paper presented at the conference of the International Association of Labour History Institutions, "The Past and Future of International Trade Unionism," Ghent, Belgium, 19-20 May 2000.

Fitzloff, Chad L. "The Limits of American Labor's Influence on the Cold War Free Labor Movement: A Case Study of Irving Brown and the International Confederation of Free Trade Unions in Tunisia and Algeria." MA thesis, Kansas State University, 2010.

Gumbrell-McCormick, Rebecca. "The International Confederation of Free Trade Unions: Structure, Ideology and Capacity to Act." PhD diss. University of Warwick, 2001.

Lewis, Harold. “The International Transport Workers' Federation (ITF), 1945-65: An Organizational and Political Anatomy." PhD diss., University of Warwick, 2003.

Meehan, Edgar J. “The British 'Left' and Foreign Policy, 1945-51.” PhD diss., London University, 1954.

Morgan, Eric. "To Act Quietly and Without Fanfare: The AFL-CIO, African-American Labor Center, and South Africa." Paper presented at the Eighth Northeastern Workshop on Southern Africa, Burlington, VT, 17-19 October 2008.

Schwartz, Morton. "Soviet Policy and the World Federation of Trade Unions, 1945-1949." PhD diss., Columbia University, 1963.

Stoner, John C. "Anti-communism, Anti-colonialism, and African Labor: The AFL-CIO in Africa, 1955-1975." PhD diss., Columbia University, 2001.

Wehrle, Edmund. "'Reprehensible Repercussions': The AFL-CIO, Free Trade Unionism, and the Vietnam War, 1947-75." PhD diss., University of Maryland, 1998. 



\section{Index}

Abel, I. W., 278, 313, 435n131

Aborn, Randolph, 55-56

Abramovitch, Raphael, 23-24, 38-39, 365n25

Acheson, Dean, 31, 363n4, 374n5-6

Adamczyk, Aloiz, 98, 421n131, 466n87

Adenauer, Konrad, 133-35, 161-62, 186, 458n23

African-American Labour Center (AALC), 26, 213, $216,226-27,233,286-92,298,320,347$

African Labour College, 179-8o, 224-25, 425n35

African Regional Conference, $169-70$

African Regional Organization (AFRO), 180, 183, 192-97 passim, 205, 225, 286

African Trade Union Confederation (ATUC), 225, 432n101

Afro-Asian Institute, 192, 246

Agency for International Development (AID), $216,226,244,258,260,286$

Agostinone, Valerio, 234

Aguirre, José Maria, 223

Airmold Products, 265

Air-Terre-Mer, 92-93, 383n79, 384n84

Aldrich, Winthrop, 55

Algeria, 162-64, 189, 192, 211, 401n87, 410n43, $411 n 46,435 \mathrm{n} 125$

All-Africa People's Conference, 180-83, 418n108

All-Africa Trade Union Federation (AATUF), $163,195,205,426 \mathrm{n} 4 \mathrm{O}$

Alliance for Labor Action, 313, 315

All-Union Central Council of Trade Unions (AUCCTU): chairman as former head of KGB, 349, 467n 92 ; exchanges visits with DGB, 285 , $302,305,336$; exchanges visits with TUC, 281, 304, 308; and Victor Reuther meeting with Shelepin, 306

Altaffer, Thomas, 432n107

Altman, Georges, 95-96, 385n91

Altschul, Frank, 278

Amalgamated Clothing Workers' Union, 246, 278, 393n31

Amalgamated Engineering Union, 336, 466n85

American Federation of Labor (AFL): agreement to cooperate with CIO in ICFTU, 70; Asian initiative in preparation for ICFTU mission, 76; betrayed by TUC association with AUCCTU, 16; Brown's appointment, 42; CIO international role revives rivalry with, 107; commits to staying in Europe, 39; declines to contribute to RAF, 119; embarks on unity process, 121; and fear of ICFTU falling under control of Europeans, 79; Free Trade Union Fund established by, 19; and FTUC not being integral part of, 22; and concept of free trade unionism, 73, 108; inches towards leadership of future anti-WFTU campaign, 30; insists on its special interests within ICFTU, 78 ; and issue of contacts with eastern bloc, 80 ; and meeting with Harriman to block concessions to CIO, 12-21; and merger terms lacking agreement on international affairs, 144-45; Reuther taken to be in the Tewson camp, 119; Schumacher as guest at 1947 convention, 48; Tewson declines invitation to executive council, 68

American Federation of Labor-Congress of Industrial Organizations (AFL-CIO): advocates stronger ICFTU anti-communist lead, 303; aims to exclude UAW from reaffiliating to ICFTU, 334; ahead of Eisenhower administration in developing strategy for Africa, 170; and Atlantic City accord, 177; and Carleton Hotel agreement, 153; commits to significant contributions to ISF, 203; conducts ongoing programme in Africa from 1960, 192; consistent stand of against colonialism, 168; demands accounting of ISF contributions, 227; insists on right to conduct own international programme, 235; and issue of CIA funding leading to general debate over international policy, 267, 270; and Paris office as symbol of interest in Europe, 207; quest for AID funding, 215

American Federation of State, County, and Municipal Employees, 450n102

American Institute for Free Labour Development (AIFLD), 261, 264, 448n94

American Labor Conference on International Affairs (ALCIA), 23-24, 38, 361n20, 361n22

Americans for Democratic Action, 266

Anaconda Mines, 259, 263-64

Anderson, John E., 56

Angleton, James, 56, 139-38, 145, 402n106, 405n109, 416n94

Anglo-American Council on Productivity, 112 
Anglo-Soviet Trade Union Committee, 14-15, 170 anti-colonialism, 7, 346

Antonini, Luigi, 100, 446n79

Arbenz, Jacobo, 446n79

Armas, Castillo, 446n79

Asian-American Free Labour Institute, 298, 320, $462 n 57$

Asian Regional Organization (ARO), 76-77

Atlantic City Accord, 175, 177, 179, 189, 192

Atlee, Clement, 9

Australian Council of Trade Unions, 80, 85

Australian Workers' Union (AWU), 85, 344

Babeu, Marcel, 419n65

Baker, Jim, 362n25

Ball, George, 268

Barrette, Paul, 292-93

Barton, Paul (Jiri Veltrusky), 223, 298, 465n77

Batista, Fulgencio, 256, 406n2, 446n79

Baylot, Jean, 138

Bay of Pigs, 239-40, 257-58

Beck, Dave, 414n81

Becu, Omer: and accusations of financial irregularity, 228, 231; biographical note, 40on79; and Brown's unauthorised travel, 211-13, 219, 224, 227; Meany hostility toward over proposed ICFTU reforms, 198-99; Meany pressure applied to through spending cuts, 216-18, 221-23; misleads ITF over move to ICFTU, 187, 420-21n27; and negotiation of terms of Brown's appointment, 207-11; and promised ICFTU post for Brown, 195-97; and proposed post of ICFTU director of organization, 139-40; reconciliation with Brown, 200-201, 206-7; reluctance to challenge for ICFTU general secretaryship, $174,183,186,415 n 83$; resignation of, $333-34$

Beichman, Arnold, 74-75, 177

Beirne, Joe: prime mover behind AIFLD, 258-59, 262, 271-73, 450n102; supports Meany over withdrawal from ICFTU, 315, 331, 333, 338-39, 340

Belgian Congo, 18o-81, 192-95, 287, 291-94, 319, 346-47

Bellanca, Frank, 117, 394n34, 398n61

belly communism, 114, 347

Benedict, Dan, 256-57, 270

Ben Seddik, Mahjoub, 193, 205-6, 412n61, 426n41

Bentum, Benjamin, 290, 48on 43

Berger, Sam, 36-37, 44, 111, 117, 121, 125, 390n12

Bergeron, André: dependence on Americans, 279-80, 463n68; and Irving Brown, 37, 279, 297, 320; as opponent of East-West trade union contacts, 306, 308-9; supports AFL-CIO in dispute with ICFTU, 320, 327, 331

Berle, Adolph, 99, 110, 446n79

Bevanism, 165, 379n46

Bevin, Ernest, 15, 44, 59-61, 69, 359n4, 374n6, $390 n 12$

Bilderburg Conference, 168

Birdsall, Paul, 86-87

Bizone, 41

Bluestein, Abraham, 19, 24, 32-39 passim

Bluestone, Irving, 469n112

Blum, Léon, 31-50

Bohlen, Charles, 36

Bolle, Martin, 58, 371n86

Bondy François, 97

Boni, Piero, 245

Bosch, Juan, 368n62

Bothereau, Robert: biographical note, 363n6; and caution over financial dependence on AFL, 32, 51, 94, 279, 379n41; conflict with Lafond, 165, $411 n 49$

Bouazza, Tayeb, 412n61

Bouladoux, Maurice, 126

Bourguiba, Habib, 168-69, 273

Bowles, Chester, 239-40

Braden, Tom: biographical note, 391n13; and CIO operation in Genoa docks, 117; hired by CIA, 111; and Saturday Evening Post exposé, 125, 271-72, 397-98n61

Brandel, Kuno, 285, 296, 302, 392n23, 458n25

Brandt, Willy: Lovestone low regard for, 133, 284, 456n7, 458n25, 466n83; relations with Reuthers, $134,246,248,420$

Bratelli, Trygve, 248

Braunthal, Alfred, 210, 223-24, 295, 301, 428n57, $462 n 61$

Brenner, Otto, 242, 280, 299, 301, 317, 455n6, 462n62

Brevière, La, 124-26, 397n6o

Brezhnev, Leonid, 282, 307, 467n92

"bridge building," 268-70, 282, 303-7, 317, 320, 344

Brinkerhoff, Charles, 259, 263, 445n75

Brodolini, Giacomo, 245

Brombart, David, 426n41

Brown, George (AFL-CIO Director of International Affairs), 150-51, 174

Brown, George (British Foreign Secretary), 457n12

Brown, Irving: alternative employment options, 61-62, 82; background, 24-25; wartime activities, 25-27 in Africa: activity in Algeria, 163-65; activity 
in Congo/Zaire, 291-93; activity in Ghana, 289-91; activity in Israel, 192-94; activity in Nigeria, 288-89; activity in Tunisia, 168-69; confined by Meany to Africa, 297-98; and eleven-country tour (1960), 193-94; and role at All-African People's Conference, 180-81; and role over formation of AATUF, 205-6; as secretary of AALC, 213, 215-216, 226-27, 233, 286-87; and Zack activities in Ghana, 290, $460 \mathrm{n} 43$

in Asia: as AFL-CIO fraternal delegate to INTUC congress (1956), 152; mission to India (1949), 70, 474n8; mission to launch Indian CCF, 386n95; mission to Vietnam (1961), 208, 427n5o; mission to Vietnam (1964), 225, 432nn107-8; mission to Vietnam (1968), 298, $463 n 67$

in ICFTU: attends African regional conference, 169-70; champions cause of affiliation to ICFTU, 232-33, 320; and collaboration with Oldenbroek, 74, 75, 104; considered unsuitable to be ICFTU director of organization, 150, 406n2; as director of ICFTU New York office, 123-25, 206-11, 295; as member of ICFTU mission to Algeria, 163-65; opposes 1952 boycott of ICFTU, 80-82; personal leadership ambitions, 226, 229-30, 434n125; and possible appointment as ICFTU assistant general secretary, 195-99; reconciliation with $\mathrm{Becu}, 200-202,204$; regrets disaffiliation from ICFTU, 320; role in preparatory committee for ICFTU founding congress, 71-73; and unauthorized travel in Africa, 211-13, 219, 220

in Europe: activity in Finland, 88-89; activity in France, 48-50, 90, 115-16, 132-33; activity in Germany, 47-48, 115, 133-34, 161-62; activity in Greece, 43-46, 94, 167; activity in Italy, 100, 115-16, 133; activities outside the field of labour, 95-96; activities with Czech exiles, 97-98; activities with Ferri-Pisani and Mediterranean Vigilance Committee, 89-95; activities with Polish anti-communists, 98, 371n85; and laffaire Dides, 138, 403-4n108; campaigns against WFTU and for Marshall Plan, 58-59; conflict over ERP-TUAC, 63-64, 68-70, 373n105, 374n6; and covert funding, 54-56, 84-88; develops relations with Ross, 135-37; and EDC crisis in France, 132-33; embattled against Victor Reuther, 117-19, 122-26; establishes permanent office, 40-41; financial arrangements of, 52-54; and financing of FO, 50-51; and growth of anti-Americanism, $165,414 \mathrm{n} 81$; and international conference of maritime workers in Naples, 103, 383n78; and launch of ICFTUE, 51-52; and links with ITSs against WFTU, 57-60, 62, 70; lobbies Ernest Bevin, 59-60; meeting with Eisenhower as NATO Supreme Commander, 383n82; and mission to Europe (1945-46), 29-39; and mission to Finland (1968), 463n69; and mission to France (1968), 298, 463n68; and Pegler press campaign, 137-38; and proposals for disciplined trade union cadre organization, 93, 133, 146, 382n71; relations with Bergeron, 279-80; relations with Bothereau, 364n6; relations with FTUC officers, 42; relations with Jouhaux, 48-49, 89-90; relations with Lovestone, 39, 43, 68, 207, 210, 235, 345; relations with Schumacher, 47-48; role in CCF, 96-97, 385n95; and tensions with CIA over "French budget," 108, 110, 121; and training programme for France, 90

Brown, Lillie, 25, 41, 71, 207

Bruce, David, 118, 382n74, 412n6o

Bruegel, John, 138, 404n109

Buiter, Harm: biographical note, 462n62; hostility of Lovestone toward, 297, 299, 301; ICFTU general secretary candidature of, 293, 296, 299, 300; and Meany's campaign against, 314-20, 324-40 passim

Bukharin, Nicolai, 20-21

Bullitt, William, 54, 369n7o

Bunche, Ralph, 421n1

Bunker, Ellsworth, 391n12

Burati, Val, $76,377 \mathrm{n} 28$

Burgess, David, 240

Burnham, James, 96

Busia, Kofi Abrefa, 287

Buu, Tran Quoc, 225, 298, 427n5o, $463 n 67$

Byrnes, James, 36, 59, 363n 4, 39on12

Caffery, Jefferson, 31, 362-63n3

Camus, Albert, 95, 385n91

Canadian Congress of Labour, 408n15

Canadian Labour Congress (CLC), 213, 220, 281, 303

Canini, Giovanni, 100-103

Carey, James B., 71, 129-30, 177, 201, 208, 251, 374n5: biographical note, 399-40on72; as firm opponent of Meany, 150, 158, 171

Carleton Hotel agreement, 153-57 passim, 170-71

Carliner, Lewis, 114, 446n 78

Carney, Jack, 113, 138, 404n109 
Castroism, 257

Cavazza, Fabio, 439n23

Central All-Indonesian Workers' Organization (SOBSI), 85

Central Intelligence Agency (CIA). See Office of Policy Coordination-Central Intelligence Agency (OPC-CIA)

Central Vigilance Committee, 91

Centre déducation syndicale international, 24

Centre of Study and Propaganda, 96

Chajn, Leon, 268, 452n105

Chamberlain, Neville, 132

Chiang kai-shek, 71, 85, 93, 141

China lobby, 140

Chinese Federation of Labour (Taiwan), 406n2

Chipman, Norris, 30-31, 36

Christian Science Monitor, 75

Church Committee, 405 n109

Churchill, Winston, 15, 23, 40, 131-32, 455n2

Citizens Exchange Corps, 266

Citizens for Victory, 21

Citrine, Sir Walter, 11-18 passim, 34, 62-63, 79, 359n4, 372n103, 373n14

Clay, General Lucius, 36, 47-48, 215, 364n11

Clouzet (French journalist), 96

Cohen, Theodore, 377n27

Cohn, Roy, 403n107

Collins, Canon John, 243

Colonial Office (British), 156, 173, 177, 417n10o

Committee for the Establishment and

Development of Free Trade Unionism in

Morocco, 412n61

Committee of the International Socialist

Conference, 367n62, 372n103

Committee to Defend America by Aiding the Allies, 21

Communication Workers of America, 258

Communist Party of France (PCF), 30-31, 115, $362 n_{3}$

Communist Party of Italy, 100

Communist Party of the Soviet Union, 281

Communist Party Opposition, 20

Confederación interamericana de trabajadores, 74

Confederación latinoamericana de sindical cristiana, 470n121

Confederación de trabajadores de Cuba, 256-57, $446 n 79$

Confederación de trabajadores de Mexico, 256

Confédération des syndicats libres du Congo, 292

Confédération française des travailleurs chrétiens (CFTC), 116, 118, 122-23, 126, 393n27

Confédération générale du travail (CGT), 31-32,
37, 40, 48-52, 92: aims for closer ties to EEC, 232, 248; leads WFTU condemnation of 1968 Warsaw Pact invasion of Czechoslovakia, 308 Confédération générale du travail-Force ouvrière (CGT-FO): AFL funding of, 52, 58, 89, 90, 108; Algerian policy of, 163-64; and CIO activities in pilot plant programme, 122; and schism within CGT, 48-51; and renewed search for AFL-CIO funding, 279-80, 463n68

Confederazione generale italiana del Lavoro (CGIL), 115-16, 245-46: aims for closer ties to EEC, 247-48; as first non-communist centre to affiliate to ETUC, 352; moves to federate with non-communist Italian unions, 351; opposes invasion of Czechoslovakia, 308, 310

Confederazione italiana dei sindacati Lavoratori: and contacts with communists, 280, 302, 309-10, 351, 474n17; and financial dependence on Americans, 101, 102, 103, 116, 122, 123; and ideological militancy of younger members, 440n27; and Labour Attaché Lane as source of finance, 101, 105, 121, 395n 45

Conference of Foreign Ministers, 44, 60

Cong-Nong, 463n67

Congress for Cultural Freedom (CCF), 95-97, $105,385-86$ n95

Congress of Industrial Organizations (CIO): AFL rejecting partnership role with, 107, 109-11; approach to international activities of, 114-16; covert funding of, 117-21, 125, 135-37; plans for programme in Europe of, 103-5, 108, 111-13; and proposal to strengthen ICFTU secretariat, 129-31; and role in founding of WFTU, 10-16 passim; and unity with AFL, 128-31, 138-47 passim; and founding of ICFTU, 68-74 passim Conroy, Pat, 392n20

Conway, Jack, 239, 271, 454n121

Cooper, Gary, 385n95

Cope, Elmer, 68, 74, 123, 373n106

Cotton, Sir John, $461 n 49$

Council for Social Progress, 258-62 passim, $446 n 78$

counterpart funds, 101, 109-20 passim, 145, 348-49, 387n1o9, 389n4, 398n62

Cousins, Frank, 170, 428n62, 466n85, 470n122, $471 n 125$

Crosland, Anthony, 439n23

Cuban Confederation of Labour (CTC), 257-57, 446n79

Cuban missile crisis, 213, 277-78

Curran, Joe, 271, 273, 384n87, 454n123

Cyprus, 173, 414n77 
Czeck National Confederation of Political Prisoners and Resisters in Exile, 97

Czechoslovakia, 74, 301, 305-10 passim, 315, 364n12, 372n103

Daily Worker (United Kingdom), 13

Daily Worker (United States), 31, 150, 363n 4

Dale, Leon, 94, 96, 110, 140, 384n87, 388n1

Dalla Chiesa, Enzo, 101, 103, 335

Dan, Phan Quang, 427n50

Das, Mohan, 136, 386n95, 404-5n109

Deakin, Arthur, 69-70, 79

Debré, Michel, $411 n 79$

Debunne, Georges, 319, 324, 328-29, 334-35, 474n17, 476n33

Defferre, Gaston, 382n72

de Gaulle, Charles, 15, 30, 164, 192, 242, $401 n 87$

Delaney, George (Phil): biographical note, 402n97; nominated for AFL-CIO director of international affairs, 142-43; relations with Lovestone and Brown, 82, 135, 136, 144

de Neufville, Lawrence, 97

Deniau, Roger, 32

Denki Rōren, 251

Dennen, Leon, 98-99, 387n102

Dennis, Les, 469n114

Detroit Economic Club, 263

Deutscher Gewerkschaftsbund (DGB): and AFL-CIO complaints over coverage by DGB press, 284-85, 445n23; AFL-CIO lack of rapport with leaders of, 115, 161, 162, 171, 217; criticizes Brown's role as director of ICFTU's New York office, 209, 213; criticizes Meany's stance at ICFTU Amsterdam congress, 229, 232; inconsistent support for AFL-CIO over UAW, 317-19, 324-25; and policy in favour of contacts with eastern bloc communists, 281-285, 302, 304, 305-6, 309, 336-340, 350

Deverall, Richard: biographical note, $376 \mathrm{n} 26$; controversial past, 76, 377n27; as FTUC representative in India and Japan, 70, 85, 250; relations with Lovestone, 76-78, 412n59; and role in ICFTU delegation to Asia, 76-77, $377 n 28$

L'affaire Dides, 138, 164, 403-4n108

Diem, Ngo Dinh, 427n5o

Doherty, William, Jr, 261, 264, 271, 445n75

Doherty, William, Sr, 17

Dohrn, Klaus, 138, 404n1o9

Dōmei. See Japanese Confederation of Labour (Dōmei)

Donovan, General William, 26, 55-56, $412 \mathrm{n} 60$

Dougherty, Tom, 85
Draper, General William, 36

Dubinsky, David: and AFL hostility towards ICFTU and CIO, 81, 116, 117, 130, 152, 153, 158; biographical note, 306n13; disenchantment of over link with CIA, 108, 110, 129, 131; and financial support for refugees, 19; as leading activist in FTUC, 22, 29, 47, 50, 51, 55, 69, 75, 95, 99, 100, 101, 102; relations with Lovestone, 21, 42

Duclos, Jacques, 362n2

Dulles, Allen: and CIA taking control of labour operations, 97, 108-9, 117; relations with Lovestone, 99, 111, 120-21

Dulles, John Foster, 152

Dunn, James, 100, 116, 118

Durand, Dana B., 440n23

Durbrow, Elbridge, 31

Economic Cooperation Administration (ECA), 109, 114, 121, 125, 392n2o

Eden, Sir Anthony, 15

Edwards, Ebby, 11, 13

Ehrhard, Ludwig, 284

Eisenhower, Dwight D., 93, 151, 170, 173, 185, 251, $263,275,364 \mathrm{n} 11,383 \mathrm{n} 82$

Eldridge, Richard, 118

Erlander, Tage, 248

Erler, Fritz, 133

Etter, Willard, 84

Eurocommunism, 248

European communities, 293

European Coal and Steel Community, 79

European Defence Community (EDC), 132-34

European Economic Community (EEC), 352

European Recovery Programme-Trade Union Advisory Committee (ERP-TUAC), 63, 68-69, 201, 372n102

European Recovery Programme Trade Union Conference, 62, 372n103

European Regional Organization, 124

European Trade Union Confederation (ETUC), 350-52

European Trade Union Secretariat (ETUS), 296, $462 n 62$

EUR-X Department, 31, 50, 55, 109, 363n 5

Evans, Lincoln, 17, 365n28

Fabian, Walter, 282

Faline, Mikhail, 38

Fane, H. F. B., 452n105

Farfield Foundation, 97

Faupl, Rudy, 123, 126, 197, 268-69, 398n65, 451n104, 452n105 
Feather, Victor, 323-39 passim

Federal Bureau of Investigation (FBI), 21-22, 31, 138, 389n3, 39o-91n12, 402n106, 403n1o7

Federal Economic Administration (FEA), 25-26, 33

Fédération générale du travail Belgique (FGTB), $58,169,232,319,335,412 \mathrm{n} 63,461 \mathrm{n} 55$

Fédération générale du travail du Kongo, 291

Federazione impiegati operai metallurgici (FIOM), 245, 439n22

Federazione italiana del lavoro, 102

Federazione italiana metallmeccanici (FIM), 166, 244, 439n22

Felce, Pierre, 297, 299, 301, 462n65, 464n71

Fenton, Frank, 41

Ferri-Pisani, Pierre, 89-95 passim, 103, 117, 382n72, 406n2, 453n118, 462n65

FIAT, 122, 133, 146, 208, 247, 382n71, 395n 45

Figueras, José, $367 \mathrm{n} 62$

Filippelli, Ronald, 103

Fimmen, Edo, 37on82, $420 n 127$

Finet, Paul, 71, 79, 378n 33

Finland, 68, 84-85, 88-89, 104, 118, 298, 388n1

Fizz Kids, 86, 89, 94, 97, 111, 117-18, 121, 125, 136-37, 144, 386n98

Ford Foundation, 124-25, 398n62

Ford, Henry, II, 262

Foreign Operations Administration (FOA), 136-37, 145, 166, 395n 45

Foreign Policy Association, 243

Forrestal, James, 56, 369n77, 377n27

Frachon, Benoit, 31, 40, 49, 163, 365n2o

Franco regime, 242, 342, 438n14

Franc-Tireur, 95-96, 110, 385n91

Frankfurter Runschau, 35

Free China Labour League (FCLL), 85, 380n55

Free Labour World, $377 \mathrm{n}_{31}$

Free Trade Union Committee (FTUC): and Atlantic City accord, 176; bank account active in 1961, 416n94; and Carleton Hotel agreement, 153-54; commercial bank loan required by, 54-55; covert funding of begins, 55 ; and Dubinsky's reduced subsidy to, 129-30, 137, 40on74; established as component of LLHR, 19; European office opened, 41; Free Trade Union News, 39; independent AFL activities funded by, 67-89 passim, 94-105 passim; Lovestone as executive secretary of, 22; and mission to Europe (1945), 29; relationship to AFL international labour relations committee, 23 Free Trade Union Fund, 23
Free World Labor Defence Fund, 241-44, 274-75, 437 n1o

Free World Trade Union Conference, 10, 12-13, 15-18

Freier Deutscher Gewerkschaftsbund (FDGB), $34,47,305$

Freitag, Walter, 133-34, 154, 161

Friedman, Jesse, 261

Friedrich Ebert Stiftung, 242, 262

Fritze, Walter, 325, 458n28

Fry, Varian, 23-34, 361n 22

Fulbright, William, 278

G-2 Intelligence, 76

Gaitskell, Hugh, 439n23

Galbraith, J. K., 307

Gallin, Dan, 450n102

Gausmann, Bill, 166, 179

Gazier, Albert, 32

Gee, Hubert, 366n 40

Geijer, Arne: biographical note, 415n84; closeness to UAW, 175, 183, 200-201, 248, 314, 324; election as ICFTU president, 175, 177; and AFL-CIO withdrawal from ICFTU, 314, 324, 328-29, 334, 336; relations with Meany, 198-99, 228-30, 232, 329, 334; and replacement of Oldenbroek by Becu, 183, 185-87, 421n128

General Confederation of Greek Workers (GSEE), 43-46, 63, 74, 94, 167, 201, 242, 303, 366n40, 39on12, 438n16

General Council of Trade Unions of Japan (Sōhyō), 76, 249-55, 325, 343, 351, 377n28, $442 \mathrm{nn} 41,442 \mathrm{n} 44,442 \mathrm{n} 46$

Geneva summit, 151, 407n6

Germer, Adolph, 47

Gewerkschaftler, Der, 285

Gewerkschaftliche Monatschafte, 285

Ghana Trade Union Congress (GTUC), 180, 287, 290

Gherman, Eftimie, 97

Gillen, William, 469n114

Giornelli, Paolo, 94-95, 393n26

Giustizia, La, 396n53

Godson, Joseph, 176, 416n87

Goldberg, Arthur, 21, 26, 117, 239-41, 245-46, 26o, 268, 393n3o

Goldberg, Harry, 85, 144, 151, 156, 165-66, 254, 345,38 on 56,440 on 27

Golden, Clinton, 125

Goldfinger, Nat, 254

Gompers, Samuel, 5, 19, 22, 133, 361n19

Gordon, Archibald, 375n14 
Gottfurcht, Hans, 33, 48, 124, 130, 136, 155, $421 n 131$

Goulart, Joao, 264

Grace, Peter, 259, 261-65, 445n75, 448n91

Grace, W. R. and Company, 259, 445n75

Graedel, Adolphe, 166, 246-47, 315, 441n33

Greece, 43-46, 57, 64, 93-94, 142, 201, 303, 384n84

Green, William, 16, 19, 22, 33, 42, 62, 69, 74, 82, 128, 359n7

Greenburg, Max, 333

Grishin, Victor, 282

Guerini crime family, 90, 382n74

Guingouin, Georges, 115

Hached, Farhat, 379n41

Hargreaves, Alan, 306, 316, 327, 476n33

Harpsund conferences, 248-49, 275

Harries, Edgar, 365n28

Harriman, Averell, 101, 111, 119-21, 246, 266, 389n4, 39on12, 455n2

Harrison, George, 82, 177, 254, 300, 416n93, $445 n 75$

Hayday, Fred, 474n18

Haywood, Alan, 396n52

Healey, Denis, 366n 44

Heine, Fritz, 133, 161, 392n23

Henderson, Loy, 31, 239, 386n95

Henson, Francis, 52

Heyer, Alfred, 224

Hillenkoetter, Admiral Roscoe, 56

Hillman, Sidney, 17, 34-35, 47, 364n13

Hiss, Alger, 31, 363n 4

Histadrut, 85, 192-93, 242, 309

Hook, Sidney, 96

Hoover, J. Edgar, 403n107

Horner, Arthur, 170

"hot autumn" (Italy), 166, 351, 474n17, 475n3o

House Un-American Activities Committee, $403 n 107$

H-T Lingual, 405n109

Humphrey, Hubert, 247, 267, 348, 271, 287-88

Hungarian uprising, 165, 277, 306, 337, 415n83

IG Metall, 57, 246, 28o, 284, 317, 392n23, 456n6

Ilg, Konrad, 24, 57, 61, 113, 122

Independent Labor League (Lovestoneites), 20-21

Indian National Trade Union Congress (INTUC), 152, 168

Indonesia, 74, 84, 374n8, 38on56

Industrial Union Department, 241, 252, 376n26, 409n31, 410n34

Inter-Asiatic Trade Union Federation, 70

International Association of Machinists (IAM),

$25,57-58,126$
International Brotherhood of Electrical Workers, 25

International Centre of Free Trade Unionists in Exile (ICFTUE), 51-52, 72, 97-99, 368n62, 409n31, 466n87

International Chemical Workers' Federation, 392n2o, 439n21, 465n79, 467n96

International Confederation of Free Trade Unions (ICFTU): foundation of, 70, 72-74 under Jaap Oldenbroek as general secretary: AFL boycott of, 80-82, 84; AFL increasingly critical of, 79, 80-82, 104; and AFL-CIO ten-point programme, 171-75, 177; and African regional conference, 169-71; and African training college, 178-79; and appointment of director of organization, 153-54, 156; CIO programmes under auspices of, 119, 121-26; and CIO proposals for restructuring secretariat, 128-31, 138-39; delegation to Algeria, 163-64; and early tensions over cold war, 75; mission to Asia, 76-78; pan-Africanist challenge to, 18o-83; and plans for new post of director of organization, 135, 139-44; and replacement of Oldenbroek, 183-88

under Omer Becu as general secretary: and allegations of financial irregularities, 226-34 passim; and Brown as director of New York office, 206, 207-13 passim, 220, 223-24; efforts to secure Japanese affiliations, 249-54; and Meany as chairman of ISF committee, 217-23 passim, 226; and Rens as potential general secretary, 293-96; structural reform of and criticisms by Meany, 195-200

under Harm Buiter as general secretary: Buiter's candidacy for general secretary of, 299-300; and efforts to retain AFL-CIO affiliation, 323-40 passim; revision of policy on contacts with communist unions, 277-78, 28182, 301-10 passim, 321; and UAW application for affiliation, $313-20$

International Cooperation Administration (ICA), 166

International Federation of Commercial, Clerical, and Technical Employees (IFCCTE), 450-51n102

International Federation of Employees, Technicians, and Managers (FIET), 316, 450 102

International Federation of Petroleum and Chemical Workers, $4500_{103}$

International Federation of Trade Unions (IFTU), 10-18 passim, 64, 69, 73, 79, 363n 5, 370n82, 373n3 
International Labor Bookshelf, 243

International Labour Organization (ILO), 41, $143,176,268-69,290,327,336,344,376 \mathrm{n} 21$, 451nn104, 105, 452n109

International Ladies' Garment Workers Union (ILGWU): as benefactor to Force ouvrière, 51; as benefactor to German social democrats, 47 ; as benefactor to ICFTUE, 97; as mainstay of FTUC, 47; as pre-war base for Lovestone and Brown, 19-29 passim

International Metalworkers' Federation (IMF): American affiliations solicited by, 57-58; American financed training programme in Italy for, 166-167; as a UAW stronghold, 113, 123-129; programmes funded by UAW Free World Labour Defence Fund, 241-59 passim, 269, 275

International Photo-Engravers Union of North America, 4, 22, 361n19

International Solidarity Fund (ISF), 179, 194-95, 198-209, 216-21, 227-34, 296, 301, 425n35

International Study Group on Freedom and Democracy, 439n23

international trade secretariats (ITSs), 18, 29, 57-58, 70, 186, 261

International Transport Workers' Federation (ITF): American railroad workers affiliation to, 58; and links with Brown, $18,33,70,140$, 157; misled over Becu's career intentions, 196, 420n127; as respectable cover for vigilance committees, 91-92, 383n78; rumours of teamsters reaffiliation to, 4700122 ; and wartime intelligence role of, 370n82, 400n79 International Union of Electrical Workers, 72 International Union of Food and Allied Workers

(IUF), 267, 449-5onn101-2

Istanbul Federation of Labour, 94

Italian-American Labor Council, 100

Iwai, Akira, 254-55

Jackson, C. D., 99, 188, 395n46, 404n109

Jagan, Cheddi, 224

Jahn, Hans, 388-89n1

Jallow, Momodou, 226

Jamela, Reuben, 195, 442n13

Japan Productivity Center, 250-51, 442n 44 Japanese Confederation of Labour (Dōmei), 253-55, 302, 443n35

Japanese Wage Research Centre, 249-56, 275 Jeffrey, Newman, 26 Jewish Labour Committee (JLC), 29, 53-54, $360 n 13$
Jockel, Helmuth, 114

Johnson, Lyndon B., 225, 247-48, 265, 268-69, 271, 278, 289, 320, 344, 398n61, 452n109

Jolis, Bert, 30, 53, 96

Jones, Jack, 336, 471n125

Jouhaux, Léon, 9, 31-34, 48, 50, 64, 90, 363n 5

July 26 Movement, 256

JX files, 138, 405n109

Kaiser, Henry, 262

Kamenev, Lev, 20

Kanalarbeiter group, 161

Kaplansky, Kalmen, 220, 281

Karamanlis, Konstantinos, 167

Karl, Albin, 134

Katayama, Takeo, 252-53

Katz, Milton, 108-117, 125, 391-92n18

Kaunda, Kenneth, 243, 273

Keenan, Joseph (Joe), 25

Kemsley, Bill, 126, 136, 141, 144, 165, 174

Kennan, George, 40, 61

Kennedy, John F., 192, 215, 238-39, 243-46, 248, 250-51, 257, 275, 28o, 436n2, 438n14, 456n7

Kennedy, Robert, 259, 271, 437n 4

Kenya African National Union, 194

Kenya Federation of Labour (KFL), 169, 179, 182, 413n64, 419n114: and funding for headquarters building, 169-72, 181, 193-94, 417n99

Kenyatta, Jomo, 413n64

Kersten, Otto, 284, 306, 308-9, 325, 467n95, $468 \mathrm{n} 100$

KGB, 282, 349, 467n82

Khanh, General Nguyen, 225

Khrushchev, Nikita, 151-52, 185, 192, 277, 467n92: meeting with Walter Reuther, 185, 188, 238, 348

Kiesinger, Kurt, 319

Killen, James, 378n32, 432n107

Kirkland, Lane, 271, 339-49, 454n121, 469n112, $473 \mathrm{n} 13$

Kirsch, Henry, 98-99, 110, 387n104, 40on74, 432-33n108

Kissel, Erich, $451 \mathrm{n} 102$

Kissinger, Henry, 168

Kithima, Alphonse, 194, 291-92

Kleine Tribune, Die, 388n1

Kloos, Andries, 330, 474n17

Kluncker, Heinz, 282-84

Koestler, Arthur, 97, 388n1

Kohler, Foy, 440n 28

Korean War, 75, 124, 343, 374n24

Krag, Jens, 248 
Krane, Jay, 76-77, 158, 172, 183, 373n1o6, 376n26, 377-78n31, 412n59, 421n131

Kreisky, Bruno, 404n1o9

Kupers, Evert, 71

Kuznetsov, V. V., 17

Ky, Air Marshall Nguyen Cao, 298

Labor League for Human Rights (LLHR), 19, 24 , 32, 39, 36on12, 407n 4

Labour Party (British), 43, 457n12

Lacoste, Robert, 163-64

Lafond, André, 133, 164-65, 401n87, $411 n 49$

La Malfa, Ugo, 439n23

Landesgruppe Deutscher Gewerkschafter, 33

Landsorganisasjonen i Norge (LO), 29, 37, 248

Landsorganisasjonen i Sverige (LO), 37-38

Lane, Tom, 10o-105, 116, 118, 121, 384n87, 395n45

Langley, David (Dan Gallin), $450 n 102$

Largentier, Auguste, 32

Laski, Harold, 43

Leber, Georg, 279-8o, 284-85, 325, 455n6, 456n7, $466 n 83$

Le Bourre, Raymond, 164

Lecouer, Auguste, 115, 463n68

Lee, Ernest, 213-14, 235, 253-55, 315, 429n73, 43on $80,435 \mathrm{n} 125,447 \mathrm{n} 85,466 \mathrm{n} 8 \mathrm{o}$

Lefranc, Georges, 50

Leskinen, Väjnö, 88-89, 381n65

Lever, Jack, 265

Levinson, Charles: biographical note, 392n20; CIO staff member in Paris, 114, 123, 396n52; favours engagement with Soviet bloc, 467n96; hostility to ICFTU, 467n96; IMF staff member, 129, 166; supported by Reuther brothers as ICF general secretary, 439n21

Lewis, Harold, 94, 196, 279, 378n84, 420n127, 427n52, 464n71

Lewis, John L., 22

Libera confederazione generale italiana del lavoro (LCGIL), 71, 100-103, 387n109, 456n8

Liberman reforms, 465n79

Lie, Haakon, 26, 59, 361-62n25, 388n1

Lindblom, Olavi, 88, 117-18

Lipset, Alexander, 264

Loan, General Nguyen Ngoc, 463n67

Lorwin, Val, 392n2o

Lovestone, Jay: background, 20-21; wartime employment, 21-22

as FTUC executive secretary: as admirer of Adenauer, 160-62, 458n23; and AFL boycott of ICFTU (1952), 80-82; and AFL complaints behind the "bill of particulars," 8o-82, 376n21; appointment as FTUC executive secretary, 19; assessment of Becu, 415n83; assessment of Ferri-Pisani, 453n18; assessment of Oldenbroek, 73; assessment of Tewson, 170; attacked by Spencer Miller, 137-38, 403n107; attacked by Westbrook Pegler, 137-38, 403n107; attitude to DGB leadership, 161-62, 458n25, 466n83; attitude to SPD leadership, 133, 162; attitude to TUC leadership, 58, 62; and concern over lack of ICFTU activity and purpose, 75, 78; confrontational tone in reporting on sister organizations, 78-81, 104, 345; and consistent support for continued AFL/AFL-CIO affiliation to ICFTU, 104, 319-20; covert funding transactions by, 54-56, 70, 85, 88-89, 94-101, 103, 108-9, 118, 123, 381n58, 383n78; disapproves of turn to left in Italy, 165; drafts ten-point programme in response to Soviet "new look," 171-72; and FTUC financial situation, 52, 54, 16; and ICFTU mission to Asia, 76-78; and Khrushchev secret speech, 151; and influence in appointing labour attachés, 176, 377n28, 415-16n87; and OPC-CIA links, 86, 110-11, 113, 117, 120-22, 38on55, 389n7, 453-54n118; opposes Carleton Hotel agreement, 154-66; outsider status of in AFL, 42; and quality of Oldenbroek-Tewson leadership in ICFTU, 79-8o, 82, 376n21, 378n38; relations with Angleton, 138, 402n106; relations with Becu, 183; relations with Brown, 25, 43, 207, 210, 236, 345; relations with Deverall, 77-78; relations with Dubinsky, 42-43, 136-37, 129-30, 151, 40on74; relations with Dulles, 99, 109-111; relations with Meany, 141, 213-14, 235, 299, 300, 464n75; relations with Oldenbroek, 78, 79-8o, 376n21, 378n38; relations with Ross, 135, 16o; relations with Schumacher, 48; and "Samuel Gompers Library," 136, 139; State Department contacts of, 31; transfers to AFL staff, 151; views $\mathrm{CIO}$ as security risk in context of CIA-funded activity, 109, 388n1, 389n5, 394n34, 397-98n61

as assistant director/director of AFL-CIO international affairs department: appointment as assistant director, 176; appointment as director, 214; assessment of Buiter, 299, 301; assessment of Feather, 334; assessment of Kersten, 468n1oo; assessment of Lumumba, 422n11; assessment of Rosenberg, 283; assessment of Ben Seddick, 426n41; assessment of Storti, 301; assessment of Weaver, 426n17; Atlantic City accord and opposition by, 176-77, 188-89; attends German construction workers' 
union congress with Meany and President Kennedy, 28o, 456n7; awarded Order of Merit of Federal Republic of Germany, 186; and campaign to update ICFTU policy on contacts with communists, $280,282,303-4,306-8,321$, $467 \mathrm{n} 9 \mathrm{o}$; campaigns to block election of Storti as ICFTU general secretary, 296-97, 299; and funding for Bentum in Ghana TUC election for general secretary, $460 \mathrm{n}_{43}$; and issue of CGIL disaffection with WFTU, 247-48, 441338 ; and issue of DGB and SPD press coverage of AFL-CIO leadership and policy, 232, 284-85; lack of enthusiasm for auxiliary institutes, 235; lobbies for financial assistance for Bergeron and FO, 279-80; lobbies over Kennedy administration appointments, 23940; meets Adenauer, 284; opposes AFL-CIO boycott of and disaffiliation from ICFTU, 319-20, 330, 337; reaction to Warsaw Pact invasion of Czechoslovakia, 307; relations with Brown, 207, 210, 235; relations with Meany, 213-14, 235, 299-300, 464n75, 474n13; role in appointment of Lee, 213-14, 429n73

Lovett, Robert, 59

Luce, Henry, 404n109

Lumumba, Patrice, 18o-81, 194, 422n11, $461 \mathrm{n} 47$

Lyon, Art, 136, 402n102

Macao, 409n32

MacArthur, General Douglas, 76, 377n28

MacDonald, Donald, 156, 430n84, 474n18

Maciolek, Josef, 98

Macmillan, Harold, 191

Maga, Hubert, 287

Mahomo, Nana, 431n93

Mahoney, Bill, 435n131, 468n1o8

Maier, Heribert, 224

Mailly, Henri, 37

Major, Louis, 58, 412n63

Makris, Fotis, 44-46, 167, 201, 225

Mandel, Ben, 31

Manpower Division (OMGUS), 25-26, 33-34, 364n11, 398n65

Mao Tse-tung, 71, 85, 93, 96

Masaryk, Jan, 372n103

Marseille docks, 90-93, 141, 382n72, 453n118

Marshall, General George C., 44, 60

Marshall Plan, 48-49, 52, 58-64, 99-101, 108-109, $112-14,122-25,145-46,367 n 50,397 n 61$

Martin, Homer, 21, 25, 52, 111, $391 \mathrm{n} 14$

Martov, Julius, 23

Marty, André, 115
Marzet (French journalist), 96

Mboya, Tom: biographical note, 412-13n64; fundraising for KFL headquarters, 169, 194; as general secretary of Kenya African National Union, 193; pro-western voice among African nationalists, 18o-83, 419n15; supports continued role in Africa for Brown, 209-12; turns Reuther against Oldenbroek, 179, 182, $419 n 14$

McCarran, Pat, 378n31, 389n7

McCarthy, Joseph, 137, 364n11, 377-78n31, 389n3, $403 n 107$

McCollum, John, 259-60

McCray, George, 180-81, 199

McLellan, Andrew, 267, 449n101

McSherry, General Frank, 34, 364n11

Meany, George: attends TUC's Blackpool conference (1945), 10-17; auxiliary institutes as increasing focus of, 214, 346; background, 10; contrasting images of, 238,346 ; interest in international affairs, 22, 42; opposes colonialism, 173, 186, 346; relations with Brown, 42, 87, 297-98; relations with Lovestone, 42, 207, 214 relations with CIO: appeasement of communism as point of difference with Reuther, 132; and security liability of $\mathrm{CIO}$ an issue in OPC-CIA programme, 108-9; and unity process avoiding issue of international affairs, 128 relations with DGB and German labour: addresses German construction workers' union congress, 280; Adenauer as greater object of sympathy than German socialists, 162; appeals to German workers to support Paris Accords and NATO membership, 134; and criticism in DGB press of personal performance at ICFTU Amsterdam congress, 232; and DGB critical press reporting of AFL-CIO leadership and policy disputes, 283-86; and DGB interest in contacts with communists, 283 ; and DGB lack of gratitude leading to growing AFL-CIO resentment, 134; Order of Merit of Federal German Republic awarded to, 186; warns Adenauer against fostering Christian trade union movement, 133-34 relations with ICFTU: animosity toward Oldenbroek precedes 1952 boycott, 80-128; and Atlantic City accord, 176-78; and attempts by ICFTU to retain AFL-CIO membership, 327-29, 337-39, 346-50; backtracks from Carleton Hotel agreement, 153-56; and Becu 
objection to Brown serving as AALC executive secretary, 226-27; and boycott of ICFTU (1968), 310; and Buiter's response to UAW application for affiliation, 312-19; campaigns against Becu within ISF committee, 216-18, 221; combative performance by at ICFTU Amsterdam congress, 230-33; in conflict with Becu over Brown's unauthorized foreign travel, 212; demands change in ICFTU leadership, 184; disaffiliation from ICFTU declared by, 319; discounts Deverall's reports from ICFTU headquarters, 77; and efforts to bolster Dōmei and cold-shoulder Sōhyō, 254-55; 195-96, 198, 199; fails to respond to Rens's letter, 294-96; and issue of ICFTU financial irregularities, 228-29; leads deputation to declare no-confidence in Oldenbroek, 183; opposes "bridge-building" and contacts with communists, 278-79; and rejection of AFL-CIO offer of black organizers for ICFTU work in Africa, 182; rejects distinction between Soviet and non-Soviet communism, 80; relations with Becu, 195-99; role in ousting Oldenbroek as general secretary, 187; speaks out against colonialism at Brussels congress, 186; and ten-point programme proposed to strengthen ICFTU's stance against communism, 173; withholds levy funds over dissatisfaction with Millard, 158; withholds support for Buiter in election for general secretary, 299-300

relations with TUC and British labour: animosity of toward Tewson, 8o; concerned over British labour support for Communist China, 132; and reports of Catholic-Irish antipathy toward TUC, 79; and Tewson private appeal for change of tone in relations, 78; Times (London) letter by opposing colonialism, 173 relations with Walter Reuther within AFL-CIO: and AIFLD role for employers, 25961; and allegations of CIA funding, 267-73; campaigns against Bowles's and Reutherites in government service, 239-40; criticizes Reuther activities in Italy, 246; defends walkout by American worker delegation to ILO, 268-69; explores CGIL disaffection within WFTU, 247-48; and joint campaign with Reuther to replace Oldenbroek, 184; obstructs Reuther's objectives in Japan, 252-53; opposes Nehru's "positive neutrality," 152; and policy towards India and Nehru as a source of friction, 151-53; rejects claim of CIA funding of AFL/AFL-CIO, 298; rejects Stevenson proposal for special advisors to UN delegation, 240-41; and visits by Mikoyan and Khrushchev, 184-85

Mediterranean Vigilance Committee (Regional Vigilance Committee for the Mediterranean), 91-95, 99, 104, 115, 382n 72, 383n78, 384n87

Meir, Golda, 192, 417n10o

Mellon, Chase, Jr, 263, 447-48n91

Mendès France, Pierre, 138, 163, 403n108

Meyer, Cord, 271

Michel, Serge, 422n11

Michigan Fund, 125

Mihajlov, Mihajlo, 449n98

Mikoyan, Anastas, 184-85, 188, 238, 348

Millard, Charles, 153-58, 171-72, 179, 183, 396n52, 408n15, 421n128

Miller, Admiral H. B., 99

Miller, Spencer, 138, 403n107

Mitterand, François, 138, 403-4n108

Mobutu, Sese Seko, 287, 289, 291-94, 319, 346-47, $461 n 47,461 n 48,461 n 49,461 n 52$

Moch, Jules, 165, 385n89

Moi, Daniel Arap, 287

Mollet, Guy, 162-64

Monnet, Jean, 462n62

Monrovia group, 192

Montana, Vanni, 102

Morgan, Ted, 6, 456n7

Morgenthau Plan, 25, 33, 35

Moro, Aldo, 246

Morocco, 168-69, 412n61

Morris, Louise Page ("Pagie"), 56, 137, 140

Morse, David, 452n105, 461n55

Morse, Wayne, 307

Mosca, Giovanni, 247-48, 441n36

Mouvement populaire de la révolution (MPR), 291

Mugabe, Robert, 195, 442n13

Mujal, Eusebio, 406n2, 446n79

Mulino, Il, 439n23

Murphy, Raymond E., 31, 50, 55, 109, 363n4, 386n95

Murphy, Robert, 386n95, 395n 45

Murray, Philip, 15, 119, 137, 399n67

Murrow, Ed, 438n14

Mutual Security Agency (MSA), 108, 113, 116, $119-26,135-36,145,166$

Nasser, Gamal Abdel, 152, 168

Nation socialiste, La, $463 \mathrm{n} 68$

National Committee for a Free Europe (NCFE), 98-99, 110, 121, 386n1oo, 387n1o2, 409n31 
National Liberation Council (Ghana), 290

Nederlands Verbond van Vakverenigingen (NVV), 330, 332, 37on82, 378n 33, 462n62

Nedzynski, Stefan: biographical note, $425 \mathrm{n} 38$; and Brown's unorthodox line over formation of AATUF, 206; experience of working under Becu, 221-23; impression of Brown, 432n105; impression of Meany, 217, 230, 346; impression of Smith (Ernst), 434n24; impression of Woodcock, 203

Nehru, Jawaharlal, 152-53, 188, 374n8, 408n18

Nenni, Pietro, 101, 165, 244-46, 275, 394n34, $440 n 27$

New York Journal-American, 137

Nigerian Trade Union Congress, 288

Nitze, Paul, 168

Nixon, Richard M., 170, 39on12

Nkomo, Joshua, 195, 422n13

Nkrumah, Kwame, 169, 180-83, 193-94, 289, $460 n 43$

Non-Aligned Movement, 152, 250

Nordhal, Konrad, 248

North Atlantic Treaty Organization (NATO), 93, 134, 142, 146, 16o-61, 245, 343, 383n82, 441n29

Nouira, Hedi, 287

Nzeribe, Gogo, 419n115

Obote, Milton, 224, 287

Odría, General Manuel, 261

Office of Policy Coordination-Central Intelligence Agency (OPC-CIA), 56, 70, 73, 85-96, 104, 108-11, 247, 266-67, 270-71, 273, $389 n_{3}$

Office of Strategic Services (OSS), 19, 21, 30, $391 n 13$

Offie, Carmel, 108, 116, 388n109, 389n3, 403n7

Oginga Odinga, Jaramogi, 194, 200, 211

OGPU, Joint State Political Directorate, USSR, 22

Ohta, Kaoru, 254

Oldenbroek, J. H.: biographical note, 370n82; as conservative ICFTU general secretary, 75 , 185, 346; challenged by AFL-CIO over ICFTU Africa policy, 182-87; and ICFTU Asia Mission and rift with Lovestone, $76-78,378 \mathrm{n} 33$; growing AFL disapproval of, 79, 8o, 82, 84, 85, $119,135,139,140$; leads ITS campaign against WFTU, 18, 33, 40, 57; resigns under pressure, 186-87; role of in creation of ICFTU, 71-72, 375n14; and tension with TUC over ICFTU policy for colonies, 179

Ollenhauer, Eric, 33, 162, 248, 439n23
OPC-CIA. See Office of Policy CoordinationCentral Intelligence Agency (OPC-CIA)

"Operation August," 270

“Operation GLADIO," 93, 104

"Operation Nenni," 244

Organización regional interamericana de Trabajadores (ORIT), 74, 262, 323, 462n 57

Organization for European Economic Cooperation-Trade Union Advisory Committee (OEEC-TUAC), 68-69, 201, $372 n 102$

Organization of African Unity, 224

Ostpolitik, 336, 344, 350, 466n83

Otero, Joaquin (Jack), 445n75, 448n95

Pager, Robert, 56

Paladino, Morris, 233, 294-316 passim, 325-39 passim, 461n57, 473n7

Pan-African Congress Refugee Centre, 243

pan-Africanism, 178-82, 224, 419n115, 422n13, 432n101

Paris Accords, 134, 146

Het Parool, 230, 232

Parri, Enrico, 100-103

Partito socialista democratico italiano (PSDI), 165-66

Partito socialista italiano (PSI), 166, 245-46, 394n34, 441n29

Pastore, Giulio, 71, 100, 122, 396n53, 456n8

Patzantzis, John, 44

PCF. See Communist Party of France (PCF)

Peace Corps, 243, 258, 266, 436n2

peaceful coexistence, 188, 452n109

Pegler, Westbrook, 137-38, 403n107

Perón, Juan, 342

Perspectives Syndicales/Labour Perspectives, 292

Petrescu, Constantin-Titel, 367n62

"Philip Murray Foundation," 137

Philipsborn, John, 86, 381n59, 384n87

Pimenov, P. T., 268

Pissas, Michael, 414n77

Pollack, Harry, 326

Pollard, Rowland P., 43on8o, 435n125

Populaire, Le, 50, 95, 385n89

Porter, Paul, 25

positive neutrality, 152, 215, 254, 286

Postal, Telegraph and Telephone International (PTTI), 223, 258-61, 425n38, 448n94, 450n102

Potofsky, Jacob: abstains in vote to disaffiliate from ICFTU, 319; approves terms of CIO project on Genoa docks, 117; biographical note, 393-94n32; ebbing support for Reuther 
in dispute with Meany, 271; financial role in support of PSI in 1963 Italian elections, 246; resignation as co-chairman of AFL-CIO international affairs committee, 160, 177, 410n34; as top-level architect of CIO international policy, 119, 153, $391 \mathrm{n} 18$

Poulsen, Juul, 267, 449n101

Prague Spring, 305-10, 320, 348

Profous, Jaraslov, 97-98, 386n98

Prokhorov, V. I., 285

Public Service International (PSI), 450-51n102

Radio Free Europe, 98

Railway Labor Executives' Association, 402n102

Ramadier, Paul, 48

Randolph, A. Philip, 178, 417n99

Rantanen, Jaako, 464n69

Rassemblement démocratique révolutionnaire, $385 n 91$

Rathbun, Ben, 26-27, 362n26

Rauh, Joseph, 239, 270-71

Regional Activities Fund (RAF), 79

Reina, Fr. Mario, 440n27

Reinhardt, Frederick, 440n29

Reischauer, Edwin O., 251

Rens, Jef, 293-96, 346

Résistance ouvrière, 32, 35, 50, 363n6

Reuther, Roy, 111

Reuther, Victor: addresses DGB executive board on UAW application for ICFTU affiliation, 317-18; advises against UAW donation to Mboya, 169; advocates IMF programme for Japan, 249; assessment of by Brown, 392n22, 395n46; assessment of by Lovestone, 114, 392n22, 393n29; assesses growing crisis in ICFTU, 130-31; assigned international responsibilities for UAW, 112; campaigns against AIFLD, 261, 263-64; and CIO organizing and training programmes via IMF, 119, 122, 146; and CIO scheme for additional ICFTU assistant general secretaries, 138-39; and CIO strategy in France and Italy, 116; and CIO training programme at La Brevière, 126; claims close links to President-elect Kennedy, 437n4; claims to speak for united AFL-CIO over Millard's appointment, 156-57; concerned by Woodcock's international stance, 425n35; concerned over AALC being funded by AID, 215; condemns ERP pilot plant scheme, 123; conducts research on CIA activity in American labour movement, 270-71; criticizes Japanese wage system, 444n62; description of, 111, 391n16; drafts AIFLD withdrawal letter, 262; establishes CIO office in Paris, 114; and first visit to Europe, 112; Free World Labor Fund and exclusive international role therein, 241; and funding sought by CIO from MSA, 125; and IMF as Reuther power base, 113; gives press interview on CIA activity within organized labour, 266-67; and issue of CIA funding for CIO, 145, 394n 34, 397n61; leads ADA team to Poland, 266; leads CIO exploratory mission to Europe, 113; meets Lindblom over aid to Finnish labour, 116; as member of combined CIO-AFL delegation to assess ERP, 113; obstructed by US embassies in Paris and Rome, 118; offered post of chief labour adviser to MSA, 113; relations with Ross, 135, 137-40 passim; role of within "Operation Nenni," 246-47; as speaker at DGB May Day rally, 114; speaks up for Brown as member of ICFTU mission to Algeria, 411n46; unhappy with outcome of merger, 144-45, 151; and visit to Shelepin, 305-6; withdrawal of UAW from AFL-CIO predicted by as inevitable, 312; and world tour to line up support for UAW at ICFTU congress, 317,330

Reuther, Walter: advocates blue collar component for Peace Corps, 434-44; and approach to unity talks, 128, 131, 141; as architect of world coordinating councils, 244, 439n21; as architect of Harpsund process, 248-49; assessment of Castro, 256; and aspiration to be AFL-CIO president, 235; and Atlantic City agreement as victory, $177-78$; belief in dialogue with opponents, 132,348 ; and Carleton Hotel agreement as victory, 153-54; challenges Meany over threat to quit ICFTU, 199-200; competes for ear of President Kennedy, 240, 437n9; concerned over ICFTU drift in Africa, 179; congratulates Eisenhower over Geneva summit, 151; contrasted with Meany as anti-communist, 238-41, 436n2; death of, 339; declines co-chairmanship of AFL-CIO international affairs committee, 160; and Democratic Party foreign policy, 244; denounces Lovestone in AFL-CIO EC, 175-76; in dispute with Meany over India and Nehru, 151-53; focuses on Latin America and proposed Council for Social Progress, 257-58, 262; and Free World Labor Defence Fund, 241; ICFTU founding congress recalled by, 72-75; and independent affiliation of UAW to ICFTU, 312, 332-33; and intensification of 
international activity and resultant conflict with Meany, 269-74; and issue of CIA funding of CIO, 348-49, 397n61; issues Administrative Letters critical of AFL-CIO leadership, 310; and legacy of opposition to Lovestone in 1930s, 391n14; meets with Mikoyan and Khrushchev, 184-85; meets with Tito, 449n98; on need to replace Lovestone and Brown, 174; nominates Becu for ICFTU general secretary, 186-87; and "Operation Nenni" and support for Italian turn to left, 244-46; opposes negative anti-communism, 107, 173, 238; overweening personal ambition of, 238; personal conception of free trade unionism, 347-48; and pressure by Johnson administration to drop allegations of CIA links to labour, 271; protests over ILO walkout, 269; and reaction to ICFTU rejection of independent affiliation, 335; relations with Nenni, 245, 441n29; resigns from AFL-CIO EC, 311; secures agreement for special AFL-CIO EC on international policy, 269; secures agreement to withdraw ten-point programme, 174; secures increased AFL-CIO contribution to ISF, 201, 203; strategy for realignment of Japanese labour movement, 250-56; as supporter of German social democrats, 133-34; turns against Oldenbroek, 182-84, 187, 420n126; and Vietnam war, 266; visit to India, 152; visit to Japan, 251-52; and withdrawal from AIFLD board membership, 258-62, 264-65

Richter, Willi, 35, 161-62, 171, 176, 183, 410n38

Riddell, John, 375n2o

Ridgeway, General Matthew, 115

Riesel, Victor, 246, 266, 270, 272, 282

Riley, John, 247, 398n61

Rockefeller, David, 16

Rockefeller Foundation, 56, 384n85

Rockefeller, John D., 56

Rockefeller, Nelson, 264, 445n72

Romualdi, Serafino, 74, 26o-66 passim, 446n79, $447 n 81$

Rosenberg, Ludwig: biographical note, 457n15; correspondence with Meany over DGB policy and press criticisms of AFL-CIO, 283-86; and DGB criticisms of Meany, 232; presses for revision of ICFTU policy against contacts with communists, 282, 302, 304, 308; regarded by Lovestone as supporter of Buiter, 301; visits Shelepin, 305-6; wavers over AFL-CIO withdrawal from ICFTU, 317, 319, 325
Ross, Mike: and appointment of Lee, 429n73; assessment of Lovestone by, 361n17; assessment of Victor Reuther by, 391n16; biographical note, 393n31; as CIO's initial link to CIA, 394n34, 397n61; death of, 213-14; and developing partnership with Brown, 135-37, 139, 143; as director of AFL-CIO international affairs department, 174, 414n8o; and Lovestone assessment of, 160; and Victor Reuther disapproval of, 140; as safe pair of hands, 401n96; as unconvincing advocate of $\mathrm{CIO}$ structural reforms to ICFTU secretariat, 131

Rousset, David, 95, 385n91

Rothschild Bank, 51

Ruane, Rosy, 429n73, 447n81

Runkle, Scott, 453n114, 454n122

Rusk, Dean, 239, 26o, 285, 448n94, $451 \mathrm{n} 104$

Rutz, Henry, 41-42, 62, 129-30, 160

Saillant, Louis, 17, 31, 36-37, 420n126

Sakwa, Paul, $381 n 59$

Salla, Joe, $117,394 \mathrm{n} 34$

Salvador, David, 256

"Samuel Gompers Library," 137-38

Sandegren, Kaare, 361-62n25

Saposs, David, 26

Saragat, Giuseppe, 100, 165, 439n23

Sartre, Jean-Paul, 95, 385n 91

Saturday Evening Post, 271, 290

Scanlon, Hugh, 336

Scharnowski, Ernst, 161, 366n47

Schevenels, Walter, 11-18 passim, 63-70 passim, $79,124,160,374 \mathrm{n} 6$

Schlesinger, Arthur M., 244-46, 57, 439-40n23, 440nn28-29

Schmidt, Carlo, 133

Schnitzler, William, 168-70, 175, 219, 263, 411-12n59, 413n65

Schoenbrun, David, 55

Schumacher, Kurt, 35, 47-48, 133, 366n49, 366-67n5o, 369n77

Scicluna, Edward, 247

Section française de l'internationale ouvrière (SFIO), 162, 384-85n89

Selassie, Haile, 287

Sender, Toni, 75

Shelepin, Alexander, 305-8, 321, 336-37, 348, $467 n 62$

Shrager, Feivel, 53

Silone, Igacio, 97, 385n91, 393n25

Silver, George, $388 \mathrm{n} 1$

Silverberg, Louis, 255 
Simonini, Alberto, 396n 53

Skagen, Ed, 442-43n 46

Smith, General Walter Bedell, 108-13 passim

Socialist International, 248

Social, Technical and Educational Program (STEP), 243-44

Sōhyō. See General Council of Trade Unions of Japan (Sōhyō)

Solidarność, 352

Solovjev, Leonid, 89

Southern Rhodesian African Trade Union Congress (SRATUC), 195

Southern Rhodesian Trade Union Congress (SRTUC), 195

Spiegel, Der, 162, 325, 414n81

Springer, Maida, 178, 180-81, 193-99 passim

Stalin, Josef, 21, 25, 40, 47, 94, 114, 131, 165, 277

Stark, Rudolf, 97

Stassen, Harold, 136, 395n 45

Steinbach, Arnold, 177

Stevenson, Adlai, 239-41

Stockholm Peace Campaign, 75

Stolz, Jiri, 373n 3

Stolz, Otto, 161

Storti, Bruno: biographical note, $456 \mathrm{n} 8$; and contacts with communist unions, 280, 302; as ICFTU president, 233, 436n137; as supporter of Buiter, 297, 299, 300, 301, 474n17

Sturmthal, Adolph, 430-31n23

Suffridge, James, 297, 299, 450-51n102

Suomen Ammattiijärjestö (SAJ), 298, 463-64n69

Suomen Ammattiliittojen Keskusjärjestö (SAK), 88-89, 117-18, 299, 463-64n69

Svenson, Henry, 126

Syndicat national des travailleurs congolais (SNTC), 194

Takano, Minoru, 141, 377n28, 443n55

Tarasov, Mikhail, 9-13 passim

Taylor, Don, 46on 45

Teamsters' Union, 174-76, 313, 315-316, 471$72 \mathrm{n} 122$

Tessier, Gaston, 126

Tet offensive, 298

Tettegah, John, 180-183, 413n65

Tewson, Vincent: attempt to resolve issue of the FTUC backbiting, 78, 378n 35; biographical note, 372n103; controls timing of schism with WFTU and formation of ICFTU, 63, 68, 70-73; criticizes Brown's interference in Europe, 68, 69, 373n105; at odds with ICFTU over Africa policy, 179, 412n63; at odds with Meany over Millard's appointment and ten-point programme, 156, 172; at odds with Meany over negative anti-communism, 71, 132; and tensions with Americans during presidency of the ICFTU, 79-80, 82

Thayer, Charles, $397 n 61$

Theodorou, Dimitris, 167, 201

Thieu, Nguyen Van, 298

Thomas, Norman, 102, 141, 244

Thompson, Ted, $477 \mathrm{n} 1$

Thorez, Maurice, 115

Tillon, Charles, 115

Tito, Josef, 142, 152, 348, 449n98

Tlili, Ahmed, 43on84, 434n125

Tobin, Dan, 19

Tofahrn, Paul, 450-51n102

Togliatti, Palmiro, 100

Touré, Sékou, 180, 182, 418n113

Tracey, Herbert, $367 \mathrm{n} 28$

Trades Union Congress (TUC); annual conference (1945), 10-13; exchanges visits with eastern bloc unions, 232, 281-82, 304, 306, 320; and increasingly fraught relations with AFL, $61-62,68-72,76,78,82,132,173,179,212$; and proprietorial interest in British colonies, 78 , 169, 412n63; and role in formation of WFTU, 14-18, 57; supports AFL-CIO in dispute with UAW by, 315-18, 324-30 passim, 335, 339

Transport and General Workers' Union (T\&GWU), 170, 466n85, 471n125

Travailleurs du Mali, 193

Tripathi, K. P., 152

Trippe, Juan, 445n75

Tronchet, Lucien, 124, 164, 396n56

Trud, 283, 472n1

Truman, Harry, S., 9, 44, 63, 101, 168

Tulatz, Herbert, 301

Turkey, 82, 84, 93-94, 40on74

Unabhängige Gewerkschaft-Organisation (UGO), 47, 74, 110, 114, 366n47

Union des syndicats des travailleurs algériens, $410 n 43$

Union des travailleurs congolais, 291

Unione italiana lavoratori metalmeccanici (UILM), 166, 244, 439n22

Unione italiana del lavoro (UIL), 8o, 102, 166, 344

Union générale des travailleurs algériens (UGTA), 163, 410n 43

Union générale tunisienne du travail (UGTT), $168,379 n 41$

Union marocaine du travail (UMT), 193, 205, 412n61, 434n125 
Union Research and Education Program (UREP), 258-59, 445n73

United Automobile Workers (UAW), 113, 166, 169, 241-65, 312-14

United Labour Congress (ULC), 288-89, 309

United Mine Workers of America, 313

United National Independence Party (Zambia), 243

United Nations Conference on Trade and Development (UNCTAD), 223

United Nations Organization (UNO), 75, 96, 191, 197, 206, 223, 240, 243, 344, 398-99n65, 454n123

United Steel Workers of America (USWA), 123, 296: Candian Division, 153, 435n131, 46on45, $468 \mathrm{n} 108$

Vetter, Heinz-Oskar, 323, 327-28, 330-32, 336-40

Viet Cong, 463n67

Vietnamese Confederation of Labour (CVT), 208, 225, 298, 427n5o, 432n108, 463n67

Viglianesi, Italo, 103, 247

Vittorelli, Paolo, 246, 441n29

Voice of America, 52

Volman, Sacha, 51, 367n62

Volonté, Franco, 122-23, 396n 53

Vorwärts, 284

Vukmanovic-Tempo, Svetozar, 449n98

Wada, Haruo, 253, 443n 55

Walters, General Vernon, 440n29, 448n94

War Production Board, 25

War Relief Fund, 44

Warsaw Pact, 307-8, 321, 336, 348, 368n99

Watson, Thomas J., 262

Watt, Robert, 41

Weaver, George L-P, 197, 240, 254, 258-59, 443n17, $451 \mathrm{n} 104$

Wehner, Herbert, 162, 248, 466n83

Weiler, Peter, 46

Weinberg, Nat, 248

Weiner, Herbert, 85, 240

Weisz, Morris, 477n 4

Welt der Arbeit, 161, 232, 284, 325-36, 458n28, $475 \mathrm{n} 23$

Werth, Alexander, 90

Wheeler, George, 34, 41, 364n12

Williams, G. Mennen, 239

Wilson, Harold, 248, 457n12

Windmuller, John, 216, 220, 333

Winn, Frank, 335

Wirtz, W. Willard, 254, 268, 451n104

Wisner, Frank, 56, 86-87, 108-10, 113, 389n3

With These Hands, 407n12
Wolf, Mortimer, 34, 41

Woll, Mathew: biographical note, $361 \mathrm{n} 19$; as chairman of FTUC and AFL international affairs committee, 19, 32, 33, 38, 42, 43; commissions ALCIA memo on FTUC programme for Europe, 23; concerned over ICFTU attempts to secure financing from Ford Foundation, 124; death of, 160; instructs Brown to seek postponement of ERP trade union conference, 61; introduces Wisner to Lovestone, 56; resigns as ICFTU consultant to UN Economic and Social Council, 75, 367n21; resigns from board of directors of NCFE, 99; weakens in support of FTUC independent activities, 139, 141

Wolnosc i Niezawislosc (WiN), 98

Woodbridge, H. S., 263

Woodcock, George: biographical note, 425n34; concerned to cut back ICFTU expenditure, 202, 203, 219, 221; establishes harmonious relationship with Meany, 203-04; and new climate in TUC-AFL-CIO relations, 202; sanguine about contacts with communists, 281, 303, 304, 354-55n2, 456n9; supports Meany over UAW application for ICFTU affiliation, $316-17,319$

Workers' Anti-Fascist League (ERGAS), 44-45

World Confederation of Labour, 470n121

World Coordinating Councils, 244, 275, 392n20, 439n 21

World Federation of Trade Unions (WFTU), 17-19, 29-50 passim, 57-80 passim, 88-91, $98,112,145,180,206,245,247-48,256,277$, 281, 283, 288, 302, 307-8, 321, 343, 351, 359n1, 418n107, 426n41, 458n2o

World Labour Conference, 1945, 12, 15, 17-18

World Medical Relief, 244

Wurf, Jerry, 450 n102

Yugoslav Confederation of Trade Unions, 281 Yugoslavia, 79, 94, 277, 301, 308, 315, 384n84 Young Catholic Workers (Spain), 242

Zack, Arnold, 290

Zander, Arnold, 58, $371 n 86$

Zenrō Kaigi, 249-54, 344, 442n44, 443n55

Zimbabwe African People's Union, 422n13

Zimmerman, Charles, 20, 29, 33, 37, 360n13

Zinoviev, Grigory, 20

510 Index 